\title{
AgradeCimientos
}

Esta Tesis es el fruto de muchos años de esfuerzo, de crecer como persona e investigadora; en definitiva, de envejecer. Un proceso en el que no he estado sola.

En el plano académico, mi mayor agradecimiento es para la directora de esta Tesis, la profesora María José Hidalgo de la Vega, gracias a quien descubrí la importancia de devolverles a las mujeres su Historia. Desde que comencé a trabajar con ella durante los estudios de máster siempre he podido contar con su apoyo y su sabiduría. Quiero también dar las gracias al profesor Dionisio Pérez Sánchez, que ha tutorizado mi trabajo en la recta final y me ha dado valiosos consejos. Para llevar a cabo mi investigación he contado además con el apoyo prestado por el Departamento de Ciencias Humanas de la Universidad de La Rioja, cuyo personal me acogió con los brazos abiertos durante la estancia de investigación que realicé en Logroño.

Esta Tesis también debe mucho a mi madre, Rolindes, que no ha podido ver los frutos de su esfuerzo educador y de todo el amor que me dio, sin los cuales no habría podido recorrer todo este camino. Eskerrik asko, ama. Llegar hasta aquí habría sido imposible sin Rodrigo, mi mayor apoyo, quien ha tenido que sufrir la tortura de leer los diversos borradores y ha estado a mi lado en los momentos de desesperación, ansiedad, miedo... pero también alegría inherentes a escribir una Tesis Doctoral. Gracias también a Alberto Martín Esquivel, quien además de brindarme su amistad siempre ha estado dispuesto a resolver todas mis dudas sobre cuestiones arqueológicas, y al resto de compañeras y compañeros de doctorado, que han hecho mi día a día en la facultad mucho más agradable. Por último, a mi familia y amistades, por apoyarme y perdonar las pocas llamadas y menos visitas que les he dedicado a lo largo de los años de preparación de mi investigación. 


\section{La Loba}

"Hay una vieja que vive en un escondrijo del alma que todos conocemos pero que muy pocos han visto. Como en los cuentos de hadas de la Europa del este, la vieja espera que los que se han extraviado, los caminantes y los buscadores acudan a verla.

Es circunspecta, a menudo peluda, y siempre gorda, y, por encima de todo, desea evitar cualquier clase de compañía. Cacarea como las gallinas, canta como las aves y por regla general emite más sonidos animales que humanos.

Podría decirse que vive entre las desgastadas laderas de granito del territorio indio de Tarahumara. O que está enterrada en las afueras de Phoenix en las inmediaciones de un pozo. Quizá la podríamos ver viajando al sur hacia Monte Albán en un viejo cacharro con el cristal trasero roto por un disparo. O esperando al borde de la autovía cerca de El Paso o desplazándose con unos camioneros a Morelia, México, o dirigiéndose al mercado de Oaxaca, cargada con unos haces de leña integrados por ramas de extrañas formas. Se la conoce con distintos nombres: La Huesera, La Trapera y La Loba.

La única tarea de La Loba consiste en recoger huesos. Recoge y conserva sobre todo lo que corre peligro de perderse. Su cueva está llena de huesos de todas las criaturas del desierto: venados, serpientes de cascabel, cuervos. Pero su especialidad son los lobos.

Se arrastra, trepa y recorre las montañas y los arroyos en busca de huesos de lobo y, cuando ha juntado un esqueleto entero, cuando el último hueso está en su sitio y tiene ante sus ojos la hermosa escultura blanca de la criatura, se sienta junto al fuego y piensa qué canción va a cantar.

Cuando ya lo ha decidido, se sitúa al lado de la criatura, levanta los brazos sobre ella y se pone a cantar. Entonces los huesos de las costillas y los huesos de las patas del lobo se cubren de carne y a la criatura le crece el pelo. La Loba canta un poco más y la criatura cobra vida y su fuerte y peluda cola se curva hacia arriba. La Loba sigue cantando y la criatura lobuna empieza a respirar.

La Loba canta con tal intensidad que el suelo del desierto se estremece y, mientras ella canta, el lobo abre los ojos, pega un brinco y escapa corriendo cañón abajo. En algún momento de su carrera, debido a la velocidad o a su chapoteo en el agua del arroyo que está cruzando, a un rayo de sol o a un rayo de luna que le ilumina directamente el costado, el lobo se transforma de repente en una mujer que corre libremente hacia el horizonte, riéndose a carcajadas.

Recuerda que, si te adentras en el desierto y está a punto de ponerse el sol y quizá te has extraviado un poquito y te sientes cansada, estás de suerte, pues bien pudiera ser que le cayeras en gracia a La Loba y ella te enseñara una cosa... una cosa del alma." 


\section{ÍNDICE}

$\begin{array}{ll}\text { INTRODUCCIÓN } & \text { p. } 7\end{array}$

CAPÍTUlo I. PRESUPUESTOS TEÓRICO-METOdOLÓGICOS p. 13

$\begin{array}{ll}\text { I.1. La vetula como sujeto histórico } & \text { p. } 14\end{array}$

I.1.1. Definiendo el sujeto de estudio p. 14

I.1.2. La vetula en la historiografía sobre la Antigüedad p. 16

I.2. Género, Historia y Gerontología Feminista p. 23

I.2.1. Mujeres e Historia $\quad$ p. 24

$\begin{array}{ll}\text { I.2.2. Vejez en femenino: la Gerontología Feminista } & \text { p. } 31\end{array}$

$\begin{array}{ll}\text { I.3. Fuentes } & \text { p. } 37\end{array}$

$\begin{array}{ll}\text { I.3.1. Fuentes literarias } & \text { p. } 38\end{array}$

$\begin{array}{ll}\text { I.3.2. Fuentes epigráficas } & \text { p. } 44\end{array}$

$\begin{array}{ll}\text { I.3.3. Restos óseos } & \text { p. } 46\end{array}$

$\begin{array}{ll}\text { I.3.4. Fuentes iconográficas } & \text { p. } 48\end{array}$

CAPÍTULO II. ENVEJECIMIENTO Y VEJEZ EN Roma $\quad$ p. 51

II.1. El estudio de la vejez en las sociedades presentes y pasadas: aspectos $\begin{array}{ll}\text { introductorios } & \text { p. } 52\end{array}$

II.2. Criterios cronológicos, demográficos, biológicos y sociales definitorios $\begin{array}{ll}\text { de la vejez en la antigua Roma } & \text { p. } 57\end{array}$

II.2.1. Periodo máximo de vida en la Antigüedad p. 57

II. 2.2. El ciclo vital y la frontera de la vejez en la antigua Roma p. 63

$\begin{array}{ll}\text { II.2.3. La dimensión demográfica de la vejez } & \text { p. } 76\end{array}$

$\begin{array}{ll}\text { II.2.4. El cuerpo envejecido p. } 88 & \text { p }\end{array}$

II.3. Vivir la vejez en primera persona: buena vejez vs. mala vejez p. 99

$\begin{array}{ll}\text { II.4. La vejez como prólogo de la muerte } & \text { p. } 110\end{array}$

$\begin{array}{ll}\text { II.5. Conclusiones } & \text { p. } 125\end{array}$

CAPÍTULO III. DIMENSIONES CRONOLÓGICA Y FÍSICA DE LA VEJEZ FEMENINA

EN ROMA $\quad$ p. 129

III.1. El ciclo vital femenino p. 130

III.2. Las vetulae en la medicina p. 135

III.2.1. La menopausia como cuestión médica p. 136

$\begin{array}{ll}\text { III.2.2. Patologías físicas y mentales } & \text { p. } 139\end{array}$

III.3. Aspecto físico p. 154

III.3.1. Representaciones artísticas de la vetula p. 156

III.3.2. El aspecto físico de la vetula en la literatura p. 166

$\begin{array}{ll}\text { III.4. Sexualidad } & \text { p. } 180\end{array}$

$\begin{array}{ll}\text { III.5. Conclusiones } & \text { p. } 194\end{array}$ 
CAPÍTUlO IV. DIMENSIONES SOCIAL Y SENTIDA DE LA VEJEZ FEMENINA EN ROMA

IV.1. La vetula en la familia

p. 198

IV.1.1. Esposa

p. 201

IV.1.2. Madre

p. 220

IV.1.3. Abuela

p. 233

IV.1.4. Otras relaciones familiares

p. 243

IV.1.5. Mujeres solas: viudas, divorciadas, solteras y vestales

p. 253

IV.1.6. Más allá de la consanguineidad: amigas, patronas y esclavas

p. 268

IV.1.7. Convivir con una vetula

p. 275

IV.2. La agencia económica de las vetulae

p. 283

IV.3. Estereotipos creadores de una identidad común

p. 293

IV.3.1. Anus ebria

p. 294

IV.3.2. La bruja

p. 306

IV.3.3. La lena

p. 323

IV .3.4. La contadora de historias

p. 328

IV.3.5. La vetula bondadosa

p. 344

IV.3.6. Estereotipos que se solapan para crear una identidad común

p. 346

IV.4. La vejez sentida de las vetulae: un acercamiento a las emociones de la vejez femenina en la antigua Roma

p. 348

IV.5. Conclusiones

p. 354

CONCLUSIONES

p. 359

ANEXOS

p. 367

Anexo 1: Fichas de las vetulae mencionadas en el texto

p. 367

Anexo: 2 Tablas

p. 383

Anexo 3: Imágenes

p. 387

ÍNDICE DE AUTORES CLÁSICOS

p. 401

REFERENCIAS

p. 411

Corpora

p. 411

Ediciones de autores clásicos

p. 412

Bibliografía

p. 420

Webgrafía

p. 468 


\section{INTRODUCCIÓN}

Durante la elaboración de nuestro Trabajo de Fin de Máster, y mientras reflexionábamos sobre cuál podía ser el tema de nuestra Tesis Doctoral, nos dimos cuenta de una ausencia. A pesar de la gran cantidad de estudios sobre las romanas antiguas que han visto la luz durante las últimas décadas, las mujeres desaparecían de ellos una vez terminaban sus años fértiles. Mencionadas en calidad de madres y abuelas, así como por sus actividades económicas y evergéticas, la etapa vital en la que se encontraban parecía pasar desapercibida. Nos propusimos entonces conocer a las vetulae y descubrir cómo era concebida la vejez femenina en la Roma antigua, iniciando un viaje al pasado que ha tomado forma en las siguientes páginas. No podíamos imaginar que las incertidumbres iniciales, fruto de adentrarnos en lo desconocido, darían paso a una experiencia tan gratificante.

\section{JUSTIFICACIÓN DEL TEMA ESCOGIDO}

Son varios los motivos que justifican la elección de las vetulae como sujeto de nuestra Tesis Doctoral. El principal es la necesidad de llenar un vacío en la producción historiográfica e investigar un aspecto del pasado que, tal y como desgranamos en el Capítulo I, apenas ha recibido atención por parte del universo académico. A pesar de encontrar referencias constantes a la ancianidad en la literatura desde la Antigüedad hasta el presente, la vejez ha sido considerada, en el ámbito académico, como un tema de estudio marginal o secundario, al que apenas se hace referencia. Esta falta de interés es especialmente relevante en el caso de las mujeres, perjudicadas por su género además de por su edad, a pesar de que un rápido repaso a la página web A Bit of History ${ }^{l}$, donde se reúnen millares de biografías femeninas de todas las épocas históricas, basta para darnos cuenta de que alcanzar la vejez nunca ha sido una rareza para las mujeres.

Este vacío historiográfico acerca de la vejez no se comprende dada fuerte presencia de la misma en nuestras sociedades. En la actualidad, en torno al 15\% de la población de los países desarrollados es vieja (Rodríguez Ávila, 2006: 11). Se calcula que en el año 2025 habrá en Europa cerca de 85 millones de personas mayores de 65

\footnotetext{
${ }^{1}$ abitofhistory.net/
} 
años, lo que se prevé que conlleve importantes cambios en la forma de concebir la vejez y su papel en nuestra sociedad (Bernárdez, 2009: 31). En el caso de España, por primera vez en su historia se ha producido una inversión demográfica, de forma que hay más personas anciana que menores de edad (IMSERSO, 2011: 34). Hacia 2050, un 30\% de la población española tendrá más de 65 años (IMSERSO, 2011: 267; Ramos Toro, 2017: 93-98; Sepúlveda, 2010: 9; Triadó y Villar, 2008: 13). Niveles parecidos se esperan para el conjunto de la Unión Europea y para el cómputo mundial, calculándose que en 2050 un 5\% de la población de la Tierra superará los 80 años (Corsi y Samek, 2013: 3; Triadó y Villar, 2014: 24).

De esta forma, a medida que avanza el envejecimiento global, la experiencia de la vejez, en el pasado reservada a una parte mínima de la población, se convertirá en la norma (Phillips et al., 2010: 122 y ss.; Troyansky, 2016: xiii). Además, se trata de una vejez feminizada, ya que las mujeres son de media más longevas. Así, en el caso de España, las mujeres mayores de 65 años suponen casi el 10\% de la población nacional, cifra que irá subiendo en las próximas décadas (IMSERSO, 2011: 599). Se trata de una situación que ya se puso de manifiesto en la Conferencia Mundial de las Naciones Unidas del Año Internacional de la Mujer, celebrada en México D.F. en 1995, en la que se subrayó la necesidad de realizar estudios que pusieran de relieve la situación de las mujeres mayores en el mundo (Ramos Toro, 2013: 271).

A pesar de su creciente presencia demográfica, el valor que nuestras sociedades dan a la juventud hace que las personas ancianas sean presentadas como "decorado humano del deterioro" (Puche, 2013: 250). Desde que somos jóvenes, se nos proporcionan mitos sobre la vejez que raramente coinciden con las experiencias reales de las personas viejas; resulta por lo tanto imprescindible examinar la creación de estos mitos y de los estereotipos relacionados con la vejez, tanto en las sociedades presentes como en las pasadas (Vertinsky, 1995: 224-225). Estos estereotipos negativos forman parte de un fenómeno de discriminación hacia la vejez, el llamado "edadismo", el cual convierte al proceso de envejecimiento en un adversario al que hay que impedir cruzar la puerta durante el mayor tiempo posible, haciendo que la sociedad, y especialmente las personas adultas, deshumanicen y marginen a las personas viejas, de forma que la única solución que les resta es tratar de alcanzar una eterna juventud que desde su mismo planteamiento resulta imposible (Achenbaum, 2010: 21; Butler, 1980: 8; Hurd,

\footnotetext{
${ }^{2}$ Del inglés ageism. Hay quienes, como Inmaculada de la Serna (2003: 69), prefieren emplear los términos "gerontofobia" o "gerofobia".
} 
2011: 132). Nadie se imagina su propia ancianidad, e incluso deseamos que ésta no llegue nunca, pero al mismo tiempo pretendemos vivir el mayor tiempo posible. Los signos biológicos de la vejez -arrugas, flacidez de la piel, calvicie, menor tono muscular, pérdida de agilidad...- se ven no como un proceso natural que afecta a todos los humanos por su condición de seres vivos finitos, sino como el resultado de haber tomado malas decisiones en la juventud al no ceder ante la industria anti-edad, con sus productos rejuvenecedores, su cirugía estética y sus interminables sesiones de gimnasio (Hurd, 2011: 2; Rodríguez Ávila, 2006: 21-22). Además, este rechazo cultural se combina con prácticas institucionales que tienden a perpetuar las desigualdades y la imagen de la persona anciana como inservible para la sociedad (Butler, 1980: 8). Así, quien se encuentra en la vejez

"se sitúa frente a una sociedad productivista y consumista (...) afanada en mostrar la vitalidad y la eterna juventud, y que precisamente por los signos que evidencian sus pérdidas le desplaza hacia la periferia, lejos de los modelos que propone, porque no corresponde a la imagen narcisista que esa sociedad tiene de sí. Los estereotipos de la vejez se levantan aún en el imaginario colectivo sobre unas personas mayores que son víctimas del cambio, incapaces intelectuales o seres anticuados" (Rodríguez Alemán, 2011: 1695).

La vejez, deseada pero temida al mismo tiempo por su relación con la muerte, es vista como alteridad, como frontera con el fin de la vida y lo desconocido (Hurd, 1999: 421). Es un hecho que está a la vista de todos pero que se convierte en una especie de secreto vergonzante cuando acontece (Beauvoir, 1996: 1). En palabras de Asunción Bernárdez,

"los ancianos están vivos, pero para el resto del mundo ya no están en este mundo.

Son un afuera, están más allá de la existencia plena. Sin futuro, están en la antesala de la desaparición. Son una forma intermedia, entre lo vivo y lo muerto, entre lo animado y lo inanimado" (Bernárdez, 2009: 33).

Resulta por ello necesario hacer frente al edadismo desde el ámbito académico e investigador, especialmente al sufrido por las mujeres, ya que son éstas las que en la actualidad y en la época que estudia esta Tesis tienen/tenían más posibilidades de vivir una vejez emprobrecida y marginal, debido a que la pérdida de belleza y fertilidad suponen para ellas la desaparición de las características por las que son valoradas en la sociedad (Hurd, 1999: 422; Olson, 1988; Phillips et al., 2010: 217 y ss.; Rippier, 1997: $1)$. 
Esta feminización de la vejez justifica también la elección de las vetulae como sujeto de estudio. Cumplimos así con la necesidad de analizar cómo interactuaban en época romana dos categorías sociales como son género y edad, partiendo de la convicción de que los estudios de género deben ser necesariamente transversales, y no atender sólo a la categoría “mujer”, sino también a cómo se relaciona ésta con otras.

Finalmente, cabe añadir la motivación personal y la atracción que sentimos hacia el tema de investigación escogido, necesarias al abordar una tarea tan ardua como la realización de una Tesis Doctoral. En este sentido suscribimos las palabras de José Carlos Bermejo cuando escribe que

"el conocimiento histórico lleva en sí algo de obscenidad, porque sirve para proyectar una serie de pasiones que el historiador se niega sistemáticamente a sacar a la luz y a las que esconde tras la cortina de humo de la racionalidad implícita en la crítica del documento" (Bermejo, 2009: 97).

En nuestro caso, a la militancia feminista se unió el descubrimiento, gracias a algunas clases de licenciatura y a las subsiguientes lecturas e investigaciones propias, de cómo las experiencias de las mujeres pasadas habían sido ignoradas por la mayoría de historiadores. Tal y como señala Amy Richlin (2013: 294), quienes se dedican al quehacer historiográfico escriben la historia que necesitan; es decir, no sólo aquella con la que sienten más cercanía, sino también la que desean mostrar a la sociedad. Y, en un mundo donde las mujeres aún sentimos que somos discriminadas e invisibilizadas en tantos ámbitos, necesitamos rescatar a nuestras antepasadas del olvido.

\section{OBJETIVOS Y ESTRUCTURA}

Planteados aquellos aspectos que justifican la realización de la investigación que culmina en nuestra Tesis Doctoral, pasamos a detallar los objetivos y estructura de la misma.

La presente investigación aborda la vejez femenina en la antigua Roma desde las cuatro dimensiones propuestas por la Sociología Gerontológica para el estudio del ciclo vital: cronológica, física, psicológica y social. Para acomodar estas categorías a nuestra investigación, hemos dividido la dimensión psicológica en dos: la parte relativa a las patologías mentales la hemos incluido en la dimensión física, por considerarla propia de la medicina, mientras que le hemos dedicado un apartado individual a la edad sentida, aquella que hace referencia a los sentimienos de las personas ancianas. Emplear esta 
estrategia permite acercarse a las vetulae desde diversos ángulos: como entres individuales, como parte de un grupo concreto -el de las mujeres viejas en Roma-, como mujeres romanas, y como parte de la sociedad romana en general. Así, vemos cómo la vejez femenina fue vivida en la antigua Roma de muy diversas formas, dependientes de la situación personal de cada mujer, pero también de tres condicionantes sociales: género, edad y clase.

Para llevar a cabo nuestro propósito hemos empleado cuatro tipos distintos de fuentes: literarias, epigráficas, iconográficas y óseas. Abarcan un periodo cronológico amplio, entre los siglos VIII a.C. y VII d.C., -aunque la mayoría están fechadas entre los siglos III a.C. y III d.C.- ya que, como señala Tim Parkin (2003: 8), la naturaleza de los testimonios que poseemos acerca de la ancianidad en la Antigüedad impide por el momento hacer una historia de la vejez en base a una estructura cronológica. Preguntando a las fuentes hemos podido cumplir con los siguientes objetivos:

- Analizar las diversas divisiones del ciclo vital propuestas en la Roma antigua, constatando cómo éstas estaban condicionadas por el género.

- Poner el foco en la vejez como etapa vital, y determinar cuáles eran las características que las romanas debían cumplir para ser consideradas vetulae.

- Analizar la concepción médica y social del cuerpo femenino envejecido, presentando un catálogo de las diversas condiciones médicas asociadas con la vejez y abordando cómo la literatura y el arte han tratado el aspecto físico de las ancianas.

- Observar los diversos roles que una vetula podía ocupar en la sociedad romana, tanto en el ámbito familiar como en el económico.

- Presentar diversos estereotipos de vejez femenina y cómo éstos se relacionan entre sí creando la figura de la anciana sabia, revestida de autoridad pero al mismo tiempo peligrosa por su relación con la magia y los ambientes marginales y eminentemente femeninos en los que actúa.

- Realizar un acercamiento preliminar a las emociones de la vejez y a cómo las vetulae se sentían con respecto a su ancianidad.

En cuanto a la estructura de la Tesis, ésta se compone de seis apartados principales. El primero de ellos corresponde a la presente introducción, y el último a las conclusiones. Los otros cuatro apartados constituyen el cuerpo del escrito, en el cual se desarrollan los objetivos planteados. 
En el Capítulo I exponemos los presupuestos teórico-metodológicos que han guiado la elaboración de esta investigación. Comenzamos señalando los criterios empleados para escoger a las mujeres que forman parte de nuestra Tesis y presentando un estado de la cuestión acerca de los estudios sobre la vejez en la Antigüedad, especialmente aquellos que mencionan a vetulae. A continuación hacemos referencia a los dos pilares metodológicos sobre los que nos hemos apoyado, la Historia de las Mujeres y de las Relaciones de Género y la Gerontología Feminista. El capitulo se cierra con una exposición de los distintos tipos de fuentes empleadas en nuestra investigación.

En el Capítulo II, «Envejecimiento y vejez en Roma», planteamos las dificultades de llevar a cabo una investigación acerca de la vejez pasada y abordamos la presencia demográfica de la ancianidad en Roma. Presentamos las cuatro dimensiones desde las que vamos a observar a las vetulae y hacemos referencia a la relación entre vejez y muerte.

En el Capítulo III, «Dimensiones cronológica y física de la vejez femenina en Roma», exponemos las dos primeras dimensiones desde las que hemos abordado la ancianidad de las romanas. Hacemos referencia a las diferencias entre el ciclo vital femenino y el masculino, a las características médicas y visuales del cuerpo envejecido y a la sexualidad de las vetulae.

En el Capítulo IV, «Dimensión social y edad sentida de la vejez femenina en Roma», analizamos las dos dimensiones restantes. Comenzamos haciendo referencia a los roles que una vetula podía ocupar en la familia romana y a cómo éstos estaban marcados por la vejez. A continuación observamos los diferentes papeles que las vetulae desempeñaron en la economía de su época. En el tercer apartado de este capítulo presentamos diversos estereotipos de vetula: anus ebria, bruja, lena, contadora de historias y mujer bondadosa. Finalmente, nos apoyamos en la Historia de las Emociones para conocer cómo se sentían las romanas siendo viejas.

A lo ya señalado se añaden el apéndice bibliográfico y los índices de abreviaturas, autores y nombres, así como tres anexos. En dos de los anexos se muestran las tablas y figuras a las que se hace referencia a lo largo del texto, mientras que en el otro aparecen recogidas todas las vetulae mencionadas. 


\title{
CAPÍTULO I \\ PRESUPUESTOS TEÓRICO-METODOLÓGICOS
}

\begin{abstract}
"We have systematically denigrated old women, kept them out the mainstream of productive life, judged them primarily in terms of failing capacities and functions, and found them pitiful. We have put old women in nursing homes with absolutely no intellectual stimulation, isolated from human warmth and nurturing contact, then condemned them for their senility. We have impoverished, disrespected, and disregarded old women, and then dismissed them as inconsequential and uninteresting. We have made old women invisible so that we do not have to confront our patriarchal myths about what makes life valuable or dying painful"
\end{abstract}

Dianne Garner (2013: 3)

"And yet, with all of our listening, we must hear the silences too. It is the voices of women that are missing, almost without exception. We lack their perception on what it was like to grow old"

Stephen Bertman (1989: 169)

En este primer capítulo se exponen las bases teóricas y metodológicas que han guiado nuestra investigación. Comenzamos definiendo el objeto de nuestro estudio, la vetula, y realizando un repaso por la historiografía existente sobre la misma, centrándonos en la Antigüedad. A continuación desarrollamos los pilares metodológicos en base a los que hemos construido esta Tesis Doctoral: la Historia de las Mujeres y de las Relaciones de Género y la Gerontología Feminista, y hacemos referencia a su aplicación a nuestra investigación. Finalmente, el capítulo se cierra con una descripción de las fuentes consultadas y la problemática relacionada con cada una de ellas. 


\section{I.1. LA VETULA COMO SUJETO HISTÓRICO}

\section{I.1.1. Definiendo el sujeto de estudio}

Abordar una investigación como la que aquí se presenta, la cual gira en torno a un sujeto histórico al que apenas se ha dado visibilidad, requiere comenzar por definir y acotar el mismo. Así pues, una de las primeras preguntas que nos hicimos al comenzar con nuestra Tesis Doctoral, a partir de la cual fueron surgiendo las siguientes, fue: ¿quiénes son las vetulae? En este apartado pretendemos dar respuesta a dicha pregunta y exponer los criterios que hemos seguido para seleccionar a las mujeres que forman parte de nuestra investigación.

Definimos vetula como mujer vieja de la antigua Roma. A pesar de que en las fuentes de época romana encontramos diversos sinónimos de la palabra vetula, como anus -proveniente según Festo (1) del gran número de años de estas mujeres-, anicula diminutivo del anterior- o casca -término de origen sabino (Var. L. 7.28)-, hemos decidido usar la primera debido a que es la palabra que con más frecuencia se emplea a partir de época imperial para referirse a las ancianas (Pascual, 2015: 27). Además, nos parece el vocablo más cercano al español actual "vieja” y, al igual que éste, sirve para designar tanto a los seres vivos como a los objetos. No ocurre lo mismo en el caso masculino, donde existiría una mayor distinción entre los términos senex (empleado solamente para el anciano), vetulus (referido a los animales y las plantas) y vetus (para los objetos) (López Pulido, 2008: 7). Una distinción parecida habría, quizás, en los momentos anteriores a la generalización de vetula como definitoria de la vejez femenina, ya que anus en un principio sólo se refería a las mujeres de avanzada edad y no se aplicaba ni a otros seres vivos ni a objetos (Pascual, 2015).

Todas las palabras empleadas para designar a la anciana romana están revestidas, en mayor o menor grado, de un simbolismo negativo que resalta la debilidad, la miseria o la comicidad de la mujer a la que se alude, y los sentimientos que ésta genera en la sociedad (Botelho, 2014a). Además, sinónimos como anus y su diminutivo anicula aparecen especialmente asociados a estereotipos denigratorios, como el de la vieja borracha o anus ebria, el de la prostituta envejecida, y el de la anciana esclava (Migdal, 2014: 57; Pascual, 2015).

Para decidir a qué mujeres consideramos como vetulae, hemos recurrido a varios criterios. El primero de ellos, cronológico, define como vetulae a todas las mujeres 
mayores de 50 años. La elección de esta cifra se relaciona con la menopausia como hito fundamental en el envejecimiento de las mujeres, así como con diversas leyes acerca del matrimonio y la fertilidad, y se justifica en el Capítulo III.

El segundo criterio se basa en apreciaciones subjetivas, tanto las nuestras, en lo tocante a las fuentes iconográficas, entre las cuales hemos seleccionado aquellas representaciones que mostraban rasgos estéticos propios de la vejez -arrugas, piel flácida, falta de piezas dentarias, etc.-, como las de los autores de las fuentes literarias consultadas, hagan éstos referencia a la edad, al aspecto físico, o a cualquier otro atributo; es decir, que consideraremos vetulae a todas aquellas mujeres que las fuentes clasifiquen como tales.

Finalmente el tercer criterio toma como base la organización familiar y la posición generacional. Así, teniendo en cuenta que las romanas solían casarse unos años antes de llegar a la veintena (D’Ambra, 2007: 76; Laes, 2015: 105; Scheidel, 2007; Treggiari, 1991: 399 y ss.), y siguiendo ciertos cálculos demográficos a los que nos referiremos con detalle en los Capítulos II y III, consideramos vetulae a aquellas mujeres presentadas en las fuentes como abuelas y bisabuelas, así como madres y tías de personas adultas.

Somos conscientes de que este último criterio debe tomarse con precaución, ya que las personas no rigen sus vidas de acuerdo a las estadísticas. Jo-Ann Shelton (2013: 236) calcula que una romana podía ser abuela a los 34 años. Por su parte, Tim Parkin (2003: 52) cree que era probable que una romana tuviese su primer nieto antes de cumplir 40 años, pero llama la atención sobre no considerar esta posibilidad como la norma. Esta edad es respaldada por Christian Laes (2015: 105), quien sin embargo señala, basándose en los datos demográficos obtenidos por Richard Saller (1994: 4950), que la media de edad de una abuela materna cuando sus nietos habían cumplido 10 años era de 61,2 años; 67,5 en el caso de la abuela paterna.

Por otra parte, nos mostramos de acuerdo con Richard Saller, quien en su conocido estudio acerca de la demografía romana llamaba la atención sobre lo impredecible de calcular los ritmos de matrimonio, nacimiento y muerte, y sobre la necesidad de distinguir "between the normative order of Roman culture and the diffuse experiences and individual choices of daily social life" (Saller, 1994: xi). Por ello hemos intentado combinar siempre que ha sido posible los datos cronológicos con otros relativos al rol familiar y social de las romanas, tal y como proponen Mary Harlow y 
Ray Laurence (2002: 2). No en vano, y como señala Marta González para el caso griego, "parece como si el tiempo de los varones pudiera ser considerado de manera absoluta y el de las mujeres sólo en términos relativos" (González González, 2015: 187); o, lo que es lo mismo, que el de los hombres se mide según las etapas de la vida pública, cronológicamente reguladas, y el de las mujeres de acuerdo a su ciclo biológico (Torrego, 2014: 210), lo que hace difícil precisar los términos de una etapa vital que carecía de ritos de paso concretos, tal y como el matrimonio marcaba el paso de puella a matrona.

Por otro lado, Mary Harlow y Ray Laurence (2011: 4) han propuesto, siguiendo criterios asociados a los ritmos de matrimonio en la sociedad romana, que puesto que las romanas de la élite solían emparejarse con hombres de 8 a 10 años mayores que ellas, serían consideradas vetulae cuando sus maridos lo fueran como senes y por lo tanto cronológicamente antes que los hombres, ya que su identidad social y estilo de vida dependían de las de sus esposos. Creemos que esta asunción entraña algunos riesgos, pues si bien podría ser válida en el caso de romanas que rondaran los 50 años cuando sus maridos alcanzaban los 60 , y se ha postulado que los segundos y terceros matrimonios tenderían a igualar la edad de los contrayentes (Hemelrijk, 1999: 11), podemos enfrentarnos a casos en los que la diferencia de edad de la pareja era tan grande que difícilmente esas mujeres serían vistas como vetulae a pesar de que estuvieran casadas con ancianos ${ }^{3}$.

\section{I.1.2. La vetula en la historiografía sobre la Antigüedad}

Las vetulae, y en general todas las personas viejas, en cuanto que parte de las sociedades del pasado, han sido un objeto de estudio tardío en el quehacer historiográfico. Ello ha provocado que las investigaciones históricas nos den a conocer de los generales y políticos romanos las circunstancias de su nacimiento, el entorno y la familia en la que crecieron, su matrimonio, y sus hazañas políticas y militares, y desde ahí describan directamente el momento de su muerte, pasando por alto los a veces no pocos años entre medias ${ }^{4}$. Del mismo modo, en el caso de las romanas, conocemos de ellas su familia de origen, su matrimonio y su descendencia, pero en múltiples ocasiones desaparecen del plano historiográfico tras dar a luz o casarse por última vez.

\footnotetext{
${ }^{3}$ Es el caso, entre otros, de los matrimonio entre Catón (80) y Salonia (una adolescente) (Plut. Cat. Mai. 24) y de Cicerón (60-61) y Publilia (14-15) (Cass. Dio 46.18; Plut. Cic. 41) (Gray-Fow, 1988: 747; Treggiari, 2007: 134).

${ }^{4}$ Una reciente excepción la encontramos en Harlow y Laurence, 2017.
} 
Además, tal y como señalan Lynn Botelho y Pat Thane (2014a: 2-4), por muchas características que compartan los estudios sobre la edad y sobre las mujeres en las sociedades pasadas, ya que ambos han tenido que empezar desde cero creando nuevos marcos metodológicos y tienen como protagonistas a otros sujetos que no son el varón adulto de la élite, parece como si la historiografía sobre la vejez se mostrara recelosa por incluir la perspectiva de género en sus investigaciones. Se trata de una reticencia que también se aprecia en los estudios de género y que como señala Clary Krekula (2007) se debe a tres factores principales: la selección que éstos han hecho de ciertos temas, el monopolio de la mujer adulta como objeto de estudio -debido a la idea de que era necesaria una identidad colectiva que pusiera el énfasis en las similitudes entre mujeres para crear un sujeto político fuerte- y la falta de conceptualización y problematización de la edad como categoría social.

De entre los trabajos que abordan la vejez de forma global, incluyendo la dimensión histórica, uno de los más relevantes es La vejez de Simone de Beauvoir, escrito en $1970^{5}$. En esta obra se hace referencia a las vetulae, aunque sólo en lo que respecta a los estereotipos negativos, y se tratan algunos de los temas que son objeto de la presente Tesis Doctoral, como las representaciones del cuerpo de la mujer envejecida, su papel en la sociedad una vez llegada la menopausia, y las diferencias de género relacionadas con el proceso de envejecer.

En 1977 el historiador Peter Laslett publicó un libro acerca de la familia que incluía un capítulo dedicado a la historia del envejecimiento y la vejez. En él abogaba por la necesidad de estudiar la vejez en contexto histórico y resaltaba la importancia de la familia como espacio de socialización de las personas ancianas. También trataba de establecer la proporción de la población anciana en las sociedades preindustriales, aunque en este caso se centraba en las épocas moderna y contemporánea. En este capítulo Peter Laslett reflexionaba sobre algunas cuestiones que en nuestro caso se contemplarán en el Capítulo IV, como la relación de las viudas con sus familias o el conflicto generacional.

Otra obra que proporciona una visión general de la ancianidad en la Historia es Historia de la Vejez, escrita por Georges Minois (1987). En ella se abordan los cambios sufridos en la conceptualización de esta etapa vital a lo largo del tiempo y se subraya la

\footnotetext{
${ }^{5}$ Para nuestra investigación hemos empleado una edición en inglés de 1996.
} 
dificultad de definir qué es la vejez en perspectiva histórica. Si bien este libro es considerado de referencia por toda la historiografía interesada en la vejez de las sociedades del pasado, no está exento de críticas, y ha sido tachado de un excesivo simplismo y de no interpretar las fuentes que emplea (Wiedemann, 1996: 275). En lo que a nuestra investigación respecta, las pocas ocasiones en las que Georges Minois hace referencia explícita a figura de la anciana se limita a describir las fuentes literarias existentes sin profundizar en su significado, aunque sí que señala que el género es un factor social que condiciona la vejez. Por otro lado, si bien llama la atención sobre la necesidad de considerar la edad como una categoría social, él mismo cae en tópicos edadistas (Minois, 1987: 14).

Otras investigaciones con contextos cronológicos amplios que también analizan la ancianidad de las mujeres son Life, death, and the elderly, editada por Margaret Pelling y Richard Smith (1991), Old Age from Antiquity to Post-Modernity, editada por Paul Johnson (1998), o un artículo en el que Patricia Vertinsky (1995) explora la relación entre la vejez femenina y el deporte.

Por otro lado, parece que en la última década se está viviendo, tal y como auguraba hace más de 30 años Philippe Ariès (Benoit-Lapierre, 1983: 64), un importante incremento de la producción historiográfica sobre la vejez. Tanto desde el campo de los Ageing Studies como desde la historiografía se está dando un impulso a estos estudios mediante la celebración de congresos y la creación de revistas especializadas como Journal of Women \& Aging, International Journal of Ageing and Later Life, Journal of Aging Studies, o Age, Culture, Humanities, las cuales se unen a la pionera The Gerontologist e incluyen los estudios de género dentro de sus perspectivas.

Sin embargo, desde la Historia de las Mujeres y la academia feminista el despegue está siendo más lento. Ello se debe en parte, como señalan Margaret Pelling y Richard Smith (1991: 10), a que la historiografía feminista ha priorizado en sus estudios las etapas de la vida asociadas a la reproducción. Cuando ha demostrado interés por la vejez, normalmente en trabajos acerca de la figura de la bruja, ha sido para declarar la marginalidad de las ancianas dentro de las sociedades en las que vivieron.

A la ausencia de obras que traten la vejez femenina desde una perspectiva global e integradora, superando el análisis de estereotipos o de una obra o género literario concretos, se le une la falta de espacios propios de discusión, debate y difusión de los resultados de las investigaciones, especialmente en el caso hispanoparlante. Se trata de 
un fenómeno al que Patricia Vertinsky (1995: 225) se refiere como "invisibilidad selectiva", el cual afecta a la herencia histórica sobre la mujer, sobre todo si tenemos en cuenta que las ancianas son la minoría que más rápidamente está creciendo en las sociedades occidentales.

En lo que respecta a obras centradas en la Antigüedad, el interés por la vejez como objeto de estudio arrancó en la década de 1980 y se ha ceñido casi por completo a los ámbitos francés y anglosajón. Encontramos algunas producciones tempranas, como las obras pioneras de Bessie Richardson (1933) sobre la vejez en Grecia y Louis Berelson (1934) en Roma, esta última inédita, así como trabajos que se acercan a la vejez desde los diversos géneros literarios de la Antigüedad (Chandler, 1948a y 1948b; Coleman-Norton, 1947; Haynes, 1963), o en relación con las esculturas que representan a personas envejecidas, normalmente del tipo anus ebria (Waldhauer, 1946).

Por otro lado, y si bien no se trata de obras que abordan de forma directa la ancianidad antigua, estudios como el de Andrew Burn (1953), el cual se interesaba por la esperanza media de vida y la longevidad en época imperial romana, abrieron el camino hacia las investigaciones de corte demográfico, entre cuyos objetivos está dilucidar cuántos años podía vivir alguien en la antigua Roma. Inspirado en los estudios demográficos, Wieslaw Suder (1978) rastreó las fuentes literarias para establecer las diferentes divisiones del ciclo vital expuestas por los autores antiguos, señalando que

"the question of how to divide people according to their age in a defined society and culture has an important significance for the determination of and for getting acquainted with the structure of the investigated population and indirectly it is also a source of information about mortality, the duration of life or persons at the threshold of their old age" (Suder, 1978: 5).

Ya en las últimas décadas del siglo XX destacan un artículo de Moses Finley $(1989)^{6}$ en el cual se plantea cómo se definía la vejez en Grecia y Roma, y las publicaciones de Simon Byl (1988a, 1988b, 2001 y 2003), quien pone el foco en aspectos médicos. Debemos incluir también las obras de Darrel Amundsen y Carol Diers (1970), y ésta última en solitario (Diers, 1974) sobre la menopausia en la Antigüedad, así como un artículo en el que Thomas Wiedemann (1996) se interroga

\footnotetext{
${ }^{6}$ La versión que aquí se emplea proviene de Falkner y Luce, 1989; no obstante, el artículo fue publicado por primera vez en el número 28:2 de la revista Greece \& Rome en 1981 (pp. 156-171).
} 
acerca de cómo vivían la vejez los esclavos, único trabajo centrado en esta temática hasta la actualidad.

Debemos tener en cuenta, por otro lado, obras colectivas como la de Thomas Falkner y Judith de Luce, Old Age in Greek and Latin Literature (1989), y Senectus 1995), editada por Umberto Mattioli, las cuales tratan las representaciones de la vejez antigua en diversos géneros literarios o autores clásicos.

El comienzo del siglo XXI ha dado varias obras destacables consagradas a la vejez romana. En primer lugar contamos con Tim Parkin, profesor de la Universidad de Manchester que puede considerarse uno de los pocos expertos en este tema, quien defendió en 1992 una Tesis Doctoral centrada en las dimensiones demográficas y legales de la vejez romana y que ha publicado varios artículos de referencia (Parkin, 1998, 1999 y 2001). Fruto de la mencionada Tesis es el libro Old Age in the Roman World (2003), un estudio completo que aborda diversos aspectos de la vejez romana pero en el que las vetulae y la perspectiva de género ocupan un papel secundario, debido según el autor a que las fuentes son insuficientes (Parkin, 2003: 11).

Otra Tesis Doctoral, en este caso de 2001, que se ha convertido en obra de referencia es Experiencig Old Age in Ancient Rome de Karen Cokayne (2003). Esta monografía, que trata la vejez romana desde tres puntos de vista (el físico, el intelectual y el emocional), se centra como en el caso anterior en los senes. Se trata de un estudio que presenta un punto de partida novedoso, ya que intenta acercarse a la vejez sentida en Roma, pero que por otro lado ha sido definido como superficial y simplista por su tendencia a comparar la época romana con la actualidad, y criticado por hacer un escaso uso de las fuentes clásicas (Gourevitch, 2004; Laes, 2005).

Un año más tarde que los dos libros mencionados, Marie-Thérèse Fontanille publicaba Vieillir à Rome (2004), un trabajo que trata de acercarse a la vejez romana desde el punto de vista demográfico, recurriendo a los textos de Plinio el Viejo y Flegón de Trales acerca del censo de los años 73-74 d.C. A pesar de lo valioso de su análisis de los fragmentos de ambos autores, una buena parte del libro se dedica a abordar cuestiones que nada tienen que ver con la demografía, sin aplicar además el suficiente análisis crítico, y su bibliografía se reduce casi por completo al ámbito francés, obviando algunas obras clave para el estudio de la vejez romana.

Cabe señalar también, tanto en sus trabajos individuales como conjuntos, a Mary Harlow y Ray Laurence (2002, 2007, 2011 y 2015), quienes tratan la vejez romana 
como parte del ciclo vital antiguo. Si bien en la introducción a la monografía colectiva Age and Ageing in the Roman Empire (Harlow y Laurence, 2007) ambos autores señalan que la vejez ha sido ampliamente estudiada y es hora de dar un paso más allá y analizarla como parte del ciclo vital, la superficialidad de algunos de los capítulos de la obra, ya señalada por Emma-Jayne Graham (2008), así como el que diez años después de su publicación aún no se haya dedicado ninguna monografía a estudiar en profundidad la vejez de las romanas y de la población esclava, entre otros sujetos ancianos, nos hace desestimar esta afirmación.

En lo que respecta a las obras en lengua castellana, Lourdes Pérez (2003: 9) ha resaltado el escaso interés que la historiografía ha mostrado por la vejez en todas las etapas históricas, incluida la Antigüedad. Entre las pocas investigaciones existentes, al igual que hemos señalado que ocurre en el resto de países, muchos trabajos se centran en analizar la perspectiva que de esta etapa de la vida dan diversos autores clásicos como Tibulo (García Leal, 1984), Cicerón (López Pulido, 2013) u Horacio (Paulin, 2011; Suárez Martínez, 1994), o bien géneros literarios concretos (Arcaz, 2012; Díez y Palacios, 2011; López Moreda, 2003).

Como ejemplo de obra de carácter más global contamos con el libro de Alfonso López La ancianidad en la Antigüedad clásica (2015), dedicado a la dimensión médica y corporal de la vejez en Grecia y Roma, el cual carece de perspectiva de género y apenas menciona a las vetulae. Este mismo autor ha dedicado varios artículos a la vejez romana, los cuales hacen un repaso superficial por las fuentes disponibles, en especial la obra ciceroniana (López Pulido, 2008 y 2013).

Una interpretación más profunda de la vejez en Roma y un análisis de los estereotipos negativos ligados a ella los encontramos en Juan Cascajero (2000), quien hace casi dos décadas ya llamaba la atención sobre la importancia de estudiar la ancianidad y la edad como concepto social a la hora de abordar las condiciones de existencia de las personas en la Antigüedad (Cascajero, 2000: 4).

Destaca también la obra colectiva Las edades de las mujeres (2002), editada por Pilar Pérez y Margarita Sánchez, en algunos de cuyos capítulos se aborda el estudio de la vejez femenina antigua. Es el caso de los trabajos de Dolores Mirón sobre la relación entre las niñas y las ancianas en Olimpia, de María José Hidalgo acerca de los ciclos vitales de las mujeres de la dinastía Antonina, y de Elisa Garrido sobre la relación entre la mujer romana y la muerte. 
A las vetulae en exclusiva han dedicado sendos artículos Elisa Garrido (2013) y Sara Paulin (2011). La primera presenta una imagen global de la vejez femenina en Roma en clave de género, mientras que la segunda aborda el estereotipo de vetula que practica la brujería. Dicho estereotipo ha sido también analizado por María José Hidalgo (2008), quien llama la atención sobre la marginalidad de la anciana como respuesta a la fobia social que ésta genera, a la cual la vetula se opone mediante la magia.

Así, vemos cómo las vetulae aparecen en obras dedicadas a la vejez en general, a la mujer romana o a la familia (Allason-Jones, 1989; Cascajero, 2000; Cokayne, 2003; Cotoner, 2007: 260; Dixon, 1992; Hidalgo, 1994; Huebner, 2013; Iacub, 2004; Laurence, 2005; Olson, 2008; Parkin, 1999, 2003 y 2011c; Pudsey, 2012; Richlin, 1984 y 1992; Shelton, 2013; Spaeth, 2014; Stratton, 2007), ocupando en muchas ocasiones papeles secundarios. Son obras que se centran en las fuentes literarias, siendo escasos los trabajos que ponen el foco en la epigrafía, el arte, o los materiales de procedencia arqueológica (Dimartino, 2008; Cano, 2012; Fuchs, 2008; Gowland, 2016; Kampmann, 2015; Matheson, 2000; Prowse, 2011; Sande, 1995). Nos encontramos, por otro lado, con más compilaciones o artículos que con libros unitarios, lo que pone de manifiesto la dificultad de abordar el análisis de la vejez antigua, más allá del estudio de caso (Otero, 2013: 101, nota 26).

Además, entre los trabajos que tratan la vejez romana algunos (Dyson, 1992; Finley, 1989; García Leal, 1984; Kebric, 1983; López Pulido, 2008 y 2013; Suder, 1995) se refieren implícitamente sólo al senex, tomando como universal la experiencia masculina y asumiendo, bien que ésta es válida para definir la vejez femenina, bien que las vetulae no son sujetos históricos a tener en cuenta. Una positiva excepción la encontramos en The Ancient Art of Growing Old de Tom Payne (2015), obra que a pesar de tomar como eje central del texto la perspectiva de Cicerón se esfuerza por resaltar la masculinidad y el elitismo de la misma.

A esto hay que añadir, tal y como señala Beate Wagner-Hasel (2011: 3), que muchos de los trabajos relativos a las vetulae (Cano, 2012; Clemeau, 1989; Cotoner, 2007; Parkin, 2003; Serrano y Baena, 1982; Suárez Martínez, 1994), ya sea como sujeto principal o secundario, tienden a tratarlas con un tono eminentemente negativo, ciñéndose a plasmar los estereotipos de la bruja o la anus ebria, los cuales además no suelen interpretar dentro del contexto de la sociedad patriarcal romana. A ellos se unen otras obras (Acerbi, 2013; Cabezas, 2003; Carbajo, 2008; Garrido 2011; Graverini, 
2006; Sepúlveda, 2010) que abordan la vejez de forma generalista, repitiendo tópicos que no analizan y sin hacer distinción alguna, ya sea atendiendo al género o el estatus.

No obstante, encontramos algunas excepciones (Gentile, 2009; Gowland, 2016; Graverini, 2006; Hallett, 1992; Harlow y Laurence, 2011; Harris, 2000; Huebner, 2013; Iriarte y Ferreira, 2015; Luce, 1993; Mencacci, 2006; Myers, 1996; Parkin, 2001; Prowse, 2011; Pugliarello, 2002; Suárez, 2003) en las que la vejez antigua es tratada en clave de género, atendiendo tanto a la literatura como a las inscripciones, los restos óseos y el arte, aunque algunas de las mismas se declaren estudios preliminares y señalen la necesidad de profundizar en el tema.

El creciente interés por la vejez histórica que viene dándose en la última década, al que ya hemos hecho alusión, se aplica también en el caso de las vetulae, habiendo aumentado los congresos dedicados a la ancianidad antigua ${ }^{7}$ y el número de publicaciones en las que son mencionadas (Díez y Palacios, 2011; Garrido, 2011 y 2013; Hidalgo, 2011; Laes, 2015; LaFosse, 2011; Manchón, 2015; Migdal, 2014; Mustakallio, 2011; Nasta, 2011; Pascual, 2015; Paulin, 2011; Wagner-Hasel, 2011). Se trata de investigaciones centradas en figuras concretas, como las de Veturia y Pudentila, o que analizan estereotipos ligados a la vejez y los significados que éstos tienen en las fuentes literarias.

Por otro lado, creemos que no sólo es necesario dar protagonismo a la vejez femenina en el ámbito académico, sino que también debemos analizar su presencia en las recreaciones museísticas, didácticas y lúdicas del Pasado, de forma que podamos transmitir a los consumidores de las mismas la diversidad existente en las sociedades pasadas.

\section{I.2. GÉNERO, HiSTORIA Y GERONTOLOGÍA FEMINISTA}

En el apartado que a continuación abordamos se exponen cuáles han sido los criterios teórico-metodológicos que han guiado la realización de nuestra investigación.

\footnotetext{
${ }^{7}$ Sirvan de muestra las V Jornadas de Estudios Clásicos y Medievales: Juventud y vejez en la Antigüedad y el Medioevo, llevadas a cabo en octubre de 2011 en la Universidad Nacional de la Plata (Argentina), el congreso "The Elders are Twice Children": Aging in Ancient Thinking celebrado en la University of Montreal (Canadá) en junio de 2017, la VIII Arachne Conference: Ages, Ageing and Old Age in the Greco-Roman World que tuvo lugar en octubre del mismo año en la University of Gothenburg (Suecia), y el IV Seminario Internacional Grupo Deméter: familias, edades y género, celebrado en Oviedo en noviembre de 2017.
} 
Hemos definido ya cuál es el sujeto principal de la Tesis Doctoral, y desgranamos ahora las herramientas conceptuales mediante las que nos hemos acercado a las vetulae y hemos interpretado las fuentes que se refieren a ellas.

\section{I.2.1. Mujeres, Género e Historia}

Hace décadas que las mujeres se convirtieron en sujeto de pleno derecho en los estudios historiográficos ${ }^{8}$. Ello permitió ampliar los puntos de vista desde los que observar el pasado, rompiendo con la idea, implícita en los trabajos historiográficos anteriores, de que el varón de la élite era el único protagonista de la Historia, la cual se articulaba sobre la concepción de los modelos masculinos como referentes simbólicos universales (Juliano, 2008: 20). Devolver su espacio a las mujeres invisibilizadas hizo que la historiografía se adentrase en "un nuevo orden de conocimiento del que surgen enunciados y prácticas metodológicas desconocidas, nuevos temas y registros sobre la evolución histórica de la humanidad" (Ramos Palomo, 2003: 32), recuperando discursos alternativos y permitiendo rastrear en el pasado la existencia de problemas que persisten en el presente (Cenarro, 2014: 9; Fernández Valencia, 2014: 164 y 2015: 29).

Es precisamente esta preocupación por el presente y su relación con el pasado lo que constituye una de las características principales de la Historia de las Mujeres. Los Women's Studies surgen en parte de la necesidad del movimiento feminista de rastrear las condiciones de las mujeres en todas las esferas del conocimiento, conjugando investigación y acción social ya que, tal y como señala Juan Cascajero (2002: 37), sólo tras ser consciente de haber compartido una específica y diferenciada experiencia histórica podrá el colectivo femenino alcanzar una identidad común como sujeto histórico.

La Historia de las Mujeres y los estudios feministas y de género han calado de tal forma en el ámbito académico ${ }^{9}$, a través de la aparición de revistas especializadas, la

\footnotetext{
${ }^{8}$ Realizar un repaso de la producción historiográfica acerca de las mujeres del pasado, incluso ciñéndonos a la Antigüedad, sobrepasa los marcos de nuestra Tesis. Sobre el tema, vid. Cid (2010 y 2015a), Ramos Palomo (2013), Rodríguez et al. (1994), Rose (2012), Segura Graíño (2006, 2008 y 2015), Smith (2013) y Val et al. (2004).

${ }^{9}$ No sin las correspondientes críticas, algunas provenientes desde dentro de la propia disciplina. Sirva de ejemplo Gloria López, para quien la Historia de las mujeres no es sólo artificial en cuanto que tiene como único objeto a la mujer, sino que además "se ha estudiado al grupo mujeres como si estuviera aislado del resto de la sociedad convirtiéndolo en un colectivo marginado" (López de la Plaza, 1993: 7). Podría incluirse también el monográfico 778 de la revista Arbor, editada por el CSIC, en cuyos artículos (Abad, 2016; Aparisi, 2016; Caballero, 2016 entre otros) se sugiere la poca utilidad que tiene en la actualidad la aplicación de la perspectiva feminista en nuestras investigaciones. Sobre la polémica generada por la
} 
realización de reuniones científicas y la creación de centros e institutos de investigación que, tal y como señala María del Carmen García, "quienes hacemos historia de las mujeres nos encontramos hoy, afortunadamente, abrumadas y abrumados por la constante producción bibliográfica que se genera en cada campo específico" (García Herrero, 2013:28) ${ }^{10}$. En el caso de la época histórica concreta que nos ocupa, coincidimos con Jimena Palacios en que "la vastedad, variedad y calidad académica de las investigaciones en torno a la mujer y las construcciones de lo femenino y lo masculino en la Antiguiedad son prueba suficiente de la validez y pertinencia de las lecturas que adoptan la teoría feminista y la perspectiva de género para el abordaje de los textos clásicos" (Palacios, 2014: 92-93).

No obstante, todavía queda un largo camino por recorrer, de la mano de nuevos desafíos sociales y aspectos del presente cuyos antecedentes y manifestaciones buscamos en el pasado (Cenarro, 2014: 10; Molet y Bernad, 2015). No en vano, Amelia Valcárcel señalaba hace dos décadas que "si hay un movimiento del cual sus componentes anuncian de continuo que no han alcanzado sus objetivos, ése es el feminista” (Valcárcel, 1994: 53). Así por ejemplo Kristina Milnor (2011: 610) cree que la historiografía acerca de las romanas está en muchas ocasiones ligada a hombres relevantes con los que se encuentran relacionadas y a los episodios vitales de éstos, sin dar a estas mujeres la entidad que poseen de forma independiente, mientras que otras autoras como Barbara Gold (2004) y Judith Hallett (2004) insisten en que todavía quedan muchas cuestiones que responder acerca de las condiciones de vida de nuestras antepasadas. Otro asunto pendiente, como señala Cándida Martínez (2017: 20-21), es consolidar los estudios de Historia de las Mujeres en los planes de enseñanza universitaria, ya que en ocasiones parece que las condiciones de las mujeres en las

publicación de este número y las críticas feministas al respecto, vid. Pérez Mendoza (2016) y https://www.change.org/p/presidencia-del-csic-retirada-del-n\%C3\%BAmero-778-de-la-revista-del-csicarbor?recruiter $=596350739 \& u t m \_$source $=$share $\_$petition\&utm $\_$medium=email\&utm campaign=share $\_$e mail responsive

${ }^{10}$ Por otro lado, la producción masiva de trabajos académicos puede jugar en nuestro detrimento. Así, David Cannadine escribe que "the imperatives for regular and rapid production are now so great and so insistent that the overall standard of published output in history is generally thought to be declining, and it is easy to see why. What might, in an earlier era, have been one big important, provocative, groundbreaking article is now salami-sliced into three, to give more impressive evidence of quantity of output" (2008: 6-7). 
sociedades pasadas son susceptibles de ser investigadas pero no dignas de ser enseñadas ${ }^{11}$.

Además, y a pesar de que los trabajos historiográficos relativos a la mujer suelen emplear la categoría "mujer" o "mujeres" en un sentido amplio ${ }^{12}$, coincidimos con Kristen Gentile (2009: 16) en que, si profundizamos un poco, veremos que normalmente se hace referencia a mujeres adultas de la élite, lo que deja fuera, como hemos apuntado en el apartado anterior, a las niñas, las ancianas, las esclavas... La categoría "mujeres" engloba a congéneres, que en virtud de su sexo comparten una misma opresión, pero al mismo tiempo constituyen un grupo heterogéneo en cuanto a las particularidades de cada una de sus integrantes y las diversas estrategias de supervivencia que han desarrollado, las cuales en ocasiones no son tenidas en cuenta (Chaparro, 2002: 71; Martínez, 1995: 44; Palacios, 2015: 37; Scott, 2001: 292).

Precisamente ha sido la poca atención que la historiografía en general, y la centrada en la Antigüedad en particular, han dedicado a la vejez femenina, el factor que ha provocado que hayamos recurrido a la Gerontología Social, y más concretamente a la Gerontología Feminista, en busca de un marco metodológico que nos ayudase a llevar a cabo nuestra investigación. La aplicación del mismo a la Tesis Doctoral se detalla en el siguiente apartado de este capítulo.

En lo que respecta a la presente Tesis Doctoral, emplearemos las palabras "vetula" y su plural "vetulae" para referirnos, en un sentido amplio, a las mujeres clasificadas como tales en virtud a los criterios expuestos en el apartado I.1.1. No queremos con ello expresar que la categoría "vetula" sea estática y homogénea, ya que coincidimos con Domingo Plácido en que "lo femenino, como toda construcción cultural, no constituye un mundo homogéneo, sino más bien heterogéneo, como corresponde a la perspectiva de una sociedad heterogénea, incluso si nos limitamos a las sociedades de Grecia y Roma” (Plácido, 2005: 19), pero al mismo tiempo creemos, como Rosa Cid (2015b: 188), que las diferencias existentes entre unas y otras romanas son compatibles con un modelo estático sobre lo femenino, presente en los discursos romanos, sobre lo que

\footnotetext{
${ }^{11}$ Para Cándida Martínez (2017: 20 y 40-41), los factores que frenan dicha consolidación son varios, como la escasa valoración de las disciplinas humanísticas, el arraigo que aún tienen los valores patriarcales en la sociedad española, o la reducción de horas y asignaturas en los planes docentes.

${ }^{12}$ Sobre lo difícil de definir la categoría "mujeres" y las diferencias entre el empleo de la forma singular y la plural, especialmente en el plano político, vid. Cascajero, 2002: n. 2; Bennett, 2006: 9 y ss.; Butler, 2007: 49; Nicholson, 2003: 74-79; Rivera, 1994: 61 y ss.; Segura Graíño, 2005: 10; Tubert, 2003: 26 y Valcárcel, 1994: 100.
} 
debía hacer y ser la población femenina. De esta forma, y aunque veremos cómo no todas las vetulae reciben el mismo tratamiento en las fuentes, existía en época romana un modelo normativo de vejez femenina que se insertaba dentro de otro modelo general de mujer. Se trata, en definitiva, tal y como señalaba Fernand Braudel (1979: 42-43) en su alegato a favor de la Historia Social, de estudiar al individuo sin perder de vista que forma parte de un conjunto, creando espacios comunes desde las diferencias.

Por otro lado, al modelo de comportamiento femenino existente en la sociedad romana se le añaden en nuestro caso las normas de edad, entendidas como las ideas y expectativas compartidas por los miembros de una cultura acerca de cómo debe comportarse una persona en función de la etapa del ciclo vital en la que se encuentre, las cuales prescriben comportamientos adecuados para cada franja etaria (Morgan y Kunkel, 2016: 92). Así, nos encontraremos con un estereotipo de vetula repulsiva, de sexualidad exacerbada, chismosa, bruja y aficionada a la bebida, que ha llegado prácticamente intacto a nuestros días y que ha servido para mantener las jerarquías de poder en lo relativo al género y la edad. No en vano, como señala Geneviève Fraisse, los estereotipos de género son repeticiones de las cualidades sociales asociadas a lo femenino y lo masculino, las cuales resumen

“en una representación muy gráfica, las atribuciones a las que cada sexo es remitido, psicológicamente, socialmente, como identidades seguras e intangibles.

El estereotipo parece no tener historia, se asemeja más bien a una invariante que se transmite de generación en generación" (Fraisse, 2016: 80).

Es por ello que, como veremos, a pesar de que el estereotipo de vetula no correspondía con la realidad de muchas de las ancianas romanas de las que nos dan noticia las fuentes, se presentaba como una imagen ligada a un orden atemporal y natural.

También haremos alusión a los términos "género", "roles de género" e "identidad de género" entre otros, en cuanto que, si bien las protagonistas de nuestro trabajo son mujeres, vivieron insertas en una sociedad patriarcal donde su género, entendido como la representación social jerarquizada de su sexo biológico, condicionó sus vidas y las fuentes que empleamos para acercarnos a ellas. La palabra "género" se ha mostrado 
como un término fácilmente reconocible pero difícil de definir (Glover y Kaplan, 2000: ix), especialmente en castellano ${ }^{13}$.

Susana Gamba define el género como "una categoría transdisciplinaria que desarrolla un enfoque globalizador y remite a los rasgos y funciones psicológicos y socioculturales que se atribuye a cada uno de los sexos en cada momento histórico y en cada sociedad" (Gamba, 2007: 119). Para Geneviève Fraisse es un concepto que permite examinar al ser sexuado en general y a los dos sexos en particular, y a éstos en la sociedad, siendo el mismo tiempo "una proposición filosófica (pensar el sexo y los sexos) y un instrumento, el medio de poner en práctica dicha proposición (hacer visible, mostrar)" (Fraisse, 2016: 48). Por su parte, Judith Butler escribió que el género es "los significados culturales que acepta el cuerpo sexuado" (Butler, 2007: 54). Nos encontramos, en definitiva, con que se trata de una categoría que nos permite analizar los significados culturales de lo masculino y lo femenino, y la forma en la que éstos afectan a las vidas de sujetos concretos.

Hay quienes por otro lado ven "género" como un sinónimo de "sexo", de "mujer", o incluso de "patriarcado" (Falcón, 2000: 255 y ss.; Sanahuja, 2005). A pesar de que se trate de términos que mantienen una estrecha relación entre sí, a lo largo de nuestro trabajo no los emplearemos como palabras intercambiables, ya que creemos que al hacerlo no tendríamos en cuenta los matices de cada una de ellas, lo que conlleva una reducción de la perspectiva y deja vacío el significado de "género" (Fraisse, 2016: 50 y ss.; Molina, 2003: 124; Morant, 2016: 20; Papí, 2003: 142; Tubert, 2003: 7$)^{14}$.

El uso de la categoría "género" ha recibido diversas críticas, en cuanto que se trata de un término demasiado amplio ${ }^{15}$ y que en ocasiones es empleado fuera de los Women's Studies para referirse a la discriminación sufrida por las mujeres de forma políticamente correcta (Escoriza, 2008: 40-42; Palomar, 2015: 21; Rose, 2012: 48; Sanahuja, 2005: 89; Tubert, 2003). Cándida Martínez escribe que, a pesar de la utilidad que tiene para la investigación,

"la noción de género, acuñada como herramienta feminista para visibilizar una estructura de dominación, se está extendiendo como sinónimo de mujeres o

\footnotetext{
${ }^{13}$ Para las dificultades de asumir la traducción del inglés gender en algunos idiomas, vid. Campillo, 2003: 89 y ss. y Fraisse, 2003.

${ }^{14}$ Sobre los distintos matices de la categoría "género" y su diferencia con "sexo", y la utilidad que esta distinción tiene para la práctica historiográfica, vid. Lapi y Sarkis, 2008: 113 y ss. y Rose, 2012: 48 y ss.

${ }^{15}$ Para un repaso por todas las formas en las que es empleado el término, vid. Palomar, 2015: 20.
} 
feminismo, dando lugar a malentendidos teóricos con consecuencias políticas y prácticas para el propio movimiento feminista. Es decir, se está sustituyendo el todo por la parte, con lo que ello comporta de error teórico y político" (Martínez, 2017: 41-42).

En el ámbito académico, coincidimos con Cristina Palomar cuando señala que "hablan de «género» algunos académicos varones que creen que se han concienciado pero, sobre todo, modernizado, al decir «género» en lugar de «sexo», y que quieren presentarse como seres sensibles y, por lo tanto, se han deslindado de una postura machista, sexista o discriminatoria" (Palomar, 2015: 21).

En el mismo sentido se manifiesta Silvia Tubert, para quien

"en muchas ocasiones el género se usa con el objeto de buscar una legitimación académica, política o social, sin importar demasiado el contenido al que hace referencia. Numerosos congresos, publicaciones, proyectos e investigaciones financiados por organismos políticos incluyen en sus programas el término género, aunque apenas tengan relación con el significado original de la palabra" (Tubert, 2003: 14).

No obstante, su utilidad y su capacidad de describir aspectos concretos de la realidad están sobradamente demostradas. Así, un uso adecuado de la perspectiva de género en la investigación implica reconocer la existencia de unas relaciones de poder que se dan entre hombres y mujeres, en general favorables a los primeros como grupo social y discriminatorias para las segundas, que han sido constituidas social e históricamente y son constitutivas de las personas, atravesando todo el entramado social y creando identidades y alteridades (Gamba, 2007: 120; Hidalgo, 2012: 16).

Creemos, por otro lado, que es la epistemología feminista la más adecuada para enfocar nuestra Tesis, ya que, como escribía Fernand Braudel (1979: 39), cada forma de historia implica una erudición que le corresponde. Así, "ha sido la capacidad del feminismo de conceptualizar, de dar nombre a realidades, procesos y situaciones hasta entonces inexistentes para la ciencia, lo que ha permitido incorporar al análisis científico la vida y la experiencia histórica de las mujeres y de otros colectivos invisibles e infravalorados por los análisis tradicionales" (Martínez, 2017: 28).

De esta forma, lo que decimos sobre el pasado no es sólo una constatación de la dominación masculina, su opresión y los roles que ésta impone, ni tampoco nos ceñimos a una concepción del patriarcado como ahistórico e inevitable, sino que intentamos poner de manifiesto también los cambios, las transgresiones y los movimientos de 
resistencia que se dan en el seno de las sociedades patriarcales y que afectan a cómo éstas perciben a las mujeres. Ya que, como escribía Moses Finley, "estudiar y escribir la historia, en conclusión, es una forma de ideología" (Finley, 1986: 16).

El hecho de escribir historia adoptando una perspectiva feminista ha recibido críticas, al igual que hemos señalado para el empleo de la categoría "género", tachándola en este caso de ser una corriente ahistórica y generalista (Nicholson, 2003: 69 y ss.; Sánchez León, 2003: 176-177), y resaltando el hecho de que las historiadoras feministas se encuentran, en tanto que mujeres, implicadas personalmente en su objeto de estudio (Sánchez León, 2003: 165). Como señala Pilar Ballarín (2017: 68), el conocimiento producido desde el feminismo no se reconoce como científico, sino como apegado a lo sentimental y producido sin que sea necesaria una formación previa. A este respecto, creemos que en el caso de la Historia de las Mujeres no existe forma de deshacerse de ser al mismo tiempo juez y parte, ya que las historiadoras la escriben en cuanto que mujeres y por lo tanto, parte invisibilizada, y los historiadores en cuanto que hombres y sujeto casi exclusivo de los relatos acerca del pasado ${ }^{16}$.

Las críticas mencionadas las percibe como superadas Geneviève Fraisse (2016: 49-50), quien cree que los tiempos de desprecio y condescendencia en los que las investigaciones feministas eran tachadas de simple militancia o de militancia disfrazada de análisis científico han quedado atrás, y que las investigaciones feministas no sólo han adquirido la entidad debida, sino que comienzan en ciertos sectores a provocar miedo debido a sus posibles consecuencias simbólicas y sociales, al considerar nociones que parecían naturales e inmutables, como la de feminidad y masculinidad, simples engranajes dentro de la maquinaria de dominación patriarcal. Una visión algo más pesimista la presenta, para el caso español, Pilar Ballarín (2017), quien cree que este miedo se traduce, en el ámbito universitario y académico, en una reacción de ciertos docentes e investigadores que ponen barreras a la inclusión de los estudios feministas en los planes educativos, y en un menor apoyo económico e institucional a iniciativas que pretenden impulsar la igualdad de género.

Por otro lado, cabe señalar que uno de los puntos fuertes de la historiografía feminista es su capacidad de constante renovación y de aprendizaje en base a las críticas

\footnotetext{
${ }^{16}$ Por otro lado, lo mismo podría alegarse en el caso de los estudios de las masculinidades o Men's Studies, los cuales han adquirido fuerza en los últimos años (Blanco y Valcuende, 2003; Medina-Vicent, 2015; Nash, 2014; Rose, 2012: 121 y ss.). Para obras de referencia sobre este aspecto en la Antigüedad, vid. Foxhall y Salmon (1998) y Masterson (2004).
} 
que se aprecian tanto desde fuera como desde el propio movimiento (Medina-Vicent, 2015: 225; Molet y Bernad, 2015; Sada, 2010: 240), lo que permite profundizar en el análisis de las fuentes disponibles y obtener de ellas información que escapaba a las interpretaciones anteriores.

\section{I.2.2. Vejez en femenino: la Gerontología Feminista}

El género, en cuanto que construcción social, interactúa con otras categorías sociales en las que influye y por las que es influido, de forma que todas ellas permanecen constantes pero a la vez se redefinen en el tiempo. Este cambio en el tiempo es especialmente relevante en una de estas categorías, la edad, ya que ésta sirve para marcar el propio paso del tiempo en las sociedades humanas y para fijar eventos y experiencias dentro del discurrir de la vida. Gema Polo explica la tendencia a dividir la vida en diversas etapas de la siguiente manera:

"el cambio del vivir social, al exigir reglas fijas que dan seguridad al tráfico y permiten adoptar decisiones rápidas, hace que en todas las civilizaciones se agregue a una determinada edad la presunción de que con ella se alcanzan unas determinadas condiciones fisicopsíquicas, con lo que se da paso, a su juicio, a que el requisito de una edad fijada sustituye totalmente al antiguo supuesto de desarrollo corporal o mental de la persona" (Polo, 2013: 183).

El proceso de envejecer se convierte así en un proceso individual, que afecta a cada ser vivo de forma personal, pero al mismo tiempo colectivo, ya que se vive en un contexto y en una sociabilidad determinados y dentro de un grupo de edad concreto, formando conciencia del sí pero también del otro que no pertenece a dicho grupo (Bernárdez, 2009: 31). Además, el envejecimiento,

"aunque en términos generales se identifique por el declive de las funciones orgánicas e intelectuales de los individuos, está atravesado por la cultura, por lo cual su conceptualización también se inserta en el desarrollo del proceso del pensamiento; en las herramientas que el pensamiento crea para hacer tal proceso inteligible" (Hernández, 2014: 95).

Desde este punto de vista, "age becomes another indispensable tool for reconceptualizing narrative, embodiment, socioeconomic organization, age ideology, epistemological bias, interpersonal relations, and the development of selfhood" (Gullette, 2003: 12). Como principio de organización social, la edad es un medio de jerarquización que define a las personas, según el cual el adulto se convierte en centro regidor, mientras que la vejez acarrea una pérdida de poder, autoridad y estatus. 
En lo que respecta a la interacción entre género y edad, se trata de una relación que cambia a lo largo del curso de la vida, ya que "las transiciones que se producen, las normas basadas en la edad y los cambios fisiológicos influyen en el modo de interpretar las funciones asignadas a los géneros y la identidad que se experimente" (Ginn y Arber, 1996: 33). De esta forma, la niña y la anciana se convierten en víctimas de una doble discriminación dentro de las sociedades patriarcales, de forma que no son sólo mujeres, y por ende subordinadas al varón adulto, sino que además no pueden cumplir con su rol de género como seres reproductores y objeto del deseo sexual masculino (Iriarte, 2015: 21). No obstante, si en el caso de la niña puede verse en ella la mujer que aún no es pero en la que se convertirá, en el caso de la vieja no ocurre lo mismo; ya no quedan esperanzas de futuro ni objetivo que cumplir -al margen de cuidar de otras personas que, por edad o por sus capacidades, tampoco son útiles a la sociedad-, sólo resta esperar a la muerte (Freixás, 2008: 47; Pascual, 2015).

Así, el paso del tiempo no afecta de la misma forma siendo mujer que siendo hombre. Se considera que los hombres maduran, mientras que las mujeres envejecen (Freixás y Luque, 2009: 193; Russell, 1987: 129). Además, la única ventaja que la sociedad suele verle al envejecer es adquirir sabiduría, pero como las mujeres no son animadas a desarrollar su inteligencia sino su belleza, no existe valor social añadido a su vejez (Grosz, 1994: 14; Stone, 2013: prefac.). Es por ello que se exige a las mujeres que conserven siempre un aspecto joven y eviten "becoming "different" from a culturally defined woman -reproductive, fertile, sexual, attractive- and crossing over into an "other", a non-reproductive, infertile, asexual, unattractive category" (Stone, 2013: 6). Por su parte, los ancianos no sólo declaran en muchas ocasiones no haber sufrido ningún tipo de trato desigual debido a su edad, sino que aplican sobre las ancianas los mismos comportamientos discriminatorios que emplea el resto de la sociedad, a pesar de encontrarse en su mismo tramo vital (Ojala et al., 2016).

Veremos que esta necesidad de las mujeres de mantener el mismo aspecto que en la juventud se daba también en época romana, siendo frecuentes las referencias a preparados que eliminan las arrugas, tintes que ocultan las canas y postizos que suplen la falta de dientes, trucos que diversos escritores dan a las romanas para que puedan seguir resultando atractivas a la mirada masculina.

Según Anna Freixás, el envejecimiento puede tratarse desde dos planteamientos sesgados: 
"partiendo de la consideración de que hombres y mujeres envejecen de forma similar, por lo que se analizan estos procesos de forma indiferenciada para ambos sexos, y reconociendo diferencias específicas entre los sexos en el envejecimiento, pero enfatizando, como explicación cuasi única, algunos aspectos como pertenecientes específicamente a cada uno de ellos" (Freixás, 1997: 32).

En el caso de la mujer se hace hincapié fundamentalmente en la menopausia, llegada la cual las ancianas pierden la feminidad que les ha otorgado el patriarcado, dejando, de manera simbólica, de ser mujeres para simplemente convertirse en viejas (Freixás, 2008: 51-53; Russell, 1987: 125). Además, al haber cumplido con todo su ciclo de explotación, y no poder llenar de forma completa su papel como madre y esposa, la anciana cae en una especie de limbo, donde es pero al mismo tiempo ya no es una mujer. Michael Foucault explicaba esta situación diciendo que "lo que no apunta a la generación o está transfigurado por ella ya no tiene ni sitio ni ley. Tampoco verbo. Se encuentra a la vez expulsado, negado y reducido al silencio" (Foucault, 1998: 6).

No faltan, por otro lado, las voces de mujeres que consideran la vejez como un momento de libertad y liberación (Freixás, 2013: 185; Shehan y Kaestle, 2009: 88). Al respecto, Simone de Beauvoir, quien también vio la ancianidad como un estado ambiguo, escribía que la mujer

“escapa al dominio de la especie con otra crisis difícil: entre los cuarenta y cinco y los cincuenta años se desarrollan los fenómenos de la menopausia, inversos con respecto a los de la pubertad (...) Entonces la mujer queda liberada de las servidumbres de la hembra; no es comparable a un eunuco, pues su vitalidad está intacta; no obstante, ya no es presa de las potencias que la superan: coincide con ella misma. Se ha dicho a veces que las mujeres mayores constituyen un «tercer sexo»; efectivamente, no son varones pero tampoco son hembras; a menudo esta autonomía fisiológica se traduce por una salud, un equilibrio, un vigor que antes no tenían" (Beauvoir, 2013: 93).

De acuerdo con esta afirmación se muestra Anna Freixás, que cree que la vejez ayuda a las mujeres a

"librarse de dos de los elementos que el patriarcado ha considerado fundamentales para su felicidad y realización: la casa y la familia (ser esposa, madre y ama de casa), se relaciona con un mayor sentimiento de felicidad, mejora de la autoestima y bienestar psicológico" (Freixás, 1997: 35).

Esta creciente libertad en la vejez ha sido discutida en lo que respecta a la Antigüedad. En el caso de Oriente Próximo, Rivkah Harris (2000: 108-112) y Fermín 
Domínguez (2002: 195) creen que las ancianas, especialmente si eran viudas, serían más libres que durante sus años reproductivos. En cuando a Grecia, Kristine Gentile (2009: 1), Dolores Mirón (2002: 65), Tim Parkin (2003: 246) y Ana Iriarte (2015: 23) postulan que las ancianas griegas, al desprenderse de su utilidad reproductora, perderían consideración en el conjunto de la sociedad pero ganarían libertad. En contra se posiciona Louise Pratt (2000: 42), quien se basa en un estudio detallado del Himno Homérico a Deméter. En el caso romano, el que las mujeres ganaban libertad de movimiento en la vejez lo señala Anastasios Nikolopoulos (2003: 54). Por su parte, Matthew Dickie (2001: 90) cree que, si bien es posible que las ancianas fuesen en la Antigüedad más libres que el resto de mujeres, se trata de una teoría que debe tomarse con cautela y para respaldar la cual no poseemos indicios suficientes. En nuestro caso, haremos referencia a este tema a lo largo del Capítulo IV.

Volviendo a la vejez como objeto de estudio, hasta hace unas décadas las investigaciones dedicadas a la ancianidad femenina resultaban prácticamente inexistentes fuera del ámbito médico, el cual además repetía la idea antigua de la vejez como etapa de enfermedad que precede a la muerte, como una segunda infancia en la que se desaprende todo lo aprendido (Gullette, 2015: 22; Iacub, 2009: 27). La vejez era vista como un tema marginal, de poco interés y menos relevancia (Twigg y Martin, 2015: 2). Hasta la aparición de la Gerontología Feminista, y su aplicación a la disciplina histórica, la falta de una base teórica para el estudio de la vejez contribuyó a "oscurecer el camino a seguir" (Reher, 1997: 64), lo que propició la aparición de obras que realizaban un simple repaso estereotipado de las creencias acerca de la vejez en las sociedades antiguas, como ya hemos señalado en el apartado anterior del presente capítulo.

La Gerontología Feminista, surgida en la última década del siglo XX, dio un vuelco a este tipo de estudios con la pretensión de documentar las experiencias de las mujeres mayores -presentes y pasadas- y promover nuevas interpretaciones del envejecimiento femenino a través del estudio y definición de dos discriminaciones: la de ser mujer y la de ser vieja. Según Anna Freixás (2008: 44), sus objetivos fundamentales son:

- Desvelar la construcción social de los valores culturales que limitan la vida de las mujeres mayores en los ámbitos afectivos, culturales, sociales, políticos y económicos. 
- Negar el carácter inevitable de la dependencia, la pobreza y la enfermedad de la ancianidad.

- Promover interpretaciones del envejecimiento femenino que reflejen la complejidad del ciclo vital de la mujer y permitan a las jóvenes adentrarse en la edad sin hacerlo de manera negativa.

En este sentido, la Gerontología Feminista ha puesto de manifiesto la necesidad de deshacerse de términos como "successful ageing" y "envejecimiento activo", ya que tienen connotaciones de actividad, productividad y autonomía, y tienden a ver como positiva solamente la vejez que no altera en demasía el aspecto y el cuerpo de la etapa adulta (Folguera, 2013: 59-60; Holstein, 2010: 56; Phillips et al., 2010: 209; Sandberg, 2013: 13). Como alternativa se han propuesto las expresiones "affirmative old age" (Sandberg, 2013: 13), “conscious ageing” (Stone, 2013: prefac.), "positive ageing" (Davis, 2006: 17) y “envejecer de forma natural", aunque Julia Twigg señala los peligros de la última, ya que "if there is no natural body, then there is no natural way to age" (Twigg, 2004: 63) ${ }^{17}$. La importancia radica, en este sentido, en tomar la vejez no como un momento de declive, sino de cambio y desarrollo, al igual que acontece a lo largo de todo el curso vital. De esta forma, se pretende eliminar diversos prejuicios acerca de los efectos físicos y psíquicos de la ancianidad, así como acabar con la división entre buena y mala vejez, la cual ya se encuentra presente en los textos que analizamos en nuestra investigación.

Finalmente, cabe destacar el enorme interés que ha despertado en los últimos años la vejez femenina, el cual puede deberse no sólo al envejecimiento de los países occidentales, sino también a que las propias teóricas del feminismo, aquellas que impulsaron los primeros estudios académicos centrados en la mujer, han alcanzado esta etapa vital (Cohen, 1985: 254; Garner, 2013: 6).

Se trata de un interés que, por otro lado, puede conducirnos en un futuro a un cambio en las percepciones sociales sobre la vejez femenina. Algunos autores (Corsi y Samek, 2013: 3; Freixás, 2008: 54) postulan que, a medida que los países occidentales se encuentren cada vez más envejecidos, las personas ancianas se convertirán en piezas fundamentales a quienes se exigirá una participación más activa en la sociedad. Una

\footnotetext{
${ }^{17}$ Para profundizar en estos términos y los aspectos positivos y negativos de emplear cada uno de ellos, vid. Ramos Toro, 2017: 153-160 y Triadó y Villar, 2014: 25-29.
} 
visión optimista defendida por Asunción Bernárdez, quien cree que el aumento de la población vieja

“está empujando a la tecnología social y empresarial a previsiones y negocios de distinta índole que cambiarán la definición tradicional de la vejez, como un simple declinar individual de la vida, a una época susceptible de generar riqueza (...) en un momento de incertidumbre en el que la familia patriarcal se encuentra en crisis y las mujeres dejan de ser las eternas cuidadoras de las personas dependientes en las familias" (Bernárdez, 2009:31).

En el caso concreto de las mujeres, una de las metas de la Gerontología Feminista en este nuevo marco sería

"la elaboración de alternativas feministas a la invalidación patriarcal de las mujeres mayores, otorgándoles reconocimiento, autoridad y poder, dándoles espacio y palabra, promoviendo una investigación ajustada a la realidad de las vidas de las mujeres que permita construir rituales habilitadores y positivos de representación de la vejez" (Freixás, 2008: 54).

En cuanto a las aplicaciones de la Gerontología Feminista a nuestra Tesis Doctoral, a lo largo de nuestra investigación hemos rastreado algunos de los aspectos que ésta considera claves para el estudio de la vejez femenina. Por un lado, la representación del cuerpo envejecido como infértil y repulsivo, pero también como reflejo de gravitas. Hemos tratado de mostrar cuáles eran los cambios físicos que se producían en las romanas a medida que envejecían, y cómo se representaban estos cambios en la sociedad. Incidiremos en la masculinidad de estas imágenes, al tiempo que trataremos de extraer de ellas las opiniones que tenían las vetulae acerca de su propia vejez.

Por otro lado, nos hemos preguntado por el lugar que las vetulae tenían en la sociedad, tanto su posición en el espacio privado como en el público. Haremos referencia a diversos estereotipos negativos de la vejez femenina, así como al papel que las ancianas tenían en la transmisión de sabiduría. Aludiremos también a las diversas formas en las que vetulae concretas incidían en el ámbito económico y realizaban actos de evergetismo.

Y finalmente, hemos abordado la posición de la vetula en la familia, sobre todo teniendo en cuenta la importancia que ésta ha tenido en las sociedades mediterráneas desde la Antigüedad, en especial para la mujer (Pichardo, 2013: 231 y ss.). La importancia de incluir la familia en los estudios sobre la vejez femenina la resalta 
Lourdes Pérez (2003: 25 y ss.; vid. también Rodríguez Ávila, 2006: 69 y ss.), especialmente cuando nos enfrentamos a sociedades que consideran ésta como un pilar fundamental, ya que en ellas las ancianas, al desaparecer su papel como madres y garantes del bienestar de las personas de su entorno, ven sus vidas seriamente afectadas y, por lo tanto, también su posición dentro del orden familiar. Es por ello que el análisis de los roles que las vetulae desempeñaban en sus familias es uno de los objetivos principales de la presente Tesis Doctoral.

\section{I.3. FUENTES}

Para la realización de la presente Tesis Doctoral hemos empleado varios tipos de fuentes, relacionándolas entre sí con la intención de obtener un conocimiento lo más profundo posible de las vetulae y de los diversos aspectos de sus vidas. Somos conscientes de las particularidades que presenta cada tipo de fuente empleada, las cuales dependen de su autor, el público esperado, la época y la intencionalidad, así como de los convencionalismos inherentes a cada una de ellas. Por ello, en nuestro análisis crítico de la documentación estudiada hemos tenido presente que su contenido nunca es arbitrario ni accidental, y que las motivaciones que se esconden tras cada vestigio del pasado son parte fundamental del mismo.

La vejez es uno de los aspectos de las sociedades pasadas que más difícil resulta rastrear en las fuentes. Se trata de un hecho que coinciden en señalar muchos de los autores que abordan este tema (Harlow y Laurence, 2002: 127; Kebric, 1983: 538; Luce, 1993; Moreno, 2015: 41; Otero, 2013: 95-96; Wiedemann, 1996: 276), a pesar de que se ha avanzado un largo camino desde las obras pioneras, aumentando los documentos a nuestra disposición y apareciendo nuevos enfoques desde los que abordar su interpretación. Por otro lado, hay quienes se muestran convencidos de que algunas de las fuentes que hemos empleado en nuestra investigación no pueden acercarnos a la realidad de la vejez femenina en las sociedades antiguas (Wagner-Hasel, 2011: 9).

Dadas estas particularidades, como señala Christian Laes (2005: 254) en un artículo que repasa los puntos fuertes y las carencias de las obras de referencia acerca de la vejez en la Antigüedad, una investigación como la que aquí se aborda necesita integrar tanto los documentos escritos como los restos arqueológicos y el arte, de forma que se interrelacionen; partiendo además del convencimiento de que todas las representaciones de una sociedad acerca de un fenómeno concreto -en este caso la 
vejez- nos hablan sobre cómo se concibe dicho fenómeno dentro de la misma, y de que debemos otorgar el valor de documento histórico a todas ellas parar obtener una visión más completa de las vetulae. Ello justifica la cronología tan amplia a la que se adscriben las fuentes que hemos empleado, así como el hecho de que hagamos referencias puntuales a autores griegos, dado que la medicina y la filosofía romanas deben tanto a la influencia griega.

En el proceso de recopilación de fuentes nos ha sido imprescindible el uso de Internet. Hace veinte años que Carlos Espejo (1998) y Joaquín Gómez-Pantoja y Ángel López (1999) señalaron la utilidad de este medio para el estudio de la Historia Antigua y el creciente interés que la historiografía mostraba por él debido a la necesidad de ir más allá de los medios tradicionales de obtención de información. A pesar de que desde entonces las tecnologías se han convertido en cotidianas en el trabajo historiográfico (Cannadine, 2008: 4; Steiner y Mahony, 2016), y es prácticamente obligado el uso de Internet como medio de búsqueda bibliográfica, existen todavía reticencias acerca de emplearlo para la obtención de fuentes, las cuales se deben en parte a que no es posible comprobar la calidad de muchos de los contenidos web cuando éstos no proceden de páginas de organismos científicos.

En lo que respecta a la presente Tesis, la red ha facilitado nuestro acceso a textos clásicos en su idioma original cuando no disponíamos de ediciones impresas bilingües, así como a las ediciones traducidas de algunas obras clásicas de menor difusión. En el caso de los textos originales, se han consultado las páginas Perseus, The Latin Library, The Roman Law Library y Lacus Curtius. Internet también nos ha dado acceso a las bases epigráficas Arachne - CIL Open Access y Epigraphik-Datenbank Clauss/Slaby (EDCS) y a las listas de abreviaturas de autores y obras clásicas, así como a los archivos de imágenes de diversos museos europeos y americanos. Navegar en la red ha sido, por lo tanto, un medio de agilizar nuestra búsqueda y ampliarla por encima de los métodos analógicos.

\section{I.3.1. Fuentes literarias}

Las principales fuentes empleadas para nuestra investigación son las literarias, las cuales fueron redactadas en un amplio marco cronológico que abarca los siglos VIII a.C. al VII d.C. Pertenecen a diversos géneros literarios, de la sátira a las epístolas, pasando por la medicina, la filosofía y el teatro, ya que cada uno de ellos nos aporta una 
visión particular sobre las vetulae y relacionarlos nos ayuda a obtener una imagen más completa y menos condicionada por sus particularidades ${ }^{18}$. Hemos accedido a ellas a través tanto de las ediciones que aparecen recogidas en el apartado de referencias como a copias de los textos colgadas en la web ${ }^{19}$. Para las abreviaturas de autores y obras clásicas hemos empleado las nomenclaturas propuestas por el Oxford Classical Dictionary y el Diccionario Griego-Español del CSIC. En el caso de los papiros, hemos acudido a la lista elaborada por la Universidad de Duke.

Para la realización de esta investigación comenzamos consultando las producciones literarias de tipo gerontológico, aquellas que tienen como tema el estudio de la vejez o que narran en primera persona lo que supone la ancianidad. Era obligado recurrir al texto más conocido de entre todos los escritos sobre la vejez en la Antigüedad, De Senectute de Cicerón. Se trata de una obra que el orador dedicó a su amigo Ático; protagonizada por Catón el Viejo, paradigma de la vejez ideal, en ella éste conversa con Escipión y Lelio acerca de cómo es ser un senex. Judith Hallett (1992: 342) y Judith de Luce (1993: 367) señalan que la ausencia de mujeres en este texto se debe no sólo al silencio acerca de la vejez femenina en las sociedades patriarcales, sino también a que el relato de Cicerón es en el fondo autobiográfico, dedicado a sí mismo y a Ático, otro senex, y por lo tanto proyecta su propia experiencia ${ }^{20}$. Ello entroncaría con la teoría de Andrew Rigsby (2011) según la cual la autobiografía era considerada en Roma como un acto de vanidad, por lo que Cicerón habría enmascarado su propio sentir bajo el personaje de Catón.

Lo mismo ocurre con el resto de relatos autobiográficos sobre la vejez en Roma, los cuales, al estar escritos por hombres de la élite, no proporcionan una visión de la mujer vieja, ni de la vejez pobre o esclava (Garrido, 2013: 551; Haynes, 1963: 35; Mencacci, 2006: 141). Es el caso de algunas cartas de Séneca (s. I d.C.), y fragmentos de obras de otros autores en los que éstos son conscientes de su ancianidad, como ocurre con Ovidio (s. I a.C. - I d.C.) y Ausonio (s. IV d.C.). A este respecto, resulta interesante la afirmación de Suzanne Dixon, según la cual "even when surrounded by women, children and slaves, men of the élite might have been only partly aware of their

\footnotetext{
${ }^{18}$ En contra se manifiesta Suzanne Dixon (2001: 12), para quien lo ideal es centrarse en un sólo género literario y tratar de conocer a fondo sus particularidades.

${ }^{19}$ En el caso de aquellas obras citadas en el texto que no figuran bajo el epígrafe "Ediciones de autores clásicos" del apartado de referencias, se trata de fragmentos que hemos consultado directamente en latín en las páginas web ya señaladas.

${ }^{20}$ En el momento de redacción del texto Cicerón tenía 62 años y Ático 65.
} 
actions unless those actions infringed on them" (Dixon, 2001: 21). Una explicación que no secundamos y que ignora la perspectiva de género la presentan Georges Minois (1987: 116), Marie-Thérèse Fontanille (2004: 32) y Alfonso López (2008: 10), quienes creen que una mayor población de senes que de vetulae en Roma sería la causa de la menor incidencia de los personajes femeninos de edad avanzada en la literatura romana.

Si bien el texto de Cicerón es la obra más completa acerca de la vejez que ha llegado a nosotros desde la Antigüedad, no fue la única. En el siglo V d.C., el griego Juan Estobeo escribía una antología dedicada a más de 500 escritores griegos y romanos de entre los siglos VIII a.C. y V d.C. que incluía un listado de citas sobre la vejez de cerca de 40 autores (Moog y Schäfer, 2008: 357). Estobeo consagró tres libros de su obra a la última etapa vital, dedicados respectivamente a opiniones positivas, negativas y sobre la inevitabilidad de la vejez y el respeto que ésta merece, lo que mostraría que el autor pretendía presentar una visión eminentemente positiva de la ancianidad (Moog y Schäfer, 2008: 355; Parkin, 2003: 58-59). Además de pasajes de obras de Platón, Menandro o Plutarco, Estobeo cita también otros textos dedicados por entero a la vejez, los cuales no han sobrevivido hasta nuestros días: un texto sobre el cuidado de los ancianos escrito por Musonio Rufo en el siglo I d.C. y dos obras completas de Junco y de Favorino de Arelate, ambos autores del siglo II d.C. Ello muestra que la vejez fue objeto de reflexión en la Antigüedad por parte de muchos autores, tanto de forma específica como ligada a otros temas. Por otro lado, debemos tener en cuenta, como señala Tim Parkin (2003: 59), que la obra de Estobeo es de difícil interpretación, ya que se trata de una mera recopilación sin contexto de opiniones positivas y negativas sobre la vejez.

Para investigar acerca de la longevidad de la vida y las etapas del ciclo vital, así como sobre el cuerpo de la vetula, contamos con las fuentes médicas, científicas y filosóficas, tanto griegas como romanas. La lectura de estos textos nos permite conocer cuáles consideraban los escritores antiguos que eran las patologías propias de la vejez y cómo el envejecimiento modificaba el cuerpo humano, datos que pueden contrastarse con la información proporcionada por el registro arqueológico.

En lo que respecta a las obras puramente médicas, hemos recurrido a textos del corpus hipocrático (ss. V - IV a.C.), así como a los tratados de Celso (ss. I a.C. - I d.C.) y Galeno (s. II d.C.). A pesar que su autor no fuera médico, se incluyen aquí también Sobre la cosmética del rostro femenino y Arte de amar, obras Ovidio (ss. I a.C. - I d.C.) 
en las que se mencionan remedios para paliar la aparición de signos de la vejez como las arrugas, las canas, o las manchas en la piel.

A la duración máxima de la vida del ser humano y las divisiones del ciclo vital hacen mención autores como Platón (ss. V - IV a.C.), Aristóteles (s. IV a.C.), Varrón (s. I a.C.), Plinio el Viejo (s. I d.C.) y Censorino (s. III d.C.). En sus textos encontramos referencias a la longevidad de pueblos semi-míticos, comparaciones entre el ciclo vital de humanos y otros animales y alusiones a patologías asociadas a la vejez. Ser el autor más tardío de todos permite a Censorino, en su obra Del día del nacimiento, recopilar las diversas divisiones del ciclo vital que realizaron autores tanto griegos como romanos y compararlas entre sí, por lo que nos ha sido de gran ayuda para el desarrollo del Capítulo II.

Por otro lado, hemos comprobado cómo la vetula se convierte en personaje recurrente en textos humorísticos, ya sea la sátira, el teatro o la novela. Un humor que era el del vir y que por lo tanto proyecta la idea que éste tenía acerca de las vetulae, creando estereotipos que no tenían por qué ajustarse a la realidad. Es precisamente en estas obras donde podemos acceder a información sobre las vetulae de las clases sociales inferiores y las esclavas, así como de los avatares cotidianos de la vejez femenina, y donde apreciamos el uso reiterado de los estereotipos que se analizan en el Capítulo IV.

En cuanto al teatro romano, que hereda del griego al personaje de la anciana, encontramos a vetulae en diversas obras de Plauto (ss. III - II a.C.) y Terencio (s. II a.C.). Las ancianas de estas tramas son esclavas que padecen las consecuencias de una vida de duro trabajo y prostitutas a quienes escasean los clientes, muchas veces alcohólicas, así como mujeres que hacen la vida imposible a sus esposos, hijos y especialmente nueras, en representación del tópico de la suegra malvada.

En lo que respecta a la sátira y la novela, aparecen vetulae en obras de Horacio (s. I a.C.), Petronio (s. I d.C.), Marcial (s. I d.C.), Persio (s. I d.C.), Juvenal (ss. I - II d.C.) y Apuleyo (s. II d.C.). El cometido principal de personajes como la anciana que sirve a los ladrones en Metamorfosis, las magas Canidia y Sagana, y vetulae sexualmente activas como Matrinia y Vetustila, es presentar mediante el humor la posición marginal de la vejez femenina en la sociedad romana, haciendo hincapié en rasgos que resultan repulsivos al narrador, como las arrugas o el olor corporal. Aparece aquí también la figura de la anciana socialmente peligrosa, ya sea aquella esclava que facilita los 
encuentros sexuales entre dos jóvenes amantes, o la bruja que desafía con sus conocimientos el mos mairoum y las leyes de la naturaleza.

La marginalidad de las ancianas también se ve reflejada en la poesía amorosa de Catulo (s. I a.C.), Propercio (s. I a.C.), Tibulo (s. I a.C.) y Ovidio (ss. I a.C. - I d.C.), en textos que aconsejan a las mujeres cómo ocultar los síntomas físicos de la vejez para resultar bellas a ojos de los hombres, o en los que el poeta advierte a su amante de que a medida que pasen los años dejará de ser sexualmente deseable, y por lo tanto socialmente invisible desde el punto de vista del vir.

A lo largo de nuestra investigación nos hemos servido también de textos mitológicos y épicos. Hemos recurrido en este caso a Hesíodo (ss. VIII - VII a.C.) y Ovidio (ss. I a.C. - I d.C.). A pesar de que la Vejez es un personaje que apenas aparece en la literatura mítica, sus efectos en los mortales son mencionados en diversas ocasiones. Narraciones como las de Aurora y Titono (Hymn. Hom. Ven. 218-240; Hor. Carm. 1.22 y 2.16) y Apolo y la Sibila (Ov. Met. 14.130-154; Phl. 99), las cuales trataremos en los capítulos sucesivos, pensadas para ayudar al ser humano a aceptar su condición de mortal, nos acercan a la forma en la que la sociedad romana concebía la vejez y el imaginario simbólico construido en torno a esta fase vital (López Saco, 2009).

No obstante, al ser episodios en los que los humanos se relacionan con divinidades, debemos tomar la precaución de pensar, como señala Louise Pratt (2000: 42), que la imagen de la vejez que se nos muestra, especialmente si se trata de divinidades con forma anciana, puede ser tanto la norma como la excepción de la sociedad, dado que el mundo divino no se rige de acuerdo a las mismas normas que el de los mortales ${ }^{21}$. Se trata, por otro lado, de una cuestión que se ha planteado si debe extrapolarse a todo el conjunto de las fuentes literarias relativas a las vetulae (Parkin, 2003: 8), y sobre la que volveremos en las siguientes páginas.

También hemos tenido en cuenta textos legales, los cuales nos informan sobre la legislación relacionada con las personas ancianas y la actitud que el Estado tenía hacia ellas. Las fuentes legales nos ayudan a contestar a cuestiones como si las romanas sabrían qué edad tenían, si existía una frontera cronológica para el paso a la vejez, o en qué situación se encontrarían las personas ancianas dependientes. A lo largo del texto

\footnotetext{
${ }^{21}$ En este sentido, vid. también Plácido, 2005: 21. Sobre los modos de conjugar mito e historia, vid. Pérez Miranda, 2011: 31 y ss.
} 
haremos referencia por lo tanto a las XII Tablas y el Digesto, así como a disposiciones legales tomadas por el Estado o diversos emperadores.

Sobre la importancia que para la administración romana tenía la edad nos informan también las noticias sobre censos o certificados de nacimiento. En el caso de los censos, hemos prestado especial atención a los datos que Plinio el Viejo (s. I d.C.) y Flegón de Trales (s. II d.C.) obtienen del realizado en los años 73-74 d.C. Hemos acudido asimismo a referencias sobre pruebas y certificados de nacimiento, como ocurre en el caso del matrimonio de Pudentila y Apuleyo en la Apología de éste último.

Finalmente, cabe mencionar todos aquellos textos que, a pesar de que no tienen como tema principal la vejez, nos informan de diversos aspectos de la misma. Se trata de cartas, discursos y obras de tipo histórico y político de autores como Cicerón (s. I a.C.), Dionisio de Halicarnaso (s. I a.C.), Virgilio (s. I a.C.), Tito Livio (ss. I a.C. - I d.C.), Valerio Máximo (ss. I a.C. - I d.C.), Séneca (s. I d.C.), Tácito (ss. I - II d.C.), Suetonio (ss. I - II d.C.), Plinio el Joven (ss. I - II d.C.), Eliano (ss. II - III d.C.) y Macrobio (s. IV d.C.).

Este tipo de documentos nos permite acceder a la experiencia de la vejez de diversos personajes, a la percepción que sus autores tienen de su propio proceso de envejecimiento y del de otras personas, a las actividades que desempeñaban senes y vetulae en la sociedad romana, tanto económicas como de otro tipo, y al papel que la ancianidad ocupaba en la familia romana. A este respecto, y como señala Robert Kebric (1983: 538), destacan las misivas de Plinio el Joven, en las que aparecen personajes como Umidia Cuadratila, y en las que se tratan temas relacionados con la vejez -como las relaciones familiares o las enfermedades-, aunque parece que en ningún momento la intención del autor es reflexionar sobre ésta.

$\mathrm{Al}$ androcentrismo de las fuentes literarias se suma en el caso de las vetulae el hecho de que muchas de ellas fueron escritas por adultos que veían lejana la vejez y, por lo tanto, reflejan un choque generacional que debe ser tenido en cuenta. Hemos tratado de diferenciar en la medida de lo posible estas obras de las de aquellos autores que escriben desde la vejez, los cuales pretenden, además de contar su propia experiencia acerca de la misma, dar una visión positiva y esperanzadora del momento vital en el que se encuentran (Arquiola, 1995: 3; Gentile, 2009: 25; Iacub, 2005: 93). 
No poseemos textos literarios escritos por vetulae que nos narren la experiencia que las romanas tenían de la vejez. Lo más cercano con lo que contamos son un poema de la griega $\mathrm{Safo}^{22}$ y los fragmentos en los que los autores de época romana dan la palabra a las vetulae, como es el caso de Horacio (Epod. 12) u Ovidio (Met. 14.130154). Además, el uso del masculino como supuesto neutro ya desde la Antigüedad (Dig. 50.16) ha podido provocar que en ocasiones seamos incapaces de distinguir cuándo un texto se refiere a ambos sexos o sólo a los hombres ${ }^{23}$. Esto hace que, como señala Barbara Gold (1993: 77), debamos recurrir a soluciones "creativas" apoyadas en la teoría feminista para extraer de estas fuentes información acerca de las romanas. No en vano, como han puesto de relieve diversas autoras dedicadas al estudio de la mujer (Francia, 1995: 54-55; Murnaghan, 2015; Rivera, 1994: 82), en ocasiones solamente podemos conocer qué opinaban de las mujeres quienes escribieron esas obras, pero no el punto de vista de las propias mujeres.

\section{I.3.2. Fuentes epigráficas}

En lo que respecta a las fuentes escritas, además de las literarias nos hemos apoyado en la epigrafía. Nuestro interés en ella se ha centrado en las relaciones familiares, especialmente en el caso de las personas dedicantes y las dedicadas en las inscripciones funerarias, así como en la edad de las mujeres conmemoradas. Un análisis en profundidad de las inscripciones de época romana y la información que éstas pueden aportarnos acerca de la vejez de las romanas supera con mucho las pretensiones de la presente Tesis Doctoral; es por ello que nuestro interés se ha centrado en buscar en ellas aquellos aspectos que habíamos destacado en la literatura para poder contrastarlos, así como datos de tipo demográfico que no pueden ser obtenidos mediante otros medios. No incluirlas, aunque sea como referencias puntuales, hubiera significado dar la espalda a documentos que nos ofrecen evidencias acerca de aspectos personales, familiares, sociales y económicos de las vetulae.

Con este fin, hemos realizado búsquedas en distintas bases de datos epigráficas virtuales empleando términos que aluden a relaciones familiares entre abuela y nieta/o, tía y sobrina/sobrino, suegra y nuera/yerno, o a edades elevadas. Es el caso por ejemplo de Ulpia Martina (CIL 3.4336) y Claudia Berus (AE 2007, 298), a quienes sus nietos

\footnotetext{
22 Para un análisis de la vejez de Safo a partir de dicho poema, vid. Benedetto, 1985; Rodríguez Somolinos, 2005 y Torné, 2006.

${ }^{23}$ Para profundizar en este aspecto, vid. Evans, 2002: 16 y ss.
} 
dedican sendos epitafios. También nos hemos interesado por inscripciones que mencionan a vetulae que aparecen en la literatura, Umidia Cuadratila ( $A E$ 1946, 174), y a aquellas relativas a actos de evergetismo protagonizados por ancianas. Al abordar la cuestión sobre el redondeo y la exageración de la edad en los epitafios, hacemos referencia a documentos epigráficos de las provincias africanas, así como de Hispania.

El uso de las fuentes epigráficas entraña ciertos riesgos, ya que nos encontramos con que no toda la población romana fue recordada mediante inscripciones, y por lo tanto dejamos fuera una parte de la sociedad cuya magnitud no podemos conocer. El registro epigráfico adolece de una falta de representatividad de los habitantes pobres y no ciudadanos de Roma, quienes en muchos casos no realizarían monumentos funerarios o los harían en materiales perecederos como la madera. Se calcula que por cada persona conmemorada en una inscripción, 65 no lo serían (Laes, 2007: 26). A ello, y siguiendo a Christian Laes (2012: 99-97), hay que añadir que:

- Se conmemora con mayor frecuencia a las personas jóvenes,

- Se conmemora más a los hombres que a las mujeres,

- Junto con inscripciones en las que la edad de la muerte está señalada con gran precisión, nos encontramos otras que tienden a redondear en cifras acabadas en 0 y 5.

- No todos los epitafios incluyen la edad de la muerte; así, por ejemplo, en el caso de Roma, sólo un 33\% de las inscripciones funerarias aluden a la edad de la persona fallecida. Ello puede deberse tanto a normas y modas en la realización de las inscripciones, como a que las personas que conmemoran a los fallecidos no conociesen la edad de los mismos.

Por otro lado, las fuentes epigráficas no sólo nos sirven en cuanto que posibles indicadores demográficos, sino que nos aportan también otros valiosos datos sobre las vetulae, como los lazos familiares ya mencionados o acciones de evergetismo o matronazgo cívico del que son protagonistas (Harlow y Laurence, 2007: 22-23).

Investigaciones como las de Kristen Gentile (2009) y Marta González (2015) ya han demostrado la utilidad de la epigrafía para estudiar a las ancianas de la Antigüedad, en este caso en contexto griego; por su parte, Christian Laes (2015) también ha realizado un acercamiento preliminar a la vejez de las romanas a través de la epigrafía, en concreto a las abuelas. De hecho, y siguiendo a Peter Keegan (2014:156), mediante las inscripciones las mujeres de época romana nos hablan directamente sobre ellas 
mismas, su familia y amistades... constituyendo así una valiosa fuente para ver cómo las romanas se veían a sí mismas y a las personas de su entorno.

En cuanto a las traducciones de las inscripciones empleadas, son nuestras mientras no se señale lo contrario. Hemos dado prioridad al significado y la claridad por encima de la fidelidad de la traducción y de las convenciones propias del soporte epigráfico.

\section{I.3.3. Restos óseos}

Además de fuentes escritas, hemos empleado otras de tipo arqueológico, entre las que están los restos óseos. A tal efecto, hemos recopilado la bibliografía existente sobre este tema. Si bien como ocurre con las fuentes epigráficas, los restos óseos no pueden ayudarnos a establecer conclusiones sólidas de corte demográfico, amplían el conocimiento que tenemos sobre las sociedades pasadas, y en este caso concreto sobre las vetulae. Los análisis llevados a cabo mediante los métodos de la Antropología Física y la Arqueología Funeraria a lo largo de toda la geografía de la dominación romana permiten conocer el sexo, la edad, las patologías, los modos de vida y las circunstancias de la muerte de los individuos presentes en el registro arqueológico, detectando enfermedades que pueden relacionarse con la sintomatología presente en los textos, así como especificidades en la dieta, episodios violentos y diferencias en el trato funerario.

No obstante, y si bien la edad de los individuos es uno de los aspectos fundamentales que la Antropología Física emplea para clasificar los esqueletos humanos, no ha sido hasta hace unos pocos años cuando ha surgido el interés por analizar la dimensión social de la edad en la disciplina arqueológica (Appleby, 2010: 145; Gilchrist, 2004: 143; Sofaer, 2011: 286). Por otro lado, y en parte debido a este despertar tardío de la Arqueología de la vejez, al incluir los restos óseos como fuente para conocer la vejez femenina en la Roma antigua, nos encontramos con diversos problemas:

- Los seres humanos sufrimos, de forma natural y como parte de nuestro envejecimiento, un proceso de osteoporosis que dificulta la conservación de los restos óseos en contextos arqueológicos (Gowland, 2016: 420).

- Desde el momento en el que se fusiona la clavícula y surge el tercer molar, procesos que ocurren en la veintena, no existen marcadores osteológicos que permitan identificar la edad de un individuo, por lo que ésta es determinada a través del estado del conjunto de los procesos degenerativos que acontecen en el esqueleto humano, los 
cuales varían de forma notable dependiendo de la situación concreta de cada persona a lo largo de su vida (Appleby, 2010: 148; Cave y Oxenham, 2016: 163). En el caso del esqueleto de las mujeres, factores ambientales, de actividad física, o de alimentación tienen mayor influencia en la estructura ósea que la menopausia y los fenómenos derivados de la misma, considerados hasta hace poco el agente de desgaste óseo más relevante (Agarwal y Beauchesne, 2011: 313) ${ }^{24}$.

- La fiabilidad de la estimación de la edad de la muerte de un individuo, empleando las técnicas generalmente aplicadas por la Antropología Física, declina rápidamente a partir de los 45-50 años.

- Las categorías de clasificación por edad de los restos óseos humanos de procedencia arqueológica, ya sea atendiendo a etapas del ciclo vital (individuos infantiles, adultos y seniles), o según la edad (creando una categoría en la que suele englobarse a todos los individuos de más de 45 o 50 años) resultan demasiado laxas para estudiar la vejez.

- El empleo de categorías tan amplias, así como el edadismo presente en las prácticas arqueológicas e historiográficas, ayudan a perpetuar la idea de que pocas personas vivían más allá de los 50 años en las sociedades pasadas (Cave y Oxenham, 2016: 164; Gilchrist, 2004: 143; Lucy, 2005: 48).

- Existe la necesidad de revisar los esqueletos ya estudiados, ya que cabe la posibilidad de que parte de los que fueron considerados como individuos adultos sean en realidad seniles (Allason-Jones, 1989: 49; Gómez Bellard, 1996: 59).

Se han propuesto algunas soluciones para paliar estos problemas y visibilizar la vejez en el registro arqueológico. Christine Cave y Marc Oxenham (2016: 167) afirman que examinar el desgaste oclusal dental es uno de los métodos más fiables para determinar la edad de los individuos arqueológicos. Por su parte, Joanna Appleby (2010: 156-158) propone emplear la combinación de diversos marcadores óseos, teniendo en cuenta tanto procesos degenerativos como eventos traumáticos que afectan no sólo a nivel fisiológico, sino también físico, ya que la apariencia de una persona resulta socialmente determinante para considerarla adulta o vieja.

\footnotetext{
${ }^{24}$ Anna Freixás señala que la existencia de una serie de factores "entre los que cabe destacar la presión social, los intereses comerciales de los laboratorios y la falta de una investigación médica de calidad, ha propiciado una explicación acerca de la menopausia degradante y estigmatizadora" (Freixás, 2008: 48), la cual habría afectado a la forma en la que interpretamos los restos óseos provenientes del registro arqueológico.
} 


\section{I.3.4. Fuentes iconográficas}

A las fuentes ya mencionadas hay que añadir las representaciones artísticas, las cuales abarcan estatuas, mosaicos, relieves funerarios y objetos de carácter cotidiano tales como lucernas o botellas cerámicas. Estas obras pueden dividirse, como analizaremos en profundidad en los Capítulos III y IV, entre aquellas que representan a mujeres de forma individualizada, como ocurre con los bustos y el arte en contextos funerarios, y las que hacen referencia a diversos estereotipos de vetula. De entre estos estereotipos el que más estudios ha generado, tanto desde el punto de vista histórico como artístico, es el de anus ebria (Dimartino, 2008; Salomonson, 1980; Waldhauer, 1946; Zanker, 1989).

El periodo cronológico que abarcan las obras consideradas en esta Tesis Doctoral transcurre entre los siglos III a.C. - III d.C. Algunas de estas piezas son creaciones romanas originales, mientras que otras parecen ser copias de arte griego, si bien este último punto está siendo discutido, tal y como mostramos en el Capítulo III.

La intencionalidad y funcionalidad de la mayoría de estas obras, en particular aquellas no individualizadas, es en la actualidad objeto de debate. Entre las motivaciones sugeridas para la realización de este tipo de piezas, tal y como iremos señalando a lo largo de las siguientes páginas, se han sugerido las religiosas, las satíricas, o el simple gusto por lo grotesco. En este sentido, no podemos olvidar que el arte, en todas sus representaciones, es una forma de expresión mediante la que se refleja la simbología de las sociedades y su escala de valores (Zanker, 1992: 20), al tiempo que sirve también como medio de modelar mentalidades al servicio de los intereses del poder, de mantener tradiciones y crear normatividades nuevas (Kampmann, 2015: 279; Stig, 2006: 105). Y ello es así por el diálogo que se establece entre quien crea la imagen, la imagen misma, y quien la admira, ya que

"las imágenes no existen por ellas mismas, flotando como nubes en el cielo, autónomas y libres en sus movimientos, imponiendo de este modo su fuerza normativa o, simplemente, constrictiva. Las imágenes viven por su fuerza productiva entre los sujetos que las acompañan (¿quién muestra dichas imágenes?) y los sujetos que las reciben (¿son capaces de creer en ellas?)” (Fraisse, 2016: 90).

Por otro lado, como señala Peter Burke, las imágenes "son testigos mudos y resulta difícil traducir a palabras el testimonio que nos ofrecen" (2001: 18); así, es arduo establecer la frontera entre lo que simboliza la imagen en su contexto y las 
interpretaciones que de ella hacemos desde el presente (Hall, 2000: 19). Incluso los retratos, que en ocasiones consideramos representaciones exactas, están sujetos a convencionalismos y pretenden, en la mayoría de las ocasiones, mostrar a la persona retratada de manera favorable. Así, por ejemplo, Elizabeth Bartman (1999: 27) señala que, a pesar de que puedan parecer individualizadas, ninguna de las representaciones de Livia tiene por qué asemejarse a su rostro real, ya que por encima de la verosimilitud se encuentra la ideología que esas esculturas pretenden transmitir. Como forma de representación, el arte

"shows people idealized forms of themselves, forms by which to recognize the categories to which their society assigns them and by which to mark their hopes and desires. It also shows people how they differ from one another both as individuals and as members of categories" (Kampen, 1997: 16).

En lo que respecta a la representación de las vetulae, como se verá a lo largo de las siguientes páginas, predomina un estilo realista en el que se subrayan los rasgos físicos característicos de la vejez: piel flácida, acentuación de la línea naso-labial, cejas con arrugas en las esquinas, atenuación de los músculos del cuello, patas de gallo, pérdida de dientes y mejillas hundidas. Son precisamente estos rasgos los que nos permiten identificar a las mujeres representadas como vetulae, ya que, incluso en el caso de los relieves funerarios, la edad no suele aparecer explicitada (Matheson, 2000: 126127).

Finalmente cabe señalar que, si bien un estudio exhaustivo de las fuentes epigráficas, arqueológicas e iconográficas no ha sido posible dados los límites teóricos y temporales a los que se ha ceñido el desarrollo de esta Tesis, somos conscientes del valor que tendría profundizar en las mismas para acercarnos a las vetulae y lo tendremos presente en futuras investigaciones. 


\title{
CAPÍTULO II \\ ENVEJECIMIENTO Y VEJEZ EN ROMA
}

\begin{abstract}
"Yo, pensando en mí mismo, encuentro cuatro causas que agravan sobremanera la vejez: primera, porque aparta de la gestión de todos los negocios; segunda, porque la salud se debilita; tercera, porque te priva de casi todos los placeres; cuarta, porque, al parecer, la muerte ya no está lejos. Reflexionemos, si os parece bien, sobre cada una de estas causas y cuán injusta es cada una"
\end{abstract}

Cic. Sen. $5.15^{25}$

En el presente capítulo realizamos un primer acercamiento a los modos en los que podemos abordar la ancianidad en las sociedades pasadas, así como al concepto de vejez en la antigua Roma. Una vejez que viene definida, en gran medida, desde el punto de vista masculino, el único presente en la obra de referencia acerca de esta etapa vital en la Antiguiedad, De Senectute de Cicerón, considerada el escrito pionero de la Gerontología (Agronin, 2014: 30; Hendricks, 1993: 343; López Pulido, 2013: 57; Rodeheaver, 1993).

El primer apartado aborda la problemática inherente al análisis de la vejez en las sociedades del pasado -y en las actuales-, partiendo de la propia definición de la ancianidad.

En el segundo apartado presentamos los criterios cronológicos, biológicos, demográficos y sociales a partir de los que se definía la vejez en Roma, los cuales nos han servido de guía al abordar e interpretar las fuentes que hemos empleado. Hemos incluido aquí las distintas divisiones del ciclo vital, la concepción médica y social de la

\footnotetext{
${ }^{25}$ Etenim, cum complector animo, quattuor reperio causas, cur senectus misera videatur: unam, quod avocet a rebus gerendis; alteram, quod corpus faciat infirmius; tertiam, quod privet fere omnibus voluptatibus; quartam, quod haud procul absit a morte. Earum, si placet, causarum quanta quamque sit iusta una quaeque, videamus.
} 
vejez, y la problemática acerca de si es posible acercarnos a la senectud mediante un estudio demográfico de las sociedades de la Antigüedad.

El tercer apartado de este capítulo está dedicado al análisis de la imagen dicotómica que presenta la vejez en Roma. Y es que, como veremos, muchos de los fragmentos literarios que tratan la ancianidad subrayan la importancia de vivir una buena vejez, alabando a ciertos sujetos que la personifican, mientras que expresan sus temores por padecer una mala senectud, la cual empequeñece todos los logros obtenidos con anterioridad y resta dignidad al ser humano. Señalamos cuáles son las características que para los romanos de la élite debía tener la ancianidad para considerarla positiva, así como qué actitudes debían evitarse para no caer en el caso contrario.

Finalmente, en el cuarto apartado se trata el tema de la última etapa vital como prólogo de la muerte. En él abordamos las diversas opiniones que los autores antiguos tenían acerca de la muerte, presentamos varios casos de suicidio en la vejez, y analizamos algunos mitos acerca de la imnortalidad y la eterna juventud.

\section{II.1. EL ESTUDIO DE LA VEJEZ EN LAS SOCIEDADES PRESENTES Y PASADAS: ASPECTOS INTRODUCTORIOS}

$\mathrm{Si}$, como ya hemos señalado, vetula y anus eran las formas más comunes de referirse a las romanas viejas, estas palabras tienen su par masculino en senex, vocablo del que derivan senectus y senatus entre otros. Si bien encontrar las palabras latinas que describen las realidades acerca de la vejez es fácil, el problema se presenta cuando pretendemos acercarnos al significado de estos conceptos en la sociedad romana.

Definir qué es una persona anciana no resulta sencillo ni siquiera si tratamos de hacerlo en nuestra sociedad contemporánea (Cruz, 2001; García González, 2005: 2223). A pesar de que todas las culturas poseen un concepto de vejez y por lo tanto se trata de una categoría universal en cuanto a la forma, sus contenidos simbólicos están condicionados temporal y espacialmente. Actualmente, la Gerontología considera que son viejas todas las personas mayores de 50 años, distinguiendo entre "tercera edad" (50-75 años) y “cuarta edad” (a partir de los 75 años) (Giró, 2011: 24) ${ }^{26}$, mientras que para la sociedad en general la frontera la establece la edad de la jubilación, 65 años en el

\footnotetext{
${ }^{26}$ Hay quienes prefieren hablar de una segunda adultez, que abarcaría entre los 50 y los 75 años, y una sola vejez (Ramos Toro, 2017: 99).
} 
caso español. Por otro lado, la vejez es una realidad cargada de connotaciones negativas, que todos poseemos en nuestro imaginario pero que al mismo tiempo es difícil de precisar, por lo que se convierte en problemática de definir, al igual que hemos señalado que ocurre con la categoría "mujer/mujeres".

Según el diccionario de la RAE, "vejez" ${ }^{27}$ es: 1. Cualidad de viejo, 2. Edad senil, senectud, 3. Achaques, manías, actitudes propias de la edad de los viejos, y 4. Dicho y narración de algo muy sabido y vulgar. Por su parte, "viejo, ja"28, tiene un total de trece acepciones, de las cuales, en lo relativo a esta Tesis Doctoral, destacan siete: 1. Dicho de un ser vivo, de edad avanzada, 2. Existente desde hace mucho tiempo o que perdura en su estado, 3. Que existió o tuvo lugar en el pasado, 4. Precedido del artículo "el" [o "la", deberíamos añadir] y pospuesto al nombre o al apellido de una persona para indicar que ésta nació antes que otra llamada igual, 7. Coloquialmente, padre y madre de una persona, 8. Apelativo afectuoso para dirigirse a una persona de confianza, y 13. En Bolivia y México, forma coloquial de mujer.

Además, se trata de una palabra aplicable a seres vivos y a objetos, que tiene tanto acepciones con connotaciones negativas como positivas -o al menos afectuosas-, y que depende de criterios subjetivos ${ }^{29}$.

Viejas son por lo tanto las madres y en algunos países de habla hispana todas las mujeres, independientemente de su edad. Viejas son las personas de edad avanzada, pero no se nos indica cuál es el cumpleaños a partir del cual la cifra comienza a considerarse alta, con lo que la definición dependerá de aspectos subjetivos como el punto de vista del espectador o las convenciones de cada sociedad concreta. Viejos podrían ser todos aquellos que hayan alcanzado la edad establecida legalmente para la jubilación, o en el en caso de la comunidad española de Castilla y León quienes formen parte del Club de los $60^{30}$, a pesar de que sigan laboralmente en activo. A un observador de 5 ó 6 años, viejas pueden resultarle todas las personas mayores de 30, mientras que alguien que ya haya cumplido los 65 puede afirmar que es joven, y en general la

\footnotetext{
${ }^{27} \mathrm{http}: / /$ dle.rae.es/?id=bSrxBGn

${ }^{28} \mathrm{http}: / /$ dle.rae.es/?id=bnRGe0W

${ }^{29}$ Lo mismo puede aplicarse a sinónimos como "anciano, na" (http://dle.rae.es/?id=2XsOc6q), "senil" (http://dle.rae.es/?id=XZjxUFk), o "vetusto, ta" (http://dle.rae.es/?id=biJnALa), aunque las definiciones de algunos de ellos tienen claramente más connotaciones negativas que las del resto.

${ }^{30}$ Se trata de un programa que incluye actividades como viajes, cursos y eventos lúdicos y está destinado al "mantenimiento y a la mejora del bienestar físico, social y mental de las personas mayores, con el objeto de favorecer su capacidad funcional y vida independiente durante el mayor tiempo posible" (http://www.serviciossociales.jcyl.es/web/jcyl/ServiciosSociales/es/Plantilla100/1284372564203// / ).
} 
sociedad le dará la razón ${ }^{31}$. Hay personas con arrugas a las que no calificaríamos como ancianas, mientras que otras que por su edad consideraríamos como tales han logrado, gracias a la cirugía estética, conservar el cutis terso de su juventud. Hay personas viejas pero "de espíritu joven", se dice de los ancianos que son "como niños grandes", o de alguno en concreto que está "hecho un chaval", existen productos que "combaten la vejez"...

Todo ello se complica si tenemos en cuenta la cultura de la eterna juventud en la que se encuentran inmersas las sociedades occidentales, a la cual ya hemos hecho referencia con anterioridad, y una de cuyas consecuencias principales es el edadismo, con un rechazo que empieza por la propia palabra "vejez". Como señala Pedro Sánchez,

"la resistencia activa a las secuelas que en el cuerpo deja la edad se convierte en uno de los imperativos de nuestras sociedades. El culto abierto a la juventud y a la salud tiene su antípoda en la vejez y la muerte que son percibidas no sólo como una adversidad personal sino también como un cierto fracaso moral, por lo que se espera de toda persona responsable que no se abandone a la usura del tiempo y que luche denodadamente por conservarse joven y sana so pena de ser objeto de menosprecio" (Sánchez Vera, 2016: 3).

Por otro lado, si se nos pidiera que pensásemos en alguien viejo, tendríamos en nuestra cabeza una imagen que compartiría muchos de los rasgos que nuestra sociedad considera como propios de la senectud: arrugas, calvicie, canas, postura encorvada, dificultad en el movimiento, pérdida de memoria, ropa de colores oscuros... Una imagen a la que, además, dotaríamos de connotaciones negativas y que probablemente no coincidiría con la descripción de muchas de las personas ancianas de nuestro entorno ni con la vejez que esperamos vivir.

En este sentido, Carme Triadó y Feliciano Villar (2008: 15-16), han identificado ocho mitos sobre la vejez que forman parte del imaginario colectivo y que, si bien en algunas ocasiones sí corresponden con la realidad de las personas ancianas, en otras sirven para obstaculizar su integración en sociedad:

\footnotetext{
${ }^{31}$ A pesar de que, como señala Anna Freixás (2013: 181), esta afirmación sea un oxímoron: no se puede ser viejo y joven al mismo tiempo. La concepción del "viejo-joven", por otro lado, entronca con una exigencia de "juvenilización” que hace que las personas ancianas sean presentadas con las características sociales atribuidas a los jóvenes, aunque ya no es encuentren en dicha fase del ciclo vital (Puche, 2013: 253).
} 
- Mito de la edad biológica, según el cual los cambios que se sufren en la vejez están causados y determinados únicamente por el paso del tiempo y acontecen por igual en toda la población de una determinada franja etaria.

- Mito de la mala salud, que contempla la vejez como un periodo marcado por enfermedades incapacitantes y pérdida de autonomía.

- Mito de la senilidad, según el cual en la ancianidad se exageran los rasgos negativos que caracterizan a las personas en su etapa adulta, especialmente el egoísmo, la irritabilidad y la demanda constante de atención, equiparando esta etapa del ciclo vital con la infancia.

- Mito del declive intelectual, o concepción de la persona vieja como incapaz de aprender cosas nuevas al mismo tiempo que olvida todo lo aprendido.

- Mito de la pobreza, que considera que se trata de personas que ya no son económicamente productivas, lo que al mismo tiempo conduce a la dependencia.

- Mito de la jubilación, según el cual la vejez se concibe como un periodo de descanso permanente y nula participación en actividades de todo tipo.

- Mito del aislamiento social, producido por la muerte de las personas de la misma generación y la no conexión cultural con los miembros más jóvenes de su entorno inmediato.

- Mito del conservadurismo, el cual percibe a las personas ancianas como apegadas a la tradición, reticentes a los cambios y en constante conflicto con las novedades culturales, políticas, sociales, etc.

Conviene resaltar, por lo tanto, que ciertos rasgos que consideramos negativos debido a la influencia del edadismo, como las arrugas, las canas, o la menopausia, son en realidad parte del proceso natural de envejecimiento en los seres humanos y no deben apreciarse como perjudiciales para la persona anciana ni para su relación con la sociedad. Es por ello que la Gerontología Social tiene como objetivo en la actualidad desterrar los mitos a los que nos hemos referido, manifestando la pluralidad de circunstancias vitales concretas que se esconden tras ellos y cómo muchas de las situaciones de la vejez que tienen connotaciones negativas pueden desaparecer si se hace un esfuerzo conjunto por cambiar la imagen percibida por la realidad de la senectud que nos rodea, mucho más amable que el estereotipo grotesco que aúna todos los rasgos negativos del envejecer.

Podría decirse, en definitiva, que la vejez es la etapa vital más social, ya que sus límites cronológicos y sus características definitorias están mucho más difusas que en el 
resto de fases del envejecimiento humano (Alba, 1992: 16; Botelho, 2014b: 44; Ceberio, 2013: 19-25; Hernández, 2014: 95; Morgan y Kunkel, 2016: 2; Pelling y Smith, 1991: 6; Sánchez Granjel, 2003: 21). Así, coincidimos con Lynn Botelho y Pat Thane en que "old age is complex. It is not merely the final stage of life, uncomplicated and universally experienced. It has different meanings for different people, whether one is already older, or whether advanced age is still in one's future, as well as according to social status, economic security, region and (...) gender" (Botelho y Thane, 2014: 3).

Esta dificultad de definir la ancianidad ha propiciado que, en aras de clarificar los términos desde los que se estudia la misma, se hable de cuatro dimensiones diferentes de la vejez (Morgan y Kunkel, 2016: 3-5; Osorio, 2010: 33; Ramos Toro, 2017: 170 y ss.; Rodríguez Ávila, 2006: 8-9; Sofaer, 2011: 286-287) ${ }^{32}$ :

- Una dimensión cronológica, la de los años que han transcurrido desde el nacimiento, la cual en principio es objetiva y que constituye la manera normativa de referirse a la edad ${ }^{33}$.

- Una dimensión física, relacionada con el ser humano en cuanto que organismo vivo y las alteraciones que se producen en el cuerpo a medida que pasan los años.

- Una dimensión psicológica, referida a la perspectiva del sí o "edad sentida" y a los cambios en la personalidad y las capacidades mentales, los cuales pueden deberse tanto a los cambios físicos a los que aludíamos antes como a factores sociales.

- Una dimensión social, que es aquella concerniente a la vejez como categoría social y a la percepción que culturalmente se tiene de las personas ancianas.

Son precisamente estos cuatro tipos de vejez los que van a guiar el desarrollo de nuestra investigación, como ya se apuntaba en el capítulo introductorio. Creemos que abordar de esta forma las condiciones vitales de las vetulae, dadas las características de las fuentes que empleamos y la dificultad de analizar la ancianidad como categoría social, nos permitirá obtener una visión más completa de nuestro tema de estudio. Además, un abordaje de este tipo nos posibilita acercarnos a la senectud femenina en la antigua Roma tanto desde una perspectiva colectiva, analizando el estereotipo de vejez

\footnotetext{
${ }^{32}$ Una división anterior, en este caso en tres etapas, la propuso Simone de Beauvoir (1996: 9), quien distingue entre vejez biológica, psicológica y existencial, omitiendo el aspecto cronológico. Por su parte autores como Thomas Cole (1992: 3) consideran que todo el peso de la definición de los límites entre etapas del ciclo vital, incluida la vejez, se encuentra en las precisiones cronológicas.

${ }^{33}$ No obstante, no todas las sociedades miden igual el paso del tiempo. Debemos incluir aquí además el fenómeno del redondeo, al cual aludimos en varios puntos de la presente Tesis.
} 
que presenta la sociedad romana, como desde una perspectiva individual, que otorga un importante valor a las experiencias personales y a cómo éstas influyen en la vejez (Dannefer y Settersten, 2010: 16; Krause, 2006: 183; Settersten, 2006: 8-9). Cubrimos de este modo la necesidad, apuntada en el Capítulo I, de investigar a las mujeres romanas como un grupo con características comunes pero resaltando al mismo tiempo su individualidad.

\section{II.2. Criterios CRONOLógicos, DEMOGRÁficos, Biológicos Y SOCIALES DEFINITORIOS DE LA VEJEZ EN LA ANTIGUA ROMA}

Si resulta complicado definir la vejez en nuestro propio imaginario cultural, el reto se vuelve más arduo cuando deseamos remontarnos unos dos milenios en el pasado. Ello se debe, como señalan diversos autores (Cokayne, 2003: 1; Garrido, 2013: 545; Parkin, 2003: 23 y ss.; Wagner-Hasel, 2011: 3), a que la definición romana de vejez era igual de flexible que la nuestra. A lo largo de este apartado veremos cómo para la sociedad romana la vejez era un concepto cronológico, pero también médico y visual.

Comenzamos analizando cuál era la edad máxima que los romanos creían que podía alcanzar un ser humano, así como las distintas divisiones del ciclo vital que realizaron diversos autores clásicos. A continuación determinamos la edad cronológica que podemos tomar como frontera de la vejez en Roma. El segundo apartado se centra en la vejez romana en perspectiva demográfica. Nos referiremos aquí a conocidos estudios sobre la demografía antigua y trataremos de responder a la pregunta de si es posible aplicar los estudios demográficos a la vejez romana, abordando asimismo la cuestión del redondeo y la exageración en la edad en la epigrafía funeraria y las declaraciones censales. En el tercer apartado tratamos de definir la vejez desde el punto de vista médico, recurriendo para ello tanto a autores griegos y romanos como a la Antropología Física y a la Gerontología. En él abordamos también la vejez como un factor visual. En definitiva, realizamos aquí un primer acercamiento a cuestiones que pretenden sentar las bases sobre las que en los dos capítulos siguientes analizaremos a las vetulae.

\section{II.2.1.Periodo máximo de vida en la Antigüedad}

En la actualidad, la medicina estima que el tiempo máximo que puede durar la vida humana es de $125 \pm 5$ años. En 1997 murió a los 126 años la mujer francesa que, de 
forma documentada, es el ser humano más longevo de la historia (Martín, 2005: 399). Un ciudadano indonesio fallecido en 2017 le disputaba tal honor, ya que alegaba tener 146 años, aunque no fue capaz de demostrarlo. Estos $125 \pm 5$ años suponen una cifra que puede aplicarse a todas las sociedades, presentes y pasadas, ya que es la edad más alta que se considera que puede alcanzarse sin alterar el organismo del ser humano. De esta forma, sabemos que habría cierto número de personas centenarias en la antigua Roma, si bien los avances médicos y las mejoras higiénicas que se han dado desde la Antigüedad han propiciado que una mayor parte de la población supere el siglo de vida.

No obstante, el tardío arranque de los estudios históricos sobre la vejez ha provocado que esta concepción no siempre esté presente, especialmente entre el público ajeno a la disciplina historiográfica. Ello puede deberse, en parte, a la confusión entre esta esperanza de vida máxima y la esperanza media de vida; es decir, el número promedio de años que viviría un grupo de personas nacidas en el mismo año en una región determinada si los movimientos en la tasa de mortalidad se mantienen estables. De esta forma, una esperanza media de vida de 30 años no significa que los miembros de una sociedad dada no puedan vivir más allá, sino que probablemente nos encontremos ante una población con una muy alta tasa de mortalidad infantil.

Remitiéndonos a los autores antiguos, uno de los que da una cifra más baja es Solón (Cen. DN 14), para quien la vida no se prolongaba más allá de los 70 años. No obstante, y dado lo bajo del número, debemos considerarla más como una edad que se creía probable poder alcanzar que como la indicación de que Solón no conoció a nadie que la sobrepasara.

Varrón (L. 6.11) nos dice que seclum (siglo) deriva de senex, ya que son 100 años el límite de supervivencia del ser humano. Se trata de un lapso de tiempo que siglos antes Platón ( $R$. 10.615b) ya había presentado como el máximo posible ${ }^{34}$. Con ellos coinciden el Digesto (33.2.8) y Censorino ( $D N$ 17), quien escribe que 100 años son la frontera que en Roma se establecía para la vida pública porque, a pesar de que se hablaba de personas que habían superado esa edad, era el límite que comúnmente se tomaba para la vida humana. Por su parte, en el siglo IV d.C. Ausonio (Ecl. 4) establece una frontera algo más baja, de 96 años.

\footnotetext{
${ }^{34}$ Censorino (DN 14 y 15) sin embargo señala que Platón tomó como límite máximo los 81 años.
} 
Sin embargo Valerio Máximo (8.7.3), al hablar sobre Varrón, fallecido con 100 años, señala que ese no es el límite de la longevidad humana. Una mayor duración conceden a la vida humana también Flegón de Trales (99), quien escribe que para los romanos el tiempo máximo que podía vivir alguien era 110 años, Plinio el Viejo (NH 7.49.160-161), que haciendo referencia a diversos autores habla de periodos máximos de 112, 116 y 124 años, y la Historia Augusta (Claud. 2.4), que fija 120 años como límite, señalado a Moisés, fallecido con 125 años, como única excepción.

La duración de la vida del ser humano, según Aristóteles (Long. 1.465a.8-10), dependía en gran medida del clima; así, las personas que vivían en lugares cálidos tendían a ser especialmente longevas, mientras que la vida de quienes habitaban parajes fríos se acortaba. Coincide con él Plinio el Viejo ( $N H$ 7.48.153-158). Por su parte Censorino $(D N$ 14) señala que hay quienes piensan que los bebés nacidos de noche tienen una esperanza de vida menor que los nacidos de día.

Por otro lado, existen casos que superan los límites referidos, tanto en el mundo romano como entre otros pueblos de la Antigüedad. Plinio el Viejo (NH 7.49.162-164) hace referencia a un censo realizado en los años 73-74 d.C. en el que, sólo en el territorio entre los Apeninos y el Po, cuatro personas declararon tener más de 120 años, dos más de 125, otras dos más de 130, y tres más de 135. Una extraordinaria longevidad que se atribuye a algunas mujeres: una vetula anónima de 132 años y Tértula, de 137. Con anterioridad a esta mención, Plinio también nombra a otras vetulae: Livia, esposa de Rutilio (97), Estatilia (99), Terencia, esposa de Cicerón (103), Clodia, esposa de Ofilio (115), Luceya (más de 100), Galeria Copiola (más de 104) y Sámula (110) (Plin. NH 7.48.158-159). Flegón de Trales (1-99), escritor de época de Adriano, presenta una lista de 99 personas de todos los estratos sociales que superaron los 100 años, entre ellas más de una docena de mujeres, empleando como fuente el mismo censo que Plinio (Tabla 1).

A ello debemos añadir las noticias sobre pueblos extranjeros especialmente longevos. Plinio el Viejo ( $N H$ 6.24.91 y 7.2.27-30) nos habla de los habitantes de Tapróbane, que sobrepasan con holgura los 100 años, y los indios cirnos y los etíopes macrobios, que alcanzan los 140, así como de un pueblo de la India cuyos integrantes no sólo llegan a vivir 130 años, sino que además no envejecen, presentando al morir aspecto adulto. Menciona también a los pandas, los cuales viven 200 años y nacen con un cabello cano que va ennegreciendo a medida que envejecen. La extraordinaria 
longevidad de estas gentes a las que Plinio dota de un aire semi-fantástico -que, por otro lado, no es único de la época romana (Alba, 1992: 12)- que debe ponerse en relación con su exotismo en cuanto que sociedades extranjeras ajenas al contexto mediterráneo, se contrapone a la corta esperanza de vida de las mujeres calingas de la India, quienes paren a los cinco años y no superan los ocho de vida.

Por otro lado, Plinio también nos habla de personajes concretos que tuvieron una larga vida, como los reyes Argantonio, muerto con 150 años, Cíniras, con 160, y Egimio, con 200 (Plin. NH 7.48.153-158). Son varios los autores (Cic. Sen. 11.34; Liv. Per. 50.5-6; Plin. $H N$ 7.14.61-62) que refieren la longevidad de Masinisa, rey de Numidia en los siglos III-II a.C., quien vivió más de 90 años y engendró a su último hijo pasados los 86. Proverbiales fueron también las largas vidas del poeta del siglo VI a.C. Epiménides de Creta, quien vivió más de 150 años (Plin. NH 7.48 y 7.52; Plut. Mor. 784b; Val. Max. 8.13.ext.5) y de Néstor, rey de Pilos, a quien Ovidio (Met. 12.170) hace declarar que tiene más de 200 años. Precisamente Néstor, junto a Príamo, Niobe, Hécuba y Laertes, es caracterizado en la literatura como extremadamente anciano, y aparece frecuentemente como comparativa en aquellos textos en los que se desea reasaltar la especial longevidad de alguien, sobre todo en fragmentos con fines cómicos (Cic. Sen. 10.31; Mart. 3.32, 3.76, 6.70, 9.29 y 10.67; Priap. 57 y 76; Sen. Ep. 77.20; Verg. Aen. 2.509-511).

Vemos, por lo tanto, que nos movemos entre personajes legendarios y mujeres y hombres reales. La proverbial longevidad de algunos de los individuos nombrados, sobre todo en el caso de los gobernantes, los dota de un halo de sabiduría y experiencia, resaltando su autoridad y la estabilidad de sus reinados. ¿Pero qué ocurre en el caso de Sámula y las personas nombradas en el censo consultado por Flegón y Plinio?

Además de la tendencia a la exageración, tema ampliamente discutido por la historiografía y sobre el que volveremos más adelante, ciertos autores, conocedores de estas historias de extrema longevidad, dan cuenta de una posible explicación para dicho fenómeno. Así, Diodoro Sículo (1.26.1-6), escribe que la larga vida que los egipcios atribuyen a algunos faraones se debe a que éstos medían el tiempo de acuerdo con los ciclos de la luna, y no con los del sol. Censorino (DN 19 y 20) y Macrobio (Sat. 1.12.3) también señalan que en las sociedades antiguas existían diversos modos de medir el tiempo, los cuales condicionaban la vida de la población. Por otro lado, debemos tener en cuenta que el propio calendario romano varió en el tiempo. En el año 46 a.C. Julio 
César emprendió una reforma en el calendario, creando un año de 365 días (366 cada cuatro años) divididos en 12 meses, el cual ha permanecido prácticamente inalterado hasta nuestros días (Cass. Dio 44.5.2; Cen. DN 20; Ov. Fast. 3.155-165; Suet. Aug. 31.2).

Los expertos no se ponen de acuerdo sobre cuántos calendarios operaron en Roma con anterioridad al juliano (Hannah, 2005: 99; Ruiz, 1976; Rüpke, 2011: 23-40). Parece ser que Rómulo, en el siglo VIII a.C., habría creado uno de base lunar con un año que constaba de 304 días divididos en 10 meses, al que también se le atribuye origen albano (Cen. DN 20; Macrob. Sat. 1.12.3; Ov. Fast. 1.27). Según Ovidio (Fast. 1.30-35) la elección del número de meses se debió a que 10 meses era el tiempo que los romanos estimaban que duraba un embarazo. Este mismo autor (Ov. Fast. 1.41; 5.428 y 6.84-89) señala que, en este calendario, mayo fue llamado así en honor a las personas ancianas (maiores), idea que recogen también Plutarco (Mor. 285b) y más tarde Ausonio (Ecl. 10.9). Alude Ovidio a los tiempos de Rómulo, regidos por la pietas:

"En otro tiempo era grande el respeto dispensado a una cabeza con canas, y las arrugas de los viejos eran objeto de consideración. Los jóvenes administraban la obra de Marte y las guerras animosas y se mantenían en sus puestos de defensa de los dioses de cada uno; la edad disminuida en sus fuerzas e inútil para sostener un arma, muchas veces, con su consejo, era de ayuda para la patria. La curia se abrió entonces sólo para los de años maduros y el apacible nombre del senado procedía de la edad. Los viejos daban leyes al pueblo, y se fijaron límites de edad determinados para ser candidato a un cargo a partir de ellos. El viejo marchaba en medio de los jóvenes, sin que éstos se lo tomasen a mal, y si sólo le acompañaba uno, en la parte de dentro. ¿Quién se iba a atrever a decir palabras ruborizantes en presencia de un viejo? La censura la proporcionaba una prolongada vejez. Rómulo reparó en esto y llamó padres a los individuos que había seleccionado; a ellos les confió el gobierno de la nueva ciudad. Por ello me siento tentado a pensar que los viejos dieron su nombre a mayo, y de esta manera se guiaron por su edad. Y Númitor pudo decir: "Rómulo, asigna este mes a los viejos", y el nieto no pudo oponerse al abuelo. Y no es ligera la prueba del honor propuesto que proporciona el mes siguiente, junio, sea así llamado por el nombre de los jóvenes” (Ov. Fast. $5.55-79)^{35}$.

\footnotetext{
${ }^{35}$ Magna fuit quondam capitis reverentia cani, inque suo pretio ruga senilis erat. Martis opus iuvenes animosaque bella gerebant, et pro dis aderant in statione suis; viribus illa minor nec habendis utilis armis consilio patriae saepe ferebat opem; nec nisi post annos patuit tunc curia seros, nomen et aetatis mite senatus habet. Iura dabat populo senior, finitaque certis legibus est aetas unde petatur honor, et
} 
Un siglo más tarde, el rey Numa habría sustituido el calendario de Rómulo por otro de 355 días y 12 meses (Cen. DN 20; Macrob. Sat. 1.13), el cual habría operado durante toda la etapa republicana, no sin periódicas modificaciones debido a los desfases que iban surgiendo (Derow, 1973 y 1976; Hannah, 2005: 106 y ss.; Ruiz, 1976).

Fueran uno, dos, o más los calendarios prejulianos, habrían provocado desajustes $\operatorname{continuados}^{36}$, sobre todo a largo plazo, una muestra de los cuales hemos representado en la Tabla 2. Las diferencias más notorias se producen entre los años posteriores al 46 a.C. y la época de vigencia del sistema de Rómulo; así, alguien que tras el 46 a.C. cumpliese 50 años, habría tenido alrededor de 58 años de acuerdo con el primer calendario. El desfase se acrecenta a medida que aumentamos las cifras: una vetula o un senex de 90 años calculados de acuerdo al calendario del fundador de la Urbs, se convertirían en menos de 74 en el juliano. De esta forma si Argantonio hubiese sido ciudadano romano, al morir con 150 años en el siglo VIII a.C., habría fallecido con 124 años del calendario juliano, una cifra que sigue siendo elevada pero algo más plausible, sobre todo si tenemos en cuenta la posibilidad de que en Tartessos el año fuese aún más corto. Si optamos por dar como válida la existencia de los tres calendarios expuestos, la variación sería menor, pero de la misma forma habría provocado desajustes ${ }^{37}$. Éstos pudieron ser los causantes, no sólo de edades cronológicas que de acuerdo al actual sistema parecen desorbitadas, sino también de las propias dudas acerca de los años cumplidos, sobre las que volveremos en el apartado dedicado a la demografía.

Por otro lado, y dejando de lado a personajes legendarios cuya longevidad debemos tomar con cautela, no podemos descartar la veracidad de las declaraciones de algunas de las personas señaladas. Sámula, Livia, Terencia, Estatila, así como los hombres y mujeres recogidos por Plinio y Flegón como inscritos en el censo de mediados del siglo I d.C., habrían nacido previamente o durante el periodo de adaptación del calendario prejuliano al juliano. No podemos saber hasta qué punto este cambio alteró sus vidas y la concepción que tenían de su edad cronológica, a pesar de que si realizamos equivalencias entre ambos años, el de 355 y el de 365 días, la

medius iuvenum, non indignantibus ipsis, ibat, et interior, si comes unus erat. Verba quis auderet coram sene digna rubore dicere? censuram longa senecta dabat. Romulus hoc vidit selectaque pectora patres dixit: ad hos urbis summa relata novae. Hinc sua maiores tribuisse vocabula Maio tangor, et aetati consuluisse suae. Et Numitor dixisse potest "da, Romule, mensem hunc senibus", nec avum sustinuisse nepos. Nec leve propositi pignus successor honoris Iunius, a iuvenum nomine dictus, habet.

${ }^{36}$ Para un análisis detallado de las variaciones del calendario romano, vid. Hannah, 2005, esp. 98-130.

37 De hecho, hasta el año 8 d.C. el calendario juliano no fue operativo como tal, ya que desde su promulgación hasta este momento hubo que compensar los días perdidos. 
diferencia es tan poco notable que no puede emplearse como justificación a declaraciones de cifras tan elevadas ${ }^{38}$. Estos senes y vetulae nacieron además antes de que se implantase el sistema de registro de nacimientos de Augusto al que haremos referencia más adelante, y por lo tanto puede que ni ellos ni la administración contasen con medios para conocer su fecha exacta de nacimiento.

Finalmente y teniendo en cuenta que las personas ancianas que podemos conocer a través de la epigrafía y de fragmentos literarios como los de Plinio y Flegón son sólo una ínfima parte de la población romana, no podemos omitir la posibilidad de que en algunos casos se trate de personas que realmente alcanzaron edades tan elevadas, y que éstas sean recogidas precisamente por cuanto que extraordinarias.

Por el contrario, sí que podemos descartar la veracidad de la extrema longevidad de algunas otras personas mencionadas. Es el caso del poeta Epiménides, ya que el calendario griego por el que debió medirse su edad cronológica constaba de años de 354 días a los que, con una periodicidad que no se ha establecido de forma clara, se añadía uno de 384 en aras de corregir los desajustes, lo que arroja un resultado muy parecido a nuestro calendario actual (Thomson, 1943).

Resultan también inverosímiles las declaraciones superiores a 130 años, sobre todo si las comparamos con los récords señalados al comienzo de este apartado. No obstante, tener en cuenta estos datos sirve para ilustrarnos acerca del riesgo de medir con nuestra división temporal actual edades de épocas pasadas y prevenirnos sobre la tendencia a desechar directamente aquellas edades que consideramos extremas sin tener en cuenta el conexto histórico en el que nos son referidas.

\section{II.2.2.EI ciclo vital y la frontera de la vejez en la antigua Roma}

Este periodo de cerca de 100 años que los romanos creían que podía durar la vida humana se encontraba dividido, al igual que en la actualidad, en diferentes etapas que juntas conforman el denominado ciclo vital, el cual sirve para institucionalizar la vida en diversas secuencias, asociando a cada una de ellas unas características concretas.

\footnotetext{
38 Tomémos como ejemplo la edad más alta apuntada en el censo de Vespasiano y Tito, la de tres individuos, L. Terentius, M. Aponius y M. Mucius, que declaran tener 140 años y que por lo tanto habrían nacido en los años 67-66 a.C. Si el calendario juliano se implantó definitivamente en el año 8 d.C., estos hombres habrían vivido de acuerdo al cómputo anterior 74-75 años, que se convertirían en 71-72 si hacemos la conversión al año de 365 días; de este modo, si el calendario juliano hubiese estado en vigor cuando nacieron, en su declaración censal habrían manifestado tener 137 años. La referencia a los cálculos matemáticos realizados se encuentra en la Tabla 2.
} 
Cuando nos enfrentamos a la concepción del ciclo vital en la antigua Roma debemos tener en cuenta que éste tiene dos dimensiones, aunque veremos que en ocasiones ambas pueden solaparse. Por un lado, nos encontramos con divisiones amplias, que generalmente adscriben a la vida una temporalidad compuesta por cuatro etapas (Amm. Marc. 14.6.4; Cic. Sen. 10.33; Diod. Sic. 10.9.5; Ov. Met. 15.200-226; Sen. Ep. 20.121.16), tantas como estaciones tiene un año: niño, joven adulto, hombre maduro y viejo para los hombres, y niña, doncella, mujer casada y vieja para las mujeres. Así, por ejemplo, para Ovidio:

"¿Y no que en apariencias cuatro se sucede el año ves, realizando las imitaciones de la edad nuestra? Pues tierno y lactante y semejantísimo de un recién nacido a la edad en la primavera nueva es. Entonces la hierba reciente y de dureza libre está turgente y sólida no es y en su esperanza deleita a los campesinos. Todas las cosas entonces florecen, y con los colores de las flores, nutricio, juega el campo, y todavía virtud en sus frondas ninguna hay. Pasa al verano, tras la primavera, más robusto el año y se hace un vigoroso joven, pues ni más robusta edad ninguna, ni más fértil, ni que más arda, ninguna hay. La releva el otoño, depuesto el fervor de la juventud, maduro y suave y, entre el joven y el viejo, en templanza intermedio, asperjado también en sus sienes de canas. Después la senil mala estación llega, erizada con paso trémulo, o expoliada de los suyos $-\mathrm{o}$ de los que tiene, blanca- de cabellos" (Ov. Met. 15.200-214)

En ocasiones puede agregarse una quinta etapa, la adolescencia (Serv. Aen. 5.295) o una sexta, dividiendo el primer estadio en dos: infancia y niñez (August. Div. Quaest. 58 y 64). En Plutarco (Mor. 392c) encontramos incluso una división en ocho etapas, en las que se distingue además entre dos tipos de ancianidad: feto, criatura, niño, muchacho, joven, hombre, viejo y anciano.

Por otro lado, contamos con una división cronológica, que puede o no coincidir con la clasificación ya expuesta, y que suele estar basada en números con significados simbólicamente relevantes, como es el caso del siete, suma de los cuatro elementos y los tres dioses principales del panteón (López Pulido, 2013: 56).

\footnotetext{
${ }^{39}$ Quid? Non in species succedere quattuor annum adspicis, aetatis peragentem imitamina nostrae? Nam tener et lactens puerique simillimus aevo vere novo est: tunc herba recens et roboris expers turget et insolida est et spe delectat agrestes; omnia tunc florent, florumque coloribus almus ludit ager, neque adhuc virtus in frondibus ulla est. Transit in aestatem post ver robustior annus fitque valens iuvenis: neque enim robustior aetas ulla nec uberior, nec quae magis ardeat, ulla est. Excipit autumnus, posito fervore iuventae maturus mitisque inter iuvenemque senemque temperie medius, sparsus quoque tempora canis. Inde senilis hiems tremulo venit horrida passu, aut spoliata suos, aut, quos habet, alba capillos.
} 
Una de las imágenes más completas acerca de la concepción del ciclo vital en la Antigüedad nos la proporciona Censorino en su obra De die natali, escrita en el año 238 d.C. como regalo de cumpleaños a su maestro. Las diversas teorías expuestas por Censorino y el resto de autores a los que nos referimos a este respecto están resumidas en la Tabla 3.

Censorino ( $D N 14)$ hace referencia en su obra a las opiniones de distintos autores acerca de las divisiones del ciclo vital y de la duración de cada una de ellas. Cita a Solón (ss. VII-VI a.C.), quien parece haber sido el primero en establecer una división basada en el número siete. Para Solón existían diez periodos vitales, a los que Censorino se refiere como septennates, de siete años de duración cada uno, el último de los cuales finalizaba a los 70 años, edad máxima que Solón creía que podía alcanzarse. Para Solón, cada etapa se caracterizaba por un hecho concreto: la primera por la caída de los dientes de leche, la segunda por los primeros síntomas de la pubertad, la tercera por la aparición de la barba, la cuarta por alcanzar la plenitud física, la quinta por la madurez sexual, la sexta por la moderación en las pasiones, la séptima por la plenitud mental y retórica, la octava por el declive en la visión, la novena por el debilitamiento de todas las facultades, y la décima por el declive previo a la muerte.

Hipócrates (ss. V-IV a.C.) también habría adoptado como clave el mismo número, dividiendo el ciclo vital en siete etapas; las seis primeras con una duración de siete años y la última, que comenzaba a los 56 años, prolongada hasta la muerte. Esta división fue tomada siglos después por el filósofo judío Filón de Alejandría (ss. I a.C. - I d.C.) (De op. 36.105).

Para los etruscos, Censorino señala que existían doce etapas, cada una de ellas de siete años también. No obstante, las dos últimas no eran demasiado deseables; pasados los 80 años los etruscos no veían necesario pedir a los dioses una vida más larga, ya que creían que una vez cumplidos los 84 el ser humano perdía todas sus facultades y no merecía la pena seguir viviendo.

Censorino cita también a Varrón (ss. II-I a.C.), para quien el ciclo vital estaba dividido en cinco etapas de 15 años de duración cada una. La primera etapa era la de los pueri (niños) y duraba hasta los 15 años. Le seguía la etapa de los adulescens (adolescentes), llamada así porque era el periodo en el que comenzaba realmente la vida de un romano (adolescere). La tercera fase, que transcurría entre los 30 y los 45 años, pertenecía a los iuneves, aquellos que defendían al Estado en el ejército. Le seguía la etapa de los seniores, llamados así porque su cuerpo empezaba a envejecer (senescere). 
Finalmente, la última etapa comenzaba al cumplir 60 años y terminaba con la muerte. Las personas que se encontraban en esta etapa eran denominadas senes. Vemos así cómo para Varrón la vida se dividía en periodos de acuerdo con las tareas asignadas al hombre: una primera etapa de aprendizaje, seguida del servicio militar, terminado el cual el ciudadano ocupaba las magistraturas, y finalmente la vejez que conducía a la muerte ${ }^{40}$.

En la misma época que Varrón, el filósofo peripatético Staseas tomó la división de Solón y añadió a esta organización dos etapas más, también de siete años cada una. Según Censorino, este autor llamó la atención sobre la dificultad de alcanzar y traspasar la última de las fases, la cual comenzaba a los 84 años. De ello podemos deducir que alcanzar esta edad no era la norma en la Roma tardorrepublicana. Para Censorino esta división en 12 etapas basadas en múltiplos de siete era la más correcta, ya que creía que era cada siete años cuando la naturaleza afectaba al cuerpo humano de tal forma que producía en él profundos cambios.

En el siglo II d.C. Aulo Gelio (NA 10.28) presentaba una división del ciclo vital en tres etapas: pueritiae, iuventae y senectae. La primera transcurría desde el momento del nacimiento hasta los 17 años, la segunda desde los 18 hasta los 45, y la tercera comenzaba a los 46 años y terminaba con la muerte. Al igual que ocurría con Varrón, su división se basa en las etapas de la vida pública del ciudadano romano. En la misma época que Gelio, Galeno (De san. 1.12, 4.1 y 5.2-3) muestra en sus textos diferentes formas de clasificar el ciclo vital. Si bien las etapas a las que hace referencia son siempre cuatro (niñez, adolescencia, juventud y vejez), las edades de comienzo de algunas de ellas no coinciden. Se trata de una división que en el siglo IV d.C. será empleada por Macrobio (In Somn. 1.6.71-76). Tal y como pone de manifiesto Wieslaw Suder (1978: 7), especialmente problemático resulta el hecho de que Galeno señale como comienzo de la niñez los siete años, y no haga referencia a una etapa anterior. Para este mismo autor (Suder, 1978: 7), el que el médico proponga varias clasificaciones se debe a que una de ellas se basaría en la biología, mientras que otra lo haría en la legislación. Algo parecido ocurre en el caso tardío de San Agustín (Div. quaest. 58), quien como ya hemos señalado fija el comienzo de la vejez en 60 años, si bien cuando él escribe la legislación consideraba exentos de pagar impuestos y de ciertos cargos a los mayores de 70 (Dig. 27.1.2, 27.1.15.11, 50.2.2.8, 50.4.3.12 y

\footnotetext{
${ }^{40}$ Para un análisis en profundidad de la relación entre ciclo vital y cursus honorum, vid. Parkin, 2003: 96 y ss.
} 
50.6.3). En lo que respecta a la vejez, Galeno le da comienzo a los 48 años, un poco más tarde que los autores que basan sus divisiones en la ostentación de cargos públicos.

Finalmente contamos con un autor tardío, Isidoro de Sevilla (ss. VI-VII d.C.), quien si bien escapa al marco cronológico de nuestra Tesis Doctoral, nos parece oportuno destacar porque en sus obras, al igual que ocurre con Plutarco, se aprecia una doble división de la vejez que se asemeja a la "tercera" y "cuarta" edades a las que nos referíamos en el apartado II.1 del presente capítulo. Así, Isidoro (Diff. 2.74-7; Etym. 11.2) plantea una división del ciclo vital en seis etapas, diferenciando entre dos momentos de vejez que él denomina senectus/aetas senioris y senium/senectus. La primera vejez, que Isidoro llama también madurez, comenzaría a los 50 años, y se caracteriza por ser "el paso de la juventud a la ancianidad: no es todavía ancianidad, pero tampoco es ya juventud" (Isid. Etym. 11.2.6) ${ }^{41}$. Le sigue la sexta y última etapa, que da comienzo a los 70 años, en la cual sólo cabe esperar la muerte. Isidoro propone por lo tanto la existencia de dos fases, una en la que comienza el declive hacia la ancianidad, pero en la que el ser humano a pesar de no ser ya joven aún tiene plenas facultades y no se le atribuyen las características negativas asociadas a la vejez, en la que la persona "aún se mantiene bastante fresca" (Isid. Etym. 11.2.25) ${ }^{42}$; y otra "digna de lástima por su debilidad y desamor" (Isid. Etym. 11.2.30) ${ }^{43}$.

De acuerdo con lo desarrollado a lo largo del presente apartado, podemos suponer que, de forma general, las teorías acerca del ciclo vital y la duración máxima de la vida antes expuestas servían de referencia a toda la sociedad romana, aunque algunas de ellas atendían a convenciones filosóficas que, para Tim Parkin (2003: 18) quizás no fuesen empleadas con rigurosidad de forma cotidiana.

Para establecer cuál es la frontera de la vejez, algunos de los autores citados se basaron en la creencia de que existían ciertas edades que marcaban momentos de especial relevancia, denominados climaterios. Siguiendo a Censorino (DN 14), los 49 años (el resultado de multiplicar el simbólico número siete por sí mismo) eran una de estas edades críticas, quizás el comienzo de la degeneración propia de la vejez. Séneca el Viejo (Suas. 6.22) señala que la muerte de Cicerón, a los 63 años, no puede considerarse prematura. Este número, el 63, también se repite en otros autores; es la

\footnotetext{
${ }^{41}$ quae est declinatio a juventute in senectutem; nondum senectus sed iam nondum iuventus.

${ }^{42}$ Senior est adhuc viridior.

${ }^{43}$ quia senium miserrimum est debilítate et odio.
} 
edad en la que, por ejemplo, Séneca señala que se siente extremadamente anciano (Sen. Ep. 12.1 y 26.1-2). Resultado de multiplicar siete y nueve, otro número con especial simbolismo dada su relación con el ciclo vital de la naturaleza, la luna y la vida y la muerte (Gavilanes, 1995), era para Aulo Gelio (NA 15.7.1-2) un cumpleaños que siempre venía acompañado de alguna desgracia o enfermedad. En este sentido, el 81 (nueve multiplicado por sí mismo), también es una edad considerada crítica (Cen. DN 14).

Si bien estas edades serían empleadas a modo de guía, diversos autores hacen referencia a otras edades como seniles. Así Periplectómeno, personaje de Plauto, aparece caracterizado como anciano a la edad de 54 años (Plaut. Mil. 628-634). Tito Livio (30.30) calificaba a Aníbal como senex cuando éste no había cumplido los 45 años; la misma edad que tenía Marcial cuando se llama a sí mismo viejo (Mart. 1.108.4). Cicerón llama senes a Craso (Cic. De Or. 2.4.15) y Póstumo (Cic. Sen. 3.7) cuando rondan los 50 años; sin embargo, un hombre fallecido en Mauretania en el siglo III con esa misma edad aparece como muerto en la "flor de la juventud" (flos iuventutis) (CIL 8.9158). Por su parte, para San Agustín (Div. quaest. 58) la vejez comienza como ya hemos señalado a los 60 años.

Vemos en definitiva cómo la Antigüedad greco-romana concebía en general la vida como un ciclo compuesto por un número variable de etapas basadas en el número siete. A pesar de esta variabilidad, se percibe cómo griegos y romanos, una vez alcanzada la etapa adulta, percibían la existencia de una transición desde la madurez a la vejez y de ésta a una vejez extrema, una transición caracterizada por una debilidad física y mental paulatina y una mayor dependencia. Es por ello quizás que algunas concepciones del ciclo vital, como la de Solón, no abarcan la ancianidad extrema, debido a la negación de las condiciones de decadencia que en ocasiones acaecen en la vejez. Hemos comprobado también cómo la división en etapas del ciclo vital se hace teniendo como protagonista al hombre, ya sea en su dimensión pública, como hace Varrón, o biológica, tomando como acontecimiento clave la aparición de la barba.

Se aprecia, por otro lado, que a pesar de las diversas teorías, éstas no se diferencian mucho entre sí, lo que podría indicar, por un lado, que la concepción que se tenía en la Antiguiedad de la vejez no varió mucho y, por otro, que las personas ancianas fueron parte reseñable de la población en todas las épocas. De hecho, Tim Parkin (1992: 134) calcula que en época clásica las personas mayores de 60 años supondrían entre el 
$5 \%$ y el $10 \%$ del total de la población, una tasa que no se aleja mucho de la actual. Vemos también cómo la edad cronológica a la que se alcanza la vejez varía según los autores y la época en la que escriben los mismos, si bien tiende a situarse el comienzo de la misma hacia los 50 años, cifra que coincide con la que se ha adoptado como criterio cronológico que caracteriza a las vetulae en nuestra investigación

Con todo, siendo la ancianidad una etapa vital eminentemente social y un fenómeno que se muestra flexible veremos cómo, especialmente en el caso de los hombres, estos límites no hacían que las personas que los sobrepasaban se sintiesen siempre viejas. Ya hemos señalado en este sentido que ciertos autores hacen una distinción entre dos fases de vejez, una en la que comienza la senectud y otra que le sigue y donde empiezan a apreciarse con claridad los síntomas de la ancianidad. Además, cabe la posibilidad de que al caracterizarse la vejez por la cercanía a la muerte, la enfermedad, y el retiro de los asuntos públicos, hubiera quienes deseasen presentarse como jóvenes a pesar de su avanzada edad cronológica.

Una vez establecida la edad a la que en Roma se consideraba que alguien había alcanzado la vejez, debemos cuestionarnos la validez del baremo cronológico, ya que en este punto surge una nueva incógnita: ¿sabían todos los romanos qué edad tenían? Y la administración, ¿conocía la edad de los habitantes de Roma?

Tim Parkin (2003: 31), si bien cree que la edad cronológica de un individuo no era un dato al que los romanos daban demasiada importancia, dedica buena parte de Old Age in the Roman World a intentar resolver las dos cuestiones que acabamos de plantear. Para este autor (Pakin, 2003: 33), gran parte de la población de Roma no conocería su edad exacta debido a que no resultaba un dato necesario para realizar acciones cotidianas, al contrario de lo que ocurre hoy en día, aunque reconoce que en algún punto de sus vidas les sería necesario saberla, ya fuera para calcular la edad mínima para contraer matrimonio, para manumitir o ser manumitido, para acceder a ciertos puestos administrativos... Esta misma idea la postula Andrew Burn (1953: 4), quien señala que muy poca gente sabría su edad exacta en Roma, por lo que tenderían a exagerar la misma o bien a emplear múltiplos de 5, fenómeno al que volveremos en las siguientes páginas.

En nuestro caso, creemos que buena parte de la población romana sería conocedora de su edad, o podría acceder con facilidad dicho dato. Tanto la literatura como la epigrafía hacen referencia a personas que señalan su edad o la de otras, entre 
ellas la población esclava (Dig. 40.1.1, 50.15.4.5 y 50.15.3; Dion. Hal. Ant. Rom. 4.6.5; Macrob. Sat. 2.5.2; Plin. NH 14.8.60; Sen. Ep. 77.20; Val. Max. 8.13), llegando en ocasiones a una precisión de meses, días, e incluso horas; una minuciosidad que por otro lado se aprecia tanto en la juventud como en la vejez. Ocurre por ejemplo con Avidia Dorotea (CIL 6.12891), fallecida con dos años, cinco meses y 24 días, y con Calvia Fortunata ( $A E$ 1994, 466), quien murió con 81 años, tres meses y cinco días de edad.

Prueba de ello son también las diversas leyes que aluden a una edad concreta. Ya en época de Rómulo una ley dictaba que para acceder a ciertos cargos sacerdotales el candidato debía haber cumplido 50 años (Dion. Hal. Ant. Rom. 2.21.3). A finales del siglo V a.C. los censores Marco Furio Camilo y Marco Postumio Albino Reginense promulgaron una ley según la cual todos aquellos romanos que habían alcanzado la vejez sin descendencia eran multados, aunque Valerio Máximo (2.9.1) no refiere cuál era la edad fijada para ser sancionado. En el siglo II a.C. se establecieron las edades mínimas para acceder al servicio militar y el cursus honorum senatorial, las cuales además fueron redefinidas a lo largo del tiempo (Parkin, 2003: 95-99). Contamos además con la legislación de Augusto sobre el matrimonio a la que aludimos varias veces a lo largo de estas páginas. Ya en el siglo IV d.C., un edicto reglaba que si las mujeres mayores de 18 años en adelante y los hombres de 20 años en adelante querían conseguir el estatus de maiores, debían probar su edad (Iust. Cod. Iust. 2.44.2). En el caso del Egipto romano, tenemos noticia de la existencia de diversos impuestos que se aplicaban a partir de cierta edad, para lo que resultaba necesario que, al menos la administración supiese la edad cronológica de sus ciudadanos, aunque no sabemos si había figuras parecidas en el resto del imperio (Parkin, 2003: 143 y 164).

La edad cronológica era también relevante en lo que respecta a las adopciones; así, Justiniano (Inst. 1.11.4) y el Digesto (17.40) señalan que la persona adoptante debía ser al menos dieciocho años mayor que la adoptada, mientras que en otras ocasiones (Gai. Inst. 1.102), a pesar de que no se fija una edad concreta, se especifica que quien adopta debe ser mayor que quien es adoptado, con una diferencia de edad suficiente como para que pudieran ser padre/madre e hijo/hija biológicos. Contamos también con las leyes que fijan la frontera de los 70 años como edad a partir de la cual desaparecen ciertas obligaciones, 50 en el caso de las todas las obligaciones que las libertas tienen para con sus patronos (Dig. 38.1.35). 
Podemos sumar aquí la legislación relativa a la obligatoriedad de informar al comprador de la edad de los esclavos en venta de ambos sexos (Dig. 19.1.21.1 y 50.15.4.5) o a la capacidad de manumisión, para lo cual la lex Aelia Sentia promulgada en época de Augusto establecía edades mínimas tanto para quien concedía la libertad

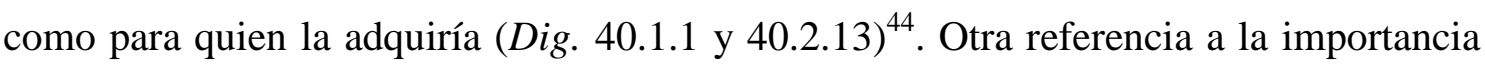
de conocer la edad de las personas esclavas la encontramos en el Edicto de los Precios de Diocleciano (Harper, 2011: 62) en el cual se establecían precios máximos de venta que variaban según sexo y edad. Aunque se trata de un documento tardío, promulgado en el 301 d.C., ello no quiere decir que la variabilidad de precios de la población esclava con atención a la edad no existiera con anterioridad.

La edad también resultaba relevante a la hora de aplicar ciertas multas y condenas, que eran suavizadas a los ancianos (Dig. 48.19.22; Plin. Ep. 10.32; Val. Max. 2.9.1). Finalmente, el criterio cronológico forma parte de disposiciones relacionadas con los testamentos, la comparecencia en juicios, la administración de bienes, y exenciones de diversa naturaleza (Dig. 22.4.6, 22.5.8, 26.1.13, 27.1.2, 27.1.15.11, 38.1.16.1, 50.2.28, 50.4.3.6, 50.4.4.6 у 50.4.3.12).

Sabemos por otro lado de la realización de diversos censos tanto en época imperial como republicana (Cic. Leg. 3.3.7; Dig. 50.15.3; Dion. Hal. Ant. Rom. 4.15.6; Phl. 1-99; Ov. Ars am. 2.665 y 3.60; Plin. NH 7.49.162-164), aunque en algunas ocasiones sólo se refieran a los hombres ciudadanos y adultos, dejando fuera a otros sectores de la población. Es el caso del censo de los años 133-129 a.C., que excluía a los menores y a las viudas (Liv. Per. 59.7). Ocurriría lo mismo con la población extranjera. Además, solamente tenemos noticia de la realización de censos ocasionales, y no podemos saber si se realizaron recuentos periódicos o sólo se dieron en momentos puntuales debido a causas concretas.

Una noticia reseñable acerca de este tipo de documentación nos la proporciona Plinio (NH 7.49), quien al hacer referencia al censo de los años 73-74 d.C. al que ya hemos hecho alusión en este capítulo, dice también que para probar la existencia de personas especialmente longevas no le ha sido necesario consultar todos los registros, sino sólo los de la región que finalmente escoge, lo que implicaría que, si así lo hubiera deseado, habría podido acceder al resto de la documentación. Además de probar la existencia del registro de los datos del censo, ¿significan las palabras de Plinio que

\footnotetext{
${ }^{44}$ Para más ejemplos de legislación donde se alude a edades concretas, vid. Gardner, 1986: 144 y ss. y 1998: 145 y ss.
} 
cualquiera que lo desease podía acceder a los mismos? Por otro lado, si tal y como cree Marie-Thérèse Fontanille (2004: 13) Flegón de Trales, quien vivió un siglo después de Plinio, también tuvo acceso a los datos censales de forma directa, ello significaría que este tipo de documentación era guardada durante un periodo largo de tiempo, lo que posibilitaría tanto a personas muy longevas como a sus familiares y a la administración conocer fechas de nacimiento y lugares de residencia. Quedaría por responder la pregunta, en este caso, de por qué Flegón decidió consultar un censo realizado décadas antes de su tiempo. Tim Parkin (2003: 38) sostiene una interpretación distinta de ambos textos y no considera que la información que proporcionan sea veraz, sino más bien un síntoma de la ineficacia de la administración para tomar datos demográficos fiables. En relación con esta hipótesis, cabría preguntarse por qué ni Plinio ni Flegón se cuestionan la veracidad de las edades con las que dan en la documentación, algo que sería de esperar que hicieran en el caso de que las hubiesen considerado falsas, como hace el primero en el caso de Argantonio (Plin. NH 7.49).

Junto a los censos, debemos tener en cuenta las referencias a los registros de nacimiento $^{45}$. A principios del siglo I d.C. Augusto introdujo, mediante las leyes Aelia Sentia y Papia Poppaea, un sistema de registro de nacimientos para los niños y niñas de condición ciudadana nacidos de matrimonios legítimos que debía realizarse en el plazo máximo de 30 días desde el nacimiento, pudiendo llevarlo a cabo tanto el padre como la madre o el abuelo (Dig. 22.3.16). Más adelante, Marco Aurelio modificó la ley para que también tuvieran que ser registradas las personas nacidas de matrimonios ilegítimos (SHA Marc. 9.7-9; Schultz, 1943: 59 y ss.). La población no ciudadana estaba exenta de esta obligatoriedad; no obstante, Fritz Schultz (1942: 83) presenta casos en los que peregrini solicitaban a la administración que sus hijos fueran registrados, de forma que si lo necesitaban en algún momento pudieran certificar su edad. Como ejemplos en los que se nos habla de este tipo de documentación, contamos con una referencia a Calígula hecha por Suetonio (Suet. Calig. 8), quien busca en los archivos el registro de nacimiento del emperador para saber cuál fue su lugar exacto de nacimiento, así como con un largo fragmento de la Apología de Apuleyo, en el cual el filósofo rebate la acusación de que se había casado con Emilia Pudentila siendo ella una vetula:

"En cuanto a la edad de Pudentila, acerca de la cual has mentido con tanto descaro, que incluso has llegado a decir que se casó conmigo cuando ya tenía sesenta años,

\footnotetext{
${ }^{45}$ Para profundizar en el análisis de este tipo de documentación, vid. Schultz, 1942 y 1943, donde se analizan las formalidades relativas a los registros de nacimiento y se muestran diversos ejemplos.
} 
voy a contestarte en pocas palabras, ya que en un asunto tan claro no es preciso discutir mucho. Al nacer Pudentila, su padre, como suelen hacer los demás padres, la inscribió en el registro civil. El documento que así lo acredita figura en el archivo público y una copia del mismo se conserva en su domicilio: ahora mismo te lo van a poner ante tus narices. Preséntale ese documento a Emiliano: que examine el precinto de lino, que reconozca la autenticidad de los sellos impresos en él, que lea los nombres de los cónsules, que saque la cuenta de los años, a ver si son los sesenta que asignaban a mi mujer. Que demuestre, al menos, que son cincuenta y cinco: concedamos que haya mentido solamente en un lustro. Es poco aún; seré más generoso. Como él mismo ha concedido a Pudentila muchos años de más, no le voy a regatear a mi vez, diez años. Mecencio ha errado con Ulises: que demuestre, por lo menos, que mi mujer tiene cincuenta años. ¿Para qué más? Como si se tratase de un delator profesional, multiplicaré los cinco años por otros cuatro y quitaré de golpe veinte años. Ordena, Máximo, que se cuenten los consulados transcurridos: si no me engaño, hallarás que la edad de Pudentila apenas sobrepasa los cuarenta años" (Apul. Apol. 89.1-5) ${ }^{46}$.

El texto de Apuleyo no sólo nos habla de la existencia de los registros de nacimiento y de la norma de inscribir en ellos a la descendencia, sino también del hecho de que, al menos en el caso de Pudentila, se conservaba una copia de la declaración en el hogar familiar.

Finalmente, tenemos noticia de algunos pocos casos concretos en los que resultaba necesario conocer con exactitud la edad cronológica. A finales del siglo III d.C., Marciana mandaba una petición a Diocleciano y Maximiano solicitándoles un favor desconocido relacionado con que aún no había cumplido los 25 años (Iust. Cod. Iust.). La respuesta que recibe es que debe presentarse ante el gobernador de su provincia y probar su edad, seguramente mediante una partida de nacimiento como la empleada en el caso de Pudentila. Por otro lado tenemos evidencias de que en ocasiones estas declaraciones de nacimiento no eran suficiente prueba de edad y se requería la entrega de otro tipo de documentación o la presencia de testigos (Dig. 22.3.13, 22.5.3.2

\footnotetext{
46 De aetate uero Pudentillae, de qua post ista satis confidenter mentitus es, ut etiam sexaginta annos natam diceres nubsisse, de e tibi paucis respondebo: nam necesse non est in re tam perspicua pluribus disputare. Pater eius natam sibi filiam more ceterorum professus est. Tabulae eius partim tabulario publico, partim domo adseruantur, quae iam tibi ob os obiciuntur. Porrige tu Aemiliano tabulas istas: linum consideret, signa quae impressa sunt recognoscat, consules legat, annos computet, quos sexaginta mulieri adsignabat. Probet quinque et quinquaginta: lustro mentitus sit. Parum hoc est, liberalius agam; nam et ipse Pudentillae multos annos largitus est. Redonabo igitur uicissim decem annos: Mezentius cum Vlixe errauit. Quinquaginta saltem annorum mulierem ostendat. Quid multis? Vt cum quadruplatore agam, bis duplum quinquennium faciam, uiginti annos semel detraham. Iube, Maxime, consules computari. Nisi fallor, inuenies nunc Pudentillae haud multo amplius quadragensimum annum aetatis ire.
} 
y 27.1.2). Así, no podemos asumir que todos los romanos y romanas llevaban encima durante su día a día una copia de su certificado de nacimiento, o que guardasen una copia en casa como hizo Pudentila, por lo que normalmente se creería lo que declarase el individuo en cuestión, requiriendo pruebas sólo cuando fuese necesario, las cuales podían encontrarse tanto en los registros de nacimiento como en el censo (Dig. 27.1.2).

No obstante, nos encontramos también con ejemplos en los que se muestra el desconocimiento de la edad exacta de una persona, tanto literarios (Hdn. 7.5.2; Mart. 6.70), como en aquellas inscripciones que contienen la fórmula plus minus. Es el caso de Mamma Donata (CIL 8.23060), fallecida con más o menos 70 años, o Merula (ILSard 1.115), con más o menos 80 (otros ejemplos de epígrafes en los que se emplea con vetulae son, por ejemplo $A E$ 1971, 138 y CIL 3.8936). En lo que respecta a nuestra investigación, resultan relevantes los resultados de un estudio realizado por Ray Laurence y Francesco Trifilò (2012), según el cual el uso del plus minus no tiene relación alguna con la vejez; es decir, que no parece que con el paso del tiempo se perdiese la noción de la edad cronológica exacta. Por otro lado, si bien este desconocimiento suele achacarse a un alto grado de analfabetismo por parte de la población romana (Duncan-Jones, 1990: 91), ocurría incluso en el caso de personas socialmente tan preeminentes como Tiberio, de quien se barajaban tres fechas para su nacimiento (Suet. Tib. 5).

A veces encontramos variaciones en las declaraciones de una misma persona. Es el caso de Aurelio Isidoro, habitante de la ciudad egipcia de Karamis durante el gobierno de Diocleciano, quien declara fechas de nacimiento distintas en cinco ocasiones, llegando a haber una diferencia de nueve años (Duncan-Jones, 1990: 80). En algunos casos, el no conocer la edad de los miembros mayores de la familia se consideraba signo de respeto; así lo expresa Ausonio:

"Ignoro tus años, mi buen padre, te lo aseguro, y pienso que tienes los mismos que yo. Debe ignorar esto un hijo; que los cuente un heredero demasiado ansioso que se preocupa más del testamento que de sus piadosas obligaciones y que enseña con ejemplo depravado a sus hijos mientras ya empiezan a ser jóvenes, de modo que tampoco querrán tener padres ancianos" (Auson. Ep. 17.25-30) ${ }^{47}$.

\footnotetext{
${ }^{47}$ Annos me nescire tuos, pater optime, testor totque putare tuos, quot reor esse meos. Nesciat hos natus, numeret properantior heres, testamenta magis quam pia vota fovens exemploque docens pravo iuvenescere natos, ut nolint patres se quoque habere senes.
} 
En cambio, en otras ocasiones era la propia persona anciana quien mentía intencionadamente sobre su edad, diciendo ser más joven de lo que realmente era para conseguir amantes o negar la proximidad de la muerte:

"Ya desde ahora acordaos de la inminente vejez: así ningún momento se os escapará infructuoso. Mientras os es posible y declaráis todavía los años que en realidad tenéis, disfrutad" (Ov. Ars am. 3.60-84) ${ }^{48}$.

"En lo que juras, Lesbia, que tú naciste en el consulado de Bruto, mientes. ¿Naciste, Lesbia, en el reinado de Numa? También mientes en esto. Pues, según cuentan tus generaciones, se dice de ti que fuiste formada con el barro de Prometeo" (Mart. 10.39)

“Ancianos decrépitos mendigan en sus oraciones el añadido de unos pocos años: simulan ser de menor edad de la que son; se halagan a sí mismos con mentiras, y se engañan tan a gusto como si a la vez le dieran el pego al destino" (Sen. Dial. $11.1)^{50}$.

La actitud que presentan las personas ancianas a las que se refieren estos fragmentos también puede interpretarse como una reacción hacia el edadismo de la sociedad en la que viven, de forma que intentar ocultar la edad real se convierte en una forma de evitar el rechazo y la marginalidad que conlleva la vejez.

Por otro lado, el estudio de la edad cronológica en época romana debe ser abordado con ciertas precauciones, ya que existían dos modos de establecerla: refiriéndose al total de años cumplidos, o al número de año que se estaba viviendo (Dig. 50.6.3 y 50.16.134; Harlow y Laurence, 2011: 16; Parkin, 2003: 26); es decir, expresando que alguien tenía, por ejemplo, 70 años, o que se encontraba en su septuagésimo año de vida, en cuyo caso la edad cronológica sería $69^{51}$. Un ejemplo de este doble uso lo encontramos en el caso de una niña fallecida con seis años en Roma, cuyo padre señala en el epitafio ambas formas de referirse a la edad cronológica: “...

\footnotetext{
${ }^{48}$ Venturae memores iam nunc estote senectae: sic nullum vobis tempus abibit iners. Dum licet, et vernos etiamnum educitis annos, ludite.

49 Consule te Bruto quod iuras, Lesbia, natam, mentiris. Nata es, Lesbia, rege Numa? Sic quoque mentiris. Namque, ut tua saecula narrant, ficta Prometheo diceris esse luto.

${ }^{50}$ Decrepiti senes paucorum annorum accessionem uotis mendicant: minores natu se ipsos esse fingunt; mendacio sibi blandiuntur et tam libenter se fallunt quam si una fata decipiant.

${ }^{51}$ Un análisis extenso sobre ambas formas de contabilizar la edad cronológica lo encontramos en Parkin, 2003: $26-30$.
} 
filiae dulcissimae quae vixit ann VI obit natali suo intrans annum septumum" (CIL 6.8517).

En definitiva, vemos cómo si no toda la población conocería su edad exacta, los hombres y mujeres romanos debían tener al menos una noción aproximada, de forma que pudiesen saber a qué leyes podían acogerse, o defenderse de acusaciones como la que recae sobre Apuleyo en relación con Pudentila. En caso de desconocimiento, podía acudirse a la administración, que emitiría certificados o documentos a partir de los censos periódicos. Administración que no siempre conocería el dato con exactitud, por lo que resultaba conveniente aportar todas las pruebas de edad posibles, entre las que estarían los certificados de nacimiento o las declaraciones de familiares o vecinos.

En lo que respecta a la vejez, a medida que envejecemos es más probable que los individuos, así como las personas allegadas a los mismos, pierdan la noción de su edad cronológica precisa (pensemos en expresiones que hoy nos resultan tan cotidianas como "cincuenta y pico", "sesenta y tantos", o "setenta y muchos"), especialmente si no se trata de un dato que se pueda conocer con inmediatez (como hacemos actualmente con nuestro documento de identidad), o que se emplee de forma habitual. Ausonio no parece conocer la edad exacta de su padre cuando éste está en vida, y aunque puede tratarse de una declaración hecha para resaltar la pietas con respecto a su progenitor, podía ocurrir que al fallecer una persona sus familiares no supiesen cuántos años tenía exactamente, y en ausencia de consulta al registro de nacimiento o por carecer del mismo, expresasen en su epitafio una edad aproximada. Puede además que una vez superada la edad máxima a partir de la cual se podían obtener ciertos beneficios y exenciones, las personas ancianas ya no necesitasen conocer cuántos años tenían y éste se convirtiese en un dato que caía en el olvido al no ser necesario para hacer ninguna gestión. No obstante, si tomamos en cuenta las inscripciones en las que se indica una edad de muerte aproximada, la vejez no parece incidir especialmente en ellas; cabe también la posibilidad de que vetulae y senes comprendan buena parte de aquellas inscripciones en las que no aparece la edad de la muerte, puede que por desconocimiento de la misma, aunque no tenemos forma de saberlo.

\section{II.2.3. La dimensión demográfica de la vejez}

¿Cuánta población anciana había en Roma? Son muchos los autores (Cherry, 2001: 1; Cokayne, 2003: 2; Marre, 2002: 175; Parkin, 1992: 5; Treggiari, 1991: 398) 
que han señalado la dificultad de describir de forma precisa la estructura de la sociedad romana debido a la carencia de un registro poblacional sistemático y a las características particulares de las fuentes de las que disponemos, especialmente la parcialidad de las mismas. Para Walter Scheidel (2000: ix), la falta de datos precisos es un obstáculo tan grande que deberíamos plantearnos seriamente hasta qué punto es relevante el estudio de la demografía en el caso de las sociedades antiguas.

No obstante, diversos autores han realizado intentos de describir la estructura demográfica romana, basándose principalmente en la epigrafía funeraria, pero también en datos como la importación y distribución de comida, la densidad de la población por hectárea, o el tamaño de la población elegible para el ejército, estudios que por otra parte proliferan en la última década (Carreras, 2014; Lo Cascio, 2000; Witcher, 2005).

Algunas investigaciones tratan de reconstruir la estructura poblacional romana realizando una comparativa con otras sociedades para las que poseemos informaciones demográficas más completas. Así, Donald Engels (1984) caracteriza a Grecia y Roma antiguas como sociedades demográficamente pre-transicionales, y cree que sus características poblacionales no diferirían demasiado de otras dos sociedades de este tipo, la de la Europa medieval y renacentista y la de la China Ming, ambas con abundante documentación censal. De esta forma, la estructura demográfica romana se habría caracterizado por tasas de nacimiento y muerte estables, lo que lleva al autor a descartar el infanticidio como una práctica habitual, ya que cree que se recurriría más bien a medios de contracepción y al aborto (Engels, 1980 y 1984: 388), teoría secundada por Ann Haentjens (2000) y por recientes análisis osteológicos (Gowland y Chamberlain, 2002) ${ }^{52}$. Señala además que los recién nacidos no deseados serían vendidos como esclavos, para lo que se apoya en los censos del Egipto romano (Engels, 1984: 391-393).

Por su parte, Caleb Finch (2009: 91) sugiere que la reconstrucción demográfica de Grecia y Roma antiguas debió ser similar a la calculada para la Europa preindustrial. De este modo, la población romana se encontraría caracterizada por una esperanza de vida al nacer de 30-45 años, 20-50\% de mortalidad antes de alcanzar la adultez, y 10-20\% de personas mayores de 60 años. De esta forma, y si tenemos en cuenta que se calcula que

\footnotetext{
${ }^{52}$ En contra, vid. Harris, 1982. Sobre el aborto y los métodos anticonceptivos en la antigua Roma, vid. Blázquez, 2000 y González Gutiérrez, 2011.
} 
en los inicios de la época imperial habría en todo el Imperio 50-60 millones ${ }^{53}$ de personas, de ellas 5-12 millones serían ancianas, a quienes habría que sumar las mujeres mayores de 50 años. La historiografía dedicada al estudio de la vejez en la Antigüedad postula una cifra más baja que la de Caleb Finch, del 6-8\%, lo que daría un total de 3-4 millones de población vieja (Cokayne, 2003: 2; Parkin, 1992: 134 y 2003: 50). Para el caso concreto del Bajo Imperio, Robert Kebric (1983: 539) calcula que una quinta parte de la población superaría los 55 años.

Sin embargo, no toda la historiografía se muestra de acuerdo con la validez de aplicar a la Antigüedad modelos de población de otros lugares y épocas. Así, Claire Hollerand y April Pudsey (2011: 1-2) creen que este tipo de tablas demográficas no pueden emplearse sin modificaciones, aunque señalan la existencia de patrones poblacionales comunes entre las sociedades antiguas y las premodernas.

Como ya hemos señalado, la mayoría de intentos de conocer la estructura demográfica romana han empleado como fuente principal las inscripciones. Destaca en este sentido un estudio de Richard Saller (1994) en el cual se aplica la simulación por ordenador a una población romana de 5.000 personas, a fin de conseguir identificar los patrones de nacimiento, matrimonio y muerte de la sociedad romana ${ }^{54}$. Este trabajo estima una esperanza media de vida de 20-30 años (Saller, 1994: 13). En el caso de la población femenina, los resultados que el autor obtiene son los siguientes (Saller, 1994: 24):

- Al nacer, las niñas romanas tendrían una esperanza media de vida de 25 años.

- Con 15 años (la edad que se asume como media del matrimonio para la mujer), de una población de 100.000 mujeres, sólo quedarían 48.732, las cuales tendrían una esperanza de vida esperada $(\mathrm{EVE})^{55}$ de 34,237 años.

- A los 50, quedarían 24.389 mujeres, con una EVE de 15,636 años.

- A los 60, quedarían 16.712 mujeres, con una EVE de 10,443 años.

\footnotetext{
53 A pesar de que cree que nunca podrá conocerse el número total de la población del imperio romano, Tim Parkin (1992: 5) se decide a tomar en cuenta ciertos números para tener un marco de referencia en los primeros años del Imperio:

- 750 mil - 1 millón para Roma ciudad,

- 5-8 millones para Italia,

- 50-60 millones para el Imperio.

${ }^{54}$ El propio autor (Saller, 1994: 24-26) reconoce de antemano las carencias de su método, señalando por ejemplo la imposibilidad de incluir en la simulación los divorcios, por lo que los individuos de la misma sólo vuelven a casarse cuando el programa estima que su cónyuge ha fallecido.

${ }^{55}$ Entendida como el número de años que puede esperar vivir una persona a determinada edad.
} 
- 1.644 llegarían a los 80 años, con una EVE de 3,567 años.

- Sólo 3 alcanzarían los 95 años, y podrían esperar cumplir 1,234 más.

Vemos así cómo a medida que una romana envejecía tenía más posibilidades de llegar a vetula. Si bien menos de la mitad de las romanas cumpliría los 15 años, el 50\% de ellas alcanzaría los 50, y un tercio de estas últimas cumpliría los 70.

Richard Saller y Brent Shaw (1984: 125), señalan que del estudio de las fuentes epigráficas se desprenden ciertos patrones que podemos aceptar como válidos para caracterizar demográficamente la sociedad romana, a pesar de lo incompleto de la documentación. Afirman, por otro lado, que la edad que figura en las inscripciones no debe ser el punto central del estudio de las mismas, sino que el objetivo es extraer información acerca de las relaciones interpersonales de las personas que aparecen en los epígrafes (Saller y Shaw, 1984: 125). Obtienen como resultado una mayor incidencia de la familia nuclear (Saller y Shaw, 1984), conclusión apoyada por Leonard Curchin (2000-2001: 536) pero distinta a la de Dale Martin (1996), quien afirma que en Roma dominaba la familia extensa y llama la atención sobre no considerar a la familia como un ente estático.

Empleando las teorías de Richard Saller, Mary Harlow y Ray Laurence (2011: 7) calculan que en Roma la mayoría de las personas sólo conocerían a su abuela materna. Por su parte, para Wieslaw Suder (1995: 33) sólo el 2\% de los niños romanos de 11 años tendrían a su abuelo paterno con vida. Tomando como base el censo egipcio, Sabine Huebner (2013: 107) calcula que en el Egipto romano el 35-40\% de la población sería dependiente, casi tanto como en las sociedades occidentales actuales ${ }^{56}$.

Jonathan Edmondson (2014: 561-563) se muestra convencido de la utilidad de los análisis epigráficos para conocer la estructura demográfica de época romana, aunque cree que hay que tomar ciertas precauciones, teniendo en cuenta los factores económicos y culturales que afectan a las inscripciones, el que estas sean más comunes en contextos urbanos que rurales, la exageración en la edad y las dataciones imprecisas. Para Ilse Mueller (2010: 302), el hecho de que sean los esposos y los hijos de las mujeres quienes suelen recordarlas en las inscripciones funerarias pudo hacer que algunas vetulae viudas y sin hijos vivos o solteras, especialmente si carecían de libertos,

\footnotetext{
${ }^{56}$ Para estos cálculos tiene en cuenta a la población menor de 15 años y mayor de 60. Habría que añadir aquí a todas aquellas personas comprendidas entre esas edades que fuesen dependientes debido a situaciones físicas y mentales concretas. Por otro lado, cabe preguntarse hasta qué punto podemos considerar como dependiente a una persona de 12 o de 70 años que disfruta de plenas capacidades y tiene autonomía para realizar todas las tareas cotidianas. Sobre las dificultades de emplear este cálculo para la Antigüedad vid. Parkin, 2003: 51.
} 
no tuvieran quién las conmemorase, a lo que podría deberse su subrepresentación en el registro epigráfico.

Por otro lado, son muchas las críticas que han recibido los análisis epigráficoestadísticos a los que hemos aludido. Andrew Burn (1953: 7) cree que no es posible descifrar la estructura etaria romana a partir de las inscripciones, ya que sólo la clase trabajadora pondría la edad en sus tumbas, debido a que los pobres no tendrían dinero para costearse un epitafio y para las clases gobernantes la edad de la muerte no sería un dato relevante que incluir. Christian Laes (2007: 26) matiza esta teoría señalando que es posible que las personas con menos recursos encargasen epígrafes funerarios, pero que lo harían en materiales perecederos y por lo tanto no han sobrevivido al paso del tiempo.

Tanto Stephen Dyson (1992: 374) como Richard Saller (1994: 18) se muestran escépticos acerca de conocer la esperanza media de vida de época romana mediante las inscripciones. Algunos autores (Martin, 1996: 41) señalan que los trabajos de Richard Saller y Brent Shaw parten de planteamientos erróneos, ya que en sus análisis emplean el número de relaciones individuales entre personas, y no las tumbas en sí. Por su parte, Francesca Cenerini (2014: 17) se plantea hasta qué punto la epigrafía representa la realidad de la persona difunta, y cómo afectan los convencionalismos a los intentos de reconstrucción demográfica.

Para Tim Parkin (1992: 6-17), las inscripciones tienen poco valor para inferir datos demográficos debido a la subrepresentación de individuos infantiles, la exageración de la edad en algunas provincias, las variaciones de patrones conmemorativos entre regiones, la falta de datos provenientes de las zonas rurales, la distribución irregular por clases sociales, los problemas cronológicos inherentes al registro epigráfico, la existencia de más inscripciones de hombres que de mujeres, y la aleatoriedad de la muestra. Estima (Parkin, 2011a: 185), aunque con cautela, una esperanza media de vida de entre 20 y 30 años, la misma adoptada por Esperanza Torrego (2014: 211).

Otro de los métodos propuestos para conocer la estructura demográfica de la antigua Roma se basa en el estudio de una tabla de edad que aparece en el Digesto, denominada Tabla de Ulpiano, si bien algunos expertos (Duncan-Jones, 1990: 98-101; Parkin, 1992: 29-30; Saller, 1994: 13-15) dudan de que pueda aplicarse con fiabilidad. La tabla, inserta en el comentario a una ley de principios del siglo I d.C., tendría como 
objetivo evaluar la importancia de las rentas vitalicias asignadas por legados según la edad del beneficiario o bien hacer cálculos relativos a donaciones testamentales, y se piensa que de ella puede obtenerse información acerca de la esperanza de vida en época romana. El texto es el que sigue:

"Escribe Ulpiano, que para la computación que se ha de hacer en los alimentos hay esta norma, que desde la primera edad hasta los veinte años se compute la cantidad de alimentos de treinta años, y que de esta cantidad se preste la Falcidia; que de los veinte años hasta los veinticinco, la de veintiocho años; desde los veinticinco años hasta los treinta, la de veinticinco; desde treinta hasta treinta y cinco años, la de veintidós; desde treinta y cinco hasta cuarenta, la de veinte años; desde cuarenta años hasta cincuenta se hace la computación de tantos años cuantos faltaren a su edad para los sesenta, deduciendo un solo año; desde cincuenta años hasta cincuenta y cinco, la de nueve años; desde cincuenta y cinco hasta sesenta años, la de siete años; y desde sesenta años, de cualquier edad que sea, la de cinco años" (Dig. 35.2.68.prf.) $)^{57}$.

Tradicionalmente del estudio del texto del Digesto se ha interpretado que la cifra de 60 años, la más alta que aparece en la tabla, es aquella que se consideraba de media como la esperanza máxima de vida. De este modo, no merecería la pena hacer cálculos exhaustivos más allá de esta cifra por el pequeño porcentaje de la población que la superaría. Bruce Frier (1982) interpreta que los datos que aparecen en la tabla provienen de una recogida de datos demográficos fiable, teoría criticada por Richard Saller (1994: 14-15). Tim Parkin (1992: 31) opina que, puesto que se trata de un texto en el que se regulan impuestos, la ley hace referencia a que las personas mayores de 60 años estaban exentas de pagarlos o tenían cierta reducción; por su parte, para Duncan-Jones (1990: 101) las tablas hacen referencia a personas de condición servil, y por lo tanto sólo podrían aplicarse a una parte concreta de la población.

En definitiva, si bien por el momento no podemos saber con exactitud el grado de fiabilidad aplicable a la tabla de Ulpiano, sí que podemos inferir que en ella se fijan los 60 años de edad cronológica como un momento remarcable dentro del ciclo vital, ya sea

\footnotetext{
${ }^{57}$ Computationi in alimentis faciendae hanc formam esse ulpianus scribit, ut a prima aetate usque ad annum vicesimum quantitas alimentorum triginta annorum computetur eiusque quantitatis falcidia praestetur, ab annis vero viginti usque ad annum vicesimum quintum annorum viginti octo, ab annis viginti quinque usque ad annos triginta annorum viginti quinque, ab annis triginta usque ad annos triginta quinque annorum viginti duo, ab annis triginta quinque usque ad annos quadraginta annorum viginti. Ab annis quadraginta usque ad annos quinquaginta tot annorum computatio fit, quot aetati eius ad annum sexagesimum deerit remisso uno anno: ab anno vero quinquagesimo usque ad annum quinquagesimum quintum annorum novem, ab annis quinquaginta quinque usque ad annum sexagesimum annorum septem, ab annis sexaginta, cuiuscumque aetatis sit, annorum quinque.
} 
porque a partir de esa edad disminuyen las obligaciones para con el Estado o porque se consideraba una cifra elevada y difícil de alcanzar.

Los datos obtenidos mediante los métodos a los que hemos aludido suelen contrastarse con tablas demográficas modelo. La idea básica de una tabla demográfica modelo es proporcionar información demográfica para sociedades para las cuales se poseen datos escasos o poco fiables, ya que posibilita testar la probabilidad de ciertas asunciones sobre la población a analizar. Todas las tablas demográficas modelo parten de la idea de que para que una población se mantenga estable debe contar con ciertos patrones, como son: un alto nivel de mortalidad infantil, que declina en los años finales de la infancia y la adolescencia, y vuelve a crecer en la vejez. Al aplicar estas tablas se asume que para que una población se mantenga estable, los porcentajes de nacimientos y muertes deben ser constantes e iguales, dando lugar a una tasa de crecimiento cero. Por lo tanto, las tablas modelo trabajan con poblaciones cerradas, sin tener en cuenta los efectos de las migraciones, las plagas, las guerras o las hambrunas, entre otros posibles factores de fluctuación.

En el caso de la Antigüedad, la tabla demográfica modelo más empleada es la Coale-Demeny Model West Level 3 Female, la cual, a pesar de que no reproduce de forma totalmente fiable la población romana, se piensa que es la que más se acercaría a la misma. De acuerdo con este modelo, podría esperarse que hubiera alrededor del 5$10 \%$ de vetulae y senes en Roma; es decir, 2,5-6 millones de personas, un dato menor al aportado por Caleb Finch y más en consonancia con el del resto de autores.

Otra de las aplicaciones de estas tablas es que pueden introducirse en simulaciones de ordenador que permiten crear una historia vital imaginaria que sigue a los individuos a medida que envejecen, como ya hiciera Richard Saller en el caso de las inscripciones. De esta forma, una simulación de este tipo podría decirnos, por ejemplo, el porcentaje de personas bajo patria potestas, o las probabilidades de que tres generaciones de una misma familia romana estuviesen vivas en un momento dado (Parkin, 2003: 51).

A pesar de que descarta el uso de tablas modelo para aplicarlas a las sociedades antiguas, por considerarlas inestables, Susan Treggiari (1991: 398) cree que gracias a ellas sí pueden establecerse ciertos patrones demográficos aplicables a la antigua Roma:

- $1 / 3$ de los individuos infantiles morirían antes de cumplir un año de vida; $1 / 2$ antes de los 10 años. 
- $1 / 3$ de las personas supervivientes a lo señalado anteriormente cumplirían 60 años; $1 / 7$ los 70 años.

- En cuanto a una división por sexos, 43\% de las mujeres vivirían 20 años y, una vez superada esa edad, a la mayoría les esperaban al menos otros 20 años de vida; en cuanto a los hombres, $18 \%$ alcanzarían los 60 años.

Por otro lado, hay investigadores (Gentile, 2009: 13) que creen que, a pesar de que las tablas demográficas no son $100 \%$ fiables al aplicarlas a la Antigüedad, sobre todo teniendo en cuenta que ninguna población es tan estable como para coincidir siempre con lo que éstas establecen, emplearlas puede ayudarnos a analizar la estructura de una población en base a ciertas claves. Finalmente, ciertos autores (Parkin, 2011a: 184; Pudsey, 2012) sugieren que los datos extraídos de los censos del Egipto romano podrían indicarnos patrones que aplicar a la totalidad del imperio, sin obviar particularidades regionales como el matrimonio entre hermanos.

En lo que respecta a la vejez, la aparente falta de personas ancianas en el registro epigráfico ha llevado a Brent Shaw (1991) a suponer que éstas eran poco valoradas en época romana. Sin embargo, creemos que pueden plantearse otras teorías que no necesariamente impliquen la devaluación de la vejez. Así, es posible que la infrarrepresentación de la ancianidad en los epitafios se deba a que muchos no contemplan la edad de la persona fallecida, ya sea porque no se consideraba necesario o porque el dato se desconocía (Edmonson, 2014: 561; Parkin, 2003: 9; Revell, 2005: 44). A este respecto, Louise Revell (2005: 60) insiste en la necesidad de estudiar las particularidades regionales para comprender que la vida no era igual en todas las partes del Imperio.

Otra posibilidad es que, al ser los hijos los dedicantes preferidos, se invisibilice la presencia de otros miembros familiares (nietos, bisnietos...) cuyo nombramiento podría indicar la condición de vetula o senex de la persona conmemorada. Podría darse también la circunstancia de que, al fallecer, la persona anciana no contase con familiares que le dedicasen un monumento funerario. Para otros autores (Laes, 2007: 32; SigismundNielsen, 1999), la edad pudo servir en los epitafios como un epíteto que indicaba la estrecha relación entre la persona difunta y los dedicantes, y por lo tanto no se hacía referencia a ella ordinariamente.

Finalmente, y dado que la epigrafía funeraria que ha llegado hasta nosotros representa solamente una pequeña porción de todos los individuos que vivieron en 
época romana, podemos encontrarnos ante rituales funerarios que no implicaban el uso de inscripciones pero que reflejarían de igual modo el aprecio que los allegados tenían por sus mayores una vez éstos fallecían.

Otro fenómeno epigráfico que afecta especialmente a las personas ancianas es el del redondeo en las edades de las inscripciones (Laes, 2012: 105; Mueller, 2010: 302). Esta tendencia al redondeo, así como al empleo de edades especialmente elevadas, parece haber incidido con más fuerza en ciertas zonas concretas de la geografía romana. Para la presencia de edades de fallecimiento muy altas, el caso más conocido es el de África, donde los análisis estadísticos de la epigrafía dan lugar a proporciones realmente elevadas de personas ancianas. Por su parte, Jonathan Edmondson (2005: 210-212) ha detectado una especial tendencia al redondeo en la actual provincia española de Salamanca, donde el $48 \%$ de las inscripciones que incluye en su estudio terminan en $0 \mathrm{y}$ el $21,4 \%$ en 5 . En esta misma región, observa que el $46 \%$ de las tumbas donde se registra la edad pertenecen a individuos mayores de 40 años, lo que interpreta como un símbolo del prestigio que las personas ancianas tenían en su sociedad.

Se han propuesto varias teorías que habrían motivado el uso del redondeo. Por un lado (Edmondson, 2005: 213), una tendencia a exagerar la edad que sería síntoma del prestigio de la vejez en las regiones en las que se da este fenómeno. En esta línea se encontraría Víctor Alba (1992: 12), para quien el redondeo, y en especial el que se da a la alza, es un fenómeno que ha acontecido hasta entrado el siglo XX. También se ha aducido que son fruto del analfabetismo, de la diferencia entre ciudad y campo, del clima, o de factores culturales indígenas que no conocemos (Dyson, 1992: 374; Parkin, 2003: 37). Tim Parkin introduce el factor económico, al señalar que edades como L o C son más baratas a la hora de encargar una inscripción que otras como XLVIII o LXXX (Parkin, 2003: 31). En nuestro caso, coincidimos con Mustapha Khanoussi y Louis Maurin (2002: 87) en que no existen razones fundadas para desconfiar de la veracidad de aquellos epitafios en los que se señalan edades superiores a la centena. Si bien las sospechas de falseamiento parecen más válidas a partir de los 120 años, ya hemos apuntado otras posibilidades además de la exageración intencionada para su existencia.

Por otro lado, está la idea de que no todos los romanos sabrían exactamente cuál era su edad, a la que ya hemos aludido anteriormente. Esta teoría la respalda Loredana Pricop (2014: 186), para quien el redondeo sería un síntoma del bajo grado de alfabetización de la sociedad romana. En su análisis de la provincia de Noricum, 
determina que de las 351 mujeres estudiadas, casi el 70\% señalaban una edad terminada en múltiplos de 5, un porcentaje que incide especialmente en las fallecidas a partir de los 55 años y en las peregrinae (Pricop, 2014: 190-207). No obstante, como ya se ha señalado, estos epígrafes funerarios conviven con otros en los que la edad es expresada con gran precisión, incluyendo meses y días. La mayor incidencia en el redondeo que Loredana Pricop encuentra en las inscripciones de peregrinae podría deberse a que los calendarios de sus culturas indígenas no coincidiesen con el romano, de forma que siguieran midiéndose por el primero -indicando en su epitafio la edad que tenían según éste-, o a que el realizar el cambio hacia el segundo provocase que no supieran muy bien cuántos años tenían exactamente.

Para Louise Revell "in the Roman period commemoration of age at death is instructed around ideas of 'correct' age, and clearly there are periods in the life course when it was considered more important to be precise about age" (Revell, 2005: 60). Esta teoría es defendida también por Ray Laurence (2007), quien a partir del estudio de las inscripciones de Pompeya llega a la conclusión de que los epitafios de mujeres tienden a presentar la edad de la muerte cuando ésta ha acontecido en su periodo reproductivo. De esta forma, la precisión no sería relevante en la vejez, sino que lo importante sería resaltar haber tenido una existencia longeva.

Debemos considerar también que no todas las edades terminadas en 0 y 5 son indicador de redondeo, un hecho que en ocasiones parecen olvidar quienes realizan estudios como los citados, o que algunas regiones del imperio romano empleaban otros números, como es el 6 en el caso egipcio (Duncan-Jones, 1990: 81). Cabe añadir también la existencia de inscripciones funerarias realizadas en vida, en las cuales en ocasiones no se deja espacio para colocar la edad de fallecimiento cuando éste acontezca (Burn, 1953: 3). No obstante, parece que el tratamiento estadístico de los datos epigráficos ha confirmado la tendencia al redondeo, lo que implicaría un conocimiento parcial de las edades de fallecimiento en época romana.

En cuanto a la distribución por sexo, nos enfrentamos aquí a dos tendencias historiográficas opuestas. A pesar de que señala que no puede demostrarlo, Peter Garnsey (1999: 100; vid. también Fontanille, 2004: 32) postula que en la Antigüedad los hombres vivían más que las mujeres. Para este autor, cuando ambos sexos tienen el mismo tratamiento en cuanto a nutrición y cuidados sanitarios, las mujeres tienden a vivir más porque son fisiológicamente más eficientes, ya que necesitan una menor 
cantidad de proteínas y calorías y son más resistentes a las enfermedades. Sin embargo, en poblaciones actuales de países del Tercer Mundo se constata la falta de mujeres, dato que para este autor (Garnsey, 1999: 101) debe achacarse a un reparto desigual de la comida en el ámbito familiar basado en la necesidad de mantener con vida a los miembros más productivos de la misma (los cuales asume que son los varones), el estatus, y el control que los hombres tendrían sobre los recursos familiares. Extrapola esta creencia a la Antigüedad, señalando que las mujeres comían menos porque al considerarlas seres inferiores inconscientemente se les atribuía una necesidad alimenticia menor, lo que conduciría a la malnutrición y a una mayor tasa de mortalidad femenina (Garnsey, 1999: 111 y ss.).

Por su parte, Alfonso López (2008: 10) cree que en época romana había el doble de senes que de vetulae, aunque no aporta datos que respalden su teoría. La misma idea la encontramos en Georges Minois (1987: 116), quien se basa en los datos aportados por las inscripciones y en la teoría de que existiría un alto porcentaje de muertes entre la población femenina debido al embarazo y el parto. Se apoya también en la figura del senex libidinoso que busca contacto sexual con mujeres jóvenes, arrastrado a este comportamiento según él por la falta de esposas de su misma edad ${ }^{58}$. No podemos tomar por válida esta hipótesis, dado que el del "viejo verde" sigue siendo en nuestros días un estereotipo muy recurrente, a pesar de que los datos demográficos demuestran que hay más ancianas que ancianos; tanto en lo que respecta a la actualidad como a la Roma antigua, debemos relacionar esta figura común en la comedia con el rechazo al cuerpo femenino envejecido que acontece en las sociedades patriarcales y con el ideal de belleza aniñada que se impone a las mujeres en las mismas, así como con la concepción de que el varón puede tener acceso cuando lo desee y como lo desee a quien constituye su objeto de deseo, transgrediendo fronteras que podrían parecer fijas como es la edad en este caso.

En el lado opuesto de las interpretacione expuestas, para Lindsay Allason-Jones (1989: 49) una revisión de los esqueletos de época romana ya estudiados, algunos de los cuales han sido considerados adultos pero mediante las nuevas técnicas podrían ser seniles, ayudaría a eliminar la concepción de que pocas mujeres sobrepasaban los 35-40

\footnotetext{
${ }^{58}$ Destaca en este sentido la visión que presenta Georges Minois del senex como víctima y no como acosador, cuando escribe que éste "debe resignarse (...) a una nueva vida conyugal agitada con una esposa demasiado joven que le engañará con sus amantes" (Minois, 1987: 116). Nada dice el autor sobre la situación de la joven matrona que se ve avocada a cuidar de un anciano y posiblemente dependiente esposo.
} 
años. Suzanne Dixon (1990: 30) y Martine de Marre (2002: 175) abogan por que, si bien los romanos tenían una mayor esperanza de vida, llegado un punto las mujeres vivirían más años que los hombres, teoría apoyada en los datos proporcionados por Andrew Burn (1953) y criticada por Tim Parkin (1992: 103) por considerarla basada en asunciones no probadas. Él (Parkin, 1992: 103-105) por su parte piensa que a pesar de que la tasa de mortalidad por maternidad sería alta, no lo sería tanto como para provocar impacto demográfico, si bien una comparación con poblaciones preindustriales de las que sí se tienen datos demográficos fiables le hace postular que los hombres tendrían en la Antigüedad más posibilidades de alcanzar la vejez que las mujeres.

En definitiva, se aprecia cómo si bien por el momento no contamos con datos fiables acerca de la estructura demográfica de la antigua Roma, en lo que respecta al marco de la presente Tesis Doctoral podemos extraer ciertas conclusiones. Por un lado, que encontrar vetulae en el registro epigráfico no resulta infrecuente, aunque probablemente nos enfrentemos a una subrepresentación debido a que no todas las inscripciones contienen la edad de la muerte y los conmemoradores preferidos son los hijos, desapareciendo relaciones familiares que nos indicarían la presencia de una vetula. Por otro lado, que no podemos saber si el número de vetulae era mayor que el de senes o viceversa, dato que además variaría previsiblemente dependiendo de la época en la que nos encontremos; es de esperar, por ejemplo, que en las décadas posteriores a la alta mortalidad masculina que supusieron diversos episodios bélicos como la II Guerra Púnica, el número de ancianos descendiese.

Hemos visto además cómo el fenómeno del redondeo en la edad parece haber afectado especialmente a las personas fallecidas en la vejez, ya fuera porque a medida que se avanza cronológicamente resulta más difícil conocer la edad que se tiene, por una tendencia a exagerar la cifra por razones de prestigio, por la influencia de convencionalismos sociales que de momento se nos escapan, o por efecto, para el caso de las inscripciones inmediatamente posteriores a la implantación del calendario juliano, porque el desajuste entre éste y el anterior impedía a algunas personas conocer su edad exacta.

Todo lo anteriormente señalado refuerza la noción de la vejez como etapa vital especialmente social, ya que incluso los datos numéricos, y por ello supuestamente veraces, están sometidos a procesos sociales que provocan variaciones regionales, temporales, de género y clase social. 


\section{II.2.4. El cuerpo envejecido}

Como proceso biológico, la vejez es el resultado de un inevitable deterioro orgánico y mental que comienza hacia los 20-25 años de edad cronológica y en la ancianidad avanza a un ritmo acelerado, provocando un rápido deterioro músculoesquelético, cardiovascular, endocrinológico y cerebral. Durante el proceso de envejecimiento, al tiempo que el sistema biológico pierde eficiencia, se ven alteradas ciertas características físicas: la piel pierde elasticidad, tenemos menos fuerza muscular, los tiempos de reacción son más prolongados, se pierde agudeza visual y auditiva, etc. (Fernández Ballesteros, 2011: 117; Reol, 2003: 11). Sin embargo, sólo un tercio de la longevidad de los seres humanos está biológica y genéticamente determinado, lo que concede gran importancia a los factores personales, de forma que cada persona envejece a una velocidad única e impredecible (Finch, 2010: 355; Reol, 2003: 12).

Este proceso de envejecimiento y su aceleración en la vejez no pasaron inadvertidos en la Antigüedad (Cic. Sen. 10.32; Dion. Hal. Ant. Rom. 4.31.4; Verg. G. 3.67). La progresiva sequedad que sufría el cuerpo humano se consideraba la culpable del deterioro asociado a la edad, siendo la muerte la sequedad definitiva (Macrob. Sat. 7.6.15-21). Aristóteles (Log. 5.466a-466b) y Galeno (Nat. Fac. 2.8) consideraban que la vejez además de seca era fría y terrosa (Byl, 1988a: 75 y ss.). Hipócrates (Aph. 1.14 y De di. 1.33), al contrario que los anteriores, caracterizaba la vejez masculina como húmeda -si bien coincidía con Aristóteles y Galeno en que es fría- y la vejez femenina como seca (Hippoc. Mul. 111 y Nat. Mul. 1).

No obstante también existía una tercera opinión, la de que la vejez era al mismo tiempo seca y húmeda. En el siglo IV d.C. Macrobio explicaba esta teoría de la siguiente manera:

"Y aquél: - Luego, si es la abundancia de humor la que tiñe los cabellos de los ancianos y los vuelve canos, ¿por qué la vejez adquirió la reputación de una completa sequedad? Aquél respondió: - Porque la vejez, al extinguirse el calor natural a causa de la edad longeva, se torna fría, y de tal frío derivan los humores gélidos y superfluos. Por lo demás, el fluido vital se secó a causa de la longevidad; por eso la vejez es seca, por la carencia de humor natural, y es húmeda a causa de la abundancia de un humor malsano producido por el frío. Ésta es también la razón de que la edad más avanzada sea víctima de los insomnios, porque el sueño, que depende sobre todo del humor, deriva del humor natural; así, por ejemplo, se tiene mucho sueño en la infancia, que es húmeda por la abundancia de humor no superfluo pero natural. Por la misma razón no es posible que los niños tengan 
canas, porque es una edad muy húmeda, ya que es húmeda no por causa del humor derivado del frío, sino porque la nutre aquel humor natural y vital. De hecho, el humor que deriva del frío de la edad o se contrae con ocasión de cualquier malsana coyuntura, tal como es superfluo, es igualmente nocivo. Tal humor lo vemos en las mujeres, amenazándolas de extrema gravedad, si no se expulsa periódicamente; lo vemos en los eunucos, provocando debilidad en las piernas, cuyos huesos, tal vez por haber estado siempre flotando en el humor superfluo, resultaron privados de vigor natural, y por ello se tuercen fácilmente, en tanto que no son capaces de soportar el peso del cuerpo colocado encima, del mismo modo que una caña se curva bajo un peso" (Macrob. Sat. 7.10.7-11) ${ }^{59}$.

Como vemos, para Macrobio la vejez era un estado parecido al de las mujeres y los eunucos, por lo que el senex no sería un vir completo.

Casi todos los autores trataron la vejez en la Antigüedad como una enfermedad en sí misma, una que además era incurable (Cic. Tim. 5.17; Sen. Ep. 108.28). Así, Virgilio (Aen.6.273-277) incluía a los viejos en el vestíbulo del Inframundo, junto con los enfermos y los pobres. Se trata de una perspectiva que la Gerontología moderna ha conservado hasta hace relativamente poco, pero que en el siglo I a.C. ya rechazaba Cicerón. Escribía el orador que "es verdad que existen muchos ancianos incapacitados a quienes no se les puede exigir ningún trabajo ni obligaciones. Pero esto no sólo es debido a la vejez sino también a la falta de salud" (Cic. Sen. 11.35) ${ }^{60}$. Estas palabras, que entroncan con los conceptos de affirmative old age y positive ageing a los que nos hemos referido en el Capítulo I, nos explican cómo no todos los ancianos son seres enfermos e incapaces de todo tipo de actividad física y/o mental, sino que muchos siguen conservando plenas capacidades, adaptadas a los cambios que han ido experimentando al envejecer.

\footnotetext{
59 Si ergo senibus abundantia humoris capillos in canitiem tinguit; cur senecta opinionem exactae siccitatis accepit? Quia senecta, inquit ille, extincto per vetustatem naturali calore fit frigida, et ex illo frigore gelidi et superflui nascuntur humores. Ceterum liquor vitalis longaevitate siccatus est: inde senecta sicca est inopia naturalis humoris, humecta est abundantia vitiosi ex frigore procreati. Hinc est quod et vigiliis aetas gravior afficitur, quia somnus, qui maxime ex humore contingit, de naturali nascitur: sicut est multus in infantia, quae humida est abundantia non superflui sed naturalis humoris. Eadem ratio est quae pueritiam canescere non patitur, cum sit humectissima, quia non ex frigore nato phlegmate humida est, sed illo naturali et vitali humore nutritur. Ille enim humor, qui aut de aetatis frigore nascitur aut cuiuslibet vitiositatis occasione contrahitur ut superfluus ita et noxius est. Hunc videmus in feminis, nisi crebro egeratur, extrema minitantem: p608hunc in eunuchis debilitatem tibiis ingerentem, quarum ossa quasi semper in superfluo humore natantia naturali vigore caruerunt et ideo facile intorquentur, dum pondus superpositi corporis ferre non possunt, sicut canna pondere sibi inposito curvatur.

${ }^{60}$ At multi ita sunt imbecilli senes, ut nullum offici aut omnino vitae munus exsequi possint. At id quidem non proprium senectutis vitium est, sed commune valetudinis.
} 
No obstante, se trata de una visión de la vejez que no parecía ser la dominante en el pensamiento clásico. Así, Terencio escribía que "la vejez es en sí misma una enfermedad" (Phorm. 575) ${ }^{61}$. La misma concepción podemos encontrarla en autores de géneros literarios tan diversos y épocas tan distantes como Plauto (Men. 755-760), Virgilio (G. 3.67), Lucrecio (3.445-469), o Séneca (Ep. 108.28).

Para los romanos por lo tanto la vejez ideal era aquella libre de enfermedades, tal y como escribía Marcial al hablar de la excelente salud del anciano Cota: "Vida no es solamente vivir, sino tener salud" (Mart. 6.70) ${ }^{62}$. Uno de los ejemplos más conocidos de vejez sana es el de Masinisa, rey de Numidia en los siglos III-II a.C. De él se decía que jamás había necesitado asistencia, ni siquiera para actividades que resultan costosas en la vejez como montar a caballo:

"Pienso que habrás oído contar, Escipión, lo que hizo Masinisa, invitado de tu abuelo. Con sus noventa años va a pie a todas partes, jamás va a caballo. Y si monta a caballo nunca se apea de él aunque llueva o hiele. Ni siquiera se cubre la cabeza. Disfruta de una salud robusta que le permite cumplir con sus obligaciones de rey. Puede ser que el ejercicio y la templanza le ayuden a conservar parte del vigor de la juventud en su ancianidad" (Cic. Sen. 11.34) ${ }^{63}$.

Ya en Roma, el ejemplo por excelencia de vejez sana era Catón, quien incluso acudió a la guerra en Hispania siendo anciano (Val. Max. 8.7.1).

Una de las características que más aparece asociada a la vejez en los autores clásicos de diversas épocas es la debilidad, tanto física (Auson. Ecl. 1.15; Ep. 6.30; Cel. Med. 2.10.4; Cic. Sen. 9.27; Liv. 10.13.6-7; Ov. Met. 7.478 y Pont. 1.4.1; Petron. Sat. 27.1-2; Sen. Ep. 67.2; Verg. Aen. 2.509-511, 5.715-717 y 12.131-132), como moral (Cic. Sen. 5.14 y 8.25; Gal. Anim. 10), esta última como agravamiento de un mal carácter que ya había quedado patente en la juventud (Cic. Sen. 3.7 y 18.65). También se mencionan en ocasiones la demencia (Apul. Apol. 53), así como la falta de memoria. En época tardoantigua, Isidoro de Sevilla señalaba que "hay quienes opinan que los

\footnotetext{
${ }^{61}$ Senectus ipsa est morbus.

${ }^{62}$ Non est uiuere, sed ualere uita est.

${ }^{63}$ Audire te arbitror, Scipio, hospes tuus avitus Masinissa quae faciat hodie nonaginta natus annos; cum ingressus iter pedibus sit, in equum omnino non ascendere; cum autem equo, ex equo non descendere; nullo imbri, nullo frigore adduci ut capite operto sit, summam esse in eo siccitatem corporis, itaque omnia exsequi regis officia et munera. Potest igitur exercitatio et temperantia etiam in senectute conservare aliquid pristini roboris.
} 
ancianos deben su nombre a la disminución de sus sentidos, porque con la vejez se debilitan" (Isid. Etym. 11.2.27) ${ }^{64}$. A este respecto se pronunciaba así Catón:

"Se me argüirá que la memoria se pierde. Creo que así es si no se ejercita o si estuviera enferma. Temístocles se había aprendido de memoria todos los nombres de sus conciudadanos. ¿Pensáis acaso que confundía a Lisímaco con Arístides cuando, de viejo, mantenía la costumbre saludar a todos? Yo no sólo recuerdo a los de mi generación que todavía viven, también recuerdo el nombre de sus padres, e incluso, el de sus abuelos. No temo perder la memoria leyendo sus epitafios, según dicen, bien al contrario, leyéndolos mantengo su memoria. Nunca he oído decir que un anciano se haya olvidado del lugar donde guardó su tesoro. Recuerdan todos los asuntos que les interesan y el día del encuentro con sus acreedores y deudores" (Cic. Sen. 7.21) $)^{65}$.

Catón insistía a lo largo de todo De Senectute en que la pérdida de memoria asociada a la vejez podía impedirse si la mente se ejercitaba lo suficiente a lo largo de toda la vida. Además, no sólo podía conservarse lo ya aprendido (Apul. Apol. 36.1-2; Sen. Ep. 68.14 y 76.1-2), sino que podían adquirirse conocimientos nuevos; el propio Catón se decidió a aprender griego siendo un senex (Cic. Sen. 8.26; Val. Max. 8.7.1).

Por otro lado, y aunque trataremos este asunto en profundidad más adelante, los textos escritos y el registro arqueológico aportan información acerca de diversas enfermedades o condiciones físicas degenerativas asociadas a la vejez: pérdida de piezas dentarias, arrugas, pérdida de visión, dificultad de movimiento, etc. (Catull. 97; Cel. Med. 2.1.22, 2.8.33, 3.17.1a, 5.26.31c y 6.6.32; Cic. Sen. 11.35-37; Hippoc. Aph. 2.39 y 6.57 y Epid. 1.12; Lucil. 19. 379; Mart. 1.72, 3.43, 3.93 y 5.43; Prop. 2.18.20; Tac. Ann. 1.34; Tib. 1.6.75-85; Verg. Aen. 2.509-511), situaciones que ponen de manifiesto pasajes como éste, ocurrido a Germánico: “Algunos, tomando su mano como si fueran a besarla, metían sus dedos en sus bocas para que [Germánico] tocara sus encías sin dientes; otros le mostraban sus miembros encorvados por la vejez" (Tac. Ann. $1.34)^{66}$.

\footnotetext{
${ }^{64}$ Senes autem quídam dictos putant a sensus diminutione, eo quod iam per vetustatem desipiant.

${ }^{65}$ At memoria minuitur. Credo, nisi eam exerceas, aut etiam si sis natura tardior. Themistocles omnium civium perceperat nomina; num igitur censetis eum, cum aetate processisset, qui Aristides esset, Lysimachum salutare solitum? Equidem non modo eos novi, qui sunt, sed eorum patres etiam et avos, nec sepulcra legens vereor, quod aiunt, ne memoriam perdam; his enim ipsis legendis in memoriam redeo mortuorum. Nec vero quemquam senem audivi oblitum, quo loco thesaurum obruisset; omnia, quae curant, meminerunt; vadimonia constituta, quis sibi, cui ipsi debeant.

${ }^{66}$ et quidam prensa manu eius per speciem exosculandi inseruerunt digitos ut vacua dentibus ora contingeret; alii curvata senio membra ostendebant.
} 
El secreto de una vejez larga y sin demasiados sobresaltos era la vida austera, tanto en lo que respecta a la alimentación como a la actividad física, lo que alejaría las enfermedades y ayudaría a mantener el equilibrio de los humores. Algunos de los pueblos a los que ya hemos aludido como extraordinariamente longevos debían su larga vida a los alimentos que ingerían. Así, según Amiano Marcelino (27.4.14), la gente que habitaba las zonas montañosas de Tracia mantenía su cuerpo fuerte y sano hasta la vejez extrema al evitar comer alimentos calientes. Herodoto (3.23) por su parte señalaba cómo los etíopes vivían más de 120 años gracias a alimentarse a base de carne y leche.

En la vejez se debía reducir la cantidad de comida (Cic. Sen. 14.46; Macrob. Sat 7.13.4), aumentar el consumo de ciertos alimentos como la miel (Gal. Nat. fac. 2.8) y evitar otros que causan una digestión pesada o dificultan la acción depuradora de los riñones (Wilkins, 2015: 65). El vino debía beberse en cantidades moderadas ya que, debido a la sequedad y rigidez del cuerpo en la vejez,

"el vino no sufre la acción contraria de un líquido incompatible y se adhiere con su fuerza intacta al cuerpo árido, y luego ocupa la región que procura al hombre la inteligencia. No hay duda de que el cuerpo de los viejos es también duro, y por ello incluso los conductos naturales se cierran al tratarse de miembros bastante duros, y cuando se bebe vino, no se produce ninguna evaporación, sino que asciende todo hasta la sede misma de los propios borrachos: miembros temblorosos, habla titubeante, locuacidad excesiva, arrebatos de cólera; a tales síntomas están supeditados tanto los jóvenes ebrios como los ancianos sobrios. Por tanto, si experimentan un ligero estímulo del vino, no contraen tales achaques, sino que les aceleran los que ya les aquejan en razón de edad" (Macrob. Sat. 7.6.20-21) ${ }^{67}$.

No obstante, en pequeñas cantidades podía ser beneficioso, ya que conducía el frío, característico de la edad, a la buena proporción de calor (Gal. Anim. 10). De hecho, Plinio el Viejo ( $N H$ 14.8.60) señala que Livia vivió una larga vejez gracias al vino de Pucino. Sin embargo, como abordaremos en profundidad en el Capítulo IV, tanto en la literatura como en el arte es frecuente la figura del senex y la vetula aficionados a la bebida.

\footnotetext{
${ }^{67}$ Unde et haec aetas ad flexum fit difficilior, quod est indicium siccitatis. Intra hos vinum nec patitur contrarietatem repugnantis humoris, et integra vi sua adhaeret corpori arido, et mox loca tenet quae sapere homini ministrant. Dura quoque esse senum corpora nulla dubitatio est: et ideo ipsi etiam naturales meatus in membris durioribus obserantur, et hausto vino exhalatio nulla contingit, sed totum ad ipsam sedem mentis ascendit. Hinc fit ut et sani senes malis ebriorum laborent, tremore membrorum, linguae titubantia, abundantia loquendi, iracundiae concitatione: quibus tam subiacent iuvenes ebrii quam senes sobrii. Si ergo levem pertulerint inpulsum vini, non accipiunt haec mala, sed incitant quibus aetatis ratione iam capti sunt.
} 
Por otro lado se recomendaba realizar ejercicios suaves, de forma que el cuerpo no se debilitase ni por la falta de movimiento ni por la fatiga de actividades físicas demasiado laboriosas (Sen. Ep. 83.3-4). Correr, nadar, o los juegos de armas debían ser sustituidos por los paseos, los dados y las tabas, rutinas que podían paliar los efectos de las enfermedades degenerativas asociadas a la ancianidad (Cic. Sen. 15.58; Suet. Aug. 71). Así, Cicerón proporcionaba los siguientes consejos para una vejez larga y saludable:

"Con el mismo ahínco que se lucha contra la enfermedad, se debe luchar contra la vejez. Se ha de cuidar la salud, se debe hacer ejercicio moderadamente, se debe tomar alimentos y beber cuanto se necesite para tomar fuerzas, pero no tanto como para quedar fatigados. Pues una cosa y otra han de ser remedio para el cuerpo, pero mucho más para la mente y el espíritu. Tanto una como el otro, mente y cuerpo, son como una lámpara, que si no se las alimenta gota a gota, se extinguen con la vejez. Los cuerpos pierden agilidad con la fatiga del ejercicio, en cambio el espíritu se hace más sutil con el adiestramiento mental. Cecilio llama «ancianos cómicos necios», a los que son crédulos, olvidadizos, apáticos, porque no son vicios propios de la vejez, sino de una vejez perezosa, indolente y amodorrada. La petulancia, la libido, que son más propias de los jóvenes que de los ancianos, no se dan en todos los jóvenes, sino en los réprobos, esa necedad senil, que suele llamarse chocheo, es propia de los ancianos frívolos, pero no de todos los ancianos" (Cic. Sen. 11.36) ${ }^{68}$.

En este fragmento, Cicerón hace también alusión a la pérdida del apetito sexual que se creía que acontecía con la vejez, y a la que hacen referencia autores como Ovidio (Am. 1.9.4), Horacio (Carm. 3.14.25), Propercio (3.5.23-24), Tibulo (1.4.27-39), o Virgilio (G. 3.95-101). Una pérdida de actividad sexual que por otro lado se debía más a una cuestión de comedimiento moral, como se aprecia en el texto anterior, que a la falta de capacidades físicas (Cic. Sen. 11.39). De hecho, ya hemos aludido a Masinisa, quien no sólo mantuvo su actividad sexual hasta una avanzada edad, sino también su capacidad reproductora. Otro ejemplo es el de Lucio Volusio Saturnino, quien murió en el siglo I d.C. con 93 años y tuvo su último hijo a los 62 (Plin. NH 7.14). Por el

\footnotetext{
68 Pugnandum tamquam contra morbum sic contra senectutem; habenda ratio valetudinis, utendum exercitationibus modicis, tantum cibi et potionis adhibendum ut reficiantur vires, non opprimantur. Nec vero corpori solum subveniendum est, sed menti atque animo multo magis; nam haec quoque, nisi tamquam lumini oleum instilles, exstinguuntur senectute. Et corpora quidem exercitationum defatigatione ingravescunt, animi autem exercendo levantur. Nam quos ait Caecilius - comicos stultos senes, hos significat credulos, obliviosos, dissolutos, quae vitia sunt non senectutis, sed inertis, ignavae, somniculosae senectutis. Ut petulantia, ut libido magis est adulescentium quam senum, nec tamen omnium adulescentium, sed non proborum, sic ista senilis stultitia, quae deliratio appellari solet, senum levium est, non omnium.
} 
contrario, cuando cuenta con cerca de 50 años Horacio (Carm. 4.1) se queja por seguir sintiendo deseo sexual, un impulso que a su edad considera molesto y que le impide concentrarse en otros asuntos. Este celibato voluntario se contrapone a la figura del senex libidinoso típico de las comedias de Plauto (Asin. 934, Bacch. 1160, Merc. 264, 305-315 y 1015-1025), a quien constantemente se reprocha mostrar una conducta impropia de su edad.

Se trata, por otro lado, de una frugalidad y moderación que debe entenderse como una virtud típicamente romana, que aunque se presenta como especialmente deseable en la vejez debía manifestarse en todas las etapas vitales, y que se consideraba una cualidad característica de la élite. Es por ello que los textos presentan esta renuncia a la opulencia como una elección gustosa, ayudada por un cuerpo envejecido que no necesita con tanta intensidad de las cosas placenteras (Cic. Sen. 14.47; Hor. Epist. 1.6.25-30 y 2.2.55). Para Peter Garnsey (1999: 70-80) la contención en el comer y el beber era una vía mediante la cual los romanos de la élite expresaban su diferencia con respecto al resto de la población, ya que para ellos se trataba de una abstinencia voluntaria, frente a la obligada de las personas pobres, que no tenían qué comer. El mismo criterio podría aplicarse a la sexualidad, cuya falta de control alude a una menor capacidad de razonamiento, a la elección de satisfacer instintos cercanos a lo animal en vez ocuparse de tareas más elevadas (Cic. Sen 12.42).

Algunas de las características físicas asociadas al proceso de envejecimiento servían en Roma para calificar a una persona como anciana, independientemente de su edad cronológica. Así, al igual que conceptos propiamente romanos como la pudicitia, la vejez era en Roma un fenómeno en parte visual (Cokayne, 2007: 220; Harlow y Laurence, 2011: 22), y por lo tanto subjetivo.

Uno de los atributos físicos más destacados de la vejez son las canas (Cass. Dio 46.18.3-4; Juv. 3.25-29; Mart. 2.34; Ov. Met. 12.464-465; Pers. 1.5-10; Plaut. Merc. 305-315; SHA Hadr. 20.80). En El militar fanfarrón de Plauto (Mil. 628-634), Palestrión se asombra de que Periplectómeno no sea viejo a pesar de sus canas ${ }^{69}$. La aparición de los primeros cabellos blancos podía solucionarse arrancándolos (Macrob. Sat. 2.5.7), y cuando el fenómeno era muy evidente se recurría a los tintes (Ov. Ars am. 3.164). No obstante, no siempre se podía engañar al espectador, lo que generaba

\footnotetext{
${ }^{69}$ Periplectómeno tiene 54 años.
} 
situaciones cómicas: “Tienes blanca la barba y el cabello negro. Ya sé por qué: no puedes teñirte la barba y el cabello, Olo, sí puedes" (Mart. 4.36) ${ }^{70}$. En ocasiones las canas eran consideradas un signo de dignidad, tal y como atribuía Plinio el Joven (Pan. 4.7) a Trajano, o de la sabiduría propia de haber vivido una larga existencia (Petron. Sat. 2.8). Así por ejemplo Latreo, calificado como ni joven ni viejo, mostraba las sienes canosas pero la fuerza de un joven (Ov. Met. 12.464), síntoma de su experiencia en la lucha, lo que le daba gran validez como guerrero.

Tras las canas sobrevenía la calvicie, la cual según Aristóteles (GA 3.11.518a) y Plinio el Viejo ( $N H$ 11.47.131) afectaba a los hombres pero no a las mujeres ni a los eunucos. La alopecia se prevenía mediante preparados de grasa de oso y láudano o bilis de toro (Plin. NH 28.46). Si no se llegaba a tiempo para esos remedios, una cabeza calva podía disimularse mediante pelucas, así como cubriendo las partes sin pelo con el cabello aún restante:

"El otro día, viéndote por casualidad sentado a ti solo, Labieno, te tomé por tres personas. Me engañó el número de tu calva: tienes cabellos a una parte y tienes a la otra, y tan largos como los que pueden sentar bien incluso a un adolescente; en su mitad, tienes la cabeza desnuda y en un largo espacio no se deja ver ni un solo pelo" (Mart. 5.49)

\begin{abstract}
"Recoges tus pocos pelos de un lado y de otro y el extenso descampado de tu reluciente calva, Marino, lo encubres con las melenas de tus sienes; pero removidos a instancias del viento se vuelven y quedan como estaban, y a tu cabeza desnuda la rodean con enormes greñas por aquí y por allí (....) ¿Quieres tú -con más naturalidad- reconocerte viejo para que por fin parezcas ser una sola persona? No hay nada más grotesco que un calvo melenudo" (Mart. 10.83) ${ }^{72}$.
\end{abstract}

Por su parte, la falta de dientes podía remediarse mediante postizos (Mart. 1.72 y 12.23). También existían medios para atenuar el efecto de las arrugas (Mart. 3.43), a los que nos referiremos en profundidad más adelante por ser considerados típicamente femeninos.

\footnotetext{
${ }^{70}$ Cana est barba tibi, nigra est coma: tinguere barbam non potes -haec causa est- et potes, Ole, comam.

${ }^{71}$ Vidissem modo forte cum sedentem solum te, Labiene, tres putaui. Caluae me numerus tuae fefellit: sunt illinc tibi, sunt et hinc capilli quales uel puerum decere possunt; nudumst in medio caput nec ullus in longa pilus area notatur.

${ }^{72}$ Raros colligis hinc et hinc capillos et latum nitidae, Marine, calvae campum temporibus tegis comatis; sed moti redeunt iubente vento reddunturque sibi caputque nudum cirris grandibus hinc et inde cingunt (...) Vis tu simplicius senem fateri, ut tandem videaris unus esse! Calvo turpius est nihil comato.
} 
Nos encontramos también con escenas en las que la vejez se presenta de forma grotesca, resaltando la pobreza y marginalidad de las personas ancianas que no contaban con apoyo económico o familiar (Cic. Sen. 5.14; Tac. Ann. 1.34). En ocasiones, estas escenas sirven para ilustrar la situación de pobreza a la que se veía avocada gran parte de la población romana en momentos políticamente convulsos:

“Aquella animosidad, que por sí sola iba tomando cuerpo, se vio avivada por la desgracia hiriente de un individuo. Un hombre de edad avanzada se precipitó en el foro llevando sobre sí las señales de todos sus sufrimientos: sus ropas estaban llenas de mugre, y más desagradable aún era el aspecto de su cuerpo consumido, lívido y macilento" (Liv. 2.23) ${ }^{73}$.

Una visión general de todos los males que podían acontecer en la vejez, algunos de los cuales ya hemos señalado y sobre los que volveremos a lo largo de las siguientes páginas, nos la proporciona Juvenal:

“«Dame larga vida, Júpiter, dame muchos años». Esto pides con semblante saludable, sólo esto pides también con el macilento. Pero ¡de cuántos y cuán persistentes males está llena una larga vejez! Contempla, ante todo, el rostro deformado y las mejillas flácidas donde antes hubo piel y unas arrugas como las que se rasca una mona ya madre en la boca revejida donde Tábraca extiende sus sombríos bosques. Muchas son las diferencias entre los jóvenes, aquel es más guapo que este y de rasgos diferentes, este es mucho más fuerte que aquel. Uno solo es el aspecto de los viejos: les tiemblan la voz y los miembros y tienen la cabeza ya calva y las narices mojadas como las de los niños; el pobre tiene que partir el pan con la encía desdentada. Tan pesado para su esposa e hijos y para sí mismo que cansaría a Coso el cazatestamentos. No son los mismos los placeres del vino y de la comida cuando el paladar está embotado; pues del coito hace tiempo que te has olvidado, o si lo intentas, tu miembro minúsculo y herniado yace $\sin$ vigor $\mathrm{y}$, aunque te lo manoseen toda la noche, sin vigor seguirá. $\mathrm{O}$, ¿es que esas canas de tu penosa entrepierna pueden esperar algo?, ¿y no está mal vista, con razón, una libido que sin fuerzas trata de alcanzar el placer? Mira ahora la decadencia de otra facultad. Pues ¿qué deleite saca de un cantante, por excepcional que sea, o del citaredo Seleuco y de los que habitualmente actúan con fulgurantes túnicas doradas? ¿Qué importa en qué lugar del gran teatro se siente el que a duras penas oirá las cornetas y el concierto de las trompetas? Es preciso que le griten

\footnotetext{
${ }^{73}$ Invidiamque eam sua sponte gliscentem insignis unius calamitas accendit. Magno natu quidam cum omnium malorum suorum insignibus se in forum proiecit. Obsita erat squalore vestis, foedior corporis habitus pallore ac macie perempti.
} 
para que su oreja oiga qué visitante le anuncia el esclavo o qué hora le dice que es. Además, la poquísima sangre que le corre por el cuerpo ya helado sólo se calienta con la fiebre, lo asedian en formación todo tipo de enfermedades; si me preguntaras sus nombres, más fácilmente te contaría cuántos amantes ha tenido Opia, cuántos enfermos se cargó Temisón en un solo otoño, a cuántos socios ha estafado Básilo, a cuántos pupilos Hirro, a cuántos tíos devora Maura la larga en un solo día, cuántos discípulos se cepilla Hamilo; más rápidamente repasaría cuántas casas de campo posee ahora el barbero que de joven me cortaba la barba recia y chirriante. Aquel anda delicado de la espalda, este de los riñones, este otro de la rabadilla; aquel otro ha perdido los dos ojos y envidia a los tuertos; los labios pálidos de este otro reciben la comida de los dedos ajenos y por su parte él, que solía sonreír a la vista de la comida, solo la abre como un polluelo de golondrina, hacia el que vuela con el pico lleno su madre en ayunas. Pero peor que cualquier pérdida de facultades físicas es la demencia, que ni recuerda los nombres de los esclavos ni reconoce la cara del amigo con el que cenó la noche anterior ni a los hijos que ha engendrado, a los que ha educado. Pues en un abominable testamento prohíbe que sean sus herederos, todos sus bienes van a parar a Fíale: tanto es el poder que tiene el aliento de una boca habilidosa, que ha pasado muchos años en un cuartucho de burdel. Y aunque sus facultades mentales estén en plena forma, sin embargo habrá de presidir los entierros de sus hijos, contemplar la pira de su amada esposa y la de su hermano y las urnas llenas con las cenizas de sus hermanas. Esta es la pena impuesta a quienes viven mucho tiempo, que, debido a que la desgracia se abate una y otra vez sobre su casa, envejecen pasando por muchas penas, permanentemente tristes y vestidos de luto" (Juv. 10.188-245) ${ }^{74}$.

\footnotetext{
74 'Da spatium uitae, multos da, Iuppiter, annos.' hoc recto uoltu, solum hoc et pallidus optas. Sed quam continuis et quantis longa senectus plena malis! Deformem et taetrum ante omnia uultum dissimilemque sui, deformem pro cute pellem pendentisque genas et talis aspice rugas quales, umbriferos ubi pandit Thabraca saltus, in uetula scalpit iam mater simia bucca. Plurima sunt iuиenum discrimina, pulchrior ille hoc atque ille alio, multum hic robustior illo: una senum facies, cum uoce trementia membra et iam leue caput madidique infantia nasi; frangendus misero gingiua panis inermi. Usque adeo grauis uxori natisque sibique, ut captatori moneat fastidia Cosso. Non eadem uini atque cibi torpente palato gaudia; nam coitus iam longa obliuio, uel si coneris, iacet exiguus cum ramice neruus et, quamuis tota palpetur nocte, iacebit. Anne aliquid sperare potest haec inguinis aegri canities? Quid quod merito suspecta libido est quae uenerem adfectat sine uiribus? Aspice partis nunc damnum alterius. nam quae cantante uoluptas, sit licet eximius, citharoedo siue Seleuco et quibus aurata mos est fulgere lacerna? Quid refert, magni sedeat qua parte theatri qui uix cornicines exaudiet atque tubarum concentus? Clamore opus est ut sentiat auris quem dicat uenisse puer, quot nuntiet horas. Praeterea minimus gelido iam in corpore sanguis febre calet sola, circumsilit agmine facto morborum omne genus, quorum si nomina quaeras, promptius expediam quot amauerit Oppia moechos, quot Themison aegros autumno occiderit uno, quot Basilus socios, quot circumscripserit Hirrus pupillos, quot longa uiros exorbeat uno Maura die, quot discipulos inclinet Hamillus; percurram citius quot uillas possideat nunc quo tondente grauis iuueni mihi barba sonabat. Ille umero, hic lumbis, hic coxa debilis; ambos perdidit ille oculos et luscis inuidet; huius pallida labra cibum accipiunt digitis alienis, ipse ad conspectum cenae diducere rectum suetus hiat tantum ceu pullus hirundinis, ad quem ore uolat pleno mater ieiuna. Sed omni membrorum damno maior
} 
En este texto Juvenal aborda el deseo de alejar la muerte lo máximo posible, pero se pregunta para qué resulta útil una larga vejez, ya que se trata de una etapa vital llena de calamidades. En su sátira, el poeta presenta una imagen exagerada y estereotipada de la senectud en la que pueden apreciarse seis de los ocho mitos sobre la vejez a los que aludíamos al comienzo de este capítulo. El mito de la edad biológica se aprecia en la idea de la vejez como causante de diversos males, y en cómo las palabras de Juvenal tienden a concebir a la población anciana como un grupo homogéneo, en contraposición a la diversidad de la juventud ${ }^{75}$. Los mitos de la mala salud y de la senilidad resultan una constante en el texto mostrado, los cuales se materializan tanto en diversas patologías físicas y mentales como en la fealdad derivada de la calvicie y la pérdida de piezas dentales. A ellos se les unen los mitos del declive intelectual y la jubilación, ya que Juvenal considera a las personas viejas como inactivas e incapaces de disfrutar de actividades que les generen felicidad. Finalmente, también está presente el mito del aislamiento social, apareciendo la vejez representada como un periodo de soledad en el que la persona anciana se convierte en una carga para su familia.

Nos encontramos en definitiva frente a una imagen eminentemente negativa de la senectud, que propicia en clave de humor la devaluación de un grupo de edad concreto, la cual a pesar de ser irreal acudiría a la mente de romanas y romanos cuando alguien les pidiese que pensasen en una vetula o un senex. A continuación analizaremos cómo esta vejez imaginada por la sociedad romana se contrapone con la vejez deseada y esperada.

\section{II.3. VIVIR LA VEJEZ EN PRIMERA PERSONA: BUENA VEJEZ VS. MALA} VEJEZ

Como se ha dejado entrever a lo largo los anteriores apartados, en Roma la vejez era un fenómeno representado de forma dual. Si bien se trataba de una etapa vital no

\footnotetext{
dementia, quae nec nomina seruorum nec uoltum agnoscit amici cum quo praeterita cenauit nocte, nec illos quos genuit, quos eduxit. Nam codice saeuo heredes uetat esse suos, bona tota feruntur ad Phialen; tantum artificis ualet halitus oris, quod steterat multis in carcere fornicis annis. Ut uigeant sensus animi, ducenda tamen sunt funera natorum, rogus aspiciendus amatae coniugis et fratris plenaeque sororibus urnae. Haec data poena diu uiuentibus, ut renouata semper clade domus multis in luctibus inque perpetuo maerore et nigra ueste senescant.

75 Esta supuesta homogeneidad de la vejez, una idea que ha llegado hasta nuestros días, está siendo rebatida por la Sociología, surgiendo diversos estudios que postulan una realidad contraria; es decir, que a medida que envejecemos los seres humanos nos parecemos menos al resto de personas de nuestra misma generación (Ramos Toro, 2017: 68).
} 
deseada por su proximidad con la muerte, el debilitamiento, y cierta pérdida de poder político y social, algunos autores, sobre todo aquellos que escriben desde su propia senectud, muestran una visión positiva de la vejez. Para Santiago López Moreda, esta visión dual “da muestras una vez más del sentido utilitarista y pragmático que impregna toda su cultura a la vez que se muestra también receptora, especialmente en el mundo de la poesía, del pensamiento griego, por lo general, señaladamente pesimista” (López Moreda, 2003: 73).

Los propios escritores romanos desarrollan esta visión de la buena y la mala vejez, caras opuestas de la moneda que dependen tanto de factores biológicos -las enfermedades o el proceso degenerativo natural-, como sociales -el estatus económico y social, la relación con la familia, etc.-, así como del momento vital en el que se encontraba el autor del texto cuando lo redactó o la distancia que lo separaba de la persona anciana que describe.

Para Cicerón eran varias las características que debía tener una buena vejez: "La ancianidad es llevadera si se defiende a sí misma, si conserva su derecho, si no está sometida a nadie, si hasta su último momento el anciano es respetado entre los suyos. Como en el adolescente hay algo de senil, también en el anciano hay algo de adolescente, lo reconozco. Quien siga esta norma podrá ser anciano de cuerpo pero no de espíritu. Tengo ahora entre mis manos el libro Los Orígenes donde recopilo todos los recuerdos de la antigüedad. Precisamente ahora acabo de recopilar los discursos más importantes de los asuntos judiciales que yo defendí. Ahora me ocupo del derecho de los augures, pontificio y civil, pero todavía estudio con mucho interés la literatura griega. Y, a la manera de los pitagóricos, recuerdo por la noche todas las acciones realizadas a lo largo del día para ejercitar la memoria. Estos son los ejercicios del ingenio, los ejercicios de la mente. Trabajando con el máximo esfuerzo en estos asuntos, no echo de menos las fuerzas físicas. También estoy siempre a disposición de los amigos, voy con frecuencia al Senado y, de vez en cuando, aporto propuestas muy meditadas y largo tiempo observadas, no con las fuerzas corporales, sino con las del espíritu. Si yo no estuviera en situación de poder realizar estas cosas, desde mi lecho me recrearía pensando en lo que no podría ejecutar. Pero, según la conducta observada a lo largo de mi vida, puedo llevarlas a cabo. Quien vive en medio de estos afanes y trabajos, no sabe en qué momento le puede sorprender la vejez. La vida va transcurriendo sin darse uno 
cuenta, no se quiebra de repente, la lámpara de la vida se va extinguiendo poco a poco, día y noche" (Cic. Sen. 11.38) ${ }^{76}$.

Este fragmento de De Senectute otorga gran importancia a la independencia y a la salud, tanto física como mental, como factor que permitía disfrutar de una buena vejez. Ésta tenía además una importante ventaja: la sabiduría acumulada a lo largo de los años gracias al estudio y las experiencias vividas (Cic. Att. 1.10 y Sen. 8.26; Sen. Ep. 67.1-2; Ter. Ad. 832; Val. Max. 8.7). Así, para Séneca:

"no tienes por qué pensar que exista para la sabiduría otra edad más apropiada que ésta, la cual, a través de numerosas pruebas y de un constante arrepentimiento, se ha dominado, y una vez moderadas las pasiones, ha alcanzado saludables progresos (...) Todo el que de viejo alcanza la sabiduría, la alcanza a través de los años" (Sen. Ep. 68.14) $)^{77}$.

Estos conocimientos adquiridos no sólo servían para cultivar el propio intelecto, sino que también eran un medio de transmitir sabiduría a las generaciones más jóvenes, tanto en lo que respecta al ámbito político como a saberes populares (Apul. Met. 4.27.58 y 9.22.1; Cic. Off. 1.34.122-123 y Sen. 3.9, 7.23, 9.29 y 14.46; Juv. 15.4.5; Macrob. Sat. 7.2.14; Pers. 2.30-34; Tac. Ann. 3.16; Tib. 1.3.85-90 y 3.5.15). Plutarco (Mor. 797e) consideraba fundamental el que los políticos, una vez ancianos, siguieran ejerciendo su oficio para aconsejar a los más jóvenes con su buena capacidad reflexiva, su sinceridad y sus conocimientos acumulados a lo largo de muchos años de experiencia. Cicerón escribía sobre el beneficio que él mismo obtuvo cuando era un adolescente a través de la amistad con Escévola:

"Quinto Mucio el augur solía contar con gracia muchas anécdotas de Cayo Lelio, su suegro, y no dudaba, cualquiera que fuera el tema de conversación, en llamarlo Sabio. Por lo que a mí respecta, mi padre me confió a Escévola una vez que tomé

\footnotetext{
${ }^{76}$ Ita enim senectus honesta est, si se ipsa defendit, si ius suum retinet, si nemini emancipata est, si usque ad ultimum spiritum dominatur in suos. Ut enim adulescentem in quo est senile aliquid, sic senem in quo est aliquid adulescentis probo; quod qui sequitur, corpore senex esse poterit, animo numquam erit. Septimus mihi liber Originum est in manibus; omnia antiquitatis monumenta colligo; causarum inlustrium quascumque defendi nunc cum maxime conficio orationes; ius augurium, pontificium, civile tracto; multum etiam Graecis litteris utor, Pythagoreorumque more exercendae memoriae gratia, quid quoque die dixerim, audierim, egerim, commemoro vesperi. Hae sunt exercitationes ingeni, haec curricula mentis, in his desudans atque elaborans corporis vires non magno opere desidero. Adsum amicis, venio in senatum frequens ultroque adfero res multum et diu cogitatas, easque tueor animi, non corporis viribus. Quas si exsequi nequirem, tamen me lectulus meus oblectaret ea ipsa cogitantem, quae iam agere non possem; sed ut possim, facit acta vita. Semper enim in his studiis laboribusque viventi non intellegitur quando obrepat senectus. Ita sensim sine sensu aetas senescit nec subito frangitur, sed diuturnitate exstinguitur.

${ }^{77}$ Non est tamen quod existimes ullam aetatem aptiorem esse ad bonam mentem quam quae se multis experimentis, longa ac frequenti rerum paenitentia domuit, quae ad salutaria mitigatis affectibus venit (...) quisquis senex ad sapientiam pervenit, annis pervenit.
} 
la toga viril, de suerte que no me apartaba nunca del lado de aquel anciano, en la medida en que yo podía y se me permitía. De esa forma, yo iba guardando en mi memoria muchos asuntos sobre los que él disertaba con inteligencia y otra sentencias breves y oportunas, y me esforzaba en hacerme más docto a partir de su experiencia" (Cic. Amic. 1.1 $)^{78}$.

Mary Harlow y Ray Laurence (2010) han estudiado este tipo de relaciones de amistad entre personas de diferentes edades, las cuales a pesar de estar representadas en las fuentes con mayor frecuencia para el caso masculino, también se darían entre mujeres. Además de su papel como transmisoras de sabiduría, estos autores postulan que las relaciones de amistad entre individuos de diferente edad se deberían también a que, a medida que se iba envejeciendo, la muerte de las personas de la misma generación provocaría la búsqueda de relaciones sociales con los más jóvenes (Harlow y Laurence, 2010: 26-27).

Una buena vejez se caracterizaba también por ser una etapa de retiro lejos del ajetreo de la Urbs, en la que desaparecían todas las cargas anteriores, algo que solamente sería accesible a las élites, a las personas que hubiesen ahorrado dinero suficiente tras largos años de trabajo, o a quienes tuviesen familiares que pudiesen mantenerlos (Cic. Fam. 1.9.21 y Sen. 3.8; Dio Cass. 69.19.2; Tac. Ann. 4.41.2) ${ }^{79}$. La idea del retiro en la vejez se debe, según Stephen Dyson (1992: 374), a que se trata de una etapa vital que para los romanos debía dedicarse a la reflexión, convirtiendo a Roma en una ciudad esencialmente joven, por lo que deberíamos situar a vetulae y senes en emplazamientos rurales o ciudades menores, si bien por el momento no ha podido confirmar su teoría. De esta forma, para este autor (Dyson, 1992: 375) los foros de las ciudades pequeñas estarían siempre llenos de personas viejas pertenecientes a todos los estratos de la sociedad, dejando pasar el tiempo y contemplando las actividades cotidianas. Para quienes aún conservaban un buen estado físico, el tiempo en el campo podía dedicarse a las tareas agrícolas (Cic. Sen. 5.24 y 17. 60), actividad considerada especialmente elevada en la cultura romana.

\footnotetext{
${ }^{78}$ Q. Mucius augur multa narrare de C. Laelio socero suo memoriter et iucunde solebat nec dubitare illum in omni sermone appellare sapientem; ego autem a patre ita eram deductus ad Scaevolam sumpta virili toga, ut, quoad possem et liceret, a senis latere numquam discederem; itaque multa ab eo prudenter disputata, multa etiam breviter et commode dicta memoriae mandabam fierique studebam eius prudentia doctior.

${ }^{79}$ Para un análisis en profundidad de la vejez masculina como momento de otium, vid. Cokayne, 2007.
} 
Marcial (4.225) imaginó un retiro en un ambiente idílico en medio de la naturaleza. A escala más reducida, el Puerto de los Ancianos de Quíos era, según Eliano (NA 12.30), un lugar donde las personas viejas podían estar en contacto con la naturaleza y admirar a los peces criados para su entretenimiento. En sus casas de campo, los senes y las vetulae podían disfrutar con moderación de los placeres que aún les estaban permitidos, como los juegos, el vino y las visitas (Cic. Leg. 1.3.10 y Sen. 14.46; Gal. Anim.10; Hor. Carm. 2.4.5 y Sat. 1.1.25-35; Tac. Ann. 4.41.2). Cornelia era conocida por recibir visitas en su retiro de Campania, a donde se había trasladado tras la muerte de sus dos hijos (Val. Max. 4.4). Por su parte, la misma villa de Alsio se convirtió en lugar de retiro para Pompeya Celerina, suegra de Plinio el Joven, y para Verginio Rufo:

"Gayo Plinio a Luceyo Albino,

Cuando fui a visitar a mi suegra en su villa de Alsio, que en un tiempo perteneció a Verginio Rufo, la simple contemplación del lugar renovó mi alma, no sin dolor, la añoranza de aquel hombre tan noble y excelente. En efecto, en este lugar se había acostumbrado a pasar su retiro e incluso lo llamaba el nidito de su vejez" (Plin. Ep. $6.10 .1)^{80}$.

No obstante, encontramos también opiniones contrarias a la costumbre del retiro. Es el caso de Séneca (Ep. 36.1) y Plutarco (Mor. 783f, 784a y 788a), para quienes el cese de actividad en la vejez conducía al abandono, la gula, el anquilosamiento y la pérdida progresiva de facultades. De esta forma, el anciano que se encerraba en casa se convertía en un ser débil y enfermizo confinado en el ámbito doméstico y por lo tanto similar a las mujeres. Sobre si las vetulae y los senes que no pertenecían a la clase política debían o no cesar sus actividades, Plutarco no expone ninguna opinión.

Como ejemplos de ancianos que siguieron políticamente activos contamos con Catón (Cic. Sen. 11.38; Liv. 39.40.11-12) y Augusto (Tac. Ann. 1.46.3), quien mantuvo un gran ritmo de trabajo ya anciano. El abogado republicano Filipo continuó con su oficio en la vejez, a pesar de sus limitaciones físicas, al igual que Livio Druso, quien además era ciego (Hor. Epist. 1.7.45-49; Val. Max. 8.7.4). Debemos añadir aquí a toda la población esclava, para quien cesar la actividad en la vejez no era una opción. No obstante, en ocasiones la idea de seguir desempeñando un cargo en la vejez no era bien vista (Tac. Hist. 1.9); así, de Galba se destacaba de manera continua su debilidad física

${ }^{80}$ C. PLINIUS ALBINO SUO S. Cum venissem in socrus meae villam Alsiensem, quae aliquamdiu Rufi Vergini fuit, ipse mihi locus optimi illius et maximi viri desiderium non sine dolore renovavit. Hunc enim colere secessum atque etiam senectutis suae nidulum vocare consueverat. 
y su carácter blando derivados de la vejez, y la incapacidad que ello le producía para gobernar el imperio de forma adecuada (Tac. Hist. 1.12, 1.23 y 1.35).

Todas estas características de la buena vejez a las que hemos hecho alusión se personifican en Espurina, amigo de Plinio el Joven:

"Gayo Plinio a Calvisio Rufo

No sé si habré pasado en mi vida algún momento más grato que el que he vivido no hace mucho en casa de Espurina; hasta tal punto que, en mi vejez, si el destino me permitiese llegar a ella, no quisiera imitar a nadie antes que a él. No hay en efecto nada mejor planificado que aquella manera de vivir. Pues, del mismo modo que me agrada sobremanera el curso de las estrellas, así también me place una vida perfectamente organizada, especialmente en la vejez. En cierto sentido, en los jóvenes no resulta incoherente una vida relajada y, por así decirlo, desordenada; en cambio, a los ancianos les conviene una existencia plácida y organizada, ya que en su caso cualquier actividad excesiva resulta inoportuna y la ambición repelente. Espurina observa escrupulosamente esta regla; más aún, consigue que esas cosas triviales - triviales si no ocurriesen a diario - sucedan con un cierto orden y, por así decirlo, de forma cíclica. Por la mañana permanece en la cama durante una hora, a continuación pide las sandalias y recorre a pie una distancia de tres millas para ejercitar tanto su cuerpo como su espíritu. Si le acompañan algunos amigos, mantiene con ellos conversaciones muy eruditas; si no, se hace leer un libro, a veces incluso en presencia de sus amigos, si ellos no ponen reparos. Luego se sienta, y continúa la lectura del libro, o mejor aún la conversación; después se sube a un carruaje, acompañado de su esposa, un singular ejemplo para su sexo, o de alguno de sus amigos, como de mí mismo recientemente. ¡Qué agradable, qué dulce retiro! ¡Cuánta tradición hay allí! ¡Qué hechos, a qué grandes hombres escuchas! ¡De qué grandes principios te imbuyes!; aunque él ha impuesto a su modestia una justa medida: no dar la impresión de que está enseñando. Después de un recorrido de siete millas, hace a pie una milla más, luego se sienta otra vez o se retira a su habitación y a su escritura. Escribe, en efecto, en latín y griego cultísimas poesías líricas, que tienen un asombroso encanto, una asombrosa dulzura, una asombrosa delicadeza, cuyo valor aumenta la personalidad del autor. Cuando se le anuncia la hora del baño (a media tarde en invierno, una hora antes en verano), da desnudo un paseo al sol, si no hace viento. Después juega a la pelota con ardor y durante mucho tiempo, pues también combate la vejez con este tipo de ejercicio. Después del baño se acuesta un rato y aplaza el momento de la comida; 
entretanto escucha mientras alguien le lee alguna cosa más trivial y agradable. Durante todo este tiempo sus amigos tienen libertad para hacer las mismas cosas u otras diferentes, si así lo prefieren. Se pone una cena tan sencilla como bien servida, en una vajilla de plata pura y antigua; también utiliza para uso corriente una vajilla de Corinto, que le agrada mucho, aunque no le apasiona. Con frecuencia la cena se enriquece con representaciones escénicas, para que los placeres de la mesa se vean sazonados por los intelectuales. La cena se prolonga algo en la noche, sobre todo en verano, sin que a nadie le parezca excesivamente larga, a causa de la amenidad con que ésta se desarrolla. El resultado es que Espurina ha conservado a los setenta y siete años intactos el sentido de la vista y del oído; además, un cuerpo ágil y lleno de vigor y de la vejez tan sólo la prudencia" (Plin. Ep. 3.1.1-10) ${ }^{81}$.

Espurina llevaba una vida moderada y ordenada. Retirado del ajetreo de la ciudad, dedicaba su tiempo a pasear a pie o en carro y jugar a la pelota, actividades recomendables en la vejez (Cel. Med. 4.26.5; Petron. Sat. 27.1-2). No se excedía en el comer y cultivaba su mente mediante la lectura, la escritura y la conversación con sus amistades. Es por ello que Plinio lo convierte en modelo de buena vejez y ansía ser como él.

Finalmente, era deseable que la vejez se viviesen en familia (Auson. Ep. 17.35-40 y Protrept. ad nep. 2.15-20; Dio Cass. 56.3.3-5; Mart. 4.13; Ov. Met. 3.133-135 y 6.500; Plin. Ep. 8.10 y 8.18.1-2; Tib. 1.10.40-45; Val. Max. 7.1.1), viendo a los hijos

81 C. PLINIUS CALVISIO RUFO SUO S. Nescio an ullum iucundius tempus exegerim, quam quo nuper apud Spurinnam fui, adeo quidem ut neminem magis in senectute, si modo senescere datum est, aemulari velim; nihil est enim illo vitae genere distinctius. Me autem ut certus siderum cursus ita vita hominum disposita delectat. Senum praesertim: nam iuvenes confusa adhuc quaedam et quasi turbata non indecent, senibus placida omnia et ordinata conveniunt, quibus industria sera turpis ambitio est. Hanc regulam Spurinna constantissime servat; quin etiam parva haec - parva si non cotidie fiant - ordine quodam et velut orbe circumagit. Mane lectulo continetur, hora secunda calceos poscit, ambulat milia passuum tria nec minus animum quam corpus exercet. Si adsunt amici, honestissimi sermones explicantur; si non, liber legitur, interdum etiam praesentibus amicis, si tamen illi non gravantur. Deinde considit, et liber rursus aut sermo libro potior; mox vehiculum ascendit, assumit uxorem singularis exempli vel aliquem amicorum, ut me proxime. Quam pulchrum illud, quam dulce secretum! quantum ibi antiquitatis! quae facta, quos viros audias! quibus praeceptis imbuare! quamvis ille hoc temperamentum modestiae suae indixerit, ne praecipere videatur. Peractis septem milibus passuum iterum ambulat mille, iterum residit vel se cubiculo ac stilo reddit. Scribit enim et quidem utraque lingua lyrica doctissima; mira illis dulcedo, mira suavitas, mira hilaritas, cuius gratiam cumulat sanctitas scribentis. Ubi hora balinei nuntiata est - est autem hieme nona, aestate octava -, in sole, si caret vento, ambulat nudus. Deinde movetur pila vehementer et diu; nam hoc quoque exercitationis genere pugnat cum senectute. Lotus accubat et paulisper cibum differt; interim audit legentem remissius aliquid et dulcius. Per hoc omne tempus liberum est amicis vel eadem facere vel alia si malint. Apponitur cena non minus nitida quam frugi, in argento puro et antiquo; sunt in usu et Corinthia, quibus delectatur nec afficitur. Frequenter comoedis cena distinguitur, ut voluptates quoque studiis condiantur. Sumit aliquid de nocte et aestate; nemini hoc longum est; tanta comitate convivium trahitur. Inde illi post septimum et septuagensimum annum aurium oculorum vigor integer, inde agile et vividum corpus solaque ex senectute prudentia. 
ocupar los espacios que la persona anciana ocupó una vez y disfrutando de la compañía de nietos y bisnietos: "En cuanto a ti, crezca tu descendencia; que aumente las hazañas de su padre y respetuosa te rodee de anciano" (Tib. 1.7.55) ${ }^{82}$. Entre las actividades diarias del ejemplar Espurina estaba dar un paseo en carruaje con su esposa, si bien éste es el único momento en el que se la menciona y no sabemos si el senex dedicada más tiempo de su jornada a la familia. Se consideraba un logro personal reunir a una amplia familia que sintiera admiración por el senex o la vetula:

"El divino Augusto, entre otras muestras de ejemplos excepcionales, conoció a un nieto de su nieta, nacido el año en el que él murió, Marco Silano. (...) Quinto Metelo Macedónico, además de dejar seis hijos, dejó once nietos y, entre nueras, yernos y todos los que lo saludaban llamándole padre, veintisiete. En las Actas del templo del divino Augusto, se encuentra que (...) Gayo Crispino Hílaro (...) ofreció un sacrificio en el Capitolio junto con sus ocho vástagos, entre los que dos eran hijas, sus veintisiete nietos, sus dieciocho bisnietos y sus ocho nietas, formando una procesión que superó a todas las habidas hasta entonces" (Plin. NH 7.13.58$60)^{83}$.

Por el contrario, perder a un familiar joven, especialmente un hijo, era una gran desgracia, no deseada ni al peor enemigo (Apul. Met. 10.28.2; Cic. Tusc. 1.35.85; Lucr. 4.1255-1256; Plin. Ep. 3.10, 4.2 y 6.16.1-2; Sen. Marc. 19.2) ${ }^{84}$. Podemos encontrarnos también con personas que habían decidido no tener descendencia de forma voluntaria, o bien que, a pesar de tener hijos, no tenían buena relación con ellos; en este caso, estos ancianos aparecen caracterizados como personas avariciosas y malvadas, y quedaban a merced de los cazafortunas (Hor. Ars P. 155-179; Mart. 11.44 y 11.83; Plaut. Trin. 400; Tac. Ann. 3.23 y 3.48 .2 ).

La avaricia y la mezquindad aparecen de hecho en los textos como características típicas de la vejez (Cic. Sen. 18.64 y 19.66; Hor. Epist. 1.1.75-80; Plaut. Bacch. 645 y Rud. 320; Tac. Hist. 1.72). Así lo ilustra la historia del senex Bato (Ov. Met. 2.675-705), quien ve cómo Mercurio roba unas vacas y acepta la recompensa que el dios le ofrece si

\footnotetext{
${ }^{82}$ At tibi succrescat proles, quae facta parentis augeat et circa stet veneranda senem.

${ }^{83}$ Divus Augustus in reliqua exemplorum raritate neptis suae nepotem vidit genitum quo excessit anno, M. Silanum (...) Q. Metellus Macedonicus, cum sex liberos relinqueret, XI nepotes reliquit, nurus vero generosque et omnes, qui se patris appellatione salutarent, XXVII. In actis temporum Divi Augusti (...) $C$. Crispinium Hilarum ex ingenua plebe Faesulana cum liberis VIII, in quo numero filiae duae fuere, nepotibus XXVII, pronepotibus XVIII, neptibus VIII, praelata pompa tum omnibus, in Capitolio immolasse.

${ }^{84}$ Para un análisis de este fenómeno a partir del registro epigráfico, vid. Laes, 2007.
} 
no da cuenta del robo. Poco después Mercurio, que no confía en Bato, regresa disfrazado y le promete que le dará una recompensa si le dice qué ha pasado con las vacas. El senex acepta la segunda recompensa, igual que aceptó la primera, y el dios, traicionado, decide metamorfosearlo en roca. La avaricia es también la característica definitoria de Euclión, el protagonista de La comedia de la olla de Plauto, y de otros senes y vetulae que aparecen en sus obras (Plaut. Asin. 150-170, Bacch. 690 y Trin. 100).

Otros ancianos se caracterizaron por ser frívolos y derrochadores (Cic. Sen. 11.36). Plutarco (Luc. 39-43) escribe del político tardorrepublicano Lúculo que si bien en su juventud era conocido por ser comedido y un gran militar, una vez anciano acabó con el respeto que le tenía la población romana dándose a una vida de frivolidades entre las que estaban la bebida, los banquetes, el juego y la construcción de edificios de coste desorbitado tanto en Roma como en otros lugares. Además, en vez de dedicar su día a día a quehaceres productivos, pasaba las horas en actividades de ocio como recitales y fiestas, modo de vida al que ya hemos señalado que se oponía Plutarco, quien sin embargo alaba que Lúculo se decidiese en su vejez a crear una amplia biblioteca a la que podía acceder cualquiera que lo desease. Íntimo amigo de Cicerón, parece que Lúculo compartía con él la idea de una senectud dedicada en su mayor parte al otium, retirada de los asuntos públicos, partiendo el tiempo entre Roma y diversas villae y compartiendo actividades con amigos y familiares. De hecho, según Plutarco, Lúculo decidió dejar la política precisamente cuando Cicerón fue enviado al exilio y Catón, otra de sus amistades, partió a Chipre.

Signos de una mala vejez eran también una acusada debilidad física, sobre todo si no se podía suplir con un ánimo fuerte (Ael. NA 6.49; Sen. Ep. 67.2; Val. Max. 8.7.4), así como caer en la dependencia, ya fuera por la pobreza, la demencia o la enfermedad (Cic. Sen. 11.38). Contrario al ejemplo de Espurina es el de Baso, amigo de Séneca que sufría una vejez llena de enfermedades, aunque lograba paliarla con su sentido del humor y mediante la aceptación de la cercanía de la muerte (Sen. Ep. 30). La miseria que acarreaba en ocasiones la vejez se muestra en las fuentes de forma cruda: "Porque este viejo es deforme, artrítico, gotoso; porque es manco y miserable, ahilado y con una hernia enorme" (Lucil. 9. 255) ${ }^{85}$. Un ejemplo extremo es el de Fineo (Ov. Met. 7.1-5),

\footnotetext{
${ }^{85}$ Quod deformis, senex arthriticus ac podagrosus est, quod mancus miserque, exilis, ramice magno.
} 
ciego y viejo, quien se encontraba condenado a un hambre perpetua, ya que las Harpías envenenaban su comida.

Resultaba también reprobable la actitud de quien se lamentaba de su condición, tanto física como económica (Hor. Ars P. 155-179; Petron. Sat. 134.6), y que mostraba un carácter agrio, amargado, propio de quienes no eran capaces de disfrutar de la vejez (Apul. Apol. 53; Cic. Sen. 18.65) y buscaban en ella las diversiones típicas de la juventud (Mart. 4.78; Plaut. Bacch. 1210). Este tipo de actitudes provocaban que la persona anciana se rechazase a sí misma, al ver en qué se había convertido, y que fuera marginada en consecuencia por la sociedad (Cic. Sen. 8.25). Un ejemplo lo encontramos en Ergásilo, personaje de la comedia Los cautivos, quien se lamenta de su estado físico y justifica así su vida como parásito:

"Yo, que me consumo con tu pena, pierdo carnes, me estoy haciendo un viejo, me muero a pedazos, pobre de mí: no soy más que hueso y pellejo, todo por ese maldito enflaquecimiento; y es que lo que como en casa no me aprovecha, en cambio, lo que tomo fuera, aunque sea poco, eso es lo que me luce" (Plaut. Capt. $135)^{86}$.

Si Espurina personificaba la buena vejez, otro romano que encontramos en los textos de Plinio el Joven (Ep. 8.18), Domicio Tulo, supone un crudo ejemplo de los aspectos negativos de la ancianidad. Tim Parkin (2003: 74) calcula que falleció con cerca de 70 años, habiéndose ganado el desprecio de sus contemporáneos. Plinio se sorprende de que el mezquino Tulo haya dejado una buena herencia a su hija, sus nietos y su biznieta, acabando con las esperanzas de los cazadores de herencias o captatores. El testamento también recoge villas y dinero para la viuda, cuyo matrimonio con Tulo había sido criticado, ya que ambos tenían una edad avanzada, ella era viuda con hijos, y él era tan repugnante física y moralmente que nadie hubiera querido casarse con él ni siquiera cuando era joven. El senex se encontraba en un estado de invalidez y dependía por completo de su esposa y los esclavos domésticos; es por ello que Plinio se sorprende ante el hecho de que Tulo quiera seguir viviendo bajo semejantes condiciones:

"Pues descoyuntado y deformado en todos sus miembros, tan sólo disfrutaba sus enormes riquezas con la mirada, y ni siquiera se podía mover en el lecho a no ser con la ayuda de alguien; más aún, incluso se hacía frotar y lavar los dientes (algo

\footnotetext{
${ }^{86}$ Ego, qui tuo maerore maceror, macesco, consenesco et tabesco miser; ossa atque pellis sum miser a macritudine; neque umquam quicquam me iuvat quod edo domi: foris aliquantillum etiam quod gusto, id beat.
} 
repugnante y miserable); él mismo solía decir, cuando se lamentaba de las humillaciones de su debilidad física, que a diario se veía obligado a chupar los dedos de sus esclavos. Sin embargo, vivía y deseaba vivir, reconfortado principalmente por su esposa, que con su devota dedicación había cambiado las anteriores críticas provocadas por su matrimonio en gran admiración” (Plin. Ep. 8.18.9-10) ${ }^{87}$.

En Domicio Tulo la fealdad física se une a la fealdad de carácter, convirtiéndose en ejemplo de que de poco sirve amasar una fortuna si no se es capaz de disfrutarla en la vejez. Tal es la pérdida de dignidad de Tulo que prefiere vivir en condiciones penosas a morir, a pesar de que ello implique una ausencia total de independencia e intimidad, de forma que incluso deben lavarle los dientes. Sólo en la muerte muestra un comportamiento verdaderamente digno, al dejar una jugosa herencia a diversos miembros de su familia, especialmente a la esposa que se encargó de él durante los últimos años. Este es el acto que redime a Tulo, y el que Plinio halaga al comienzo de la epístola.

La dependencia, sea o no tan extrema como en el caso de Domicio Tulo, es un factor que culturalmente se considera inherente a la vejez y que sigue estando sujeto a debate en la actualidad. Hemos señalado cómo Plinio el Joven cuestiona la decisión de Tulo de continuar viviendo en las condiciones físicas en las que se encuentra, que le afectan a él en cuanto que sufridor de las mismas, pero también a familiares y esclavos por los cuidados a los que lo someten. En época clásica no existía un sistema de cuidados en instituciones destinadas a personas desfavorecidas, el cual surgirá de la mano de las primeras organizaciones cristianas (Huebner, 2013: 198). Por ello los senex y vetulae como Tulo, así como el resto de la población romana en condiciones de dependencia, se encontrarían a merced de la buena disposición de su familia para brindarles el tiempo y los cuidados necesarios o de contar con el dinero suficiente para costearse personal esclavo que se encargase de ellos. En caso contrario se verían abocados a la marginalidad, la indigencia y probablemente la muerte.

De la visión dual de la vejez que se desprende del análisis de figuras como la de Espurina y Domicio Tulo se aprecia, por un lado, que la posición que se adopte depende

\footnotetext{
${ }^{87}$ Quippe omnibus membris extortus et fractus, tantas opes solis oculis obibat, ac ne in lectulo quidem nisi ab aliis movebatur; quin etiam - foedum miserandumque dictu - dentes lavandos fricandosque praebebat. Auditum frequenter ex ipso, cum quereretur de contumeliis debilitatis suae, digitos se servorum suorum cotidie lingere. Vivebat tamen et vivere volebat, sustentante maxime uxore, quae culpam incohati matrimonii in gloriam perseverantia verterat.
} 
en gran medida del momento vital en el que se encontrase el autor del texto. Así, los fragmentos escritos en la vejez tienden a ver ésta como positiva, un momento de reposo en el que disfrutar de la compañía de los seres queridos y del tiempo de ocio. No obstante, Cicerón señala que la conformidad con la propia vejez y la consideración de esta etapa como positiva no se daba siempre entre las personas ancianas, si bien no sabemos hasta qué punto esta afirmación está condicionada por el estereotipo de anciano quejica:

"Con frecuencia, junto con Cayo Lelio, aquí presente, suelo admirarme, Marco Catón, de tu excelente y completo dominio de todos los conocimientos, y principalmente por el hecho de que la vejez jamás haya sido onerosa y nefasta para ti, cosa contraria a lo que suelen decir la mayoría de los ancianos que afirman que ellos soportan una carga más pesada que el Etna" (Cic. Sen. 2.4) ${ }^{88}$.

Según Plinio, Domicio Tulo era consciente de lo miserable de su estado y de la pérdida de dignidad e intimidad que suponía necesitar ayuda para las tareas más básicas, por lo que probablemente no tuviese una imagen demasiado positiva de sí mismo. No obstante la situación no le parecía tan insoportable como para suicidarse, lo que puede deberse a que pesaba más en él el miedo a la muerte, o a que encontraba en su día a día aspectos por los que consideraba que merecía la pena seguir con vida.

Por otro lado, se aprecia cómo la caracterización de una vejez como buena o mala se basaba también en si la vetula o el senex se comportaba de acuerdo a las normas de edad que socialmente se le imponían. Mostrar comportamientos inadecuados en la ancianidad podía afear una vida entera de logros y reconocimiento (Auson. Prof. Burd. 10.40-55; Plut. Luc. 39-43). Una buena vejez la vivía quien interiorizaba que se encontraba en los últimos años de su vida y se comportaba como se esperaba que lo hiciera, manteniendo un estilo de vida moderado (Cic. Sen. 20.72; Hor. Sat. 2.1.57-60; Juv. 10.355; Mart. 10.23; Ov. Am. 1.9.4). Si bien resultaba adecuado recordar las hazañas de juventud, no lo era intentar emularlas (Auson. App. 6; Cic. Sen. 9.27, Scaur. 3 y Tusc. 1.45.109; Plaut. Trin. 44; Sen Ep. 122.7; Tac. Ann. 6.32.4), ya que "a cada edad le conviene una conducta distinta" (Plaut. Merc. 984) ${ }^{89}$. Séneca se refería así a esta situación:

\footnotetext{
${ }^{88}$ Saepe numero admirari soleo cum hoc C. Laelio cum ceterarum rerum tuam excellentem, M. Cato, perfectamque sapientiam, tum vel maxime quod numquam tibi senectutem gravem esse senserim, quae plerisque senibus sic odiosa est, ut onus se Aetna gravius dicant sustinere.

${ }^{89}$ aetatem aliam aliud factum condecet.
} 
“Analiza en tu interior a cada uno: te encontrarás con viejos que se preparan con gran empeño para la consecución de honores, para largos viajes, para grandes negocios. Pues bien, ¿qué cosa hay más vergonzosa que un viejo que comienza a vivir?" (Sen. Ep. 13.17) ${ }^{90}$.

Vemos, en resumen, que la percepción de vivir una buena o una mala vejez estaba en Roma determinada principalmente por dos de las dimensiones de la ancianidad a las que hacíamos alusión con anterioridad: la dimensión personal o "vejez sentida", y la social, la percepción que el resto de la sociedad tenía de una vetula o de un senex de acuerdo a su relación con ellos y a la distancia que los separaba del estereotipo ideal existente. Así, tal y como señala Juan Cascajero:

"es contra los viejos que se atreven a infringir la norma que otros grupos de edad les imponen, contra quienes se dispone lo más granado, lo más hiriente y malvado de la diatriba, del sarcasmo, del ridículo y de la mofa, expresados tanto en la palabra hablada como en la escrita y, aún, en la iconografía" (Cascajero, 2000: 15).

\section{II.4. LA VEJEZ COMO PRÓLOGO DE LA MUERTE}

"Parió la Noche el maldito Moros, a la negra Ker y a Tánato; parió también a Hipnos y engendró la tribu de los Sueños. Luego además la diosa, la oscura Noche, dio a luz sin acostarse con nadie a la Burla, al doloroso Lamento y a las Hespérides que, al otro lado del ilustre Océano, cuidan de las bellas manzanas de oro y de los árboles que producen fruto. Parió igualmente a las Moiras y las Keres, vengadoras implacables: a Cloto, a Láquesis y a Átropo que conceden a los mortales, cuando nacen, la posesión del bien y del mal y persiguen los delitos de hombres y dioses. Nunca cejan las diosas en su terrible cólera antes de aplicar un amargo castigo a quien comente delitos. También alumbró a Némesis, azote para los mortales, la funesta Noche. Después ella tuvo al Engaño, la Ternura y la funesta Vejez, y engendró a la astuta Eris" (Hes. Th. 211-225) ${ }^{91}$.

\footnotetext{
90 Circumspice tecum singulos: occurrent tibi senes qui se cum maxime ad ambitionem, ad peregrinationes, ad negotiandum parent. Quid est autem turpius quam senex vivere incipiens?

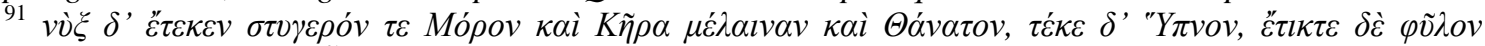

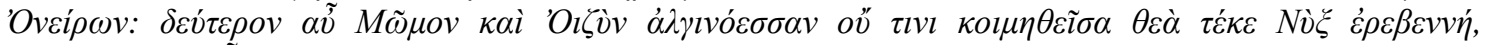

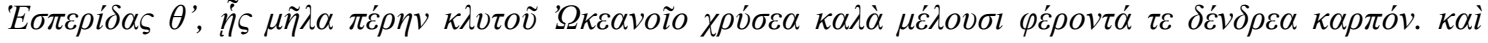

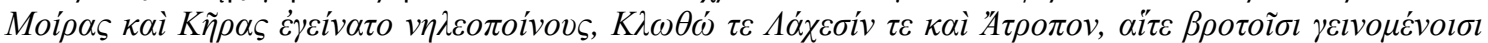

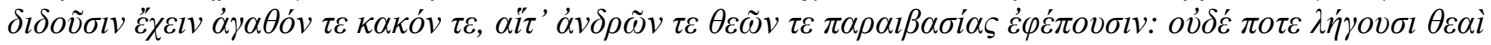

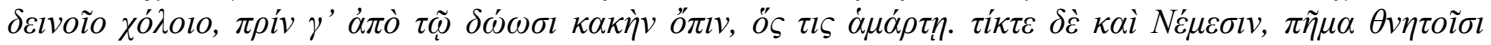

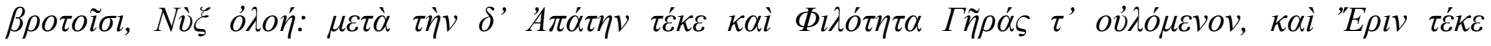

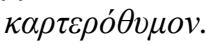


Este fragmento de la Teogonía sirve para ilustrar cómo en el mundo greco-romano antiguo existía una estrecha relación entre la noche, la muerte y la vejez, relación a la que aludiremos en varias partes de nuestra Tesis Doctoral. Noche era la madre de Moro (la muerte como destino), Cer (la muerte como fin), Tánato (la muerte como tal), las Moiras (que decidían el destino de los mortales) y Geras (la vejez). Esta última es una divinidad abstracta a quien no se atribuye ninguna actuación en la mitología, y que aparece mencionada junto con su temible familia en Cicerón (Nat. D. 3.17), Virgilio (Aen. 6.268) y Séneca (Herc. 686). Geras, el homónimo griego de Senectus, aparece representado en las cerámicas griegas como un anciano flaco apoyado en un bastón, y se lo contrapone a la figura del joven y fuerte Heracles (Fig. 1).

Uno de los motivos por los que la vejez genera rechazo y miedo en el ser humano es que se trata de la etapa vital que precede a la muerte. A medida que pasan los años, la certeza de la muerte se hace más patente; un hecho que en la juventud se piensa lejano, abstracto, algo que les ocurre a otras personas -las personas viejas-, se cierne sobre las conciencias a medida que el propio sujeto se acerca a la ancianidad (Cic. Sen. 5.15; Hor. Sat. 1.4.125-129 y 2.1.57-60; Macrob. Sat. 2.7.3). Surge en el individuo una nostalgia característica de la vejez (Hor. Ars P. 155-179; Lundgren, 2010: 250), que Cicerón expresaba así:

"Pero vuelvo de nuevo al hecho de la muerte que siempre está amenazante. ¿Por qué la muerte es la desazón perenne de la vejez, cuando bien se sabe que está siempre presente y que también es común a la juventud?" (Cic. Sen. 19.67) ${ }^{92}$.

Una muerte que por otro lado él mismo, bajo el personaje de Catón, veía cada vez más cercana: "Yo mismo no entiendo por qué motivo no me atrevo a exponer mi opinión acerca de la muerte pues, cuanto más cerca estoy de ella, creo que vivo más consciente de su realidad" (Cic. Sen. 21.77) $)^{93}$.

En Roma, tanto mujeres como hombres recibían el mismo tratamiento al fallecer, dependiendo éste de las posibilidades económicas del difunto y de su familia, si bien Rebecca Gowland (2016) señala que los enterramientos de las vetulae tienden a ser más marginales que los de los senes. No obstante la muerte, como fenómeno, tenía una especial relación con las mujeres, ya que eran ellas quienes supervisaban los rituales a

\footnotetext{
92 Sed redeo ad mortem impendentem. Quod est istud crimen senectutis, cum id ei videatis cum adulescentia esse commune?

${ }^{93}$ Non enim video cur, quid ipse sentiam de morte, non audeam vobis dicere, quod eo cernere mihi melius videor, quo ab ea propius absum.
} 
los que se sometía al cadáver (García-Gelabert, 2002: 193). Además, como veremos más adelante, las mujeres, y en especial las vetulae, aparecen frecuentemente relacionadas con la noche, la muerte y los cadáveres.

La sociedad romana concebía la muerte como un acontecimiento que igualaba a todas las personas (Aur. 9.33; Hor. Carm. 1.28 .15 y 2.18.32; Sen. Marc. 20.2), independientemente de su origen social o los logros que hubieran alcanzado a lo largo de su existencia: "La pálida muerte golpea con el mismo pie las chozas de los pobres y los palacios de los reyes" (Hor. Carm. 1.4.13) ${ }^{94}$. Se trataba, además, de un momento ineludible, que comenzaba a acercarse desde el nacimiento (Hor. Epist. 1.16.75; Lucr. 3.1079; Ov. Fast. 6.772-773; Sen. Dial. 1.1.; Marc. 21.14, Pol. 11.2):

"Tú, a quien se le ha permitido tocar las encinas de Tarpeya y ceñir con su primera fronda tu cabellera, si eres sensato, Colino, aprovecha por entero tus días y piensa siempre que es el último que tienes presente. Nadie ha tenido la suerte de aplacar a las tres vírgenes hilanderas: respetan el día que han señalado. Puede que seas más rico que Crispo, más firme que el mismísimo Trásea y más refinado que el elegante Melior: Laquesis no añade ni un hilo a su tarea, pone en movimiento los husos de sus hermanas y siempre una de ellas corta el hilo" (Mart. 4.54) ${ }^{95}$.

En este texto Marcial nos presenta a las Parcas, Nona, Decima y Morta, personificación del destino vital y de su predecible final: la muerte. Manifestación romana de las Moiras griegas, no son sin embargo divinidades totalmente equivalentes $^{96}$. Las Parcas son hijas de la Noche, y por lo tanto hermanas de Senectus. $\mathrm{Su}$ existencia simbolizaba la creencia en unas normas que regulaban el mundo, a las cuales debían plegarse los seres humanos. Las Parcas eran divinidades proféticas del alumbramiento, la muerte y el tiempo. Estaban asociadas a espacios nocturnos iluminados por la luna, además de a la magia y al tejido, actividad femenina por excelencia de la Antigüedad. De hecho el hilado era, como señala Marcial, el medio a través del cual controlaban el destino de los humanos: Nona tensaba el hilo que simbolizaba la vida, Decima lo enrollaba y medía con la vara, y Morta lo cortaba llegado el momento de la muerte (Auson. Par. 29.5; CIL 3.2609; Diod. Sic. 4.36.6; Hor.

\footnotetext{
${ }^{94}$ Pallida mors aequo pulsat pede pauperum tabernas regumque turres.

${ }^{95}$ O cui Tarpeias licuit contingere quercus et meritas prima cingere fronde comas, si sapis, utaris totis, Colline, diebus extremumque tibi semper adesse putes. Lanificas nulli tres exorare puellas contigit: obseruant quem statuere diem. Diuitior Crispo, Thrasea constantior ipso, lautior et nitido sis Meliore licet: nil adicit penso Lachesis, fusosque sororum explicat et semper de tribus una secat.

${ }^{96}$ Para una comparación entre las Parcas y las Moiras, vid. Carbó y Pérez, 2009-2010.
} 
Carm. 2.3.10-15; Mart. 9.17, 9.76 y 10.44; Ov. Fast. 3.801 y Met. 2.654 y 8.452). Más adelante veremos cómo nocturnidad, magia, capacidad de profetizar, hilado, y muerte, son elementos que se encontraban en Roma íntimamente relacionados con la figura de la vetula.

Las Parcas se encontraban en el foro de Roma en forma de tres estatuas denominadas tria Fata (las tres hadas o tres destinos) (Hülsen, 1905: 23). En Hispania, encontramos vestigios de su culto en un ara del siglo II d.C. localizada en Termes (Soria) (Mangas et al., 2013), y Pausanias (2.4.7; 3.11 .10 y 5.15.5) nos habla de la existencia de templos dedicados a las Moiras en Corinto, Esparta y Olimpia.

En ocasiones, estas tres hermanas son representadas como vetulae, lo que sirve para subrayar su cercanía con la muerte. Catulo las describe como ancianas temblorosas, aunque al mismo tiempo temibles:

"Una vez que éstos acomodaron sus miembros en sitiales de un blanco nieve, ampliamente se prepararon unas mesas con variados manjares; he aquí que, mientras tanto, agitando sus cuerpos con un débil temblor, las Parcas empezaron a predecir cantos verídicos. Un vestido blanco que cubría sus cuerpos temblorosos les caía hasta los pies con franja de púrpura; por otra parte, unas cintas rosadas les ceñían sus cabezas blancas y sus manos seguían ritualmente una labor eterna. $\mathrm{La}$ izquierda empuñaba la rueca cubierta de suave lana; la derecha, entonces, tirando suavemente formaba hilos con los dedos vueltos, después, retorciéndolos con el pulgar inclinado, hacía girar el huso en equilibrio por el redondo disco y de esta manera, sus dientes, eliminando la aspereza igualaban siempre el trabajo y los trozos mordidos de lana quedaban pegados a sus resecos labios, los que antes habían sobresalido del hilo alisado. Delante de sus pies los suaves vellones de lana blanca los guardaban cestillos de mimbre. Entonces ellas, mientras tiraban de estos copos, con voz clara entonaron estas profecías en un canto divino, un canto que, después, ninguna época acusará de falsedad" (Catull. 64.303-324) ${ }^{97}$.

Esta caracterización se debe también a que, en ocasiones, y ya desde la Antigüedad, se iguala a las hilanderas con las Grayas, otras tres hermanas mitológicas,

\footnotetext{
${ }^{97}$ qui postquam niveis flexerunt sedibus artus large multiplici constructae sunt dape mensae, cum interea infirmo quatientes corpora motu veridicos Parcae coeperunt edere cantus. His corpus tremulum complectens undique vestis candida purpurea talos incinxerat ora, at roseae niveo residebant vertice vittae, aeternumque manus carpebant rite laborem. Laeva colum molli lana retinebat amictum, dextera tum leviter deducens fila supinis formabat digitis, tum prono in pollice torquens libratum tereti versabat turbine fusum, atque ita decerpens aequabat semper opus dens, laneaque aridulis haerebant morsa labellis, quae prius in levi fuerant exstantia filo: ante pedes autem candentis mollia lanae vellera virgati custodibant calathisci. Haec tum clarisona pellentes vellera voce talia divino fuderunt carmine fata, carmine, perfidiae quod post nulla arguet aetas.
} 
viejas desde el nacimiento y que compartían un diente y un ojo que se iban turnando (Hes. Th. 270). De hecho, esta imagen es la que con más fuerza ha sobrevivido con el paso del tiempo, de forma que ha sido empleada en cuadros y en populares recreaciones mitológicas dirigidas al público infantil (Fig. 2). Las Parcas también son representadas con diferentes edades (Hes. Sc. 259-260), adoptando el papel de personificaciones del ciclo vital, encarnando las etapas de puella, matrona, y vetula (Fig. 3$)^{98}$.

Si bien alcanzar cierta edad en la Antigüedad suponía que las Parcas podían cortar el hilo en cualquier momento, algunos autores (Scheidel, 2013: 47; Shaw, 1996: 118120) han calculado que las personas ancianas de la antigua Roma corrían más riesgo de fallecer en los meses de septiembre-octubre, coincidiendo con la llegada de enfermedades estacionales como el resfriado, así como con picos de malaria. Esta afirmación parece respaldarla Horacio (Epist. 1.7.5), quien hace referencia a los meses de agosto-septiembre como tiempo en el que tiene especial incidencia la muerte. Por el contrario, los meses más seguros eran junio y julio.

Un vez llegaba el momento de enfrentarse a los últimos minutos de vida, la muerte más deseada para una persona anciana en Roma era aquella que acontecía tras una larga y feliz existencia y junto a los seres queridos, como le ocurrió a Quinto Metelo en el siglo II a.C. (Val. Max. 7.1.1). Era deseable que la salud fuese buena hasta el último momento, de forma que pudiera disfrutarse de todos los días vividos (Plin. Ep. 2.1.4). La muerte, además, resultaba tranquila si acontecía en la vejez:

"El fruto de la senectud, como he dicho anteriormente varias veces, es el recuerdo y acopio de los buenos provechos. Sin embargo todas las cosas originadas por la propia naturaleza, se deben tener por cosas buenas. ¿Qué es más propio, según la naturaleza, que los ancianos mueran? También alcanza lo mismo a los jóvenes que se topan con una naturaleza adversa y repugnante. Me parece que la muerte de un joven es como sofocar la fuerza de una llama con un chorro de agua. La vejez por el contrario, consumido el fuego, se extingue sin violencia, sin que ellos hagan nada. Las manzanas, si están verdes, no se desprenden de la rama a no ser con violencia, por el contrario caen por sí mismas si están maduras y muy sazonadas. Como la violencia quita la vida a los adolescentes, la madurez quita la vida a los ancianos. Una madurez que a mí me resulta agradable, de tal manera que yo llegaré

\footnotetext{
${ }^{98}$ Para un análisis en profundidad de las representaciones iconográficas de las Parcas/Moiras, vid. Angeli, 1991.
} 
a la muerte tranquilamente como si después de una larga navegación, al llegar al puerto volviera a ver la tierra" (Cic. Sen. 19.71) ${ }^{99}$.

Estas muertes que podríamos calificar como "naturales", debidas a la vejez o a enfermedades provocadas o agravadas por la misma, no son frecuentes en las fuentes literarias, pobablemente porque se consideraban un hecho cotidiano, típico del proceso de envejecer. Así, lo usual en estos casos sería dar simplemente la noticia del fallecimiento y mostrar tristeza por el mismo, incluyendo en ocasiones detalles como una extraordinaria longevidad o salud, o aludiendo a sus disposiciones testamentarias (Cic. Att. 1.3; Plin. Ep. 2.1.4, 4.10 y 5.1). Los casos excepcionales en los cuales el escritor se extiende en la descripción se deben a su especial relación con el difunto, o al deseo de mostrar a éste como exemplum.

Por otro lado, la muerte puede llegar de forma voluntaria. No son pocos los casos de suicidio de personas ancianas que nos son referidos en las fuentes. Georges Minois (1987: 128) señala que los primeros siglos de nuestra era vivieron una "ola de suicidios" debido a la influencia del estoicismo y la supuesta devaluación de la vejez en época imperial. Esta idea la retoma Alfonso López (2008: 19 y 2017: 24), quien habla de "auténtico raudal". Contrario a estas propuestas se muestra Gregorio Hinojo (1991 y 2010), quien piensa que la incidencia del suicidio en las fuentes del periodo se debe a que la muerte voluntaria se convirtió en topos literario:

"La descripción de muchas muertes voluntarias no es necesariamente consecuencia ni síntoma de que hubiera un número excesivo de suicidios, muy superior al de otras épocas, sino que puede explicarse por el gusto y la delectación de los lectores, y consiguientemente de los escritores, por la muerte y los aspectos relacionados con ella, como ritos funerarios, crímenes violentos y sangrientos, parricidios, resurrección de cadáveres, suicidios personales y colectivos, etc." (Hinojo, 2010: $58)$.

Para este mismo autor (Hinojo, 1991: 146), además del gusto de los lectores debemos tener en cuenta como posible factor del auge de esta literatura la realidad

\footnotetext{
${ }^{99}$ Fructus autem senectutis est, ut saepe dixi, ante partorum bonorum memoria et copia. Omnia autem quae secundum naturam fiunt sunt habenda in bonis. Quid est autem tam secundum naturam quam senibus emori? Quod idem contingit adulescentibus adversante et repugnante natura. Itaque adulescentes mihi mori sic videntur, ut cum aquae multitudine flammae vis opprimitur, senes autem sic, ut cum sua sponte nulla adhibita vi consumptus ignis exstinguitur; et quasi poma ex arboribus, cruda si sunt, vix evelluntur, si matura et cocta, decidunt, sic vitam adulescentibus vis aufert, senibus maturitas; quae quidem mihi tam iucunda est, ut, quo propius ad mortem accedam, quasi terram videre videar aliquandoque in portum ex longa navigatione esse venturus.
} 
social y política de la época, especialmente el aire represivo del Principado, y la influencia de las corrientes filosóficas que veían en la muerte, sobre todo en el suicidio, una forma de librarse de las desgracias de la vida. Una visión no negativa del suicidio, contraria a la opinión de la moral cristiana que vendrá después, que se dejaría notar en las diversas formas de nombrar el acto de quitarse la vida en latín ${ }^{100}$.

El suicidio, por otro lado, podía ser una forma de evitar los problemas físicos y mentales de la ancianidad extrema, si bien siempre podía recurrirse al arrepentimiento en el último momento, como le ocurrió a Sexto Vistilio (Tac. Ann. 6.2.9). Los ejemplos de suicidio en la vejez de los que disponemos en las fuentes, no obstante, no son calificados de la misma forma. Un tono positivo tienen en Tácito los suicidios de Séneca (Tac Ann. 14.63.3) y la familia de Lucio Vetere al completo (Tac. Ann. 6.10-11), ambos casos motivados por cuestiones políticas. Lo mismo ocurre con Sextilia, madre de Vitelio, quien falleció bien obligada por su hijo al ayuno, o bien tras ingerir un veneno por miedo a los acontecimientos políticos del momento (Suet. Vit. 14.5; Tac. Hist. 67). Sin embargo, si bien el suicidio de Caninio Rebilo fue una forma de evitar una vejez enferma, la forma de llevarlo a cabo no fue la más correcta:

“Caninio Rebilo, entre los primeros por su ciencia jurídica y por sus riquezas, escapó de los sufrimientos de una triste vejez abriéndose las venas y dejando escapar su sangre; no se lo creía capaz de afrontar con firmeza el trance de darse la muerte a causa de la infamia de sus afeminadas pasiones" (Tac. Ann. 13.30) ${ }^{101}$.

Las enfermedades que se agravaban con la vejez también aparecen en las fuentes como aliciente para quitarse la vida ${ }^{102}$. Ático, romano republicano conocido por su amistad con Cicerón, decidió morir por inanición a los 77 años. Tras haber tenido una vida libre de enfermedades, en sus últimos años sufrió un mal que Moses Finley (1989: 16) identifica con el cáncer de recto o de intestino y cuyos síntomas le llevaron a quitarse la vida (Nep. Att. 21). Un detallado ejemplo de suicidio debido al padecimiento de patologías nos lo proporciona Plinio el Joven al respecto de su amigo Corelio Rufo, de quien escribe que

\footnotetext{
${ }^{100}$ Para un análisis en profundidad de las diversas formas latinas de la palabra "suicidio", vid. Hinojo, 2010.

${ }^{101}$ Caninius Rebilus, ex primoribus peritia legum et pecuniae magnitudine, cruciatus aegrae senectae misso per venas sanguine effugit, haud creditus sufficere ad constantiam sumendae mortis, ob libidines muliebriter infamis.

${ }^{102}$ Para un catálogo de muertes voluntarias en la vejez durante la Antigüedad, vid. López Pulido, 2017.
} 
"aunque tenía muchos motivos para seguir viviendo: una óptima conciencia, una óptima reputación, una influencia grandísima, y además una hija, una esposa, una nieta, hermanas y, entre otros seres querido, muchos verdaderos amigos. Pero sufría de una enfermedad tan larga, tan injusta, que estos bienes tan importantes que le ataban a la vida fueron superados por las razones que le impulsaban a la muerte. Desde la edad de treinta y dos años, como le oía decir a menudo, sufría de un acceso de gota. Mientras fue un hombre joven, la venció y superó con abstinencia y sobriedad en su modo de vida; recientemente, cuando se agravaba con la llegada de la vejez, la sobrellevaba con la fuerza de su espíritu, aunque soportaba increíbles tormentos e indignísimos sufrimientos. Pues ya el dolor no estaba confinado, como antes, sólo a los pies, sino que se extendía por todas las extremidades (...) Se había agravado la enfermerdad, que intentó aplacar con un régimen alimenticio estricto; finalmente, al continuar empeorando, la esquivó con firmeza. Ya habían pasado dos días, tres, cuatro: se negaba a comer. Su esposa Hispula me envió a un amigo común, Gayo Geminio, con la noticia tristísima de que Corelio había decidido morir y que no podían disuadirle ni sus ruegos ni los de su hija (...) Ciertamente, vivió sesenta y siete años, edad que es suficientemente avanzada incluso para los hombres más fuertes, lo sé” (Plin. Ep. 1.12.3-11) ${ }^{103}$.

Plinio admira la decisión que ha tomado su amigo, y vemos cómo su elección se basa en que, si bien en apariencia vive una buena vejez, con los elementos que en el apartado anterior considerábamos definitorios de la misma -familia, amistades, buena reputación, una posición influyente-, la gota amenaza con convertirla en una mala vejez y por lo tanto innecesaria de ser vivida, ya que como hemos visto unos años finales teñidos de desgracia podían ensombrecer toda una existencia anterior plagada de logros. La carta de Plinio hace referencia también al proceso de agravamiento de las enfermedades crónicas, en este caso la gota, y a cómo los síntomas que provocan las mismas a menudo empeoran con la edad, hasta hacerse insoportables. A través del testimonio de Plinio, vemos cómo a pesar de tratarse de una persona ya vieja y que toma

\footnotetext{
103 quamquam plurimas vivendi causas habentem, optimam conscientiam optimam famam, maximam auctoritatem, praeterea filiam uxorem nepotem sorores, interque tot pignora veros amicos. Sed tam longa, tam iniqua valetudine conflictabatur, ut haec tanta pretia vivendi mortis rationibus vincerentur. Tertio et tricensimo anno, ut ipsum audiebam, pedum dolore correptus est. (...) Hunc abstinentia sanctitate, quoad viridis aetas, vicit et fregit; novissime cum senectute ingravescentem viribus animi sustinebat, cum quidem incredibiles cruciatus et indignissima tormenta pateretur. Iam enim dolor non pedibus solis ut prius insidebat, sed omnia membra pervagabatur. (...) Increverat valetudo, quam temperantia mitigare temptavit; perseverantem constantia fugit. Iam dies alter tertius quartus: abstinebat cibo. Misit ad me uxor eius Hispulla communem amicum C. Geminium cum tristissimo nuntio, destinasse Corellium mori nec aut suis aut filiae precibus inflecti (...) Implevit quidem annum septimum et sexagensimum, quae aetas etiam robustissimis satis longa est; scio.
} 
la determinación de morir para acabar con una agonía que afecta a su día a día, sus familiares y amigos intentan convencerle de que siga viviendo. No ocurría lo mismo en el caso ya mencionado de Domicio Tulo, probablemente porque éste último ni siquiera era capaz de realizar por sí mismo las tareas más sencillas, mientras que Rufo parece haber conservado cierta independencia física y todas sus capacidades mentales hasta el momento del suicidio. Se aprecia así la existencia de unos sentimientos complejos acerca de la muerte y del cuidado de las personas enfermas y dependientes, asunto que trataremos en profundidad en el Capítulo IV.

También las vetulae recurrían al suicidio como forma de eludir el sufrimiento, el debilitamiento y la pobreza asociados a la vejez. Así, Valerio Máximo narra un episodio ocurrido en el año 18 a.C. cuando viajaba junto a Sexto Pompeyo:

"Ocurrió entonces que una dama de lo más distinguida, pero muy entrada en años, después de exponer a sus conciudadanos los motivos que la impulsaban a renunciar a su vida, decidió envenenarse; y pensaba que su muerte sería más gloriosa si tenía lugar en presencia de Pompeyo. Este hombre, adornado de todas las buenas cualidades y de reconocida humanidad, no tuvo el valor de negarse a los ruegos de la anciana. Fue, pues, a su encuentro y, después de haber intentado en vano durante mucho tiempo disuadirla de su propósito por medio de las más elocuentes palabras que manaban de su boca como de una fuente purísima de oratoria, decidió permitirle que cumpliera su designio. La mujer, que tenía más de noventa años, pero se hallaba en plenas facultades corporales y anímicas, se recostó sobre su lecho que parecía mejor ataviado que de costumbre y, apoyándose sobre uno de sus codos, le dijo a Pompeyo: «Sin duda alguna, Sexto Pompeyo, te darán las gracias más bien los dioses que abandono que aquellos a los que me dirijo, porque no desdeñaste ni exhortarme a vivir ni verme morir. Pero yo que he visto siempre cómo la fortuna me sonreía, para no verme obligada a ver su cara triste por el deseo de vivir, quiero cambiar lo que me queda de vida por una muerte feliz, ya que dejo tras de mí dos hijas y un nutrido grupo de nietos». En seguida exhortó a sus hijas a vivir en paz y concordia, les distribuyó su patrimonio, confió a su hija mayor los objetos sagrados y la obligación de mantener viva su memoria, tomó con mano firme la copa que contenía el veneno, hizo libaciones en honor de Mercurio, para que la condujera por fáciles caminos a la parte mejor de los infiernos, y bebió con avidez el mortal brebaje. A continuación iba describiendo sucesivamente las partes de su cuerpo por las que se extendía el frío de la muerte y, cuando se dio cuenta de que éste se iba apoderando de sus entrañas y de su corazón, suplicó a sus hijas que 
cumplieran con ella el último deber de cerrarle los ojos. Por lo que a nosotros se refiere, aunque estábamos atónitos ante un espectáculo tan novedoso, nos abandonó dejándonos con los ojos bañados en lágrimas" (Val. Max. 2.6.8) ${ }^{104}$.

Este episodio sirve a Valerio Máximo para resaltar la bondad y humanidad de Sexto Pompeyo, que detiene su viaje para asistir en sus últimos momentos a una desconocida, así como para presentar a la vetula como ejemplo de mujer serena y de amor materno. Vemos, por otro lado, cómo la mujer escoge el veneno como medio de quitarse la vida, un recurso típicamente femenino.

Otros personajes recurren al suicidio como forma de evitar una muerte peor. Es el caso, por ejemplo, de la vetula que vive con los ladrones en Lucio o el asno (Luc. Asin. 24), aunque no pudo evitar el maltrato de su cadáver, que es lanzado barranco abajo ${ }^{105}$.

El miedo a la muerte y a una ancianidad enferma lleva aparejado el deseo de alcanzar la inmortalidad o, al menos, de posponer el fin lo máximo posible (Luc. Pr. Im. 2). Así lo mostraba Esopo, en el siglo VI a.C., con la historia El viejo y la muerte:

"En una ocasión un viejo, que venía de cortar leña, la llevaba encima y recorría un largo camino. Al descargar el peso, fatigado, llamó a la Muerte. La muerte se apareció y le preguntó por qué motivo la llamaba, y el viejo dijo: «Para que me lleves la carga». La fábula muestra que todos los hombres quieren a la vida, aunque tengan una existencia miserable" (Aesop. 60) ${ }^{106}$.

\footnotetext{
${ }^{104}$ forte enim euenit ut tunc summae dignitatis ibi femina, sed ultimae iam senectutis, reddita ratione ciuibus cur excedere uita deberet, ueneno consumere se destinarit mortemque suam Pompei praesentia clariorem fieri magni aestimaret. nec preces eius uir ille, ut omnibus uirtutibus, ita humanitatis quoque laude instructissimus, aspernari sustinuit. uenit itaque ad eam facundissimoque sermone, qui ore eius quasi e beato quodam eloquentiae fonte manabat, ab incepto consilio diu nequicquam reuocare conatus ad ultimum propositum exequi passus est. quae nonagesimum annum transgressa cum summa et animi et corporis sinceritate lectulo, quantum dinoscere erat, cotidiana consuetudine cultius strato recubans et innixa cubito 'tibi quidem' inquit, 'Sex. Pompei, dii magis quos relinquo quam quos peto gratias referant, quod nec hortator uitae meae nec mortis spectator esse fastidisti. ceterum ipsa hilarem fortunae uultum semper experta, ne auiditate lucis tristem intueri cogar, reliquias spiritus mei prospero fine, duas filias et uno nepotum gregem superstitem relictura permuto'. cohortata deinde ad concordiam suos distributo eis patrimonio et cultu suo sacrisque domesticis maiori filiae traditis poculum, in quo uenenum temperatum erat, constanti dextera arripuit. tum defusis Mercurio delibamentis et inuocato numine eius, ut se placido itinere in meliorem sedis infernae deduceret partem, cupido haustu mortiferam traxit potionem ac sermone significans quasnam subinde partes corporis sui rigor occuparet, cum iam uisceribus eum et cordi imminere esset elocuta, filiarum manus ad supremum opprimendorum oculorum officium aduocauit. nostros autem, tametsi nouo spectaculo obstupefacti erant, suffusos tamen lacrimis dimisit.

${ }^{105}$ En la versión de Apuleyo (Met. 6.30.7) no puede saberse si la vetula se suicida o la cuelgan los ladrones.

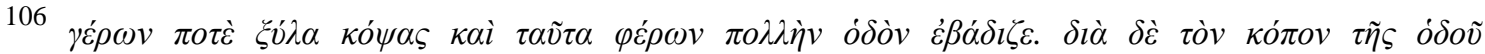

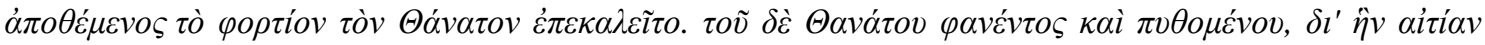

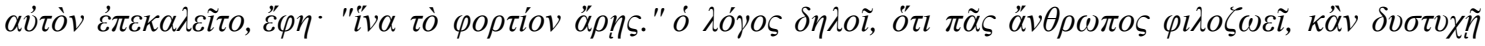
$\lambda i \alpha v$.
} 
Por otro lado, la inmortalidad era una cualidad accesible sólo a las divinidades, aunque incluso a éstas les podía resultar pesada una vida sin fin (Cic. Sen. 23. 85; Ov. Met. 1.662-663). Para ilustrar el peligro de desear la inmortalidad, en la Antigüedad existían diversos episodios mitológicos, los cuales eran una forma de hacer entender a los humanos que a diferencia de los dioses ellos eran mortales y que pretender la vida eterna podía acarrear horribles consecuencias.

Una de estas historias míticas se refiere al amor entre la diosa Aurora y el mortal Titono (Hom. Il. 11.1; Hymn. Hom. Ven. 218-238: Ov. Am. 1.13.1 y 2.5.35: Prop. 2.18.7-11). La diosa pidió a Zeus que concediera a su esposo la inmortalidad, sin acordarse de pedir también la eterna juventud, por lo que Titono alcanzó la ancianidad extrema. Convertido en un viejo decrépito, Aurora acabó encerrando a su esposo en una habitación, donde su cuerpo fue consumiéndose poco a poco, si bien su voz nunca dejó de escucharse. Dependiendo de la versión del mito a la que acudamos, al final de la historia Titono acaba convertido en cigarra, un animal que se pensaba especialmente longevo (Moreno, 2015).

Además de la historia de Aurora y Titono, contamos también con el personaje de Endimion, de quien se enamoró Selene: pidiendo para él la inmortalidad, sólo consiguió que su amante se sumiera en un sueño eterno (Apollod. Bibl. 1.7.5). Un mortal que consigue evitar estas terribles consecuencias y rejuvenecer es Esón, padre de Jasón, quien pide a Medea que devuelva la juventud a su progenitor. Medea prepara una pócima y, tras rajar la garganta de su suegro, vierte el preparado, de forma que:

"su barba y sus cabellos, perdiendo la blancura de las canas, adquirieron de súbito un negro color. Escapa derrotada la flacura, se van la palidez y la decrepitud, se rellenan las huecas arrugas con nueva carne y sus miembros recobran su plenitud; se admira Esón y se recuerda cómo era hace cuarenta años" (Ov. Met. 7.289$294)^{107}$.

Tras devolver la juventud a Esón, Medea se encamina hacia casa de Pelias, tío y gran enemigo de Jasón, y promete a las hijas de éste que lo rejuvenecerá también, mostrándoles su gran poder convirtiendo a un carnero en cordero lechal (Ov. Met. 7.300-324). No obstante, se trata de un engaño para dar muerte a Pelias, que es descuartizado por sus propias hijas, incitadas por Medea.

\footnotetext{
107 barba comaeque canitie posita nigrum rapuere colorem, pulsa fugit macies, abeunt pallorque situsque, adiectoque cavae supplentur corpore rugae, membraque luxuriant: Aeson miratur et olim ante quater denos hunc se reminiscitur annos.
} 
Endimión y Titono tienen su par femenino en la Sibila. La narración se enmarca en un episodio en el que la Sibila acompaña a Eneas al Inframundo a modo de guía. Él la llama diosa, a lo que ella responde:

"Ni soy diosa ni debes tú juzgar a un mortal digno del honor del sagrado incienso; y para que no yerres por ignorancia, se me ofreció una vida eterna e inmortal, si mi virginidad se hubiera abierto al amor de Febo. Él, con esta esperanza y deseando seducirme con regalos, me dijo: «Elige lo que desees, doncella de Cumas; obtendrás tu deseo». Cogí un puñado de polvo y se lo mostré; le pedí, insensata, que me fuera dado vivir tantos cumpleaños como motas tuviera el polvo. Se me olvidó pedir que aquellos años fuesen además juveniles hasta el último. Y tales años y una juventud eterna me ofrecía él, si yo consentía la unión amorosa; desdeñé aquel presente de Febo y permanezco doncella; pero ya la edad más feliz me ha dado la espalda y con paso tembloroso llega la achacosa vejez, que he de soportar por mucho tiempo; pues a la vista tienes los siete siglos que ya he vivido; y aún me resta, para igualar las motas de polvo, ver trescientas cosechas y trescientas vendimias. Tiempo llegará en que tan prolongada vida acorte mi elevada estatura, y mis miembros, consumidos por la vejez, se vean reducidos a un peso insignificante. No parecerá que fui amada y gusté a un dios; quizá hasta el mismo Febo no me reconozca o niegue haberme amado. Hasta ese punto dirán que he cambiado; y nadie podrá verme, pero se me reconocerá por la voz; sólo la voz me dejarán los hados" (Ov. Met. 14.130-154) ${ }^{108}$.

En la historia de la Sibila envejecer se presenta como un proceso de metamorfosis. Por otro lado, y como señala Emilia Cairo (2011: 6), la Sibila es uno de los pocos personajes metamorfoseados que puede hablar durante y después de su transformación, lo que habría servido al poeta para feminizar y humanizar el mito, haciendo de la narradora la protagonista de la historia. De la extrema longevidad de este personaje nos habla también Flegón de Trales (99), quien pone en boca de la profetisa un lamento en

\footnotetext{
108 'nec dea sum,' dixit 'nec sacri turis honore humanum dignare caput, neu nescius erres, lux aeterna mihi carituraque fine dabatur, si mea virginitas Phoebo patuisset amanti. Dum tamen hanc sperat, dum praecorrumpere donis me cupit, "elige," ait "virgo Cumaea, quid optes: optatis potiere tuis." Ego pulveris hausti ostendens cumulum, quot haberet corpora pulvis, tot mihi natales contingere vana rogavi; excidit, ut peterem iuvenes quoque protinus annos. Hos tamen ille mihi dabat aeternamque iuventam, si Venerem paterer: contempto munere Phoebi innuba permaneo; sed iam felicior aetas terga dedit, tremuloque gradu venit aegra senectus, quae patienda diu est. nam iam mihi saecula septem acta, tamen superest, numeros ut pulveris aequem, ter centum messes, ter centum musta videre. Tempus erit, cum de tanto me corpore parvam longa dies faciet, consumptaque membra senecta ad minimum redigentur onus: nec amata videbor nec placuisse deo, Phoebus quoque forsitan ipse vel non cognoscet, vel dilexisse negabit: usque adeo mutata ferar nullique videnda, voce tamen noscar; vocem mihi fata relinquent.'
} 
el que maldice su larga vida y su destino de desaparecer en el aire y no poder obtener sepultura.

Las historias de la Sibila y Titono comparten ciertas similitudes. Por un lado, los cambios que experimenta el amor en la vejez, tema al que volveremos a lo largo de los Capítulos III y IV. La Sibila, antaño deseada por un dios, se encuentra sola. Titono, por su parte, es un senex con una amante inmortal a la que ya no puede satisfacer. También se lamentaba de ello Safo, quien envejece rodeada de mujeres jóvenes que van llegando y son sustituidas por otras muchachas cuando se marchan, siendo ella la única en la que se aprecia el paso del tiempo (Rodríguez Somolinos, 2005: 131).

Por otro lado, la insistencia en la voz como elemento que quedará tras su desaparición/muerte. El eco en que se convierten ambos personajes tras una larga vida puede interpretarse como la memoria, lo único que perdura después del fallecimiento. Mediante la transmisión de la memoria de generación en generación, las personas pueden aspirar a continuar "vivas" al morir. Podría parecer que la poetisa Safo, al hacer alusión a la relación entre Aurora y Titono, compartía este anhelo, siendo sus obras el eco que sobrevivirá al paso del tiempo (Rodríguez Somolinos, 2005: 134). Destaca en este sentido la mención a la cigarra, animal en el que fue transformado Titono y que como ya hemos señalado era considerado especialmente longevo en la mitología grecoromana, incluso eterno, siendo a veces empleado para caracterizar a las personas ancianas (CEG 592; Hom. Il. 3.150-151; Mart. 3.93).

Finalmente, ambos mitos tienen como tema central la persecución de dos deseos imposibles e irreconciliables: no morir y no envejecer (González González, 2015: 167). No se puede seguir viviendo sin envejecer, ni se puede evitar la vejez de otra forma que no sea falleciendo antes de tiempo, a menos que se sea una divinidad. Así, las historias de Titono y la Sibila estaban pensadas para ayudar a los seres humanos a aceptar su mortalidad y no desear ser como los dioses, eternamente jóvenes. Es por ello que Beate Wagner-Hasel (2011: 8-9) cree que ambos mitos servían como símbolo de la necesaria renovación generacional. La irreflexiva juventud de los personajes de estas historias, incapaces de pensar en la ancianidad porque la sienten ajena, es la que conduce al agonizante desenlace. No obstante, se observa cómo en ambos casos es la figura femenina la responsable del deseo mal formulado, lo que sirve para subrayar el carácter impulsivo e irreflexivo con el que la mentalidad patriarcal caracteriza a la mujer. Aurora, que no envejece en cuanto que diosa, y la Sibila, insensata, olvidan desear la eterna juventud junto a la inmortalidad. 
Vemos, por otro lado, que incluso los dioses se ven afectados por la mortalidad de los seres humanos. Es por ello que Ovidio recrea las quejas que algunas divinidades, entre las que está Aurora, presentan a Júpiter cuando se le concede la vida eterna a Hércules:

"Se queja la Palantíade [Aurora] de la vejez de su esposo; se queja la dulce Ceres de que Yasión está envejeciendo; Mulcíbero pide para Erictonio otra vida; también afecta a Venus la preocupación por el futuro e intenta pactar la renovación de los años de Anquises" (Ov. Met. 9.420-425) ${ }^{109}$.

A estos ruegos Júpiter responde que ni siquiera él, padre de los dioses, puede conceder de forma arbitraria la eterna juventud, ya que se encuentra sometido a los designios de las Parcas:

“Oh, si sentís algún respeto por mí, ¿adónde queréis ir a parar? ¿Alguno se imagina que tiene tanto poder como para vencer también al hado? Gracias a los hados volvió Yolao a los años que había vivido; gracias a los hados deben convertirse en jóvenes los hijos de Calírroe, no por sus intrigas o por sus armas. Para que incluso vosotros llevéis esto con mejor ánimo, también a mí me dominan los hados; si tuviera poder para cambiarlos, no encorvarían a mi querido Éaco los años del ocaso, y Radamanto conservaría la perpetua flor de la edad, junto con mi querido Minos, que, debido al peso de la amarga vejez, es objeto de desprecio y ya no reina con el orden de antaño" (Ov. Met. 430-439; vid. también Ov. Met. 5.532 y Tib. 1.7.1 $)^{110}$.

Otra forma de abordar esta inevitabilidad de la muerte era tratar todo lo relacionado con ella de forma cómica, lo que permitía distanciarse del fenómeno y hacerlo menos real (Gómez Santa Cruz, 2013: 35). En ocasiones este humor está presente incluso en algunas inscripciones funerarias, en las que el poeta emplea el epígrafe para establecer un diálogo entre la persona fallecida, la muerte y el viandante (Gómez Pallarès, 2007).

En la relación entre muerte y humor juegan también un papel importante las historias de fantasmas, así como las situaciones cómicas donde personas ancianas,

\footnotetext{
${ }^{109}$ Queritur veteres Pallantias annos coniugis esse sui, queritur canescere mitis Iasiona Ceres, repetitum Mulciber aevum poscit Ericthonio, Venerem quoque cura futuri tangit, et Anchisae renovare paciscitur annos.

110 'O! nostri siqua est reverentia,' dixit 'quo ruitis? tantumne aliquis sibi posse videtur, fata quoque ut superet? fatis Iolaus in annos, quos egit, rediit. fatiiuvenescere debent Calliroe geniti, non ambitione nec armis. Vos etiam, quoque hoc animo meliore feratis, me quoque fata regunt. quae si mutare valerem, nec nostrum seri curvarent Aeacon anni, perpetuumque aevi florem Rhadamanthus haberet cum Minoe meo, qui propter amara senectae pondera despicitur, nec quo prius ordine regnat'.
} 
especialmente vetulae, son descritas de forma grotesca (Apul. Met. 4.7; Mart. 3.32, 3.93; Priap. 57), y las narraciones de lúgubre ambientación que convierten hechos tétricos en situaciones cómicas. De hecho, este tipo de historias parecen haber sido tan populares que constituyen en sí mismas un tipo de comedia ${ }^{111}$.

Dos ejemplos detacables de humor relacionado con la muerte los encontramos en Horacio y Apuleyo. La historia de Horacio (Sat. 1.8), nos lleva a los jardines que Mecenas había construido en el Esquilino sobre lo que antes fuera un cementerio. Allí acuden de noche Canidia y Sagana -dos brujas cuyas figuras analizaremos en profundidad en el Capítulo IV- para robar cadáveres. Horacio presenta la escena de forma tétrica, haciendo referencia a los esqueletos humanos que hay bajo el jardín (quo modo tristes albis informem spectabant ossibus agrum), a la nocturnidad en la que se amparan las brujas (simul ac uaga luna decorum protulit os), y a la terrible transgresión que suponen sus actos. El episodio termina cuando el dios Príapo, que hace las veces de narrador, lanza una ventosidad, deshaciendo la tensión que transmite la escena y haciendo que Sagana y Canidia huyan despavoridas, lo que provoca la risa del público.

El episodio de Apuleyo (Met. 2.21-31) tiene, como el de Horacio, consecuencias funestas para el protagonista pero cómicas para el lector. Durante un banquete, Telifrón cuenta a los invitados una experiencia terrorífica vivida en Larisa, ciudad de Tesalia, región famosa por su relación con la magia. El protagonista de la historia, necesitado de dinero, se ofrece para vigilar un cadáver durante una noche, ya que si éste queda sin vigilancia "las hechiceras pegan mordiscos a los rostros de los muertos y lo que arrancan les sirve de instrumento para sus artes mágicas" (Apul. Met. 2.21.7) ${ }^{112}$. Telifrón se queda a solas con el fallecido y a medida que avanza la noche la atmósfera se hace más tensa y le invade el miedo. Es entonces cuando lo visita una comadreja que parece mirarlo. Tras echar al animal de la habitación, Telifrón se queda dormido. Cuando despierta comprueba aterrotizado el cadáver, por si durante su sueño éste había sido atacado por las brujas. El alivio por el perfecto estado del cuerpo le dura poco, ya que no sólo pronuncia ante los familiares unas palabras poco acertadas que hacen que no perciba el dinero prometido, sino que además el muerto vuelve a la vida para anunciarle que las hechiceras se han confudido de sujeto y le han arrancado nariz y orejas al vigilante en vez de al finado, lo que causa la risa de quienes presencia la escena

\footnotetext{
${ }^{111}$ Sobre este tipo de comedias y su funcionalidad, vid. Lillo, 2011: 24 y ss.

112 sagae mulieres ora mortuorum passim demorsicant, eaque sunt illis artis magicae supplementa.
} 
y, volviendo al tiempo de la narración, del público al que Telifrón está contando la historia.

Vemos cómo en ambos episodios la atmósfera tensa y macabra provocada por la presencia de la muerte y de personas que pretenden relacionarse con ella de forma socialmente no aceptada se rompe mediante un final cómico e inesperado. El humor se constituye en una vía mediante la cual se pueden abordar aspectos que de otro modo resultan dolorosos, funestos o tabú, y que sirve para aceptar la existencia de los mismos, en este caso la muerte, una vía que en ocasiones emplean las propias personas fallecidas o que sienten próximo su final (Coppin y Gaspard, 2017).

En definitiva, tal y como ocurre en el caso de la vejez, de forma global pueden apreciarse dos visiones acerca de la muerte. Por un lado, una concepción de la muerte como un hecho ineludible y no necesariamente indeseable, sobre todo si ésta acontecía tras una vida larga y feliz (Juv. 10.335). Por otro lado, la representación de la muerte como el peor de los males, un momento que había que alejar del pensamiento mediante la risa y tratar de posponer lo máximo posible, aunque sin desear la inmortalidad, pues hemos visto que ello podía tener consecuencias peores que la propia muerte.

\section{II.5. CONCLUSIONES}

Este segundo capítulo de nuestra Tesis Doctoral nos ha permitido acercarnos a las cuatro causas que en las palabras de Cicerón (Sen. 5.15) que citábamos al comienzo del mismo hacían de la vejez en Roma una etapa vital con connotaciones negativas: el cese de la actividad laboral, la ausencia de salud, la pérdida de los placeres vitales y la cercanía de la muerte. En realidad, y como ya hemos señalado, las circunstancias que Cicerón cita como adversas no son más que un truco, cuatro puntos que el orador se extiende en rebatir durante el resto de la obra.

Son además causas que deben matizarse atendiendo al género y la clase. No toda la población romana podría permitirse poner fin a su actividad laboral llegada la vejez y, en el caso de esclavas y esclavos, la decisión no estaba siquiera en sus manos. De la misma forma, aquellas tareas relacionadas con el mantenimiento de la economía doméstica y el cuidado de personas dependientes, eminentemente femeninas, seguirían formando parte de la cotidianeidad de las vetulae. 
A lo largo de las anteriores páginas hemos tratado de ver cómo se reflejan en las fuentes de época romana las cuatro dimensiones de la vejez a las que aludíamos al comienzo de este capítulo: la cronológica, la física, la psicológica y la social.

Así, hemos hecho referencia a las diversas divisiones del ciclo vital que existieron en la Antigüedad, y a las diferentes edades cronológicas que se establecieron como frontera para la vejez, comprobando cómo incluso un dato que en principio puede parecer tan objetivo como el numérico está sujeto a cambios y convenciones.

A continuación hemos abordado la dimensión física, aludiendo a las teorías que concebían la vejez como una enfermedad en sí y a las principales patologías propias de la ancianidad que podemos rastrear en las fuentes literarias.

Finalmente, hemos visto cómo se manifiestan las dimensiones psicológica y social de la senectud, aludiendo a diversas percepciones que la sociedad romana tenía acerca de las personas ancianas y poniendo de manifiesto la existencia de dos tipos de vejez, aquella considerada como buena y que merece ser vivida, y aquella vista como mala y que debe evitarse por todos los medios. A través de los testimonios de las fuentes literarias, se ha señalado cómo algunos de los ochos mitos sobre la ancianidad que existen en las sociedades actuales -edad biológica, mala salud, senilidad, declive intelectual, pobreza, jubilación, aislamiento social y conservadurismo- estaban presentes ya en la Antigüedad.

Por otro lado, vemos que aquellas características que los escritores mencionados señalan como constitutivas de una buena vejez son las mismas que postula la Gerontología actual: ausencia de procesos patológicos graves, posibilidad de llevar una vida independiente realizando autónomamente las actividades cotidianas, percibir la vida pasada con satisfacción y la presente con felicidad, sin lamentar haber llegado a la vejez, adaptarse a los cambios en estilo de vida y posición social que conlleva la ancianidad, y participar activamente en la sociedad apoyándose en redes familiares y de amistad. Por el contrario, la mala vejez se caracterizaría por no poseer uno o varios de los rasgos señalados, aunándose en una misma persona frecuentemente todas las características negativas, como les ocurre a los "ancianos cómicos necios" mencionados por Cicerón. En ocasiones, las consecuencias negativas de la vejez se convierten en una carga tan pesada que lleva a senes como Corelio Rufo al suicidio, en un intento de que su dignidad quede intacta en la memoria familiar y colectiva.

A pesar de que resulta difícil saber qué pensaban sobre sí mismas las personas ancianas, testimonios como el de Cicerón nos permiten apreciar que estos autores veían 
su propia vejez de acuerdo a las divisiones positiva y negativa existentes en su sociedad. Esta vejez sentida, que dependía de las circunstancias sociales, familiares, de salud, económicas, etc. de cada individuo, en general parece arrojar una visión positiva de la propia ancianidad. En ocasiones, incluso puede despertar la envidia de personas más jóvenes, como declara Plinio en el caso de Espurina. No obstante, sabemos de ciertos senes y vetulae a quienes el día a día en la vejez no les resultaba satisfactorio y por ello, ya fuera por poner fin a su sufrimiento o por no manchar con una senectud agónica un recorrido vital lleno de éxitos, recurrieron al suicidio.

Para poner fin a este Capítulo II hemos querido hacer una breve referencia a la relación entre vejez y muerte, a la concepción de la primera como un momento en el que se espera constantemente la llegada de la segunda, y a los diversos tipos de muerte que podían darse en la ancianidad, fuese esta voluntaria o fruto del natural envejecimiento humano.

Hemos aludido también al deseo de inmortalidad y a los mitos que mostraban qué podía ocurrir a quienes ansiasen la vida eterna. Otros personajes mitológicos, las Parcas, nos han servido para señalar la estrecha relación que en la Antigüedad clásica existía entre la muerte, las ancianas, las tareas femeninas como el hilado, y la adivinación, tema que retomaremos en el Capítulo IV.

A lo largo del capítulo hemos constatado cómo la vejez, al contrario de lo que opinaba Georges Minois (1987: 18), sí era considerada como una categoría con entidad propia en la antigua Roma. La sociedad romana concebía la existencia de una parte de la población a la que denominaba anciana en base a diversos criterios cronológicos, médicos, legales, visuales y sociales, y sobre la que reflexionaban de forma cotidiana. A pesar de ser conscientes de que se trataba de un grupo que presentaba una gran variedad interna, también le asignaron características comunes, tanto positivas como negativas, y generaron estereotipos que representaron en la literatura y el arte y que es de esperar que operasen en el día a día y afectasen a la forma en la que las personas ancianas se veían a sí mismas y eran vistas por la sociedad.

Precisamente algunos autores como Cicerón, quien escribe desde su propia vejez, o Plinio en las descripciones que en ocasiones hace de ciertos senes y vetulae, buscan contrarrestar la existencia de los estereotipos negativos que asocian ancianidad con enfermedad, declive, marginalidad y muerte. Presentan un modelo alternativo, más real, 
condicionado por las características particulares de la persona vieja, el cual en general parece arrojar un balance positivo de la senectud como etapa vital. No obstante, no debemos olvidar que quienes se ajustan a estas descripciones son en su mayoría hombres pertenecientes a las capas altas de la sociedad, por lo que resulta obligado preguntarse, como haremos en las siguientes páginas, cómo era la vejez de las mujeres y de la población trabajadora y esclava.

En definitiva, a lo largo de este Capítulo II se ha intentado situar el marco conceptual desde el cual abordaremos la vejez femenina en la antigua Roma, exponiendo las dificultades de realizar una investigación como la que proponemos en nuestra Tesis Doctoral y esbozando ciertas cuestiones que se desarrollarán en profundidad en los siguientes dos capítulos. 


\section{CAPÍTULO III \\ DIMENSIONES CRONOLÓGICA Y FÍSICA DE LA VEJEZ FEMENINA EN ROMA}

“... (de las Musas de violáceo ceñidor) hermosos dones, muchachas,

... aguda ira melodiosa.

(ha marchitado mi) piel en un tiempo (suave) ya la vejez

(blancos) se han vuelto mis cabellos antes negros,

mi ánimo está apesadumbrado, las rodillas no me sostienen,

las que antes eran ligeras para danzar como cervatos.

(Por ello) me lamento a menudo. Pero ¿qué podría hacer?

Siendo mortal no es posible escapar a la vejez.

Pues también contaban de Titono, que una vez la Aurora de brazos rosados por amor... llegó hasta los confines de la tierra llevándolo consigo, a él, que entonces era hermoso y joven, pero sin embargo lo alcanzó con el tiempo la grisácea vejez, y aun teniendo una esposa inmortal"

Safo, PKÖLN.inv.21351re+21376+POXY.1787 $7^{113}$

En el Capítulo II hemos tratado de establecer cómo se manifestaban en la Roma antigua las cuatro dimensiones que la Gerontología Social atribuye a la vejez. A continuación, nuestro objetivo es analizar este mismo fenómeno poniendo el foco en las vetulae. Para ello empleamos dos capítulos.

En el Capítulo III analizamos las dos dimensiones de la vejez que se consideran naturales: la edad cronológica y la edad física. Incluimos aquí también parte de la dimensión psicológica de la vejez, aquella referida a los cambios y patologías mentales relacionados con el envejecimiento, ya que creemos que es mejor abordarla en el apartado correspondiente a la medicina.

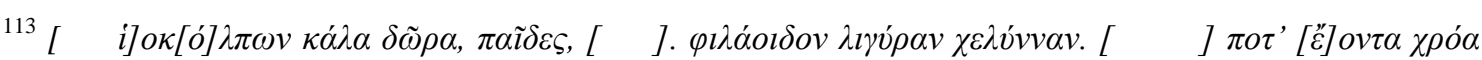

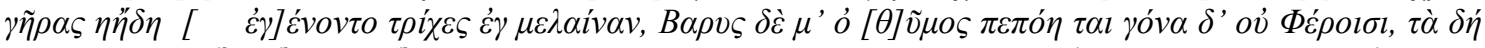

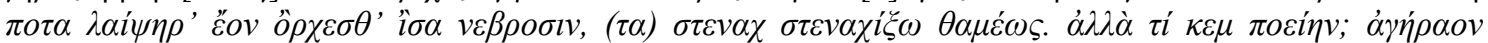

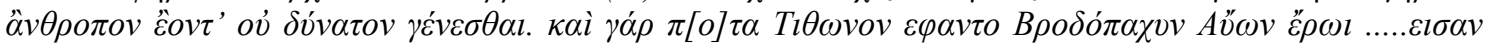

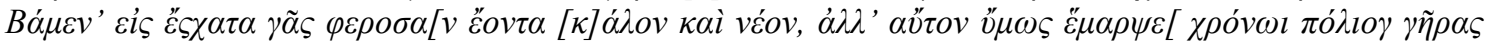

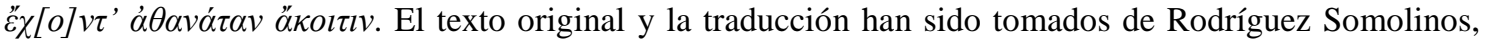
2005: 130.
} 
En el último capítulo trataremos las dos dimensiones restantes, aquellas más dependientes del contexto social: la edad sentida y la edad social.

En cuanto al presente capítulo, en el primer apartado se analizan el ciclo vital femenino y las diferencias de éste con respecto al masculino. Profundizamos aquí sobre la razón de considerar los 50 años como frontera cronológica para la vejez femenina en la antigua Roma, apoyándonos para ello en las fuentes escritas y en diversas interpretaciones historiográficas.

A continuación abordamos el cuerpo de la vetula desde la medicina, empleando tanto la literatura médica como los resultados obtenidos a través del análisis de restos óseos. Nos centramos especialmente en la menopausica como proceso biológico y en las diversas patologías físicas y mentales que afectarían a las ancianas romanas, pero también hacemos referencia a la relación entre vejez y dependencia y a las situaciones de abuso físico en la senectud.

El tercer apartado de este capítulo gira en torno al aspecto físico de las vetulae y a la vejez como fenómeno visual. A través de la literatura y del arte ahondamos en el significado social de las representaciones del cuerpo envejecido, así como en la oposición entre el ideal de belleza femenino y el aspecto externo de la vetula.

Finalmente, el capítulo se cierra con un análisis sobre la sexualidad de las vetulae, la negación social de la misma y la reacción masculina ante ancianas que muestran abiertamente su erotismo. Abordamos también la relación de este tipo de representaciones literarias con el humor, la marginalidad y la transgresión.

\section{III.1. CiClo Vital FEMENino}

En el capítulo anterior nos hemos acercado a las diversas divisiones del ciclo vital que existían en la Antigüedad, las cuales atendían tanto a criterios cronológicos como biológicos. Hemos visto también cómo algunas de ellas, si no la mayoría, son de carácter masculino y están basadas en el ejercicio de las magistraturas públicas o en la elegibilidad para el ejército. Es por ello que Thomas Falkner (1995: 71) y Mary Harlow (2007: 197) se muestran convencidos de que es imposible aplicar un mismo modelo de ciclo vital a hombres y mujeres, y de que las divisiones a las que hemos aludido en el capítulo anterior tratan de imponer el modelo masculino a la mujer, sin tener en cuenta posibles particularidades. En esta línea, las referencias a que las mujeres envejecen más 
rápidamente que los hombres (Arist. Long. 5.466a-466b; Plin. NH 7.4.37), derivadas de la concepción de que como seres inferiores a los varones la duración de su vida debía ser menor, nos hacen plantearnos la posibilidad de que su ciclo vital se concibiese de una forma distinta al masculino.

Sugerimos, al igual que hacen otras autoras (Allason-Jones, 1989: 28; DeanJones, 1994: 2; Pérez Cantó, 2002), que en la Antigüedad la vida de las mujeres era percibida en términos eminentemente biológicos, por lo que el ciclo vital femenino estaría dividido en diversas etapas que clasificarían a las mujeres dependiendo del momento reproductivo en el que se encontrasen y a los atributos visuales característicos de cada uno de ellos. De acuerdo a este criterio, las posibilidades son varias.

Ya hemos aludido a divisiones amplias del ciclo vital, basadas en las cuatro estaciones del año: niña, doncella, mujer casada y vieja para las mujeres; niño, joven adulto, hombre maduro y viejo para los hombres (Amm. Marc. 14.6.4; Cic. Sen. 10.33; Diod. Sic. 10.9.5; Ov. Met. 15.200-226; Sen. Ep. 20.121.16). Por su parte, Lindsay Allason-Jones (1989: 28) propone una partición en siete etapas: nacimiento, pubertad, matrimonio, etapa procreadora, menopausia, vejez, y muerte. Si eliminamos la muerte de su clasificación obtendríamos un par femenino a los modelos tardíos propuestos por San Agustín y San Isidoro a los que nos hemos referido en el capítulo anterior. Una tercera opción sería una división en tres etapas: antes del periodo reproductivo, durante el periodo reproductivo, y tras el periodo reproductivo, lo que Pilar Pérez (2002: 172) ha denominado “edad sexual”. Esta división es la que sigue Mary Harlow (2007: 197) cuando afirma que para las romanas sólo había dos edades cronológicas relevantes, los 12 años -el mínimo legal para concebir-, y los 50 -el máximo para concebir-, conformando así tres etapas vitales que abarcan los momentos anterior, mediano y posterior a estas cifras.

Estas tres fases, puella, matrona y vetula son, como hemos señalado en el Capítulo II, uno de los modos de representar a las Parcas, imagen que sirve para personificar el ciclo vital de los seres humanos y especialmente el de las mujeres. Nona, Decima y Morta se convierten así en divinidades que presiden los momentos críticos de la vida, los periodos de transición de una fase del ciclo vital al siguiente. Esta división tripartita es la que encontramos también en Hipócrates (Nat. Mul. 1), así como en un mosaico hallado en una villa de Vallon (Friburgo, Suiza), datado en el siglo II d.C. (Fig. 4 y 5). Además, se ha postulado que las tres fases del desempeño del sacerdocio vestal fueran una imitación del ciclo vital femenino, en sustitución de la labor reproductiva 
que estas mujeres no podían llevar a cabo mientras estaban en el cargo (Saquete, 2000: 67). Así, la niñez se identificaría con los años de aprendizaje de los ritos, la edad adulta fértil con el desempeño de dichos ritos y la vejez con la función de ejercer de maestras de las más jóvenes.

En lo que respecta al inicio de la vejez de las romanas, como ya hemos señalado en el capítulo introductorio, a efectos de la presente Tesis Doctoral consideramos vetulae a todas las mujeres mayores de 50 años. Es una edad que también toman como referencia diversos autores (Amundsen y Diers, 1970: 84; Cokayne, 2003: 1-3; Diers, 1974: 934; Harris, 2000: 88; Torrego, 2104: 210) y que se basa principalmente en la lex Papia Poppaea y la media de edad a la que se alcanzaba la menopausia, calculada a partir de las fuentes literarias y los estudios de la medicina moderna ${ }^{114}$. En el caso de los hombres, estos mismos criterios legales y de fertilidad hacen que la historiografía (Harlow y Laurence, 2011: 8; Huebner, 2013: 109; Parkin, 2003: 36) coincida en poner como frontera para la entrada en la ancianidad los 60 años, si bien como ya hemos señalado en el capítulo anterior los autores antiguos divergen respecto a la cifra.

A pesar de que a lo largo de nuestra investigación tomamos como base estas edades diferenciadas, debemos tener en cuenta que, al considerarse el plural masculino como universal (Dig. 50.16.1, 50.16.40.1, 50.16.152 y 50.16.163.1), algunas informaciones respecto a la edad de la vejez que están en masculino pueden referirse también a las mujeres, y que ciertos autores pudieron establecer de forma general una frontera de la vejez en 60 años para ambos sexos. Ello explicaría, por ejemplo, por qué se ha interpretado que Sabina, fallecida en Dougga "un año después de alcanzar la vejez" (CIL 8.1542, 8.15511 y 8.26673) ${ }^{115}$, murió con 61 años, a pesar de que la edad cronológica del fallecimiento no esté indicada en su epígrafe funerario (Khanoussi y Maurin, 2002: 432-433, no 1074).

Las teorías sobre la existencia de ciclos reproductivos diferentes para mujeres y hombres y sobre la menopausia como un fenómeno que podía ocurrir a diferentes edades las encontramos en los autores antiguos. Aristóteles ( $G A 7.5 .585 \mathrm{~b}$ ) señala que las menstruaciones comienzan a retirarse hacia los 40 años en la mayoría de mujeres. Expresa la posibilidad de concebir a los 50 años, pero nunca por encima de dicha edad.

\footnotetext{
114 Judith de Luce (1993: 361) comparte la idea de la menopausia como frontera para la vejez, aunque la sitúa de media en los 40 años. Una vida reproductiva más corta determina también Eva Cantarella (1995: 115), para quien una romana que se casaba a los 12 años habría tenido de media dos décadas de fertilidad. 115 vixitq(ue) at u/num unde est sen[ec]/tae exordium.
} 
Para Platón (R. 5.460d-461c), las mujeres podían quedarse embarazadas entre los 20 y los 40 años, mientras que el periodo reproductivo de los hombres se alargaba hasta los 55 años. En el corpus hipocrático (Hippoc. Coac. Pr. 30.502) se señala una media de 42 años para la menopausia, una cifra relacionada con el especial simbolismo de los múltiplos de siete. Para Dionisio de Halicarnaso (Ant. Rom. 4.6.5) las mujeres son fértiles hasta los 50 años. Sorano (Gyn. 1.20 y 1.22) y Plinio el Viejo (NH 7.14) establecen la misma franja etaria para la menopausia, entre 40 y 50 años, si bien el primero reconoce que hay mujeres cuya menstruación no cesa hasta los 60 años y que se trata de un fenómeno que depende de las circunstancias concretas de cada fémina. No obstante, expresa que para que un nuevo matrimonio se realice con la intención de tener descendencia la esposa debe tener entre 14 y 40 años (Sor. Gyn. 1.34). Sorano tuvo que tener en cuenta el periodo de tiempo que una pareja necesita para lograr un embarazo tras el matrimonio, de forma que la mayor parte de las mujeres de la época en la que escribe, el siglo II d.C., no debían alcanzar la menopausia hasta al menos mediada la cuarentena. Por otro lado, el Digesto (19.1.21.1) establece la obligatoriedad de informar de si una esclava es estéril o mayor de 50 años en el momento de la venta, de lo que se infiere que si no imposible al menos sí se creía improbable la concepción a partir de dicha edad. Quien refiere un margen más amplio es Oribasio (Ec. 142 apud Amundsen y Diers, 1970: 82), que sitúa la menopausia entre los 35 y los 60 años.

La existencia de rangos de edad amplios para la menopausia puede deberse a que ésta es un fenómeno que es considerado de dos formas distintas: como un evento concreto o como un proceso. Como evento, la menopausia es la condición que comienza al finalizar la última menstruación, poniendo fin a la vida reproductiva de la mujer. Esta es la concepción que encontramos en aquellos autores que hablan de edades concretas, como Dionisio de Halicarnaso. Como proceso, hace referencia a un periodo de varios meses, o incluso años, en los que el ciclo menstrual se vuelve irregular hasta cesar por completo $^{116}$. Especial conocimiento de este cese gradual lo expresa Sorano (Gyn. 1.20.1), quien habla de periodos de flujo irregular previos a la desaparición de la menstruación.

\footnotetext{
${ }^{116}$ Se trata de un proceso que la Gerontología divide actualmente en cuatro fases: premenopausia (periodo anterior a la menopausia, caracterizado por menstruaciones irregulares), perimenopausia (periodo que comprende ciertas alteraciones endocrinas consecuencia del cese de la ovulación), menopausia (cese del sangrado menstrual), y postmenopausia (etapa que comienza trascurridos doce meses de la última menstruación).
} 
La lex Papia Poppaea a la que nos hemos referido ofrece apoyo a la noción de 50 años como la edad media en la que las romanas dejaban de ser fértiles. Fue promulgada por Augusto en el año 9 d.C. como parte de su programa de ensalzamiento de los valores familiares republicanos y se complementaba con otras leyes como la lex Iulia de Maritandis Ordinibus y el Senatus Consultum Pernicianum. La ley, que pretendía incentivar la reproducción, dictaba que los hombres mayores de 60 años y las mujeres mayores de 50 que no estuvieran casados tendrían ciertas restricciones para recibir herencias y quedarían por detrás de candidatos con hijos al concurrir a puestos políticos (Gai. Inst. 2.111 y 2.286; Suet. Claud. 23; Tac. Ann. 3.25; Ulp. 26). En un comentario a esta legislación, el Digesto señala además que la liberta mayor de 50 años no está obligada a prestarle servicios al patrono (Dig. 38.1.35). La legislación augustea tiene sus antecedentes en una ley del siglo $\mathrm{V}$ a.C. que, según Valerio Máximo, disponía lo siguiente:

"Los censores Camilo y Postumio obligaron a todos aquellos que habían llegado a la vejez sin contraer matrimonio a entregar una suma de dinero al erario público, a título de castigo. Estos ancianos serían dignos de un segundo castigo, si se atrevieran a protestar, de alguna manera, contra una norma tan justa. El reproche se les hacía en estos severos términos: «La naturaleza de la misma manera que promulgó para vosotros la ley de nacer, así promulgó la de engendrar; vuestros padres, al alimentaros, os han transmitido la obligación, si es que aún existe la vergüenza, de alimentar y educar a sus nietos. Hay que añadir que la fortuna os ha concedido un largo tiempo para pagar esta deuda, mientras que vosotros habéis dejado pasar los años sin haber adquirido el nombre de marido y padre. Id, pues, y pagad la multa impuesta a vuestro celibato, no por odio, sino para que sea útil a los que tienen muchos hijos»" (Val. Max. 2.9.1) ${ }^{117}$.

No sabemos cuál es la edad a la que esta ley contemplaba que debía aplicarse la multa, ni si afectaba sólo a los hombres o también a las mujeres, pero de la referencia de Valerio Máximo puede deducirse que ya a principios de la República existía un baremo por el que considerar que alguien había alcanzado la vejez.

\footnotetext{
${ }^{117}$ Camillus et Postumius censores aera poenae nomine eos, qui ad senectutem caelibes peruenerant, in aerarium deferre iusserunt, iterum puniri dignos, si quo modo de tam iusta constitutione queri sunt ausi, cum in hunc modum increparentur: 'natura uobis quemadmodum nascendi, ita gignendi legem scribit, parentesque uos alendo nepotum nutriendorum debito, si quis est pudor, alligauerunt. accedit his quod etiam fortuna longam praestandi huiusce muneris aduocationem estis adsecuti, cum interim consumpti sunt anni uestri et mariti et patris nomine uacui. ite igitur et non odiosam exsoluite stipem, utilem posteritati numerosae'.
} 
Claudio modificó las disposiciones de Augusto promulgando un senatus consultum que señalaba como aceptable el matrimonio entre un hombre mayor de 60 años y una mujer menor de 50, ya que se creía que aún había posibilidades de concebir. No ocurría lo mismo en el caso de que una mujer mayor de 50 años quisiera casarse con un hombre menor de 60, ya que se consideraba una unión inpar, incapaz de producir descendencia. Finalmente, una referencia tardía nos la ofrece San Agustín (Contra Iul. 3.11.22 y $D e$ Civ. D. 16.28), quien señala que, si bien las parejas de ancianos y aquellas en las que la suma de la edad de los cónyuges superase 100 no podían tener hijos a pesar de que la mujer siguiese menstruando, la unión entre un senex y una mujer joven y entre una vetula y un hombre joven sí tenía posibilidades de resultar fértil.

Vemos por lo tanto cómo en la antigua Roma el ciclo vital de las mujeres estaba regido por la biología. De alguna forma ello lo equiparaba al ciclo masculino, ya que si éste se centraba en los escalones del cometido público, el femenino hacía lo propio al tomar como eje la función principal que las mujeres tenían como ciudadanas romanas, la procreación. Nos encontramos así con tres etapas principales (antes, durante y después de los años fértiles), a las que podemos añadir momentos de transición entre unas y otras.

En lo que respecta a la vejez, hemos optado por fijar la frontera cronológica en 50 años apoyándonos en las fuentes escritas y las investigaciones historiográficas. Hemos tomado la menopausia como un momento puntual para ayudarnos en nuestra investigación, a pesar de que somos conscientes de que se trata de un proceso que se alarga en el tiempo. Los 50 años son además una frontera que como veremos en los siguientes apartados puede verse alterada debido a factores físicos y de percepción social.

\section{III.2. LAS VETULAE EN LA MEDICINA}

La vejez, como ya hemos visto en el capítulo anterior, era concebida en la Antigüedad como el resultado de un proceso de deterioro que alteraba el cuerpo, volviéndolo más húmedo o más seco dependiendo del autor al que leamos. Algunos escritores tratan la vejez como una enfermedad más, la última y más grave que vive el ser humano, mientras que otros aluden a que la ancianidad, si bien es más proclive a la 
falta de salud, no es en sí un estado patológico. La pérdida de facultades físicas y mentales se consideraba un proceso propio del último tramo de la vida, y todo lo que podía hacerse era prevenir una debilidad extrema a través de una dieta austera, ejercicio moderado y el fortalecimiento de la memoria a través de diversas técnicas.

En este apartado pretendemos acercarnos a las patologías consideradas propias de la vejez en la antigua Roma, haciendo hincapié en aquellas que afectaron a las vetulae. Para ello, hemos empleado tanto tratados de medicina como textos literarios que hacen referencia a enfermedades que se experimentan en la ancianidad. Además, nos hemos ayudado de evidencias proporcionadas por la Antropología Física para ilustrar cómo algunas de estas alteraciones dejan huellas en el esqueleto que pueden ser identificadas.

\section{III.2.1.La menopausia como cuestión médica}

Los tratados de medicina de la Antigüedad dedican poca atención al cuerpo de la mujer, siendo la excepción aquellos procesos relacionados con su capacidad procreadora: la gestación, el parto, los cuidados a los que debían someterse las madres tras dar a luz y las alteraciones de la menstruación. Tal y como expresa Helen King,

"In Hippocratic gynaecology, to be a woman is to menstruate. This poses the problem of women who do not menstruate: they may be ill, in which case drugs or mechanical procedures can be used to induce menstruation; they may be pregnant, in which case there is no danger to their health because the excess blood is contributing to the foetus; or they may be past the menopause, that natural process of 'drying out' which transforms even a wet and spongy female body into something that does not need to bleed" (King, 2001: 76).

Esta máxima no sólo se aplica a las obras del corpus hipocrático, sino también a los textos de otros autores como Sorano, Celso o Galeno. Los escritores de tratados médicos, que obtenían de la exploración física y de la información proporcionada por mujeres los conocimientos que han quedado reflejados en los tratados médicos de la Antigüedad, reinterpretaban estos datos a la luz de su concepción de la mujer como ser inferior al hombre, cuyo papel fundamental era proporcionar descendencia legítima (Dean-Jones, 1994: 27; King, 2005: 143). Al concebir a las mujeres como madres potenciales, las féminas no menstruantes se situaban fuera de sus preocupaciones; de esta forma, apenas hallaremos referencias a procesos fisiológicos que afectan solamente a mujeres menopáusicas (Cokayne, 2003: 37). Una excepción la encontramos en una lucerna hallada en León, de fabricación hispana, en la cual se aprecia una escena en la 
que una vetula, identificada por la delgadez de su cuerpo y la flacidez de su piel, está siendo sometida a un análisis ginecológico (Fig. 6) (Morillo, 1999: 200 y 446).

Algo parecido ocurre en el caso de la vejez en general, ya que si bien diversos autores (Cel. Med. 5.26.6 y 5.26.31c; Hippoc. Aph. 1.2, Nat. Mul. 1; Plin. NH 7.50.170 y 11.117.282) hacen referencia a cómo ciertas enfermedades afectan de forma diferente al paciente dependiendo de su edad, también en el caso de las mujeres, no se ha conservado ningún tratado médico que aborde la salud en la vejez de forma específica, por lo que tenemos que conformarnos con referencias aisladas, dispersas a lo largo de la literatura médica. De esta forma, la vetula se encuentra casi ausente en los textos médicos de la Antigüedad tanto por ser mujer como por ser anciana.

Dada la centralidad que la capacidad reproductora de las mujeres presenta en los tratados médicos antiguos, en el caso de la vetula el foco debe ponerse en la menopausia como acontecimiento que marca el fin de la fertilidad y, por lo tanto, del principal cometido de la mujer en la sociedad romana. La Sociedad Internacional del Climaterio define la menopausia como el cese permanente de la menstruación, resultante de la pérdida de la actividad folicular ovárica (Ceberio, 2013: apéndice). Se trata como ya hemos señalado de un proceso paulatino, por lo que a veces no resulta fácil fijar el momento preciso en el que acontece, al contrario de lo que ocurre con la menarquía, ya que es más sencillo recordar o verificar una cosa cuando ocurre por primera vez que cuando deja de ocurrir.

En el caso de la Antigüedad greco-romana, Carol Diers (1974: 931) fija la edad media de la menarquía en los 13,5 años, una tendencia que continuaría hasta c. $1500^{118}$. Los escritos médicos sitúan la menarquía durante el decimotercer o decimocuarto año de vida de la mujer (Sor. Gyn. 1.20), coincidiendo en este sentido con las fuentes legales, que establecen la edad mínima de matrimonio en 12 años (Dean-Jones, 1994: 47-48; Diers, 1974: 933). En cuanto a la menopausia, los estudios (Amundsen y Diers, 1970: 84; Diers, 1974: 934) sugieren una media de 50 años, dentro de un amplio umbral entre los 35 y los 60 años, cálculos que como hemos visto coinciden con las cifras dadas en las fuentes literarias ${ }^{119}$. A este respecto, si tomamos datos de sociedades en las que no se emplean métodos de control de la natalidad químicos como los actuales, como era

\footnotetext{
118 Mary Harlow y Ray Laurence (2002: 13-15) llaman la atención sobre no considerar estos cálculos como universales y tener en cuenta posibles variaciones regionales.

${ }^{119}$ En la actualidad, la retirada de la menstruación se fija entre los 45 y 55 años (García García, 2017:224).
} 
el caso de Roma, se constata cómo las mujeres que conciben su último hijo a una edad más avanzada tienden a vivir más años, se retrasa en ellas el momento de la menopausia, y su cuerpo tarda más en mostrar signos de envejecimiento; de la misma forma, esos hijos tardíos suelen ser también especialmente longevos (Hin et al., 2016).

La medicina antigua no parece preocuparse por la menopausia como fenómeno médico; de hecho, ni siquiera desarrolló una palabra concreta para referirse a ella. Esto puede deberse, como señala Kristen Gentile (2009: 55), a que los tratados médicos greco-romanos sólo se preocupan por las patologías y la menopausia no era considerada como tal, sino parte de un proceso natural que además no necesitaba supervisión en cuanto que el cuerpo menopáusico ya no era capaz de concebir ${ }^{120}$. Vemos entonces que en los textos médicos la menopausia aparece mencionada en relación con diversos problemas de salud derivados de la falta de ciclo menstrual, pero no por sí misma.

Una de las afecciones que la medicina de la Antigüedad relaciona con la menopausia es la histeria, patología fruto de un movimiento del útero y que por otro lado también podía darse en las viudas, a pesar de que aún menstruasen (Gal. De loc. aff. 6.5.424; Hippoc. Nat. Mul. 3). Los remedios varían entre la aplicación de calor, el masaje, las sangrías o los emplastos (Cel. Med. 4.27; Gal. De loc. aff. 6.5.420), los cuales según Helen King (2011: 222-224) se aplicarían las propias pacientes y nada tienen que ver con la masturbación que tradicionalmente se ha sugerido. La histeria venía acompañada muchas veces de apnea, dolores abdominales, desfallecimientos y sofocos (Gal. De loc. aff. 6.5.417-424; Hippoc. Mul. 1.7), síntomas asociados a los cambios hormonales derivados de la menopausia. Para Sorano (Gyn. 1.15) los movimientos del útero, provocados por la retracción del mismo, se acompañaban de la contracción de los pechos, que perdían grasa y quedaban flácidos.

La pérdida de la menstruación también era según la medicina antigua la causante de hemorragias, debidas a que la sangre que ya no se expulsaba mensualmente se acumulaba y acababa saliendo por vía vaginal, anal u oral (Gal. Nat. Fac. 2.8, 5.8.370 y 6.5.417). Estos episodios producían un enfriamiento del cuerpo que, según Galeno (De loc. aff. 6.5.432-433), provocaba que apenas se pudieran percibir el pulso y la respiración de la enferma, generando también espasmos y abatimiento. Además de ser

\footnotetext{
${ }^{120}$ De hecho, la patologización de la menopausia resulta un hecho reciente que se da solamente en Occidente y que las investigaciones ponen en relación con el edadismo y el culto a la eterna juventud (García García, 2017).
} 
más frío, el cuerpo de las vetulae era más seco que en su juventud, contraponiéndose así al cuerpo del senex, que se humedecía con la edad, pero al mismo tiempo haciéndolo más masculino, ya que los hombres eran memos húmedos que las mujeres (Hippoc. Mul. 111 y Nat. Mul. 1). Se aprecia aquí por lo tanto una homogeneización del cuerpo envejecido que va eliminando las distancias entre los sexos. Si los hombres, que tienen menos humedad, la ganan con la edad, y las mujeres, que son más húmedas, la pierden, obtenemos como resultado cuerpos más parecidos entre sí. Nos encontramos con un fenómeno, el de la homogeneización o androgenización en la vejez, que sigue dándose en nuestros días, y mediante el cual ancianas y ancianos integran características físicas y roles sociales que en la etapa adulta correspondían al género contrario (Livson, 1983; Phillips et al., 2010: 109).

Junto con estos síntomas recogidos de las fuentes médicas, las romanas presentarían también algunos otros que acompañan a la menopausia, ya fuesen de tipo genital, metabólico, circulatorio, locomotriz, nervioso, endocrino, digestivo, respiratorio, psíquico, urinario o dermatológico, los cuales se resumen en la Tabla 4.

\section{III.2.2.Patologías físicas y mentales}

Además de la menopausia, las vetulae padecerían otros cambios fisiológicos, compartidos en este caso con los senes. Al acelerarse el proceso de envejecimiento en la vejez, los seres humanos experimentamos el deterioro de los sistemas y las funciones del organismo, originado por el desgaste de los años vividos, al tiempo que adquirimos una mayor predisposición a enfermar física y mentalmente y el organismo pierde capacidad de adaptación a situaciones nuevas (Ceberio, 2013: apéndice). Patologías que en la juventud provocaban un malestar pasajero y que tenían una rápida recuperación pueden convertirse, en el caso de las personas ancianas, en procesos que generan incapacidades permanentes y dolores crónicos, lo que a su vez deriva en estados de dependencia (Hippoc. Aph. 2.39; Gannon, 2005: 48).

En la actualidad, el 70-80\% de las personas mayores de 65 años sufre problemas cardiovasculares, el 50-60\% problemas osteoarticulares, el 90\% problemas sensoriales, el $20-25 \%$ diabetes o enfermedades pulmonares, y el $10 \%$ experimenta deterioro cognitivo (Ribera, 2011: 227). Este tipo de patologías estarían también presentes en la población anciana de la antigua Roma, incidiendo en ella en porcentajes parecidos a los actuales, si bien estos pueden haberse modificado con el paso del tiempo debido a las mejoras higiénicas y sanitarias, y también a agentes como la exposición a mayores 
niveles de contaminación y radiación, o la ingesta de alimentos especialmente grasos y/o azucarados.

Ya se ha señalado que en época romana la vejez se veía como una etapa especialmente débil y proclive a la enfermedad, e incluso como una enfermedad en sí misma (Apul. Met. 5.9.8; Cic. Sen. 9.27 y 11.34 y Tim. 5.17; Hor. Epist. 1.7.45-49; Liv. 10.13.6-7; Macrob. Sat. 7.10.7-11; Ov. Tr. 8.4; Tac. Ann. 14.33, 14.38.4 y 14.45.1; Tib. 1.4.27-39; Val. Max. 8.7.4; Ver. Aen. 5.715-717, 7.440-441 y 12.131-132); si bien Plinio el Viejo ( $N H$ 7.50.170) escribe que una de las pocas ventajas físicas que trae consigo la vejez es una menor probabilidad de sucumbir a diversas epidemias. Por ese motivo, Celso (Med. 2.10.4) aconsejaba no practicar sangrías a las personas ancianas, al igual que tampoco eran convenientes en la población infantil. En el caso de las vetulae se trataba de una debilidad doble, ya que les afectaría tanto por mujeres como por ancianas. Es por ello que en el año 107 d.C. Plinio el Joven se sorprendía de que Umidia Cuadratila hubiera fallecido a los 79 años, "habiendo conservado hasta su última enfermedad todo su vigor, y además un cuerpo robusto y fuerte, raro en una matrona romana" (Plin. Ep. 7.24) ${ }^{121}$.

Relacionados con la pérdida de fortaleza estarían los temblores, especialmente los de las manos (Juv. 10.198; Ov. Fast. 5.512 y Met. 10.414; Plin. Ep. 2.1.4; Verg. Aen. 2.509-511), algunos de los cuales son identificados por Bartolomé Segura (2007: 98-99) como los síntomas de la enfermedad de Parkinson. A la debilidad muscular que dificulta el movimiento se uniría la fragilidad ósea, fruto de la pérdida de densidad de los huesos y una peor capacidad para absorber calcio. Ello derivaría en una pérdida de estatura (Arist. GA 1.1.500b), agravada por el encorvamiento de la columna vertebral. El debilitamiento óseo también conllevaría el aumento del riesgo de padecer fracturas, además de un periodo más largo de curación de las mismas (Cel. Med. 5.16.6). La fractura que más frecuentemente se relaciona con la vejez, tanto en la actualidad como en época romana, es la rotura de cadera (Plin. Ep. 2.1.5).

Las vetulae sufrirían también otras patologías derivadas del desgaste de huesos y articulaciones, entre las cuales destacan la gota, el reumatismo y los aplastamientos vertebrales, que provocarían dolores, extremidades retorcidas y dificultades en algunos

\footnotetext{
${ }^{121}$ usque ad novissimam valetudinem viridis, atque etiam ultra matronalem modum compacto corpore et
} robusto. 
movimientos (Cic. Att. 1.5.8; Hor. Carm. 1.9.15; Lucil. 9.255; Baxarías, 2002: 205-207; García Prósper y Polo, 2003: 305). La medicina antigua proponía como remedios paliativos los masajes y las friegas con preparados a base higo y leche humana, u otros como descansar los miembros afectados dentro de sacos de trigo (Apul. Met. 5.10.1-2; Hdn. 2.15.4; Hippoc. Aph. 3.31, 6.29 y Epid. 4.42; Luc. Sat. 7; Plin. NH 23.63, 22.57 y 28.21). Se trata de métodos que para Simon Byl (1988b: 100) eran de poca o ninguna ayuda, razón por la cual Plinio el Joven (Ep. 1.12) habla del suicidio como una forma de poner fin al padecimiento de la gota.

En el registro arqueológico resulta frecuente identificar huellas de artrosis, procesos crónicos y progresivos no inflamatorios producidos por la pérdida del cartílago de las articulaciones y la consiguiente lesión debida al contacto directo de las superficies óseas adyacentes, cuya causa es en el $80 \%$ de los casos el envejecimiento (Baxarías, 2002: 97; Caldarini et al., 2015; García Prósper y Polo, 2003: 305; Gowland, 2017b: 83; Minozzi et al., 2012: 270; Polo y García, 2002: 144;). La artrosis está presente, por ejemplo, en el 35\% de las articulaciones de los individuos recuperados en Pompeya (Laurence, 2005: 89), muchas veces acompañada de osteoporosis (Fox, 2005: 76).

En el caso de las vetulae, la artrosis más frecuente parece haber sido la de rodilla, aunque también padecerían artrosis en la cadera, las manos, los pies y la columna vertebral, como la artrosis lumbar del esqueleto T.237 aparecido en una necrópolis en Tarragona, fechado entre los siglos III-IV d.C., una mujer mayor de 65 años con una patología severa que le habría provocado importantes dolores (Baxarías, 2002: 102103). Una forma extrema de artritis, la espondilitis anquilosante, se ha detectado en una mujer mayor de 50 años encontrada en la necrópolis Colatina (Roma), activa entre los siglos I a.C. y III d.C. (Fig. 7). Esta patología, junto con el desgaste que presenta en las articulaciones de las rodillas, habría provocado que esta vetula tuviese una postura encorvada que le daría una apariencia siniestra, la cual sería la causa de que presentase un tratamiento funerario distinto al resto de individuos de la necrópolis, de carácter marginal (Minozzi et al., 2012: 271).

En el anterior capítulo hemos hecho referencia a la pérdida de piezas dentales, una patología que sería común en la vejez romana y que podía suplirse con postizos: "Tais tiene los dientes negros; Lecania, blancos. ¿Cuál es la razón? Ésta los tiene comprados, 
aquélla naturales" (Mart. 5.43) ${ }^{122}$. Se trataba de un problema tan común en época romana que incluso aparece mencionado en el Digesto:

“Aquel a quien le falta algún diente no es tenido por enfermo; porque una gran parte de los hombres carece de algún diente, y no por eso son enfermos; principalmente, porque nacemos sin dientes, y no por eso estamos menos sanos hasta que tenemos dientes, pues de otro modo ningún anciano estaría sano" (Dig. 21.1.11) ${ }^{123}$.

En la literatura, la falta de dientes resulta recurrente para caracterizar la vejez, especialmente cuando se desea resaltar la decrepitud de la persona aludida (Hor. Epod. 8; Juv. 10.198; Luc. Dial. Mort. 6; Mart. 3.93 y 8.57; Plaut. Mostell. 275-280; Sen. Ep. 12; Tac. Ann. 1.34). Así ocurre por ejemplo en un Priapeo en el que la pérdida de una pieza dental sirve para subrayar la marginalidad de la vetula, su proximidad con la muerte y la repulsa que el narrador siente hacia la anciana:

"Cierta mujer más vieja que la madre de Héctor, hermana, según creo, de la Sibila de Cumas y de la misma edad de Hécale, a la que Teseo, a su regreso, encontró en la pira funeraria, suele venir aquí con renqueante paso y alzando al cielo sus arrugadas manos, pide que nunca le falte una verga. Mientras me suplicaba así ayer escupió uno de sus tres dientes: «Llévatelo lejos», le dije, «y deja que permanezca oculto bajo tu túnica andrajosa y tu roja estola, como debe siempre ser, y que tema la luz del día ese miembro indecente, macilento, de tan enorme abertura y de prominente nariz pilosa, que lo tomarías por Epicuro en enorme bostezo» (Priap. $12)^{124}$.

No obstante, también nos encontramos con ejemplos contrarios: Aristóteles señala que conoce casos de ancianas a las que en vez de perder dientes, en la vejez les salen las muelas del juicio a edades tan avanzadas como los 80 años (Arist. GA 2.4.501b) y Plinio el Viejo ( $N H$ 11.63.167) escribe que si bien los dientes pueden caerse en la vejez, es posible que broten piezas nuevas, supuesto para el que no hemos encontrado paralelos en la medicina moderna.

\footnotetext{
${ }^{122}$ Thais habet nigros, niueos Laecania dentes. Quae ratio est? Emptos haec habet, illa suos.

${ }^{123}$ Cui dens abest, non est morbosas; magna enim pars hominum aliquo dente caret, neque ideo morbosi sunt; praesertim quum sine dentibus nascimur, nec ideo minus sani sumus, domec dentes habearnus, alioquia nullus senex sanas esset.

${ }^{124}$ Quaedam haud iunior Hectoris parente, Cumaeae soror, ut puto, Sibyllae, aequalis tibi, quam domum revertens Theseus repperit in rogo iacentem, infirmo solet huc gradu venire rugosasque manus ad astra tollens, ne desit sibi, mentulam rogare. Hesterna quoque luce dum precatur, dentem de tribus exscreavit unum. 'Tolle' inquam 'procul ac iube latere scissa sub tunica stolaque rufa, ut semper solet, et timere lucem, qui tanto patet indecens hiatu, barbato macer eminente naso, ut credas Epicuron oscitari'.
} 
La falta de dientes es una de las patologías características de la vejez que con más frecuencia se detecta en el registro arqueológico, y que además en época romana parece haber incidido más en las mujeres que en los hombres (Laurence, 2005: 90; Salvatierra et al., 1996; Sande, 1995: 33). Para este fenómeno se han sugerido dos explicaciones. Por un lado, tal y como señala Siri Sande (1995: 33), la medicina ha descubierto que los embarazos causan un intenso desgaste en los dientes de la gestante, lo que en sociedades con alta tasa de nacimiento como la romana podría explicar las patologías a las que hemos aludido. Por otro lado, análisis de isótopos de colágeno femoral como los llevados a cabo en el yacimiento de Isola Sacra en 105 individuos sugieren diferencias en las dietas de hombres y mujeres (Prowse, 2011: 420-421). En este caso concreto, las mujeres habrían consumido más recursos terrestres y menos recursos marinos que los hombres, lo que podría haber provocado déficit vitamínicos. Además, el análisis de las mandíbulas y dientes de este mismo yacimiento reflejó que las mujeres tuvieron una mayor pérdida de piezas dentales que los hombres, sobre todo en los casos de los individuos ancianos, y que eran más proclives a padecer cálculos bucales y abscesos (Prowse, 2011: 422). Finalmente, cabe destacar que se detectaron diferencias en las dietas de los esqueletos femeninos jóvenes y seniles, lo que Tracy Prowse (2011: 428) relaciona con la idea de que a las jóvenes se les exigía tener una dieta moderada que favoreciese la salud y evitase el aumento de peso, mientras que en las vetulae estas restricciones ya no se considerarían necesarias. Esta teoría, basada en las ideas de Rufo de Éfeso (s. II d.C.) recogidas por Oribasio (Inc. 18.10 apud Garnsey, 1999: 101), es defendida también por Lisa Alberici y Mary Harlow (2007) y por Peter Garnsey (1999: 101 y ss.).

Además de la falta de algunas piezas dentales, las vetulae también padecerían caries, quistes, mandíbula desigual debida a los hábitos masticatorios y la pérdida de dientes, oscurecimiento dental, desgastes severos, úlceras y abscesos bucales $\mathrm{y}$ enfermedades en las encías, con la consiguiente halitosis (Catull. 97; Cel. Med. 2.8.33; Hor. Epod. 8; Plin. NH 22.23; Salvatierra et al., 1996; Sande, 1995). Entre los individuos de una necrópolis tardorromana de Tarragona, casi el 10\% presentan huellas de infecciones bucales, son múltiples los casos de abscesos y se observa un alto grado de desgaste por atrición en los individuos mayores de 40 años de ambos sexos (Baxarías, 2002: 113-115 y 173). Destaca el esqueleto 102, que presenta una ausencia total de dientes en la mandíbula, con los problemas que ello conlleva para la ingesta de alimentos sólidos (Baxarias, 2002: 106). 
La ceguera, o los problemas de visión, serían comunes en la vejez romana. A partir de los 45-50 años, el cuerpo humano experimenta ciertos cambios en la córnea, el iris y la pupila, que suelen derivar en astigmatismo y pérdida progresiva de visión (Schieber, 2011: 130). En la actualidad, la OMS calcula que el 65\% de las personas visualmente impedidas tienen más de 50 años, lo que lleva a Lisa Trentin (2013: 104) a suponer que un importante número de quienes alcanzasen la ancianidad en Roma tendrían problemas de visión. A este respecto, Galeno (De usu p. 10.5) señala que en la vejez la córnea se arruga paulatinamente, dañando al mismo tiempo la pupila, pudiendo llegar a la ceguera absoluta.

En la literatura encontramos diversos ejemplos de problemas de visión en la vejez, referidos tanto a la falta de un ojo como a la pérdida total o parcial de la vista o a la dificultad de enfocar o leer de cerca (Cel. Med. 6.6.32; Cic. Sen. 11.37; Hippoc. Aph. 3.31 y Epid. 1.12; Juv. 10.217 y 10.230; Luc. Dial. Mort. 6; Mart. 2.33, 4.65 y 12.22; Plin. NH 28.2; Plut. Mor. 626; Suet. Aug. 79.2; Val. Max. 8.7.4). Marcial se mofa de Lelia, quien pone solución a su calvicie y su falta de dientes pero no puede hacer lo mismo con uno de sus ojos: "Llevas -y no te avergüenzas- dientes y cabellos comprados. ¿Qué harás con el ojo, Lelia? No se puede comprar” (Mart. 12.23) ${ }^{125}$.

La vista no sería el único de los sentidos que las vetulae verían afectados, ya que también sufrirían una pérdida paulatina de audición, olfato, gusto y sensibilidad al tacto (Hippoc. Aph. 3.31; Juv. 10.200-215; Luc. Tim. 2). En lo que respecta a la sordera, basándose en datos actuales Lynn Rose (2006: 18) calcula que alrededor del 30\% de la población mayor de 65 años de la antigua Grecia padecería pérdida total o casi total de la audición, cifra que podemos aplicar también a vetulae y senes romanos. Una sordera profunda implicaría una reducción en la capacidad comunicativa de los ancianos que la padeciesen y, si las personas del entorno no realizaban un esfuerzo por adaptarse a la nueva situación, aislamiento social.

Por otro lado, junto con las ya señaladas serían de esperar otras muchas patologías, sobre todo a medida que fuese aumentando la edad de la vetula: cardiopatías, problemas de coagulación, gangrena, ictus, derrames cerebrales, apoplejías, problemas estomacales, renales y pulmonares, incontinencia urinaria, deshidratación, alteraciones del sistema nervioso y fracturas y golpes derivados de

\footnotetext{
${ }^{125}$ Dentibus atque comis - nec te pudet - uteris emptis. Quid facies oculo, Laelia? non emitur.
} 
caídas (Arist. GA 3.19.521b у Iии. 23.478b.21; Cass. Dio 68.33.3; Cel. Med. 2.1.22, 3.17.1a y 5.26.31c; Hippoc. Aph. 2.20 y 6.57; Lucil. 4.140; Plin. NH 11.117 y 30.22; Suet. Aug. 79-80) ${ }^{126}$. También incidiría en la población romana anciana el cáncer (Polo y García, 2002: 143).

Basándose en los tratados de Hipocrátes (siglos V-IV a.C.), Celso (siglos I a.C. - I d.C.) y Celio Aureliano (siglo V d.C.), Jean-Marie André (2006: 216-217) ha elaborado una lista de una treintena de enfermedades que en la Antigüedad se asociaban a la vejez (Tabla 5), muchas de las cuales se encuentran presentes en los tres autores; de esta forma vemos que, a pesar de la distancia cronológica que media entre ellos, hay ciertas patologías que siempre son consideradas como características de la ancianidad, como la tos y los problemas renales.

No podemos olvidar por otro lado problemas de salud que serían comunes a toda la población romana, como hongos, pústulas y afecciones gastrointestinales. Se trata de dolencias que se extenderían rápidamente entre la ciudadanía debido al contacto diario. Además, debemos tener en cuenta los brotes epidémicos de enfermedades como la malaria, los cuales según algunos cálculos arrasarían Roma capital más o menos cada cuatro años (Scheidel, 2013: 51).

Junto con las patologías propiamente dichas hemos de tener en cuenta también diversas condiciones derivadas del modo de vida de las personas ancianas: fracturas mal sanadas que provocaban cojeras o pérdida de movilidad en el tronco superior e inferior y que empeorarían con la edad, heridas que no terminaban de curar y generarían infecciones y dolores, etc. (Tac. Hist. 1.9). También serían frecuentes las amputaciones y desfiguraciones derivadas de los accidentes, el ejercicio de ciertos oficios, las infecciones, la tortura, o los episodios de violencia ${ }^{127}$. En algunos casos, estas condiciones dieron lugar incluso a cognomina; así, por ejemplo, Cocles (tuerto) o Scaevola (zurdo), el cual provenía del sobrenombre que se le dio a Cayo Mucio, quien puso la mano en el fuego hasta calcinársela (Liv. 2.12.9-13.1; Val. Max. 3.3.1).

Estas condiciones podían ser motivo de risa y vergüenza (Liv. 45.39.17-18). En el siglo III a.C., el cónsul Espurio Carvilio evitaba ser visto en público porque se

\footnotetext{
${ }^{126}$ Para un análisis exhaustivo de las patologías asociadas a la vejez en la actualidad, la mayoría de las cuales estarían también presentes en la Antigüedad, vid. Rodríguez Ávila, 2006: 22 y ss.

${ }^{127}$ Sobre las distintas modalidades de castigo corporal y tortura existentes en la antigua Roma, vid. Espejo, 1996.
} 
avergonzaba de su cojera, fruto de una herida de guerra (Cic. De or. 2.249). Dos siglos más tarde, Cicerón escribía lo siguiente:

"Para comenzar por el cuerpo, ¿no ves cómo los hombres, si tienen en sus miembros algo deforme, debilitado o disminuido, lo ocultan?, ¿cómo, incluso se esfuerzan y trabajan para que, si pueden conseguirlo, no se note su defecto físico o se note lo menos posible? (...) Pues, si creemos que la deformidad y la mutilación del cuerpo deben ser evitadas por sí mismas, ¿por qué no hemos de buscar también por sí misma, y quizás con mayor razón, la dignidad de nuestra figura?” (Cic. Fin. $5.17)^{128}$.

De la misma forma, Augusto escribía, en una carta a Livia acerca de Claudio, que su condición física podía hacerlo objeto de risa por parte de "los hombres, que tienen por costumbre burlarse de estas cosas" (Suet. Claud. 4) ${ }^{129}$. Se estaba refiriendo quizás a sí mismo, cuando se mofaba de la columna deformada del padre del emperador Galba (Macrob. Sat. 2.4.8.). Los cuerpos encorvados y las dificultades en el movimiento eran también frecuentemente usados para ridiculizar a las vetulae, o bien para resaltar su desgraciada situación (Apul. Met. 4.7; Ov. Met. 14.142-151; Plaut. Merc. 670-675; Priap. 12; Prop. 2.18.20).

Además de los problemas físicos, las ancianas romanas también experimentarían problemas psicológicos y psiquiátricos: pérdida de agilidad mental, dificultades en el habla y en el aprendizaje, pérdida momentánea de memoria, así como males más graves como la demencia o la enfermedad de Alzheimer (Apul. Apol. 53; Hor. Sat. 2.3.215220; Juv. 10. 230-235; Plin. NH 11.112.270; Plut. Mor. 650). En los dos últimos casos, el día a día de las vetulae se habría complicado, ya que la demencia trae consigo síntomas como pérdidas graves de memoria y de habilidades sociales, dificultad para efectuar actividades que antes eran familiares o habituales, desorientación en tiempo y espacio, cambios bruscos en el humor y el comportamiento, y cambios en la personalidad (Ceberio, 2013: 94 y ss.; Rodríguez Ávila, 2006: 41-45).

Esta pérdida de capacidades mentales se asociaba a una menor autonomía y fuerza que es propia de la vejez, y se esperaba que aconteciera junto con la debilidad física (Lucr. 3.445-469). En el caso de los escritores romanos, la pérdida de la memoria y la

\footnotetext{
${ }^{128}$ Atque ut a corpore ordiar, videsne ut, si quae in membris prava aut debilitata aut inminuta sint, occultent homines? ut etiam contendant et elaborent, si efficere possint, ut aut non appareat corporis vitium aut quam minimum appareat? (...) nam si pravitatem inminutionemque corporis propter se fugiendam putamus, cur non etiam, ac fortasse magis, propter se formae dignitatem sequamur?

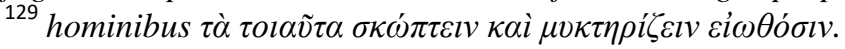


lucidez mental aparecen como un mal peor que cualquier dolencia física (Hor. Carm. 1.31.20; Sen. Contr. 1.pref. 2; Sen. Dial. 1.13.5). Cicerón, en un fragmento citado en el Capítulo II, hace referencia a "esa necedad senil, que suele llamarse chocheo" (Cic. Sen. 11.36) ${ }^{130}$ que puede identificarse con los cambios que acabamos de describir, la cual advertía que no afectaba a todos los ancianos. Para el orador, podía combatirse el declive cognitivo ejercitando la mente con actividades como la lectura, al igual que hicieron todos los hombres que citaba como ejemplo de ancianidad mentalmente sana, con Catón a la cabeza (Cic. Sen. 7.21 y 7.23; Sen. Ep. 27; Val. Max. 8.7.1). En el siglo I d.C. Areteo de Capadocia (SD 1.6) distinguía entre locura transitoria, locura permanente y locura provocada por la vejez, ésta última irreversible. Por su parte, Cátulo (17), Plinio (NH 7.24) y Juvenal (10.230) aludieron a la incapacidad de recordar los nombres y reconocer las caras de las personas más cercanas, como le ocurrió a Mesala Corvino, que llegó a olvidar su propio nombre.

Algunos autores equipararon la demencia y otras patologías mentales en la vejez con vivir una segunda infancia, una comparación que seguimos empleando en la actualidad $^{131}$. Se trata de una caracterización que se empleaba tanto con fines cómicos como para resaltar la crueldad de la vejez (Aristid. Or. 28.60; Catull. 17; Juv. 10.195; Luc. Dial. Mort. 27; Mart. 6.70; Sen. Ep. 12.1-5; Var. Sat. Men. 44). Varrón dedicó a este tema la Sátira Menipea 91, pero de ella sólo nos han llegado el título y dos palabras. Suetonio (Galb. 14) aludió a que los consejeros del anciano emperador Galba eran conocidos como sus paedagogi, y Juvenal (10.90 y 13.33) asignó un tutor al senex Tiberio y retrató al anciano Fescenio levando la bulla. El fenómeno de la vejez como una segunda infancia tenía incluso su propio término, repuerascere, el cual según Tim Parkin (2011b: 29) fue acuñado por Plauto en el siguiente pasaje:

"DEMIFÓN - A ver, Lisímaco, ¿qué edad me echas?

LISÍMACO - Una edad como para tener ya un pie en la sepultura, un viejo gastado, decrépito.

DE - Te equivocas, Lisímaco, soy un muchacho de siete años.

LI - Pero ¿estás en tu juicio, decir que eres un chico?

DE - Es la pura verdad.

\footnotetext{
${ }^{130}$ ista senilis stultitia, quae deliratio appellari solet.

${ }^{131}$ Para un repaso histórico sobre el tópico de la vejez como una segunda infancia, vid. Covey (19921993).
} 
LI - Ahora comprendo lo que quieres decir: cuando se pone uno viejo y se pierde el sentido y la razón, dicen que se vuelve uno como un niño" (Merc. 290-295) ${ }^{132}$.

En ocasiones, actitudes que podrían ser sintomáticas de una patología mental se suman a otras que no tienen por qué serlo pero que estaban estigmatizadas por la sociedad, como la permanencia del deseo sexual en la vejez:

"Construir casitas, uncir ratones a un carrito, jugar a pares y nones, cabalgar sobre una larga caña... Si eso le gusta a un hombre de barba crecida, es que se ha apoderado de él la locura. Y si el razonamiento demuestra que más pueril que todo eso es enamorarse, y que no hay diferencia entre que, como hacías en otro tiempo, cuando tenías tres años, juegues en la arena, y que angustiado llores por el amor de una cortesana, entonces te pregunto: ¿vas a hacer lo que antaño hizo Polemón una vez convertido? ¿Vas a dejar las enseñas de tu enfermedad -vendas, codal y bufandas-, al modo en que se cuenta que aquél, estando bebido, se quitó a hurtadillas las coronas del cuello cuando lo reprendió la voz del maestro que estaba en ayunas?" (Hor. Sat. 2.3.245-260) ${ }^{133}$.

Otro de los cambios psicológicos que se dan en la vejez y sobre el que nos hablan los autores clásicos es el mal carácter de vetulae y senes, sobre todo en el caso de las mujeres, que se nos presentan como más irritables y coléricas que los hombres por naturaleza:

"La ira de aquéllos en quienes hay más de húmedo crece poco a poco, porque no está dispuesto para ellos el calor, sino que lo adquieren con la agitación; así pues, las iras de los niños y de las mujeres son más vehementes que profundas y más ligeras mientras comienzan. En las edades áridas la ira es violenta y potente, pero sin ir a más ni agrandarse mucho, porque al calor que empieza a declinar sigue el frío: los viejos son difíciles y quejumbrosos, como los enfermos y los convalecientes" (Sen. Dial. 2.19.4-5; vid. también Arist. GA 9.1.608b y Plut. Mor. $457 b)^{134}$.

\footnotetext{
${ }^{132}$ DEM - Quid tibi ego aetatis videor? LYS - Acherunticus, senex vetus, decrepitus. DEM - Pervorse vides. Puer sum, Lysimache, septuennis. LYS - Sanun es, qui puerum te esse dicas? DEM - Vera praedico. LYS - Modo hercle in mentem venit, quid tu diceres: senex quom extemplo est, iam nec sentit nec sapit, aiunt solere eum rusum repuerascere.

${ }^{133}$ Aedificare casas, plostello adiungere muris, ludere par inpar, equitare in harundine longa siquem delectet barbatum, amentia verset. Si puerilius his ratio esse evincet amare nec quicquam differre, utrumne in pulvere, trimus quale prius, ludas opus, an meretricis amore sollicitus plores: quaero, faciasne quod olim mutatus Polemon? Ponas insignia morbi, fasciolas, cubital, focalia, potus ut ille dicitur ex collo furtim carpsisse coronas, postquam est inpransi correptus voce magistri?

${ }^{134}$ Quibus umidi plus inest, eorum paulatim crescit ira, quia non est paratus illis calor sed motu adquiritur ; itaque puerorum feminarumque irae acres magis quam graves sunt levioresque dum
} 
"No en vano, los filósofos definen la cólera como una úlcera del espíritu, duradera y a veces incluso crónica, una úlcera que suele nacer en caracteres blandos. Y, por eso, con grandes posibilidades de acertar, aseguran que las personas enfermizas suelen encolerizarse más que las sanas, las mujeres más que los hombres, los ancianos más que los jóvenes y los desafortunados más que los que son felices" (Amm. Marc. 27.7.4) ${ }^{135}$.

El padecimiento de enfermedades mentales degenerativas influiría también en la consideración que las personas ancianas tendrían en la sociedad. De esta forma, una vetula autónoma, sin patologías incapacitantes ni crónicas y con una mente lúcida, sería vista socialmente más joven que una vetula dependiente, con enfermedades que limitasen su libertad de movimiento o le impidiesen realizar tareas cotidianas, así como con síntomas de demencia, independientemente de la edad cronológica de ambas.

La dependencia, a la cual nos hemos referido en varias ocasiones, supone un punto clave en el estudio de la vejez, si bien apenas es mencionada en los trabajos historiográficos. Ello se debe, como señala Rebecca Gowland (2017a), a que usualmente se piensa que las personas ancianas no están discapacitadas, sino que simplemente son viejas. Hoy en día se calcula que el $15 \%$ de la población mundial posee algún grado de discapacidad -conlleve o no dependencia-, y que cerca de 2 millones de personas adultas tienen problemas significativos para funcionar con normalidad (Roberts, 2017: xiii). En la actualidad, la Gerontología considera que la calificación de una persona como dependiente debe evaluarse en relación con diversos factores: coherencia discursiva, orientación, aseo, vestido, alimentación, excreción, movimiento, capacidad de desplazamiento, gestión, ocio, etc. (García Martínez, 2001: 258). Si no todas, muchas de estas capacidades se encontraban limitadas en el caso de Domicio Tulo, quien no sería una excepción en la Antigüedad. Otro ejemplo lo encontramos en un senex casado con una mujer muy joven que, al contrario que la esposa de Tulo, no se preocupaba demasiado por su dependiente esposo, el cual además de limitaciones físicas seguramente padecía también algún tipo de demencia:

"Se trata de un hombre muy sin gracia y sin más discreción que la de un niño de dos años que duerme en la cuna que forman los brazos temblorosos de su padre.

incipiunt. Siccis aetatibus vehemens robustaque est ira, sed sine incremento, non multum sibi adiciens, quia inclinaturum calorem frigus insequitur. Senes difficiles et queruli sunt, ut aegri et convalescents.

${ }^{135}$ Hanc enim ulcus esse animi diuturnum interdumque perpetuum prudentes definiunt, nasci ex mentis mollitia consuetum, id adserentes argumento probabili, quod iracundiores sunt incolumibus languidi, et feminae maribus, et iuvenibus senes, et felicibus aerumnosi. 
Éste, aunque está casado con una joven en la flor más tierna de la vida, esto es, una niña más delicada que un tierno cabritillo, a la que hay que vigilar con más tiento que a las uvas más maduras, le permite divertirse como le place; para él no vale un comino, ni se levanta de su rincón, sino que se queda echado como el olmo en el foso abatido por el hacha lígur, sintiéndolo todo tal como si no existiera nadie en ninguna parte. Así es ese estúpido paisano mío que ni ve nada, ni oye nada, ni sabe tampoco quién es él mismo, ni si existe o no existe" (Catull. 17) ${ }^{136}$.

Este senex tenía problemas visuales, auditivos y de movilidad, y además padecía una demencia que le había hecho perder la noción de sí mismo y de su entorno. Conviviendo con una esposa joven que no le prestaba los cuidados debidos, cabe preguntarse cuál sería la calidad de vida de este hombre. Si bien parece que no estaba desatendido, ya que si no hubiera sido imposible que sobriviviese en sus condiciones, no sabemos si quienes se encargaban de él -familiares, esclavos- atenderían todas sus necesidades y hasta qué punto se encontraría integrado en su entorno.

Si bien Séneca (Ep. 67.2) se mostraba agradecido porque la vejez lo había postrado en la cama, con la consiguiente necesidad de cuidadores que le proveyesen alimento, medicamentos, lectura, aseo, etc., la concepción de la dependencia como una situación que debe evitarse nos lleva a interpretar la declaración de este autor como una excepción. Así, Séneca el Viejo (Contr. 7.4) hace referencia a una vetula ciega que trataba de impedir que su hijo saliese de viaje, ya que no podía valerse sola, y Marcial (9.80) presenta a una anciana incapaz de alimentarse por sí misma. La imposibilidad de comer de forma autónoma aparece referida también en Juvenal (10. 230), y Luciano (Dial. Mort. 6) hace alusión a un anciano ciego de 90 años que debía ser llevado a todas partes por sus esclavos. A estas situaciones de dependencia prolongadas deben añadirse otras temporales debidas a enfermedades pasajeras y a la recuperación de caídas o accidentes cardiovasculares, así como los momentos de agonía más o menos prolongada previos al fallecimiento.

Por otro lado, debemos incluir en este apartado dedicado a la medicina las consecuencias que los abusos tendrían en la población anciana de Roma. En la actualidad, se calcula que entre el 2 y el $10 \%$ de los ancianos del mundo sufre abusos,

\footnotetext{
${ }^{136}$ Insulsissimus est homo, nec sapit pueri instar bimuli tremula patris dormientis in ulna. Cui cum sit viridissimo nupta flore puella et puella tenellulo delicatior haedo, adservanda nigerrimis diligentius uuis, ludere hanc sinit ut lubet, nec pili facit uni, nec se subleuat ex sua parte, sed velut alnus in fossa Liguri iacet suppernata securi, tantundem omnia sentiens quam si nulla sit usquam; talis iste meus stupor nil videt, nihil audit, ipse qui sit, utrum sit an non sit, id quoque nescit.
} 
los cuales son físicos al menos en el $25 \%$ de los casos; además, las mujeres tienen casi el doble de posibilidades de sufrir abusos en la vejez que los hombres (Gowland, 2017b: 72-75). Las vetulae podían ser maltratadas por sus maridos, por otros miembros de la familia, o por sus patronos/amos (Lucil. 7.196 y 9.256-258; Plaut. Aul. 43). Además, sus condiciones físicas las harían especialmente vulnerables a los ladrones y otros delincuentes.

En la Antigüedad, al maltrato que podían sufrir las personas ancianas en el ámbito doméstico se une la constante violencia física que sufriría la población esclava, la cual se produciría también en su vejez y provocaría lesiones graves, amputaciones y dolores crónicos (Bradley, 2000: 111; López Barja de Quiroga, 2007). Así, por ejemplo, Augusto mandó romper las piernas a su secretario Talo (Suet. Aug. 67) y Vedio Polión quiso arrojar a un esclavo a las pirañas (Plin. NH 9.39; Sen. Clem. 1.18.2). Plauto incluye la violencia entre las actividades cotidianas de las esclavas: "Nosotros lo que necesitamos es una esclava que sepa tejer, moler, hacer leña, que hile su ración, barra la casa, reciba sus palos, que tenga a diario la comida a punto para toda la familia" (Plaut. Merc. 395-398) ${ }^{137}$. La esclava teatral Estáfila recibe una paliza de su dueño por el simple hecho de que éste no quiere que se entere de dónde guarda el oro: “¿Que por qué te pego, desgraciada? Pues para que lo seas de verdad y para que lleves una vejez tal como te la mereces, de mala que eres" (Plaut. Aul. 43) ${ }^{138}$. La domina de Escafa, otra esclava teatral, amenaza con matarla de hambre ante lo que considera que ha sido una impertinencia: “¡Soberano Júpiter, qué calamidad tiene asiento en mi propia casa! Mal rayo me parta, si no es que mato a esa vieja a fuerza de sed, de hambre y de frío!" (Plaut. Mostell. 191-193) ${ }^{139}$. Por su parte, Suetonio hace referencia a cómo los esclavos eran abandonados o asesinados en época de Claudio:

"En vista de que algunas personas, hartas de cuidar de sus esclavos enfermos y debilitados, los exponían en la isla de Esculapio, [Claudio] estableció que quedaran libres todos aquellos que fueran expuestos, y que no volvieran a caer bajo la autoridad de su dueño si sanaban; pero que si alguien prefería matar a uno de sus esclavos a exponerlo, incurriera en el delito de asesinato" (Suet. Claud. 25) ${ }^{140}$.

\footnotetext{
${ }^{137}$ Nihil opust nobis ancilla nisi quae texat, quae molat, lignum caedat, pensum faciat, aedis verrat, vapulet, quae habeat cottidianum familiae coctum cibum.

${ }^{138}$ Ut misera sis atque ut te dignam mala malam aetatem exigas.

${ }^{139}$ Pro Iuppiter, nam quod malum versatur meae domi illud? Di deaeque me omnes pessumis exemplis interficiant, nisi ego illam anum interfecero siti fameque atque algu.

${ }^{140}$ Cum quidam aegra et adfecta mancipia in insulam Aesculapi taedio medendi exponerent, omnes qui exponerentur liberos esse sanxit, nec redire in dicionem domini, si convaluissent; quod si quis necare quem mallet quam exponere, caedis crimine teneri.
} 
Sabemos también de momentos en los que decisiones políticas llevan al asesinato indiscriminado de personas esclavizadas, entre las que pudieron estar vetulae y senes, a quienes probablemente se aplicó una violencia extrema (Tac. Hist. 3.34). A un nivel más cotidiano, la epigrafía muestra cómo en la actual Pozzuoli el encargado de los servicios funerarios proporcionaba, a cambio de cuatro sestercios, los medios necesarios para ejecutar a un esclavo o esclava $(A E 1971,88)$.

Por otro lado, a pesar de la excepción señalada en el apartado correspondiente a las representaciones artísticas, vetulae y senes no parecen haber sido un botín de guerra deseado, y serían objeto de todo tipo de violencia tras la victoria:

"Irrumpieron en la ciudad cuarenta mil hombres armados y un contingente de porteadores y vivanderos aún mayor y más corrompido a la hora del desenfreno y de la crueldad. Ni dignidad ni edad suponían una protección para evitar que se mezclaran las violaciones a los asesinatos y los asesinatos a las violaciones. A los ancianos proyectos y a las mujeres de edad avanzada, gente de poco valor como botín, los convertían en objeto de escarnio" (Tac. Hist. 3.33) ${ }^{141}$.

En el esqueleto, las marcas de abuso en ancianos presentan patrones similares a las del maltrato infantil: fracturas en cráneo, huesos faciales, dentadura, cuello, extremidades superiores y torso (Gowland, 2017b: 76). Se trata de evidencias que pueden confundirse con fracturas propias del desgaste óseo que conlleva la vejez, por lo que en estos casos resulta necesario buscar identificadores de traumas continuos que han ido sanando. En un estudio publicado en 2017, Rebecca Gowland identifica esqueletos de personas ancianas de época romana que presentan traumatismos ocurridos tanto ante como peri mortem. Algunas de las vetulae que esta autora incluye en su trabajo muestran fracturas sanadas de cúbito y radio, signos habituales de violencia continuada en ancianos. Destaca la marginalidad de algunos de estos enterramientos, así como tres esqueletos de vetulae que sufrieron una violencia extrema:

- La mujer 135 del yacimiento de Bourne, Lincolnshire, que presenta una fractura peri-mortem en el hueso frontal.

- La mujer 2265 del cementerio de Watersmeet, vetula que cabe la posibilidad de que fuera enterrada viva.

\footnotetext{
${ }^{141}$ Quadraginta armatorum milia inrupere, calonum lixarumque amplior numerus et in libidinem ac saevitiam corruptior. non dignitas, non aetas protegebat quo minus stupra caedibus, caedes stupris miscerentur. grandaevos senes, exacta aetate feminas, vilis ad praedam, in ludibrium trahebant.
} 
- La mujer 4255 del cementerio de The Mount, York, quien presenta fracturas que demuestran extrema violencia peri-mortem en clavícula y maxila, así como marcas de puñaladas.

$\mathrm{Al}$ estudio de esta autora pueden añadirse otros ejemplos arqueológicos, como un esqueleto femenino senil del siglo I d.C. encontrado en Valencia que presenta un traumatismo en el hueso frontal (García Prósper y Polo, 2003: 305), o una mujer sepultada entre los siglos I-III d.C. en Roma. El esqueleto de esta última presenta marcadores de actividades físicas pesadas continuadas y múltiples episodios traumáticos en el cráneo ocurridos en distintos momentos, a los que se añaden marcas de fracturas en mandíbula, brazos y clavículas, así como señales de múltiples partos (Minozzi et al., 2012: 274) (Fig. 8). El análisis de los restos óseos de esta vetula ha llevado a los investigadores a señalar que las evidencias de "multiple traumatic events in the skeleton of this old woman reveal living conditions characterized by numerous episodes of violence, hypothesizing that the individual may have been the victim of repeated illtreatment during the course of her life" (Minozzi et al., 2012: 274), lo que junto a la simplicidad de su enterramiento hace suponer que se trataba de una esclava.

Si bien los ejemplos que hemos señalado son pocos, y no podemos extraer de ellos suposiciones generalizadas acerca de las condiciones de vida de las vetulae, sirven para ilustrar la violencia a la que en ocasiones serían sometidas. De esta forma, queda abierto un nuevo objeto de estudio, en el que deben integrarse tanto los restos óseos como las fuentes escritas e iconográficas. Por otro lado, la consideración de muchos de estos enterramientos como pertenecientes a ancianas esclavas o de clase no propietaria respalda la teoría planteada por Serena Witzke (2016) según la cual, a pesar de que la cultura de la violencia contra las mujeres se encontraba onmipresente en la sociedad romana, la posibilidad de sufrir violencia física era mucho menor en el caso de las mujeres de la élite.

Finalmente, cabe destacar cómo además del género, en lo concerniente al presente apartado resulta de gran relevancia también el estatus de las vetulae. Si bien el envejecer era un proceso común a todas las ancianas romanas, no era vivido de la misma forma por todas ellas. Algunas vetulae podrían permitirse servicios médicos y costearse medicamentos que sanasen, o al menos aliviasen, las patologías que padecían, mientras que otras tendrían que recurrir a los remedios caseros. De la misma forma, es de esperar que las condiciones físicas de una vetula que había dedicado su vida a trabajar en el 
campo no fueran las mismas que las de una de familia senatorial, que podía delegar hasta las tareas más cotidianas en el personal esclavo. Por otro lado, como demuestra el registro arqueológico, el cual podemos complementar con las fuentes literarias, las ancianas más vulnerables a la violencia reiterada eran usualmente aquellas de baja extracción social.

Una vez afectadas por una patología incapaciante o convertidas en personas dependientes, la perspectiva de futuro tampoco era la misma para todas las vetulae, como ya hemos señalado y como volveremos a concretar en el Capítulo IV. Una anciana rica podía permitirse ser llevada de un lado a otro en litera y tendría a su disposición a personas que podían hacer por ella cualquier tarea, desde ayudar con la higiene personal hasta ir al mercado. Incluso padeciendo una situación extrema, como en el caso ya referido de Domicio Tulo (Plin. Ep. 8.18), podrían mantener una posición relativamente confortable, mientras que las ancianas esclavas quedarían a merced de las decisiones y la compasión de quienes las poseían y las vetulae libres pobres dependerían de los medios económicos de su familia y los lazos de afectividad que tuvieran con la misma.

\section{III.3. ASPECTO FÍSICO}

La vejez modifica el cuerpo de las personas de dos maneras fundamentales. La primera de ellas, como acabamos de ver, son las patologías y condiciones médicas derivadas de la aceleración del ritmo del envejecimiento físico a partir de los 50 años, así como de las situaciones de abuso que viven algunas personas, especialmente marcadas en el caso de la población esclava de Roma. La segunda de las modificaciones, que también tiene relación con el proceso de envejecimiento biológico y en ocasiones es consecuencia directa de algunas de las patologías mencionadas, es el aspecto físico. Este segundo factor cobra especial relevancia si tenemos en cuenta el carácter eminentemente social de la vejez como etapa vital y la importancia que lo visual tiene en este contexto. Así, como señala Susan Bordo,

"The body -what we eat, how we dress, the daily rituals through which we attend to the body- is a medium of culture (...) is a powerful symbolic form, a surface on which the central rules, hierarchies, and even metaphysical commitments of a culture are inscribed and thus reinforced through the concrete language of the body" (Bordo, 1995: 165). 
En el caso de las vetulae, se añade además la importancia que las sociedades patriarcales dan al cuerpo de la mujer como objeto de disfrute masculino. Como señala Elizabeth Grosz,

"Patriarchal oppression (...) justifies itself, at least in part, by connecting women much more closely than men to the body. (...) Relying on essentialism, naturalism and biologism, misogynist thought confines women to the biological requirements of reproduction on the assumption that (...) women are somehow more biological, more corporeal, and more natural than men" (Grosz, 1994: 14).

En este sentido, la antigua Roma no era una excepción. Las referencias al cuerpo femenino abundan en la literatura y giran en torno a diversos temas: castidad (Ov. Am. 2.5; Plaut. Amph. 840; Sen. Ep. 9.88), sexo (Catull. 68b.70-72; Ov. Am. 1.5.9-25), lujo (Liv. 34; Mart. 8.68.7), procreación (Hippoc. Mul. y Nat. Mul.; Plin. NH 7.13; Sor. Gyn.)... Como señala Ovidio (Medic. 1 y 55), el cuidado del cuerpo era esencial para la mujer, de forma que alcanzase un ideal de belleza de piel suave y pálida, sin manchas, ni vello, ni arrugas ${ }^{142}$.

No obstante, todas las características descritas aluden al cuerpo de la mujer que se encuentra en sus años fértiles y que por lo tanto es de importancia para el Estado. En el momento en el que la menopausia marcaba el final del ciclo reproductor de la romana, su cuerpo se convertía en objeto de poco interés. Es por ello que, como veremos en este apartado y en el siguiente, la mayoría de las referencias que los autores clásicos hacen al cuerpo de la vetula se enmarcan en situaciones donde las ancianas ocupan roles asociados a mujeres jóvenes y fértiles, como la prostituta que se niega a reconocer que sus años de trabajo han pasado o la matrona que trata de seducir a hombres jóvenes a cambio de regalos. Se trata, por lo tanto, de episodios en los que se pretende resaltar lo ofensivo de las conductas de sus protagonistas, impropias para su edad.

De este modo, el cuerpo se convierte en un asunto central en el caso de las ancianas, ya que es al mismo tiempo invisible, rechazado por los hombres por estar alejado de la imagen ideal de feminidad, e hipersensible, ya que es una de las características principales por las que definimos la vejez y además una de las que más repulsión nos provoca (Twigg, 2004: 62). Se trata por otro lado de una situación que puede afectar de forma drástica a la percepción que de sí mismas y de la vejez tienen las mujeres, ya que "the stigma associated with aging may be internalized by older women

\footnotetext{
${ }^{142}$ Para una reflexión sobre el concepto de belleza en Roma, vid. Beltrani, 2016 y Olson, 2008: 58.
} 
and experienced as a profound sense of shame and aversion towards their own and other older women's bodies" (Hurd, 1999: 422).

En el caso de las vetulae, intentar evitar el rechazo de la sociedad hacia sus cuerpos las llevaría a emplear productos protésicos y cosméticos que alterasen su aspecto, así como a ocultar su edad real para parecer más jóvenes y por lo tanto atractivas, tal y como hemos señalado en el capítulo anterior.

\section{III.3.1.Representaciones artísticas de la vetula}

A pesar de que la vejez está presente en la literatura clásica desde Homero, no es hasta el siglo V a.C. cuando tenemos noticia de su aparición en el arte (Dimartino, 2008: 69). En el arte romano abundan ejemplos de vetulae, los cuales son la expresión gráfica de la doble visión que parece haber existido en la antigua Roma sobre la vejez femenina, y sobre la vejez en general, a la cual hacemos alusión en varias ocasiones a lo largo de la presente Tesis Doctoral. En el caso de la estatuaria, la procedencia de este tipo de representaciones ha sido objeto de debate, ya que si bien tradicionalmente se alude a estas estatuas como copias romanas de originales helenísticos (Cano, 2012: 295; Parkin, 2003: 86), otros estudios (Pollard, 2008; Sande, 1995: 35 y ss.; Waldhauer, 1946: 241) apuntan a que muchas de ellas presentan características típicamente romanas, y que puede además rastrearse su evolución cronológica:

"Reasonably realistic-looking female portraiture originated later than the male one. In the earlier examples, from around the middle of the $1^{\text {st }}$ century B.C., signs of age are alluded to with great discretion. A little later, in the $3^{\text {rd }}$ quarter of the same century, age is indicated not as much through wrinkles as through a stretching of the skin across the bone structure of the face, which gives the women the look of unfortunate victims of repeated face-lifts. It is only in the Augustan period that more harmonious renderings of old women appear, showing an interplay between taut and slack portions of the skin without going to extremes" (Sande, 1995: 4243).

En cuanto a la tipología de las representaciones artísticas de la vetula, si bien en todas las obras se resaltan las arrugas, la delgadez, la falta de dientes y la flacidez de la piel como características inherentes a las ancianas, podemos distinguir tres grupos de piezas. Por un lado nos encontramos con representaciones, tanto bustos como relieves y retratos funerarios, que cronológicamente abarcan toda nuestra época de estudio, en las que las vetulae se caracterizan por la gravitas, mostrando una expresión de severidad y 
sobriedad que encajaría con la rectitud moral que se les atribuía y la posición de respeto que ocupaban dentro de la familia, aspectos a los que haremos referencia en el Capítulo IV (Figs. 9-14). En estos casos, estas mujeres pueden interpretarse como personificaciones de las virtudes que toda mujer romana debía tener, las cuales han alcanzado la perfección en la vejez (Matheson, 2000: 129). En este sentido, las estatuas de vetulae tendrían la misma funcionalidad que Natalie Boymel atribuye a todas las imágenes de mujeres de época romana:

“women's images were used on public historical reliefs because they were uniquely recognizable signs of the private world. Set into a public context and noticeable precisely because of their rarity, women's images carried special meaning about the ideal and idealized relationship between public and private, and they appeared during three periods in which that relationship was of primary concern to the Roman ruling class: the time of Augustus, (...) of the Antonine emperors, and of Septimius Severus. Women's images in these periods helped to define the nature of the Roman social and political universe" (Boymel, 1991: 219).

No obstante, al mismo tiempo que representan rasgos universales del estereotipo de vejez están individualizadas, retratando a mujeres concretas. El principal problema existente a la hora de analizar este tipo de iconografía es que aunque contamos con evidencias de retratos de mujeres maduras/ancianas, no se preserva la edad de las mismas, por lo que ésta debe inferirse de sus rasgos físicos (Matheson, 2000: 126). Ello implica que en ocasiones dejaremos fuera de nuestra investigación a vetulae que no son representadas con los rasgos característicos de la vejez, complicando el análisis sobre la percepción propia y social de la vejez femenina. Dos casos que sí podemos reseñar son los de Livia y su nuera Antonia Minor, quienes siguen representándose como adultas jóvenes a pesar de haber alcanzado las ocho y siete décadas de existencia respectivamente. Como señala Elizabeth Bartman (1999: 117), para el caso de Livia las únicas excepciones las encontramos un camafeo de época de Tibero en el que aparece como una mujer madura, aunque no como una vetula, y un busto encontrado en Ampurias en el que son visibles la piel flácida de las mejillas y el hundimiento nasolabial debido a la falta de piezas dentales (Fig. 15-16). A principios del siglo XX Katharine Esdaile (1914) añadía la posibilidad de una tercera pieza, tradicionalmente identificada con Agripina. En cuanto a Antonia, contamos con un busto realizado durante el gobierno de Calígula en el que se la representa con las mejillas hundidas y la 
piel del rostro flácida, pero que sin duda no corresponde con el aspecto que debía tener por aquel entonces, con más de 70 años (Kokkinos, 1992: 128) (Fig. 17).

Las figuras de Livia y Antonia se contraponen a la de otras mujeres de la misma época que deciden representarse como vetulae. Ocurre así por ejemplo con el relieve funerario de Antistia Plutia (CIL 6.2170) y una estatua localizada en Palombara Sabina (Fig. 18). Tal y como señalan Mary Harlow y Ray Laurence (2017) para el caso de Augusto, el que Livia no aparezca retratada como una anciana se debe a que sus imágenes reflejan su utilidad para con el estado romano, en cuanto que mujer fértil y matrona que educa a su descendencia. La vejez acaba con esa utilidad, y por lo tanto no parece digna de ser representada como virtud pública. En cuanto a Antonia, Nikos Kokkinos (1992: 128) apunta a la posibilidad de que siga representándose como una mujer joven para emparejarla con las figuras de su esposo Druso, fallecido con 29 años, si bien también podría aplicársele la misma explicación que a las estatuas de Livia. Y es que, como escribe María José Hidalgo, en la dinastía Julio-Claudia las representaciones de las mujeres imperiales

"adquieren unos rasgos idealizados propios del mos maiorum, con las virtudes de la matrona romana y asimilándose en sus funciones a las diosas del panteón grecoromano, con el objetivo de difundir la imagen de una mujer, esposa o madre romana ligada al ámbito familiar y a la procreación, que actuaría en el imaginario colectivo y serviría de cohesión ideológica a nivel social y territorial" (Hidalgo 2012: 55).

En contraposición a las representaciones ya mencionadas, contamos con otro grupo en el que las vetulae adquieren un carácter grotesco. Dentro de este grupo se encuadran las máscaras de teatro que representan a ancianas, y que han quedado plasmadas en mosaicos y joyería (Fig. 19-21). Según Julio Pólux (4.133-164 apud Fuchs, 2008: n. 8, 9 y 12), retórico de finales del siglo II d.C., existían siete tipos de máscaras teatrales que representaban a ancianas, tres usadas para la comedia y cuatro para la tragedia:

- Vieja delgada con arrugas finas y numerosas, blanca, pálida y vista de perfil, que representa el papel de la lena.

- Vieja gorda con grandes arrugas debidas al sobrepeso, con un cordón alrededor del pelo. 
- Vieja esclava guardiana de la casa, con la nariz respingona y dos dientes en cada mandíbula.

- Vieja de largo y lánguido pelo blanco, un poco pálida, que sobrepasa a todos en edad y dignidad.

- Mujer libre, algo madura, de corpulencia media, rubia y con axilas velludas, lo que es signo de mala suerte y/o de maldad.

- Esclava madura encargada de los trabajos domésticos, de piel flácida.

- Vieja esclava encargada de las tareas domésticas, muy pálida y con el pelo totalmente blanco envuelto en un tocado de piel de oveja.

Además de las máscaras de teatro, que representan diversos personajes fácilmente reconocibles por el público como el de la prostituta envejecida, la suegra o la lena, pertenecen a esta categoría de representaciones grotescas esculturas de vetulae que ejemplifican el estereotipo de anus ebria, el cual trataremos con profundidad en el Capítulo IV, en las que se resalta la fealdad de la mujer y la desesperación de la vejez como etapa vital indeseable. Inciden en ellas las arrugas, la falta de piezas dentales y la flacidez de la piel. En ocasiones insinúan o muestran uno de sus pechos, y se cubren la cabeza con un pañuelo sencillo. Se trata de esculturas de mármol o caliza en las que una vetula sedente y con las piernas cruzadas, con marcadas arrugas en labios, torso y extremidades superiores, así como señales de falta de piezas dentales, abraza un lagynos o recipiente cerámico destinado a contener vino. Su rostro muestra una expresión que podría interpretarse como fruto, bien de los efectos del vino, bien de la situación de desesperación que conlleva una vejez penosa. Ejemplares de estas estatuas tipo anus ebria se encuentran en el Museo Capitolino (Fig. 22), la Glyptoteca de Múnich (Fig. 23) y Córdoba, entre otros lugares, y han sido datadas entre los siglos II a.C. y II d.C. (Serrano y Baena, 1982: 146).

En cuanto a su interpretación, ciertos autores (Cano, 2012: 296; Serrano y Baena, 1982: 146) piensan que este tipo de estatuas no muestran escenas reales, sino que se trata de representaciones de la crueldad romana, caricaturas del estereotipo de anciana a la que asolan los males y cuyo único consuelo es el vino: "Es la burla, el escarnio, el desprecio, lo que se ve claramente en ellas. Tal vez sea la triste satisfacción de ver en estas obras a la joven bella y orgullosa que, con el tiempo, acaba siendo una triste vieja borracha, tirada en la calle" (Cano, 2012: 297). Por su parte, para Siri Sande (1995: 44) estarían relacionadas con Baco y tendrían por lo tanto connotaciones religiosas, idea que 
sustenta no sólo en el vino como elemento común, sino también en las hiedras que ya hemos mencionado. Esta teoría es apoyada por Elizabeth Pollard (2008: 139-140), quien no obstante sugiere también que podría tratarse de representaciones de brujas realizando un hechizo.

El registro arqueológico nos ha permitido obtener versiones a pequeña escala de estas obras, las cuales además cuentan con la particularidad de tener forma de botella. Se trata de piezas de procedencia oriental y africana que comenzarían a fabricarse en el siglo IV a.C. en la zona de Cnido, y de las cuales tenemos ejemplares de los siglos II-III d.C. en España (Bernal, 1995; Quevedo, 2010: 45) (Fig. 24-26). Otras piezas se conservan en Boston, Ontario y Pérgamo, entre otros lugares. En Alemania se encontró además un molde que fue empleado para su fabricación, aunque se perdió durante la II Guerra Mundial y actualmente sólo conservamos dibujos (Quevedo, 2010: 46-47).

Las botellas están hechas en terracota, miden entre 10 y 25 centímetros de alto y reproducen las características de la estatuaria, si bien en este caso el rostro de la vetula se asemeja más a los rasgos de las máscaras teatrales que al realismo de piezas como la de Múnich. En alguna de estas terracotas nos encontramos también con velos, hiedra y la característica boca entreabierta; no obstante, si en el caso de las estatuas la vetula parece estar sentada en el suelo, en las botellas lo hace sobre una silla. A pesar de que se piensa que estas botellas eran productos de lujo, dado el alto coste de transporte desde centros productivos como el de Cnido y que han sido encontradas en viviendas lujosas como es el caso de la pieza de Cartagena, hallada en la domus de la Fortuna-, las pastas con las que se fabricaron son rudas, y el tratamiento de los pliegues de la ropa y de los rasgos faciales no es siempre cuidadoso (Quevedo, 2010: 46).

La funcionalidad de estas piezas de anus ebria no está clara, aunque todos los expertos se mueven entre el vino o los aceites/ungüentos como productos que contendrían (Quevedo, 2010: 48). La teoría del vino se vería reforzada por la iconografía. No obstante, si como sugiere Elizabeth Pollard para las estatuas, las terracotas representan a brujas, la conexión de éstas y de las ancianas romanas en general con las pociones, los filtros amorosos y las preparaciones medicinales podría servir como apoyo a su funcionalidad como contenedores de ungüentos y otros productos medicinales o cosméticos. Un análisis de contenido realizado a la botella encontrada en Valencia dio como resultado que su interior estuvo revestido con un impermeabilizante a base de resina pinácea, lo que ha llevado a sugerir que contuvo un 
aceite de origen vegetal, aunque no puede saberse qué tipo de aceite era o si fue el único líquido para el que se usó la pieza (Roldán et al., 2007: 248-249).

Una variante de las estatuas del tipo anus ebria la suponen las de la vieja del mercado. Se trata de piezas en las que la vetula, en quien como en los ejemplos anteriores se exageran los rasgos físicos de la vejez, porta una cesta (Fig. 27-29). Tanto en este caso como en el de la anus ebria, el hincapié que el autor ha puesto en representar rasgos como la flacidez de los senos o las arrugas del rostro no se interpretan aquí como signos de gravitas, sino que parecen haber sido realizadas para recalcar la marginalidad de la anciana. Deben incluirse aquí también piezas que por su postura o por estar incompletas no podemos adscribir claramente a un tipo u otro, pero que también muestran exageración de rasgos físicos y gesto desesperado (Fig. 30-32).

Además de estas esculturas de gran tamaño, existen otras más pequeñas que parecen deleitarse en mostrar con rigurosidad el cuerpo semidesnudo de la vetula (Fig. 33). Un ejemplo literario que nos habla de la existencia de estas piezas de arte y que además puede ilustrarnos sobre su funcionalidad nos lo presenta Plinio el Joven:

"Gayo Plinio a Anio Severo,

Con el dinero que he recibido de una herencia, me acabo de comprar una estatua de bronce corintio, pequeña pero encantadora y bien terminada, al menos según puedo juzgar yo, que tengo en todas las materias en general, y en ésta en particular un conocimiento limitado. Sin embargo, esta estatua creo que puedo apreciarla. Se trata de una figura desnuda, que no puede ocultar sus defectos, si es que hay algunos, ni disimular sus virtudes. Representa un anciano de pie, sus huesos, tendones, nervios, venas, arrugas, se ven como si se tratase de un ser vivo; los cabellos escasos y en retirada, la frente ancha, el rostro anguloso, el cuello delgado; los músculos flácidos, el pecho caído, el vientre hundido; por la espalda, según se puede deducir, aparenta la misma edad" (Plin. Ep. 3.6.1-3) ${ }^{143}$.

A pesar de que la traducción del texto clásico que hemos empleado aquí haga referencia a un anciano, existen dudas al respecto del sexo de la estatuilla. Para Saara Lilja (1978: 60), el que Plinio emplee las palabras "senem stantem", que pueden aplicarse tanto a hombres como a mujeres, y que se refiera a los pechos como

\footnotetext{
${ }^{143}$ Ex hereditate quae mihi obvenit, emi proxime Corinthium signum, modicum quidem sed festivum et expressum, quantum ego sapio, qui fortasse in omni re, in hac certe perquam exiguum sapio: hoc tamen signum ego quoque intellego. Est enim nudum, nec aut vitia si qua sunt celat, aut laudes parum ostentat. Effingit senem stantem; ossa musculi nervi, venae rugae etiam ut spirantis apparent; rari et cedentes capilli, lata frons, contracta facies, exile collum; pendent lacerti, papillae iacent, venter recessit; a tergo quoque eadem aetas ut a tergo.
} 
"papillae", palabra que se usa para aludir a los senos flácidos de las mujeres, son datos que indican que lo que Plinio adquirió fue la imagen de una vetula. En cuanto a la escasez de cabello, a pesar de ser una característica típica del senex, también podía darse en las ancianas. Esta teoría la postula también Adrian Sherwin-White (1966: 226), para quien esta estatua sería una más del tipo vetula que habría tenido su origen en el siglo I a.C.

El tercer grupo estaría compuesto por el resto de las representaciones de vetulae. Se trata de piezas que no parecen retratos personalizados pero que tampoco tienen intencionalidad grotesca. Es el caso de un sarcófago datado en el siglo II d.C. en el que se ha esculpido una escena de victoria bélica (Fig. 34). En la parte frontal del mismo, entre hombres capturados como botín de guerra, se encuentra una anciana que parece proteger a un niño de un soldado romano que desea llevárselo. Se cubre la cabeza con un pañuelo que ya hemos visto que es característico de otras representaciones de vetulae, y lleva al descubierto el pecho derecho. A pesar de que, como hemos señalado, las ancianas no solían ser parte del botín de guerra, esta excepción parece haber sido hecha para despertar la compasión y/o la ternura de quien contemplase la escena o bien, como apunta Carla Rubiera (2014: 113), para simbolizar la decadencia y la decrepitud del pueblo vencido. Otro sarcófago, en este caso del siglo III d.C., muestra a una anciana junto a un hombre y una mujer joven (Fig. 35). Finalmente, queremos hacer referencia a una pieza de terracota, datada entre el siglo I a.C. y el siglo I d.C., que representa a una vetula tocando la flauta, muestra de los trabajos realizados por las ancianas romanas (Fig. 36).

Podríamos pensar que las representaciones del segundo tipo horrorizarían al espectador romano y se convertirían en parte de colecciones de personas con gusto por lo grotesco. Ésta es, de hecho, una de las interpretaciones más comunes acerca del significado de este tipo de obras de arte, la de que su funcionalidad es resaltar la alteridad de las ancianas mediante la burla y la sobreexposición de los rasgos de la vejez (Cano, 2012: 297; Mitchell, 2013: 283; Quevedo, 2010: 45; Serrano, 1982: 146). No obstante, en un fragmento posterior de su carta a Anio Severo, Plinio escribe que ha decidido regalar la estatua al templo de Júpiter, ya que le "parece que es un regalo digno 
de un templo y de un dios" (Plin. Ep. 3.6.5) ${ }^{144}$. Las palabras de Plinio pueden interpretarse como una referencia personal, que sólo él y Severo podían comprender, o también podemos pensar que las figuras que representan a vetulae cuyo cuerpo desnudo muestra con crudeza los efectos de la vejez podían tener en Roma un significado religioso.

Podemos rastrear paralelos sobre la relación entre viejas desnudas y creencias religiosas en la antigua Grecia, concretamente en el personaje de Baubo, anciana con la que se topa Demeter mientras vaga buscando a Perséfone (Arn. Adv. nat. 5.25-26; Clem. Al. Propt. 2.20). En el mito, Baubo levanta su falda y muestra sus genitales a la diosa, en un gesto llamado anasyrma ( $\dot{\alpha} v \hat{\alpha} \sigma v \rho \mu \alpha)$ que, dependiendo de la versión que leamos, tiene el fin de divertirla o de mostrar su descontento porque la divinidad ha rechazado la bebida que la vieja le ofrecía. Las representaciones de Baubo que evocan este mito han dado nombre a una tipología artística concreta y son de tres tipos principales: figuras en las que la cara se encuentra directamente sobre las piernas, figuras en las que una mujer se retira delicadamente la falda para dejar entrever el pubis, y figuras en las que una anciana de expresión burlona y agresiva levanta su falda dejando expuesta la vulva entera (Olender, 1985; Suter, 2015). La desnudez de estas imágenes se relaciona con descubrir aquello que está escondido/cubierto, la curación, la fertilidad y la protección, así como con experiencias de liberación, intimidad y transmisión de conocimientos entre mujeres, al enseñar una anciana a otras mujeres lo que de ordinario permanece oculto, es decir sus conocimientos (Ormand, 2015; Valdés, 2015). Se trata además de enseñanzas femeninas que generan la desconfianza de los hombres, ya que pueden resultar preligrosas para ellos, mientras que para las mujeres es sobre todo un momento de diversión y recocijo en compañía de otras féminas (Valdés, 2015: 25). De esta forma, las piezas como la mencionada por Plinio pueden tener un significado parecido a las representaciones de Baubo, las cuales además llegan hasta época romana (Michaelides, 2004: 307). En esta línea, se ha identificado a estas vetulae como devotas de Dioniso (Dimartino, 2008: 69; Sande, 1995: 44).

Algunos autores (Michaelides, 2004: 309; Pollard, 2008: 153; Wace, 1904), considerando también un significado religioso-supersticioso, atribuyen a las reprentaciones una funcionalidad protectora. Las comparan a otras piezas de naturaleza

\footnotetext{
144 videtur enim dignum templo dignum deo donum.
} 
obscena, como el fascinus, sugiriendo una función de amuleto contra el mal de ojo y diversos seres malignos.

Elizabeth Pollard (2008) cree que las obras de características grotescas son representaciones de la bruja de la Antigüedad, figura que abordaremos en el Capítulo IV. Se basa en que, a pesar de que a estas estatuas les falta un atributo significativo de las brujas literarias, el pelo alborotado, muestran el resto de características de personajes como Canidia y Meroe: "If she looks like a witch, drinks like a witch, corrupts young women like a witch, and enviously stares like a witch, can we not conclude that she may well have been a witch, at least in the minds of the contemporary viewers?" (Pollard, 2008: 155). Así, estatuas como las ya aludidas no representarían a vetulae que vuelven del mercado, sino que el autor habría querido representar a una maga que porta en la cesta los ingredientes necesarios para realizar sus pociones (Pollard, 2008: 139-140).

Para Mary Harlow y Ray Laurence (2011:12) y Marcela Nasta (2011: 245), la existencia de los dos tipos diferenciados de imágenes artísticas de la vejez femenina a los que hemos aludido se basa en el estatus de la persona representada. Las esculturas que resaltan los rasgos negativos encarnarían a mujeres de baja extracción social, mientras que las caracterizadas por la gravitas mostrarían a vetulae de la élite. Por el contrario, Amy Richlin (1992: 110 y ss.) resalta los elementos de prestigio que portan algunas de estas mujeres, tanto las descritas por la literatura como las representadas escultóricamente, y las identifica con féminas pudientes. De hecho, exhibir demasiado lujo era considerado síntoma de vulgaridad y soberbia, la cual afecta especialmente a las mujeres ricas (Juv. 6.300 y ss; Sen. Ben. 7.9.4; Val. Max. 9.1.3). Esta teoría del vestuario lujoso la apoya Siri Sande, para quien las estatuas que muestran escenas cotidianas, así como las de tipo anus ebria, representan a mujeres no de las clases populares sino de la élite, señalando además que

"this lack of dignity combined with high social status and old age are deliberate, and that an important point in the rendering of the "old hags" is the paradox that there were women, who ought to be models for good female conduct have turned into the very opposite" (Sande, 1995: 45).

De esta forma, las obras en las que una vetula vestida de forma lujosa aparece cometiendo actos de impudicitia serían según esta teoría exempla que ofrecerían a las romanas modelos de conducta que no debían seguir. No obstante, debemos tener en cuenta que en ocasiones incluso las esclavas lucían joyas para indicar la riqueza de sus 
amos, y que no resulta infrecuente la alusión a mujeres de condición humilde que llevan brazalates de plata y collares de oro, invirtiendo todo su dinero en aparentar un patrimonio que realmente no poseen (Juv. 6.350 y ss.; Plaut. Men. 9.18; Sen. Dial. 9.1.8; Olson, 2008: 43 y ss.).

Una diferencia, a nuestro juicio destacable, que sí parece existir entre los dos tipos principales de estatuaria es que, mientras que las piezas que podríamos denominar "respetables", parecen haber sido encargadas por la propia vetula representada o por un familiar o persona cercana, aquellas obras que encarnan el estereotipo de vetula físicamente indeseable son una imagen idealizada e impersonal cuyo significado no tiene relación con la memoria individual y/o familiar. Mientras que las primeras habrían sido creadas para adornar las domus, no sabemos muy bien cuál era la funcionalidad de las segundas, si bien hemos señalado algunas posibilidades.

Por otro lado, si comparamos las representaciones iconográficas con la literatura, tal y como se hace a lo largo del presente capítulo y del siguiente, veremos cómo las obras de tipo grotesco podrían identificarse con las figuras de la bruja, la anus ebria o las mujeres que participan en el festival de Anna Perenna, al cual hacemos alusión el en Capítulo IV. Las obras del tipo anus ebria bien pueden ser una variante de las figuras de Baubo sedente, en las que la obscenidad no se muestra mediante el descubrimiento de los genitales sino a través del lagynos como símbolo de cómo el abuso del vino conduce a la impudicitia. En cuanto a los bustos de actitud serena y severa, podemos ver en ellos a algunas de las abuelas y madres de las que hablaremos más adelante. En este sentido, las primeras piezas podrían tener un significado religioso, apotropaico o simplemente denigratorio, mientras que las segundas podían suponer un ejemplo de recta moral a seguir para quienes las contemplasen, formando parte de la memoria familiar.

No obstante, ninguna de todas las teorías propuestas ha podido demostrarse, por lo que este tipo de representaciones necesitan de un análisis en profundidad que tenga en cuenta diversas variables que condicionaban las estatuas de ancianas de época romana, como el público al que estaban destinadas, quiénes las encargaban, quiénes las realizaban, o qué grado de control tenían las mujeres que aparecen representadas sobre la forma en la que eran esculpidas (Boehringer y Sebillotte, 2015: 101; Matheson, 2000: 129; Wood, 2001: 22). 


\section{III.3.2.EI aspecto físico de la vetula en la literatura}

En cuanto a la literatura, las referencias al aspecto físico de la vetula están en línea con las piezas de arte que resaltan lo grotesco. Las arrugas, la flacidez de la piel, o la falta de piezas dentales, características que, en cuanto que son representadas en las obras escultóricas individualizadas, podemos pensar que no resultaban del desagrado de quienes las pagaron, parecen horrorizar a los escritores de la época. Así, para Ovidio son un mal del que lamentarse: "El paso del tiempo arruinará vuestra belleza, y vuestra cara atractiva se verá surcada de arrugas. Tiempo vendrá en que al miraros al espejo sentiréis pesar, y la misma pesadumbre será otra causa más de arrugas" (Ov. Medic. $45)^{145}$. Este mismo autor (Ov. Pont. 3.1.117 y 3.1.145), dice de Livia que tiene la hermosura de Venus cuando cuenta con cerca de 70 años, si bien parece más un intento de adularla que una opinión real. Juvenal advierte al esposo sobre lo que puede esperar con una mujer envejecida:

“¿Y por qué Sertorio arde en deseos de Bíbula? Si escrutas la verdad, se ha enamorado del rostro, no de la esposa. Pero que se le marquen tres arrugas y que se le torne flácido el cutis reseco, que los dientes se le ennegrezcan y que los ojos se le achiquen; un liberto le espetará: «Recoge tus bártulos y lárgate. No molestas, no haces más que sonrojarte. ¡Fuera de ahí! ¡Aprisa! Ya viene otra con la nariz enjuta»" (Juv.6.143-148) ${ }^{146}$.

Por su parte, la esclava plautina Escafa aconseja a una mujer más joven que tenga cuidado con los hombres, ya que se olvidarán de ella cuando le llegue la vejez:

"Ves lo que soy yo ahora y lo que fui antes; no he sido yo menos amada que tú; también yo tenía sólo un único amor; y después que la edad cambió el color de mis cabellos, me dejó y me abandonó. Lo mismo te va a pasar a ti” (Plaut. Mostell. $200-203)^{147}$.

La característica física más asociada con la vejez son las arrugas, las cuales podían aparecer en la frente, la cara, el cuello, el vientre, o las extremidades (Cic. Sen. 18.62; Hor. Carm. 2.12.1 y Epod. 8 y 12; Juv. 10-191-198; Mart. 3.42 y 3.93; Ov. Am.

\footnotetext{
${ }^{145}$ Certus amor morum est: formam populabitur aetas, et placitus rugis vultus aratus erit. Tempus erit, quo vos speculum vidisse pigebit, et veniet rugis altera causa dolor.

${ }^{146}$ Cur desiderio Bibulae Sertorius ardet? Si uerum excutias, facies non uxor amatur. Tres rugae subeant et se cutis arida laxet, fiant obscuri dentes oculique minores, 'collige sarcinulas' dicet libertus 'et exi. Iam grauis es nobis et saepe emungeris. Exi ocius et propera. sicco uenit altera naso'. La nariz enjuta hace referencia a la acción continuada de sonarse como típica de la vejez y de la enfermedad.

${ }_{147}$ Vides quae sim; et quae fui ante. Nihilo ego quam nunc tu amata sum; atque uni modo gessi morem: qui pol me, ubi aetate hoc caput colorem commutavit, reliquit deseruitque me. Tibi idem futurum credo.
} 
1.8.45 y 1.8.110; Prop. 4.5.67). Existían diversos métodos para deshacerse de ellas, tales como la goma arábiga, la harina de cebaba, las raíces de lirio, la grasa de cisne, el aceite de almendras, el excremento de cocodrilo, el triturado de plomo, la pasta de hueso de buey blanco, o la leche de burra (Hippoc. Mul. 188; Hor. Epod. 12; Ov. Ars am. 3.269270 y Medic. 55, 67-68 y 70-79; Plin. NH 21.74, 23.42, 28.70 y 30.30). No obstante, Marcial recomendaba no emplear estos remedios de forma excesiva, ya que podían provocar el efecto contrario al deseado:

"Intentando ocultar las arrugas de tu vientre con ungüento de harina de habas, Pola, embadurnas tu vientre, no mis labios. Déjese sencillamente destapado un defecto, quizás pequeño; el defecto que se tapa, todos piensan que es mayor" (Mart. $3.42)^{148}$.

Además de a las arrugas, los autores clásicos hacen referencia a la sequedad de la piel, a las manchas faciales, a la flacidez -especialmente en el caso de los pechos- y a la delgadez corporal (Hippoc. Morb. 1.22; Hor. Epod. 8; Juv. 6.145 y 10.194; Mart. 3.93; Ov. Medic. 80-100).

Las canas son otro de los atributos físicos que se presentan como típicos de la vejez. Existían diferentes formas de deshacerse de ellas: teñirlas, aplicarse ungüentos, o arrancarlas (Mart. 14.27; Ov. Ars am. 2.666 y 3.164; Plin. NH 28.46 y 30.134; Prop. 3.25.13; Tib. 1.8.33-45). A este último método recurría Julia, la hija de Augusto, tratando de ocultar los cambios que el paso del tiempo habían provocado en ella:

"Julia había empezado muy pronto a tener canas, que solía arrancarse a escondidas. Un día se presentó de improviso su padre y sorprendió a sus peinadoras. Augusto fingió no haberse percatado de las canas sobre las ropas de estas mujeres, y dejando pasar un tiempo charlando de otros asuntos, trajo la conversación al tema de la edad, y preguntó a su hija si, pasados algunos años, preferiría tener canas o ser calva. Y como Julia respondiera; «Yo, padre, prefiero tener canas». Augusto le echó en cara su mentira con esta réplica: «¿Por qué, entonces, estas mujeres se dan tanta prisa en dejarte calva?»" (Macrob. Sat. 2.5.7) ${ }^{149}$.

\footnotetext{
${ }^{148}$ Lomento rugas uteri quod condere temptas, Polla, tibi uentrem, non mihi labra linis. Simpliciter pateat uitium fortasse pusillum: quod tegitur, maius creditur esse malum.

${ }^{149}$ Eadem Iulia mature habere coeperat canos, quos legere secrete solebat. Subitus interventus patris aliquando oppressit ornatrices. Dissimulavit Augustus deprehensis super vestem earum canis: et aliis sermonibus tempore extracto induxit aetatis mentionem, interrogavitque filiam, utrum post aliquot annos cana esse mallet an calva: et cum illa respondisset: Ego, pater, cana esse malo, sic illi mendacium obiecit: Quid ergo istae te calvam tam cito faciunt?
} 
En cuanto a este pasaje de Macrobio, destaca la edad que tiene Julia cuando acontecen estos hechos, 38 años, una edad que para el escritor (Macrob. Sat. 2.5.2) está próxima a la vejez, ilustrando así la convicción de que las mujeres envejecían más rápidamente que los hombres. En ocasiones, no obstante, las canas se presentan como síntoma de ancianidad venerable (Petron. Sat. 2.8; Plin. Pan. 4.7; Prop. 3.5.23).

Por otro lado, las fuentes literarias muestran que había un destino peor que un pelo canoso: la calvicie. Si bien, como ya hemos visto, Aristóteles (GA 3.11.518a) y Plinio ( $N H$ 11.47.131) señalan que la calvicie es típica de los hombres, éste último da cuenta de algunas excepciones: "se han encontrado, sin embargo, algunas mujeres afectadas por la pérdida del cabello, así como por la aparición de vello en el rostro, cuando cesa la menstruación" (Plin. $N H$ 11.94) ${ }^{150}$. Se refiere a la alopecia androgenética, que en la actualidad afecta al 50\% de las mujeres en algún punto de su vida, incidiendo especialmente tras la menopausia (Rivera y Guerra Tapia, 2008). Está asociada a los cambios hormonales que acontecen junto con la pérdida de la menstruación, los cuales provocan además la aparición de vello en la cara, tal y como comenta Plinio. A la calvicie femenina también hace referencia Hipócrates (Mul. 189), quien señala como remedios las heces de paloma, el láudano, el comino, el rábano, la cebolla y la acelga.

Los autores satíricos y poéticos ridiculizan a las vetulae con poco pelo (Mart. 12.6 y 12.32; Ov. Am. 1.8.110), especialmente a aquellas que trataban de disimular la alopecia con pelucas o diferentes peinados, pero sin conseguirlo (Hor. Sat. 1.8; Mart. $1.72 ; 10.83$ y 12.23$)$ :

“¿Por qué no te beso, Filenis? Estás calva. ¿Por qué no te beso, Filenis? Eres pelirroja. ¿Por qué no te beso, Filenis? Estás tuerta. El que besa todo esto, Filenis, es un mamón" (Mart. 2.33) ${ }^{151}$.

"La mujer que tenga una rala cabellera, ponga un guardián en su puerta o compóngasela siempre en el templo de la Buena Diosa. A una mujer se le avisó de repente que yo llegaba: ella azorada se puso al revés la peluca. Que les sobrevenga a nuestros enemigos tan desagradable motivo de vergüenza y caiga esa ignominia sobre las nueras de los partos. Vergonzoso es una res sin cuernos, vergonzoso un

\footnotetext{
150 inventae tamen quaedam defluvio capitis invalidae, ut et lanugine oris, cum menstrui cursus stetere. ${ }^{151}$ Cur non basio te, Philaeni? calua es. Cur non basio te, Philaeni? rufa es. Cur non basio te, Philaeni? lusca es. Haec qui basiat, o Philaeni, fellat.
} 
campo sin hierba, un arbusto sin hojas y una cabeza sin pelo" (Ov. Ars am. 3.243$250)^{152}$.

En las mujeres, la falta de pelo en la vejez se relaciona con la pérdida del erotismo (Myerowitz, 1995: 85). En la Antigüedad, el cabello de la mujer era un componente esencial de su belleza y una de las características más comunes a la hora de aludir a la feminidad; así, la cabellera suele emplearse como parte de los epítetos que caracterizan a diosas y otros seres mitológicos femeninos como las ninfas (Hes. Th. 625 y 634; Hom. Il. 6.92 y 10.5; Ov. Met. 2.235; Verg. Aen. 1.315). El cabello de la romana era uno de los principales determinantes de su atractivo físico; atado, al contrario que el de los hombres, simbolizaba el rol pasivo de la mujer (Bartman, 2001: 3). Además, los poetas romanos hacían referencia al cabello como parte sexualizada del cuerpo para evitar mencionar los genitales de forma explícita (Richlin, 1992: 45; Sebesta, 1997: 533). Por ello las romanas respetables solían llevar el pelo recogido y cubierto; mostrar en público la belleza destinada al disfrute del esposo podía traer funestas consecuencias:

"Rígida fue también la arrogancia de Cayo Sulpicio Galo en su calidad de marido.

Repudió a su mujer, porque se enteró de que se había mostrado fuera de casa con la cabeza descubierta. La sentencia era tajante, pero en cierta manera fundada en sólidas razones. En efecto, le dijo: «la ley hace que te limites a agradar únicamente a mis ojos para los que sólo debes realzar tu belleza; para ellos debes procurarte los objetos necesarios para tu arreglo personal, para ellos debes ser atractiva y, en fin, ellos deben ser los jueces de tu hermosura. Cualquier otra mirada que atraigas sobre ti, por una provocación incluso inocente, te hace necesariamente sospechosa y digna de atención»" (Val. Max. 6.3.10) ${ }^{153}$.

Por otro lado, si las vetulae perdían pelo en la cabeza, no ocurría lo mismo con el resto del cuerpo. Las ancianas romanas son caracterizadas como peludas en partes del cuerpo donde a las mujeres deseables no les crecía vello, como la nariz o la barbilla (Plin. NH 11.94.230; Priap. 12). También poseen abúndate vello en el pubis y las axilas, que las jóvenes se depilaban con resina, pasta de higos, cremas y pinzas para mostrar un aspecto aniñado y encajar en el ideal de belleza de los romanos (CIL

\footnotetext{
${ }^{152}$ Quae male crinita est, custodem in limine ponat, orneturve Bonae semper in aede deae. Dictus eram subito cuidam venisse puellae: turbida perversas induit illa comas. Hostibus eveniat tam foedi causa pudoris, inque nurus Parthas dedecus illud eat. Turpe pecus mutilum, turpis sine gramine campus, et sine fronde frutex, et sine crine caput.

${ }^{153}$ Horridum C. quoque Sulpicii Galli maritale supercilium: nam uxorem dimisit, quod eam capite aperto foris uersatam cognouerat, abscisa sententia, sed tamen aliqua ratione munita: 'lex enim' inquit 'tibi meos tantum praefinit oculos, quibus formam tuam adprobes. his decoris instrumenta conpara, his esto speciosa, horum te certiori crede notitiae. ulterior tui conspectus superuacua inritatione arcessitus in suspicione et crimine haereat necesse est'.
} 
6.37965; Mart. 3.74 y 9.37; Ov. Am. 1.7.51 y Ars am. 3.309 y 3.190-195; Plin. NH 14.123, 23.63 y 26.164; Prop. 2.22; Sen. Ep. 56.2) $)^{154}$.

Como ya hemos señalado en el anterior apartado, la falta de piezas dentales sería una patología común en las vetulae, la cual en ocasiones podía paliarse con el uso de postizos (Hor. Sat. 1.8; Mart. 1.72 y 12.32). Más allá de los problemas masticatorios que ello pudiera generar, la falta de dientes y la negrura de los mismos es empleada en la literatura para oponerse

"a un parámetro de belleza importante como lo era para los antiguos, tanto como hoy para nosotros, el cuidado, la conservación y blancura de los dientes; blancura que, en el caso de las mujeres, debía contrastar con el rojo de los labios, tanto como la palidez del rostro contrastaba con el rubor de las mejillas" (Nasta, 2011: 234).

El deterioro óseo propio de la vejez, así como la realización de determinadas tareas de forma reiterada, afectarían al cuerpo de las vetulae, provocando jorobas y espaldas curvadas que también se someten al escarnio de los escritores antiguos y debido a las cuales algunas mujeres deberían caminar apoyadas en un bastón (Apul. Met. 4.7; Hippoc. Aph. 26; Ov. Am. 1.8.113; Plaut. Asin. 125 у Curc. 1-2 y 134; Prop. 2.18.20; Sen. Herc. 696).

Además de por todos estos rasgos físicos, las vetulae también aparecen caracterizadas en las fuentes literarias por su mal olor. Sus axilas, su sudor y todo su cuerpo en general desprendían un olor desagradable (Hor. Epod. 8 y 12; Mart. 3.93 y 9.62; Ov. Ars am. 3.190-195). Para Plinio el Viejo ( $N H$ 11.115.227), la halitosis era un mal común en la vejez, debido sin duda tanto a la falta de una higiene adecuada como a la pérdida de piezas dentales, las caries y los abscesos bucales que sufriría buena parte de la población de Roma. No obstante, el mal olor de las vetulae se concentraba en sus genitales y su ano, los cuales Horacio compara con los de una vaca (Hor. Epod. 8.5-6). La estrecha relación que en la literatura de época romana parecen tener los genitales femeninos y el mal olor se debe, para Amy Richlin (1992: 68-69), al hecho de que los escritores romanos eran hombres $\mathrm{y}$, al carecer de vagina, trataban de distanciarse de la misma dotándola de unas características repulsivas. Por ello Juvenal (6.129-139) hace

\footnotetext{
${ }^{154}$ Para Xavier Sierra (2011), parte de la población romana eliminaba el vello corporal para evitar el contagio de parásitos. En el caso concreto del pubis, la costumbre de la depilación podría haber empezado entre las prostitutas y haberse extendido después a toda la población femenina (Kenward, 1999).
} 
referencia al prurito de la vagina, y las relaciones sexuales con vetulae se presentan, como veremos en el siguiente apartado, como episodios desagradables.

Las mujeres trataban de ocultar el mal olor empleando desodorantes y perfumes ${ }^{155}$ y recurriendo a la depilación (Ov. Ars am. 3.190-195; Plin. NH 21.121 y 21.142), aunque, como ocurría en los anteriores casos, estos remedios no siempre funcionaban:

"ESCAFA- Porque a fe mía que una mujer huele bien cuando no huele a nada; esas viejas que se untan de perfumes, todas recompuestas, esos vejestorios sin dientes que pretenden tapar sus defectos a fuerza de afeites, cuando el sudor se combina con los perfumes, huelen exactamente igual que un batiburrillo de salsas de un cocinero; no puedes saber a lo que huelen, lo único de que te das cuenta es de que huelen mal.

FILÓLAQUES- (Al público) ¡Anda que no está bien enterada de todo, qué cosa más lista de mujer! Y además es que tiene razón; seguro que la mayoría de vosotros está de acuerdo con ella, sobre todo los que tenéis en casa una mujer vieja que os cazó por medio de su dote" (Plaut. Mostell. 275-280) ${ }^{156}$.

En ocasiones, el aroma de las vetulae se asemeja al de un cadáver, pútrido y vil (Apul. Met. 4.7; Mart. 3.32 y 3.93; Priap. 57), comparación que sirve también para resaltar su proximidad con la muerte. Si bien Alison Keith (2000: 104) establece una relación entre los cadáveres de mujeres y el erotismo en la épica latina, especialmente en el caso de las jóvenes vírgenes, en lo que respecta a las vetulae la comparación parece tener un propósito más bien denigrador, pretendiendo también destacar la liminalidad de las ancianas en cuanto que seres que pronto viajarán al mundo de los muertos.

Estas referencias al olor de las ancianas remarcan la posición social en la que las coloca el escritor, siendo el hedor corporal típico de las clases bajas y los personajes marginales (Potter, 2002: 171). Vemos así como

\footnotetext{
${ }^{155}$ David Potter (2002: 175 y ss.) resalta la ambivalencia que sobre los perfumes y desodorantes existía en la mentalidad romana, derivada del choque entre el ideal tradicional y la realidad de época tardorrepublicana e imperial, por lo que el uso de este tipo de sustancias servía para señalar la decadencia de la sociedad. Así, mientras Plinio ( $N H$ 13.20) creía que los perfumes eran banalidades superfluas de influencia oriental que servían para ocultar una mala higiene, se trataba de productos que estaban solamente al alcance de las clases pudientes y que se presentan como elementos esenciales para seducir (Ov. Medic. 20).

${ }^{156}$ SC. Quia ecastor mulier recte olet, ubi nihil olet. Nam istae veteres, quae se unguentis unctitant, interpoles, vetulae, edentulae, quae vitia corporis fuco occulunt, ubi sese sudor cum unguentis consociavit, ilico itidem olent, quasi cum una multa iura confudit cocus. Quid olant nescias, nisi id unum, ni male olere intellegas.

PHILOL. Vt perdocte cuncta callet. nihil hac docta doctius. Verum illud esse maxima adeo pars vestrorum intellegit, quibus anus domi sunt uxores, quae vos dote meruerunt.
} 
"a la hora de referirse a los olores, la distinción entre 'aromas embriagadores' e 'inmundas pestilencias', se corresponda o no con las sensaciones referentes, sirve a los segmentos sociales que la emplean para instituir identidades y distinciones correspondientes a las divisiones socialmente significativas según la ideología dominante" (Díaz, 1998: 138).

Arrugas, flacidez, mal olor, calvicie, pérdida de dientes... todos estos son los rasgos que los escritores latinos usan para describir a una misma mujer, quien personifica la ancianidad no deseada, la figura de la vetula marginada por la sociedad, alejada de la gravitas que desprendían los bustos a los que hemos hecho referencia en anteriores páginas. Se trata de episodios cuyo propósito es resaltar la fealdad de las ancianas, en contraposición con la belleza de la juventud (Mart. 8.79; Ov. Medic. 1), generando en el público un sentimiento de repulsa que deriva en risa:

"Aunque tú estés en tu casa y te emperifollen en plena Subura y te confeccionen, Gala, los pelos que te faltan y de noche te quites los dientes lo mismo que los vestidos de seda y te acuestes guardada en cien redomas y tu cara no duerma contigo, haces guiños con las mismas cejas que te ponen por la mañana y no sientes el más mínimo respeto por tu coño encanecido, al que puedes contar ya entre tus abuelos. A pesar de todo prometes el oro y el moro; pero mi polla es sorda; y aunque sea tuerta, te ve ella a pesar de todo" (Mart. 9.37) ${ }^{157}$.

Esta marginalidad suele resaltarse mediante la animalización de la vetula. Ocurre así, por ejemplo, con Vetustila en Marcial (en quien la vejez viene señalada desde su mismo nombre), o con la mujer que intenta seducir a Horacio:

"Cuando tienes trescientos consulados, Vetustila, y tres pelos y cuatro dientes, pecho de cigarra, piernas y color de hormiga; cuando tienes una frente más arrugada que tu estola y unos pechos que parecen telarañas; cuando los cocodrilos del Nilo tienen estrecha la boca comparada con la abertura de la tuya, y croan mejor las ranas de Rávena, y es más dulce el zumbido de los mosquitos de Venecia, y tu vista alcanza lo que alcanzan las lechuzas por la mañana, y hueles a lo que los machos cabríos, y tienes la rabadilla de una ánade flaca, y tu coño le gana a huesudo a un viejo cínico; cuando el bañero, apagadas las luces, te permite entrar mezclada con las prostitutas de los sepulcros; cuando para ti es invierno en pleno agosto y ni una calentura puede quitarte el frío, tienes la osadía de querer

${ }^{157}$ Cum sis ipsa domi mediaque ornere Subura, fiant absentes et tibi, Galla, comae, nec dentes aliter quam Serica nocte reponas, et iaceas centum condita pyxidibus, nec tecum facies tua dormiat, innuis illo quod tibi prolatum est mane supercilio, et te nulla movet cani reverentia cunni, quem potes inter avos iam numerare tuos. Promittis sescenta tamen; sed mentula surda est, et sit lusca licet, te tamen illa videt. 
casarte después de enviudar doscientas veces y pretendes como loca calentar a un hombre con tus cenizas. ¿Qué, si lo pretendiera la losa de Satia? ¿Quién te llamará compañera, quién mi oíslo, a ti, a quien hace poco Filomelo había llamado abuela? Y si te empeñas en que hagan cosquillas a tu cadáver, que se prepare un lecho de los del comedor de Acoro, el único que le va a tu himeneo, y que el incinerador presente las teas a la recién casada: solamente una antorcha funeraria puede penetrar en semejante coño" (Mart. 3.93) ${ }^{158}$.

“¿Qué pretendes, mujer más que digna de los negruzcos elefantes? ¿Por qué me mandas regalos y por qué tablillas, a mí que ni soy un mozo robusto ni tengo embotadas las narices? Pues yo huelo, fino como nadie, si acaso un pulpo o un cabrón hediondo se cobijan en un sobaco hirsuto; y mejor de lo que un perro sagaz ventea el escondite de un cochino. Qué sudor y qué peste brota de todas las partes de su cuerpo, cuando con mi miembro claudicante se afana en sosegar su furia desbocada; y al empaparse de sudor ya no le duran la tiza de la cara ni el colorete de cagajón de cocodrilo y al calentarse rompe los tirantes y hasta el dosel del lecho; o cuando espolea mis hastíos con sañudas palabras: «Con Inaquia estás menos flojo que conmigo: a Inaquia eres capaz de hacérselo tres veces en la noche, y conmigo siempre estás tan blando que hasta te faltan fuerzas para una. Mal rayo parta a Lesbia, que cuando yo buscaba a un toro me puso delante a un impotente. (...) ¡Ay de mí, desdichada, a la que tú rehúyes, como teme la cordera a los sañudos lobos y a los leones los corzos!»”. (Hor. Epod. 12) ${ }^{159}$.

La intención de los poetas es aquí bestializar a la vetula, despojarla de su humanidad. No en vano, lo animal se ha constituido históricamente como aquello que ha representado la Otredad por antonomasia, como ser a partir de la cual el humano se

\footnotetext{
${ }^{158}$ Cum tibi trecenti consules, Vetustilla, et tres capilli quattuorque sint dentes, pectus cicadae, crus colorque formicae; rugosiorem cum geras stola frontem et araneorum cassibus pares mammas; cum conparata rictibus tuis ora Niliacus habeat corcodilus angusta, meliusque ranae garriant Rauennates, et Atrianus dulcius culix cantet, uideasque quantum noctuae uident mane, et illud oleas quod uiri capellarum, et anatis habeas orthopygium macrae, senemque Cynicum uincat osseus cunnus; cum te lucerna balneator extincta admittat inter bustuarias moechas; cum bruma mensem sit tibi per Augustum regelare nec te pestilentia possit: audes ducentas nuptuire post mortes uirumque demens cineribus tuis quaeris prurire. Quid si Sattiae uelit saxum? Quis coniugem te, quis uocabit uxorem, Philomelus auiam quam uocauerat nuper? Quod si cadauer exiges tuum scalpi, sternatur Acori de triclinio lectus, halassionem qui tuum decet solus, tustorque taedas praeferat nouae nuptae: intrare in istum sola fax potest cunnum.

${ }^{159}$ Quid tibi vis, mulier nigris dignissima barris? Munera quid mihi quidve tabellas mittis nec firmo iuveni neque naris obesae? Namque sagacius unus odoror, polypus an gravis hirsutis cubet hircus in alis quam canis acer ubi lateat sus. Qui sudor vietis et quam malus undique membris crescit odor, cum pene Soluto indomitam properat rabiem sedare, neque illi iam manet umida creta colorque stercore fucatus crocodili iamque Subando tenta cubilia tectaque rumpit. Vel mea cum saevis agitat fastidia verbis: 'Inachia langues minus ac me; Inachiam ter nocte potes, mihi Semper ad unum mollis opus. Pereat male quae te Lesbia quaerenti taurum monstravit inertem. (...) O ego non felix, quam tu fugis, ut pavet acris agna lupos capreaeque leones!'
} 
autodefine como distinto y superior, pero hacia el que al mismo tiempo siente temor (Puleo, 2007: 70; Tomàs, 2015: 139). El sujeto que es objeto de la animalización se percibe como subhumano, en un proceso que afecta de forma especial a las mujeres, en base a la relación que la mentalidad patriarcal ha establecido entre mujer y naturaleza, y dado que su capacidad de gestación y su supuesto instinto maternal son rasgos que tienen en común con la mayor parte de las especies animales (Rudman y Mescher, 2012: 2). Así, la designación de las mujeres como Naturaleza o como mediación entre Naturaleza y Cultura se ha manifestado y aún se manifiesta en un lenguaje insultante que asimila «la Mujer» a «la hembra», reduciéndola a funciones sexuales y reproductoras (Puleo, 2007: 72-73). En este sentido, una de las referencias escritas más antiguas sobre la animalización femenina la encontramos en el Yambo de las mujeres de Semónides (s. VII a.C.), en el cual se describen los diversos modelos de mujeres existentes atribuyendo a cada una un animal concreto, modelos que resultan ser todos negativos, con la excepción de la mujer-abeja, el prototipo de esposa ideal ${ }^{160}$. En los textos aludidos se compara el olor corporal de la anciana con el de la cabra y el jabalí, animales velludos y rudos, de forma que

"la actualización del tópico del mal olor conlleva la bestialización de la mujer, construyendo así su deseo como amenaza de violencia física o abuso sexual al tiempo que, desplazándola del plano humano, le atribuyen una fealdad bestial que marca la relación sexual con ella como repugnante" (Nasta, 2011: 239).

En el caso del fragmento horaciano, el poeta se presenta como un perro de caza, metáfora muy empleada en la obra de este autor y en la literatura romana en general (Meyer, 2014: 108), y lo hace con un fin satírico: no se trata del sabueso que persigue a la doncella convertida en un animal ágil y bello, como la cierva ${ }^{161}$, sino que la vetula es presentada como un jabalí, poco estético, que se relaciona con las axilas velludas de la protagonista del texto y que también sirve para caracterizar a la bruja Sagana (Hor. Epod. 5). La escena de caza, por otro lado, se presenta como símbolo de que, "como los animales salvajes, las mujeres debían ser capturadas y domesticadas para integrarlas en la sociedad civilizada" (Mirón, 2005: 85). En el caso de las vetulae mencionadas, se trataría de convertirlas en el modelo ideal de anciana sobria, severa, y carente de sexualidad.

\footnotetext{
${ }^{160}$ Un análisis detallado de la animalización femenina en el texto de Semónides lo encontramos en Egoscózabal, 2003.

${ }^{161}$ Comparación que encontramos por ejemplo en Hor. Carm. 1.23 y Ov. Ars am. 1.765 y Met. 505.
} 
En cuanto a Vetustila, su descripción alude prácticamente a toda su anatomía: es flaca, su boca es más grande que la de un cocodrilo -comparación que puede referirse a la forma de su vagina (López Rodríguez, 2009: 77)-, y su voz resulta tan desagradable como el croar de la rana y el zumbido del mosquito, animal éste último especialmente molesto. La alusión a la voz de Vetustila, la cual se convierte en un ruido animal y con ello opuesto a los sonidos coherentes del hablar, no es sino una forma más de negar su humanidad. Denegándoles la capacidad de razonamiento y de expresar el mismo mediante un lenguaje coherente, y por lo tanto apto para la vida política (Tomàs, 2015: 149), los escritores romanos reducen a las mujeres a su cuerpo. Por otro lado, la vetula no tiene muy buena vista, como la lechuza, ave considerada funesta y embaucadora y que se asocia con la brujería por su nocturnidad (Ael. NA 1.29) ${ }^{162}$, y sus piernas son delgadas y frágiles como las de una hormiga. El cabello de las vetulae se compara con el pelaje animal o con los propios animales; así, Canidia tiene un pelo áspero "de rabiosas víboras" (Hor. Epod. 5), detalle que nos recuerda a Medusa, y el de su compañera Sagana es rígido como las púas de los erizos de mar (Hor. Epod. 5). La animalización que se hace de la vetula pretende, en definitiva, ridiculizar los rasgos físicos característicos de la vejez y alejarla del prototipo de belleza femenino imperante en la sociedad romana.

A menudo, un aspecto físico desagradable va acompañado de una moral reprochable. Para la fisiognomía, el cuerpo era el espejo del carácter, de forma que a partir de la observación del primero podía describirse el segundo. De esta forma, por ejemplo, las heridas en la espalda de la población esclava indicaban castigos infligidos por sus dueños, y por lo tanto indicaban las faltas cometidas; del mismo modo, las cicatrices en el rostro se asociaban con criminales a los que se había marcado permanentemente para resaltar su posición social (Petron. Sat. 102.15) ${ }^{163}$. No obstante, en ocasiones la asociación es más sutil, y la simple fealdad física es significado de una moral corrompida. En lo que respecta a la vejez, la aplicación de las teorías fisiognómicas se aprecia en la descripción de vetulae y senes. Así, el físico del senex Tiberio, tan desmejorado que le obligaba a vivir retirado de la vida social, era para Tácito (Ann. 4.57) el reflejo exterior de su crueldad y sus vicios. Las striges, brujas que se transforman en aves, son ancianas que adoptan una forma física repulsiva acorde con

\footnotetext{
${ }^{162}$ Sobre el simbolismo cambiante de la lechuza, vid. Alvar, 2009: 190-192.

${ }^{163}$ Para las cicatrices como memoria social del cuerpo, vid. Baroin, 2002.
} 
los actos antinaturales que realizan (Apul. Met. 2.22.2-4). Canidia, Sagana y el resto de vetulae brujas de la literatura latina están caracterizadas por la fealdad (Hor. Ep. 5 y Sat. $1.8)$.

Hemos visto también cómo el cuerpo deformado y dependiente, así como el cuerpo envejecido en general, es visto con repulsión. Ello se debe, en parte, a que es presentado como contrapuesto al cuerpo ideal del vir: sano, atlético, fuerte, autónomo, etc. La autonomía física resulta de especial relevancia para el hombre romano, ya que perderla supone depender de la ayuda de los Otros -las mujeres, los esclavos y las esclavas- para sobrevivir. Tácito describe al legado Hordeonio Flaco, poco respetado por sus tropas, como un hombre

“inválido por su edad y por la enfermedad de sus piernas, carente de firmeza y de autoridad. No era capaz de imponer disciplina ni siquiera a un ejército tranquilo, y tanto más se inflamaban aquellos hombres enloquecidos ante la debilidad de quien trataba de contenerlos" (Tac. Hist. 1.9) ${ }^{164}$.

Si bien en el caso de los veteranos desfigurados y/o discapacitados, la sociedad romana encontraba algo que admirar, en cuanto que habían adquirido esa condición luchando por Roma (Liv. 2.23.4 y 39.16), en lo que respecta a las ancianas no había nada de honorable en sus deformidades. Cuando los escritores hacen referencia a vetulae físicamente repulsivas están hablando al mismo tiempo de su comportamiento moralmente reprochable y de cómo sus acciones las colocan en una posición socialmente marginada. Animalizadas, deshumanizadas y con un comportamiento alejado del ideal, estas mujeres se contraponen a la matrona, exponiéndose así al insulto y el desprecio del vir.

Las vetulae que deseasen evitar un aspecto desagradable, en la medida de lo posible, tenían la opción, como ya hemos visto, de disimular los efectos físicos del envejecimiento mediante una serie de rituales estéticos, empleando remedios que debían aplicarse en su justa medida, de forma que el engaño no resultase demasiado evidente. Luciano lo describe de la siguiente manera:

"En efecto, si alguien tiene ocasión de ver a las mujeres cuando se levantan por la mañana de su lecho nocturno, pensará que una mujer es más fea que esos animales cuyo nombre es de mal augurio citar en las primeras horas de la mañana. Por eso se

\footnotetext{
${ }^{164}$ Superior exercitus legatum Hordeonium Flaccum spernebat, senecta ac debilitate pedum invalidum, sine constantia, sine auctoritate: ne quieto quidem milite regimen; adeo furentes infirmitate retinentis ultro accendebantur.
} 
encierran cuidadosamente en su casa, para que ningún hombre las vea. Están rodeadas de mujeres viejas y de un tropel de muchachas tan feas como ellas, que maquillan sus desgraciados rostros con pomadas diversas. Porque no se lavan el sopor del sueño con agua limpia y se aplican enseguida a algún trabajo serio, sino que muchas mezclas de polvos perfumados dan un tono más alegre al color desagradable de su piel y, como si se tratara de una procesión pública, cada una se encarga de un cometido diferente, con palanganas de plata, aguamaniles, espejos y un montón de cajas, como si fuera la tienda de un droguero, muchos tarros llenos de mucha desgracia, en los que tienen a mano dentífricos y artilugios para ennegrecer los párpados. La mayor parte de su esfuerzo lo consume en el trenzado de sus cabellos. En efecto, por medio de pigmentos que son capaces de enrojecer sus cabellos tanto como el sol de mediodía, tiñen sus rizos de un rubio brillante, lo mismo que tiñen la lana, reprobando a su propia naturaleza. Y las que se consideran satisfechas con sus cabellos negros, gastan todo el dinero de sus maridos en perfumes de casi toda Arabia que exhalan sus cabellos, utilizan instrumentos de hierro calentados en una débil llama para ensortijar a la fuerza sus bucles, y mechones elaborados estilosamente bajan hasta sus cejas, dejando un estrecho espacio en la frente, mientras que por detrás las trenzas flotan arrogantemente hasta las espaldas. A continuación vienen las sandalias tejidas de múltiples colores, que se clavan en la carne oprimiendo sus pies, y sus velos transparentes que pasan por vestidos, para dar la apariencia de que andan desnudas. Todo su interior puede reconocerse mejor que su cara, aparte de sus pechos exageradamente prominentes, que llevan de un lado a otro atados como prisioneros. ¿Pero qué necesidad hay de contar escándalos todavía más llamativos que éstos? Piedras preciosas de Eritrea que valen más de un talento cuelgan de sus orejas, o serpientes en sus muñecas y brazos, que ojalá fueran realmente serpientes en vez de oro. Sus cabezas están rodeadas de coronas como constelaciones de piedras de la India, de sus cuellos cuelgan costosísimos collares, y el desgraciado oro desciende totalmente hasta las puntas de sus pies, oprimiendo cualquier parte del tobillo que quede desnuda, aunque merecerían tener sus piernas encadenadas con hierro por los talones. Y una vez que todo su cuerpo ha sido embaucado con la belleza engañosa de un atractivo bastardo, enrojecen sus mejillas impúdicas con pinturas rojas, para que su tinte carmesí pueda dar color a su palidísima y fofa piel" (Luc. Am. 39-41) ${ }^{165}$.

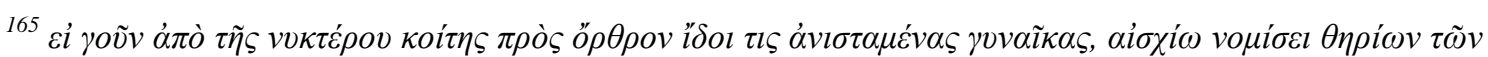

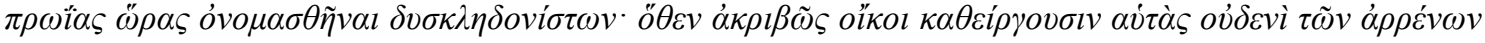

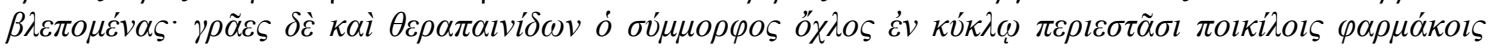


Las mujeres que describe Luciano emplean buena parte de su tiempo y de la energía de sus esclavas en transformar su aspecto para parecer más atractivas. Usan para ello multitud de productos, muchos de ellos importados, que vacían las arcas de sus esposos, una afición que ya hemos señalado que los escritores romanos consideraban típicamente femenina. Si bien estas mujeres suscitan el rechazo de Luciano cuando muestran su aspecto natural, tampoco le agrada al escritor el resultado, que rompe con la tradicional austeridad de la matrona.

A los cuidados del cuerpo como tal, Luciano añade aspectos relacionados con el vestido y el peinado. Sobre la importancia del cuidado del cabello y la ropa, Kelly Olson señala que,

"clothing is important to a society's sense of itself. Clothing, for instance, relates to gendered behavioral ideals: women's clothing has often encapsulated cultural anxiety over gender, embodying both women's model characteristics and ideal relations between the sexes. Clothing in past cultures was also capable of both forming and classifying character and morality. (...) And because clothing constructed a social persona for the wearer at the same time as it signified that wearer's identity, in many preindustrial societies, clothing was the material creator of social position and an important tool of social regulation. Ideally, clothing was a system of signs that reflected, indeed helped construct, the social order, and fashion thus became a weapon in the hands of the privileged, which they used to distinguish themselves from the lower classes" (Olson, 2008: 1).

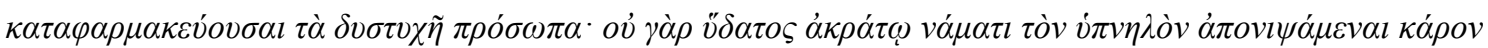

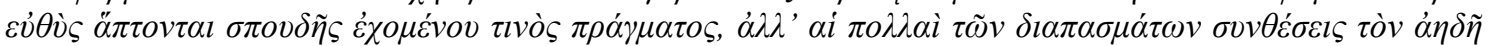

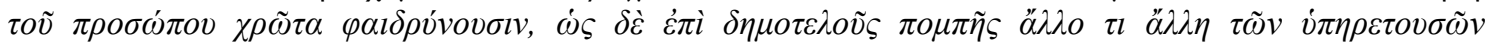

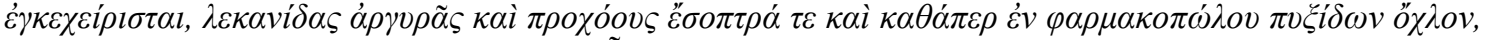

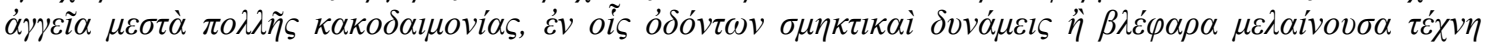

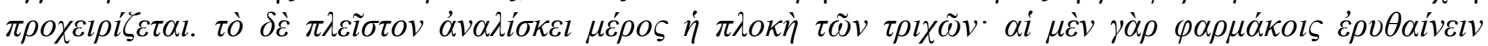

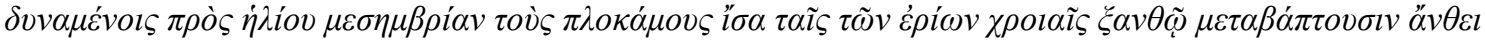

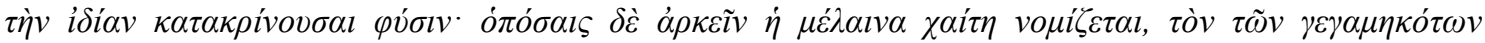

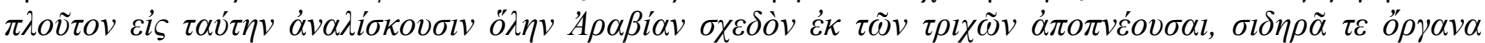

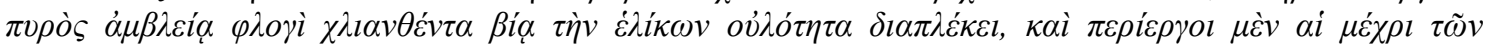

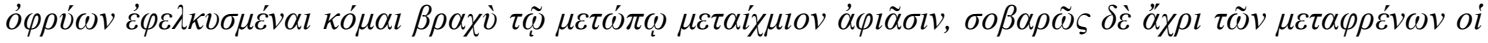

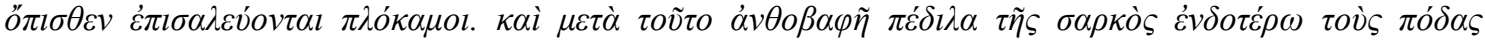

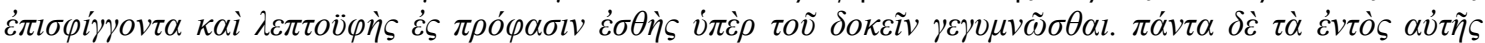

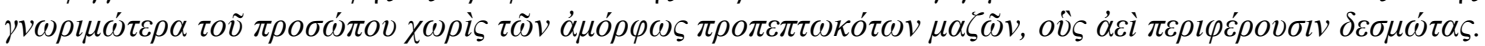

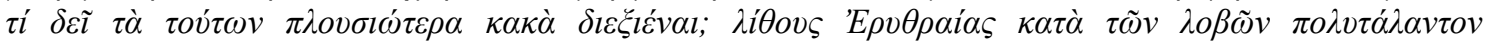

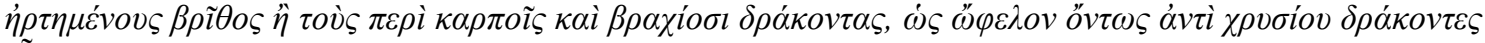

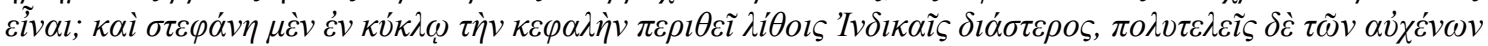

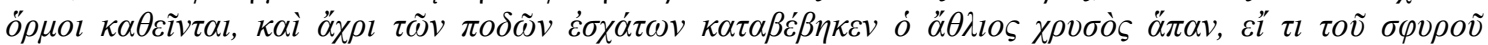

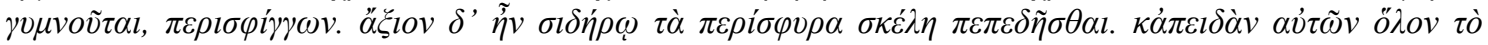

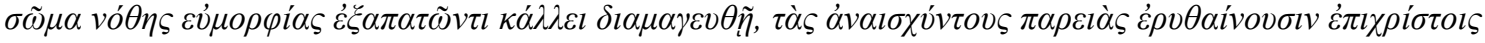

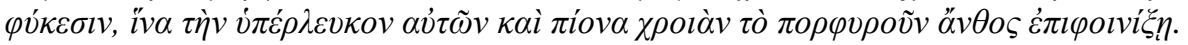


El vestido es el envoltorio social del cuerpo, es lo primero que vemos de una persona además de su rostro, y por lo tanto sirve para clasificar a los sujetos de acuerdo con la moralidad de cada sociedad (Aguilar, 2011: 68; D’Ambra, 2007: 5; Twigg, 2015: 56-58). En el caso de las romanas, por ejemplo, el vestido era una demostración pública de su pudicitia, una manifestación visual de la castidad y la modestia obligadas en la matrona. Para Ria Berg,

"material, form, and function were the basic message-bearing units of clothing, and their modesty and simplicity was an important signal. (...) Those clothes signal pudor, pudicitia, verecundia, or honos of the wearer. (...) Thus clothing protected, or even created a movable private sphere around women in public" (Berg, 2002: $32)$.

Debido a la posición que ocupaban en la sociedad, las vetulae debían vestir de forma austera. Se esperaba de las viudas que vistieran en colores oscuros y no llevaran joyas ni otros adornos (Olson, 2008: 41-42). En el caso del pelo, lo correcto era un peinado simple pero elegante (Kleiner y Matheson, 2000: 12), como si fuese su pelo natural y no una peluca, o "as if it were done at home, rather than at a salon" (Matheson, 2000: 128), como muestran los bustos de las Figs. 11 y 18.

En definitiva, a lo largo de este apartado dedicado al aspecto físico de las vetulae hemos visto cómo la normativización del cuerpo de la mujer se constituye en una estrategia de control social muy efectiva (Bordo, 1995: 166). Las arrugas, la falta de dientes, la flacidez, etc., características físicas propias de la vejez, no eran vistas por los autores romanos como aspectos positivos, ya que alejaban a las mujeres del ideal de la puella poética de piel tersa y pechos firmes, la cual no necesitaba de artificios para resultar atractiva. Si bien estos rasgos aparecen representados en la estatuaria para dotar a las esculturas de realismo e individualizarlas, y son además elementos visuales que servían en la mentalidad romana para identificar la vejez femenina, no aparecen en los textos si no es con objetivo denigratorio. El cuerpo de las vetulae no era nombrado positivamente si no era para hacer referencia a mujeres que cronológicamente eran ancianas pero visualmente no lo parecían, como ocurre con Meroe en Metamorfosis (1.7.7) de Apuleyo y con una hechicera nombrada en Diálogos de las heteras (4) de Luciano, aunque se trata de dos excepciones, ya que ambas son brujas y por lo tanto capaces de mantenerse atractivas a pesar del paso de los años. 
De esta forma, los autores clásicos incitaban a las mujeres a que ocultasen los signos físicos de la vejez, incluso si eran mujeres de la élite como Julia. No obstante, debían hacerlo al gusto del varón, ya que si éste consideraba que los remedios eran excesivos o que no cumplían con su función, el castigo era la humillación y la risa, como ocurre con Pola y como Séneca (Helv. 16.4) indica a Helvia. Este cuerpo envejecido que disgustaba a los romanos era sometido a escarnio público mediante el empleo de personajes que encarnan todos los rasgos negativos posibles (Paulin, 2011: 2). De esta forma,

"En este proceso, el grupo adquiere una fisionomía específica que lo diferencia de los demás. Esta uniformidad se obtiene enfatizando, e incluso exagerando, las similitudes entre los miembros del mismo grupo. Las variantes individuales son minimizadas en un proceso que va hasta la negación o incapacidad de percibirlas" (Amossy y Herrschberg, 2001: 49).

El rechazo se subrayaba mediante la animalización, estrategia que servía para deshumanizar a la vetula y marginarla socialmente, y también resaltando la estrecha relación entre estas mujeres y la muerte, que, como ya hemos visto, es además un modo de distanciarse de todo lo macabro. Por otro lado, el horrible aspecto de las ancianas actuaba como una externalización de su personalidad, que como se desarrolla a lo largo de la presente Tesis Doctoral era vista como huraña, mezquina, avariciosa, libidinosa, aficionada a la bebida y presta al engaño y al uso de la magia.

\section{III.4. SEXUALIDAD}

A lo largo del presente capítulo hemos señalado que el rol primordial que la sociedad romana asignaba a la mujer era el de madre. ¿Pero qué ocurría cuando una mujer ya no podía cumplir con este papel, cuando se agotaban sus años fértiles? La vetula ya no era la atractiva puella ni la fértil matrona, y se convertía entonces en un sujeto sin utilidad social, improductivo y no deseable, un ser invisible, innombrable, que había perdido todo significado sexual; o peor aún, en un cuerpo rechazado, repulsivo, sobre el que caían el insulto y la burla (Beauvoir, 1996: 40; Díez y Palacios, 2011: 3-5; Minois, 1987: 119; Parkin, 1998: 33).

Pero, aunque no pudiese concebir, la vetula sí era capaz de tener deseo sexual. La medicina demostró hace más de medio siglo que las capacidades físicas para mantener relaciones sexuales no se ven alteradas de forma significativa hasta los 80-90 años, 
quedando claro que son las patologías y los factores psíquico-sociales los que limitan en su mayoría la sexualidad de los mayores (Masters y Johnson, 1966; Weg, 1983: 7-8). A pesar de ello, y aunque se ha demostrado que un alto porcentaje de las personas ancianas mantiene al menos esporádicamente relaciones sexuales (Cabrera, 2009), en la actualidad sigue vigente la idea de que la sexualidad es reprobable en la vejez, e incluso una enfermedad mental, tal y como sentenciase el psiquiatra alemán Richard von KrafftEbing (1939: 52) ${ }^{166}$ al incluirla dentro de la paradoxia, o deseo erótico experimentado en etapas de la vida -infancia y vejez- en las que no debería existir. Se trata de una noción que encontramos en escritores clásicos como Horacio: "Cuando golpeas contra tu paladar añoso balbucientes palabras de amor, ¿en qué medida estás más cuerdo que el que construye casitas?" (Hor. Sat. 2.3.270-275) ${ }^{167}$. Por ello, vemos cómo es precisamente la sociedad la que niega a las personas ancianas el derecho a la sexualidad, ya que ven ésta como un sinónimo de juventud (Freixás y Luque, 2009: 192; Weg, 1983: 3). Como señalaba Simone de Beauvoir,

"If old people show the same desires, the same feelings and the same requirements as the young, the world looks upon them with disgust: in them love and jealousy seem revolting or absurd, sexuality repulsive and violence ludicrous. They are required to be a standing example of all the virtues" (Beauvoir, 1996: 3).

En el caso de la sociedad romana, hemos apuntado en el Capítulo II que se pensaba que el deseo sexual debía acabarse en la vejez (Cic. Off. 1.34.122-123 y Sen. 12.42; Ov. Am. 1.9.4; Plut. 145A; Prop. 3.5.23-24; Tib 1.4.27-39; Verg. G. 3.95-101), aunque no sabemos cómo se reflejaba esta máxima en el día a día de la población romana:

"Yo creo que es mejor que antes de irnos dictemos una ley para todos los viejos, por la que quedarán obligados y sujetos; caso de que llegue a nuestro conocimiento que un individuo que haya cumplido los sesenta, ya sea casado o, qué diablos, también sin casar, es un mujeriego, será el susodicho perseguido en virtud de esta ley: decidiremos que ha perdido la cabeza y, por nosotros, en la indigencia se verá el que disipe su haber" (Plaut. Merc. 1015-1020) ${ }^{168}$.

\footnotetext{
${ }^{166}$ La obra original fue publicada por Rebman Company en 1886.

${ }^{167}$ Cum balba feris annoso verba palato, aedificante casas qui sanior?

168 Immo dicamus senibus legem censeo, prius quam abeamus, qua se lege teneant contentique sint. Annos gnatus sexaginta qui erit, si quem scibimus si maritum sive hercle adeo caelibem scortarier, cum eo nos hac lege agemus: inscitum arbitrabimur, et per nos quidem hercle egebit qui suom prodegerit.
} 
De este modo, vemos que aunque la sexualidad en la vejez es negada en cuanto que impropia, no es considerada inexistente (Catull. 16). En lo que respecta a los hombres, su permanencia se permitía en ciertas ocasiones, pero en las mujeres el impulso sexual debía desaparecer por completo (Mart. 4.50). En el caso de las matronae, porque su libido era tolerada solamente cuando iba encaminada a la procreación, y en el caso de las prostitutas, porque la vejez ponía fin a su atractivo erótico (Luc. Am. 25; Sen. Helv. 16.4). Por otro lado, coincidimos con Suzanne Dixon (2003: 112) cuando señala que el amor y el sexo debieron ser componentes deseados en la pareja romana, y que lo seguirían siendo en los matrimonios que pasasen su vejez en compañía. Esta era, no obstante, una sexualidad que se vivía en privado y sobre la que las fuentes callan, sobre todo en cuanto a lo que las romanas pensaban y sentían al respecto.

Las fuentes literarias, por lo tanto, emplean la sexualidad de las vetulae como una forma más de rechazo hacia la vejez femenina. Como ya hemos visto, la belleza de la mujer, para los romanos, se perdía con la edad: "La hermosura es un bien quebradizo, y conforme va ganando en años disminuye y se consume ella misma con el transcurrir del tiempo" (Ov. Ars am. 2.113-114) ${ }^{169}$. Es por ello que son frecuentes los pasajes en los que el poeta aconseja a la amante que aproveche su juventud (Hor. Carm. 2.11.5-10; Tib. 1.4.27-39 y 1.6.75-84). Así lo expresan escritores de diversas épocas:

"Ay, tarde se llama al amor, tarde a la juventud, cuando la canosa vejez ha teñido la anciana cabeza. Entonces hay deseos de belleza: entonces se cambia el color del cabello para disimular los años, teñido con corteza de verde nuez. Entonces aparece la preocupación por arrancar de raíz las canas y de ofrecer, pulidas las arrugas, un rostro nuevo. Pero tú, mientras florece para ti la edad de la primavera, disfrútala: ella se desliz con no lento paso. No atormentes a Márato; el haber vencido a un joven, ¿qué gloria reporta? Sé rigurosa, niña, con los viejos cargados de años. Perdona, por favor, a un joven. No tiene enfermedad grave, sino que el exceso de amor hace palidecer su cuerpo" (Tib 1.8.41-54) ${ }^{170}$.

\footnotetext{
${ }^{169}$ Forma bonum fragile est, quantumque accedit ad annos fit minor, et spatio carpitur ipsa suo.

${ }^{170}$ Heu sero revocatur amor seroque iuventas, cum vetus infecit cana senecta caput. Tum studium formae est: coma tum mutatur, ut annos dissimulet viridi cortice tincta nucis; tollere tum cura est albos a stirpe capillos et faciem dempta pelle referre novam. At tu, dum primi floret tibi temporis aetas, utere: non tardo labitur illa pede. Neu Marathum torque: puero quae gloria victo est? In veteres esto dura, puella, senes. Parce precor tenero: non illi sontica causa est, sed nimius luto corpora tingit amor.
} 
“¡Vivamos, Lesbia mía, y amemos, y todos los rumores de los viejos, demasiado severos, valorémoslos en un sólo céntimo! Los soles pueden morir y renacer; nosotros, cuando haya muerto de una vez para siempre la breve luz de la vida, debemos dormir una sola noche eterna" (Catull. 5) ${ }^{171}$.

"Ya desde ahora acordaos de la inminente vejez: así ningún momento se os escapará infructuoso. Mientras os es posible y declaráis todavía los años que en realidad tenéis, disfrutad: los años pasan igual que el agua de un río; la corriente que ha pasado no podrá regresar a su fuente, ni la hora que ha pasado puede tampoco volver. Hay que aprovecharse de la edad: con rápido pie se desliza la edad y no es tan buena la que viene luego como la que hubo antes. Estas ramas que ahora blanquean por la escarcha, las he visto yo cubiertas de violetas y de estas espinas me regalaron una bonita corona. Tiempo vendrá en el que tú, que ahora rechazas a tus amantes, yacerás anciana y muerta de frío en la soledad de la noche, y las nocturnas peleas no romperán tu puerta, ni encontrarás por la mañana tus umbrales sembrados de pétalos de rosa. ¡Cuán presto, infeliz de mí, se tornan flácidos los cuerpos cubriéndose de arrugas, y desaparece el color que había en un rostro hermoso!, y los cabellos blancos, que tú juras haber tenido desde que eras doncella, ¡qué pronto se extienden por toda la cabeza! La culebra se despoja de su vejez al mismo tiempo que de su delgada piel y no por echar cuernos se vuelven viejos los ciervos; nuestros bienes, en cambio, escapan sin remedio: coged la flor, porque si no la cogéis, caerá por sí sola marchita. Añádele a eso que también los alumbramientos abrevian el tiempo de juventud: un campo envejece con las continuas cosechas" (Ov. Ars am. 3.59-82) $)^{172}$.

En estos pasajes se advierte cierto temor al envejecimiento, en especial a la pérdida de belleza que la sociedad percibe en la vejez; una pérdida de atractivo que afecta también al hombre pero incide sobre todo en la mujer. Por otro lado, si bien en estos fragmentos los sentimientos predominantes son el miedo y la tristeza, nos encontramos con otros de temática parecida, pero en los que el poeta asume el papel del

\footnotetext{
${ }^{171}$ Vivamus mea Lesbia, atque amemus, rumoresque senum severiorum omnes unius aestimemus assis! Soles occidere et redire possunt: nobis cum semel occidit brevis lux, nox est perpetua una dormienda.

${ }^{172}$ Venturae memores iam nunc estote senectae: sic nullum vobis tempus abibit iners. Dum licet, et vernos etiamnum educitis annos, ludite: eunt anni more fluentis aquae; nec quae praeteriit, iterum revocabitur unda, nec quae praeteriit, hora redire potest. Utendum est aetate: cito pede labitur aetas, nec bona tam sequitur, quam bona prima fuit. Hos ego, qui canent, frutices violaria vidi: hac mihi de spina grata corona data est. Tempus erit, quo tu, quae nunc excludis amantes, frigida deserta nocte iacebis anus, nec tua frangetur nocturna ianua rixa, sparsa nec invenies limina mane rosa. Quam cito (me miserum!) laxantur corpora rugis, et perit in nitido qui fuit ore color. Quasque fuisse tibi canas a virgine iuras, spargentur subito per caput omne comae. Anguibus exuitur tenui cum pelle vetustas, nec faciunt cervos cornua iacta senes: nostra sine auxilio fugiunt bona; carpite florem, qui, nisi carptus erit, turpiter ipse cadet. Adde, quod et partus faciunt breviora iuventae tempora: continua messe senescit ager.
} 
amante rechazado que, o bien se ríe de la mujer que una vez se desentendió de él, ya que ahora se ha convertido en una anciana fea, o bien avisa a la joven que no lo quiere que su venganza se materializará en forma de decrepitud. Esta actitud la presenta Propercio (2.18.20 y 3.25) con respecto a Cintia, a quien señala lo cerca que está de convertirse en una anciana encorvada agobiada por el peso de los años y rechazada debido a su físico envejecido, y también se aprecia en Horacio, quien se expresas así:

"Ya no tiran piedras tan a menudo a tus ventanas cerradas los mozos insolentes, ni te quitan el sueño; y se aficiona al umbral la misma puerta que antes movía tan fácilmente sus bisagras. Cada vez menos y menos oyes que te digan: «iMientras yo, que soy tuyo, me consumo en largas noches, tú estás durmiendo, Lidia?». Al contrario, vieja y despreciada, llorarás por los mujeriegos arrogantes en una calleja solitaria, mientras el viento de Tracia más haga sentir su bacanal, bajo la luna nueva; cuando tu ardiente amor y tu pasión -la misma que a las madres de los caballos suele volver locas- se agiten en tu hígado ulcerado. Y no dejarás de lamentar que la alegre juventud prefiera la verdeante hiedra y el oscuro mirto, y que las hojas secas se las dedique al compañero del invierno, al viento Euro.” (Hor. Carm. 1.25$)^{173}$.

"Los dioses, Lice, han escuchado mis promesas; las han escuchado. Lice: te haces vieja y quieres, sin embargo, parecer hermosa; y andas de fiesta y bebes sin recato, y una vez bebida, con un canto temblón provocas a un Cupido que no llega. Y es que él está al acecho en las mejillas tan hermosas de Quía, que está en la flor de la edad y es ducha en hacer sonar la cítara; pues él al volar deja de lado, esquivo, las áridas encinas y escapa de ti porque te afean tus dientes amarillos, tus arrugas y las nieves que cubren tu cabeza. Ya ni las púrpuras de Cos ni las piedras preciosas te devuelven unos tiempos que el volar de los días ha metido y encerrado en calendarios bien notorios. ¿A dónde se fue el encanto -jay!-, a dónde el color, a dónde aquel movimiento tan gracioso? ¿Qué tienes tú de aquélla, de aquella que amores respiraba, que secuestrado a mí mismo me tenía; de aquel rostro que triunfó después de Cínara, y también famoso por sus artes seductoras? Mas a Cínara le dio pocos años el destino que a Lice había de guardar por largo tiempo, hasta igualarla

\footnotetext{
${ }^{173}$ Parcius iunctas quatiunt fenestras iactibus crebris iuvenes proterui nec tibi somnos adimunt amatque ianua limen, quae prius multum facilis movebat cardines. Audis minus et minus iam: 'Me tuo longas perevnte noctes, Lydia, dormis?' Invicem moechos anus arrogantis flebis in solo levis angiportu Thracio bacchante magis sub interlunia vento, cum tibi flagrans amor et libido, quae solet matres furiare equorum, saeviet circa iecur ulcerosum non sine questu, laeta quod pubes hedera virenti gaudeat pulla magis atque myrto, aridas frondes hiemis sodali dedicet Euro.
} 
en edad a una decrépita corneja; para que los mozos ardientes, y no sin mucha risa, pudieran ver deshecha en cenizas a la antorcha" (Hor. Carm. 4.13) ${ }^{174}$.

Lidia, que todavía es hermosa, tiene cada vez menos pretendientes, los cuales pronto desaparecerán, ya que los efectos de la vejez eliminarán su atractivo. Su vida se volverá triste y llena de lamentos, se sumirá en la pobreza y será objeto de mofa y rechazo. Un rechazo que ya comienza a vivir Lice, que no puede competir con la belleza de las mujeres jóvenes y, a pesar de que trata de aparentar menos años a través del adorno, no consigue engañar al público. La vejez se convierte en motivo de exclusión social, ya que la única mujer físicamente atractiva es la puella, tal y como deja patente Horacio al referirse a Cloris, a quien recomienda -como también hace con Lice- que realice actividades apropiadas para su edad, y no aquellas típicas de las doncellas:

“Tú, mujer del pobre Íbico, pon coto de una vez a tus desmadres y a esos afanes tan mal vistos. Tú, que más cerca estás de un funeral -y no precisamente prematuro-, deja de jugar entre las mozas y de esparcir nieblas sobre las estrellas relucientes. No porque algo le siente bien a Fóloe también a ti te cuadra, Cloris. Con mejor derecho asalta tu hija las casas de los mozos, como una Tíade a la que el son del pandero excita. A ella la obliga su pasión por Noto a retozar como una corza en celo; pero a ti lo que te va son las lanas esquiladas junto a la célebre Luceria, no las cítaras ni la flor purpúrea de la rosa, ni vieja como eres los jarros hasta las heces apurados" (Hor. Carm. 3.15) ${ }^{175}$.

Tanto en este último fragmento como en el caso de Lice, vemos cómo Horacio recurre a la comparación de las vetulae con mujeres más jóvenes. No se trata aquí tanto de hacer referencia a la vejez como segunda infancia, a pesar de que se insiste en que cada edad tiene un comportamiento adecuado, sino de contraponer las figuras de la joven hermosa y la vieja repulsiva, de ofrecer al lector imágenes opuestas que resalten la marginalidad de las ancianas a las que se hace alusión.

\footnotetext{
${ }^{174}$ Audivere, Lyce, di mea vota, di audivere, Lyce: fis anus, et tamen vis formosa videri ludisque et bibis impudens et cantu tremulo pota Cupidinem lentum sollicitas. Ille virentis et doctae psallere Chiae pulchris excubat in genis. Importunus enim transvolat aridas quercus et refugit te quia luridi dentes, te quia rugae turpant et capitis nives. Nec Coae referunt iam tibi purpurae nec cari lapides tempora, quae semel notis condita fastis inclusit volucris dies. Quo fugit Venus, heu, quoue color, decens quo motus? Quid habes illius, illius, quae spirabat amores, quae me surpuerat mihi, felix post Cinaram notaque et artium gratarum facies? Sed Cinarae brevis annos fata dederunt, servatura diu parem cornicis vetulae temporibus Lycen, possent ut iuvenes visere fervidi multo non sine risu dilapsam in cineres facem.

${ }^{175}$ Uxor pauperis Ibyci, tandem nequitiae fige modum tuae famosisque laboribus; maturo propior desine funeri inter ludere virgines et stellis nebulam spargere candidis. Non, si quid Pholoen satis, et te, Chlori, decet. Filia rectius expugnat iuvenum domos, pulso Thyias uti concita tympano. Illam cogit amor Nothi lasciva similem ludere capreae: te lanae prope nobilem tonsae Luceriam, non citharae decent nec flos purpureus rosae nec poti vetulam faece tenus cadi.
} 
Estos fragmentos ilustran cómo la sexualidad se concebía en la vejez como un deseo ridículo, propio de senes y vetulae dementes (Cic. Sen. 11.36). La literatura nos presenta la figura del senex que persigue a las mujeres, especialmente a las jóvenes, sin percatarse de que ha perdido su potencia sexual. Incluso el dios Príapo tiene problemas para saciar su libido llegada la ancianidad (Priap. 76). El senex libidinoso se convierte en un personaje de la comedia y la sátira, compitiendo con hombres más jóvenes por el amor de una doncella o una prostituta (Mart. 4.50; Ov. Am. 1.9.4; Plaut. Merc. 264 y 305-315).

Las relaciones sexuales en la vejez se censuran incluso si ambos miembros de la pareja son ancianos (Plaut. Aul. 162-165). Dión Casio se dirige duramente a Cicerón, reprobando su relación con Cerelia, una mujer adinerada con la que mantuvo relaciones comerciales y de amistad ${ }^{176}$ (Cass. Dio 46.18.3-4; Cic. Att. 12.51, 13.21a, 13.22, 14.19 y 15.1 y Fam. 13.72).

Por su parte, Tibulo advierte a Delia de lo que ocurrirá cuando ambos alcancen la vejez: "Entretanto, mientras el destino lo consiente, amémonos. Ya llegará la Muerte con su cabeza cubierta de tinieblas, ya se deslizará la edad de la pereza; no estará bien visto amar, ni decirnos ternezas con la cabeza canosa" (Tib. 1.1.70-75) ${ }^{177}$. Vemos cómo el poeta intenta aquí resaltar el desvalor social que para el cuerpo femenino supone el paso del tiempo. Si en el caso maculino el tópico de aprovechar la juventud hace referencia a las hazañas políticas y militares, en lo que respecta a las mujeres se alude a una belleza física perecedera y se las insta a buscar un hombre con quien compartir su vida una vez dejen de resultar atractivas.

Cuando se alude directamente a la sexualidad de las vetulae, la literatura las caracteriza de forma tan grotesca que no se espera de ellas que resulten atractivas para ningún hombre (Luc. Am. 25; Mart. 2.34 y 9.37; Priap. 12). Para ello se exagera su edad, se las compara con cadáveres -rasgo al que nos hemos referido con anterioridad-, y se insinúa que la única forma que tienen de acceder al sexo es contratando servicios de prostitución:

\footnotetext{
${ }^{176}$ Cicerón aplica a Cerelia el adjetivo de necessaria, el cual Marilyn Skinner (2010: 15) interpreta como sinónimo de íntima amiga o de una persona conectada mediante lazos familiares a raíz del matrimonio fallido entre el orador y Publilia.

${ }^{177}$ Interea, dum fata sinunt, iungamus amores: iam veniet tenebris Mors adoperta caput, iam subrepet iners aetas, nec amare decebit, dicere nec cano blanditias capite.
} 
"Hija de Pirra, madrastra de Néstor, a quien una Níobe joven vio canosa, un Laertes viejo llamó abuela, Príamo ama, Tiestes suegra, sobreviviente ya a todas las cornejas, enterrada al fin en este sepulcro, se pone cachonda Plucia con el calvo Melantión" (Mart. 10.67) ${ }^{178}$.

"Y de esto, también se dio cuenta el acusador; pues dejó caer, en un determinado momento que esa mujer había preferido que se le quitara la vida antes que la castidad. Pero inmediatamente se apartó de este tema y no dijo nada más sobre la castidad, temiendo -creo yo- darnos un motivo de risa y guasa. Pues es cosa sabida que era terriblemente fea y además, vieja. Siendo así que, aunque esta sarda hubiera sido lasciva, ¿qué sospecha puede haber de lujuria o de amor relacionada con ella?" (Cic. Scaur. 5-6) ${ }^{179}$.

"Quieres que se te tiren gratis a pesar de que eres fea y vieja. Cosa bien ridícula es: quieres dar y no quieres dar" (Mart. 7.75) ${ }^{180}$.

Se censura especialmente a las vetulae que, a pesar de la opinión general, consideran que aún son atractivas y buscan satisfacer su deseo sexual. Así, Marcial (3.32) explica a Matrinia que es demasiado vieja para resultarle deseable. Del mismo modo, son atacadas por expresar deseo sexual Ligeya y una anciana a la que menciona Juvenal:

“¿Por qué, Ligeya, mesas tu decrépito coño? ¿Por qué atizas los rescoldos de tus propios despojos? Tales primores están bien en las jóvenes; pero tú ya ni vieja puedes parecer. Eso, créeme, Ligeya, no resulta bonito que lo haga la madre de Héctor, sino su esposa. Te equivocas si te parece éste un coño: la polla ha dejado de interesarse por él. Por tanto, Ligeya, si tienes vergüenza, no pretendas mesarle la barba a un león muerto" (Mart. 10.90) ${ }^{181}$.

\footnotetext{
${ }^{178}$ Se creía que las cornejas vivían cinco veces más que el ser humano. Pyrrhae filia, Nestoris noverca, quam vidit Niobe puella canam, Laertes aviam senex vocavit, nutricem Priamus, socrum Thyestes, iam cornicibus omnibus superstes, hoc tandem sita prurit in sepulchro calvo Plutia cum Melanthione.

${ }^{179}$ Qui tamen ipsi mortem ita laudant ut fugere vitam vetent atque id contra foedus fieri dicant legemque naturae. Aliam quidem causam mortis voluntariae nullam profecto iustam reperietis. atque hoc ille vidit; nam iecit quodam loco vita illam mulierem spoliari quam pudicitia maluisse. Sed refugit statim nec de pudicitia plura dixit veritus, credo, ne quem inridendi nobis daret et iocandi locum. constat enim illam cum deformitate summa fuisse, tum etiam senectute. qua re quae potest, quamvis salsa ista Sarda fuerit, ulla libidinis aut amoris esse suspicio?

${ }^{180}$ Vis futui gratis, cum sis deformis anusque. Res perridicula est: uis dare nec dare uis.

${ }^{181}$ Quid vellis vetulum, Ligeia, cunnum? Quid busti cineres tui lacessis? Tales munditiae decent puellas — Nam tu iam nec anus potes videri - ; istud, crede mihi, Ligeia, belle non mater facit Hectoris, sed uxor. Erras, si tibi cunnus hic videtur, ad quem mentula pertinere desit. Quare si pudor est, Ligeia, noli Barbam vellere mortuo leoni.
} 
"Esto, bien puedes concederlo a las mujeres jóvenes, pero tú, a la que ya empujan ochenta y seis años, ¿amas todavía en griego? Este lenguaje es impúdico en una vieja. Cada vez que interviene aquel lascivo ¡vida y alma mía!, usas entre el gentío palabras que acabas de dejar entre las mantas. ¿Qué ingle no excitaría una voz acariciante y libertina? Es como si te palpara. Sin embargo, cuando ya se te caen las plumas, aunque digas eso con más lujuria que Hemón y que Carpóforo, tu rostro te delata la edad" (Juv. 6.190-199) ${ }^{182}$.

Ambos textos aluden a lo repulsiva que era para el hombre romano la idea de mantener relaciones sexuales con una vetula y, en concreto, la repugnancia que sentían al ver a una anciana que buscaba satisfacer sus deseos eróticos. El deseo sexual, que en las mujeres debía ser moderado, resultaba del todo reprobable en las vetulae. Ligeya es especialmente censurable en este sentido, ya que a pesar de ser vieja, se arrancaba el vello púbico, una actitud que era de esperar en las doncellas que buscanban resultar atractivas al amante, pero que se encuentra fuera de lugar en la vejez.

En las vetulae sexualmente activas se encarna el mito de la matriz como un animal voraz y deseoso de sexo (Gal. De loc. aff. 6.5.425; Sor. Gyn. 1.8), un fenómeno simbólico presente en muchas sociedades y al que se ha dado el nombre de vagina dentata (Richlin, 1984: 72-73; Walker, 2013: 17). Los genitales femeninos, que en la literatura romana no suelen aparecen mencionados de forma explícita, se muestran aquí para resaltar su repugnancia. Al mismo tiempo, el varón que se enfrenta a ellos señala su rechazo hacia un gesto que le avergüenza e incomoda, que desvela lo prohibido, lo que la edad debía haber convertido en inexistente (Lincoln, 1979: 231; Suter, 2015). Las vetulae que muestran abiertamente su sexualidad reivindican una libido que debieron contener en la juventud y que ahora, lejos de ocultar, exhiben para terror del público masculino, liberadas de las cargas del embarazo y el parto, así como de la pudicitia debida a su esposo, probablemente ya fallecido.

Esta caracterización entronca con la animalización a la que ya hemos señalado que se sometía a las ancianas romanas. Si bien los ejemplos de Vetustila y el Epodo 12 de Horacio resultaban ilustrativos al respecto, es no obstante en el Epodo 8 de Horacio

\footnotetext{
${ }^{182}$ Dones tamen ista puellis, tune etiam, quam sextus et octogensimus annus pulsat, adhuc Graece? Non est hic sermo pudicus in uetula. Quotiens lasciuum interuenit illud zoe kai psyche, modo sub lodice relictis uteris in turba. Quod enim non excitet inguen uox blanda et nequam? Digitos habet. Ut tamen omnes subsidant pinnae, dicas haec mollius Haemo quamquam et Carpophoro, facies tua conputat annos.
} 
en el que podemos apreciar mejor la animalización de la vejez femenina con objetivo denigratorio:

“¿Que me preguntes tú, que estás podrida por un siglo largo, qué es lo que enerva mis fuerzas, cuando tienes negros los dientes y con sus arrugas ara tu frente una vejez ya antigua, y entre tus áridas nalgas se abre algo así como el culo de una vaca descompuesta! Verdad es que me excita tu pecho, tus tetas fofas como las ubres de una yegua, tu vientre blando, y tus muslos flacos, empalmados a unas piernas tumefactas. Que seas muy feliz, y que encabecen tu entierro las imágenes triunfales, y que ninguna casada ande cargada de perlas más redondas. ¿Qué más da que a los librillos estoicos les guste andar tirados entre los cojines de seda de tu casa? ¿Es que por ello se han de quedar menos embotados mis tendones, que no saben de letras, y menos lánguido mi miembro? Para hacer que de mi altiva ingle se levante, tendrás que hacer un esfuerzo con la boca" (Hor. Epod. 8) ${ }^{183}$.

En este caso la animalización de la vetula, y el texto en general, sirven para resaltar la fealdad de la protagonista, la repulsión que el sujeto masculino siente hacia su cuerpo, así como para provocar la risa del público al presentar a una mujer como la nombrada tratando de resultar sexualmente atractiva. Así, se relaciona la flacidez de sus pechos con los de una yegua, animal considerado bello y presumido pero sexualmente insaciable, tanto que es capaz de copular con un asno a pesar de lo inferior de éste (Ael. 2.10), en clara alusión a las matronae que se acostaban con esclavos, actores o gladiadores (Juv. 6.85-90 y 110-114). La yegua es un animal noble, lo que indicaría el alto estatus social de la vetula descrita, pero mala esposa, ya que es poco trabajadora en el hogar y su belleza resulta una condena para el marido, al que acecha constantemente la sospecha del adulterio. Por otro lado, las referencias a la vaca, animal del que el ser humano se beneficia de múltiples formas y asociado a la fertilidad por su aportación de leche, resaltan la lujuria de la vetula así como su mal olor corporal, una constante al referirse a la vejez femenina y al señalar su pertenencia a un grupo social marginal (Potter, 2002).

En el caso del Epodo 12, al final del mismo se aprecia cómo los roles de género se invierten. Ya no es el hombre quien busca a su amante, sino que es la vetula, quien se expresa en primera persona, la que adopta el papel de animal cazador y dominante -

\footnotetext{
${ }^{183}$ Rogare longo putidam te saeculo, viris quid enervet meas, cum sit tibi dens ater et rugis vetus frontem senectus exaret hietque turpis inter aridas natis podex velut crudae bovis. Sed incitat me pectus et mammae putres equina quales ubera venterque mollis et femur tumentibus exile suris additum. Esto beata, funus atque imagines ducant triumphales tuom nec sit marita, quae rotundioribus onusta bacis ambulet. Quid? Quod libelli Stoici inter Sericos iacere pulvillos amant inlitterati num minus nervi rigent minusve languet fascinum? Qod ut superbo povoces ab inguine, ore allaborandum est tibi.
} 
perro y león- y persigue al poeta, resaltando la transgresión de la mujer y ridiculizando su deseo sexual desmedido (Meyer, 2014: 108).

No obstante, en ocasiones el vir muestra su intención de tener encuentros sexuales con la vetula de buen grado (Luc. Rhet. p. 24; Mart. 11.29), a pesar de que Horacio (Epod. 12.1-3) señale que la única manera de hacerlo sea de la forma que los romanos creían que copulaban los elefantes, espalda contra espalda. Marcial reprende a Baso porque desprecia a las jóvenes y le atraen las ancianas:

"Arrechas ante las viejas; las jóvenes, Baso, te hastían: no te gustan las guapas, sino las moribundas. ¿No hay en ello, respóndeme por favor, una locura? ¿No es la tuya una verga demente? ¡Siendo capaz con Hécuba, eres impotente con Andrómaca! (Mart. 3.76) ${ }^{184}$.

Las vetulae, especialmente las viudas, se presentan en la literatura latina como un objetivo sexual fácil, siempre dispuestas a recibir a cualquier amante, debido a que dada su elevada edad ya no pueden ser selectivas a la hora de escoger pareja o, en el caso de las prostitutas, clientes (Juv. 4.4). De esta forma, se convierten en el recurso que todo hombre tiene al alcance de la mano si busca sexo y el resto de opciones fallan (Juv. 3.109-114). En el caso de las prostitutas, además, la especial situación de vulnerabilidad que sufren por cuanto que vetulae pudo llevarlas a vivir episodios violentos debidos a la necesidad de dinero:

"Si no tiene belleza alguna, y es una vieja loba, y una prostituta, necesita dinero, y sale al paso. Ella se moverá, como si cribara el trigo con sus nalgas. La agarro y le doy mil bofetadas en la cara y en los labios a esta Zopirión, y le rompo los dientes de delante" (Lucil. 9.256-258) ${ }^{185}$.

En ocasiones el encuentro sexual entre un hombre y una vetula se produce porque la anciana aparenta ser más joven, como es el caso de Meroe:

"Reducido como estaba a una necesidad extrema, busco alojamiento en la posada de una tal Meroe, vieja pero aún de bastante buen ver, y le cuento los motivos de mi largo viaje, y las incidencias del angustioso regreso a mi hogar y del malhadado robo. La posadera me trató desde el primer momento con la mayor amabilidad que

\footnotetext{
${ }^{184}$ Arrigis ad uetulas, fastidis, Basse, puellas, nec formonsa tibi, sed moritura placet. Hic, rogo, non furor est, non haec est mentula demens? Cum possis Hecaben, non potes Andromachen!

${ }^{185}$ Si nihil ad faciem est si olim lupa prostibulumque, nummi opus, atque subit. Crisabit ut si frumentum clunibus vannat. Arripio, et rostrum labeasque hoc vociferanti percutió dentesque advorsos discutio omnis.
} 
darse puede, me ofreció una cena grata y gratuita y después, excitada por el fuego del deseo, me llevó a su alcoba" (Apul. Met. 1.7.7) ${ }^{186}$.

Por su parte, Ovidio cuenta en el Arte de amar las ventajas que tiene acostarse con una vetula debido a su experiencia y a que está deseosa de complacer al amante, aunque de nuevo se le pide que disimule lo máximo posible su edad ${ }^{187}$ :

"No preguntes qué edad tiene ni bajo qué consulado nació (atribución esa que corresponde al severo censor), sobre todo si ya no está en la flor de la vida, si ha pasado su mejor edad y se arranca ya las canas. Esta edad, ¡oh jóvenes!, tiene sus ventajas, e incluso un poco más avanzada. Ese campo dará buena cosecha: ése es, por tanto, el campo que habrá que sembrar. Mientras el vigor y la edad lo permiten, soportad las fatigas: pronto vendrá la encorvada vejez con paso silencioso. O hendid el mar con los remos, o la tierra con el arado, o poned vuestras manos guerreras en las armas fieras. O bien dedicad a las mujeres vuestros riñones, vuestro vigor y energía: también esto es una milicia, también esto procura riquezas. Añade que ellas tienen mayor pericia en la acción y poseen lo único que engendra artistas: la experiencia. Ellas arreglan con refinamiento los desperfectos de los años y consiguen con sus cuidados no parecer viejas; a tu gusto hacen el amor en mil posturas: ninguna pintura enseña más modalidades. Con ellas se experimenta el placer, sin previa provocación. El placer disfrútenlo por igual la mujer y el hombre. Odio las uniones que no satisfacen a ambos: por eso es por lo que me atrae menos el amor de un efebo; odio a la que se entrega porque es necesario entregarse, $y$, seca, piensa para sus adentros en la lana que ha de trabajar. El placer que se da por obligación no me es grato: que ninguna mujer se sienta obligada conmigo. Me gusta oír sus palabras confesándome sus goces, y que me pida que vaya más despacio, que me aguante; vea yo los ojos desmayados de mi amada fuera de sí; que desfallezca y no me deje seguir tocándola por más tiempo. Estos bienes no los concedió natura a la primera juventud, sino que suelen venir inmediatamente después de los siete lustros. Que beban mostos recientes los que tengan prisa; a mí que un cántaro embodegado en época de antiguos cónsules me escancie su vino añejo. No puede el plátano, si no es ya crecido, ser un obstáculo para Febo y los prados, cuando empiezan a brotar, pinchan los pies descalzos. ¿Acaso se podría poner a Hermione por delante de Helena? ¿Y Gorge preferible a su madre? En fin,

\footnotetext{
${ }^{186}$ Et utpote ultime adfectus ad quandam cauponam Meroen, anum sed admodum scitulam, devorto, eique causas et peregrinationis diuturnae et domuitionis anxiae et spoliationis [diuturnae et dum] miserae refero; quae me nimis quam humane tractare adorta cenae gratae atque gratuitae ac mox urigine percita cubili suo adplicat.

${ }^{187}$ Nótese que Ovidio considera maduras a las mujeres de 35 años (“inmediatamente después de los siete lustros").
} 
si quieres alcanzar una Venus entrada en años, quienquiera que seas, con sólo perseverar conseguirás la justa recompensa" (Ov. Ars am. 2.665-700) ${ }^{188}$.

Marcial parece aceptar de buen grado a la anciana Filis, aunque más que por su atractivo lo hace porque espera obtener beneficios de su relación con ella:

"Cuando, con tu decrépita diestra, empiezas a tocarme mi alicaído miembro, me siento degollar, Filis, por tu pulgar. Ya cuando me llamas «ratón», cuando «ojitos míos», creo que, con un esfuerzo, soy capaz de ponerme en forma de diez horas. Ignoras el flirteo; dime: «Te daré cien mil sestercios y te daré unas cuantas fanegas de tierra de Setia; acéptame vinos, una casa, esclavos, bandejas con oro engasado, mesas». No hacen falta los dedos: menéamela así, Filis" (Mart. 11.29) ${ }^{189}$.

Vemos en resumen cómo la sexualidad de la vetula, al igual que ocurre con su cuerpo y su aspecto físico, es un frecuente motivo de risa y repulsa en la literatura romana. Para Elizabeth Pollard (2008: 124) se trataría de un humor obsceno compartido por los hombres, especialmente los de la élite. Así, en su papel de "castigo y elemento represor de una sexualidad repugnante y un apetito erótico siempre insatisfecho, la risa masculina opera como restauradora de la humanidad, como el triunfo de la cultura sobre el apetito animal" (Nasta, 2011: 251). De esta forma, el vir clasificaba a las mujeres según fueran o no sexualmente aceptables, dándoles un modelo al que aspirar o señalando cuáles eran los comportamientos a evitar.

El humor sirve, al igual que hemos señalado que ocurre con la muerte, para abordar situaciones que de otra forma suscitan temor o desagrado, en este caso la

\footnotetext{
${ }^{188}$ Nec quotus annus eat, nec quo sit nata, require, Consule, quae rigidus munera Censor habet: Praecipue si flore caret, meliusque peractum tempus, et albentes iam legit illa comas. Utilis, o iuvenes, aut haec, aut serior aetas: iste feret segetes, iste serendus ager. Dum vires annique sinunt, tolerate labores: iam veniet tacito curva senecta pede. Aut mare remigiis, aut vomere findite terras, aut fera belligeras addite in arma manus, aut latus et vires operamque adferte puellis: hoc quoque militia est, hoc quoque quaerit opes. Adde, quod est illis operum prudentia maior, solus et artifices qui facit, usus adest:illae munditiis annorum damna rependunt, et faciunt cura, ne videantur anus. Utque velis, venerem iungunt per mille figuras: invenit plures nulla tabella modos. Illis sentitur non inritata voluptas: quod iuvet, ex aequo femina virque ferant. Odi concubitus, qui non utrumque resolvunt; hoc est, cur pueri tangar amore minus. Odi quae praebet, quia sit praebere necesse, siccaque de lana cogitat ipsa sua. Quae datur officio, non est mihi grata voluptas: officium faciat nulla puella mihi. Me voces audire iuvat sua gaudia fassas, quaeque morer meme sustineamque rogent. Aspiciam dominae victos amentis ocellos: langueat, et tangi se vetet illa diu. Haec bona non primae tribuit natura iuventae, quae cito post septem lustra venire solent. Qui properant, nova musta bibant: mihi fundat avitum Consulibus priscis condita testa merum. Nec platanus, nisi sera, potest obsistere Phoebo, et laedunt nudos prata novella pedes. Scilicet Hermionen Helenae praeponere posses, et melior Gorge, quam sua mater, erat? At venerem quicumque voles adtingere seram, si modo duraris, praemia digna feres.

${ }^{189}$ Languida cum vetula tractare virilia dextra coepisti, jugulor pollice, Phylli, tuo. Jam cum me murem, cum me tua lumina dicis, horis me refici vix puto posse decem. Blanditias nescis: "dabo" dic "tibi milia centum et dabo Setini jugera certa soli; accipe vina, domum, pueros, chrysendeta, mensas". Nil opus est digitis: sic mihi, Phylli, frica.
} 
existencia de vetulae sexualmente activas, impudicae, y que no temen a las normas sociales que les prohíben mostrar su cuerpo. Tal y como señala Amy Richlin, "it seems at least possible that invective against vetulae constitutes a sort of apotropaic satire that attempts to belittle and control the power of old women, pitting the phallus against the threat of sterility, death, and the chtonic forces" (Richlin, 1992: 113). De esta forma, dada su debilidad física y su aspecto inocuo, la risa se emplea como medio de recuperar la posición de superioridad del varón sobre la anciana, tal y como resume Apuleyo en un fragmento de Metamorfosis: “¿Es que vas a temer acaso la vigilancia de una vieja medio muerta, con la que podrás acabar de una sola coz, aunque sea de tu pie cojo?" (Apul. Met. 6.26.8) ${ }^{190}$.

Esta función se cumple incluso cuando el poeta tiene relaciones sexuales con la vetula a pesar de que la considera repugnante. Para Barbette Spaeth este tipo de episodios tienen su explicación en que "the Romans told these stories to one another at least in part to encourage each other to laugh at them, and thus to reinforce the social structures regarding the proper sexual role for a man" (Spaeth, 2010: 258). Creemos, en este sentido, que la dominación sexual a la que el vir somete a la vetula, además de una forma simbólica de rechazar la esterilidad, era también la respuesta que los romanos daban a la amenaza que constituye en las sociedades patriarcales la figura de una mujer que, al no correr riesgo de embarazo, puede vivir su sexualidad de forma más libre que la matrona fértil, sobre todo si era viuda, divorciada o soltera, y no dependía de ningún hombre. Dado que la mentalidad patriarcal romana no concebía que la mujer pudiese tener otro tipo de poder real que no fuese el erótico, ésta vía se convierte en la forma en la que atacar a la vetula. A este respecto, Dolores Mirón escribe que

"Por mucho que las fuentes alerten sobre la peligrosidad de las mujeres a través del deseo, este mensaje reiterativo acerca del poder seductor de las mujeres significa también reiterar que no hay otro poder posible para ellas. Después de todo, en el pensamiento patriarcal clásico, era mucho menos peligrosa una mujer seductora, denostada pero esencialmente femenina, que una mujer guerrera o con actividad política directa e independientemente, es decir, una mujer desarrollando papeles masculinos y, por lo tanto, lo que se consideraba el verdadero poder" (Mirón, 2010: 121).

\footnotetext{
${ }^{190}$ An custodiam anus semimortuae formidabis, quam licet claudi pedis tui calce unica finire poteris?
} 
De esta forma, las escenas de sexo entre anciana y poeta simbolizan cómo el vir es capaz de someter incluso a los seres que, aunque en apariencia son inocuos, pueden convertirse en los más marginales, peligrosos e incontrolables, poniendo fin así a la ansiedad que le genera la existencia de los mismos.

Cabe resaltar que a lo largo del último apartado nos hemos referido siempre al sexo. Salvo los textos en los que los amantes son aún jóvenes, no están presentes los sentimientos amorosos. Una excepción la encontramos quizás en Ovidio, quien aunque no habla de amor ni afecto, sí que subraya la importancia de que ambos amantes disfruten de sus encuentros.

Si bien como veremos en el siguiente capítulo las vetulae aparecen caracterizadas en la literatura como mujeres cariñosas, especialmente con los miembros más jóvenes de la familia, y gozan también del amor de quienes las rodean, la sexualidad queda al margen de estas relaciones afectivas. No sólo se anulan los deseos de las ancianas, sino que además se rechaza la posibilidad de que los hombres que se sienten atraídos por las vetulae puedan establecer con ellas otro vínculo que no sea el sexual.

\section{III.5. CONCLUSIONES}

El presente capítulo se abría con el análisis de la dimensión cronológica de la vejez femenina. Hemos mostrado cómo el ciclo vital de las romanas se percibía como diferente al de los romanos, si bien es el segundo el que más frecuentemente aparece en la literatura y se toma como experiencia universal. El ciclo vital femenino se regía, fundamentalmente, por las etapas biológicas de la reproducción, que son las que condicionan en gran medida la opinión que los textos tienen sobre el aspecto físico y la sexualidad de las vetulae. Hemos señalado también cómo las romanas alcanzaban la vejez antes que sus pares masculinos, tanto en el aspecto cronológico -50 frente a 60 años- como en el social -para Juvenal, apenas aparece la primera arruga; para Ovidio, a partir de los 35 años-, prontitud que podía deberse tanto a la diferencia de edad dentro de los matrimonios como al ideal de belleza femenino, con un cuerpo que debía ser joven, terso, sin manchas ni arrugas.

En el segundo apartado hemos abordado el cuerpo de la vetula desde la perspectiva médica. A pesar de que las fuentes escritas no muestran referencias explícitas al respecto, creemos que los profesionales de la medicina en la Antigüedad 
afrontarían de forma cotidiana los síntomas de las patologías conectadas con la vejez. Las vetulae apenas son mencionadas en los tratados de medicina, pero cuando esto ocurre son tratadas como una paciente más, sin tomar su edad como un rasgo a tener en cuenta. El análisis de las patologías relacionadas con la vejez nos ha llevado también a subrayar la importancia de profundizar en dos aspectos relacionados con el cuerpo envejecido que en ocasiones se encuentran ligados entre sí, la dependencia y el maltrato, sobre los que volveremos en el Capítulo IV.

Acercarnos a la dimensión física de la vejez ha requerido profundizar no sólo en los aspectos médicos, sino también en la apariencia externa de las vetulae y en cómo ésta condicionaba su posición en sociedad. La literatura y el arte nos han dejado testimonio de cómo los rasgos físicos relacionados con la vejez eran en Roma símbolo de un prestigio que sólo puede ganarse con el paso de los años, pero también de cómo las arrugas, las canas y la piel flácida podían convertirse en características definitorias de alteridad. Diversos escritores que cronológicamente cubren todo el periodo clásico emplearon el aspecto externo de las ancianas para contraponer su figura a la de la belleza de la puella, ridiculizar sus deseos y mostrar a sus jóvenes amantes lo cruel que puede resultar el paso del tiempo.

El estereotipo de vetula físicamente repulsiva y sexualmente activa encarna lo abyecto según lo define Julia Kristeva (1982) y lo aplican a la vejez Chris Gilleard y Paul Higgs (2011). Lo abyecto repugna, pero también fascina en cuanto que no respeta fronteras, clasificaciones, ni normas. Lo abyecto está relacionado con el asco, lo obsceno, lo hediondo, la muerte y la falta de humanidad (Figari, 2009), atributos que hemos visto que están íntimamente ligados a la forma en la que la literatura y el arte antiguos representan el cuerpo envejecido de la vetula y los deseos que provienen del mismo. La anciana se presenta como incapaz de contenerse y de controlar su cuerpo, y por lo tanto más cercana a los animales que a los seres humanos. Pero existe además otra situación en la que el cuerpo envejecido, en este caso independientemente del género, es considerado abyecto precisamente por esa falta de control. Se trata de las personas dependientes, aquellas que no dominan las habilidades físicas básicas movimiento, habla, aparato excretor, etc.- y han perdido también capacidades mentales. En ellas además se conjugan frecuentemente, en las referencias literarias, un cuerpo y una personalidad que generan desprecio y desagrado, subrayando así su marginalidad y su diferencia con respecto al vir. 


\title{
CAPÍTULO IV \\ DIMENSIONES SOCIAL Y SENTIDA DE LA VEJEZ FEMENINA EN ROMA
}

\begin{abstract}
"Se elegía a alguna pariente de edad, y a sus probadas y comprobadas costumbres se confiaba toda la prole de la misma familia. En su presencia no se permitía nada que pudiera parecer expresión grosera o acción vergonzosa. Con una virtud que infundía respeto, moderaba incluso los esparcimientos de los niños, no ya sólo sus aficiones e inquietudes"
\end{abstract}

Tac. Dial. $28.5-6^{191}$

En este capítulo abordamos la dimensión social de la vejez de las romanas e intentamos acercarnos a cómo percibían las vetulae su propia ancianidad. Comenzamos analizando los distintos roles que una vetula podía ocupar en la familia: esposa, viuda, madre, abuela, etc. Tratamos también la vida social de las vetulae, sus redes de socialización y sus actividades de ocio.

A continuación estudiamos la ingerencia de las ancianas en el ámbito económico, tanto a través de su actividad laboral como mediante acciones evergéticas.

El tercer apartado está dedicado a los estereotipos literarios de vetula: bruja, lena, anus ebria, mujer sabia y bondadosa. A ellos debemos unir la figura de la vetula de sexualidad desmedida, la cual ya se ha presentado en el capítulo anterior. Se trata de estereotipos eminentemente negativos, aunque en ocasiones también positivos, que se unen para generar una identidad común, la vetula repulsiva y alcohólica, que emplea sus poderosos conocimientos para dañar a los hombres mediante la magia.

\footnotetext{
${ }^{191}$ Eligebatur autem maior aliqua natu propinqua, cuius probatis spectatisque moribus omnis eiusdem familiae suboles committeretur; coram qua neque dicere fas erat quod turpe dictu, neque facere quod inhonestum factu videretur. Ac non studia modo curasque, sed remissiones etiam lususque puerorum sanctitate quadam ac verecundia temperabat.
} 
Finalmente, abordamos la cuestión de la vejez sentida de las vetulae. A través de documentos literarios y epigráficos, y a pesar de la falta de testimonios de primera mano, recurrimos a la Historia de las Emociones para tratar de interpretar cómo vivían las ancianas romanas su propia vejez, cómo se sentían habitando un cuerpo envejecido, y cómo les afectaba la forma en la que eran percibidas por la sociedad.

\section{IV.1. LA VETULA EN LA FAMILIA ROMANA}

La familia fue uno de los pilares sobre los que se sostuvo la sociedad romana desde sus orígenes. Son numerosos los trabajos que insisten en la importancia de la familia como institución en Roma y que la analizan desde distintos puntos de vista ${ }^{192}$. Se trata además del ámbito en el que comenzó a estudiarse a las mujeres romanas, dado su papel como reproductoras y supervisoras de los asuntos domésticos.

Dependiendo del enfoque, pueden hacerse diversas definiciones de la familia romana, las cuales pueden incluir solamente a quienes viven bajo un mismo techo o también a los parientes que viven separados, así como tener en cuenta o no las relaciones de esclavitud (Dig. 38.10.10) ${ }^{193}$. En nuestro caso, hemos decidido abordar a las esclavas ancianas dentro de este apartado, en el epígrafe en el que analizamos las relaciones no consanguíneas. Un esquema orientativo con los nombres que se daban a los diversos miembros de la familia puede encontrarse en la Fig. 37.

La historiografía que ha estudiado a la familia romana parece ponerse de acuerdo en que habitualmente sería la familia nuclear la que conviviría bajo el mismo techo (Curchin, 2000-2001: 536; Parkin, 2011b: 276; Treggiari 1991: 410-412). Según JensArne Dickmann (2011: 56-57), en una domus no podrían vivir más de dos generaciones familiares juntas, tanto por motivos demográficos como de organización espacial, si bien no podemos saber hasta qué punto la economía obligaba a las familias pobres a una realidad distinta. Es por ello que deben tenerse en cuenta posibles variables cronológicas, geográficas y económicas, como han señalado diversos autores (Dixon, 1992: 42; Edmondson, 2005; Evans, 2006: 312; Harders, 2012: 11.14).

\footnotetext{
192 Unos pocos ejemplos son George, 2005; Huebner y Nathan, 2017; Laurence y Strömberg, 2012 y Rawson, 2011.

${ }^{193}$ Sobre este aspecto, vid. Bradley, 1996: 97; Dixon, 1992: 3-5; Gardner, 1998: 1; Parkin, 2011b: 276277 y Treggiari, 1991: 410-412.
} 
Al incluir en este apartado a abuelas, tías, y otras familiares que no pertenecen a la familia nuclear, reconocemos dos hechos. Por un lado, que la realidad no tiene por qué coincidir siempre con el ideal de familia referido por las fuentes escritas y menos teniendo en cuenta que, en el caso de la literatura, aluden a una parte ínfima de la población. Así, nos encontraremos con abuelas que vivieron con sus nietas y madres que siguieron compartiendo techo con sus hijos a pesar de que éstos ya eran adultos y tenían su propia familia stricto sensu. Por otro lado, que a pesar de no compartir un hogar, las vetulae mantuvieron relaciones de afecto, económicas y políticas con sus hijas e hijos, nueras y yernos, hermanas, etc. A pesar de que la epigrafía parezca indicar que el foco de los afectos se encontraba en la familia nuclear, podemos encontrarnos ante un uso social que no siempre tiene por qué reflejar la realidad. Así lo cree, por ejemplo, Claude-Emmanuelle Centlivres (2012: 14), quien en su estudio sobre las relaciones familiares de Plinio el Joven señala que si éste se mostraba tan flexible en ellas -como veremos más adelante-, teniendo en cuenta su recta moral, es porque las variables a la familia nuclear cerrada debían ser totalmente comunes, al menos en época imperial.

Desde un punto de vista público, la familia era uno de los pilares fundamentales sobre los que se apoyó el Estado romano desde sus inicios monárquicos. La familia estaba íntimamente ligada al desarrollo histórico romano mediante diversos episodios histórico-legendarios: la disyuntiva de escoger entre esposos y hermanos de las mujeres sabinas, la violación de Lucrecia, la revuelta de Coriolano, etc. (Dion. Hal. Ant. Rom. 8.40-54.2; Liv. 1.9-13, 1.57.6-59.13 y 2.40.1-12; Ov. Fast. 3.205-225; Val. Max. 5.2.1 y 5.4.1). Era además la familia la encargada de garantizar la continuidad del Estado mediante la (re)producción de nuevos ciudadanos.

Desde un punto de vista privado e individual, la familia es una "matriz de intercambio, [y] se constituye en uno de los pilares principales de la vida psíquica de las personas. Es la base de un modelo relacional que permite crear otras relaciones. (...) Pautas, normas, funciones, mandatos, se encarnan en cada uno de sus miembros que, por oposición o similitud, se identifican con su grupo familiar. (...) Además, la familia provee a cada uno de sus integrantes un sentimiento de identidad independiente que se encuentra mediatizado, en cierta medida, por el sentido de pertenencia" (Ceberio, 2013: cap 1). 
En época romana, la familia era, al menos en lo que respecta a la norma, el entorno en el que las mujeres desarrollaban su vida y su principal propósito social, la procreación. Además, la familia supone un ámbito muy propicio para estudiar a las vetulae y la vejez en general, ya que es en ella donde de forma más evidente se aprecia la incidencia del ciclo vital de las personas. Es en el seno familiar donde se nace, se crece y se fallece, y donde más influyen las circunstancias individuales como la enfermedad, la dependencia y los acontecimientos de la vida diaria. Observando la posición de las personas viejas dentro de la organización familiar obtendremos información acerca de situaciones individuales, pero también sobre la relación con el resto de miembros del grupo, y de cómo la forma en la que las ancianas se relacionan varía dependiendo del grupo de edad con que lo hagan. No sólo podemos apreciar cuál es la posición de las vetulae en la familia, sino también cómo la estructura del grupo familiar se ve condicionada por contar con una persona anciana. Accedemos así al conocimiento de dos dimensiones de la ancianidad, la individual y la colectiva.

A lo largo del presente apartado nos acercaremos a los diversos roles familiares que podía desempeñar una vetula. Somos conscientes de que muchos de ellos exigen una perspectiva que contemple el conjunto del ciclo vital, y no sólo la vejez; para ser abuela hace falta ser madre -o madrastra-, de la misma forma que para ser una anciana que lleva más de medio siglo de matrimonio a sus espaldas hace falta haber sido una joven matrona que se casó con un hombre también joven. No obstante, nos limitaremos aquí a observar cómo era la participación en el desarrollo familiar de las vetulae, cómo interactuaban con los distintos miembros de la familia y qué implicaba ser una anciana en una familia romana.

Para este fin, haremos referencia tanto a mujeres históricas como a personajes literarios. Algunas vetulae aparecerán en varias ocasiones, en relación con los distintos roles familiares que desempeñaron; es el caso, por ejemplo, de Cornelia, Livia o Antonia Minor. Un ejemplo de estos diversos roles lo encontramos en Pompeia Ammia, quien fue conmemorada aludiendo a varias de las categorías familiares que podía ocupar una vetula:

“A Pompeia Ammia, liberta de Quinto, fallecida con 60 años. Suegra de Arellio Estrabón, madre de Arellia Sophe, abuela de Pupio Arellio Estrabón, madre de 
Lucio Arellio Segundo, madre de Lucio Arellio Optati, madre de Calenis Aeliana.

Lo puso Lucio Arelio Orentes para sí, su esposa, y los suyos" (CIL 6.5280) ${ }^{194}$.

\section{IV.1.1. Esposa $^{195}$}

En el libro octavo de Metamorfosis, el senex Lelex narra una historia en la que Júpiter y Mercurio están viajando por Frigia. Cansados, buscan asilo en diferentes casas, pero nadie los acoge, hasta que se encuentran con una pareja de ancianos que vive en una cabaña muy humilde, techada con paja, a la que no obstante se sienten apegados:

"Pero la piadosa anciana Baucis y Filemón, de la misma edad, habían pasado juntos en aquella cabaña sus años de juventud, en aquella cabaña envejecieron y, reconociendo su pobreza y soportándola con serenidad, la hicieron más llevadera.

Preguntar allí por amos o criados no sirve de nada: ellos dos son la casa entera, los mismos a mandar y a obedecer" (Ov. Met. 8.630-637) ${ }^{196}$.

Baucis y Filemón son extremadamente pobres: apenas tienen qué comer, su ropa de cama es vieja, la mesa está coja y la vajilla es humilde (Ov. Met. 6.645-670). Ni siquiera pueden poseer esclavos. A pesar de su situación, el matrimonio se comporta con sus invitados de forma generosa, ofreciéndoles todo lo que tienen (Ov. Met. 679). Los dioses, sorprendidos por la amabilidad de la pareja y deseando vengarse de quienes no los acogieron en sus casas, piden a sus anfitriones que vayan con ellos monte arriba, a donde suben ayudados por bastones y torpes por lo avanzado de su edad (Ov. Met. 694). Mientras ascienden, Júpiter y Mercurio han inundado la región, dejando solamente en pie la casa de Baucis y Filemón, la cual trasforman en un templo:

"Y mientras se admiran de lo sucedido, mientras lamentan la suerte de sus vecinos, aquella vieja choza, pequeña incluso para sus dos dueños, se convierte en un templo; las columnas han sustituido a los postes bifurcados, la paja de la techumbre amarillea y parece un techo de oro, las puertas son cinceladas y el suelo se recubre de mármoles. Entonces, tales frases dejó salir el Saturnio de su boca serena: «Decidme, anciano justo y esposa digna de un esposo justo, cuáles son vuestros deseos». Cambiando unas pocas palabras con Baucis, Filemón reveló a los dioses

${ }^{194}$ Pompeiae Q(uinti) l(ibertae) Ammiae decessit ann(os) LX socra Arelli / Strabonis mater Arelliae Sophe avia Pup(i) Arelli / Strabonis mater L(uci) Arelli Secundi mater L(uci) Arelli Optati / mater Calenis Ael(i)anaes titulum posuit L(ucius) Arellius Orentes / sibi et uxori suae et suis omnibus.

${ }^{195}$ En la Roma antigua existieron diferentes formas de uniones matrimoniales, tanto dentro como fuera de la legalidad, pero no es nuestro cometido diferenciar entre ellas. Por ello, haremos referencia a parejas de las que forme parte una vetula, independientemente de si eran o no matrimonios legales. Para profundizar en este aspecto, vid. Jeppesen-Wigelsworth, 2010 y Treggiari, 1991.

${ }^{196}$ Sed pia Baucis anus parilique aetate Philemon illa sunt annis iuncti iuvenalibus, illa consenuere casa paupertatemque fatendo effecere levem nec iniqua mente ferendo; nec refert, dominos illic famulosne requiras: tota domus duo sunt, idem parentque iubentque. 
el común acuerdo: «Pedimos ser sacerdotes y custodiar vuestro templo y, puesto que hemos vivido en concordia, que una misma hora nos lleve a los dos, y que no tenga yo que contemplar la pira de mi esposa, ni tenga ella que ocuparse de mi entierro». Sus peticiones fueron atendidas; ejercieron la custodia del templo mientras les fue concedida la vida. Debilitados por los años y la vejez, en una ocasión en que se encontraban delante de las gradas del santuario narrando lo acontecido en el lugar, Baucis vio cubrirse de hojas a Filemón, el viejo Filemón cubrirse de hojas a Baucis. Y cuando ya la copa del árbol se alzaba sobre sus dos rostros, se decían, mientras podían, frases el uno al otro; «Adiós, esposo; adiós esposa», dijeron al mismo tiempo y al mismo tiempo una rama cubrió su boca haciéndola desaparecer. Todavía los habitantes de Bitinia enseñan allí los árboles vecinos, surgidos de sus dos cuerpos. (Ov. Met. 8.695-720)"197.

La historia de Baucis y Filemón sirve para ilustrar el ideal del matrimonio romano. Ambos llevan juntos toda su vida y jamás han dejado de sentir mutuo afecto. A pesar de su extrema pobreza, parece que lo único que necesitan es estar juntos. Cuando los dioses les preguntan qué desean, contestan que quieren evitar el dolor de ver morir al otro.

Para escribir esta historia, al margen de la discusión sobre de dónde pudo Ovidio haber obtenido la idea original (Gowers, 2005: 332-334), el poeta parece haberse inspirado en un famoso y longevo matrimonio de su época, el de Livia y Augusto ${ }^{198}$. Las similitudes entre la pareja imperial y Baucis y Filemón son varias. Por un lado, el haber vivido juntos muchos años y haber alcanzado la ancianidad. Además, ambos son matrimonios sin descendencia: en Metamorfosis no se menciona que Baucis y Filemón tengan hijos ${ }^{199}$, y a pesar de que tanto Livia como Augusto aportaron hijos al

\footnotetext{
197 dumque ea mirantur, dum deflent fata suorum, illa vetus dominis etiam casa parva duobus vertitur in templum: furcas subiere columnae, stramina flavescunt aurataque tecta videntur caelataeque fores adopertaque marmore tellus. Talia tum placido Saturnius edidit ore: "dicite, iuste senex et femina coniuge iusto digna, quid optetis". Cum Baucide pauca locutus iudicium superis aperit commune Philemon: "esse sacerdotes delubraque vestra tueri poscimus, et quoniam concordes egimus annos, auferat hora duos eadem, nec coniugis umquam busta meae videam, neu sim tumulandus ab illa". Vota fides sequitur: templi tutela fuere, donec vita data est; annis aevoque soluti ante gradus sacros cum starent forte locique narrarent casus, frondere Philemona Baucis, Baucida conspexit senior frondere Philemon. Iamque super geminos crescente cacumine vultus mutua, dum licuit, reddebant dicta "vale" que "o coniunx" dixere simul, simul abdita texit ora frutex: ostendit adhuc Thyneius illic incola de gemino vicinos corpore truncos.

${ }^{198}$ Metamorfosis termina de escribirse en la primera década del siglo I d.C. (Knox, 2009: xviii); por entonces Augusto tendría cerca de 70 años, mientras que Livia tendría más de 60 y llevaría junto a él más de cuatro décadas.

${ }^{199}$ Esta omisión, así como la ausencia de prole que llore su muerte o lleve a cabo un funeral, hace pensar que el matrimonio no tuvo descendencia, o que si la tuvo murió prematuramente (Gowers, 2005: 349).
} 
matrimonio, su unión resultó estéril ${ }^{200}$. Comparten también el haber llevado una vida austera. En el caso de la historia ovidiana, ésta parece haber venido impuesta por la situación económica ${ }^{201}$, mientras que en Livia y Augusto fue una elección personal con connotaciones políticas. Augusto procuraba ser ejemplo de sobriedad y moderación (Suet. Aug. 71-72), tanto en lo que respecta a su hogar como al vestir y al alimento:

"La sobriedad de su mobiliario y de su ajuar queda patente en los lechos y mesas que se han conservado hasta nuestros días, la mayor parte de los cuales apenas serían dignos del buen tono de un particular. Según dicen, durmió siempre en una cama baja y arreglada con modestia. Rara vez utilizó otro vestido que el de estar por casa, confeccionado por su hermana, su mujer, su hija y sus nietas" (Suet. Aug. $73)^{202}$

Por su parte Livia, a pesar de que probablemente fue la mujer más rica de finales del siglo I a.C. y principios del siglo I d.C. (Cid, 2014: 189), aparece representada en la estatuaria sin joyas, y era conocida por su austeridad. Por otro lado, la inundación del valle y la transformación de la cabaña en un lujoso templo son hechos que pueden relacionarse con la obra arquitectónica de época augustea, tanto en lo que respecta a la dedicación y remodelación de templos como al resto del programa constructivo llevado a cabo por el princeps y su esposa (Ov. Fast. 1.649; Suet. Aug. 29-31). Finalmente, Ovidio resalta varias veces a lo largo de la narración la etapa vital en la que se encuentran los protagonistas. De esta forma, como señala Emily Gowers (2005), Baucis y Filemón, en cuanto que personas ancianas, son las representantes simbólicas de un pasado ideal en el que la vida se regía mediante el mos maiorum, una época de rectitud a la que intenta volver Augusto con la colaboración de Livia.

Como acabamos de resaltar, la narración de Ovidio entronca con la vuelta a la moral tradicional llevada a cabo por Augusto, y no sólo en lo que respecta a la familia; nos enfrentamos en definitiva a un relato ejemplarizante sobre cómo aquellas personas que no respetan a las divinidades son castigadas, mientras que aquellas que demuestran su devoción son premiadas. Así, vemos cómo Baucis y Filemón se muestran como exemplum de romanitas a través de varios elementos: el matrimonio duradero, la

\footnotetext{
${ }^{200}$ Tuvieron un hijo que murió al poco de nacer (Suet. Aug. 63).

${ }^{201}$ En esta pareja se encarna el mito del pobre feliz, el cual obvia la situación material en la que viven las personas pobres. En el caso de la antigua Roma, la pobreza extrema conllevaba malnutrición, enfermedades, esclavitud por deudas, mendicidad, e incluso muerte. Para otros ejemplos de este tópico, vid. Ov. Fast. 4.506-529 y 5.500-6.620.

${ }^{202}$ Instrumenti eius et supellectilis parsimonia apparet etiam nunc residuis lectis atque mensis, quorum pleraque vix privatae elegantiae sint. Ne toro quidem cubuisse aiunt nisi humili et modice instrato. Veste non temere alia quam domestica usus est, ab sorore et uxore et filia neptibusque confecta.
} 
felicidad de una vida austera, la pietas para con los dioses, la hospitalidad debida a quien pide asilo, la calidad moral de quien ante la posibilidad de pedir lo que desee escoge evitar presenciar la pérdida de sus seres queridos, etc.

En lo que respecta al ejemplo de vida matrimonial ideal, era deseable una unión longeva y fértil (Cass. Dio 56.3.3-5; Catull. 109; Mart. 4.13; Plaut. Mostell. 224-226; Tib 1.10.40-45; Verg. Aen. 4.28-29) ${ }^{203}$. El matrimonio perfecto era aquél que se vivía en armonía y duraba hasta la muerte: "Felices tres y más veces son aquellos a los que una unión no interrumpida tiene juntos, y a los que un amor no quebrado por reproches tristes no los separa hasta el supremo día" (Hor. Carm. 1.13.15-20) ${ }^{204}$. Cuando el yerno de Arria la Mayor intenta disuadirla de que se quite la vida preguntándole si, en caso de encontrarse él condenado a muerte, desearía que su hija compartiese su destino -tal y como ella desea compartir el de su esposo Peto-, ella le contesta que "si ha vivido tanto tiempo y con tanta armonía contigo como yo con Peto, lo quiero" (Plin. Ep. 3.16.10) ${ }^{205}$.

La epigrafía proporciona abundante información acerca de estas parejas. Tito Sexto Magno, fallecido en el siglo II d.C. con 95 años, realizó en vida una inscripción funeraria para sí mismo y para su esposa, Sextia Treptes, muerta a los 75 (NSA-1919338); no sabemos si se trataba de su primer matrimonio o no, pero intuimos que vivieron juntos su vejez. Un caso parecido es el de la pareja formada por Caiantia Sumaria y Caiantius Primitivus, si bien en esta inscripción no figura la edad de fallecimiento del esposo, sólo la de ella -80 años- y que él realizó el monumento en vida $(C I L 3.4755)^{206}$. A pesar de que no indican cuál es la relación existente entre ambos, Arelia Saturnina, muerta con 72 años, y Cayo Julio Rogato, con 92, parecen haber sido una pareja de ancianos ( $A E$ 1972, 776).

La larga duración de los matrimonios era utilizada en la epigrafía para ilustrar el ideal; ocurre así con Maurentia y Lupo, que vivieron juntos 50 años (CIL 3.14524), y con Aurelia y Flavio, que compartieron 35 años de vida (CIL 5.1880). En ocasiones la precisión de la duración de la pareja llega hasta los meses, como en esta inscripción del siglo I o II d.C.: “Consagrado a los dioses Manes. A Cayo Lusio Lucifero. Valeria

\footnotetext{
${ }^{203}$ Para profundizar en este aspecto, vid. Treggiari, 1991, esp. cap. 8 (pp. 229-261) y Williams, 1958.

${ }^{204}$ Felices ter et amplius quos inrupta tenet copula nec malis divolsus querimoniis suprema citius solvet amor die.

${ }^{205}$ Si tam diu tantaque concordia vixerit tecum quam ego cum Paeto, volo.

${ }^{206}$ Brent Shaw y Richard Saller (1984) creen que se trata de un matrimonio entre primos.
} 
Justina a su primer y querido esposo, con quien vivió 48 años y 10 meses. Vivió 70 años. Se lo hizo mereciéndolo a su incomparable esposo" (CIL 11.4483) ${ }^{207}$.

En otras ocasiones, la edad de la fallecida, junto con el hecho de que solamente estuvo casada con un hombre, sirven también para deducir la existencia de un matrimonio longevo:
"Consagrado a los dioses Manes. Postumia Matronila, esposa incomparable, buena madre, abuela dedicada, pudica, religiosa, trabajadora, frugal, eficiente, vigilante, solícita, mujer de un solo hombre y una sola cama, una matrona trabajadora y fiel. Vivió 53 años, 5 meses y 3 días (CIL 8.11294) ${ }^{208}$.

Se esperaba que las esposas cuidasen de sus maridos envejecidos, especialmente si tenemos en cuenta que usualmente serían cerca de una década más jóvenes que ellos (Lucil. 26.461). En Dión Casio (56.3.3-5) encontramos resumidas las características ideales que debía poseer una esposa: que fuera casta, que desarrollase su vida en el espacio doméstico y se encargase de los quehaceres de la domus, que diera al marido descendencia, que se alegrase por la buena salud del esposo y le atendiera en la enfermedad, y que supiera calmar en él el ardor de la juventud y el mal temperamento de la vejez. Eliano encontró paralelos para este comportamiento ideal en la naturaleza:

"Los alciones hembras colocan en mitad de la espalda a los machos debilitados por la vejez y así los llevan de una parte a otra. En cambio, en la especie humana las mujeres desprecian a sus maridos cuando empiezan a envejecer y, en lugar de mirarlos a ellos, dirigen su mirada hacia los jovencitos. Y los maridos beben los vientos por las mocitas, sin prestar atención alguna a las esposas entradas un tanto en años, y a estas personas que gozan del don de la razón no les da vergüenza vivir siguiendo una conducta más irracional que la que llevan los animales irracionales" (Ael. NA 7.17) $)^{209}$.

Tibulo imaginó una vejez bucólica en la que la esposa servía al senex, que disfrutaba del campo y era feliz viviendo de forma austera:

\footnotetext{
207 D(is) M(anibus) / C(aio) Lusio Lu/cifero Va/leria Iusti/na virginio / et co(n)iugi ca/rissimo cu/m $<q=O>$ uo con/vixit anni/s XLVIII me/ns(ibus) X qui vix/it annis LXX / co(n)iugi inco/mparabili b(ene) $m($ erenti).

${ }^{208} D($ is $)$ M(anibus) s(acrum) / Postumia Matronilla inco $<m=N>$ pa/rabilis coniux mater bona avia / piissima pudica religiosa laborio/sa frugi effica $\langle n=X>s$ vigilans sollicita / univir(i)a unicuba [t]otius industriae et fidei / matrona vixit annis n(umero) LIII mensibus n(umero) V diebus tribus.

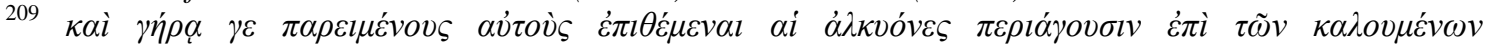

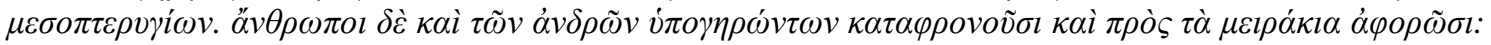

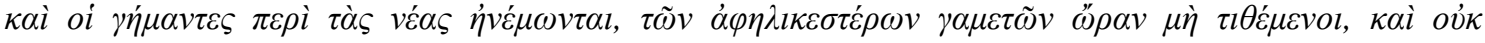

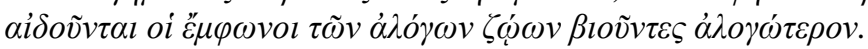


"Mucho más digno de elogio es este a quien en medio de una familia servicial le sorprende la perezosa vejez en estrecha cabaña. Él mismo va siguiendo a sus ovejas, su hijo a los corderos y a él cansado, a la vuelta, le tiene preparada agua caliente su mujer" (Tib. 1.10.40-45) ${ }^{210}$.

Un matrimonio ideal era aquél en el que la vejez no ponía fin al afecto, como ocurre en el caso de Baucis y Filemón. A este respecto, Susan Treggiari (1991: 253) llama la atención sobre el hecho de considerar las distintas formas de afecto que puede haber en una pareja: amor, atracción sexual, fidelidad, compañerismo, cariño... Marcial deseó a su amigo Pudente un matrimonio longevo caracterizado por la concordia y la atracción sexual:

"Rufo, Claudia Peregrina se casa con mi amigo Pudente: que la felicidad del cielo descienda sobre tus antorchas, oh Himeneo. Tan felizmente se une el precioso cinamomo al nardo, los vinos másicos a los panales de Teseo; y los olmos no se enlazan mejor a las jóvenes parras, ni el loto siente más ansia de las aguas, ni el mirto de las riberas. Sincera Concordia, reina perpetuamente en su lecho, y que Venus se muestre siempre favorable a esta pareja tan equilibrada. Que ella ame a su marido, un día ya anciano, pero que tampoco a su marido ella le parezca anciana ni aun cuando haya llegado a serlo" (Mart. 4.13) ${ }^{211}$.

Además de la felicidad conyugal, son dos los aspectos que queremos resaltar del pasaje de Marcial. Por un lado, que el poeta espera que Peregrina ame a su esposo cuando éste sea un senex; por el contrario, lo que desea para Pudente es que jamás vea en su mujer a la vetula en la que se ha convertido, presumiblemente fea e indeseable, para que no caiga en el error del marido del que habla Eliano. Por otro lado, que el fragmento expuesto hace referencia a un tema poco frecuente en las fuentes literarias romanas: el sexo en el matrimonio, sobre todo aquél que acontece en la vejez y que por lo tanto no tiene como fin la procreación.

El cariño aparece como un rasgo especialmente deseable dentro de la pareja, incluso por encima de la búsqueda de descendencia. El primer divorcio de la historia de Roma se dio en el año 230 a.C. (Dion. Hal. Ant. Rom. 2.25.7; Gell. NA 4.3.1). Espurio

\footnotetext{
${ }^{210}$ Quam potius laudandus hic est, quem prole parata occupat in parva pigra senecta casa. Ipse suas sectatur oves, at filius agnos, et calidam fesso conparat uxor aquam.

${ }^{211}$ Claudia, Rufe, meo nubit Peregrina Pudenti: macte esto taedis, o Hymenaee, tuis. Tam bene rara suo miscentur cinnama nardo, Massica Theseis tam bene uina fauis; nec melius teneris iunguntur uitibus ulmi, nec plus lotos aquas, litora myrtus amat. Candida perpetuo reside, Concordia, lecto, tamque pari Semper sit Venus aequa ingo: diligat illa senem quondam, sed et ipsa marito tum quoque, cum fuerit, non uideatur anus.
} 
Carvilio decidió separarse de su esposa porque era estéril, decisión que Valerio Máximo consideraba errónea:

"El divorcio entre esposa y marido no se dio en Roma hasta el año 520 de su fundación. Espurio Carvilio fue el primero que repudió a su mujer a causa de su esterilidad. Éste, aunque parecía obrar por un motivo respetable, fue duramente criticado porque se tenía la idea de que ni siquiera el deseo de tener hijos debía anteponerse a la felicidad conyugal" (Val. Max. 2.1.4) ${ }^{212}$.

Suzanne Dixon (1996: 103) señala que la idea de que el matrimonio perfecto era uno en el que existía cariño entre los cónyuges surgió a finales de la República, y que se trata de un concepto de armonía basado en el mutuo apoyo y la compañía, y en compartir el deleite por ver crecer a las próximas generaciones. La armonía, la dulzura y el cariño en la pareja son características que aparecen tanto en las fuentes literarias como en la epigrafía para ilustrar la existencia de un matrimonio feliz (Cic. Off. 1.51; CIL 9.1837 y 11.654; Hor. Ep. 2.2.133; Plut. Mor. 140E y 143A). Las cartas de Cicerón a su esposa Terencia, así como a otras personas a las que el orador habla de ella, están cargadas de afecto, al menos hasta el momento de su divorcio (Cic. Att. 1.18.1 y 3.19.3 y Fam. 14.2, 14.3, 14.5, 14.7, 14.8 y 14.14). Así, por ejemplo, le escribió lo siguiente en el año 58 a.C., durante su destierro:

"Si la fortuna nos ha reservado para la esperanza de recuperar algún bien, mi error es menor, pero si estos males son ya inamovibles, yo anhelo verte cuanto antes, vida mía, y morir en tus brazos, puesto que ni los dioses a los que tú has venerado siempre santísimamente, ni los hombres a los que yo serví toda mi vida, nos han recompensado de forma alguna" (Cic. Fam. 14.4.1) ${ }^{213}$.

Del mismo modo, la correspondencia entre Augusto y Livia también está escrita en tono cariñoso (Suet. Claud. 4). De hecho, Tácito (Ann. 5.1) criticó a Livia por ser uxor facilis, demasiado cariñosa/solícita/indulgente con Augusto ${ }^{214}$. Desde el exilio, Ovidio escribió a su esposa acerca de su deseo de cubrirla de besos (Ov. Pont. 1.4). En época republicana, el matrimonio entre Salvia y Quinto Bitínico estuvo caracterizado por una armonía de 60 años (CIL 1.1220).

\footnotetext{
${ }^{212}$ Repudium inter uxorem et uirum a condita urbe usque ad centesimum et quinquagesimum annum nullum intercessit. primus autem Sp. Caruilius uxorem sterilitatis causa dimisit. qui, quamquam tolerabili ratione motus uidebatur, reprehensione tamen non caruit, quia ne cupiditatem quidem liberorum coniugali fidei praeponi debuisse arbitrabantur.

${ }^{213}$ Quod si nos ad aliquam alicuius commodi aliquando recuperandi spem fortuna reservavit, minus est erratum a nobis; si haec mala fixa sunt, ego vero te quam primum, mea vita, cupio videre et in tuo complexu emori, quoniam neque di, quos tu castissime coluisti, neque homines, quibus ego semper servivi, nobis gratiam rettulerunt.

${ }^{214}$ Sobre los posibles significados de esta expresión, vid. Treggiari, 1991: 241-242.
} 
Para Susan Treggiari (1991: 223), este ideal de matrimonio armonioso choca con la realidad, surgiendo una tradición literaria "anti-matrimonio" que alcanzó su plenitud en época de Juvenal -como demostrarían sus sátiras-, pero que como veremos podemos rastrear ya en la República media. Este topos literario rompe con la noción de un matrimonio feliz en el que la esposa venera al marido. Apuleyo hace hablar a las hermanas de Psique de la siguiente manera sobre sus ancianos compañeros:

“«En cambio para mí, para desgracia mía, me ha tocado en suerte un marido más viejo que mi padre, más calvo que una calabaza, más enano y más endeble que un niño y que tiene toda la casa bajo llave, guardada con cerrojos y cadenas». La otra hermana prosiguió así: «Y yo tengo que aguantar a un marido baldado y doblado por el reumatismo y que, por esa razón, muy raramente rinde tributo a mis encantos. Me paso la mayor parte de mi vida dándole fricciones a sus dedos deformados y duros como piedras, quemando estas manos mías, tan delicadas, con compresas malolientes, con trapos sucios, y con fétidas cataplasmas, no representando el papel de esposa abnegada, sino, más bien, desempeñando el penoso trabajo de una enfermera»" (Apul. Met. 5.9.8 - 5.10.1-2) ${ }^{215}$.

La concordia era consideraba una importante virtud en el matrimonio, debiendo evitar las discusiones (Plut. Mor. 139D-E, 142E y 143D). Así lo señala la pareja formada por Postumia Paulina y Caravasio Secundo, que hace referencia a un matrimonio de 37 años sine quaerella (CIL 5.3710). Las desavenencias matrimoniales se solucionaban acudiendo al templo de Juno Viriplaca, donde marido y esposa se exponían sus problemas y regresaban al hogar una vez restaurada la jerarquía patriarcal. Para Valerio Máximo, esta "terapia de pareja" servía para que las mujeres recordasen cuál era su posición en el matrimonio y, como ilustra el nombre de la diosa a cuyo templo se acude, los hombres calmasen un estado que intuimos podía ser de agresividad e incluso violencia ${ }^{216}$ :

"Cada vez que tenía lugar una discusión entre marido y mujer ambos se dirigían al templo de la diosa Viriplaca, situado en el Palatino, y allí, después de decirse mutuamente lo que les venía en gana, deponían su encono interior y volvían a casa reconciliados. La diosa debe ser venerada, y no sé si también obsequiada, con

\footnotetext{
${ }^{215}$ At ego misera primum patre meo seniorem maritum sortita sum, dein cucurbita caluiorem et quouis puero pusilliorem, cunctam domum seris et catenis obditam custodientem". Suscipit alia: "Ego uero maritum articulari etiam morbo complicatum curuatumque ac per hoc rarissimo uenerem meam recolentem sustineo, plerumque detortos et duratos in lapidem digitos eius perfricans, fementis olidis et pannis sordidis et faetidis cataplasmatibus manus tam delicatas istas adurens, nec uxoris officiosam faciem sed medicae laboriosam personam sustinens...

${ }^{216}$ En esta línea se posicionan Robert Kaster (2005: 25) y Amparo Pedregal (2007: 427).
} 
nuestros más personales y mejores sacrificios como guardiana de la paz doméstica y cotidiana. Su mismo nombre expresa, sin querer herir la igualdad del mutuo amor, el honor que las mujeres han de tributar a la supremacía de los hombres" (Val. Max. 2.1.6) ${ }^{217}$.

Los enfrentamientos entre marido y esposa con muchos años de matrimonio a sus espaldas eran usados frecuentemente en el teatro con fines humorísticos. Vemos así cómo el estereotipo y la a veces contraria realidad convivieron al menos desde época republicana. El teatro retrataba a vetulae que administraban el patrimonio doméstico y no dejaban que sus esposos dilapidasen el dinero, que los controlaban y estaban siempre de mal humor, y a senes que consumían prostitución, gastaban los ahorros domésticos, trataban a sus esposas con desprecio y les mentían (Plaut. Asin. 95). Es por ello que Plauto hace declarar al senex Periplectómeno las ventajas de permanecer soltero:

"PERIPLECTÓMENO- Pues eso es una tontería, que lo que gastas con una mala mujer o con un enemigo es cosa perdida, pero en un buen huésped y un amigo son los gastos una ganancia. También lo que empleas en el culto divino es para una persona de cabeza una ganancia. Yo, gracias a los dioses, tengo lo suficiente para ofrecerte hospitalidad de buena gana; come, bebe, disfruta a placer en mi compañía, llena tu alma de optimismo: libre es mi casa, libre quiero gozar de la vida; porque yo, gracias a los dioses puedo decirlo, hubiera podido por mis riquezas casarme con una mujer rica y noble; pero mira, no tengo ganas de meter en mi casa a alguien que me esté siempre ladrando" (Plaut. Mil. 674-680) ${ }^{218}$.

Plauto emplea aquí el tópico de esposa castradora y ahorradora en extremo. Usa además la estrategia de la animalización ya referida en el Capítulo III para subrayar la irracionalidad de la esposa imaginada y lo inaguantable del matrimonio. En estos casos, la esposa se convierte en un mal necesario para garantizar la continuidad de la familia y la ciudad, un mal que en la vejez ya no es preciso y por ello suscita quejas (Cic. Fin. 5.65; Gel. NA 1.6; Lucil. 26.456; Sen. Ep. 1.9.17-18). En Asinaria de Plauto, Artemona

\footnotetext{
217 Quotiens uero inter uirum et uxorem aliquid iurgi intercesserat, in sacellum deae Viriplacae, quod est in Palatio, ueniebant et ibi inuicem locuti quae uoluerant contentione animorum deposita concordes reuertebantur. dea nomen hoc a placandis uiris fertur adsecuta, ueneranda quidem et nescio an praecipuis et exquisitis sacrificiis colenda utpote cotidianae ac domesticae pacis custos, in pari iugo caritatis ipsa sui appellatione uirorum maiestati debitum a feminis reddens honorem.

${ }^{218}$ Per. - Morus es. Nam in mala uxore atque inimico si quid sumas, sumptus est, in bono hospite atque amico quaestus est quod sumitur et quod in divinis rebus sumptumst, sapienti lucrumst. Deum virtute est te unde hospitio accipiam apud me comiter: es, bibe, animo obsequere mecum atque onera te hilaritudine. Liberae sunt aedis, liber sum autem ego: mei volo vivere. Nam mihi, deum virtute dicam, propter divitias meas licuit uxorem dotatam genere summo ducere; sed nolo mi oblatratricem in aedis intro mittere.
} 
descubre que su esposo no sólo está gastando el dinero en alcohol, sino que además se disputa los favores de una prostituta con el hijo de ambos:

“ARTEMONA - Por favor, ¿dices que mi marido está ahí de copeo con mi hijo y que le han dado a la fulana veinte minas y que el padre comete una desvergüenza tal a sabiendas de su hijo?

GORRÓN - Artemona, no vuelvas a creerme de aquí en adelante ni un pelo de nada, si es que me coges en mentira ahora.

ART. - ¡Y yo, pajolera de mí, que pensaba que tenía un marido modelo, un hombre no bebedor, una persona de mérito, ordenado, amante en extremo de su mujer!

GO. - Pues ahora sábete, que es el más pillo de todos los mortales, un borracho, un donnadie, un libertino que no puede ver a su mujer ni en pintura.

ART. - Bien sabe Dios que, si no fuera verdad todo eso que dices, no haría las cosas que está haciendo ahora.

GO. - Te juro que yo también le había tenido siempre por una persona como dios manda, pero con esta jugada, se me ha quedado al descubierto. ¡Mira que ponerse de copeo con el hijo y repartirse con él la amiga, el viejo ese decrépito!

ART. - ¡Demonio, ésas son las cenas a las que sale todas las noches! Se pone con que va a casa de Arquidemo, de Quereas, de Queréstrato, de Clinias, de Cremes, Cratino, Dinias, o Demóstenes, y lo que hace en realidad es corromper a su hijo en casa de una fulana y dedicarse a corretear locales de mala fama.

GO. - ¿Por qué no das orden a tus esclavas de que se lo lleven en volandas a casa?

ART. - ¡Espérate, te juro que le voy a hacer la vida imposible!

GO. - Ése no me cabe duda que va a ser su destino, al menos mientras estés tú casada con él.

ART. - Desde luego. Ése era el que no estaba dedicado más que a su trabajo en el senado o a atender a sus clientes y por eso luego, agotado del trabajo, se llevaba la santa noche roncando; por dar el jornal fuera es por lo que vuelve a mí cansado por la noche; el campo ajeno lo ara y el propio lo deja baldío, y además no contento con ser él un canalla, coge y corrompe también a su hijo.

GO. - Acércate conmigo por aquí, verás cómo le coges con las manos en la masa.

ART. - Te juro que no hay nada que hiciera con más gusto.

GO. - ¡Un momento!

ART. - ¿Qué pasa?

GO. - ¿Si divisaras a tu marido tumbado en el diván con una corona de flores a la cabeza y abrazado a su amiga, si lo vieras, podrías reconocerlo? 
ART. - Sí que puedo, demonio.

GO. - ¡Ea!, mira, ahí le tienes.

ART. - ¡Muerta soy!

GO. - Espera un poco; vamos a observar desde aquí a escondidas qué hacen sin que ellos nos vean.

ARGIRIPO - Padre, ¿cuándo vas a acabar de abrazarla?

DEMÉNETO - Yo te confieso, hijo mío...

ARG. - ¿El qué?

DE. - Que estoy completamente con el alma en los pies por culpa del amor de ésta.

GO. - ¿Oyes lo que dice?

ART. - Y tanto que lo oigo.

DE. - ¡Y que no le voy yo a quitar a mi mujer su mantón preferido para traértelo a

ti! Te juro que no me harían renunciar a ello ni por un año de vida de mi mujer.

GO. - ¿Crees tú que es hoy cuando ha empezado a frecuentar las casas públicas?

ART. - ¡Demonio, él era quien me estaba sisando, mientras yo sospechaba de mis esclavas y las hacía atormentar sin que fueran culpables!

ARG. - Padre, di que nos sirvan vino; ya hace mucho que me tomé la primera copa.

DE. - Sírvenos vino, muchacho, empieza por mi derecha, y tú, por mi izquierda, venga, dame un beso.

ART. - ¡Ay, pobre de mí, muerta soy, cómo la besa el maldito, el viejo, con un pie en la sepultura que está ya!

DE. - Dios mío, un aliento un poco más dulce que el de mi mujer.

FILENIO - Oye, dime, ¿es que a tu mujer le huele el aliento?

DE. - Agua sucia preferiría beber, si fuera preciso, que no besarla a ella.

ART. - ¿Te parece bonito? Te juro que te la vas a ganar por haber dicho esa injuria contra mí. Deja, vuelve a casa y verás cómo te hago saber las consecuencias que trae el hablar mal de una esposa que tiene su dote" (Plaut. Asin. 855-895) ${ }^{219}$.

\footnotetext{
${ }^{219}$ ARTEMONA Ain tu meum virum hic potare, obsecro, cum filio et ad amicam detulisse argenti viginti minas meoque filio sciente id facere flagitium patrem? PARASITVS Neque divini neque mi humani posthac quicquam accreduas, Artemona, si huius rei me mendacem inveneris. ART. At scelesta ego praeter alios meum virum frugi rata, siccum, frugi, continentem, amantem uxoris maxume. PAR. At nunc dehinc scito illum ante omnes minimi mortalem preti, madidum, nihili, incontinentem atque osorem uxoris suae. ART. Pol ni istaec vera essent, numquam faceret ea quae nunc facit. PAR. Ego quoque hercle illum antehac hominem semper sum frugi ratus, verum hoc facto sese ostendit, qui quidem cum filio potet una atque una amicam ductet, decrepitus senex. ART. Hoc ecastor est quod ille it ad cenam cottidie. ait sese ire ad Archidemum, Chaeream, Chaerestratum, Cliniam, Chremem, Cratinum, Diniam, Demosthenem: is apud scortum corruptelae est liberis, lustris studet. PAR. Quin tu illum iubes ancillas rapere sublimen domum? ART. Tace modo. ne <ego> illum ecastor miserum habebo. P. Ego istuc scio,
} 
Artemona pensaba que tenía un esposo modelo, que la suya era una relación ejemplar, pero descubre que su marido tiene un comportamiento inadecuado, especialmente para su edad. Él la desprecia y hace referencia a su mal olor -rasgo característico de las vetulae, como hemos visto en el capítulo anterior-, pero no puede divorciarse porque es ella quien tiene dinero. Por otro lado, Artemona aparece caracterizada como una mujer controladora, vengativa y severa: no duda en torturar a sus esclavas cuando sospecha que le roban dinero y, cuando descubre las actividades de su marido, decide castigarlo.

Finalmente, Lucilio nos presenta una muestra de cómo la mala relación en un matrimonio envejecido y la idea de la esposa como dominadora se usaban como justificación de la violencia por parte del marido, incluso del asesinato: "Mataré a mi mujer vieja y rijosa, antes que castrarme a mí mismo" (Lucil. 7.196) ${ }^{220}$.

No obstante, también nos encontramos con parejas de vetulae y senes que se profesaban afecto y vivían en concordia. Un ejemplo es el matrimonio formado por Livia y Augusto, en el cual siempre se mantuvo el amor (Suet. Aug. 62; Barrett, 2002: 120: Burns, 2007: 9). Augusto confiaba en el criterio de Livia con respecto a todo tipo de asuntos. Así lo refleja, por ejemplo, una carta escrita cuando ambos habían alcanzado ya la vejez, en la que le preguntaba su parecer sobre cómo debía comportarse con Claudio:
"Cumpliendo tu encargo, mi querida Livia, hablé con tu hijo mayor acerca de lo que debía hacerse con tu nieto Tiberio durante los Juegos de Marte. Los dos estamos, por otra parte, de acuerdo en que debemos decidir de una vez por todas

\footnotetext{
ita fore illi dum quidem cum illo nupta eris. ART. Ego censeo. eum etiam hominem in senatu dare operam aut clientibus, ibi labore delassatum noctem totam stertere: ille opere foris faciendo lassus noctu <ad me> advenit; fundum alienum arat, incultum familiarem deserit. is etiam corruptus porro suom corrumpit filium. PAR. Sequere hac me modo, iam faxo ipsum hominem manifesto opprimas. ART. Nihil ecastor est quod facere mavelim. P. Mane dum. A. Quid est? PAR. Possis, si forte accubantem tuom virum conspexeris cum corona amplexum amicam, si videas, cognoscere? A. Possum ecastor. P. Em tibi hominem. A. Perii. P. Paulisper mane. Aucupemus ex insidiis clanculum quam rem gerant. ARG. Quid modi, pater, amplexando facies? DEM. Fateor, gnate mi-ARG. Quid fatere? DEM. Me ex amore huius corruptum oppido. PAR. Audin quid ait? ART. Audio. DEM. Egon ut non domo uxori meae subripiam in deliciis pallam quam habet, atque ad te deferam, non edepol conduci possum vita uxoris annua. PAR. Censen tu illum hodie primum ire adsuetum esse in ganeum? ART. Ille ecastor suppilabat me, quod ancillas meas suspicabar atque insontis miseras cruciabam. ARG. Pater, iube dari vinum; iam dudum factum est cum primum bibi. DEM. Da, puere, ab summo. age tu interibi ab infimo da savium. ART. Perii misera, ut osculatur carnufex, capuli decus. DEM. Edepol animam suaviorem aliquanto quam uxoris meae. PHIL. Dic amabo, an fetet anima uxoris tuae? DEM. Nauteam bibere malim, si necessum sit, quam illam oscularier. ART. Ain tandem? edepol ne tu istuc cum malo magno tuo. Dixisti in me. sine, revenias modo domum, faxo ut scias quid pericli sit dotatae uxori vitium dicere.

${ }^{220}$ Vetulam atque virosam uxorem caedam potius quam castrem egomet me.
} 
qué criterio hemos de seguir respecto a él. Pues si es apto, por decirlo así, en todos los sentidos, ¿qué motivo tenemos para dudar en promocionarlo haciéndole pasar gradualmente por las mismas etapas que hemos hecho pasar a sus hermanos? Y si, por el contrario, pensamos que es inferior, que tiene dañadas sus facultades físicas o mentales, no hay que proporcionar a los hombres, que tienen por costumbre burlarse de estas cosas y ridiculizarlas, la ocasión de reírse no sólo de él, sino también de nosotros. (...) Ahí tienes nuestras opiniones, mi querida Livia, con las que debemos adoptar, de una vez por todas, una resolución sobre este asunto" (Suet. Claud. 4) 221 .

La buena relación existente en este matrimonio trascendió lo familiar para convertirse en ejemplo público a seguir. En el año 9 a.C. aconteció la dedicación del Ara Pacis, el monumento de Augusto dedicado a la alabanza de su familia. La celebración se realizó el 30 de enero, coincidiendo con el 49 o 50 cumpleaños de Livia, lo que pondría de manifiesto la importancia que el princeps daba a su esposa ${ }^{222}$. Cualquiera de las dos posibles edades de Livia resulta relevante; la primera es una cifra climatérica, mientras que la segunda es la que hemos establecido que hace las veces de frontera para la vejez femenina. Dos años más tarde, en el 7 a.C., Livia construyó el pórtico que lleva su nombre y un santuario dedicado a Concordia, referencia a la armonía conyugal (Ov. Fast. 1.649). Una vez dedicado el templo, organizó un banquete al que invitó a las mujeres prominentes de Roma.

En ocasiones nos encontramos no con matrimonios longevos, sino con personas que decidieron unirse siendo ya ancianas, o al menos en su madurez. En la sátira, la poesía y el teatro, estas uniones son mencionadas con fines cómicos, resaltando lo absurdo de una relación entre dos personas cercanas a la muerte y que ya no pueden procrear: "Si un hombre de más de mediana edad, se casa con una mujer de edad media, si se da el caso de que la vieja se queda en estado del viejo, ¿no crees que la criatura

\footnotetext{
${ }^{221}$ Collocutus sum cum Tiberio, ut mandasti, mea Livia, quid nepoti tuo Tiberio faciendum esset ludis Martialibus. Consentit autem uterque nostrum, semel nobis esse statvendum, quod consilium in illo sequamur. Nam si est artius, ut ita dicam, holocleros, quid est quod dubitemus, quin per eosdem articulos et gradus producendus sit, per quos frater eius productus sit? Sin autem $\dot{\lambda} \alpha \tau \tau \tilde{\omega} \sigma \theta \alpha$ sentimus eum et

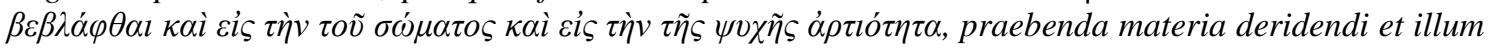

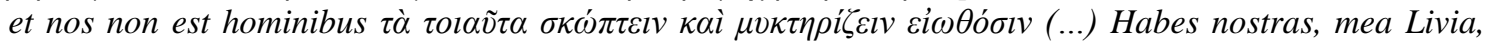
sententias, quibus placet semel de tota re aliquid constitui".

${ }^{222}$ Como fecha del nacimiento de Livia se proponen los años 59 y 58 a.C. (Barrett, 2002: xvii).
} 
recibe de todas formas el nombre de Póstumo?" (Plaut. Aul. 162-164; vid. también Var. L. 7.28$)^{223}$.

Un matrimonio entre una vetula y un senex que parece haber tenido como motivación el amor es el del ya mencionado Domicio Tulo y su esposa. Tulo, cuya situación de dependencia hemos comentado, testó de forma generosa a favor de su mujer:

"Ésta ha recibido unas hermosísimas villas y ha recibido también gran cantidad de dinero, esa esposa excelente y tan sacrificada, y que tantos más méritos había hecho ante su marido cuando más había sido criticada por haberse casado con él. Pues parecía poco decoroso que ella, una mujer de noble linaje, de una conducta ejemplar, en el ocaso de la edad, que había enviudado hacía ya mucho tiempo y de cuyo matrimonio había tenido hijos, se hubiese casado con un rico anciano y tan disminuido físicamente, que podía causar repugnancia a una esposa con la que se hubiese casado cuando era joven y estaba sano" (Plin. Ep. 8.18.8) ${ }^{224}$.

La esposa de Tulo, cuyo nombre no conocemos, se casó con él tras muchos años de viudedad, con hijos que previsiblemente se ocuparían de ella en caso de necesitarlo, y teniendo ya una edad avanzada. Además, del texto de Plinio se deduce que no pasaba apuros económicos, por lo que el dinero no parece una motivación, a pesar de que Tulo era muy rico. Esta mujer, que se arriesgaba a perder la imagen de matrona ejemplar que poseía en su entorno, decidió no obstante casarse con un hombre, no sólo anciano, sino además dependiente y de moral reprobable. Si unimos a esto la devoción que pareció sentir por él y los cuidados que le dedicó, el motivo que la empujó al matrimonio paree haber sido el amor.

Las fuentes nos hablan también de la existencia de relaciones extramatrimoniales entre una vetula y un senex. Es el caso, por ejemplo, de Cicerón y Cerelia, con quien el orador habría sido infiel a su esposa Publilia. Aunque no se sabe con seguridad, se piensa que Cerelia pertenecía a una adinerada familia ecuestre, de donde provendría su rico patrimonio (Cic. Att. 12.51 y 15.26 y Fam. 13.72; Lapini, 2016: 92). Mantuvieron una relación de amistad tan íntima que en sus cartas el orador se atrevía a expresarle abiertamente su opinión acerca del gobierno de César, y Cerelia obtuvo una copia de De

\footnotetext{
${ }^{223}$ Post mediam aetatem qui media ducit uxorem domum, si eam senex anum praegnatem fortuito fecerit, quid dubitas, quin sit paratum nomen puero Postumus?

${ }^{224}$ Accepit amoenissimas villas, accepit magnam pecuniam uxor optima et patientissima ac tanto melius de viro merita, quanto magis est reprehensa quod nupsit. Nam mulier natalibus clara, moribus proba, aetate declivis, diu vidua mater olim, parum decore secuta matrimonium videbatur divitis senis ita perditi morbo, ut esse taedio posset uxori, quam iuvenis sanusque duxisset.
} 
Finibus antes de que estuviera lista la versión definitiva (Cic. Att. 13.21a.2). Alison Jeppesen-Wigelsworth (2010: 55) sugiere incluso que Cerelia pudo haber sido mecenas de Cicerón. Dión Casio insinúa que esta relación fue más allá; puede que en ella el orador encontrase una compañera más culta que Publilia, ya que compartía con ella el interés por la filosofía y la política. Cerelia vivió alrededor de 80 años, y su amorío con Cicerón se sitúa cuando ella tiene unos 70 y él 60, una diferencia resaltable si tenemos en cuenta que él rozaba el límite de la edad considerada apta para procrear, pero ella había sobrepasado la frontera de la fertilidad hacía mucho (Austin, 1946; Salinsbury, 2001: 39). Dion Casio hace referencia a esta relación de la siguiente forma:

“¿Quién no ve los delicados mantos que llevas? ¿Quién no huele tus canas repeinadas? ¿Quién no sabe que repudiaste a tu primera mujer, que te dio dos hijos, $\mathrm{y}$, siendo ya viejísimo, tomaste otra, que era una adolescente, para pagar tus préstamos? Sin embargo, tampoco retuviste a esta, para poder tener así segura a Cerelia, con la que cometiste adulterio -aunque era una vieja tan vieja que te llevaba más años que tú a la joven aquella con la que te casaste- y a la que escribes unas cartas como las que podría escribir un hombre rijoso y deslenguado atraído por una mujer septuagenaria" (Cass. Dio 46.18.3-4) 225 .

A Dión Casio no sólo le parece escandaloso que dos ancianos mantengan una relación, en la que además parece existir atracción sexual, sino también el que Cicerón cuide su imagen para sus encuentros con Cerelia, comportándose de una forma que no corresponde a su edad. No sólo se divorcia de Terencia para buscar una esposa mucho más joven, sino que además engaña a ésta con una anciana. El rechazo que siente hacia la pareja lo vuelca sobre la vetula, de quien resalta su vejez contraponiendo su figura a la de la joven Publilia. Además, vemos en esta actitud cómo Cicerón contradice sus propias ideas sobre lo adecuado para la vejez, ya que en De Senetute su alter-ego Catón se muestra contrario a la actividad sexual en la ancianidad:

“¿Por qué cuento esto? Para que comprendáis que si no podemos rechazar la lujuria, ni con la razón, ni con la sabiduría, se ha de estar inmensamente agradecidos a la vejez que se encarga de que no gocemos de lo que no nos conviene. En efecto, el placer impide la reflexión, es enemigo de la razón, de la

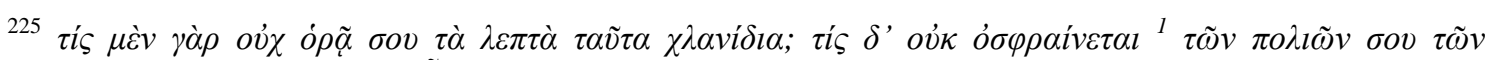

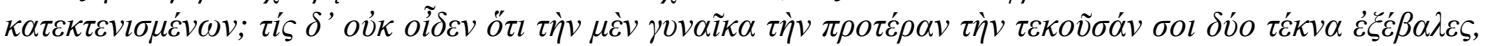

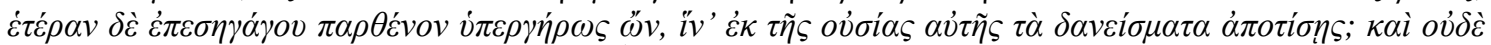

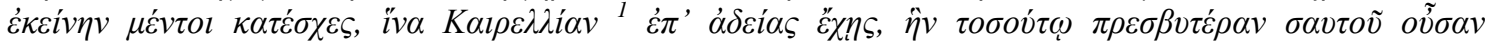

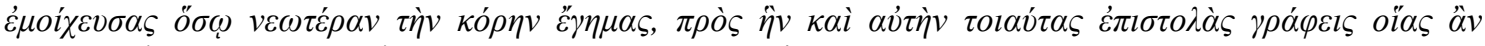

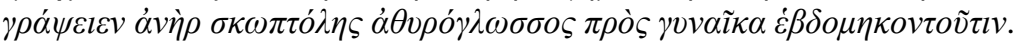


mente. Ofusca, por así decirlo, los ojos del alma, y no tiene ninguna relación con la virtud" (Cic. Sen. 12.42) 226 .

Finalmente, sabemos también de la existencia de relaciones entre una vetula y un hombre más joven que ella, ya sea dentro o fuera del matrimonio. Son parejas que generan rechazo social por romper con la moral vigente, y las muestras de amor entre ellos resultan repulsivas (Plut. Mor. 749E; Prop. 2.18). No sólo se trata de hombres que se unen a mujeres mayores que ellos, cuando lo esperado era lo contrario, sino que además las vetulae rompen con el decoro debido tanto por género como por edad, llegando a actuar de forma ridícula:

"Que los hombres son saqueados, sea como fuere, por las mujeres, ya las amen, ya sean amados por ellas, lo aprendemos, ciertamente, con ejemplos. Una mujer que no era inexperta y que disimulaba sus años yendo siempre bien arreglada, tenía atrapado a un hombre de mediana edad, cuyo corazón lo había conquistado una hermosa joven. Queriendo las dos mujeres parecerse al hombre, comenzaron, cada una por su lado, a arrancarle los cabellos. Y mientras él pensaba que las mujeres le estaban acicalando cuidadosamente, de pronto se vio calvo, pues la muchacha le había arrancado todos los cabellos canos y la vieja todos los negros" (Phaed. $2.2)^{227}$.

Si en el caso de un senex que se siente atraído por una joven el motivo suele ser la lujuria, sobre estas uniones recae además la sospecha del interés económico. Aparece aquí la figura de los captatores, personas dedicadas a complacer a vetulae y senes adinerados para que los incluyan en sus testamentos, sobre la cual incidiremos más adelante:

"Gemelo pide en matrimonio a Maronila, y la desea y la acosa y le suplica y le ofrece regalos. - ¿Tan guapa es? - Ca, no hay cosa más fea. - ¿Qué busca, pues, y le agrada en ella? - Tose" (Mart. 1.10) ${ }^{228}$.

\footnotetext{
${ }^{226}$ Quorsus hoc? Ut intellegeretis, si voluptatem aspernari ratione et sapientia non possemus, magnam habendam esse senectuti gratiam, quae efficeret, ut id non liberet, quod non operteret. Impedit enim consilium voluptas, rationi inimica est, mentis, ut ita dicam, praestringit oculos, nec habet ullum cum virtute commercium.

${ }^{227}$ A feminis utcumque spoliari viros, ament, amentur, nempe exemplis discimus. Aetatis mediae quendam mulier non rudis tenebat annos celans elegantia, animosque eiusdem pulchra iuvenis ceperat. Ambae, videri dum volunt illi pares, capillos homini legere coepere invicem. Qui se putaret pingi cura mulierum, calvus repente factus est; nam funditus canos puella, nigros anus evellerat.

${ }^{228}$ Petit Gemellus nuptias Maronillae et cupit et instat et precatur et donat. Adeone pulchra est? Immo foedius nil est. Quid ergo in illa petitur et placet? Tussit.
} 
"Un pobretón muerto de hambre se había casado con una rica y vieja: Gelio le da de comer a su mujer y se la folla" (Mart. 9.80) $)^{229}$.

Así, por ejemplo, las mujeres de la familia de Talna no veían con buenos ojos su matrimonio con Cornificia ya que, debido a su edad, lo único atractivo en ella parece ser el dinero: "Cornificia, hija de Quinto, ya entrada en años y casada varias veces; pero las mujeres no están de acuerdo, porque han averiguado que no tiene más que ochocientos mil sestercios" (Cic. Att. 13.28.4) ${ }^{230}$. Además, existían otras desventajas de casarse con una mujer madura, tanto si era soltera como si era viuda o divorciada:

"Una viuda, cuando se disuelve un matrimonio, se queda tal como había venido a él; tampoco aporta nada que no pueda reclamar, sino que viene ya desflorada de antemano por otro; además, será muy poco dócil a todo aquello que se pretenda enseñarle; no le inspirará confianza su nuevo hogar y, al mismo tiempo, ella también despertará suspicacias, por la ruptura de su anterior matrimonio. Si perdió a su marido, porque se lo arrebató la muerte, como mujer de siniestro presagio, cuyo matrimonio acarreará desgracia, no es en modo alguno deseable para esposa. Si se ha divorciado de él, entonces lleva sobre sí cualquiera de estas dos faltas: o ha resultado tan inaguantable, que ha sido repudiada, o ha sido tan insolente, que ha repudiado a su marido" (Apul. Apol. 92.8-10) ${ }^{231}$.

En este sentido, uno de los casos más conocidos es el del matrimonio entre la rica viuda Pudentila y el escritor Apuleyo, el cual tuvo lugar en el siglo II d.C. A pesar de que la edad estimada de Pudentila varía dependiendo de la referencia que usemos entre los 30 y los 60 años (Apul. Apol. 67.3 y 89.1-5; Benke, 2005: 21; Fantham, 1995: 225; Harlow, 2007: 201; Hidalgo, 2011: 217; Hunink, 1998: 284; Walcot, 1991: 17), hemos decidido tratarla como vetula debido a que es así como la presenta la acusación del caso de Apología, y que lo que nos interesa para nuestra investigación es precisamente qué pensaba la sociedad romana de una mujer madura/vieja que mantenía una relación con un hombre más joven que ella. La historia resumida de este matrimonio, relatada por el propio Apuleyo (Apol. 68.2-69.3), es la que sigue. Emilia Pudentila era una aristócrata romano-africana que en su juventud había contraído matrimonio con Sicino Amico.

\footnotetext{
${ }^{229}$ Duxerat esuriens locupletem pauper anumque: uxorem pascit Gellius et futuit.

${ }^{230}$ Cornificiam, Q. filiam, vetulam sane et multarum nuptiarum; non esse probatum mulieribus, quod ita reperirent rem non maiorem d_c_c_c_. hoc putavi te scire oportere.

${ }^{231}$ Vidua autem qualis nuptiis uenit, talis diuortio digreditur. Nihil affert inreposcibile, sed uenit iam ab alio praeflorata, certe tibi ad quae uelis minime docilis, non minus suspectans nouam domum quam ipsa iam ob unum diuortium suspectanda; siue illa morte amisit maritum, ut scaeui ominis mulier et infausti coniugii minime appetenda, seu repudio digressa est, utramuis habens culpam mulier, quae aut tam intolerabilis fuit ut repudiaretur, aut tam insolens ut repudiaret.
} 
Fruto de esa unión nacieron dos hijos, Ponciano y Pudente. Siendo ambos menores falleció Sicinio, convirtiendo a Pudentila en una rica viuda. Los hijos quedaron bajo la potestad del abuelo paterno, quien insistía a Pudentila para que se casara con el hermano de su difunto esposo, Sicinio Claro, bajo la amenaza de desheredar a sus nietos. Pudentila acabó aceptando, pero consiguió retrasar la boda lo suficiente para que el paterfamilias falleciera, quedando Ponciano, ya mayor de edad, como tutor de su hermano, y deshaciéndose el compromiso con Claro. Es entonces cuando Pudentila, tras catorce años de viudedad, manifiestó su deseo de volver a casarse:

"Liberada de tal escrúpulo, como fuera pedida en matrimonio por los hombres más importantes, decidió que no debía permanecer en su viudedad durante más tiempo; porque aunque pudiera soportar el tedio que supone la soledad, no podía, sin embargo, aguantar el malestar físico que tal situación le originaba. Esta mujer de castidad probada había soportado los largos años de su viudedad intachable sin dar lugar a habladurías; pero, privada del uso habitual del matrimonio, debilitada por la prolongada abstinencia, que iba atrofiando sus órganos, aquejada de graves trastornos de matriz, se veía a menudo al borde de la muerte, a causa de las crisis dolorosas, que la dejaban completamente extenuada. Los médicos y las comadronas estaban de acuerdo en que esta dolencia se debía a la ausencia de vida conyugal; creían, pues, que su mal iba en aumento de día en día, que su enfermedad se agravaba y que, mientras aún le quedasen algunas posibilidades por su edad, se debía poner remedio a su salud mediante el matrimonio" (Apul. Apol. 69.1-3) $)^{232}$.

Aquí Apuleyo comienza a presentarse como el salvador de Pudentila, quien finalmente la librará de los problemas histéricos, de los cuales ya hablábamos en el Capítulo III. La unión se presenta, por lo tanto, como un hecho beneficioso para Pudentila, quien en el momento de la muerte de su suegro parece ser una mujer aún fértil pero cercana a la menopausia.

Apuleyo conoció a Pudentila con cerca de 30 años, cuando durante una estancia en Oea se encontró con Ponciano, con quien había compartido estudios en Atenas. Apuleyo fue invitado a pasar un tiempo en casa de Pudentila, donde vivía Ponciano,

\footnotetext{
${ }^{232}$ Eo scrupulo liberata cum a principibus uiris in matrimonium peteretur, decreuit sibi diutius in uiduitate non permanendum. Quippe ut solitudinis taedium perpeti posset, tamen aegritudine $>m>$ corporis ferre non poterat. Mulier sancte pudica, tot annis uiduitatis sine culpa, sine fabula, assuetudine coniugis torpens et diutino situ uiscerum saucia, uitiatis intimis uteri saepe ad extremum uitae discrimen doloribus obortis exanimabatur. Medici cum obstetricibus consentiebant penuria matrimonii morbum quaesitum, malum in dies augeri, aegritudinem ingrauescere; dum aetatis aliquid supersit, nubtiis ualitudinem medicandum.
} 
quien sugirió a su amigo que contrajese matrimonio con su madre (Apul. Apol. 73.3-8). El filósofo nos presenta a una viuda perdidamente enamorada del pretendiente que le ha buscado su hijo; en cuanto a él, si bien en un principio Pudentila no parece agradarle mucho, acaba sintiéndose atraído por ella. La aparente felicidad del matrimonio duró poco, ya que la familia de Pudentila acusó a Apuleyo de haberla seducido empleando la magia, la cual habría usado también para asesinar a Ponciano, con el fin de obtener toda la fortuna de la viuda, que superaba los cuatro millones de sestercios (Apul. Apol. 67.2, 70.3, 71.4-7 y 93.2-6). El instaurador del proceso fue Sicinio Emiliano, otro de los hermanos de Sicinio Amico, que al parecer contaba con el apoyo de Herennio Rufo, suegro de Ponciano.

Son varias las ocasiones en las que Apuleyo resalta en su discurso las desventajas de casarse con una mujer ya madura y por ende poco atractiva (Apul. Apol. 27.10; 66.12; 73.3-8 y 92.3-7). El cuerpo de Pudentila y sus sentimientos se exponen ante el jurado y los asistentes para que Apuleyo pueda salir indemne. Se hace referencia a su impudicitia por ser sexualmente activa, se presentan ante el jurado las cartas que cruzó con su hijo, y se cuestiona su cordura (Apul. Apol. 67.3, 78.5, 80.1 y 82-84). El acusado se esfuerza en demostrar que Pudentila es más joven de lo que la acusación declara, ya que desea librarse de la etiqueta de captator y para la sociedad no existe otro motivo que el dinero para casarse con una vetula. No obstante, de su discurso se desprende que Ponciano pudo haber propiciado el matrimonio para asegurarse parte del patrimonio de su madre, el cual compartiría con su hermano Pudente y su amigo Apuleyo. Vemos de esta forma, tal y como resume María José Hidalgo, que

\footnotetext{
"Pudentila, tal y como se deduce de la imagen construida por su esposo el sofista, con sus luces y sus sombras, se mantiene en el límite de lo social e ideológicamente permitido. Es poderosa, toma decisiones propias, pero su visibilidad parece escasa y no deja más recuerdos a nivel social que los que su marido nos aporta por medio de su interesada memoria" (Hidalgo, 2011: 221).
}

En resumen, en el presente apartado hemos mostrado cómo la vejez no modificaba en demasía las atribuciones de una esposa romana. Si bien ya no se le exigía procrear, debía seguir siendo quien controlase los asuntos domésticos y quien se encargase de las tareas de cuidado, especialmente en el caso del marido. De éste debía ser soporte ante las posibles penurias de la vejez. Las fuentes literarias nada nos dicen de cómo se esperaba que actuasen los romanos ante las patologías y limitaciones físicas 
que podían experimentar sus esposas en la ancianidad, tarea que probablemente relegarían en otros familiares femeninos -hijas, nueras, etc.- o en el personal esclavo. Por otro lado, sin bien parece que a las romanas no debía importarles el aspecto físico de los hombres con los que se habían casado, ya que la edad les añadía el atractivo de la experiencia -si bien las declaraciones de las hermanas de Psique nos señalan que no siempre debió ser así-, a ellos se les aconsejaba que evitasen mostrar el desagrado que les producía el cuerpo envejecido de su esposa, recordándoles que siempre podían buscar consuelo en una joven y tersa prostituta.

Hemos visto cómo hubo matrimonios que cumplieron con el ideal y vivieron una vejez en armonía. En algunos de ellos probablemente se mantuvieron el amor y la atracción, si bien las fuentes literarias omiten hablar acerca de la sexualidad en la vejez como algo positivo. Junto a estos ejemplos, hemos analizado otros en los que la convivencia, ya fuera de forma habitual o puntual, no era demasiado agradable. Finalmente hemos mostrado cómo, a pesar de la norma social, en la antigua Roma el amor no tenía edad. Las uniones entre un senex y una vetula, así como entre una vetula y un hombre más joven, parecen haber formado parte de la cotidianeidad romana; no destinadas a la procreación, deben buscarse en ellas otras motivaciones como los intereses económicos y familiares o el afecto y la pasión, factor este último que, debido al edadismo, era negado en la Antigüedad.

\section{IV.1.2. Madre}

En la antigua Roma, al igual que en todas las sociedades patriarcales, el valor principal de la mujer era su capacidad de concebir y además de criar a su descendencia en el papel de madre. La relación de afecto, cuidado y obediencia entre una madre romana y su descendencia era una que seguía en pie con el paso del tiempo. Es por ello que las fuentes hablan de la pérdida de hijos e hijas como el peor mal que podía acontecerle a una madre (Apul. Met. 10.28.2; Ov. Met. 3.133-135, 6.320-323 y 6.500; Plin. Ep. 3.10; Sen. Helv. 16.2 y 18 y Marc. 16 y 19). Los hijos e hijas adultos se nos presentan como sustento de sus progenitores en la vejez y como su máximo apoyo emocional. Además, la autoridad de la materfamilias iría creciendo a medida que ésta envejecía y aumentaba el número de personas bajo su supervisión familiar. 
En este sentido, las fuentes nos han dejado muchos más testimonios de la relación entre una madre anciana y sus hijos adultos, que entre ésta y sus hijas adultas ${ }^{233}$. Ello se debe, como señalan diversas autoras (Cid, 2018: 120; Dixon, 2003: 116; Strong, 2012: 121), a que, al ser relaciones exclusivamente femeninas, quedan al margen de la conciencia masculina, y por lo tanto del interés de los escritores antiguos. Además, las referencias a las vetulae en su maternidad suelen hacerse en base a un protagonista masculino, su hijo, empleando a la madre como justificación del buen comportamiento de su descendencia, o como correctora de sus malas acciones. Nos enfrentamos, por lo tanto, a un sesgo de género en la documentación disponible, el cual condiciona los resultados de nuestra investigación.

Uno de los episodios que mejor muestra la importancia de la figura de la madre anciana en la historia de Roma tiene como protagonistas a Veturia y su hijo Coriolano. El episodio, acontecido hacia el año 488 a.C., ha quedado reflejado en diversos autores de entre los siglos I a.C. y III d.C. (Cass. Dio 5.18.8-11; Liv. 2.40.1-12; Plut. Cor. 4 y 23-37; Val. Max. 1.8.4, 5.2.1 y 5.4.1), si bien quien más información propociona es Dionisio de Halicarnaso (Ant. Rom. 8.40-54.2) ${ }^{234}$. Coriolano, reconocido general romano que había sido expulsado de Roma, se había aliado con el ejército volsco y machaba contra la Urbs. Tras varios intentos fallidos de convencerle de firmar la paz, una mujer de nombre Valeria decidió crear una comitiva de matronae encabezada por Veturia y Volumnia, madre y esposa de Coriolano respectivamente ${ }^{235}$. Veturia aceptó la propuesta de Valeria, no sin objetar que era poco lo que podía hacer, en tanto que mujer:

"Habéis recurrido a una esperanza débil y flaca, Valeria: la ayuda de nosotras, las infelices mujeres, que, aunque tenemos buena disposición hacia nuestra patria y la voluntad de salvar a los ciudadanos, sean como sean, carecemos de la fuerza y del poder para hacer lo que queremos" (Dion. Hal. Ant. Rom. 8.41.1) ${ }^{236}$.

El grupo de mujeres marchó al campamento de los volscos y, tras un emotivo encuentro entre madre e hijo, Veturia pidió a Coriolano que firmase la paz con Roma,

\footnotetext{
${ }^{233}$ Por ejemplo, son numerosos los excelentes estudios que han puesto de manifiesto la importancia de las madres en la política romana, tanto en la obtención de poder para sus hijos como en el uso de la maternidad como vía desde la que obtener prestigio para sí mismas (Cid, 2014; Hidalgo, 2003 y 2009 entre otros).

${ }^{234}$ Para un estudio en profundidad de la historia de Veturia y Coriolano, vid. Redondo-Moyano, 2016.

${ }^{235}$ En Plutarco Volumnia es la madre de Coriolano y Vergilia la esposa.

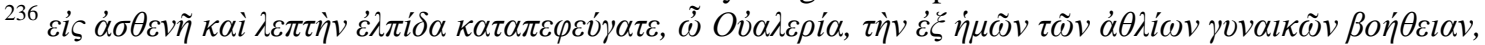

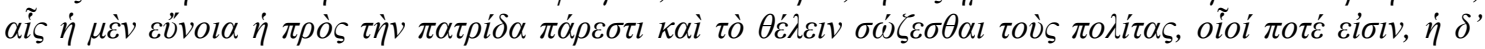

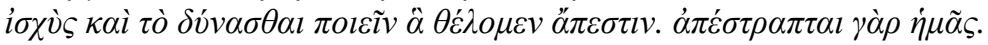


ya que de lo contrario la desgracia se cerniría sobre la ciudadanía romana y sobre sí misma:

"Así que, o bien con tu propia mano me sacrificas a las Furias a mí, tu madre, que me opongo a ti, y emprendes entonces la guerra contra tu patria, o bien, avergonzándote ante la impureza del matricidio, cedes ante tu madre y le concedes voluntariamente este favor. (...) Cuando tu padre te dejó huérfano, me encargué de ti, que eras un niño pequeño, y por ti permanecí viuda y sufrí pacientemente los trabajos de tu crianza, siendo para ti no sólo madre, sino también padre, nodriza, hermana y todo lo mas querido. Cuando te hicieste un hombre, aunque me era posible, entonces, liberarme de las preocupaciones casándome con otro hombre, criar otros hijos y depositar muchas esperanzas sustentadoras de mi ancianidad, no quise, sino que permanecí en el mismo hogar y me contenté con la misma vida, centrando en ti sólo todos mis placeres y ganancias, en los que, en parte involuntaria, en parte voluntariamente, me defraudaste y me hiciste la más desgraciada de todas las madres. (...) Y mi vida de después, si también a ésa hay que llamarla vida, desde que te marchaste dejándome sola a mí a y estos niños, se ha consumido en esta inmundicia y en estos gastados vestidos de luto. A cambio de todo esto te pido este favor, yo, que nunca te resulté una carga, no lo seré en el futuro, mientras viva: que te reconcilies con tus conciudadanos ya, y dejes de guardar ese rencor implacable contra tu patria, y con esto pido obtener un bien común para nosotros dos, no para mí sola" (Dion. Hal. Ant. Rom. 8.51.2-52.2) 237. $^{237}$

En el discurso de Veturia se aprecia cómo las madres exigían en ocasiones a sus hijos que cumplieran con la pietas debida, recurriendo para ello tanto al cuerpo reproductor y proveedor de alimentos como al esfuerzo económico y afectivo que supone la crianza. Veturia, en quien la vejez viene marcada en su mismo nombre y que es denominada "mujer de avanzada edad" (Liv. 2.40.2) ${ }^{238}$, aparece caracterizada por una

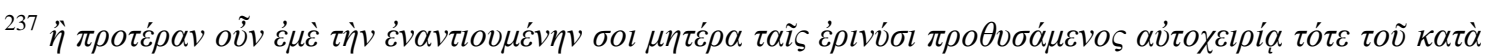

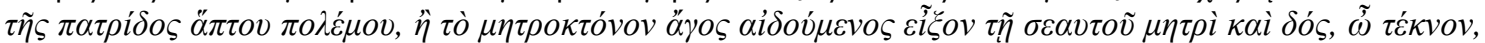

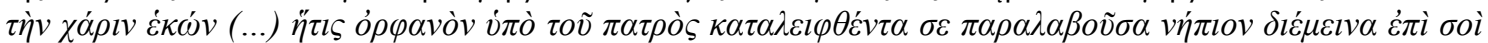

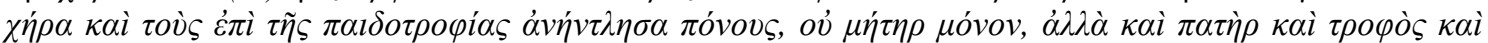

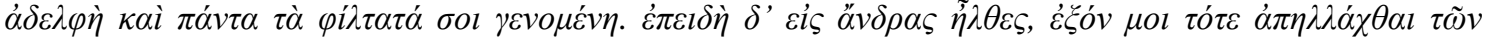

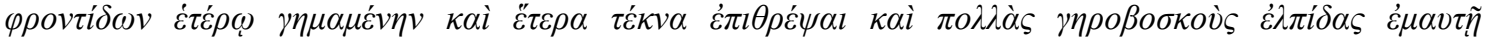

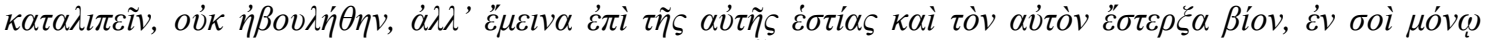

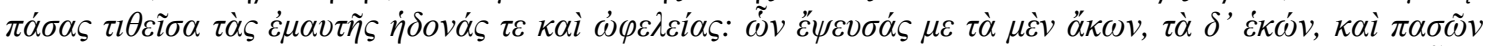

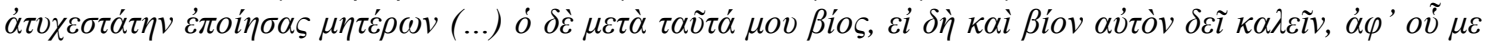

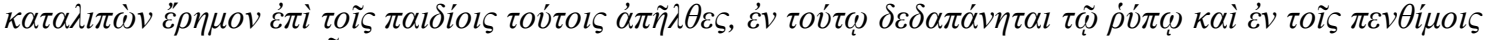

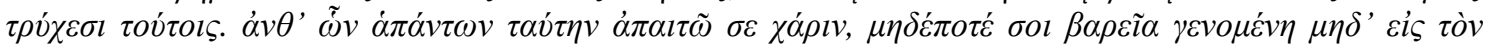

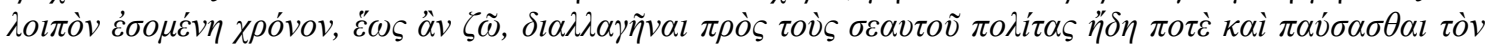

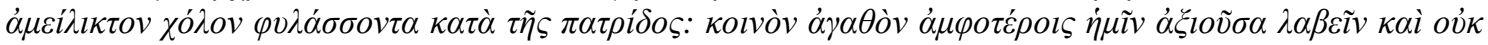

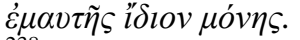

${ }^{238}$ magno matu mulier.
} 
auctoritas típica de la madre romana, que además va incrementándose a medida que ésta envejece. Es retratada como una mujer sabia, conocedora a la perfección de la situación política del momento y de la historia de Roma. Es al mismo tiempo firme y compasiva, recordando a Coriolano la importancia de la romanitas pero sin olvidar el amor que siente por él. Por su parte, el hijo también se muestra emocionado al ver a su madre, tratándola con los honores propios de los magistrados, apresurándose a abrazarla, reconociendo su error y asegurándole que a pesar de que parta hacia el destierro no perderá el contacto con ella ni con el resto de su familia. Vemos también cómo, ante la ausencia del paterfamilias, la responsabilidad de mantener la familia recae sobre ambas mujeres, Veturia y Volumnia, en calidad de abuela y madre de los hijos menores de Coriolano.

Siglos después del episodio de Veturia, Cornelia reprendía a su hijo Cayo por las decisiones políticas que había tomado, temiendo que corriese la misma suerte que su hermano Tiberio, cosa que acabó ocurriendo en el año 121 a.C. En una carta conservada por Cornelio Nepote, cuya autenticidad es objeto de discusión (Dixon, 2007: xiii; López López, 2008), Cornelia escribía a Cayo lo siguiente:

"Me atrevería a jurar con toda solemnidad que, con excepción de los asesinos de Tiberio Graco, no ha habido enemigo que me haya causado tanto malestar y sufrimiento como tú con todas estas cosas, siendo así que era obligación tuya ocupar el lugar de todos los hijos que he traído al mundo anteriormente, y poner el mayor empeño en que mi vejez transcurra lo más libre posible de preocupaciones y por el contrario procurar que todos tus actos me sirvieran de felicidad, considerando además como un acto de impiedad obrar en contra de mi voluntad, sobre todo tratándose de asuntos de gran importancia y encontrándome como me encuentro al borde mismo de la muerte. ¿Ni siquiera saber que me resta tan corto tiempo de vida te impide seguir siendo un enemigo mío y una ruina para el Estado? ¿Cuándo se pondrá fin a todo esto? ¿Cuándo se acabará este delirio en nuestra familia? ¿Llegará alguna vez el día en que se ponga freno a esta demencia? ¿Dejaremos alguna vez de tener y de provocar rencillas? ¿Llegaremos alguna vez a sentir vergüenza de involucrar al Estado en todo tipo de perturbaciones? Mas si no te es posible evitar todo esto, una vez que yo haya muerto, trata de obtener el tribunado; por mí podrás hacer todo lo que te parezca, cuando yo no tenga ya capacidad para sentir" (Nep. Fr. 2) ${ }^{239}$.

\footnotetext{
${ }^{239}$ Verbis conceptis deierare ausim, praeterquam qui Tiberium Gracchum necarunt, neminem inimicum tantum molestiae tantumque laboris, quantum te ob has res, mihi tradidisse: quem oportebat omnium
} 
Fueran o no estas palabras escritas por Cornelia, se aprecia en ellas la influencia que las madres romanas podían tener en sus hijos adultos. Una actitud que además no se consideraría reprochable, ya que Cornelia se convirtió en modelo de esposa, viuda y madre, encarnando en el imaginario romano a la perfecta matrona: fue una esposa ejemplar, tuvo 12 hijos -sólo una hija y dos hijos llegaron a la edad adulta-, criándolos y educándolos tanto a ellos como a sus nietos, y se encargó de que sus hijos alcanzaran una notable posición política y de que su hija se casase con un hombre influyente, beneficiando a toda la familia. La carta nos dice, además, cómo la sociedad romana esperaba que los hijos cuidasen de sus madres ancianas y cómo estas vetulae no dudaban en reprochar a su descendencia los quebraderos de cabeza inherentes a la crianza, resaltando la autoridad de la figura materna y reivindicando su derecho de sentirse orgullosas de haber criado a hombres que cumplían con su cometido político y familiar. Por otro lado, se aprecia cómo en ambos discursos las madres emplean su edad como forma de convencer a sus hijos, bien sea buscando en ellos compasión, o como forma de reforzar su autoridad.

El republicano Ático mantuvo una estrecha relación con su madre Cecilia, fallecida con 90 años. Cuando se encontraba lejos de ella parece haber mostrado interés por su estado, como se deduce de las noticias que al respecto le envía Cicerón (Att. 1.7 y 1.8). Por ello, Cornelio Nepote convierte a Ático en ejemplo de pietas:

"Y de la piedad de Ático, ¿qué más puedo traer al recuerdo? Yo mismo le vi enorgullecerse durante los funerales de su madre, a la que había perdido a la edad de noventa años, de que durante sesenta y siete no había tenido necesidad de reconciliarse con ella y de no haber estado nunca en rivalidad con su hermana, que era casi de su misma edad. Esto demuestra que entre ellos nunca hubo ningún disgusto, o que fue tan indulgente con los suyos que llegara a pensar que era un sacrilegio dejarse llevar de la ira contra aquellos a quienes estaba obligado a amar" (Nep. Att. 17) ${ }^{240}$.

eorum, quos antehac habui liberos, partis [eorum] tolerare atque curare, ut quam minimum sollicitudinis in senecta haberem, utique, quaecumque ageres, ea velles maxime mihi placere, atque uti nefas haberes rerum maiorum adversum meam sententiam quicquam facere, praesertim mihi, cui parva pars vitae superest. Ne id quidem tam breve spatium potest opitulari, quin et mihi adversere et rem publicam profliges? Denique quae pausa erit? Ecquando desinet familia nostra insanire? Ecquando modus ei rei haberi poterit? Ecquando desinemus et habentes et praebentes molestiis insistere? Ecquando perpudescet miscenda atque perturbanda re publica? Sed si omnino id fieri non potest, ubi ego mortua ero, petito tribunatum: per me facito quod lubebit, cum ego non sentiam.

${ }^{240}$ De pietate autem Attici quid plura commemorem? Cum hoc ipsum vere gloriantem audierim in funere matris suae, quam extulit annorum XC, cum esset VII et LX, se numquam cum matre in gratiam redisse, numquam cum sorore fuisse in simultate, quam prope aequalem habebat. Quod est signum aut nullam 
De las palabras de Nepote se desprende que, si bien en alguna ocasión Cecilia pudo tener con Ático alguna desavenencia, como les ocurrió a Cornelia y Veturia con su descendencia, en este caso el hijo procuró no traicionar la pietas debida a su madre y no crear un conflicto.

En cuanto a la relación entre las vetulae y sus hijas, Suzanne Dixon cree que las visitas entre ambas serían frecuentes:

"The married daughter visiting her mother might seek and provide advice. A mother, no matter how wealthy and influential, might need the daughter's solace in widowed old age, as much as an indigent widow needs the material support of her adult children" (Dixon, 1992: 140).

Esta misma autora sugiere que, durante ausencias más o menos prolongada de los esposos, las matronae irían a vivir con sus madres (Dixon, 1990: 217). En las fuentes literarias las hijas sirven a las madres como únicos soportes en una vejez marcada por la pobreza y la dependencia -ya sea física, económica o emocional. Como ejemplo podemos tomar este episodio narrado por Plinio el Viejo y acontecido hacia el año 150 a.C. ${ }^{241}$ :

"A una mujer humilde de la plebe y, por eso, desconocida, que acababa de parir, estando su madre encerrada en la cárcel para sufrir suplicio, como, después de haber conseguido la entrada, el portero siempre la echaba antes de que le diera algo de comida, la cogieron alimentándola a sus pechos. Por este hecho digno de admiración su piedad fue recompensada con la salvación de su madre, y ambas recompensadas con alimentación perpetua y, además, aquel lugar fue consgrado a la diosa Piedad" (Plin. NH 7.36) ${ }^{242}$.

El mismo episodio es referido por Valerio Máximo:

"Perdonadme, vetustísimos hogares, y vosotros, fuegos inextinguibles, si desde el sacratísimo templo de Vesta he de pasar, dentro del entramado de mi obra, a un lugar que en Roma resulta más indispensable que honroso. La tierna piedad filial no puede ser envilecida, ni por la más negra suerte, ni por alguna inmundicia; más aún, se manifiesta con más pujanza cuanto más tristes son las circunstancias. En

umquam inter eos querimoniam intercessisse aut hunc ea fuisse in suos indulgentia, ut, quos amare deberet, irasci eis nefas duceret.

${ }^{241}$ Un caso similar, pero entre una hija y su padre anciano, lo cuenta Valerio Máximo (5.4.ext.1).

242 Pietatis exempla infinita quidem toto orbe extitere, sed romae unum, cui comparari cuncta non possint. humilis in plebe et ideo ignobilis puerpera, supplicii causa carcere inclusa matre cum impetrasset aditum, a ianitore semper excussa ante, ne quid inferret cibi, deprehensa est uberibus suis alens eam. quo miraculo matris salus donata pietati est, ambaeque perpetuis alimentis, et locus ille eidem consecratus deae, c. quinctio m. acilio cos. Templo pietatis extructo in illius carceris sede. 
cierta ocasión, un pretor entregó a un triunviro, para que la ejecutara en la cárcel, a una mujer de condición libre que había sido condenada por su tribunal a sufrir la pena de muerte. El jefe de los guardianes de la cárcel a quien se la entregaron, movido de compasión no la estranguló inmediatamente, sino que le concedió permiso a la hija de la encarcelada para entrar y estar con ella, no sin antes haberla registrado cuidadosamente, no fuera que introdujera consigo algún alimento. El carcelero creía que la mujer moriría enseguida de inanición, pero, como pasaran ya muchos días sin que hubiera fallecido, comenzó a preguntarse cuál sería el motivo por el que había logrado sobrevivir durante tanto tiempo. Examinó a la hija con más atención y pudo advertir cómo ésta, con su seno al descubierto, amamantaba a su propia madre para aliviar su desfallecimiento por hambre. La novedad de un hecho tan extraordinario fue referida al triunviro por el mismo carcelero, por el triunviro al pretor, por el pretor al consejo de los jueces y éste fue el motivo de que la mujer quedara totalmente libre de su pena. ¿Hasta dónde no se introduce o qué medios no excogita la piedad filial que es capaz de encontrar un ardid tan novedoso para salvar la vida de una madre encarcelada? ¿Qué puede haber más inusitado e inaudito que ver a una madre alimentada a los pechos de sus propia hija? Alguno podía pensar que éste es un hecho que va contra la naturaleza, si la primera ley de la naturaleza no fuera la de amar a los padres" (Val. Max. 5.4.7) ${ }^{243}$.

Unas madres que necesitaban de su prole para sobrevivir son las vetulae que prostituían a sus hijas, un fenómeno analizado en profundidad por Anise Strong (2012), quien responde a la pregunta de por qué una prostituta querría tener descendencia aludiendo a la seguridad que ello les aportaría en la vejez:

"Prostitutes, particularly given their lack of a larger family structure, must have desired protection and support in their old age as much as anyone else in antiquity. This anxiety about the need for geriatric care would have been particularly cogent for prostitutes given their short career spans. (...) Since marriage was rarely an option, and other women's work -like waving- relatively unprofitable, the main

\footnotetext{
${ }^{243}$ Ignoscite, uetustissimi foci, ueniamque aeterni date ignes, si a uestro sacratissimo templo ad necessarium magis quam speciosum urbis locum contextus operis nostri progressus fuerit: nulla enim acerbitate fortunae, nullis sordibus pretium carae pietatis euilescit, quin etiam eo certius quo miserius experimentum habet. Sanguinis ingenui mulierem praetor apud tribunal suum capitali crimine damnatam triumuiro in carcere necandam tradidit. quo receptam is, qui custodiae praeerat, misericordia motus non protinus strangulauit: aditum quoque ad eam filiae, sed diligenter excussae, ne quid cibi inferret, dedit existimans futurum ut inedia consumeretur. cum autem plures iam dies intercederent, secum ipse quaerens quidnam esset quo tam diu sustentaretur, curiosius obseruata filia animaduertit illam exerto ubere famem matris lactis sui subsidio lenientem. quae tam admirabilis spectaculi nouitas ab ipso ad triumuirum, a triumuiro ad praetorem, a praetore ad consilium iudicum perlata remissionem poenae mulieri impetrauit. quo non penetrat aut quid non excogitat pietas, quae in carcere seruandae genetricis nouam rationem inuenit? quid enim tam inusitatum, quid tam inauditum quam matrem uberibus natae alitam? putarit aliquis hoc contra rerum naturam factum, nisi diligere parentis prima naturae lex esset.
} 
retirement option for older prostitutes was to become a madam and live off a share of the earnings of younger, more attractive women. The easiest way to find such apprentices was to bear them and raise them" (Strong, 2012: 124).

Son varios los ejemplos literarios que tenemos de este tipo de relaciones madrehija. En La Cestita de Plauto, la vieja prostituta Sira recuerda constantemente a su hija Gimnasio y a los espectadores lo necesarios que son para ella los beneficios económicos que obteniene prostituyendo a su hija, quien parece estar de acuerdo con su actitud (Plaut. Cist. 105 y 120-145). Siglos después, Luciano recreaba una situación parecida en el diálogo entre Cróbile y su hija Corina, en el que la madre intenta convencer a la hija de que se haga prostituta:

“CRÓBILE. - Así será. Pero escucha de mi boca los consejos acerca de lo que tienes que hacer y cómo tienes que comportarte con los hombres. Pues no tenemos nosotras otro medio de vida, hija. ¿Es que no sabes de qué mala manera hemos ido viviendo estos dos años desde que murió tu bendito padre? Cuando él vivía teníamos de todo en cantidad suficiente. Pues trabajaba como herrero y tenía una gran fama en el Pireo y puedes aún oír a la gente jurar que después de Filino ya no habrá otro herrero. Tras su fallecimiento, entregué las tenazas y el yunque y el martillo por dos minas, minas de las que comimos siete meses. Luego fui saliendo adelante a duras penas, bien tejiendo, bien moviendo la rueca, bien haciendo girar el huso. Y te iba dando de comer, hija, poniendo en ello mis esperanzas.

CORINA. - ¿A la mina te refieres?

CR. - No, sino que echaba cuentas de que al llegar ya a esta edad me alimentarías y te las arreglarías con facilidad y te harías rica y tendrías vestidos de púrpura y criadas. (...)

CR. - Sobre todo con estos últimos, hija; esos son sin duda los que más pagan. Los guapos quieren pagar con su cara bonita. Y tú preocúpate siempre de la ganancia si quieres que en breve todas señalándote con el dedo digan: ¿No ves a Corina la hija de Cróbile, cómo nada en la abundancia y cómo ha hecho a su madre la mujer más feliz del mundo? ¿Qué dices? ¿Lo harás? Lo harás, ya lo sé y aventajarás de buen corro a todas las demás. Ahora vete a bañarte por si llega a casa hoy también el jovencito Éucrito, que te lo tenía prometido" (Luc. Dial. Meret. 6.1-2) ${ }^{244}$.

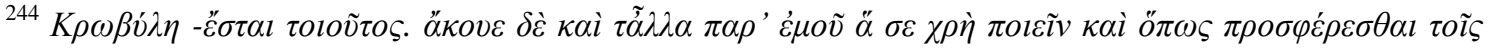

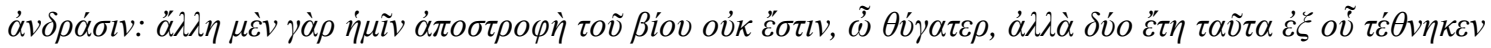

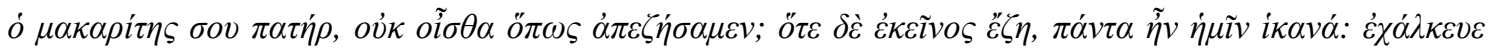

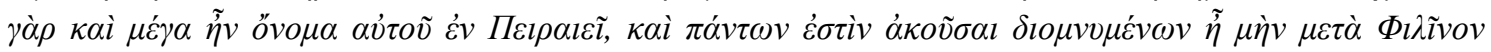

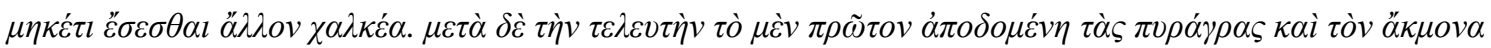


Coincidimos con Anise Strong (2012: 126) cuando señala que estos episodios, que hacen referencia a una realidad de pobreza femenina, estaban pensados al mismo tiempo para hacer reír al público masculino de la élite viendo cómo una madre pedía a su hija, no que se casase y fundase una familia, sino que se entregase a múltiples hombres. Estas referencias satisfacían así el deseo sexual de los varones, al tiempo que incidían en el estereotipo de vetula avariciosa, dispuesta a cualquier cosa por dinero. Es por ello que, en la última parte del diálogo de Luciano, la madre ya no se contenta con que su hija gane lo suficiente para cubrir las necesidades básicas de ambas, sino que aspira al lujo y al exceso, característica propiamente femenina.

Contamos finalmente con un caso tardío, del siglo IV d.C., proveniente de Egipto, que refuerza la realidad de las situaciones humorísticas descritas. Teodora, una mujer viuda o soltera, que vivía en extrema pobreza, había vendido a su hija como prostituta ( $B G U$ 4.1024, 2.6-8). Uno de sus clientes, al parecer celoso de que se viera con más hombres, asesinó a la hija de Teodora, por lo que la vetula decidió apelar a las autoridades y pedirle al asesino una indenmización, ya que el dinero obtenido de la prostitución era su única fuente de recursos. Finalmente, el asesino fue ajusticiado y Teodora recibió una décima parte de sus posesiones.

Por otro lado, a pesar de que no poseemos información al respecto, es probable que esta situación en la que las madres ancianas necesitaban del trabajo de sus hijas, y también del de sus hijos, no se limitase a quienes ejercían la prostitución, sino que se diera en general en la población trabajadora, actuando la descendencia como soporte económico y de cuidados de las vetulae.

Todos estos ejemplos nos han servido para ver cómo, a diferencia de lo que ocurría en el caso masculino, donde las madres ancianas buscaban el éxito de sus hijos y el orgullo y el prestigio que ello les acarreaba a ellas, en las hijas parecen exigir cuidados más cotidianos y materiales, de mantenimiento vital, como comida, ropa, o

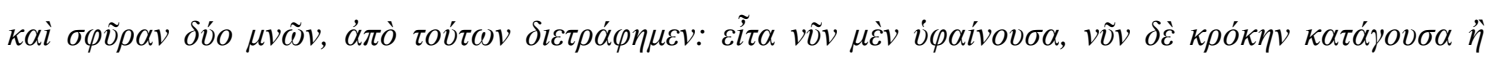

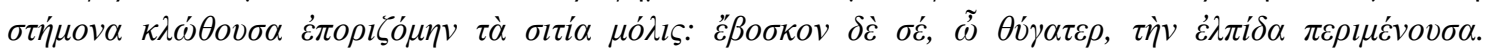

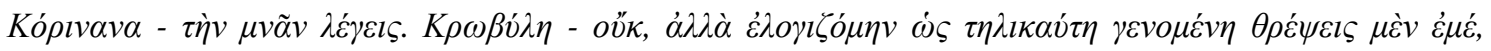

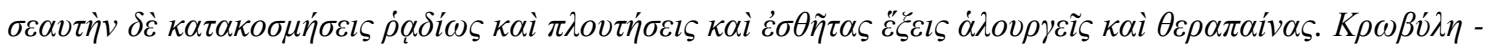

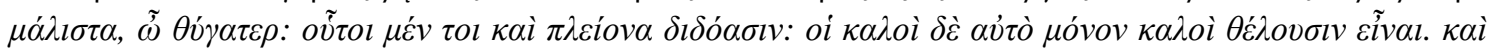

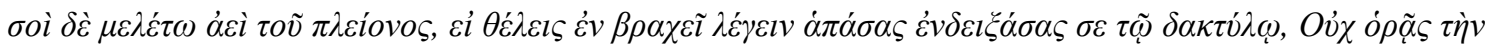

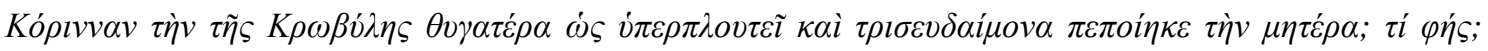

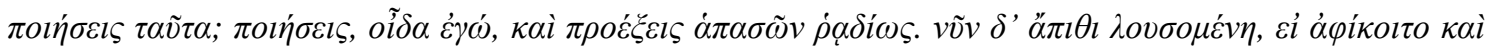

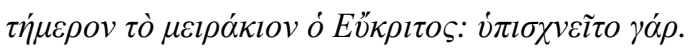


dinero. Se trata de un tipo de relación que se aprecia tanto en el caso de la éite como de mujeres socialmente marginadas como las prostitutas. Puede que ello sea indicio de la existencia de una relación más estrecha con ellas que con sus hermanos, pero también de la tradicional atribución femenina de las tareas de cuidado.

Los papiros del Egipto romano nos presentan múltiples casos de vetulae viudas de entre los siglos I-III d.C. que vivían con sus hijas e hijos, como el de Tatithoes (60), Esersythis (70) y Sentaos (75) (BF 11-Ar-1; BF 171-Pr-14; BF 117-Ar-6). En ocasiones, habitaban en casas cuya propiedad poseía la vetula. Kronous, de 78 años, vivía en su propia casa junto a un hijo de 46 años y la esposa y el hijo de éste, una situación que llevaba sucediendo al menos desde que la cabeza de familia tenía 64 años (BF 117-Ar12 y $B F$ 131-Ar-12). La vetula Tasoucharion, de 74 años, acogió en su casa a una hija (56), dos hijos (46 y 56), y una nieta (6) (BF 201-Ar-9).

Pruebas de la estrecha relación entre las madres romanas y su descendencia las encontramos también en la epigrafía. En el registro epigráfico las inscripciones que conmemoran a madres son frecuentes, ya que son los hijos e hijas los dedicantes naturales, tanto por la norma social como porque en ocasiones se ven obligados a hacerlo por testamento, como le ocurre a Cecilio Saturnino, hijo y heredero de Claudia Rogata, fallecida con 75 años ( $A E$ 1981, 934). Maturo dedica una inscripción a su padre, fallecido con 80 años, y a su madre, aún viva, de la misma edad ( $A E$ 1906, 117). Flavia Venusta, fallecida en África con 123 años, es conmemorada por su familia (CIL 8.11494), y Seccia, fallecida con 60 años, por su esposo y sus hijos (CIL 3.1243); de su epitafio se deduce que, o bien nos encontramos ante un matrimonio en el que el esposo es más joven, o bien él también había alcanzado la ancianidad.

Las inscripciones dedicadas a madres ancianas nos muestran a mujeres de todos los estratos sociales y provenientes de todas las regiones del imperio romano. En el año 299 d.C. Aelia Secundula, cristiana fallecida con 75 años, es recordada en un largo epígrafe -lo que sugiere que bien ella o bien su familia tenían una economía holgadaque la caracteriza como sobria y nutrix (CIL 8.20277). La verna Sura, quien alcanzó los 60 años, es conmemorada por su hijo (CIL 3.2800). Julia Beronice dedica un epitafio a sus dos progenitores, ambos libertos, Julia Tyche y Lucio Julio Laurencio, fallecidos con 70 y 50 años respectivamente (ERAE 294). De este caso destaca que Julia Tyche, liberta de Julia Valeria, fue propietaria de su esposo, a quien manumitió. Por otro lado, estos son sólo unos pocos de los muchos ejemplos que pueden recogerse en un rastreo 
preliminar de las fuentes epigráficas, y una ínfima parte de los que surgirían al realizar un estudio exhaustivo de las mismas.

No obstante, la literatura también nos ofrece testimonios de madres que tienen una mala relación con su prole. En ocasiones las madres incluso aparecen como causantes de las desgracias de sus hijos, normalmente movidas por el resentimiento o la envidia. Un ejemplo lo encontramos en un episodio ocurrido en el año 52 d.C.:

"En el consulado de Fausto Sila y Salvio Otón es condenado al exilio Furio Escriboniano, bajo el alegato de que especulaba por medio de adivinos caldeos sobre el fin del príncipe. Se implicaba en la acusación a su madre Vibia, a la que se imputaba el no soportar con paciencia su suerte anterior, pues había sido relegada” (Tac. Ann. 12.52.1) $)^{245}$.

Tiberio despreciaba abiertamente a su madre Livia, un odio que se acrecentó en la vejez de ésta, impidiendo que tras la muerte de Augusto se le concediese el título de Madre de la Patria y no visitándola durante un largo periodo de enfermedad (Suet. Tib. 50; Tac. Ann. 1.14). La aversión que sentía hacia Livia pudo ser una de las causas, según Tácito, de que Tiberio decidiera retirarse al campo siendo ya un senex: "Se dice asimismo que había sido empujado por la intemperancia de su madre, a la que no quería como compañera en el reinado y de la que no podía librarse por haber recibido el reinado mismo como regalo de ella" (Tac. Ann. 4.57) ${ }^{246}$. No obstante, a pesar de esta mala relación Livia debió ejercer sobre su hijo una gran influencia, o al menos infundirle respeto, ya que según Tácito fue tras su muerte cuando "la dominación de Tiberio se hizo ya brutal y agobiante. Pues mientras vivió Augusta quedaba todavía un refugio, porque Tiberio tenía un respeto inveterado a su madre y ni Sejano osaba anteponerse a su autoridad" (Tac. Ann. 5.3) ${ }^{247}$. Es el propio Tácito (Ann. 2.71.2) quien nos habla de cómo Livia y Tiberio confabularon juntos para organizar la muerte de Germánico en el 19 d.C., cuando Livia tenía casi 80 años. En el asunto se vio implicada

\footnotetext{
${ }^{245}$ Fausto Sulla Salvio Othone consulibus Furius Scribonianus in exilium agitur, quasi finem principis per Chaldaeos scrutaretur. adnectebatur crimini Vibia mater eius, ut casus prioris (nam relegata erat) impatiens. pater Scriboniani Camillus arma per Dalmatiam moverat; idque ad clementiam trahebat Caesar, quod stirpem hostilem iterum conservaret. neque tamen exuli longa posthac vita fuit: morte fortuita an per venenum extinctus esset, ut quisque credidit, vulgavere. de mathematicis Italia pellendis factum senatus consultum atrox et inritum. laudati dehinc oratione principis qui ob angustias familiaris ordine senatorio sponte cederent, motique qui remanendo impudentiam paupertati adicerent.

${ }^{246}$ Traditur etiam matris impotentia extrusum quam dominationis sociam aspernabatur neque depellere poterat, cum dominationem ipsam donum eius accepisset.

${ }^{247}$ Ceterum ex eo praerupta iam et urgens dominatio: nam incolumi Augusta erat adhuc perfugium, quia Tiberio inveteratum erga matrem obsequium neque Seianus audebat auctoritati parentis antire.
} 
Munacia Plancina, esposa de Calpurnio Pisón e íntima amiga de Livia, quien fue condenada a muerte pero salvada por la Augusta.

Otro ejemplo de actitud reprochable para con una madre ya anciana lo encontramos en Pudente, hijo menor de Pudentila. En un principio su relación parece haber sido muy estrecha. Vivieron juntos hasta la muerte de Ponciano, y Pudentila tenía con él la suficiente confianza como para hablarle de sus sentimientos amorosos (Apul. Apol. 84.7.1 y 98.1), pero cuando Pudente pasó a vivir con su tío la actitud hacia su madre cambió, y Apuleyo lo acusó de inmiscuirse en su intimidad:

“Eres capaz acaso de husmear qué es lo que hace en la intimidad de su alcoba, no digo una cortesana, sino cualquier otra mujer e incluso tu propia madre? ¿No vas a respetar en ella absolutamente nada, ni siquiera su condición sagrada de madre, que es algo único? ¡Ojalá no hubiera sido fértil tu vientre, Pudentila! La esterilidad habría sido preferible a concebir hijos semejantes. ¡Oh, los diez meses infaustos de gravidez! ¡Oh, catorce años de una viudedad que nadie te agradece! La víbora, según tengo entendido, sale reptando a la luz de la vida, tras haber devorado el seno de su mare, y de ese modo, nace gracias a un parricidio: en cambio, a ti, Pudentila, te prodiga los más crueles mordiscos un hijo ya adulto, mientras aún estás viva y lo estás viendo. Se hace la disección de tu silencio, se desgarra tu pudor, se escarba en tu corazón, se sacan a la luz pública los más íntimos secretos de tus entrañas. ¿Esta es la gratitud con la que recompensas, como un hijo piadoso, a tu madre, por haberte dado la vida, por haberte consguido una herencia, por haberte criado y educado durante catorce largos años?" (Apul. Apol. 85.4-7) ${ }^{248}$.

La actitud que Pudente tenía con ella hizo que, estando muy enferma, Pudentila decidiera hacer testamento y desheredarlo. No obstante, Apuleyo la disuadió de que lo hiciera, según declaró él mismo en el juicio (Apul. Apol. 99.3).

Una relación materno-filial que siempre se nos presenta como poco cordial es la de la madrastra y sus hijastras e hijastros. La madrastra encarnaba a la mujer ambiciosa, que buscaba ampliar su patrimonio a través de la unión con un rico viudo o divorciado, y que para ello debía eliminar al resto de herederos. Ante la mirada de las brujas que pretendían matarlo para emplear su cuerpo como ingrediente de sus hechizos, un niño

\footnotetext{
248 Tune quid in cubiculo agat perquiris, ne mater tua non dico amatrix, sed ne omnino femina sit? <Nihil> ne tu in ea cogitas nisi unam parentis religionem? O infelix uterum tuum, Pudentilla, o sterilitas liberis potior, o infausti decem menses, o ingrati XIIII anni uiduitatis! Vipera, ut audio, exeso matris utero in lucem proserpit atque ita parricidio gignitur; at enim tibi a filio iam adulto acerbiores morsus uiuenti et uidenti offeruntur. Silentium tuum laniatur, pudor tuus carpitur, pectus tuum foditur, uiscera intima protrahuntur. Hascine gratias bonus filius matri rependis ob datam uitam, ob adquisitam hereditatem, ob XIIII annorum longas alimonias?
} 
delaraba lo siguiente: “¿por qué me miras como una madrastra o como una fiera atacada con la espada?" (Hor. Epod. 5) $)^{249}$.

Las madrastras malvadas de la literatura llegaron a recurrir a la magia para deshacerse de sus esposos, quedarse con la herencia, y acabar con la armonía familiar:

"Tal vez, lector quisquilloso, te meterás con mi relato y formularás la siguiente objeción: si eras un borrico (todo lo listo que se quiera) encerrado entre las cuatro paredes de un molino, ¿cómo podías enterarte de lo que esas dos mujeres habían fraguado, según dices, en el mayor secreto? Pues bien, vas a ver cómo el hombre muy despierto que habita bajo esta apariencia animal llegó a conocer todo cuanto se ideó contra la vida de mi molinero. A eso del mediodía se presentó de pronto en el molino una mujer con el atuendo de los acusados y desfigurada por una indecible tristeza: vestida a medias con míseros andrajos, los pies desnudos por completo; su palidez igualaba la del boj; horriblemente demacrada; su cabellera canosa, alborotada y manchada de ceniza, le caía por delante tapándole casi totalmente el rostro. En estas condiciones pasa suavemente su brazo por la espalda del molinero, como si tuviera que contarle algún secreto; lo arrastra hacia su habitación, donde permaneció largas horas con la puerta cerrada. Pero, como entretanto se había terminado el trigo que los obreros estaban moliendo y había que pedir más, los esclavos de antecámara se pusieron a llamar al dueño y a reclamarle una tarea suplementaria. Después de llamar a voz en grito una y otra vez sin que el amo diera la menor respuesta, se ponen a golpear fuertemente la puerta y, como estaba muy bien sujeta por las barras, empezaron a temer lo peor; de un violento empujón, haciendo saltar el gozne o rompiéndolo, logran por fin abrirse paso. La mujer no aparece por parte ninguna, y se encuentran con el amo colgado de una viga, estrangulado y ya sin aliento. Le sueltan la soga que tenía al cuello y lo sacan de allí; entre los más angustiosos suspiros y los más vivos lamentos, le administran las últimas abluciones. Y, cumplidos esos deberes fúnebres, acompañan a la sepultura en nutrido cortejo. Al día siguiente acudió su hija, que vivía casada en una aldea cercana. Llegó angustiada, dando tirones a su cabellera suelta y golpeándose el pecho con ambas manos. Nadie le había dado noticias de la catástrofe familiar, pero estaba enterada de todo porque, en sueños, se le había aparecido su padre en lamentable estado -todavía llevaba el nudo atado al cuello- y le había revelado en detalle la conducta criminal de su madrastra, con sus infidelidades y sus maleficios; además también le explicó cómo había sido él mismo víctima de un fantasma y conducido a los infiernos. Después de atormentarse largo rato y hartarse de llorar,

${ }^{249}$ quid ut noverca me intueris aut uti petita ferro belua? 
la intervención de sus familiares acabó de calmar su dolor. A los ocho días, cumplidos ya junto a la sepultura los solemnes ritos fúnebres, sacó a subasta toda la herencia: esclavos, muebles y animales." (Apul. Met. 9.30-31) ${ }^{250}$.

Vemos cómo esta malicia propia de las madrastras se contrapone a la figura de la madre anciana, caracterizada por la dedicación hacia su prole. En su papel de madres, las vetulae se nos presentan como mujeres preocupadas por el bienestar familiar, tanto en lo que respecta a los aspectos más cotidianos, como la comida y el vestido, como a otros relativos a la reputación y el poder político. Dispuestas a dar todo cuanto tienen por su descendencia, no obstante también exigen de ella el cumplimiento de la pietas. Y, cuando lo hacen, emplean como arma su estadio vital, tanto como forma de generar compasión como de expresar su autoridad, así como de recordar a sus hijas e hijos que los sacrificios que hicieron por ellos cuando eran jóvenes matronae, al parirlos, criarlos y educarlos, deben ser correspondidos procurándoles una vejez tranquila y haciendo que se sientan orgullosas de sus acciones.

\section{IV.1.3. Abuela}

En la actualidad, los abuelos y abuelas, y especialmente las segundas, son las personas preferidas para cuidar de nietas y nietos en ausencia de los padres. Ello se debe a tres motivos principales: son personas que tienen experiencia en el cuidado, están cercanas a los progenitores y les unen a ellos lazos afectivos, y realizan el trabajo de forma altruista. Además, se trata de personas ya jubiladas, y que aparentemente tienen menos obligaciones y más tiempo libre que otros miembros de la familia. Las personas ancianas se convierten así en sustentadoras familiares y, a cambio, se dice de ellas que reciben el amor incondicional de quienes están a su cargo, y que ello es compensación

\footnotetext{
${ }^{250}$ Vnde autem tu, astutule asine, intra terminos pistrini contentus, quid secreto, ut adfirmas, mulieres gesserint scire potuisti? Accipe igitur quem ad modum homo curiosus iumenti faciem sustinens cuncta quae in perniciem pistoris mei gesta sunt cognovi. Diem ferme circa mediam repente intra pistrinum mulier reatu miraque tristitie deformis apparuit, flebili centunculo semiamicta, nudis et intectis pedibus, lurore buxeo macieque foedata, et discerptae comae semicanae sordentes inspersu cineris pleramque eius anteventulae contegebant faciem. Haec talis manu pistori clementer iniecta, quasi quippiam secreto conlocutura, in suum sibi cubiculum deducit eum et abducta fore quam diutissime demoratur. Sed cum esset iam confectum omne frumentum, quod inter manus opifices tractaverant, necessarioque peti deberet aliud, servuli cubiculum propter adstantes dominum vocabant operique supplementum postulabant. Atque ut illis (iterum et) saepicule [et inter] vocaliter clamantibus nullus respondit dominus, iam forem pulsare validius, et, quod diligentissime fuerat oppessulata, maius peiusque aliquid opinantes, nisu valido reducto vel diffracto cardine, tandem patefaciunt aditum. Nec uspiam reperta illa muliere vident e quodam tigillo constrictum iamque exanimem pendere dominum, eumque nodo cervicis absolutum detractumque summis plangoribus summisque lamentationibus atque ultimo lavacro procurant, peractisque feralibus officiis, frequenti prosequente comitatu, tradunt sepulturae.
} 
suficiente por unos esfuerzos que no deberían corresponder con la etapa vital en la que se encuentran.

El rol de la abuela cuidadora parece haber llegado a nuestros días desde la Antigüedad. Según un estudio realizado por Ville Vuolanto (2017) en el Egipto romano, ante la ausencia temporal o permanente de los progenitores, las escogidas para cuidar a los hijos e hijas eran las abuelas, incluso por encima de otros parientes masculinos que podrían parecer una opción más natural en un sistema patrilocal como el romano. Cabe entonces preguntarse si este cuidado era voluntario o impuesto, y qué relación se establecía entre la abuela y la persona a su cargo.

La epigrafía nos deja algunos ejemplos de nietas y nietos que conmemoraron a sus abuelas, en soledad o junto a más familiares, así como de la situación inversa ( $A E$ 1975, 388 y 1994, 466; ASP 2004, 117,5; CIL 2.813, 6.9720, 8.3944 y 8.26736). Por señalar algunos ejemplos: Cornia Faustina dedicó una inscripción a su avia María Faustina, fallecida con 75 años (AE 2013, 1925), Publio Aelio hizo lo propio con su avia Ulpia Martina, fallecida con 80 años (CIL 3.4336), y Julia Helice y Rufina conmemoraron a Clodia Rufina, su avia y matertera, respectivamente (CIL 2.4352). Podemos ver en estas inscripciones la existencia de relaciones de afecto, o al menos de respeto a las obligaciones familiares.

Este fenómeno se aprecia también en la literatura. Los nietos y nietas eran considerados un consuelo en la vejez, especialmente si los hijos e hijas habían fallecido (Plin. Ep. 1.12.3, 8.10 y 8.11; Sen. Marc. 16 y Helv. 18). El vacío provocado por las ausencias podía así llenarse con las risas infantiles y la relación de cariño que se establecía entre la abuela y su nieta o nieto. La avia de Ático lo apreciaba tanto que según Cicerón (Att. 1.3) murió de nostalgia por su ausencia.

Algunas abuelas se hicieron cargo de sus nietas y nietos de forma permanente, debido a la muerte de sus progenitores o a que tres generaciones de una misma familia convivían en la misma casa. Por ejemplo, Suzanne Dixon (2007: 24) cree que la tardorrepublicana Cornelia se hizo responsable de los hijos de Tiberio y Cayo tras su muerte, contando con Sempronia como ayuda para su crianza. Lo mismo parece haber ocurrido en el caso de Umidia Cuadratila, a quien nos referiremos más adelante. Livia supervisó la crianza de sus nietos y bisnietos, tarea que tras su muerte asumió Antonia Minor (Suet. Calig. 10). En otros casos, sin embargo, la situación parece ser temporal, 
debida a la ausencia de la madre y el padre. En el año 117 d.C. Eudaimonis escribía una carta a su nuera Aline, quien parece estar a punto de dar a luz (P. Brem. 63) ${ }^{251}$. En ella, Eudaimonis da cuenta de cómo progresa en los estudios su nieta, hija de Aline, quien está a su cargo. No sabemos cuántos años tenía Eudaimonis cuando escribe la carta (quizás aún no fuese una vetula), pero sí que ejercía el papel de abuela cuidadora mientras su nuera y su hijo estaban ausentes, supervisando la educación de su nieta. En otra carta escrita también por ella, enviada en este caso a su hijo Apolonios, Eudaimonis hace referencia a otra nieta de la que está cuidando (P. Giss. 21), y en una tercera se preocupa por la salud de los nietos que no están con ella (P. Giss. 23). En una cuarta carta, enviada por la ya mencionada Aline a Tetes, la esclava de confianza de Eudaimonis, la emisora muestra su preocupación porque su hija Heraidous, que se encuentra bajo el cuidado de la abuela, no le envía saludos en la carta que ha escrito a su padre (P. Giss. 78); puede que en este caso Heraidous se sintiese más unida a la abuela con la que convivía que a la madre a la que no veía.

Al igual que Eudaimonis, las fuentes nos presentan a otras aviae que se encargaron de la educación de sus nepotes. Este papel lo ejerció, por ejemplo, Cornelia Publiana, y así lo hizo constar su nieto en su epitafio (CIL 6.1478). Normalmente, este cuidado sería compartido con los esclavos y esclavas domésticos o con personal a sueldo. Así lo atestiguan las inscripciones en las que la abuela y la nutrix conmemoran juntas a una niña o niño fallecidos (CIL 6.20938). En otras ocasiones, los epítetos avia y nutrix se refieren a la misma mujer, indicando que se trata de abuelas que cuidaron de sus nietas o nietos desde su infancia, probablemente en ausencia de la madre. Es el caso de Postumia Paulina -a cuyo matrimonio en concordia ya hemos aludido-, aviae et nutrici de Cavarasia Faustina (CIL 5.3710), así como el de Claudia Berus. La inscripción relativa a esa última se encontró en la necrópolis de Isola Sacra (Roma), y ha sido datada en época de Claudio o Nerón (Laes, 2015: 100). En ella, esta vetula de posible origen egipcio y cerca de 70 años (Laes, 2015: 106) es conmemorada de la siguiente forma: "Consagrado a los Dioses Manes. A Claudia Berus, la más dulce avia y nutrix. Se lo hicieron, bien mereciéndolo, sus nietos Tiberio Claudio Máximo y Claudia Matrona" (AE 2007, 298) ${ }^{252}$.

\footnotetext{
${ }^{251}$ Sobre la familia de Eudaimonis, vid. Goñi, 2015: 201 y ss.

${ }^{252}$ D(is) M(anibus) / Cl(audiae) Beruti / aviae et nutri/ci suae dulcis/sime Ti(berius) Cl(audius) Ma/ximus et Cl(audia) Ma/trona nepotes / eius melius / merenti / fecerunt. La edad de la muerte de Claudia Berus, que no aparece en su epitafio, es inferida por Christian Laes (2015: 105-106) en base a cálculos generacionales.
} 
Los lazos afectivos que surgían de estas situaciones se mantienen en el tiempo; así, Vespasiano siempre tuvo un enorme cariño a su abuela Tértula, el cuál sobrevivió a la muerte de la avia:

"[Vespasiano] fue educado por su abuela Tértula en su finca de Cosa. Por este motivo, incluso cuando ya era emperador, visitó con mucha frecuencia este su lugar de nacimiento, e hizo que la casa permaneciera tal y como había sido en otro tiempo, para que en su visita pudiera seguir recreando con todos los objetos que le eran familiares; honró asimismo la memoria de su abuela con especial reverencia, llegando incluso a beber siempre en su pequeña copa de plata los días solemnes y festivos" (Suet. Vesp. 2) ) $^{253}$.

Las abuelas aparecen como las encargadas de transmitir las normas morales, empleando para ello una mezcla de severidad y cariño, que aparece como típica de las aviae. No obstante, en ocasiones la cercanía de la abuela y la excesiva indulgencia de ésta podían tener consecuencias negativas; así, Dión Casio escribe que Livia y Antonia empeoraron la situación de Claudio:

"No obstante, no fue tanto por estas flaquezas por las que se pervirtió como por los libertos y las mujeres con los que se relacionaba. Pues de forma más evidente en el caso de sus pares, él fue manejado por sus esclavos y por sus mujeres. Pues se crió desde la infancia entre enfermedades y grandes miedos, y por esto fingía ser más estúpido de lo que en realidad era; lo que él mismo llegó a admitir ante el Senado. Durante mucho tiempo vivió con su abuela Livia y, más tarde, con su madre Antonia, y con sus libertos. Además, siempre mantuvo un trato muy estrecho con las mujeres. Y así no adquirió ninguna virtud propia de un hombre libre de modo que, aunque él era quien gobernaba sobre todos los romanos y sus súbditos, estaba sometido a esclavitud" (Cass. Dio 60.2.4-5) ${ }^{254}$.

No obstante, al margen de la animadversión que Dión Casio parece sentir por las mujeres de la familia imperial, la mayoría de referencias a las abuelas en las fuentes literarias son positivas, especialmente cuando los escritores hablan en primera persona:

\footnotetext{
253 educatus sub paterna avia Tertulla in praediis Cosanis. Quare princeps quoque et locum incunabulorum assidue frequentavit, manente villa qualis fuerat olim, ne quid scilicet oculorum consuetudini deperiret; et aviae memoriam tanto opere dilexit, ut sollemnibus ac festis diebus pocillo quoque eius argenteo potare perseveraverit.

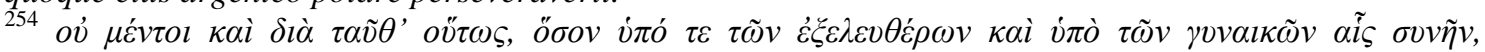

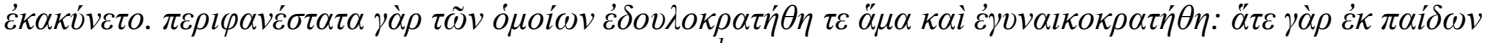

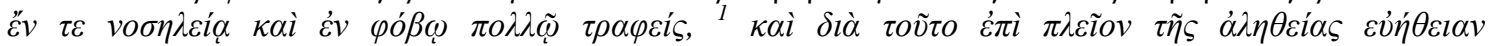

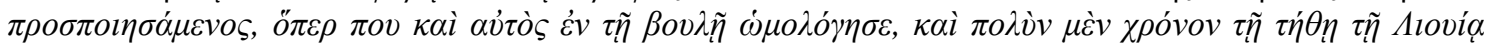

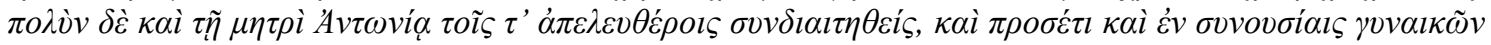

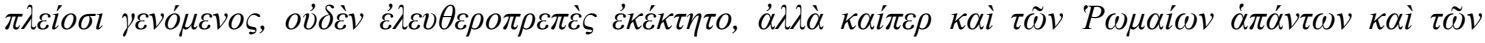
$\dot{v} \pi \eta \kappa o ́ \omega v \alpha \dot{\tau} \tau \tilde{\omega} v \kappa \rho \alpha \tau \tilde{\omega} v \varepsilon \dot{\varepsilon} \delta \varepsilon \delta o v ́ \lambda \omega \tau o$.
} 
"Emilia Corintia Maura, mi abuela. Habla ahora, cumplidora de atención de un nieto, de la abuela Emilia, que fue la esposa del recién recordado Arbonio. El nombre se le dio de broma: porque tiempo atrás fue llamada "la Mora" entre sus compañeras por su tez morena. Pero no era ella negra de corazón, que lo tenía más claro que el cisne y más blanco que la nieve virgen. Y nada propicia a perdonar los placeres vergonzantes, mantuvo a los suyos y a sí misma más derechos que una plomada. Ella fue la que con palabras blandas me llenó de austeros consejos, sacándome de la cuna y del pecho de mi madre. Proporcionad, Manes eternamente tranquilos, unas cenizas sosegadas a mi abuela, si es que soy capaz de hablar lleno

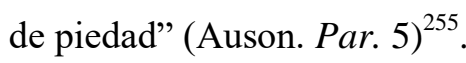

Emilia, la abuela materna de Ausonio, aparece como la encargada del cuidado de éste a muy pronta edad, sustituyendo a su madre, no sabemos si tras la muerte de ésta o antes (Auson. Par. 2).

A pesar de que, según Plinio el Joven, Umidia Cuadratila no fue precisamente una vetula ejemplar, se encargó de que su nieto Umidio tuviera una educación adecuada y no mostrase conductas inapropiadas:

“Gayo Plinio a Rosiano Gémino,

Umidia Cuadratila ha muerto con casi ochenta años de edad, habiendo conservado hasta su última enfermedad todo su vigor, y además un cuerpo robusto y fuerte, raro en una matrona romana. Ha muerto dejando un testamento muy correcto: ha nombrado heredero a su nieto, en dos terceras partes, y a su nieta, en la tercera restante. A la nieta la he tratado poco, pero su nieto es un íntimo amigo mío; es un joven extraordinario, que inspira, incluso entre aquellos con los que no está emparentado por vínculos de sangre, un afecto familiar. En primer lugar, y a pesar de ser de notable belleza, se libró tanto en su infancia como en su juventud de figurar en las conversaciones insidiosas de los envidiosos; se casó a los veinticuatro años, y hubiese sido padre si algún dios hubiese atendido a sus ruegos. Ha vivido en casa de su refinada abuela con gran austeridad, pero sin excluir una gran deferencia. Cuadratila tenía su propia compañía de pantomimos, a los que favorecía con una indulgencia mayor de la que convenía a una dama de alcurnia. Sin embargo, Cuadrado nunca contempló sus representaciones ni en casa, ni en el teatro, ni tampoco aquélla se lo exigía. Ella misma me contó una vez, cuando me

\footnotetext{
${ }^{255}$ Aemilia Corinthia Maura avia. Aemiliam nunc fare aviam, pia cura nepotis, coniunx praedicto quae fuit Arborio. Nomen huic ioculare datum, cute fusca quod olim aequales inter Maura vocata fuit. Sed non atra animo, qui clarior esset olore et non calcata qui nive candidior. Et non deliciis ignoscere prompta pudendis ad perpendiculum seque suosque habuit, haec me praereptum cunis et ab ubere matris blanda sub austeris inbuit inperiis. Tanquillos aviae cineres praestate, quieti aeternum manes, si pia verba loquor.
} 
confió la supervisión de los estudios de su nieto, que, siendo una mujer y teniendo el tiempo libre propio de su sexo, tenía la costumbre de relajarse con el juego de las damas o de contemplar a sus pantomimos, pero que siempre ordenaba a su nieto que se fuese y estudiase; comportamiento que, en mi opinión, se debía no menos al respeto que al amor. Te asombrarás; yo también me asombré. En los últimos Juegos Sacerdotales, que se iniciaron con una representación de pantomimos, al coincidir a la salida del teatro Cuadrado y yo, éste me comentó: «¿Podrás crees que hoy he visto por primera vez bailando a uno de los libertos de mi abuela?». Esto me dijo su nieto. Pero, por Hércules, entretanto hombres que no tenían nada que ver con Cuadratila corrían hacia el teatro en honor a ella (me avergüenza utilizar la palabra honor) y, para adularla, saltaban en sus asientos, aplaudían, mostraban su admiración y luego imitaban cada uno de los gestos de su patrona con cantos. Ahora éstos recibirán del heredero, que nunca los había visto actuar, unos insignificantes legados, gratificación por su actuación en el teatro. Te cuento estas cosas, porque sueles escuchar con agrado cualquier acontecimiento novedoso que haya sucedido, y luego porque me resulta muy grato renovar, al escribirlos de nuevo, los acontecimientos que me han causado placer. Me alegro, en efecto, del sentido familiar de la difunta y de los miramientos mostrados a este excelente joven; soy también feliz porque la casa que un día perteneció a Gayo Casio, que fue el fundador y padre de la escuela Casiana, tendrá un dueño no inferior. Mi querido amigo Cuadrado la adornará con su presencia y la honrará, y de nuevo le devolverá aquella antigua dignidad, celebridad y gloria, cuando salga de ella él, un orador tan notable, como Casio lo fue jurisconsulto. Adiós" (Plin. Ep. 7.24) ${ }^{256}$.

\footnotetext{
${ }^{256}$ C. PLINIUS GEMINO SUO S. Umidia Quadratilla paulo minus octogensimo aetatis anno decessit usque ad novissimam valetudinem viridis, atque etiam ultra matronalem modum compacto corpore et robusto. Decessit honestissimo testamento: reliquit heredes ex besse nepotem, ex tertia parte neptem. Neptem parum novi, nepotem familiarissime diligo, adulescentem singularem nec iis tantum, quos sanguine attingit, inter propinquos amandum. Ac primum conspicuus forma omnes sermones malignorum et puer et iuvenis evasit, intra quartum et vicensimum annum maritus, et si deus adnuisset pater. Vixit in contubernio aviae delicatae severissime, et tamen obsequentissime. Habebat illa pantomimos fovebatque, effusius quam principi feminae convenit. Hos Quadratus non in theatro, non domi spectabat, nec illa exigebat. Audivi ipsam cum mihi commendaret nepotis sui studia, solere se, ut feminam in illo otio sexus, laxare animum lusu calculorum, solere spectare pantomimos suos, sed cum factura esset alterutrum, semper se nepoti suo praecepisse abiret studeretque; quod mihi non amore eius magis facere quam reverentia videbatur. Miraberis, et ego miratus sum. Proximis sacerdotalibus ludis, productis in commissione pantomimis, cum simul theatro ego et Quadratus egrederemur, ait mihi: 'Scis me hodie primum vidisse saltantem aviae meae libertum?' Hoc nepos. At hercule alienissimi homines in honorem Quadratillae - pudet me dixisse honorem - per adulationis officium in theatrum cursitabant exsultabant plaudebant mirabantur ac deinde singulos gestus dominae cum canticis reddebant; qui nunc exiguissima legata, theatralis operae corollarium, accipient ab herede, qui non spectabat. Haec, quia soles si quid incidit novi non invitus audire, deinde quia iucundum est mihi quod ceperam gaudium scribendo retractare. Gaudeo enim pietate defunctae, honore optimi iuvenis; laetor etiam quod domus aliquando $C$. Cassi, huius qui Cassianae scholae princeps et parens fuit, serviet domino non minori. Implebit enim
} 
Umidia falleció hacia el año 107 d.C. con 79 años. Además de la referencia de Plinio, contamos con otros documentos sobre esta mujer. Entre ellos, inscripciones relativas a sus acciones evergéticas y a sus negocios, las cuales comentaremos más adelante en este capítulo. En otro epígrafe aparecen mencionados una de sus esclavas y dos de sus esclavos: "Consagrado a los Dioses Manes. Venusta, sierva de Umidia Cuadratila, quien vivió 25 años. Se lo hicieron, mereciéndolo, Evangelus y Agathemerus, sus compañeros de servidumbre" (CIL 6.28526) $)^{257}$. También contamos con dos inscripciones en las que aparece nombrada, en una de ellas con su nombre completo:

“Umidia Cuadratila, hija de Cayo" (CIL 15.7567) ${ }^{258}$.

"Umidia Cuadratila Asconia Secunda, hija de Cayo" (EAOR 4.47) ${ }^{259}$.

Ronald Syme (1979: 289) se pregunta por qué Umidio escogió llevar el nombre de su abuela, en vez del de su padre, y llega a la conclusión de que fue una elección personal. Podríamos encontrarnos ante un caso en el que Umidia, probablemente viuda ya que Plinio no menciona a su esposo, acogiese a Umidio y su nieta tras la muerte de sus progenitores. Habiéndose encargado ella de la crianza de ambos, y dada la importancia que esta vetula tenía en su ciudad natal, es posible que Umidio decidiese adoptar su nombre por considerarlo ilustre, y quizás también por unirle a su abuela una estrecha relación. Poco sabemos de la relación entre Umidia y su nieta, a excepción de la parte de la herencia que le ha correspondido, la cual es menor que la de Umidio por varias posibles razones: que se trata de una mujer, que ya estuviera casada y por lo tanto tuviese un esposo que la mantuviera -al contrario que Umidio, que seguía soltero y de estar casado habría sido el cabeza de familia-, que el nieto reciba mayor cantidad por ser el paterfamilias -a falta de su padre y de su abuelo, el marido de Umidia- y el garante de la continuidad familiar, o que se trate de una simple cuestión de preferencias afectivas.

Encargarse de sus nietos no impidió a Umidia tener una activa vida social. Acudía al teatro, contaba con una compañía de pantomimos para su entretenimiento, jugaba a las damas -no sabemos si con sus esclavos o sus amistades-, y atendía a esos hombres que, en palabras de Plinio, corrían hacia ella. A pesar de que algunos autores (Dobson,

illam Quadratus meus et decebit, rursusque ei pristinam dignitatem celebritatem gloriam reddet, cum tantus orator inde procedet, quantus iuris ille consultus. Vale.

${ }^{257} D$ (is) M(anibus) / Venustae Ummidi[ae] / Quadratillae / ser(vae) vix(it) ann(os) XXV / Euangelus et / Agathemer(us) cons(ervi)/bene merenti.

${ }^{258}$ Um(m)idiae C(ai) f(iliae) Quadratill[ae].

${ }^{259}$ Umidia C(ai) f(ilia) Quadratilla / Asconia Secunda. 
1981: 82; Fantham et al., 1994: 350; Kebric, 1983: 544) definen los gustos de Umidia, y a ella misma, como extravagantes y excesivos, no son más que una representación de las diversas formas de ocio disponibles para las mujeres romanas -especialmente para las de la élite-, como las mascotas, la música, o los juegos de mesa (Allason-Jones, 1989: 164166). Para Alison Jeppensen-Wigelsworth (2010: 166), la intención de la carta de Plinio es emplear a Umidia como ejemplo de mala matrona para resaltar las bondades de su nieto Umidio; nos parece sin embargo que las palabras de Plinio arrojan una visión general favorable a la vetula. Si bien éste se escandaliza ante alguno de sus comportamientos, alaba su testamento, el haberle escogido a él como educador de Umidio, y el que haya tomado todo tipo de precauciones para que su nieto crezca de acuerdo a lo moralmente aceptable, haciendo uso de la severidad que ya hemos dicho que se asocia a las abuelas. Así lo creen también David Sick (1999: 336) y Jacqueline Carlon, quien escribe que:

“Under Pliny’s careful hand, Umidia's quationable activities become part of her grandson's success rather than a stain on his reputation because she is an exceptional woman, of formidable physique and character, who manages to keep her feminine weaknesses from affecting his future" (Carlon, 2009: 211).

Al igual que hiciera Umidia, la literatura jurídica nos presenta otros casos de abuelas que decidieron favorecer a sus nietas. Por ejemplo, una avia que regaló un esclavo a su nieta (Cod. Iust. 7.60.2), y una bisabuela que regaló la dote a su bisnieta (Cod. Iust. 5.12.6). Una avia que, al igual que Umidia, empleó su prestigio para tratar de favorecer a su nieto en el ámbito público fue Taedia Secunda, quien en el siglo I d.C. colocó en Pompeya un cartel electoral a favor de su nepos Lucio, que se presentaba a edil $(\text { CIL 4.7469) })^{260}$.

En ocasiones las abuelas aparecen como cumplidoras del mos maiorum incluso en contra del bienestar de sus nietas y nietos. En el año 24 d.C.,

"el pretor Plaucio Silvano precipitó al vacío a su esposa, Apronia; arrastrado ante el César por su suegro Lucio Apronio, respondió en términos incoherentes algo así como que él estaba profundamente dormido y por ello no se había dado cuenta, y que su esposa había buscado voluntariamente la muerte. Sin dudarlo Tiberio marcha a la casa e inspecciona el dormitorio, en el que se veían huellas de su resistencia y de que se le había hecho fuerza. Da cuenta al senado, y al nombrarse

\footnotetext{
${ }^{260}$ Sobre los carteles electorales en los que las mujeres apoyan a diversos candidatos, vid. Savunen, 1995.
} 
el tribunal, Urgulania, abuela de Silvano, envió a su nieto un puñal. Se creyó que lo hacía como por aviso del príncipe, en virtud de la amistad de Augusta con Urgulania. El reo, tras intentar en vano hacer uso del arma, pidió que le abrieran las venas. Seguidamente es acusada Numantina, su primera esposa, de haber causado con encantamientos y bebedizos la locura de su marido, pero se la declara inocente" (Tac. Ann. 4.22) ${ }^{261}$.

Urgulania se encargó de restaurar el orden y de limpiar la reputación de la familia tras el crimen cometido por su nieto. Vemos entonces cómo algunas abuelas actuaban en el ámbito público para favorecer a su familia. Una actuación que en algunos casos tenía respaldo jurídico, ya que el Digesto (26.10.1.6) hace referencia a cómo una abuela podía iniciar acciones legales contra el guardián de un menor si éste no cumplía correctamente con su cometido.

Las abuelas, al igual que las madres, sirvieron en Roma para construir la memoria familiar. Al hacerse emperador, Claudio divinizó a su abuela Livia, Diva Augusta, para hacer gala pública de sus orígenes y reforzar su posición. Al mismo tiempo, como señala Rosa Cid, esta acción resaltaba la importancia pública de Livia en concreto y de las mujeres imperiales en general: "De haberse tratado de una mujer impopular, Claudio no la habría elegido para reforzar su papel de emperador; con tales decisiones, también estaba mostrando que el nuevo régimen no podía prescindir de las mujeres de la familia" (Cid, 2014: 192). Otro ejemplo es el de Vespasiano, quien ya hemos visto cómo visitaba con frecuencia la finca en la que lo crió su avia Tértula y usaba además su copa de plata en días señalados.

Los escritores aluden a las abuelas de distintos personajes para destacar la nobleza de su familia o para mostrarles ejemplos a seguir. Para insuflar ansias de grandeza al joven Libón Druso, el senador Firmio Cato hacía referencia a la importancia de algunos de sus antepasados, entre los que estaba su tía-abuela Escribonia, esposa de Augusto (Tac. Ann. 2.27.2). Cuando en el año 97 d.C. Junio Máurico pidió a Plinio el Joven que buscase un marido adecuado para su sobrina y éste le ofreció a Minicio Aciliano como el mejor candidato, su avia apareció como un punto a favor del pretendiente: "Su abuela

${ }^{261}$ Plautius Silvanus praetor incertis causis Aproniam coniugem in praeceps iecit, tractusque ad Caesarem ab L. Apronio socero turbata mente respondit, tamquam ipse somno gravis atque eo ignarus, et uxor sponte mortem sumpsisset. non cunctanter Tiberius pergit in domum, visit cubiculum, in quo reluctantis et impulsae vestigia cernebantur. refert ad senatum, datisque iudicibus Vrgulania Silvani avia pugionem nepoti misit. quod perinde creditum quasi principis monitu ob amicitiam Augustae cum Vrgulania. reus frustra temptato ferro venas praebuit exolvendas. mox Numantina, prior uxor eius, accusata iniecisse carminibus et veneficiis vaecordiam marito, insons iudicatur. 
materna es Serrana Prócula del municipio de Patavio. Ya conoces las costumbres del lugar: pero Serrana es incluso un ejemplo de dignidad para con sus conciudadanos" (Plin. Ep. 14.6) $)^{262}$.

A veces eran los propios nietos y nietas quienes hacían referencia a sus abuelas como forma de ensalzar la memoria familiar. Fania, nieta de Arria la Mayor, contó a Plinio el Joven "muchas cosas de su abuela (...) hechos que te causarán, según creo, la misma admiración al leerlos que a mí al escucharlos" (Plin. Ep. 3.16.2-3) ${ }^{263}$. A finales del siglo I a.C. o mediados del siglo I d.C., Valeria remodeló un santuario en Paestum y recordó a su abuela Sabina, que ya lo había remodelado con antelación ( $A E$ 1996,468; Paestum 158; Cooley, 2013: 40). Acilia Sedata Septumina y Manio Acilio Fronto, nietos de Acilia Plecusa, rica liberta hispana del siglo II d.C., explicitaron la identidad de su avia en sendas inscripciones (CIL 2.2019 y 2.2020).

No obstante, a pesar del sentimiento de afecto que parece desprenderse de las fuentes hasta ahora expuestas, en ocasiones también nos encontramos con abuelas que no mantuvieron una buena relación con sus nietas y nietos, llegando al extremo del asesinato, como en este episodio ocurrido en el año 143 a.C.:

“A presencia del pretor Marco Popilio Lenas fue llevada una mujer que había matado a su madre a bastonazos. Los jueces no se pronunciaron ni en pro ni en contra, porque estaba sobradamente averiguado que dicha madre, dejándose llevar por el odio hacia su hija, había envenenado a sus propios nietos y que el dolor había sido la causa de que la mujer vengara un parricidio con otro parricidio. Se juzgó que, de estos dos delitos, el uno no era digno de venganza, el otro indigno de perdón" (Val. Max. 8.1.c1) $)^{264}$.

Si en el caso de Umidia y Tértula la relación con sus nietos fue positiva, en otras ocasiones el tiempo compartido entre abuela y nieto resultaba perjudicial; así ocurre en opinión de Dión Casio con Claudio, ya que crecer en un entorno rodeado de mujeres acrecentó sus problemas físicos y mentals y además a falta de una fuerte influencia masculina no pudo convertirse en un completo vir.

\footnotetext{
${ }^{262}$ Habet aviam maternam Serranam Proculam e municipio Patavio. Nosti loci mores: Serrana tamen Patavinis quoque severitatis exemplum est.

${ }^{263}$ Multa referebat aviae suae (...) quae tibi existimo tam mirabilia legenti fore, quam mihi audienti fuerunt.

${ }^{264}$ Apud M. Popilium Laenatem praetorem quaedam, quod matrem fuste percussam interemerat, causam dixit. de qua neutram in partem latae sententiae sunt, quia abunde constabat eandem ueneno necatorum liberorum dolore commotam, quos auia filiae infensa sustulerat, parricidium ultam esse parricidio. quorum alterum ultione, alterum absolutione non dignum iudicatum est.
} 
De la misma forma, nos encontramos con nietos que no se mostraron generosos con sus abuelas y bisabuelas. Es el caso, por ejemplo, del emperador Calígula, que despreciaba a su bisabuela Livia y mantuvo una relación ambigua con su abuela Antonia Minor, ya que si bien al ascender al trono le concedió los mismo honores que tenía Livia (Suet. Calig. 15.2), poco después su actitud cambió por completo:

"A su bisabuela Livia Augusta solía llamarla "Ulises con faldas", e incluso se atrevió a acusarla en una carta al Senado de tener un oscuro origen. (...) Cuando su abuela Antonia le pidió una audiencia privada, se negó a recibirla a menos que se hallara presente el prefecto Macrón, y, a fuerza de humillaciones y disgustos de este tipo, provocó su muerte, administrándole, no obstante, también veneno, según la opinión de algunos; una vez muerta no le rindió ningún honor, e incluso contempló su pira ardiente desde su triclinio" (Suet. Calig. 23.2) ${ }^{265}$.

La expresión Ulixem stolatum, al presentarnos a una Livia que hoy en día caracterizaríamos como marimandona, sirve también para resumir la figura de la abuela, dotada al mismo tiempo de la afectividad que tradicionalmente se atribuye a las mujeres, y de la autoridad y severidad que aportan años al cargo del correcto funcionamiento de la estructura familiar. Le asigna, por lo tanto, cualidades tanto femeninas como masculinas. Una auctoritas y una gravitas que vienen propiciadas por la asexualidad y la androgenización que acontecen en la vejez en las sociedades edadistas, de forma que la anciana ya no es una mujer como tal, y por lo tanto se consideran en ella válidas actitudes que se apartan de su rol genérico.

\section{IV.1.4. Otras relaciones familiares}

Además de esposas, madres, abuelas y bisabuelas, en ocasiones las fuentes nos hablan de vetulae que ocupan otras posiciones en la familia. Es el caso, por ejemplo, de las tías, tanto la matertera como la amita. Es de suponer que la relación de estas mujeres con sus sobrinas y sobrinos dependería de diversas circunstancias: lo estrecho de la relación con sus progenitores, la distancia geográfica que les separaba, las circunstancias personales de la materteralamita... Al igual que las abuelas, las tías podían ocupar el lugar de una madre que había fallecido y hacer las veces de consejeras y educadoras (Pers. 2.30-34; Val. Max. 1.5.4). Ausonio describe a sus dos tías, Emilia

\footnotetext{
${ }^{265}$ Liviam Augustam proaviam "Ulixem stolatum" identidem appellans, etiam ignobilitatis quadam ad senatum epistula arguer (...) Aviae Antoniae secretum petenti denegavit, nisi ut interveniret Macro praefectus, ac per istius modi indignitates et taedia causa exstitit mortis, dato tamen, ut quidam putant, et veneno; nec defunctae ullum honorem habuit prospexitque e triclinio ardentem rogum.
} 
Hilaria y Julia Catafronia, ambas con voto de castidad, como igual de importantes que una madre:

"Emilia Hilaria, mi tía materna, con votos de virginidad. Y tú, tía materna en la línea de parentesco, pero digna de ser recordada en el lugar de una madre por el piadoso cariño de un hijo, Emilia, recibiste ya en la cuna el apellido de Hilaria, pues alegre y dulce te mostrabas en tu rostro infantil; sin embargo, te volvías como un muchacho bien a las claras, al practicar las artes de la medicina siguiendo la costumbre de los hombres. El sexo femenino siempre te causó odio y de ahí creció tu deseo por consagrar tu virginidad. Durante sesenta y tres años la cultivaste y el final de tu vida fue el mismo que el de tu castidad. Estas palabras, por haber hecho de madre para mí con tus consejos y tu amor, te devuelvo como hijo a modo de últimas exequias" (Auson. Par. 6) ${ }^{266}$.

“Julia Catafronia, mi tía paterna: ¿Cómo no hacer partícipe, Musa, de mis fúnebres lamentos a mi tía Catafronia? Mantuvo soltera su deseo de una religiosa virginidad hasta ser una anciana austera; y me dio como una madre lo que pudo tener a pesar de su magra fortuna. Por ello mi saludo te recuerda y, llamándote igual que una madre, te envío mi triste adiós" (Auson. Par. 26) ${ }^{267}$.

Calpurnia Hispula, amita de la tercera mujer de Plinio el Joven, cuidó de la joven, también llamada Calpurnia, tras la muerte de sus progenitores. En la correspondencia que Plinio mantuvo con ella éste le agradeció la buena educación que le había dado. Se da además el caso de que Calpurnia y Plinio se conocían desde la infancia de éste, ya que la vetula y la madre del escritor eran amigas, y él también se había beneficiado de sus buenos consejos:

"Gayo Plinio a Calpurnia Hispula,

Puesto que eres un modelo de amor familiar y has amado a tu excelente y amantísimo hermano con el mismo cariño que él a ti, y amas a su hija como si ella fuese tuya, y no sólo le ofreces el cariño de una tía, sino incluso ocupas el lugar del padre que ella perdió, no tengo la menor duda de que para ti será un motivo de gran alegría saber que se ha mostrado digna de su padre, digna de ti, digna de su abuelo. Es extraordinariamente inteligente; extraordinariamente frugal; me ama, lo que es

\footnotetext{
${ }^{266}$ Aemilia Hilaria matertera virgo devota. Tuque gradu generis matertera, sed vice matris adfectu nati commemoranda pio, Aemilia, in cunis Hilari cognomen adepta, quod laeta et pueri comis ad effigiem, reddebas verum non dissimulanter ephebum, more virum medicis artibus experiens, feminei sexus odium tibi semper et inde crevit devotae virginitatis amor. Quae tibi septenos novies est culta per annos quique aevi finis, ipse pudicitiae. Haec, quia uti mater monitis et amore fovebas, supremis reddo filius exequiis.

${ }^{267}$ Iulia Caraphronia amita. Quin et funereis amitam inpertire querellis, Musa, Cataphroniam. Innuba devotae quae virginitatis amorem parcaque anus coluit: et mihi, quod potuit, quamvis de paupere summa, mater uti, adtribuit. Ergo commemorata have maestumque vocata pro genetrice vale.
} 
un claro indicio de su virtud. Añade a esas virtudes el interés por los estudios literarios, que le ha inspirado el amor que siente por mí. Guarda copias de mis obras, que lee una y otra vez, e incluso las aprende de memoria. ¿Qué angustia siente cuando ve que voy a pleitear en un tribunal, qué felicidad cuando ve que ya he terminado! (...) Por estos motivos estoy plenamente convencido de que nuestra armonía será eterna e incluso será mayor cada día que pase. Pues no me ama por mi juventud ni por mi belleza, que poco a poco declinan y envejecen, sino por mi prestigio, y ningún otro sentimiento sería adecuado en una persona que ha sido educada por tus manos, que ha sido instruida en tus preceptos, que en tu compañía no ha visto nada que no haya sido puro y honesto, y que por último ha llegado a amarme a causa de las alabanzas que haces de mí. Pues, como tú respetabas a mi madre como lo haría una hija, desde la infancia solías aconsejarme, darme ánimos, y augurar que yo llegaría a ser un hombre tal como ahora le parezco a mi esposa. Por ello te damos las gracias a porfía, yo por habérmela dado a mí, ella por haberme dado a ella, como si nos hubieses elegido el uno para el otro. Adiós" (Plin. Ep. 4.19) ${ }^{268}$.

Por ello, cuando su esposa sufrió un aborto, Plinio escribió a Calpurnia para comunicarle la triste noticia. En esta carta escribió de ella que el cariño que le profesaba a su sobrina era "incluso más dulce que el amor de una madre" (Plin. Ep. 8.11) ${ }^{269}$, y le pidió que explicase al abuelo de la joven lo ocurrido, de forma que éste pudiera perdonar a su nieta por no haber concebido al tan esperado bisnieto. La relación entre ambas mujeres también debía ser buena, ya que cuando falleció el abuelo Calpurnia corrió a consolar a su tía (Plin. Ep. 10.120-121).

Séneca alabó a su matertera, tanto por el apoyo emocional y económico que le había prestado a él, como por ser confidente y consejera de su madre:

"Y aún me había callado tu mayor consuelo, tu hermana, ese corazón tan apegado a

ti, al que se trasladan todas tus preocupaciones para ser compartidas, ese espíritu

\footnotetext{
268

C. Plinius Calpurniae Hispullae suae s. Cum sis pietatis exemplum, fratremque optimum et amantissimum tui pari caritate dilexeris, filiamque eius ut tuam diligas, nec tantum amitae ei affectum verum etiam patris amissi repraesentes, non dubito maximo tibi gaudio fore cum cognoveris dignam patre dignam te dignam avo evadere. Summum est acumen summa frugalitas; amat me, quod castitatis indicium est. Accedit his studium litterarum, quod ex mei caritate concepit. Meos libellos habet lectitat ediscit etiam. Qua illa sollicitudine cum videor acturus, quanto cum egi gaudio afficitur! (...) His ex causis in spem certissimam adducor, perpetuam nobis maioremque in dies futuram esse concordiam. Non enim aetatem meam aut corpus, quae paulatim occidunt ac senescunt, sed gloriam diligit. Nec aliud decet tuis manibus educatam, tuis praeceptis institutam, quae nihil in contubernio tuo viderit, nisi sanctum honestumque, quae denique amare me ex tua praedicatione consueverit. Nam cum matrem meam parentis loco vererere, me a pueritia statim formare laudare, talemque qualis nunc uxori meae videor, ominari solebas. Certatim ergo tibi gratias agimus, ego quod illam mihi, illa quod me sibi dederis, quasi invicem elegeris. Vale.

${ }^{269}$ Cum affectum tuum erga fratris filiam cogito etiam materna indulgentia molliorem.
} 
maternal para todos nosotros. Con ella has mezclado tus lágrimas, en su regazo has tenido el primer respiro. Cierto es que ella se guía siempre por tus sentimientos; en mi persona, sin embargo, no se lamenta sólo por ti. En sus manos fui traído a la Ciudad, gracias a sus cuidados afectuosos y maternales me restablecí tras un largo tiempo de enfermedad; ella desplegó su influencia en apoyo a mi cuestura...” (Sen. Helv. 19.1-2) ${ }^{270}$.

Al igual que ocurría entre la madre y la tía de Séneca, las hermanas podían mantener relaciones afectivas fuertes nutridas con frecuentes visitas. Además, teniendo en cuenta la diferencia de edad que podía haber entre los hijos e hijas de un mismo matrimonio, a quienes podían sumarse los tenidos en matrimonios anteriores, es probable que hermanas y hermanos mayores cuidasen de los más jóvenes, surgiendo vínculos igual de fuertes que con los progenitores.

El Egipto romano nos ha propocionado documentación a través de la cual podemos obtener información de este tipo de relaciones. Conocemos, por ejemplo, a un hombre llamado Athas, de 56 años, que vivía en la misma casa con sus dos hermanas, Therobatis, de 48, y Therothbechis, de 44 ( $B F$ 173-Pr-3; Huebner, en prensa). Aparentemente, los tres estaban solteros. Sabemos también de tres personas de sexo desconocido, de 62, 68 y 78 años, que compartían un mismo techo, las cuales han sido identificadas como hermanos o hermanas que decidieron pasar la vejez en compañía (BF 31-Ox-6; Huebner, 2013: 168). De la misma forma, Papontos, un hombre de 57 años, vivía con su hermana Tetoeus en casa de su cuñado, de 74 años, junto con el hijo de 45 años de la pareja y otro varón, de 21 años, que no era hijo de ninguna de las personas con las que convivía; en este caso el motivo de vivir todos juntos parece ser que los hombres compartían oficio ( $B F$ 117-Ox-2; Huebner, en prensa). No sabemos la edad de Tetoeus, pero tomando en cuenta la de su esposo y la de su hijo, seguramente sería una vetula.

Una vetula también podía ocupar el papel de suegra. La socra, nombre que también se aplicaba a la abuela del cónyuge (Dig. 50.16.146), suele aparecer como enemiga en la sátira y el teatro. Especialmente crudo con la suegra se muestra Juvenal:

\footnotetext{
${ }^{270}$ Maximum adhuc solacium tuum tacueram, sororem tuam, illud fidelissimum tibi pectus, in quod omnes curae tuae pro indiuiso transferuntur, illum animum omnibus nobis maternum. Cum hac tu lacrimas tuas miscuisti, in huius primum respirasti sinu. Illa quidem adfectus tuos semper sequitur; in mea tamen persona non tantum pro te dolet. Illius manibus in urbem perlatus sum, illius pio maternoque nutricio per longum tempus aeger conualui; illa pro quaestura mea gratiam suam extendit...
} 
"Si vive tu suegra, desespera ya de la concordia. Ella enseña a su hija a divertirse con los despojos del marido empobrecido, le enseña a contestar de modo fino y elegante los billetes que le manda el seductor; ella, la suegra, es la que engaña o sujeta con dinero a los esclavos. La esposa entonces, a la que nada duele, manda llamar al médico Arquígenes, y se echa encima pesadas mantas. Mientras, el adúltero ya está escondido, pues entró secretamente; impaciente por la espera calla y se rasca el carajo. ¿Acaso esperarías que la madre le transmita costumbres honestas, diferentes de las que ella misma tiene? A esta torpe vieja le es útil, desde luego, criar una hija con hábitos decentes" (Juv. 6.230-240) 271 $^{2}$.

Esta misma noción la encontramos en Tibulo, quien alaba a la madre de su amante Delia, ya que es ella quien propicia sus encuentros amorosos a espaldas del marido, haciendo una tarea más propia de una lena:

"No te perdono por ti misma; me conmueve tu madre y aplaca mis explosiones de cólera esa anciana adorable. Ella te conduce hasta mí en medio de las tinieblas y con mucho miedo, secretamente, une silenciosas nuestras manos. Ella me espera de noche fija en la puerta y, de lejos, conoce el ruido de mis pisadas cuando llego. Vive para mí muchos años, dulce anciana; si se me permitiera, querría contigo compartir los míos. Gracias a ti os amaré para siempre a ti y a tu hija. Cualquier falta que cometa, ella es, pese a todo, sangre tuya" (Tib. 1.6.57-65) ${ }^{272}$.

La suegra por lo tanto impide que haya armonía familiar. Y lo hace tanto en detrimento de su yerno como de su hijo, odiando a la mujer con la que se ha casado (Ov. Fast. 2.624-626; Ter. Her. 230). Jamás están contentas con sus nueras, ni siquiera si las han escogido ellas:

" Que todas las mujeres se afanen siempre en lo mismo y lo mismo rechacen! ¡Que no hayas de encontrar una sola que se aparte de la condición de los demás! Y así, todas las suegras odian unánimes a sus nueras. Y el mismo afán y pareja terquedad ponen en llevar la contraria a sus maridos. Me parece que todas han aprendido en la

\footnotetext{
${ }^{271}$ Desperanda tibi salua concordia socru. Illa docet spoliis nudi gaudere mariti, illa docet missis a corruptore tabellis nil rude nec simplex rescribere, decipit illa custodes aut aere domat. tum corpore sano aduocat Archigenen onerosaque pallia iactat. Abditus interea latet et secretus adulter inpatiensque morae silet et praeputia ducit. Scilicet expectas ut tradat mater honestos atque alios mores quam quos habet? Utile porro filiolam turpi uetulae producere turpem.

${ }^{272}$ Non ego te propter parco tibi, sed tua mater me movet atque iras aurea vincit anus. Haec mihi te adducit tenebris multoque timore coniungit nostras clam taciturna manus, haec foribusque manet noctu me adfixa proculque cognoscit strepitus me veniente pedum. Vive diu mihi, dulcis anus: proprios ego tecum, sit modo fas, annos contribuisse velim. Te semper natamque tuam te propter amabo: quicquid agit, sanguis est tamen illa tuos.
} 
misma escuela de la malicia; y, si existe tal escuela, estoy seguro de que mi mujer es la maestra" (Ter. Hec. 200-204) ${ }^{273}$.

"Pues no hay una sola de vosotras que no quiera que se le case un hijo; y a vuestro gusto se les dan los partidos. Cuando se han casado empujados por vosotras, empujados por vosotras, se deshacen de sus mujeres" (Ter. Her. 240) ${ }^{274}$.

En el siglo II d.C. una mujer de nombre desconocido escribía una carta a su hijo para quejarse del comportamiento de su nuera ( $S B$ 3.62644). En la misma época, Didymarion enviaba una misiva a Paniskos, hermano de su yerno, con el cual tenía una excelente relación, para comunicarle el mal trato que Paniskos tenía con su esposa, la hija de Didymarion (P. Petaus 29). Un siglo más tarde, otro hombre del mismo nombre escribía una carta a su esposa Plutogenia, en la que le reprochaba que tomase decisiones sin consultarle, haciendo referencia a cómo había heredado ese comportamiento de su madre Heliodora (P. Mich. III 217) ${ }^{275}$.

Terencio hace a Sóstrata lamentarse de este estereotipo:

"SÓSTRATA - (A solas) ¡Por Pólux, por unas pocas que hacen que todas parezcamos merecedoras de reproche, que todas por igual seamos injustamente odiadas por nuestros maridos! ¡Pues válgame los dioses, que estoy libre de lo que ahora me achaca el mío! Pero no es fácil disculparse; pues a la gente se le ha metido en la cabeza que todas las suegras son unas perversas. Y yo, por Pólux, no lo soy; pues no la he tratado de forma distinta que si hubiera sido una hija. No sé cómo me ha ocurrido esto. Pero ipor Pólux, que espero, y mucho, que mi hijo regrese ya a casa!" (Ter. Her. 275-280) ${ }^{276}$.

Por su parte, Plutarco aconseja a la futura esposa tener una buena relación con la suegra, y hacerle ver que no piensa alejarla de su hijo:

"En Leptis, ciudad de Libia, es costumbre del pais que, un día después de la boda, la novia envíe a pedir una olla a la madre del novio, pero ésta no se la da y contesta que no tiene ninguna, para que aquella, conociendo desde un principio los

\footnotetext{
${ }^{273}$ Utin omnes mulieres eadem aeque studeant nolintque omnia neque declinatam quicquam ab aliarum ingenio ullam reperias! Itaque adeo uno animo omnes socrus oderunt nurus. Viris esse advorsas aeque studiumst, simili' pertinaciast, in eodemque omnes mihi videntur ludo doctae ad malitiam; et $\langle e i\rangle l u d o$, si ullus est, magistram hanc esse sati' certo scio.

${ }^{274}$ Nam vostrarum nullast quin gnatum velit ducere uxorem; et quae vobis placitast condicio datur: ubi duxere inpulsu vostro, vostro inpulsu $\langle$ ea $\rangle$ sdem exigunt.

${ }_{275}$ Para el motivo de la disputa entre Paniskos y Plutogenia, vid. Goñi, 2015: 219-221.

${ }^{276}$ Edepol ne nos sumus inique aeque omnes invisae viris propter paucas, quae omnes faciunt dignae ut videamur malo. Nam ita me di ament, quod me accusat nunc vir, sum extra noxiam. Sed non facile est expurgatu: ita animum induxerunt socrus omnis esse iniquas: haud pol mequidem; nam numquam secus habui illam ac si ex me esset gnata, nec qui hoc mi eveniat scio; nisi pol filium multimodis iam exspecto ut redeat domum.
} 
sentimientos de madrastra de la suegra, si más tarde le sucede algo más penoso, no se enoje ni se enfade. Conviene que la mujer, sabiendo esto, evite los pretextos. Los celos de la madre del marido por el amor de su hijo hacia la nuera son una realidad. La única medicina para este estado del alma es ganarse, particularmente, el afecto del marido hacia ella sin apartarlo de su madre y sin menoscabar el cariño que siente hacia ella" (Plut. Mor. 143A-B) ${ }^{277}$.

Son varios los ejemplos de suegras que compartieron casa con sus nueras y yernos, con una convivencia que no podemos saber si era buena o mala (Juv. 14.220; Ov. Fast. 2.626). La viuda Thephrokos, de más de 50 años, vivía en casa de su yerno junto a su hija y el niño de tres años del matrimonio (BF 131-He-2). En algunos casos, tanto la suegra como la nuera eran vetulae (BF 117-Ar-6 y 131-Ar-12).

Las fuentes también nos hablan de casos en los que la relación con la suegra era buena, o al menos fluida. En el año 117 d.C. la ya aludida Eudaimonis escribió una carta a su nuera Aline en la que le reprochaba haberle enviado poco dinero para subsistir y le pedía que le mandase más o no podría soportar el invierno (P. Brem. 63). Resulta llamativo que sea ella la encargada de proveer a la vetula, y no el hijo de ésta, lo que puede remitir a que era Aline quien controlaba la economía doméstica. Un ejemplo de armonía entre suegra y yerno de época republicana nos lo presenta Tito Livio (39.9-14) en el contexto del escándalo de las Bacanales del 186 a.C. Duronia, una mujer ya madura, si no anciana, fue empujada por su segundo esposo, Tito Sempronio Rutilo, a iniciar en los misterios báquicos al hijo que tuvo en su primer matrimonio, Publio Ebucio. Tras descubrir lo deshonroso de los ritos que debía cumplir, Ebucio se enfrentó a su madre y su padrastro, fue expulsado de casa, y acudió a buscar ayuda a casa de su tía paterna Ebucia, una vetula viuda respetada por la comunidad. Informó también al cónsul Postumio, quien al no saber qué hacer decidió pedir consejo a su suegra, Sulpicia, a quien usó como intermediaria para acceder al testimonio de las mujeres implicadas en el asunto. Los interrogatorios tuvieron lugar en casa de la vetula, en la que probablemente también viviesen su hija y su yerno. Durante uno de los interrogatorios, Hispula, prostituta y amante de Ebucio, confesó ante Postumio y su

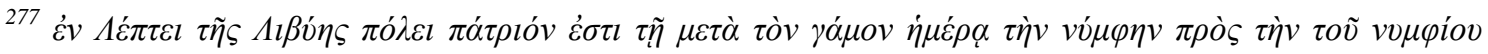

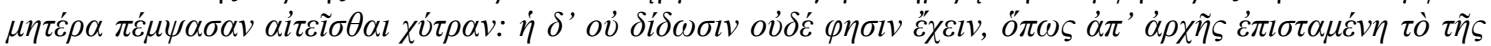

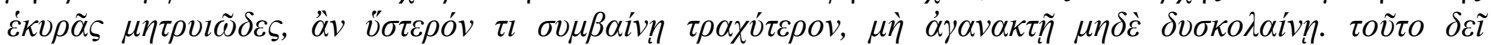

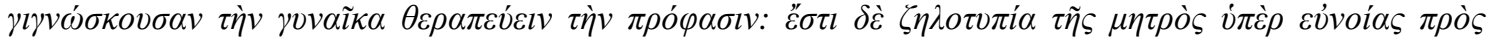

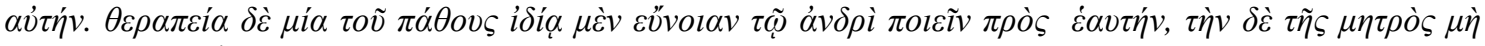
$\pi \varepsilon \rho l \sigma \pi \tilde{\alpha} v \mu \eta \delta^{\prime} \varepsilon \dot{\lambda} \lambda \alpha \tau \tau o \tilde{v} v$.
} 
suegra haber sido iniciada en los misterios, y a continuación rogó a Sulpicia que su falta fuera perdonada. Del episodio destacan varios hechos. Por un lado, la confianza que el cónsul tenía en su suegra, a quien pidió ayuda y permitió participar en los interrogatorios. Por otro, que Hispula rogó clemencia a Sulpicia, a pesar de que ésta no tenía poder real, aunque probablemente sí la auctoritas necesaria como para influir en las decisiones de su yerno. Y, finalmente, el papel de la vetula como intermediaria, aportando serenidad a un ambiente tenso y tratando en todo momento de ayudar a las otras mujeres, tanto a Ebucia como a Hispula. Sulpicia aparece, por lo tanto, como elemento que pone fin a la agresividad masculina mediante un ánimo calmado y pacificador:

"En ese momento Postumio, montando en cólera, le dijo que también ahora creía ella [Hispula] estar charlando con su amante y no en casa de una dama respetabilísima y hablando con un cónsul; Sulpicia, por su parte, alzó a la aterrada mujer y trataba a un tiempo de animarla y de aplacar las iras de su yerno" (Liv. 39.13.3) ${ }^{278}$.

Otro ejemplo de buena relación suegra-yerno, ya de época imperial, lo encontramos en la relación que mantenían Plinio el Joven y Pompeya Celerina, madre de la segunda esposa del primero, tal y como se muestra en la correspondencia que cruzaron:

"Gayo Plinio a Pompeya Celerina, su suegra,

¡Cuántos tesoros tienes en tus propiedades de Ocrículo, Narnia, Cársulas, en tu amada Perusia, incluso hasta unos baños en Narnia! Una sola de mis cartas, breve y ya antigua (pues las tuyas ya no hacen falta) pone todo ello a mi disposición. En verdad que mis propiedades no son tan mías como las tuyas; se diferencian, sin embargo, en que los tuyos me reciben con mayor atención y cordialidad que los míos. Tal vez eso mismo te suceda a ti, si alguna vez te desvías hacia mis tierras. Me gustaría que lo hicieses, en primer lugar, para que pudieses disfrutar de nuestras posesiones como yo disfruto de las tuyas; después para que mi servidumbre, que me recibe con despreocupación y casi con negligencia, se espabile un poco. Pues los esclavos, a causa de la propia familiaridad, pierden el temor a los amos considerados, pero se estimulan con las nuevas caras y se

\footnotetext{
${ }^{278}$ Hic Postumius accensus ira tum quoque ait eam cum Aebutio se amatore cauillari credere, non in domo grauissimae feminae et cum consule loqui. et Sulpicia attollere pauentem, simul illam adhortari, simul iram generi lenire.
} 
esfuerzan en congraciarse con sus amos por medio de otras personas antes que por ellos mismos. Adiós" (Plin. Ep. 1.4) ${ }^{279}$.

Plinio no sólo consideraba como suyas las posesiones de Pompeya, sino también su dinero. En una ocasión en la que deseaba adquirir unos terrenos y necesitaba tres millones de sestercios, declaró: "se lo pediré a mi suegra, cuyo capital utilizo como si fuese el mío propio" (Plin. Ep. 3.19.8) ${ }^{280}$. En otra alusión a Pompeya en las cartas de Plinio, éste estaba a punto de defender en juicio a Junio Pastor, acusado de un delito que se desconoce; Pompeya apareció en sus sueños una noche y le pidió de rodillas que desistiera de la defensa, aunque sin resultados (Plin. Ep. 1.18).

Como hacíamos en el caso de las abuelas, podemos apreciar la existencia de este tipo de relaciones también en el registro epigráfico. Estos patrones conmemorativos pueden responder a que las fallecidas no tenían descendencia propia, a que sí la tuvieron pero habían muerto antes que ellas o su relación no era buena, o a que estas hermanas/tías/suegras eran tan importantes en sus vidas que quisieron dejar una señal para la posteridad.

Auctus dedicó un epitafio a su hermana Cornelia, fallecida con 85 años ( $A E$ 1980, 518), y Flavia Restituta hizo lo propio con su hermana Flavia Dativa, muerta con 60 años (CIL 8.11586). En Corduba, una persona cuyo nombre no conocemos dedicaba esta inscripción a su hermana: "Consagrado a los Dioses Manes. Publicia Martia, hermana incomparable, que vivió 71 años, piadosa. Que la tierra te sea leve" (CIL 2$7.522)^{281}$.

Contamos también con personas que dedicaron inscripciones a sus amitae y materterae ( $A E$ 1993, 903; CIL 2.4352, 2.6188, y 3.10038). En el siglo III d.C. Valentino conmemoró a su amita Aurelia Valentina, muerta con 77 años, 8 meses y 21 días, y a su avunculus Aurelio Victorino, fallecido con 80 años, 7 meses y 5 días, en

\footnotetext{
${ }^{279}$ C. PLINIUS POMPEIAE CELERINAE SOCRUI S. Quantum copiarum in Ocriculano, in Narniensi, in Carsulano, in Perusino tuo, in Narniensi vero etiam balineum! Ex epistulis meis, nam iam tuis opus non est: una illa brevis et verus sufficit. Non mehercule tam mea sunt quae mea sunt, quam quae tua; hoc tamen differunt, quod sollicitius et intentius tui me quam mei excipiunt. Idem fortasse eveniet tibi, si quando in nostra deverteris. Quod velim facias, primum ut perinde nostris rebus ac nos tuis perfruaris, deinde ut mei expergiscantur aliquando, qui me secure ac prope neglegenter exspectant. Nam mitium dominorum apud servos ipsa consuetudine metus exolescit; novitatibus excitantur, probarique dominis per alios magis quam per ipsos laborant. Vale.

${ }^{280}$ accipiam a socru, cuius arca non secus ac mea utor.

${ }^{281} D($ is) M(anibus) s(acrum) / Public(ia) Martia / incomparabilis soror / vixit annis LXXI / pia in suis / $s($ it) t(ibi) t(erra) l(evis).
} 
calidad de heredero (CIL 6.2774). Otros casos son por ejemplo los de vetulae como Antonia Máxima, Aurelia Titulla o Anna Calediga:

“Consagrado a los Dioses Manes. Aquí yace Antonia Máxima. Vivió 70 años. Antonia Matrona se lo hizo a su muy pía amita" $(A E 1967,630)^{282}$.

“Consagrado a los Dioses Manes. A Aurelia Titula Arguriana, que vivió 70 años. Lo puso a su muy pía amita Aurelia Titula Cambria" $(A E 1986,548)^{283}$.

"Consagrado a los Dioses Manes. Lo erigió Anino para Anna Calediga, pía matertera, que vivió 80 años" (CIL 2.6299) ${ }^{284}$.

En el siglo III d.C. Emilia Rogatila dedicaba a su matertera una inscripción junto a su hijo:

"Flavia Publicia, hija de Lucio, vestal máxima y muy pía, cuya santidad y su preocupación por los ritos que ha celebrado, con una conducta digna de alabanza a lo largo de todos los estadios del sacerdocio, la cual ha sido comprobada por el espíritu de la sagrada madre Vesta. De Emilia Rogatila, de rango senatorial, la hija de su hermana, junto a Minucio Honorato Marcelo Emiliano, un niño de rango senatorial, su hijo, en razón de su extraordinaria piedad para con ellos" ( $C I L$ $6.32414)^{285}$.

De la misma forma, se han documentado inscripciones en las que una suegra aparece como dedicada o dedicante ( $A E$ 1983, 376; CIL 2.3232, 3.7458, 8.1213 y 8.13092). En ocasiones aparece también la hija o hijo de la fallecida, pero en otras es sólo el yerno o la nuera quien asume la responsabilidad de la conmemoración, puede que por la ausencia de familia directa:

"Consagrado a los Dioses Manes. Bonita, vivió 71 años. Julio Longiniano, centurión, a su suegra y Processa, hija, a su madre, lo hicieron mereciéndoselo" $(\text { CIL 8.2906) })^{286}$.

\footnotetext{
${ }^{282} \mathrm{D}($ is $)$ M(anibus) s(acrum) / Antonia Maxima / h(ic) s(ita) e(st) /v(ixit) an(nos) LXX / Antonia Matrona / amit(a)e piis(s)im(a)e f(ecit).

${ }^{283}$ D(is) M(anibus) s(acrum) / Aur(eliae) Titullae / Argurianae / qu(a)e v(ixit) an(nos) LX Aur(elia) / Titulla Cam/bria amitae / p(ientissimae) p(osuit).

${ }^{284} \mathrm{D}$ (is) M(anibus) / Aninus / posui(t) An/nae Cale/dig(a)e mate/rter(a)e pia/e qu(a)e vi/<x=CS〉it a/nnis $L X X X$.

${ }^{285}$ Flaviae L(uci) fil(iae) / Publiciae v(irgini) V(estali) max(imae) / sanctissimae piissimaeq(ue) / cuius sanctissimam et / religiosam curam sacror(um) / quam per omnes gradus / sacerdotii laudabili admi/nistratione operatur numen / sanctissimae Vestae matris / comprobavit / Aemilia Rogatilla c(larissima) f(emina) sororis fil(ia) / cum Minucio Honorato Marcello / Aemiliano c(larissimo) p(uero) filio suo / ob eximiam eius erga se / pietatem.

${ }^{286} D($ is $)$ M(anibus) / Bonittae / vix(it) a(nnos) LXXI / Iul(ius) Longini/anus |(centurio) leg(ionis) / socrae et / Processa / fil(ia) matri / m\{a\}erenti.
} 
“Consagrado a los Dioses Manes. Flavia Apama, vivió 50 años. Cayo Annio a su suegra, se lo hizo mereciéndoselo. Que la tierra te sea leve" $(A E 1985,920)^{287}$.

\section{IV.1.5. Mujeres solas: viudas, divorciadas, solteras y vestales}

Resulta difícil saber cuántas mujeres estaban solas en la Roma antigua, ya fuera porque no se habían casado nunca o porque eran viudas o divorciadas. Sabine Huebner (en prensa) ha tratado de hacer el cálculo basándose en los censos del Egipto romano. Tomando en cuenta a las personas libres mayores de 15 años (edad que toma como media para el matrimonio), ha descubierto que el $42 \%$ de quienes aparecen en la documentación que ha empleado no tenían pareja. Algunos de estos hombres y mujeres habían estado casados con anterioridad, pero otros no, y casi el 50\% compartía casa con otras personas.

En el caso de las vetulae, si se cumplía la norma de que fueran varios años más jóvenes que sus esposos, es de esperar que muchas de las que alcanzasen edades altas lo hicieran siendo viudas. Además de las posibles herencias por parte de su familia de origen, si la viuda se había casado cum manu se convertía en una más de las herederas de la familia de su esposo, lo que podía engrosar su patrimonio de forma considerable. Esta opción fue limitada legalmente a mediados del siglo II a.C. La falta de hombres a consecuencia la II Guerra Púnica dejó a algunas mujeres en una situación especialmente favorable, al heredar tanto de sus familiares consaguíneos como de los de su familia política. Es por ello que en el año 169 a.C. se promulgó la lex Voconia, que prohibía nombrar como heredera a una mujer a quienes tuviesen un patrimonio por encima de los 100.000 ases, así como dejar a alguien en forma de legado una cantidad mayor que la que se dejaba al heredero (Montañana, 2002: 160).

En época tardorrepublicana, Cornelia decidió no volver a casarse tras la muerte de su esposo Tiberio, ni siquiera cuando el rey de Egipto le pidió matrimonio (Plut. Ti. Gracch. 1.7). Ejemplo de matrona y univira, tras enviudar con menos de 40 años pasó buena parte de su adultez y toda su vejez soltera, viviendo entre la ciudad de Roma y su villa de Campania, a donde acabó retirándose, al parecer en compañía de su hija Sempronia, también viuda ${ }^{288}$. En dicha villa llevaba una intensa actividad intelectual y social:

\footnotetext{
${ }^{287} D($ is $)$ M(anibus) / Fla(via) Apama / vix(it) anni[s] L / C(aius) Annius O() / socrae suae / bene merent [i] / fecit / s(it) t(ibi) t(erra) l(evis).

${ }^{288}$ No se sabe con certeza cuándo se produjo este retiro, si después de la muerte de su esposo (154 a.C.), del asesinato de su hijo Tiberio (132 a.C.) o del de su hijo Cayo (121 a.C.) (Dixon, 2007: 44).
} 
"Dícese de Cornelia haber manifestado en muchas ocasiones, que llevaba con entereza y magnanimidad sus infortunios; y que acerca de la consagración de los lugares en que perecieron sus hijos, solía expresar que los muertos habían tenido dignos sepulcros. Su vida la pasó después en los campos llamados Misenos, sin alterar en nada el tenor acostumbrado de ella. Gustaba, en efecto, del trato de gentes, y por su inclinación a la hospitalidad, tenía buena mesa, frecuentando siempre su casa griegos y literatos, y recibiendo dones de ella todos los reyes, y enviándoselos recíprocamente. Escuchábasela con gusto cuando a los concurrentes les explicaba la conducta y tenor de vida de su padre Escipión Africano, y se hacía admirar cuando sin llanto y sin lágrimas hablaba de sus hijos, y refería sus desventuras y sus hazañas, como si tratara de personas de otros tiempos, a los que le preguntaban. Por lo cual algunos creyeron que había perdido el juicio por la vejez o por la grandeza de sus males, y héchose insensata con tantas desgracias; siendo ellos los verdaderamente insensatos, por no advertir cuánto conduce para no dejarse vencer del dolor, sobre el buen carácter, el haber nacido y educádose convenientemente, y que si la fortuna mientras dura, hace muchas veces degenerar la virtud, en la caída no le quita el llevar los males con una resignación digna de elogio" (Plut. C. Gracch. 19) ${ }^{289}$.

Unos siglos más tarde, en época Julio-Claudia, Livia aumentó su poder y su patrimonio al quedarse viuda, ya que heredó un tercio de la fortuna de Augusto, una situación que ya hemos visto que veía con desagrado su hijo Tiberio (Barrett, 2002: 96). Su influencia era tal que durante la grave enfermedad que sufrió en el año 22 d.C., con 80-81 años, los ecuestres le dedicaron una estatua a Fortuna (Tac. Ann. 3.71) y se acuñaron monedas con la leyenda Salus Augusta (RIC 1(2), 97, n47), ligando su salud al bienestar del Estado (Hidalgo, 2012: 67). Otra mujer de la misma dinastía, Antonia Minor, que al morir su esposo Druso contaba con 27 años, decidió no volver a casarse:

“Antonia, por su parte, una mujer que superó en méritos la celebridad de los varones de su familia, respondió al amor de su marido con una fidelidad extraordinaria. Después de la muerte de éste, ella, aún en la flor de su belleza y de

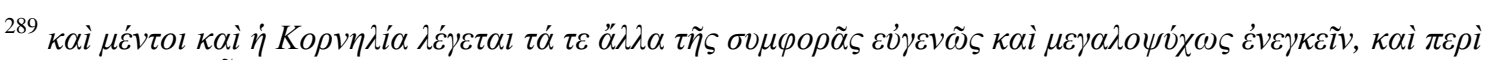

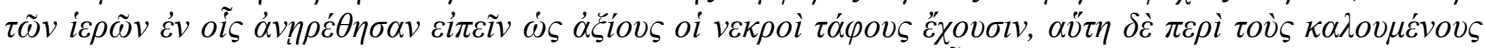

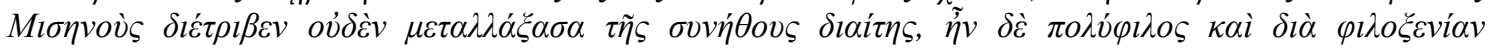

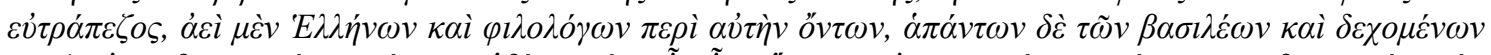

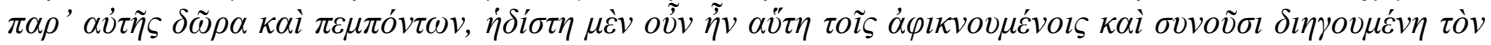

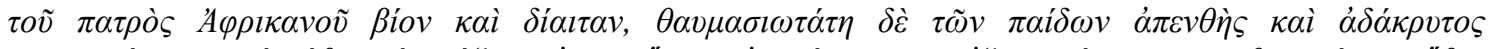

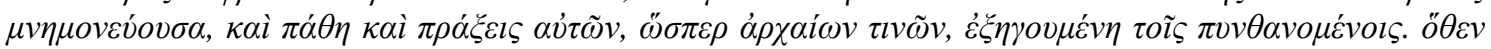

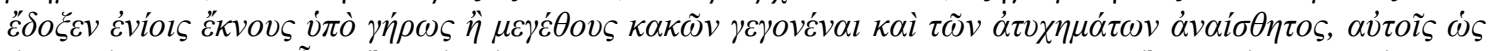

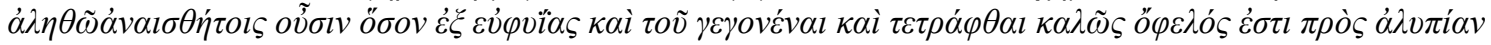

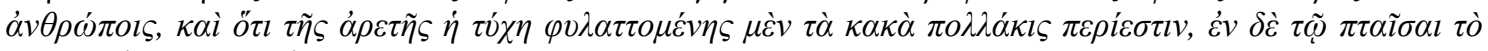

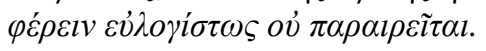


su edad, a cambio de los goces conyugales tuvo únicamente la convivencia con su suegra. Así pues, en el mismo lecho se extinguió el vigor juvenil de su esposo y fue envejeciendo la esposa con la experiencia de su viudedad a cuestas" (Val. Max. $4.3 .3)^{290}$.

Después de que su esposo Cayo Casio Longino se suicidase en el año 42 a.C., Junia Silana Tertia, que estaba en la treintena, decidió no volver a casarse. Falleció medio siglo después, en el año 22 d.C., con unos 95 años (Treggiari, 2007: 152). Rica, viuda y sin descendencia, su testamento se distribuyó entre prácticamente todas las personas de la élite de Roma, a excepción del emperador Tiberio:

“También Junia, sobrina de Catón, esposa de Gayo Casio y hermana de Marco, terminó su vida entonces, a los sesenta y cuatro años de la batalla de Filipos. Su testamento dio lugar a muchos comentarios, porque siendo enormemente rica y tras haber nombrado con honor a casi todos los prohombres de Roma, omitió al César. Tiberio lo tomó liberalmente y no impidió que su funeral se solemnizara con un elogio ante los Rostros y demás ceremonias. Marchaban delante las imágenes de veinte ilustres familias: Manlios, Quincios y otros nombres de similar nobleza. Pero brillaban sobre todos Casio y Bruto precisamente porque sus imágenes no estaban a la vista" (Tac. Ann. 3.76) ${ }^{291}$.

Tras participar en la conspiración que acabó con la vida de su esposo Domiciano y nombró emperador a Nerva en el año 96 d.C., Domicia Longina, que por aquel entonces era una mujer madura, decidió pasar el resto de sus días como una viuda retirada de la vida pública, en su villa de Gabii (Cass. Dio 67.15; Suet. Dom. 14.1) ${ }^{292}$. Según Dión Casio (67.15) temía que Domiciano, de conocido carácter sanguinario, hubiese planeado asesinarla, lo que la empujó a participar en la conspiración. Desde su retiro, siguió invirtiendo su gran fortuna en acciones evergéticas y dirigiendo entre otros un negocio de fabricación de ladrillos (CIL 15.548.1-15.550.24). A pesar de no vivir en la capital, no perdió contacto con la vida política de la misma, manteniendo poderosas amistades e

\footnotetext{
${ }^{290}$ Antonia quoque, femina laudibus uirilem familiae suae claritatem supergressa, amorem mariti egregia fide pensauit, quae post eius excessum forma <et> aetate florens conuictum socrus pro coniugio habuit, in eodemque toro alterius adulescentiae uigor extinctus est, alterius uiduitatis experientia consenuit. hoc cubiculum talibus experimentis summam inponat.

${ }^{291}$ Et Iunia sexagesimo quarto post Philippensem aciem anno supremum diem explevit, Catone avunculo genita, C. Cassii uxor, M. Bruti soror. testamentum eius multo apud vulgum rumore fuit, quia in magnis opibus cum ferme cunctos proceres cum honore nominavisset Caesarem omisit. Quod civiliter acceptum neque prohibuit quo minus laudatione pro rostris ceterisque sollemnibus funus cohonestaretur. Viginti clarissimarum familiarum imagines antelatae sunt, Manlii, Quinctii aliaque eiusdem nobilitatis nomina. sed praefulgebant Cassius atque Brutus eo ipso quod effigies eorum non visebantur.

${ }^{292}$ Se ha planteado la posibilidad de que volviese a contraer matrimonio, pero parece poco probable (Burns, 2007: 100; Chausson, 2003: 123; Hidalgo, 2012: 94).
} 
influyendo en las princesas imperiales y la moda femenina de la época (Joseph. Vit. 76). Falleció entre los años 126 y 140 d.C., con alrededor de 80 años (CIL 14.2795; Chausson, 2003: 102).

A mediados del siglo II d.C., tras enviudar de su primer esposo, Pudentila vivió sola hasta volver a casarse, 14 años después, si bien era visitada por sus familiares. Durante ese tiempo, "revisaba con la mayor pericia las cuentas que le presentaban sus granjeros, sus pastores y sus caballerizos" (Apul. Apol. 87.6) ${ }^{293}$, lo que demuestra su independencia. Ausonio nos muestra, ya en contexto cristiano, a diversas mujeres de su familia que decidieron permanecer solteras toda o gran parte de su vida. Ya hemos hecho alusión a sus tías Emilia Hilaria y Julia Catafronia, a las que se une su hermana:

"Julia Driadia, mi hermana. Si hubo alguna virtud que quisiera poseer cualquier mujer sabia, no careció de ella mi hermana Driadia. Y además, tuvo otras muchas que gustaría tener el sexo más fuerte y la nobleza de las fuerzas. Bastante cultivada para proteger su vida con la rueca y su fama, cultivada en las buenas costumbres y para enseñarlas a los suyos. Para ella era más querida la verdad que la vida y su única preocupación era conocer a Dios y amar a su hermano más que a los demás. Quedó todavía joven sin marido pero, con su vida discreta y sus costumbres, se igualó a las ancianas austeras y alargó durante sesenta años su vida placentera y murió en la misma casa y bajo el mismo techo que su padre" (Auson. Par. 12) ${ }^{294}$.

Cabe preguntarse qué ocurría cuando la viuda no poseía las riquezas de las mujeres a las que acabamos de aludir. En este sentido, ya hemos hecho referencia a mujeres que se ven obligadas a prostituir a sus hijas tras la muerte de sus esposos. Siendo éstos casos extremos, creemos que en general las vetulae viudas que no pudieran mantenerse por sí mismas acudirían a sus familiares más cercanos para evitar caer en la pobreza.

Existía también la posibilidad de que una vetula romana estuviese soltera, ya fuera porque nunca se había casado o porque estaba divorciada. No obstante, las fuentes no suelen referir este tipo de situaciones de forma explícita, por lo que muchas ancianas que nos aparecen sin marido en la documentación podrían ser solteras, viudas, o incluso

\footnotetext{
${ }^{293}$ neget eam rationibus uilliconum et upilionum et equisonum sollertissime subscripsisse.

${ }^{294}$ Iulia Dryadia soror. Si qua fuit virtus, cuperet quam femina prudens esse suam, soror hac Dryadia haud caruit, quin etiam multas habuit, quas sexus habere fortior optaret nobilitasque virum, docta satis vitamque colu famamque tueri, docta bonos mores ipsa suosque docens, et verum vita cui carius unaque cura nosse deum et fratrem diligere ante alios. Coniuge adhuc iuvenis caruit, sed seria vitans moribus austeras aequiperavit anus produxitque hilarem per sena decennia vitam, inque domo ac tecto, quo pater, oppetiit.
} 
casadas aunque no se mencione una pareja. Tras divorciarse de Cicerón, Terencia, que por entonces tenía aproximadamente 52 años (Treggiari, 2007: 31), no volvió a contraer matrimonio aparentemente (Treggiari, 2007: 152). Fallecida con 103 años, poseía una gran fortuna que acrecentó en su vejez mediante herencias y negocios (Cic. Att. 2.4.5 y 13.46; Plin. NH 7.48.158-159; Plut. Cic. 8 y 46; Val. Max. 8.13.6; Ferrer, 2013; Treggiari, 2007: 143 y ss.). Divorciada de Augusto, Escribonia acompañó en el año 2 a.C. a su hija Julia al exilio. Tras la muerte de Julia, apoyó políticamente a su sobrinonieto Escribonio Libón Druso, quien acabó suicidándose poco antes de la muerte de Escribonia, fallecida con más de 80 años (Sen. Ep. 70.10; Leon, 1951: 174-175; Posadas, 2013: 271).

Los papiros del Egipto romano aportan evidencias sobre vetulae solteras. Algunas viven con la familia de su hermano. Es el caso de una mujer de 70 años que en el año 117 d.C. vivía con la viuda de su hermano (53), su sobrino (32) y sus sobrinas (33 y 28) (BF 117-Ar-1). Catorce años más tarde, ambas vetulae habían fallecido y una de las mujeres jóvenes ya no vivía en la casa, pudiendo haberse casado o fallecido ( $B F$ 131Ar-3).

Otro caso de soltería es el de las vírgenes vestales. Comenzaban su servicio en el templo de Vesta siendo niñas, y su sacerdocio duraba 30 años. A pesar de que una vez pasado este tiempo estas mujeres aún estarían en edad de concebir, parece ser que la mayoría decidían seguir solteras:

"Una vez pasados los treinta años nada impedía que las que quisieran se casaran, tras dejar sus cintas y las restantes insignias del sacerdocio. Y no pocas lo hicieron, pero el final de sus vidas les resultó poco envidiable y muy infeliz. De modo que las demás, tomando como un presagio las desgracias de aquéllas, permanecieron vírgenes en el templo hasta su muerte, y entonces se nombraba de nuevo a otra por los pontífices para completar el número" (Dion. Hal. Ant. Rom. 2.67.2) ${ }^{295}$.

"Después de pasado este tiempo, a la que quiere se le permite casarse y abrazar otro género de vida, retirándose del sacerdocio; aunque se dice que no han sido muchas las que se han valido de esta concesión, y que a las que se han valido de ella no les han sucedido las cosas prósperamente, sino que entregadas al arrepentimiento y al disgusto por el resto de sus días, han sido causa de

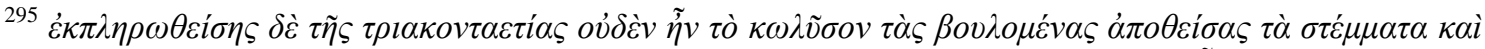

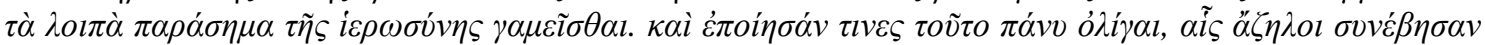

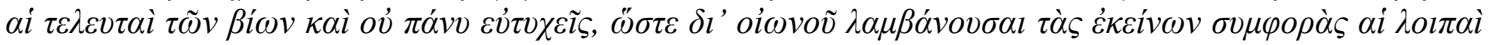

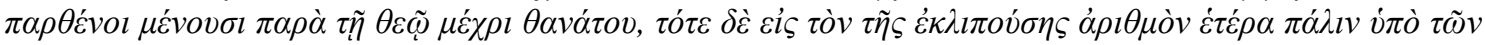

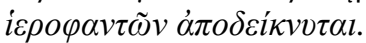


superstición para las demás, tanto que hasta la vejez y la muerte han aguantado permaneciendo vírgenes" (Plut. Num. 10.2) 296. $^{296}$

Aquellas vestales que decidían permanecer en el cargo podían ocuparlo durante periodos tan largos de tiempo como Occia, quien en el siglo I d.C. sirvió en el templo durante 57 años (Tac. Ann. 2.86).

Las vestales disfrutaban de una serie de prerrogativas, como la capacidad de testar, gracias a las cuales muchas de ellas, que además provenían de familias adineradas, reunían un gran patrimonio (Dion Hal. Ant Rom. 67; Plut. Num. 10). Al no tener esposo ni descendencia, su riqueza beneficiaría principalmente a su familia, sobre cuyas mujeres recaía la responsabilidad de cuidar de ellas en caso de enfermedad e, intuimos, también de dependencia:

"Estoy inquieto por la enfermedad de Fania. La contrajo mientras cuidaba de la vestal Junia, al principio por voluntad propia (pues Junia es pariente suya), luego también por orden de los pontífices. Pues las vírgenes vestales, cuando son obligadas por una grave enfermedad a abandonar el templo de Vesta, son confiadas al cuidado y protección de mujeres casadas" (Plin. Ep. 7.19) ${ }^{297}$.

En este caso, puede que la tarea de cuidadora tuviera funestas consecuencias y Fania falleciera debido a la enfermedad contraída, con más de 90 años, ya que su estado parece bastante grave y Plinio no vuelve a informarnos sobre ella (Shelton, 2013: 90).

A medida que acumulaban años de cargo, a la influencia que ya tenían por su familia de origen se la uniría la derivada del sacerdocio, de forma que podían intervenir incluso en los asuntos públicos. Ya hemos hecho referencia a Flavia Publicia, conmemorada por su sobrina y el hijo de ésta en agradecimiento a la ayuda que les había prestado (CIL 6.32414). En el año 22 d.C. Torcuata intercedió ante Tiberio para que fuera benevolente con su hermano Cayo, acusado de concusión durante su mandato como procónsul en Asia. Tiberio decidió exiliarlo a la isla de Cinto, y "añadió que ésa era también la petición de Torcuata, la hermana de Silano, vírgen vestal de una santidad a la antigua" (Tac. Ann. 3.69.6).

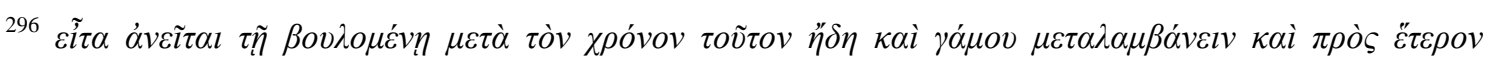

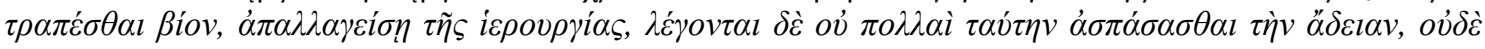

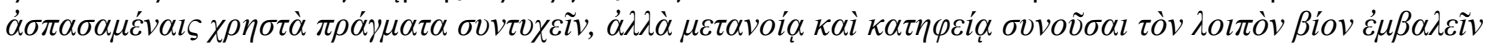

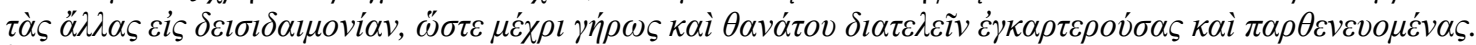
${ }^{297}$ Angit me Fanniae valetudo. Contraxit hanc dum assidet Iuniae virgini, sponte primum -est enim affinis-, deinde etiam ex auctoritate pontificum. Nam virgines, cum vi morbi atrio Vestae coguntur excedere, matronarum curae custodiaeque mandantur.
} 
Una vetula rica sin pareja atraía a los captatores (Juv. 1.37-40; Mart. 11.29; Plaut. Mostell. 275-280; Tac. Hist. 1.73). Se trataba de mujeres y hombres que trataban de ganarse la simpatía de vetulae y senes adinerados con la intención de obtener beneficios en vida $\mathrm{y}$, sobre todo, tras la muerte de la persona anciana en cuestión. El de los captatores es un fenómeno que parece haber sido común ya en el siglo II a.C., si bien pudo aumentar hacia finales de la República e inicios del Imperio debido a que cada vez era más frecuente encontrar matrimonios sin descendencia (Hartmann, 2012: 436; Tracy, 1980: 399). Hacia el año 55 d.C. Agripina evitó el matrimonio entre su amiga Junia Silana y Sextio Africano, al considerar que él era un captator:

"Ninguna cosa humana es tan inestable e insegura como la fama de poder no apoyada en la propia fuerza. Al instante quedó desierto el umbral de Agripina: nadie la consolaba, nadie la visitaba salvo unas pocas mujeres, no se sabe si por amor o por odio. Entre ellas estaba Junia Silana, a la que Mesalina había alejado del matrimonio con Gayo Silio, según ya conté más arriba; era mujer notable por su linaje, por su belleza y su lascivia, y había disfrutado largo tiempo de la predilección de Agripina; luego surgieron entre ellas rencores que quedaron ocultos, porque Agripina había hecho desistir de casarse con Silana a Sextio Africano, un joven noble, diciéndole una y otra vez que era una mujer impúdica y de edad ya caduca; y no por reservarse a Africano para sí, sino para evitar que un marido se aprovechase de las riquezas de Silana y de su falta de hijos" (Tac. Ann. $13.19 .1-2)^{298}$

Junia se vengó de Agripina llevándola a juicio. Cuando se le notificó la acusación, Agripina utilizó la edad de Junia y su soltería como insulto contra ella:

"Agripina, echando mano de su carácter altivo, dijo: «No me extraña que Silana, que nunca ha tenido hijos, desconozca los afectos propios de una madre; y es que las madres no cambian de hijos como hace una impúdica con sus amantes. Además, si Iturio y Calvisio, tras haber devorado sus fortunas enteras, como último recurso venden a saldo a una vieja la tarea de presentar una acusación, no por mí ha de recaer sobre mí la infamia y sobre el César la conciencia de un parricidio»"

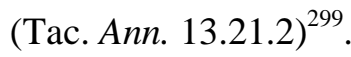

\footnotetext{
${ }^{298}$ Nihil rerum mortalium tam instabile ac fluxum est quam fama potentiae non sua vi nixa[e]. statim relictum Agrippinae limen: nemo solari, nemo adire praeter paucas feminas, amore an odio incertas. Ex quibus erat Iunia Silana, quam matrimonio C. Sili a Messalina depulsam supra rettuli, insignis genere forma lascivia, et Agrippinae diu percara, mox occultis inter eas offensionibus, quia Sextium Africanum nobilem iuvenem a nuptiis Silanae deterruerat Agrippina, impudicam et vergentem annis dictitans, non ut Africanum sibi seponeret, sed ne opibus et orbitate Silanae maritus poteretur.

${ }^{299}$ Et Agrippina ferociae memor "non miror" inquit, "Silanam numquam edito partu matrum adfectus ignotos habere; neque enim proinde a parentibus liberi quam ab impudica adulteri mutantur. nec si
} 
Las acciones de los cazadores de herencias, que tenían el foro y los mercados como lugar de captación, se basaban en la costumbre socialmente establecida de que las amistades debían ser incluidas en el testamento. A la víctima debían ofrecérsele regalos con los que ganarse su confianza:

"Hay quienes dan caza a las viudas avaras con pastas y frutas, y tienden el lazo a los viejos, a fin de meterlos en sus viveros" (Hor. Ep. 1.1.75-80) ${ }^{300}$.

"Porque envías grandes regalos a los viejos y a las viudas ¿quieres, Gargiliano, que te llame generoso? No hay ser más avaro ni persona más abyecta que tú y sólo tú, que puedes llamar regalos a tus insidias. Así de complaciente es el anzuelo falaz con los peces ansiosos, así engaña a las estúpidas fieras un astuto cebo. Qué es ser generoso, qué es hacer regalos, voy a enseñártelo, por si no lo sabes: hazme regalos a mí, Gargiliano" (Mart. 4.56) ${ }^{301}$.

No obstante, los captatores son criticados en las fuentes literarias precisamente porque el prestar ayuda a los amigos mediante acciones como hacer recados, procurar cuidados durante las enfermedades, o hacer compañía, se daban por sentadas en las relaciones de amicitia, sin esperar nada a cambio, y no con un objetivo económico. Así lo ilustra Luciano en un diálogo ficticio entre divinidades:

"PLUTÓN - ¿Conoces al anciano aquel, me refiero al viejo y rico Eucrates, que no tiene descendencia, pero sí cincuenta mil que van detrás de él para conseguir su herencia?

HERMES - Sí; quieres decir el de Sicione. ¿Qué pasa con él?

PL. - A él, déjale vivir, Hermes, que pueda sumar otros tantos a los noventa años que tiene ya, y si es posible, a aduladores suyos como el joven Carino, Damón y también otros, arrástralos uno detrás de otro aquí abajo.

HE. - Tus intenciones son un poco extrañas, a mi parecer.

PL. - En absoluto, todo es por una causa justa y honesta. Dime si no con qué intención pretenden su muerte, si no es con la de conseguir sus riquezas, además sin tener ningún parentesco con el anciano. Pero lo peor del caso es que a pesar de que desean ese terrible desenlace, le cuidan, la gente les ve, y a pesar de los muchos sacrificios que prometen si se cura, todo el mundo sabe lo que traman. En

Iturius et Calvisius adesis omnibus fortunis novissimam suscipiendae accusationis operam anui rependunt, ideo aut mihi infamia parricidii aut Caesari conscientia subeunda est".

${ }^{300}$ Sunt qui frustis et pomis uiduas uenentur auaras excipiantque senes, quos in uiuaria mittant.

${ }^{301}$ Munera quod senibus uiduisque ingentia mittis, uis te munificum, Gargiliane, uocem? Sordidius nihil est, nihil est te spurcius uno, qui potes insidias dona uocare tuas: sic auidis fallax indulget piscibus hamus, callida sic stultas decipit esca feras. Quid sit largiri, quid sit donare docebo, si nescis: dona, Gargiliane, mihi. 
fin, que es una adulación bastante hipócrita la practicada por estos individuos. Por esta razón me gustaría la inmortalidad del viejo y la muerte de ellos, esperando con sus bocas codiciosas, en vano abiertas.

HE. - Provocaría la risa de muchos tal desenlace, por pasarse de listos. Aquél también obra por su lado: alimenta sus ilusiones, dándoles falsas esperanzas, en fin, que parece que tenga un pie en la tumba, y en realidad tiene mucha más salud que los otros que son jóvenes, que ya se han repartido, mentalmente, la herencia, y mientras tanto, en el fondo de sus corazones se prometen una vida llena de dicha y prosperidad.

PL. - Muy bien: pues que Eucrates quede liberado de su vejez y vuelva de nuevo a la juventud, como Yolao, y que esos malvados sufran la muerte que se merecen y vengan inmediatamente hacia aquí, arrancándoles las esperanzas y los sueños de riqueza de los que viven.

HE. - Por eso no debes preocuparte, Plutón, pues yo te los traigo de uno en uno. Son siete, si no me equivoco.

PL. - Pues arrástralos hasta aquí, y el viejo, tornada ya su vejez en juventud, participará en el fúnebre cortejo, acompañando a cada uno a su tumba" (Luc. Dial. Mort. 5) ${ }^{302}$.

Existían incluso personas a quienes se consideraba cazadores de testamentos profesionales, como Régulo, de quien nos habla Plinio el Joven. Régulo, que pretendía hacerse rico consiguiendo que vetulae y senes testasen a su favor (Plin. Ep. 2.20.12-14), se acercó a la moribunda Verania, viuda de Lucio Calpurnio Pisón Frugi, para preguntarle cuándo había nacido a fin de calcular cuánto le quedaba de vida, actitud que Plinio desaprueba profundamente:

“¿Qué desvergüenza de hombre, que fue a visitar a una mujer enferma, de cuyo marido había sido el mayor enemigo, y para ella misma el ser más odioso! Pase, si

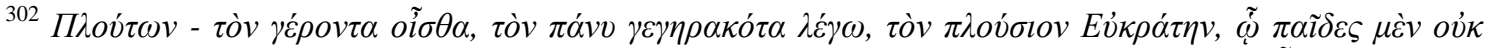

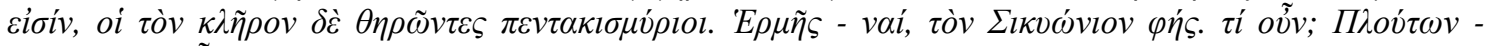

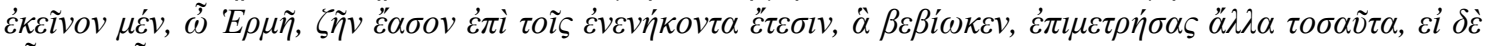

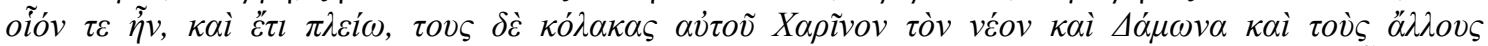

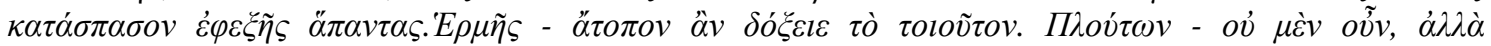

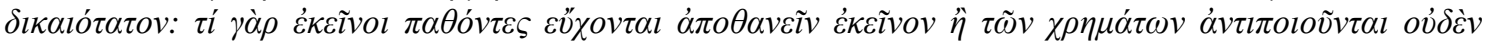

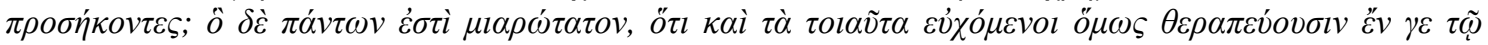

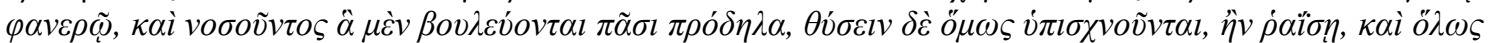

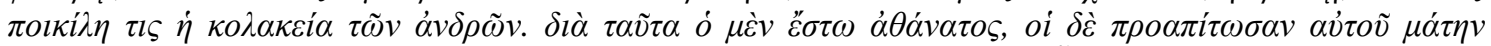

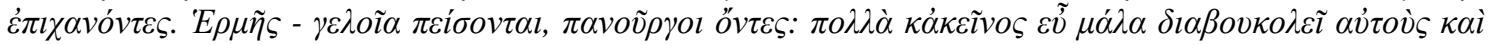

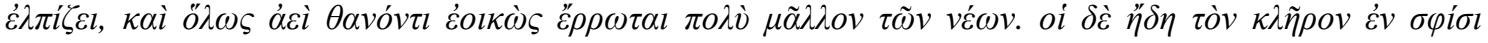

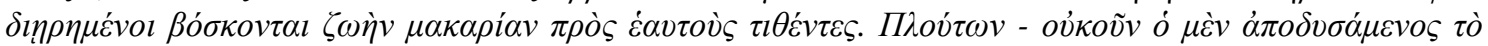

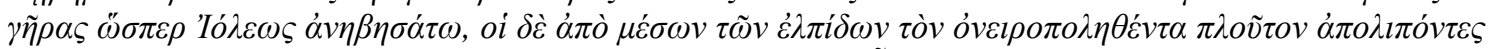

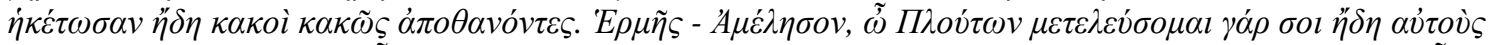

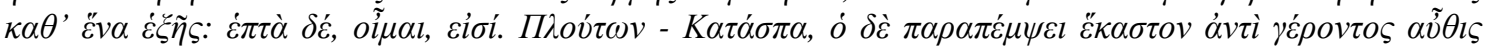

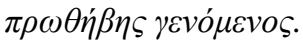


se hubiese limitado a visitarla; pero se sentó muy cerca del lecho, y le preguntó en qué día y a qué hora había nacido" (Plin. Ep. 2.20.3)

Verania no fue la única viuda de la que Régulo pretendía sacar beneficio, demostrando para Plinio su falta de moral:

"Aurelia, una dama de alta alcurnia, se había puesto para acudir a la firma de su testamento sus mejores galas. Como Régulo hubiese acudido para firmar como testigo, le dijo: «Te ruego que me las dejes en tu testamento». Aurelia pensaba que Régulo se estaba burlando de ella, pero aquél insistía muy serio; para no alargarme más, la obligó a abrir su testamento y dejarle la vestimenta que llevaba puesta: la vigiló mientras escribía, comprobó si lo había escrito. Desde luego, Aurelia vive todavía, pero él la obligó a hacer esto como si estuviese a punto de morir" (Plin. Ep. 2.20.10-11) $)^{304}$.

La mayoría de las veces los captatores parecen ser personas pobres que buscan mejorar su situación:

"Después, viviendo en compañía de una vieja, al principio satisfacía los placeres del bajo vientre a costa de ella, fingiendo que estaba enamorado de una mujer de unos setenta y cuatro años, que aún conservaba algunos dientes, postizos de oro. Pero, por mi pobreza, resistí la prueba, y el hambre hacía que me supieran a gloria aquellos besos helados, echados como desde un ataúd. Por un pelo no fui heredero de todos sus bienes, de no ser porque un maldito criado reveló que yo había comprado veneno para emplearlo contra ella" (Luc. Rhet. p. 24) ${ }^{305}$.

No obstante, también encontramos en la literatura captatores ricos que deseaban ampliar su ya abultado patrimonio, así como personas pertenecientes a la élite social pero necesitadas de dinero, las cuales según Elke Hartmann (2012: 439) aumentaron a medida que avanzaba la época altoimperial debido a la disminución de las oportunidades de hacerse con un botín de guerra. A pesar de que no puede ser calificado como captator, Plinio el Joven escribe en varias cartas que ha recibido parte de la herencia de alguna mujer rica, ya sea dinero o propiedades (Plin. Ep. 4.10, 5.1 y 7.11).

\footnotetext{
${ }^{303}$ Primum impudentiam hominis, qui venerit ad aegram, cuius marito inimicissimus, ipsi invisissimus fuerat! Esto, si venit tantum; at ille etiam proximus toro sedit, quo die qua hora nata esset interrogavit.

${ }^{304}$ Aurelia ornata femina signatura testamentum sumpserat pulcherrimas tunicas. Regulus cum venisset ad signandum, 'Rogo' inquit 'has mihi leges.' Aurelia ludere hominem putabat, ille serio instabat; ne multa, coegit mulierem aperire tabulas ac sibi tunicas quas erat induta legare; observavit scribentem, inspexit an scripsisset. Et Aurelia quidem vivit, ille tamen istud tamquam morituram coegit.

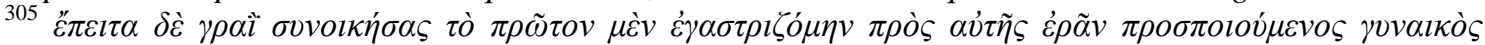

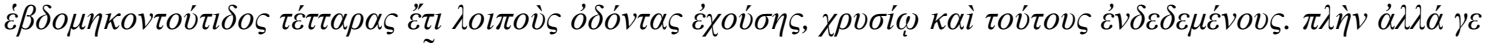

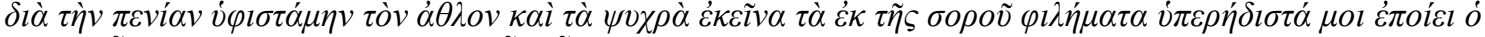

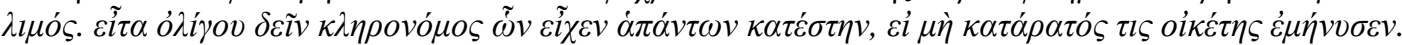


Por su parte, si bien Filomena parece estar pasando necesidades económicas en la vejez, no era el caso cuando tiempo atrás ejercía como captatora:

"Una señora de las más respetables, llamada Filomena, que antaño había aprovechado su juventud para escamotear muchas herencias, ahora, vieja y ajada, presentaba a los ancianos sin familia un hijo y una hija que tenía; intentaba asî transmitir a sus sucesores su propia profesión" (Petron. Sat. 140) ${ }^{306}$.

La víctima perfecta era una que no tuviese pareja ni descendencia (Auson. Ecl. 1.45; Juv. 4.19; Luc. Dial. Mort. 9; Mart. 11.44; Pers. 6.49-54; Petron. Sat. 140; Tac. Ann. 13.19.1-2 y 14.40.1). Podía darse también el caso de que el captator colaborase con una esposa avariciosa o un esclavo deseoso de deshacerse de su amo (Hor. Sat. 2.5.70-73). Una de las estrategias de los captatores era, como hemos visto, intentar contraer matrimonio con la vetula o el senex: "Paula desea casarse conmigo, yo no quiero a Paula por esposa: es vieja. La querría si fuese más vieja” (Mart. 10.8) ${ }^{307}$. También había que recurrir a los halagos y los regalos, y mostrarse dispuesto a ayudar, sobre todo en la enfermedad (Luc. Dial. Mort. 9; Mart. 12.90). A pesar de que la persona captada tuviera hijos, podía enfadarse con ellos o podían fallecer antes que su progenitor. Horacio imaginó un diálogo entre Tiresias y Ulises en el que el primero decía al segundo lo siguiente:

"Ya te lo he dicho y te lo digo otra vez: con astucia y donde sea, procura cazar testamentos de viejos; y si uno o dos son lo bastante listos como para eludir la emboscada después de roer el anzuelo, no pierdas tus esperanzas ni abandones decepcionado el oficio. Si alguna vez en el Foro se debate un pleito, grande o pequeño, de aquel de los dos litigantes que sea rico y sin hijos, del sinvergüenza que en su osadía lleva a los tribunales a un hombre decente, de aquél hazte tú defensor; y al ciudadano que es superior por su fama y derecho, desprécialo si en su casa hay un hijo o una esposa fecunda. Supongamos que dices: «Publio» o «Quinto -y es que a las orejas blandas les gusta su nombre-, tus méritos me han hecho tu amigo. Yo conozco las vueltas que tiene el derecho, y se me da bien la defensa de pleitos; cualquiera me arrancará los ojos antes de que logre hacerte de menos a ti y quitarte una migaja. Es cosa mía el que tú nada pierdas y que no te tomen el pelo». Mándale que se vaya a casa y que se cuide el pellejo; conviértete en su defensor, aguanta y resiste, ya sea que la roja canícula raje las mudas

\footnotetext{
306 Matrona inter primas honesta, Philomela nomine, quae multas saepe hereditates officio aetatis extorserat, tum anus et floris extincti, filium filiamque ingerebat orbis senibus, et, per hanc successionem artem suam perseverabat extendere.

${ }^{307}$ Nubere Paula cupit nobis, ego ducere Paulam nolo: anus est. Vellem, si magis esset anus.
} 
estatuas, ya que Furio, hinchado de grasientas tripas de cava, escupa canosa nieve en invierno sobre los Alpes. «¿No ves -dirá alguno dándole con el codo al que esté a su lado- qué paciente es, qué bueno con los amigos, y cuánto se esfuerza?» Nadarán hacia ti los atunes y crecerán en tus viveros. Además, si alguno cría en medio de grandes riquezas a un hijo reconocido de mala salud, procura que no te deje al desnudo la adulación manifiesta al padre soltero; ábrete camino con suavidad hacia tus esperanzas, mostrándote amable, a fin de que te inscriba como segundo heredero; y si una desgracia manda al Orco al muchacho, ocupes tú el lugar que queda vacío. Esta jugada falla muy raramente. (...) Lo que te voy a contar sucedió cuando yo ya era viejo. En Tebas, una pícara vieja fue enterrada de esta manera, en virtud de su testamento: el cadáver, generosamente untado de aceite, lo llevó el heredero en sus hombros desnudos, sin duda para ver si después de muerta lograba escaparse; y es que creo que en la vida la había acosado en exceso. Tú acércate con cautela, y ni cejes en la tarea, ni te pases por tu falta de tacto. Al que es antipático y puntilloso le molestará un charlatán: más allá del "no" y del "sí" mantente callado. Hazte el Davo de la comedia y quédate cabizbajo, como quien tiene miedo. Esfuérzate en ser obsequioso: si el aire arrecia, avísale que tenga cuidado y se cubra su cabecita; sácalo de entre la turba protegiéndolo con tus espaldas; si es hablador, arrima la oreja. Al que es poco tratable le gusta el elogio; hasta que levantando las manos al cielo te diga «iEh, ya está bien!», aprémialo e hincha con tu charla ampulosa el odre que crece. Cuando él te haya librado de tu servidumbre y de tus largos cuidados y, estando seguro de que estás despierto, hayas oído: «De la cuarta parte sea Ulises el heredero», suelta de tiempo en tiempo algo así como: «¿Así que ahora ya no está Dama, mi compañero? ¿De dónde sacaré yo uno tan valiente y tan fiel?»; y si puedes, suelta unas lágrimas; hay modos de ocultar la expresión que denuncia alegría. El sepulcro, si lo ha dejado a tu arbitrio, házselo sin tacañerías, y un funeral que el vecindario alabe como algo egregio. Si alguno de los coherederos es más viejo que tú y tose de mala manera, dile que en caso de que quiera comprar una finca o una casa de la parte que a ti te toca, estarás encantado de dejársela en nada" (Hor. Sat. 2.5.25-105) ${ }^{308}$.

\footnotetext{
${ }^{308}$ Dixi equidem et dico: captes astutus ubique testamenta senum neu, si vafer unus et alter insidiatorem praeroso fugerit hamo, aut spem deponas aut artem inlusus omittas. Magna minorve foro si res certabitur olim, vivet uter locuples sine gnatis, inprobus, ultro qui meliorem audax vocet in ius, illius esto defensor; fama civem causaque priorem sperne, domi si gnatus erit fecundave coniux. "Quinte" puta aut "Publi"gaudent praenomine molles auriculae-"tibi me virtus tua fecit amicum. Ius anceps novi, causas defendere possum; eripiet quivis oculos citius mihi quam te contemptum cassa nuce pauperet; haec mea cura est, nequid tu perdas neu sis iocus". Ire domum atque pelliculam curare iube; fi cognitor ipse, persta atque obdura: seu rubra Canicula findet infantis statuas, seu pingui tentus omaso Furius hibernas cana nive conspuet Alpis. "Nonne vides" aliquis cubito stantem prope tangens inquiet, "ut patiens, ut amicis aptus, ut acer?" Plures adnabunt thynni et cetaria crescent. Sicui praeterea validus male filius in
} 
En el caso de que la víctima tuviera familia, el éxito de los cazadores de herencias le suponía un gran perjuicio:

“Gustándote Fíleros, comprado por toda tu dote, consientes, Gala, en que tus tres

hijos perezcan de hambre. Tanta consideración se presta a un coño con canas, al que ya no le está bien ni un amor casto. Que los dioses te hagan para siempre la coima de Fíleros, ;oh madre peor todavía que Poncia!" (Mart. 2.34) 309.

Por otro lado, a pesar de los esfuerzos, los captatores podían ver sus planes truncados: "Si un viejo, al quedarse solo, modifica el testamento, el cliente visitador se dirigirá a otra mansión" (Sen. Ep. 2.19.4) (10 $^{310}$ Podía ocurrir que no recibieran nada de lo esperado, como les pasó también a quienes deseaban formar parte del testamento de Domicio Tulo (Plin. Ep. 8.18.1-2), o que fuera menos de lo pensado. Así les ocurrió a quienes rodeaban a Umidia Cuadratila con la intención de enriquecerse a su muerte y también a Herennio Rufo y su esposa, ya que Ponciano legó su patrimonio a su hermano y a su madre, en vez de a su esposa, conocedor de las intenciones de sus suegros (Apul. Apol. 97.7; Plin. Ep. 7.14). Varios captatores podían buscar beneficios de una misma persona y, tras el fallecimiento, comprobar que ésta sólo había nombrado heredero a uno de ellos (Luc. Dial. Mort. 9). Al riesgo de perder lo invertido se le podía unir la impaciencia por la existencia de un senex o vetula que vivía mucho más de lo esperado, incluso más que quien ansiaba su herencia (Luc. Dial. Mort. 8). Luciano hace al captator Terpsión lamentarse por haber fallecido antes que el senex de quien esperaba obtener beneficio:

"PLUTÓN.- Terpsión, todo esto sucede con mucha más lógica de lo que tú te imaginas. Si no ¿por qué deseáis con tanto fervor los bienes ajenos y cuidáis a ancianos sin descendencia, intentando así haceros pasar por hijos suyos? Con esta

\footnotetext{
re praeclara sublatus aletur, ne manifestum caelibis obsequium nudet te, leniter in spem adrepe officiosus, ut et scribare secundus heres et, siquis casus puerum egerit Orco, in vacuom venias: perraro haec alea fallit (...) me sene quod dicam factum est. anus inproba Thebis ex testamento sic est elata: cadáver unctum oleo largo nudis umeris tulit heres, scilicet elabi si posset mortua; credo, quod nimium institerat viventi. Cautus adito neu desis operae neve immoderatus abundes. Difficilem et morosum offendet garrulus: ultra 'non' 'etiam' sileas; Davus sis comicus atque stes capite obstipo, multum similis metuenti. Obsequio grassare; mone, si increbruit aura, cautus uti velet carum caput; extrahe turba oppositis umeris; aurem substringe loquaci. Inportunus amat laudari: donec 'ohe iam' ad caelum manibus sublatis dixerit, urge: crescentem tumidis infla sermonibus utrem. Cum te servitio longo curaque levarit, et certum vigilans "quartae sit partis Ulixes" audieris "heres": "ergo nunc Dama sodalist nusquam est? Unde mihi tam fortem tamque fidelem?" Sparge subinde et, si paulum potes inlacrimare, est gaudia prodentem voltum celare. Sepulcrum permissum arbitrio sine sordibus exstrue: funus egregie factum laudet vicinia. Siquis forte coheredum senior male tussiet, huic tu dic, ex parte tua seu fundi sive domus sit emptor, gaudentem nummo te addicere.

${ }^{309}$ Cum placeat Phileros tota tibi dote redemptus, tres pateris natos, Galla, perire fame. Praestatur cano tanta indulgentia cunno quem nec casta potest iam decuisse Venus. Perpetuam di te faciant Philerotis amicam, o mater, qua nec Pontia deterior.

${ }^{310}$ Mutabunt testamenta destituti senes, migrabit ad aliud limen salutator.
} 
conducta os convertís en objeto de burla, con mucha razón, pues acabáis siendo enterrados antes que ellos, cosa que agrada a los demás, ya que cuanto más fuerte es vuestro deseo de ver muertos a estos ancianos, más divertida es para los demás vuestra muerte. Pienso que de algún modo, habéis ideado un arte nuevo: encandilados por esos ancianos, sobre todo si no tienen descendencia, pues los que sí tienen no os encandilan. Ya ha habido muchos ancianos, sin embargo, que comprendiendo este afecto vuestro tan ambiguo, incluso con descendencia, fingen odiar a sus hijos, para poder gozar también de vosotros como amantes, pero cuando llega el momento de la verdad, aquéllos que fueron su escolta durante mucho tiempo son excluidos de su testamento, entonces de forma justa la naturaleza otorga esos bienes a los hijos verdaderos, mientras tanto vosotros, los burlados, tan sólo os queda el rechinar de dientes y la furia.

TERPSIÓN.- Tienes mucha razón. ¡Cuántas riquezas mías devoró Túcrito haciendo ver que iba a morirse a cada momento y en cuánto me veía llegar exhalaba unos gemidos que parecían una especie de hondos graznidos iguales a los de un polluelo recién salido del cascarón! Entonces yo, totalmente engañado, pensando que ya estaba con un pie en la tumba, continuamente le mandaba regalos, para que mis rivales no me ganasen en la largueza de mis dones. Casi siempre la preocupación me hacía estar tumbado en la cama sin poder dormir, contando y clasificando uno por uno los bienes del anciano. Esto fue, sin duda, lo que me mató: la preocupación y el insomnio. Y él, mientras tanto, después de haberse tragado todos mis cebos, estaba ayer en mi entierro riéndose a carcajada limpia” (Luc. Dial. Mort. 6) ${ }^{311}$.

Para evitar esta situación, algunos captatores eran capaces de recurrir incluso al asesinato, si bien el plan no siempre era llevado a cabo con éxito:

"Confíale al perdido de Esceva esa madre longeva: su diestra piadosa no cometerá ningún crimen -ipues sí que es extraño que el lobo no ataque a patadas ni el buey

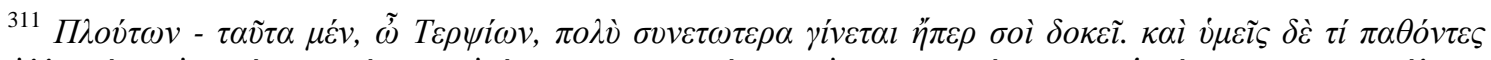

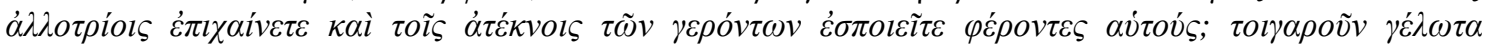

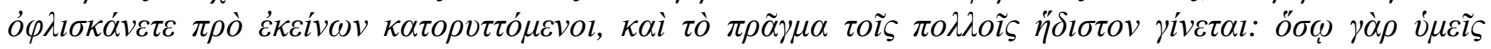

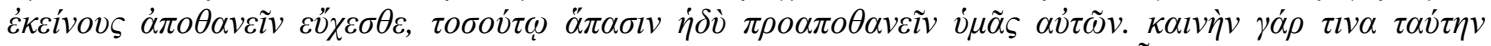

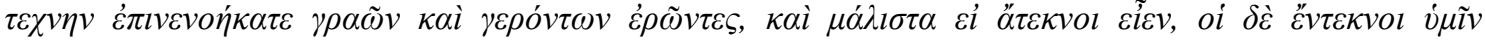

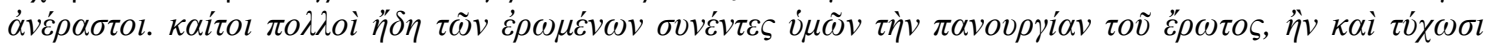

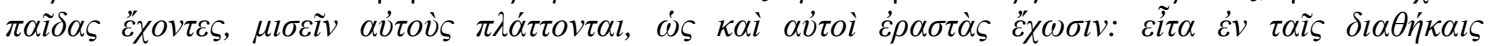

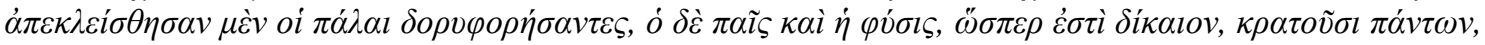

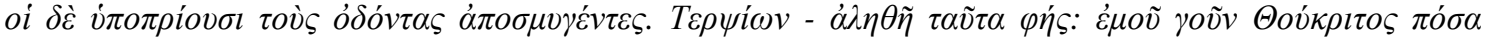

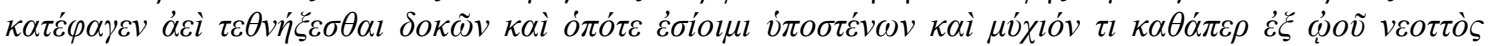

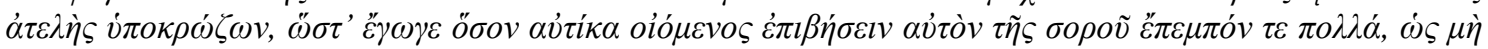

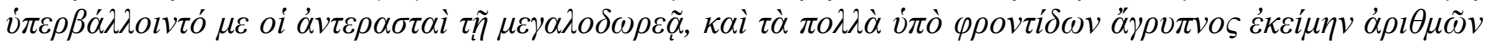

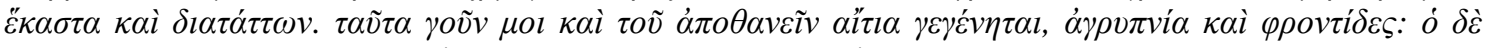

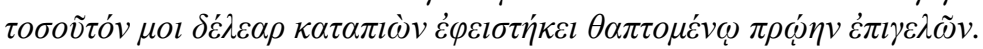


con sus dientes!-: pero será la maligna cicuta, emponzoñando la miel, la que quite de en medio a la vieja" (Hor. Sat. 2.1.54-57) ${ }^{312}$.

"De ahí la muerte súbita de viejos que no han hecho testamento" (Juv. 1.144) ${ }^{313}$.

"ZENOFANTES - ¿Cómo fue tu muerte, Calidemides? Ya debes saber que yo fallecí atragantado, por comer más de la cuenta, mientras era parásito de Dinias. Tú fuiste testigo de mi muerte.

CALIDEMIDES - Sí que lo fui, Zenofantes. El mío fue un caso realmente raro. Seguramente conoces al anciano Pteodoro, ¿verdad?

ZE. - ¿Aquél tan rico y sin hijos con el que pasabas todo el tiempo?

CA. - Precisamente a ese cuidaba yo con gran esmero y dedicación, pues había prometido hacerme heredero suyo. Pero, como la cosa se iba alargando demasiado y el viejo tenía más años que Titono, ideé un plan para poder gozar antes de su herencia: compré veneno y convencí al copero para que, cuando Pteodoro estuviese sediento -suele tomar bastante vino y del bueno-, echase mi fórmula en su copa; aceptó mi propuesta a cambio de su libertad.

ZE. - Entonces, ¿qué sucedió? Me da la impresión de que lo que dirás va a sorprenderme.

CA. - Pues verás: después de tomar un baño, fuimos a la mesa, donde se encontraban ya las dos copas preparadas por el joven copero, una era para Pteodoro, la cual contenía veneno y la otra para mí, pero no sé cómo, se equivocó y me dio a mí la copa con el veneno. Así que, mientras él bebía tranquilamente, yo caía al suelo muerto. ¿Y ahora, por qué te ríes, Zenofantes? Está muy mal burlarse de un amigo.

ZE. - Es que tu historia me parece muy divertida, Calidemides. ¿Y cuál fue la reacción del viejo?

CA. - Al principio se sorprendió al verme caer al suelo. Pero, enseguida se percató de lo ocurrido, y también él rió mucho, pensando en el penoso error del copero.

ZE. - Fue muy arriesgado coger ese atajo. Por el camino normal, habrías llegado a gozar de su herencia, de forma más lenta pero segura" (Luc. Dial. Mort. 7)

\footnotetext{
312 Scaevae vivacem crede nepoti matrem: nil faciet sceleris pia dextera-mirum, ut neque calce lupus quemquam neque dente petit bos-, sed mala tollet anum vitiato melle cicuta.

${ }_{313}^{313}$ Hinc subitae mortes atque intestata senectus.

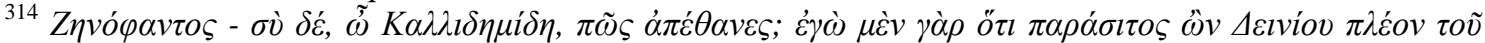

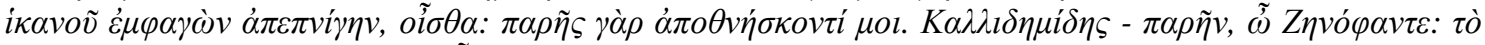

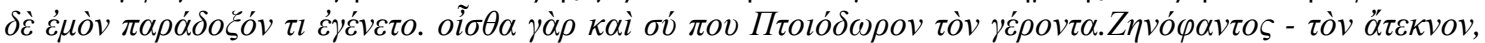

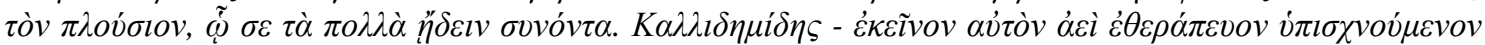

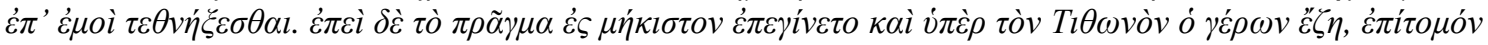

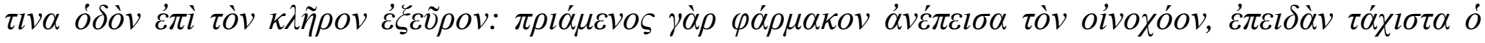

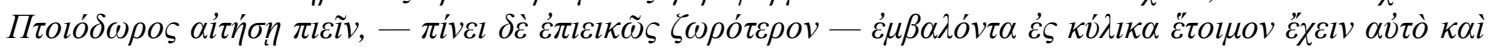


Una vez muerta la vetula, los captatores se moverían en busca de otra víctima con la que engrosar su patrimonio. No obstante, en ocasiones estas relaciones, aunque movidas por el interés económico, pudieron librar del aislamiento a vetulae y senes que no tenían familia y procurarles los cuidados necesarios en la vejez.

\section{IV.1.6. Más allá de la consanguineidad: amigas, patronas y esclavas}

En el presente apartado queremos analizar aquellas relaciones que las vetulae tendrían fuera del ámbito familiar. Nos referiremos a las relaciones de amistad, de clientela, y de esclavitud.

Las fuentes escritas nos hablan de relaciones de amistad entre mujeres forjadas en la juventud y que continuaron en la ancianidad. La amistad de Urgulania con Livia fue la que hizo posible que la primera enviase a su nieto el puñal con el que se quitó la vida, restaurando en la medida de lo posible el honor familiar (Tac. Ann. 4.22). También hemos hecho referencia a cómo la relación con la Augusta salvó de la condena a muerte a Munacia Plancina. En el año 33 d.C., muerta Livia, Munacia volvió a ser acusada y decidió suicidarse al presentir que no iba a tener la misma suerte que en la anterior ocasión (Tac. Ann. 2.71.2). Livia también mantuvo una amistad con Salomé, hermana de Herodes el Grande. Se habían conocido durante el viaje que Livia y Augusto habían realizado a Siria hacia el año 20 a.C., y estuvieron en contacto hasta la muerte de Salomé tres décadas después (Barrett, 2002: 182).

Además de Calpurnia Hispula, otra amiga de su madre con la que Plinio mantuvo relación, al menos económica, es Corelia, a quien vendió unas propiedades que había heredado (Plin. Ep. 7.11). De la misma forma, Cicerón mantuvo una estrecha relación con Cecilia, la madre de Ático, de quien cuidó en su ausencia (Cic. Att. 1.7 y 1.8). Tanto él como Terencia frecuentaban su compañía y la de su hermana: "[Terencia] Os quiere muchísimo a ti, a tu hermana y a tu madre: ella y la pequeña Tulia, delicia de mi alma,

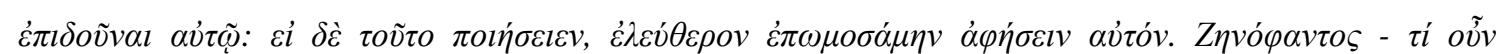

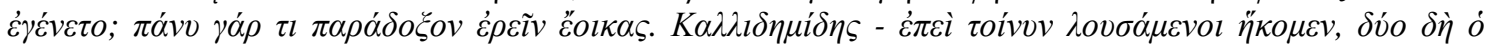

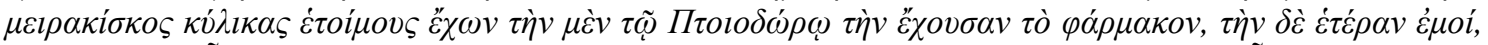

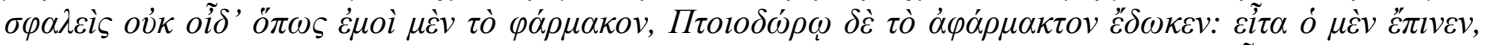

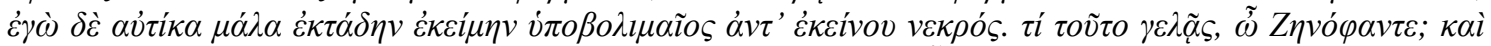

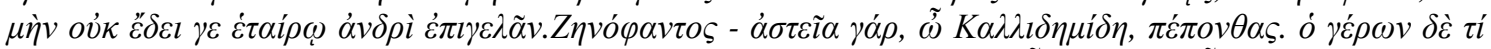

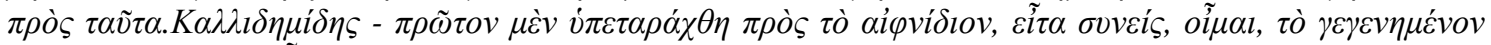

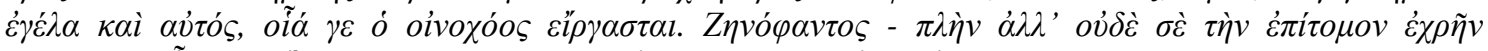

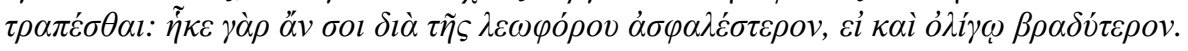


te mandan muchos saludos" (Cic. Att. 1.5.8; vid. también Cic. Att. 2.3) 315 $^{315}$ También sabemos de otras amistades de Terencia, con las cuales probablemente siguió teniendo contacto una vez divorciada y hasta su muerte (Cic. Fam. 5.6.1). En Cásina, Plauto nos muestra la amistad entre Cleústrata y Mírrina, vecinas que se visitan para charlar sobre la cotidianeidad y la vida íntima y que se muestran su afecto. En una de esas visitas, Cleústrata cuenta a su amiga cómo ha descubierto que su esposo, el senex Lisídamo, se ha enamorado de una joven esclava:

CLEÚSTRATA - Hola, Mírrina.

MÍRRINA - Caray, Cleústrata, hola. Pero, dime, ¿por qué se te ve tan triste?

CL. - Así suelen estar las malcasadas: lo mismo dentro que fuera de la casa, siempre hay motivo de disgusto. Pues oye, yo iba precisamente a tu casa.

Mí. - Anda, y yo iba a la tuya. Pero, ¿qué es lo que te da disgusto ahora? Porque lo que te disgusta a ti, me produce a mí también pena.

CL. - Bien que te lo creo, hija, porque con razón eres para mí la más querida de todas las vecinas, ni hay otra que tenga tantas cualidades, como yo para mí las quisiera.

MÍ. - Eres muy amable. Pero estoy deseando saber qué es lo que te pasa.

CL. - Sufro en casa unos desdenes espantosos.

Mí. - ¿Cómo? ¿Qué es lo que ocurre? Dime, por favor, que no acabo de comprender bien de qué te quejas.

CL. - Mi marido me ultraja de una manera espantosa y yo no tengo medios de hacer valer mis derechos.

Mí. - Pues es una cosa rara, si es que es verdad lo que dices, porque, por lo general, son los maridos los que no pueden hacer valer sus derechos con sus mujeres.

CL. - Sí, se empeña en contra de mi voluntad en dar a su capataz una joven esclava, que me pertenece a mí, que ha sido criada de lo mío, y la cosa es que en realidad es él quien está enamorado de ella.

Mí. - Dime, por favor, que aquí podemos hablar con tranquilidad, estamos entre nosotras (Plaut. Cas. 171-196) ${ }^{316}$.

\footnotetext{
${ }^{315}$ Et te et sororem tuam et matrem maxime diligit salutemque tibi plurimam ascribit et Tulliola, deliciae nostrae.

${ }^{316}$ CLEOSTRATA. Myrrhina, salue. MYRRHINA. Salue mecastor: sed quid tus tristis, amabo? CLE. Ita solent omnes quae sunt male nuptae: Domi et foris aegre quod sit satis semper est. Nam ego ibam ad te. MY. Et pol ego istuc ad te. Sed quid est, quod tuo nunc animo aegrest? Nam quod tibist aegre, idem mihist diuidiae. CLE. Credo ecastor: nam uicinam neminem amo merito magis quam te nec qua in plura sint mihi quae ego uelim. MY. Amo te, atque istuc expeto scire quid sit. CLE. Vir Pessumis me modis despicatur domi. MY. Hem. CLE. Quid est? MY. Dic idem hoc-nam pol hau satis meo corde accepi
} 
Además de aludir a la amistad entre estas dos mujeres, este fragmento hace referencia a los estereotipos de senex libidinoso y de esposa amargada a los que ya hacíamos referencia en el apartado dedicado al matrimonio. Resalta el hecho de que la queja de Cleústrata no sólo esté motivada por el enamoramiento de su marido, sino también porque ha decidido entregar a una de sus esclavas sin su consentimiento, tomando como propio parte del patrimonio de ella.

Las fuentes epigráficas disponibles hacen alusión a vetulae patronas; es el caso, por ejemplo, de las patronae Valeria Prisca, Aurelia Placentina, Veturia Daphne y Galeria (CIL 2.3970, 3.1229, 6.5047 y 6.18860). Torcuata, la vestal a la que ya hemos hecho referencia y que falleció con 64 años, fue conmemorada en calidad de patrona por sus libertos Juvenio y Actio (CIL 6.2127 y 6.2128). Julia Irene dedicó un epitafio a su patrona, la resinaría Julia Agele, fallecida con 80 años (CIL 6.9855). Un caso reseñable es el de Argentaria Verana, quien es al mismo tiempo patrona y tía de Argentario Vegetino: “Consagrado a los Dioses Manes. A Argentaria Verana, fallecida con 65 años. Lo hizo Argentario Vegentino a su matertera y patrona. Aquí descansa. Que la tierra le sea leve" ( $A E$ 1993, 903) ${ }^{317}$. Contamos también con el ejemplo de Terencia, quien manumitió a un esclavo de nombre Diocles, que se había encargado de la educación de su hijo Quinto (Treggiari, 2007: 143). Una vez libre, Diocles fundó una escuela, cuyos beneficios compartiría con Terencia. Parte de las visitas que Cornelia recibía en su villa, a las que ya hemos aludido, serían probablemente en calidad de patrona (Plut. C. Gracch. 19).

De la misma forma, es de esperar que hubiera libertas, tanto de mujeres como de hombres, que alcanzaron la ancianidad. En este caso, es de nuevo la epigrafía la fuente que nos ofrece la información sobre estas vetulae. Libertas que alcanzaron la vejez fueron, por ejemplo, Octavia Fortunata (61), Serva Cleopatra (65) y Minucia (97) ( $A E$ 1968, 570 y 1978, 232; CIL 6.2281). En Macedonia, Publia Gavinia dedicaba una inscripción a la liberta Fortunata, fallecida con 61 años, que había sido su nutrix, lo que indica la estrecha relación que hubo entre ambas, factor que quizás incluso fue determinante a la hora de liberarla de su esclavitud (CIA 28).

querells tuas-opsecro. CLE. Vir me habet pessumis despicatam modis Nec mihi ius meum optinendi optiost. MY. Mira sunt, uera si praedicas: nam uiri ius suom ad mulieres optinere haud queunt. CLE. Quin mihi ancillulam ingratiis postulat, quae meast, quae meo educta sumptu siet, vilico se suo dare: sed ipsus eam amat. MY. Obsecro, tace. nam hic nunc licet dicere. nos sumus.

${ }_{317}[D($ is $)]$ M(anibus) s(acrum) / [Ar]gent(ariae) Veranae Emer(itensi) ann(orum) LXV Ar(gentarius) / [Ve]getinus materterae et patro/[n] ae faciendum curavit / h(ic) s(ita) e(st) s(it) t(ibi) t(erra) l(evis) 
La edad no modificaría en demasía las relaciones que se establecerían entre estas vetulae, ya fueran patronas o libertas, sobre todo en el primer caso. En cuanto que patrona, una vetula seguramente poseyera un patrimonio mayor que en su juventud, lo que podría beneficiar a sus libertas y libertos. En cuanto que liberta, probablemente habría alcanzado esa condición debido a los años de servicio prestados. Sus obligaciones para con quien la poseyó desaparecían cumplidos los 50 años, como ya hemos señalado en el Capítulo II, si bien es posible que siguiera estando unida en mayor o menor medida su antiguo amo.

Finalmente, hemos de hacer referencia al papel que desempeñaban en la familia las vetulae esclavas. Una de las tareas que podía desempeñar una esclava anciana, y que la relacionaba estrechamente con los miembros de la familia en la que servía, era la de nutrix, trabajo que por otro lado era llevado a cabo también mujeres libres. El pañuelo con el que algunas de estas mujeres cubren su cabeza en las representaciones artísticas, típico de las esclavas y las mujeres de condición humilde -que hemos visto que caracteriza a algunas de las imágenes de vetulae del tipo grotesco-, parece delatar su origen social. Era un oficio que debía comportar cierto prestigio social (Cid, 2016: 130), especialmente cuando se ejercía para familias tan relevantes como los Escipiones o la familia imperial (CIL 6.8943 y 6.16128); así lo señala Dión Crisóstomo (7.144) y lo atestiguan las numerosas mujeres que se reconocen nutrices en sus epitafios, como es el caso de las vetulae Flavia (CIL 3.8350), Rubria (CIL 6.9245) y Birria ( $A E$ 1980, 326). Las nutrices ancianas no se dedicaban, como las jóvenes, al amamantamiento; de hecho, en ocasiones estas mujeres aparecen denominadas como nutrices assae, en referencia a que la relación que establecen con niñas y niños no abarca la alimentación con leche materna ( $A E$ 1989, 213; CIL 6.29497). Su cometido era el de supervisar su día a día, tanto en lo que respecta al cuidado como a la educación y el tiempo de ocio (Hor. Ars $P$. 115, Carm. 3.4.10 y Epist. 2.1.100; Lucil. Fr. 955; Ov. Fast. 6.130). Se trataba, en definitiva, de propiciar la socialización más primitiva de quienes estaban a su cargo mediante los juegos, las canciones y los cuentos (Cid, 2016: 135). Ausonio (Ep. 10.2.90) cree conveniente que el niño crezca entre los cuentos y las nanas de su nodriza, lo que le permite disfrutar al mismo tiempo que aprende. En el apartado correspondiente a las abuelas y las bisabuelas hemos visto cómo algunas de ellas también podían desempeñar esta tarea, en ocasiones impuesta por el fallecimiento de la madre. Requería 
que la mujer escogida fuese afectiva pero al mismo tiempo severa, si bien en ocasiones el cariño las volvía indulgentes (Auson. Protrept. ad nep. 2.69; Tac. Dial. 28.5-6).

La historiografía se ha planteado cómo era el nexo que se establecía entre la nutrix y la persona a su cargo (Joshel, 1986; Sparreboom, 2009). Las fuentes, tanto literarias como epigráficas, atestiguan el estrecho vínculo que en ocasiones desarrollaban las nutrices con las personas a las que cuidaban, poniéndolas incluso por encima de su familia. Así, unos párrafos más arriba ya hemos hecho referencia a la relación entre Publia Gavinia y Fortunata. Ausonio escribía que "amará las arrugas de su nodriza quien huye de su madre" (Auson. Protrept. ad nep. 2.18-20) ) $^{318}$. En algunas inscripciones la cuidadora comparte dedicación con diversos familiares de la persona fallecida (CIL 5.8902, 6.25301, 6.35123). Es el caso de este niño muerto con dos años, a quien su abuela y su nutrix dedicaron un epitafio: "Consagrado a los Dioses Manes. Juvenal. Vivió dos años, tres meses, nueve días y una hora. Canuleia Tyche, su abuela y Erasena Libas, su nutrix, lo hicieron para él y los suyos" (CIL 6.20938) ${ }^{319}$. Del texto parece desprenderse que tras la muerte de la madre, o de ambos progenitores, la abuela se hizo cargo del niño y empleó a Erasena para que lo amamantase o cuidase de él. En ocasiones surgían afectos que podían durar más allá de los años de la infancia:

“Consagrado a los Dioses Manes. Aquí yace Julia Pistrix, que vivió 100? años.

Julio Basso, centurión de la legión XXII Primigenia, a su querida nutrix" (CIL $8.2889)^{320}$.

"Consagrado a los Dioses Manes. Volumnia Procla, hija de Cayo, a Volumnia Dynamidi, nutrix assa y liberta. Vivió 105 años" (CIL 6.29497) ${ }^{321}$.

En este segundo caso nos encontramos con otra mujer que parece haber alcanzado la libertad gracias a la relación de afectividad que se generó entre ella y la mujer de la que cuidó.

La nutrix de Nerón lo consolaba y aconsejaba siendo éste ya emperador (Suet. Ner. 42). Esta mujer, junto a otra de las nutrices del emperador, se hizo cargo de depositar sus restos mortales en la tumba (Suet. Ner. 50). Filis, nodriza de Domiciano, "le rindió los últimos honores en su finca situada a las afueras de Roma, en la Vía

\footnotetext{
318 rugas nutricis amabit, qui refugit matrem.

${ }^{319}$ Dis Man(ibus) / Iuvenalis / v(ixit) a(nnos) II m(enses) III d(ies) IX h(oram) I / Canuleia Tyche / avia et / Erasena Libas / nutrix fecer(unt) / et sibi et suis.

${ }^{320} D($ is $)$ M(anibus) s(acrum) / Iulia Pistrix / vixit annis C[3] / h(ic) s(ita) / Iulius Bassus / |(centurio) leg(ionis) XXII Prim(igeniae) / nutrici optimae.

${ }^{321} D($ is $)$ M(anibus) / Volumniae / Dynamidi / Volumnia / C(ai) f(ilia) Procla / nutrici / assae et / lib(ertae) v(ixit) a(nnos) $C V$.
} 
Latina, pero luego llevó en secreto sus restos al templo de la familia Flavia y los mezcló con las cenizas de Julia, la hija de Tito, a la que también había criado" (Suet. Dom. 17) ${ }^{322}$. Cicerón (Amic. 20.74) consideraba que debía hacerse una distinción entre aquellas relaciones de afecto y amistad que surgían en la infancia con nutrices y pedagogos, y las que llegaban en la etapa adulta. A pesar de que creía que las segundas eran más valiosas, la referencia a que una persona adulta podía seguir manteniendo contacto con quien cuidó de ella en su infancia sirve para ilustrar la duración de este tipo de vínculos. Sabemos también que Plinio el Joven (Ep. 6.3) regaló una granja a quien fuera su niñera, como forma de expresar que de adulto era él quien cuidaba de ella, que presumiblemente ya fuera una vetula. El Digesto (33.2.34) también hace referencia a cómo en ocasiones las nutrices recibían herencias y podían disfrutar de los bienes de quienes estaban a su cuidado.

En ocasiones, y entrando ahora en el plano de la mitología, el afecto que estas mujeres sentían hacia quienes cuidaban, especialmente si eran mujeres, las llevaba a cometer actos que transgredían las normas sociales. Es el caso, por ejemplo, de la vieja nutrix de Mirra, quien la ayudó a llevar a cabo su incestuoso propósito (Ov. Met. 10.382-464; Pérez Miranda, 2011: 90). Esta vetula era tan fiel a la niña a quien cuidó que engañó a Ciniras para que mantuviera relaciones sexuales con su propia hija a pesar de que era consciente de lo terrible del acto.

El que en muchos casos estas mujeres se nos presenten como ancianas, o como mujeres maduras, se debería a una doble motivación: por un lado, se trataría de mujeres experimentadas, que probablemente ya habían criado a sus propios hijos o a los de otras mujeres, y cuyo bagaje vital propiciaría que sus enseñanzas fueran más ricas; por otro lado, se daba una ocupación a mujeres que habrían perdido su anterior rol. En el caso de las esclavas, el cuerpo envejecido sería poco apto para las tareas más laboriosas. En cuanto a las mujeres libres, la crianza es un trabajo que, como hemos señalado para las esclavas, no tiene una alta exigencia física; en cuanto al ámbito familiar, pasados los años fértiles el peso de traer al mundo herederos recaería sobre las mujeres más jóvenes, herederos que cuidarían las abuelas.

Las vetulae esclavas nos aparecen también como cuidadoras de mujeres jóvenes, haciendo tanto el papel de guardianas de su castidad como de compañeras en las tareas cotidianas (Tib. 1.3.85-90). Dentro del ámbito familiar, las esclavas ancianas eran

\footnotetext{
${ }^{322}$ Phyllis nutrix in suburbano suo Latina via funeravit, sed reliquias templo Flaviae gentis clam intulit cineribusque Iuliae Titi filiae, quam et ipsam educarat, conmiscuit.
} 
además mujeres en las que se podía confiar, sobre todo si habían permanecido con la misma familia desde su juventud:

"Y asiste a este consejo una esclava anciana, heredada de su madre; ahora se dedica al huso, pues ha cesado ya de trabajar con la aguja; de ello la ha jubilado. Y ella emitirá la primera un juicio, y luego las demás, inferiores en edad y menos competentes" (Juv. 6.495-500) . $^{323}$

La confianza de la que gozaban algunas esclavas, como el caso de las nutrices, les haría vivir una vejez relativamente cómoda. Antonia Caenis, fallecida con cerca de 70 años, fue esclava de Antonia Minor (Suet. Dom. 13 y Vesp. 3 y 21). Liberada tras la muerte de ésta, se convirtió en amante de Vespasiano hasta su muerte, influyendo en las decisiones políticas del emperador y despertando el recelo de Domiciano:

"Fue por aquel entonces cuando murió Cenis, la concubina de Vespasiano. Hago mención de ella a causa de su extrema fidelidad y porque estaba dotada con la más excelente de las memorias. He aquí un ejemplo: su dueña, Antonia, la madre de Claudio, la empleó como secretaria para escribir una carta a Tiberio acerca de Sejano y le ordenó inmediatamente que borrase el mensaje, que no quedara traza alguna de él. Y entonces ella respondió: «Es inútil, ama, que me des esta orden; pues no sólo esta, sino cualquier otra cosa que me dictes la llevaré siempre conmigo en mi mente y nunca podrá borrarse». Y no sólo me parece haber sido una mujer norable por este motivo, sino también porque Vespasiano disfrutaba tan en exceso de ella. Esto le proporcionó la mayor influencia y amasó riquezas indecibles, al punto de que se pensó que él logró hacer dinero a través de ella, actuando Cenis como intermediaria. Pues ella recibía grandes sumas de diversas procedencias, a veces vendiendo gobernaciones, a veces procuradurías, generalatos o sacerdocios, y hasta en ocasiones decisiones imperiales. Pues aunque Vespasiano no mató nunca a nadie para hacerse con su dinero, sí que perdonó la vida a muchos de los que se lo entregaron, y mientras que era Cenis la que recibía el dinero, muchos sospechaban que era Vespasiano el que de buena gana le permitía actuar así” (Cass. Dio 66.14)

\footnotetext{
${ }^{323}$ Est in consilio materna admotaque lanis emerita quae cessat acu; sententia prima huius erit, post hanc aetate atque arte minores censebunt.

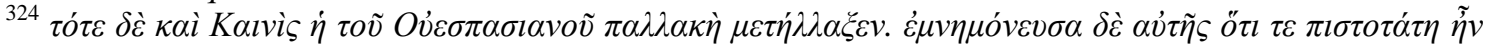

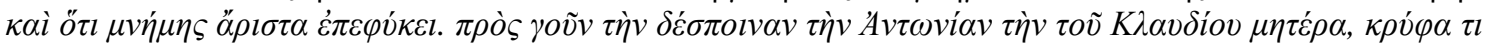

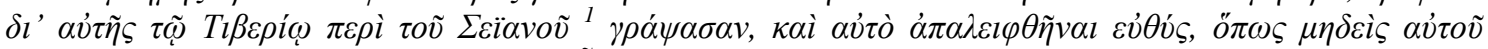

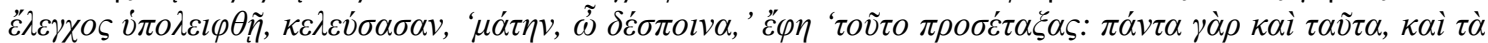

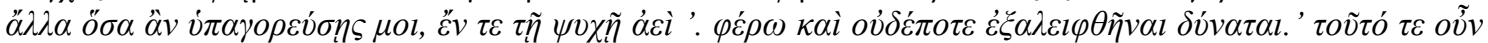

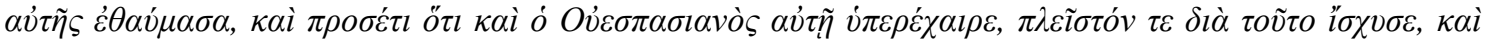

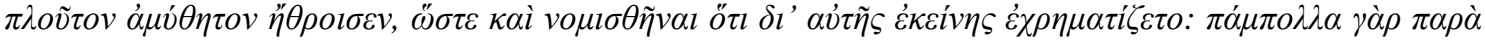

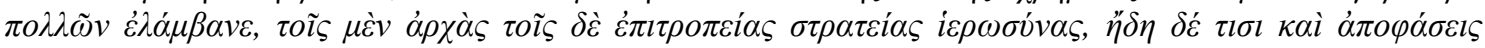


En resumen, a lo largo del presente apartado hemos visto cómo las vetulae podían establecer lazos con otras personas al margen de la consanguinidad. Amigas, esclavas, libertas y patronas, se trata de diversos papeles que fueron desempeñados por las vetulae, ya fuera de forma libre o impuesta, y a través de los cuales se relacionaron con otras mujeres y con los hombres.

\section{IV.1.7. Convivir con una vetula}

El proceso de envejecer conllevaba en Roma, como hemos visto, el paso por diversas etapas vitales en las que se iba adquiriendo mayor poder tanto en el seno familiar como en el ámbito público, especialmente en el caso de los varones. En lo privado, el poder del paterfamilias abarcaba incluso la capacidad de decidir sobre la vida y la muerte de aquellos que se encontraban bajo su tutela. Además, controlaba los negocios y propiedades familiares. Pero no todos los romanos alcanzaban este estatus; hombres adultos, plenamente integrados en la vida pública y con hijos e incluso nietos, se encontraban bajo la potestas de un miembro de la familia que en ocasiones podía ser extremadamente anciano. Una patria potestas creada por Rómulo para limitar el poder de los hijos, de la que se alegraban algunos autores, como Dionisio de Halicarnaso (Ant. Rom. 2.26), y cuya dureza ilustra Cicerón:

"Apio, anciano y además ciego, con cuatro hijos y cinco hijas, gobernaba tanto su casa como su hacienda. Mantenía su espíritu siempre tenso igual que un arco, y, ni siquiera, ya cansado por la edad, sucumbía. Mantenía su autoridad, el mando sobre los suyos. Le temían sus siervos, le respetaban sus hijos, pero todos le querían. En su casa estaban vigentes las costumbres patrias y la disciplina" (Cic. Sen. 11.37) ${ }^{325}$.

Esta situación, con las limitaciones económicas y de poder que conllevaba, así como el hecho de convivir con familiares dementes o muy enfermos y las propias tensiones existentes entre las distintas generaciones, haría surgir conflictos entre jóvenes, adultos y ancianos ${ }^{326}$. En el caso de las mujeres, estuvieran bajo el control de su familia paterna o de la del esposo (XII Tablas 5.1), su patrimonio estaría formado por

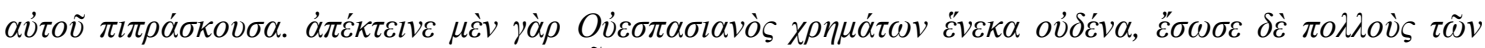

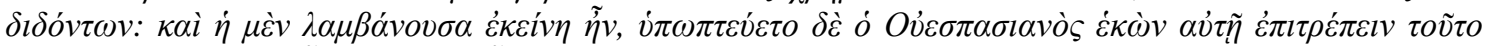

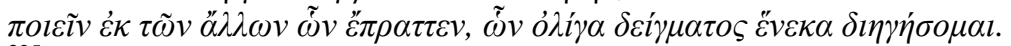

${ }^{325}$ Quattuor robustos filios, quinque filias, tantam domum, tantas clientelas Appius regebat et caecus et senex, intentum enim animum tamquam arcum habebat nec languescens succumbebat senectuti. Tenebat non modo auctoritatem, sed etiam imperium in suos: metuebant servi, verebantur liberi, carum omnes habebant; vigebat in illa domo mos patrius et disciplina.

${ }^{326}$ La historiografía ha tratado en profundidad este tema. Sobre la dimensión real que tendrían estos conflictos, vid. entre otros Baldwin, 1976; Bertman, 1976; Cokayne, 2003: 153 y ss.; Dixon, 1999; Isayev, 2007; López Pulido, 2008: 8; Plescia, 1976 y Reinhold, 1970. 
la dote, las aportaciones de su familia, las de la familia de su esposo, y los beneficios que ella obtuviese por su trabajo. Algunas mujeres solteras, viudas o divorciadas debieron alcanzar la vejez con un patrimonio considerable en sus arcas. De hecho, Elke Hartmann (2012: 441) opina que muchas vetulae ricas tendrían una fortuna mayor que los senes de su mismo grupo social, ya que no tenían que invertir patrimonio en su cursus honorum -aunque sí que pudieron hacerlo en el de sus hijos, nietos u otros miembros de su familia-, y era probable que hubiesen heredado bienes tanto de su familia de origen como de la de su esposo. Ello podía atraer el interés, como ya hemos visto, de los captatores, pero también provocar recelos entre los familiares que esperaban recibir mediante testamento el patrimonio de la anciana rica.

El concepto de pietas imponía a los hijos la obligación de respetar, cuidar y reverenciar a sus progenitores, tanto a su padre como a su madre, una noción extensiva al resto de familiares adultos y viejos (Luc. Am. 19; Ov. Fast. 5.526; Plin. Ep. 2.18.2 y 3.8.2; Plut. Mor. 479f; Tib. 1.7.55). Se trata un respeto y cuidado que en la Antigüedad se tomaba como natural y para el que se buscaron paralelos entre los animales; así, en época imperial, Eliano (NA 6.61) hacía referencia a cómo los elefantes jóvenes ceden su comida a los mayores, los cuidan y los protegen de los peligros derivados de la debilidad de la vejez. Una veneración a los mayores que Valerio Máximo creía desaparecida en la época en la que escribía (siglo I d.C.), y que situaba en un pasado remoto e idílico:

"La juventud tributaba a la ancianidad tal alta y sumisa veneración que parecía que los ancianos eran padres comunes de todos los jóvenes. Por este motivo éstos, los días en que se celebraba reunión del senado, acompañaban hasta la sala de sesiones a alguno de los senadores, bien a un familiar, bien a un amigo de sus padres; y allí, clavados ante la puerta, los esperaban hasta el momento de volver a acompañarlos a sus respectivas casas. Con esta voluntaria espera iban fortaleciendo sus cuerpos y sus espíritus para afrontar diligentemente los futuros cargos públicos y, con esta modesta preparación para los trabajos y las fatigas, se hacían dignos de enseñar a los demás sus propias virtudes que muy pronto habrían de manifestarse ante los ojos de todo el pueblo. Cuando los jóvenes eran invitados a una cena, preguntaban con antelación y con sumo interés quiénes iban a ser invitados, para no quitar, al llegar temprano, el puesto a uno de más edad; y, una vez terminada la cena, esperaban a que aquéllos se levantaran y salieran primero. De lo dicho se infiere que, durante el transcurso del banquete y en presencia de los mayores, solían hablar 
poco y con mesura. Nuestros antepasados, durante los banquetes, tenían la costumbre de cantar al son de la flauta las hazañas de los que les habían precedido, compendiadas en un poema, para hacer que los jóvenes sintieran deseos de imitarlas. ¿Puede haber algo más noble y más útil que esta rivalidad? Los jóvenes rendían el homenaje que se debe a la ancianidad, los ancianos, por su parte, acompañaban, alimentándolos, los entusiasmos de quienes se estaban preparando para la vida activa" (Val. Max. 2.1.9-10) ${ }^{327}$.

Por otro lado, la pietas era también un sistema de reciprocidad, mediante el cual los progenitores proveían a su descendencia en la infancia con la idea de que ésta les ayudase a ellos en la vejez. Alfonso López Pulido (2015: 111) y Tim Parkin (1999: 124) piensan que la pietas actuaría en el mundo romano como una especie de seguro en la vejez, de forma que las personas ancianas tuvieran la certeza de que su familia iba a hacerse cargo de ellas cuando no pudieran mantenerse por sí mismas. En el Egipto romano esta idea se materializaba en ocasiones a través de contratos en los que los descendientes de una persona llegaban a un acuerdo sobre quién se haría cargo de ella cuando alcanzase la vejez. En el año 211 d.C., Isidoro renunció a su parte de la herencia a cambio de no tener que encargarse de cuidar, vestir y alimentar a su vieja madre $(P$. Lond. 3.932). También podía darse el caso contrario, en el que un senex o una vetula decidieran adelantar la herencia para procurarse una vejez tranquila. Es el caso de una mujer de nombre desconocido del siglo I d.C., quien transfirió sus propiedades a sus tres hijas a cambio de que se ocupasen de ella hasta el día de su muerte, o de Herminone, quien en el siglo II d.C. traspasó sus bienes a su hija a cambio de recibir una pensión regular el resto de su vida (BGU 4.1013 y $P$. Oxy. 3.472).

Dada la importancia de la pietas, el Estado no habría visto la necesidad de legislar sobre la situación de las personas ancianas, siempre y cuando no se dieran casos extremos (Parkin, 1999: 131). Una excepción nos la muestra Valerio Máximo (1.1.13) cuando hace referencia a una ley según la cual los parricidas eran arrojados al mar

\footnotetext{
327 Senectuti iunenta ita cumulatum et circumspectum honorem reddebat, tamquam maiores natu adulescentium communes patres essent. Quocirca iunenes senatus die utique aliquem ex patribus conscriptis aut propinquum aut paternum amicum ad curiam deducebant adfixique ualuis expectabant, donec reducendi etiam officio fungerentur. Qua quidem uoluntaria statione et corpora et animos ad publica officia inpigre sustinenda roborabant breuique processurarum in lucem uirtutum suarum uerecunda laboris meditatione ipsi doctores erant. Inuitati ad cenam diligenter quaerebant quinam ei conuiuio essent interfuturi, ne seniorum aduentum discubitu praecurrerent, sublataque mensa priores consurgere et abire patiebantur. Ex quibus apparet cenae quoque tempore quam parco et quam modesto sermone his praesentibus soliti sint uti. Maiores natu in conuiuiis ad tibias egregia superiorum opera carmine conprehensa pangebant, quo ad ea imitanda iunentutem alacriorem redderent. Quid hoc splendidius, quid etiam utilius certamine? Pubertas canis suum decus reddebat, defuncta [uiri] cursu aetas ingredientes actuosam uitam feruoris nutrimentis prosequebatur.
} 
cosidos a pellejos de cuero. Además, los senes -no sabemos si también las vetulaepodían recurrir a la justicia cuando consideraban que el respeto debido a su edad se había roto:

"Domicio Corbulón, que había sido pretor, presentó ante el senado una querella contra Lucio Sila, joven noble, porque en el espectáculo de gladiadores no le había cedido el sitio. En favor de Corbulón estaba su edad, las costumbres de los mayores, la simpatía de los viejos..." (Tac. Ann. 3.31.3) ) $^{328}$.

Por otro lado, donde no actuaba el Estado podían hacerlo los propios senes y vetulae. En el siglo II d.C. la romano-egipcia Theogiton echó de casa a su hijo Apolonio porque no cumplía con los deberes que tenía para con ella como madre anciana (P. Fay. 124). De la misma forma, seguramente muchos padres y madres ancianos recurrieron a expulsar a sus descendientes de casa o a desheredarlos como forma de castigarlos por desatenderlos.

La pietas tenía en Roma como máximo exponente a Eneas, que huyó de Troya cargando con su anciano padre Anquises sobre los hombros, quien probablemente fuese también dependiente (Pérez Miranda, 2011: 75). Un peso que, por otro lado, Eneas no consideraba tal: "Ea, padre querido, monta sobre mi cuello. Te sostendré en mis hombros. No va a agobiarme el peso de esta carga. Y pase lo que pase, uno ha de ser el riesgo, una la salvación para los dos" (Verg. Aen. 2.27.707-710) ${ }^{329}$. En el caso de las madres, ya hemos hecho referencia al respeto que los hermanos Graco sentían hacia su madre Cornelia, y a cómo Coriolano cedió ante la petición de Veturia. Durante la erupción del Vesubio del año 79 d.C. Plinio el Joven trató de emular a Eneas salvando a su madre, que entonces tenía más de 50 años, de la nube tóxica generada por el volcán:

"Poco después aquella nube empezó a descender sobre la tierra y a cubrir el mar; había ya rodeado y ocultado la isla de Cápreas, y había borrado de nuestra vista el promontorio de Miseno. Entonces mi madre empezó a rogarme, a suplicarme, a ordenarme que huyese del modo que fuese; diciéndome que un hombre joven podía hacerlo, pero que ella, entorpecida por la edad y su exceso de peso, no podía, y que moriría en paz, si no había sido la causa de mi muerte. Yo le respondí que no me pondría a salvo, a no ser con ella; después, asiéndola de la mano, la obligo a acelerar el paso. Me obedece con dificultad, y se reprocha ser la causa de mi

\footnotetext{
${ }^{328}$ Domitius Corbulo praetura functus de L. Sulla nobili iuvene questus est apud senatum quod sibi inter spectacula gladiatorum loco non decessisset. pro Corbulone aetas, patrius mos, studia seniorum erant... ${ }^{329}$ ergo age, care pater, cervici imponere nostrae; ipse subibo umeris nec me labor iste gravabit; quo res cumque cadent, unum et commune periclum, una salus ambobus erit
} 
demora. Ya caía la ceniza, pero todavía escasa. Volví la vista atrás: una densa nube negra ser cernía sobre nosotros por la espalda, y nos seguía a la manera de un torrente que se esparcía sobre la tierra" (Plin. Ep. 6.20.11-13) ${ }^{330}$.

Un fuerte sentido de la pietas lo mostraron también la mujer que amantó a su anciana madre en la cárcel o Ático, que evitó a toda costa los conflictos con su madre (Nep. Att. 17; Val Max. 5.4.7). No obstante, el cumplimiento de la pietas podía generar en ocasiones dilemas difíciles de resolver. Así, Séneca hace referencia a una madre ciega que trató de impedir que su hijo fuera a rescatar al padre secuestrado por los piratas, ya que entonces ella quedaría desamparada:

"Un hombre casado y con un hijo se marchó de viaje. Capturado por los piratas, escribió cartas a su esposa y a su hijo para pedirles que lo rescataran. La esposa perdió los ojos de tanto llorar. El hijo se dispone a partir para rescatar a su padre, pero su madre le reclama la manutención. Resuelto él a no quedarse, ella pretende que se lo encarcele" (Sen. Contr. 7.4) $)^{331}$.

La duda en este caso es quién corría mayor peligro, si el padre cautivo o la madre ciega. A favor de la madre se esgrimía que tenía el derecho de exigirle a su hijo un sustento, ya que ella lo crió; a favor del padre, que a él también se le debía pietas.

Por otro lado, la pietas también actuaría en sentido contrario, viéndose los progenitores obligados a cuidar de las generaciones futuras. Las vetulae aparecen en las fuentes no sólo como personas a las que cuidar, sino también como sustentadoras de la familia. Es el caso, como hemos visto, de mujeres como Livia, Antonia Minor y Umidia Cuadratila. Otro ejemplo lo es el de Apio Claudio Juliano, quien en el siglo III d.C., legó a su hija una casa para que cuidase en ella a su descendencia una vez que fuera una pulchra anus (CIL 10.1688).

En el día a día, la pietas se manifestaría sobre todo en el caso de las personas ancianas dependientes. Ya hemos hecho referencia a diversos casos de dependencia, como el de Domicio Tulo o el de la vetula ciega que trató de impedir que su hijo saliera de viaje. En el siglo III d.C. Lucrecia Octavia contrajo matrimonio con Lucrecio Ignacio

\footnotetext{
${ }^{330}$ Non moratus ultra proripit se effusoque cursu periculo aufertur. Nec multo post illa nubes descendere in terras, operire maria; cinxerat Capreas et absconderat, Miseni quod procurrit abstulerat. Tum mater orare hortari iubere, quoquo modo fugerem; posse enim iuvenem, se et annis et corpore gravem bene morituram, si mihi causa mortis non fuisset. Ego contra salvum me nisi una non futurum; dein manum eius amplexus addere gradum cogo. Paret aegre incusatque se, quod me moretur. Iam cinis, adhuc tamen rarus. Respicio: densa caligo tergis imminebat, quae nos torrentis modo infusa terrae sequebatur. ${ }^{331}$ Quidam, cum haberet uxorem et ex ea filium, peregre profectus est. a piratis captus scripsit de redemptione epistulas uxori et filio. uxor flendo oculos perdidit. filium euntem ad redemptionem patris alumenta poscit; non remanentem alligari volt.
} 
Rufo y cuidó de él en su vejez. Quedó viuda joven y su marido le legó una pequeña tierra y una casa compartida. La pareja no tuvo hijos; de lo contrario, éstos habrían heredado todo el patrimonio de su padre y habrían podido mantener a Lucrecia, que quedó en situación de pobreza ( $P$. Diog. 10). La dependencia física haría que quienes la padeciesen necesitasen una atención constante que, de no procurarse, podía empeorar su situación hasta la muerte.

También podía darse el caso de que la materfamilias, o cualquier otro familiar anciano, sufriera demencia (Apul. Apol. 53; Arist. Mem. 12.453b.5; Cic. Sen. 7.21; Hor. Sat. 2.3.280-285). Debido a su avanzada edad, hubo quienes pensaron que Cornelia padecía demencia por su hábito de recordar las hazañas de sus hijos (Plut. C. Gracch. 19). El padecimiento de enfermedades mentales incapacitantes consta ya en las XII Tablas, que refieren lo siguiente: "Si alguien está loco y no tiene custodio, que la potestad sobre él y sus bienes sea de sus agnados y gentiles" (XII Tablas 5.7) ${ }^{332}$. En estos casos, Tim Parkin (1999: 131) piensa que los miembros capaces de la familia se harían cargo de las responsabilidades diarias de la domus y, en el caso del paterfamilias, se nombraría además un tutor que se encargase de los asuntos legales.

De las situaciones de demencia podían aprovecharse como hemos visto los captatores, pero también los hijos, para así deshacerse del peso de la patria potestas. Séneca (Contr. 2.3) cuenta que un hijo, que había violado a una mujer y, a pesar de haber sido perdonado por el padre de ésta, no había obtenido el perdón de su propio padre, lo acusó de demencia para evitar ser condenado. Este mismo autor (Sen. Contr 2.4) refiere otro caso en el que un anciano fue acusado de demencia por su hijo. Se trata de un hombre que, una vez fallecido uno de sus hijos, reconoció al vástago que éste tuvo con una prostituta. Uno de los hermanos del fallecido quiso entonces que su padre fuera declarado incapaz para evitar que adoptase al nieto y perder parte de la futura herencia.

Cabe preguntarse quién cuidaría de los senes y vetulae dependientes. Ya hemos visto cómo la esposa, y en general las mujeres de la familia, eran las personas socialmente destinadas a cuidar de las personas enfermas o dependientes. No podemos saber si ocurría lo mismo en el caso contrario, ya que no hemos encontrado ninguna referencia literaria a esposos $\mathrm{u}$ otros familiares masculinos que atienden a vetulae, con excepción quizás del hijo de la anciana ciega. Cuando la economía lo permitiese, las

\footnotetext{
${ }^{332}$ Si furiosus escit ast ei custos nec escit, agnatum gentiliumque in eo pecuniaque eius potstas esto.
} 
mujeres estarían ayudadas por el personal esclavo. A este respecto cabe resaltar un caso, de momento el único que conocemos, de una mujer calificada en una inscripción como nutrix en la vejez (CIL 5.8902). El epígrafe, encontrado en Como, fue realizado en vida por el duovir Lucio Sentio September para sí mismo y para distintos miembros de su familia, entre los que se encuentra Barbarae nutriculae senectutis suae. Si bien gramaticalmente también podría interpretarse que Barbara era anciana, a principios del siglo XX Thomas Lund (1910: 169) señalaba la posibilidad que parece más probable: que fuera una esclava de Lucio Sentio, encargada de asistirlo en su vejez. Además de por única, esta inscripción resulta interesante en varios aspectos. Por un lado, porque presenta un testimonio, además del literario, sobre los cuidados en la vejez y sobre la identidad de las y los cuidadores. Por otro lado, porque Barbara era lo suficiente importante en la vida de Lucio como para que éste decidiera incluirla en su epitafio, remitiéndonos a las relaciones de afecto que se generan entre persona cuidada y cuidadora a las que hacíamos alusión con anterioridad. Y, finalmente, por el vocabulario empleado. Que Barbara fuera una nutrix nos habla de la amplitud de definición de la palabra, ligada no sólo a la infancia sino también a la vejez -y, posiblemente, también a la adultez-, y supone un ejemplo de la concepción de la vejez como segunda infancia.

En lo que respecta a la convivencia y el día a día de las vetulae en su entorno familiar y social, en el Capítulo II hacíamos referencia a la vejez como tiempo de retiro, y a la disyuntiva que presentaban los escritores romanos acerca de si era o no conveniente abandonar la política una vez convertido en senex. Hemos aclarado también que se trata de una opción que sólo estaría disponible para los ancianos ricos. Por ello, pretendemos ahora acercarnos a si existía un equivalente femenino al retiro en la vejez, así como averiguar qué actividades de ocio realizaban las vetulae. Cabe preguntarse cuáles de las actividades referidas en el segundo capítulo eran consideradas apropiadas para ambos sexos pero no podemos caracterizar como femeninas debido al empleo del masculino universal.

A lo largo de las anteriores páginas hemos visto cómo algunas vetulae optaban por retirarse a sus posesiones campestres en la vejez. No obstante, este cambio de residencia, que les propiciaría un día a día más relajado, lejos del ajetreo de la Urbs, no significó el fin de su vida social, ni de su participación en los asuntos públicos. En sus villae estas mujeres recibirían visitas de amistades, pero también seguirían controlando sus posesiones, así como sus negocios. Por ello Plutarco (C. Gracch. 19) nos dice que 
Cornelia no alteró en nada sus actividades, y lo mismo hemos señalado que hizo por ejemplo Domicia Longina (CIL 15.548.1-15.550.24; Joseph. Vit. 76).

Como ejemplo de las actividades sociales cotidianas de una vetula contamos con el caso de Umidia Cuadratila, quien jugaba a las damas, entretenimiento considerado propio de mujeres, y asistía a las representaciones de su compañía de pantomimas, ya fuera de forma privada o en el teatro (Ov. Ars am. 3.355-369; Plin. Ep. 7.24). Además, tendría una ajetreada vida social, atendiendo tanto a sus amistades como a todas aquellas personas que esperaban obtener de ella beneficios económicos. Otra actividad cotidiana de la que podían disfrutar las vetulae, en este caso considerada moralmente más adecuada, es la religión. Tal y como han señalado autoras como Rosa Cid (2011:63) y Pilar Pavón (2015), la religión era uno de los principales medios que tenía una mujer romana para incidir en los asuntos públicos, y donde es presentada al margen de su familia, en conjunción con otras mujeres con quienes comparte culto. Cuando en el siglo V a.C. Valeria acude a Veturia y Volumnia en busca de ayuda, les recuerda que han compartido espacios y rituales religiosos, lo que las ha unido:

"Si queda algo humano y bondadoso en alguna parte de tu alma, Veturia, compadécete, como mujer, de las mujeres que una vez compartieron contigo sacrificios y ritos, y, tomando contigo a Volumnia, la buena mujer de Marcio, a sus hijos y a nosotras suplicantes -que también somos de noble nacimiento- con estos niños, vete junto a tu hijo y trata de convencerlo, ruégale con insistencia y no dejes de suplicarle pidiéndole un único favor a cambio de muchos: que haga la paz con sus conciudadanos y regrese a su patria que desea recibirlo; pues tú lo convencerás, tenlo por seguro, y, siendo un hombre piadoso, no permitirá que tú estés postrada a sus pies" (Dion. Hal. Ant. Rom. 8.40.3) ${ }^{333}$.

Livia dedicó los últimos años de su vida a organizar el culto imperial, proclamándose sacerdotisa del mismo, tarea que le permitía mantener una posición social influyente, al tiempo que honraba la memoria de su esposo y consolidaba la posición política de la familia Julio-Claudia en general y de Tiberio en particular (Cid, 1998). Las fuentes nos muestran también a vetulae participando en ritos religiosos, en algunos casos como sacerdotisas -ya hemos visto cómo muchas vestales continuaban en

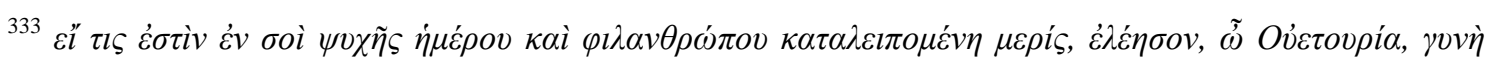

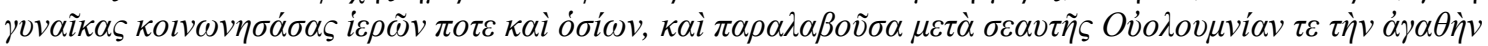

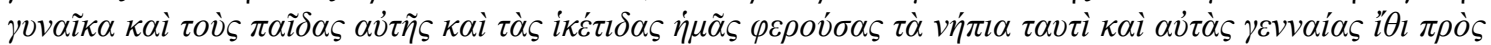

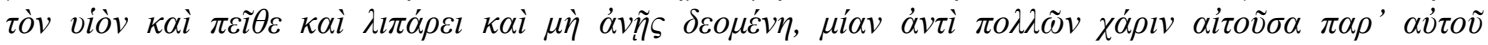

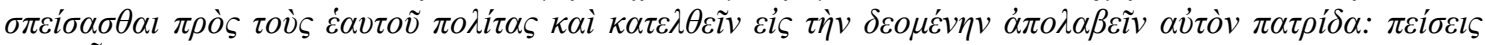

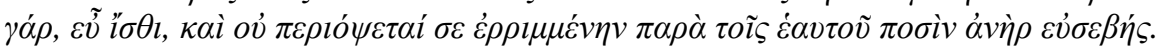


su puesto hasta la muerte- (Dion. Hal. Ant. Rom. 2.67; Ov. Fast. 2.571; Petron. Sat.133138.4; Priap. 12; Tac. Ann. 11.32.2).

Por otro lado, hemos visto cómo las ancianas romanas tenían amplias redes sociales, manteniendo una estrecha relación con los miembros de su familia, pero también con otras personas fuera de ella, tanto mujeres como hombres.

Vemos por lo tanto cómo, en lo que respecta a las relaciones de edad, la familia romana debe interpretarse como un ente dinámico en el que el día a día de vetulae y senes dependería de diversos factores. A medida que fueran envejeciendo, las ancianas romanas irían ganando en autoridad y sabiduría, convirtiéndose, en ausencia de sus maridos, en las cabezas de familia. La familia de Ático, con una abuela que falleció anciana, una madre que alcanzó los 90, y una hija que superó los 60 (Alvarez, 2016), puede ilustrarnos acerca de cuántas vetulae podía haber en una misma familia en cada generación, así como sobre cuántos ejemplos de ancianas tendría en su entorno más inmediato un romano o romana a lo largo de su vida. En este sentido, otro ejemplo, aunque ya tardío, es el de la familia de Ausonio, que vivió la ancianidad de una abuela, dos tías y una hermana. No obstante, debemos tener en cuenta que se trata de casos provenientes de la élite; las condiciones laborales e higiénico-sanitarias de la clase trabajadora, así como la ausencia de una familia en sentido estricto en el caso esclavo, podrían modificar sustancialmente esta perspectiva.

\section{IV.2. LA AGENCIA ECONÓMICA DE LAS VETULAE}

Una vez analizados los roles que las vetulae podían ocupar dentro de la familia romana, queremos preguntarnos ahora por su agencia económica. A pesar de que en la literatura romana la mujer aparece ligada al ámbito doméstico, se trata de una imagen teórica que chocaba con la realidad de las mujeres de las clases populares, integradas en el mundo laboral, y también con las de la élite, quienes incidían en el ámbito económico mediante acciones evergéticas y el control de distintos negocios. A ellas hay que añadir a las esclavas, los beneficios de cuyo trabajo iban a parar a sus dueños, así como a las mujeres que trabajaban en negocios familiares sin cobrar, y a aquellas que vendían puntualmente excedentes domésticos artesanales o alimenticios (Medina, 2014: 49). 
La mayoría de las romanas, por lo tanto, debieron desempeñar distintos oficios en la vejez, hasta que sus condiciones físicas o mentales se lo impidiesen. La epigrafía proporciona numerosos testimonios de mujeres trabajadoras ${ }^{334}$. Una vetula podría realizar sin problema trabajos como los asociados con el tejido -hilandera, tejedora, modista, zurcidora, bordadora, etc.-, la venta de diversos productos de forma habitual o puntual -debido al excendente doméstico-, la medicina, la crianza y educación -como las nutrices-, o las labores domésticas. Así, Philtates, fallecida con 68 años, era ornatrix (AE 1976, 311), Licinia Primigenia, muerta con 71 años, unguentaria (CIL 10.1965), Claudia, fallecida con 75, obstetrix (CIL 6.9720), y Julia Agele, muerta con 80, resinaria (CIL 6.9855) ${ }^{335}$. Por su parte, Julia Soteridi, quien vivió 80 años, ejerció como lanipendae, vendedora de lana y ropa, al parecer junto a sus cuatro esclavas o libertas (CIL 6.9498; Fernández Uriel, 2011). A labores textiles se dedicó también Caesia Celsa, muerta a los 75 años (CIL 2.1699). Dos mujeres hispanas de nombre Ambata, una fallecida con 75 años y la otra con 55, eran medicae (HEp 1994, 199 y 2000, 81). Vibia Crispa, fallecida con 67 años en la zona de Río Tinto, ha sido interpretada como una minera (CIL 2.967; Blázquez, 1989: 129); si bien podría darse la posibilidad de que siguiera trabajando en la mina siendo una vetula, Silvia Medina (2014: 112-113) se muestra cautelosa al respecto. Podría ser que se tratase del trabajo que Vibia desempeñó en su juventud, o que tuviese un oficio relacionado con la minería pero no la extracción del mineral en sí. A pesar de que no conocemos la edad que alcanzó, Urbana es calificada de quasillaria veterana, lo que podría indicar que era una mujer madura o vieja (CIL 6.6346). Ninguna de estas vetulae tuvo por qué abandonar su oficio en la vejez, no fuera favorecidas por sus circunstancias económicas o forzadas por alguna patología incapacitante.

En lo que respecta a la literatura, las vetulae aparecen trabajando como posaderas (Apul. Met. 1.21 y 1.7.7), sacerdotisas (Petron. Sat. 133-138), actrices, o parteras:

"MISIS - Ya te he oído hace rato, Arquilis: mandas traer a Lesbia. Por Pólux que es una mujer borracha y atrevida, y no muy digna de que se le ponga en sus manos a una primeriza. Sin embargo, la traeré. (A los espectadores) ¡Hay que ver con la terquedad de este vejestorio, porque es su comadre de jarro! Dioses, os lo suplico,

\footnotetext{
${ }^{334}$ Para la conceptualización del trabajo femenino y los distintos oficios que desempeñaban las mujeres en Roma, vid. Alfaro, 2010; Fernández Uriel, 2011; Medina, 2011 y 2014 y Rubiera, 2014.

335 Peluquera, perfumista, comadrona y depiladora con resina, respectivamente.
} 
dadle a la muchacha facilidad en el parto, y a la partera oportunidad de equivocarse más bien con otras" (Ter. An. 227-235) 336 .

"La comediante Luceya declamó en la escena a los cien años. Durante el consulado de Gayo Popeo y Quinto Sulpicio, en los juegos votivos por la salud del divino Augusto, la actriz de intermedios Galeria Copiola fue llevada de nuevo a la escena cuando tenía ciento cuatro años; había sido presentada como principiante por el edil de la plebe Marco Pomponio noventa y un años antes, durante el consulado de Gayo Mario y Gneo Carbón; fue llevada de nuevo por Pompeyo Magno en la dedicación de un gran teatro, siendo ya anciana, como una cosa extraordinaria" (Plin. NH 7.48.158-159) ${ }^{337}$.

Galeria Copiola actuó por primera vez con 13 años en el 82 a.C. Nacida en el 95 a.C., ya en el 55 a.C. se había presentado en el escenario como una anciana, a pesar de que tenía 40 años. El que fuera una excepción podría remitir a lo difícil que resultaba para una actriz, y por lo tanto esclava o de baja condición social, alcanzar la vejez, o al menos hacerlo manteniendo su oficio. Otra vetula que encontramos en los escenarios, en este caso en el año 59 d.C. es Elia Catela, quien a diferencia de Galeria provenía de una familia adinerada y actuó obligada por Nerón, quien también instó a cantar a otros senes y vetulae:

"Posteriormente, instituyo una nueva clase de festival, llamado las Juvenalia o Juegos de la Juventud. Se celebraron en honor de su barba, pues fue entonces cuando se afeitó por primera vez; los pelos fueron colocados en una pequena esfera de oro y ofrecidos a Jupiter Capitolino. Para este festival, se obligó a miembros de las familias más nobles, asi como a otros, a ofrecer alguna clase de exhibición. Por ejemplo, Elia Catela, una dama prominente no sólo por su familia y su riqueza, sino también por su avanzada edad (era octogenaria), bailó en una pantomima. Otros, quienes por culpa de su avanzada edad o por enfermedad no podian ejecutar nada por sí mismos, tenían que cantar en los coros. Todos se dedicaron a practicar lo mejor que podían cualquier talento que poseyeran; y todas las personas más

\footnotetext{
${ }^{336}$ Audivi, Archylis, iamdudum: Lesbiam adduci iubes. Sane pol illa temulentast mulier et temeraria nec sati' digna quoi committas primo partu mulierem. Tamen eam adducam? inportunitatem spectate aniculae quia compotrix eius est. di, date facultatem obsecro huic pariundi atque illi in aliis potiu' peccandi locum.

${ }^{337}$ Lucceia mima $c$ annis in scaena pronuntiavit. Galeria $C$ emboliaria reducta est in scaenam $C$. Poppaeo Q. Sulpicio cos. ludis pro salute Divi Augusti votivis annum ciiii agens; producta fuerat tirocinio a M. Pomponio aedile plebis C. Mario Cn. Carbone cos. ante annos xci, a magno Pompeio magni theatri dedicatione anus pro miraculo reducta.
} 
distinguidas, hombres y mujeres, niñas y adolescentes, ancianas y ancianos, asistieron a escuelas designadas para ello" (Cass. Dio 62.19.1-2)

En el ámbito rural, una anciana sin limitaciones físicas ni mentales graves no tendría problemas para cumplir con todas las tareas correspondientes al oficio de villica: preparación de la comida, limpieza y orden del hogar, recogida de agua, limpieza de la ropa, cuidado de personas enfermas, preparación del pan y de las conservas de alimentos, o coser y tejer entre otras (Medina, 2011: 49). Donde quizás la vejez sí pusiese más límites sería en el desarrollo de los trabajos relacionados con el campo, tanto agrícolas como ganaderos, si bien había tareas, como la cosecha de la mielga, que eran consideradas propias de ancianas (Plin. $N H$ 13.47.132).

No obstante, en ocasiones ni siquiera el tener un trabajo remunerado salvaba a las vetulae de vivir en condiciones de extrema pobreza. En cuanto que mujeres y ancianas, eran además especialmente susceptibles a caer en esta situación. El Estado romano no contaba con ayudas para las personas ancianas, por lo que éstas dependían de sí mismas, de sus familias y de otras redes de ayuda, como las amistades o la comunidad:

"Se les puede legar a las ciudades también lo que corresponde al honor y al ornato de la ciudad; para ornato, por ejemplo, lo que se hubiere legado para construir un foro, un teatro, un estadio; para honor, por ejemplo, lo que se hubiere dejado para hacer una fiesta, o una cacería, o para juegos escénicos, o juegos circenses, o lo que se hubiere dejado para repartirlo entre los ciudadanos, o para banquetes. Además de esto, se responde que pertenece al honor de la ciudad, lo que se hubiere dejado para alimentos de los débiles por su edad, por ejemplo, los más ancianos, los niños y las niñas" (Dig. 30.122.pr.) $)^{339}$.

"Una escribió así en los codicios: «pido que consintáis que Negidio, Ticio y Dión, libertos míos, ancianos y enfermos, pasen la vejez en los lugaren en que ahora

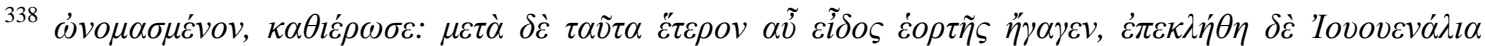

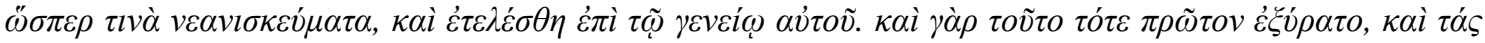

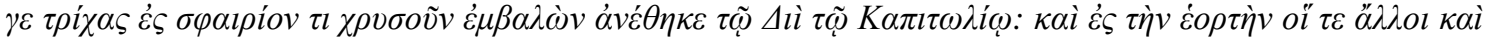

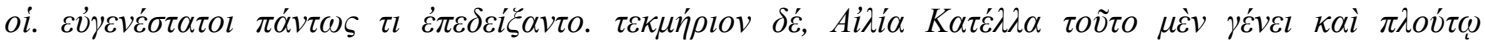

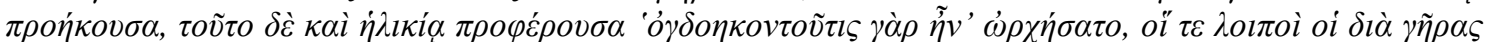

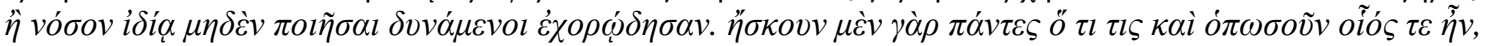

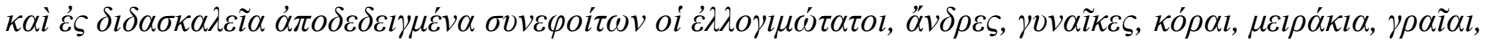

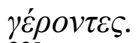

${ }^{339}$ Civitatibus legan potest etiam quod ad honorem ornatumque civitatis pertinet; ad ornatum, puta quod ad instruendum forum, theatrum, etadi am legatum fucnit; ad honorem, puta quod ad munus edendum 'venationenive, ludos seenicos, ludos Circenses, relictum fuenit, ant quod ad divilo nem singulorum civium, vl epulum relictum fuerit. Loe amplius, quod in alimenta infirmae aetatis, puta senioribus, vel pueris puellisque relictum fuerit, ad honorem civitatis pertinere respondetui.
} 
viven»; preguntó, si en virtud de esta cláusula deberán recibir por fideicomiso los mencionados libertos el usufructo de los lugares en que moran, habiendo conseguido sin controversia lo demás que especialmente se les legó. Respondió, que con las palabras que se exponían se pidió que los herederos consintieran que aquéllos estuviesen allí de la misma manera que ella lo consentía" (Dig. 33.2.33.2) $)^{340}$.

Ya en el siglo III d.C., Heliogábalo intentó buscar una solución al problema de la mendicidad:

"Regaló al pueblo enanos y enanas, bufones, viejos cantores y toda clase de músicos y pantomimos; pero asignó a aquellos que ya no servían para nada a distintas ciudades a cada uno, para que estas les proveyeran de alimentos, con el fin de que no se vieran incomodadas con la aparición de nuevos mendigos" (SHA Sev. $34.1-3)^{341}$.

Ya hemos hecho alusión a Eudaimonis, quien pedía a su nuera que le enviase más dinero o no podría soportar el invierno (P. Brem. 63). Eudaimonis dirigía un taller textil familiar, el cual si tenemos en cuenta la alusión anterior no siempre debía dar el suficiente beneficio $^{342}$. En el siglo II d.C., Apuleyo refiere cómo la esposa de Herennio Rufino tuvo que recurrir a la prostitución para mantener a la familia, ya que él se gastó todo su patrimonio; cuando esta mujer llegó a la vejez y no pudo seguir prostituyéndose, tuvo que sustituirla su hija (Apul. Apol. 74-76.2). Cuando todos los recursos fallaban, nos encontramos en las fuentes con situaciones como éstas:

"Pero la que no fue fiel a nadie, después, vencida por la vejez, sin recursos, tuerce el hilo de la rueca con mano temblorosa y anuda sólidas cuerdas en la tela tejida a sueldo y carda y limpia la lana de un vellón de nieve. La observan contentos grupos de jóvenes y comentan que, con razón, sufre de vieja tantos males" (Tib. 1.6.75$85)^{343}$.

\footnotetext{
${ }^{340}$ Codicillis ita scripsit: "negidium titium dionem libertos meos senes et infirmos peto in locis, in quibus nunc agunt, senescere patiamini": quaero, an ex hoc capite liberti supra scripti ex fideicommisso fructus locorum, quibus morantur, recipere debeant, cum alia, quae eis specialiter legata sunt, sine controversia consecuti sunt. Respondit verbis quae proponerentur id petitum, ut ad eum modum paterentur heredes ibi eos esse, ad quem modum ipsa patiebatur.

${ }^{341}$ Nanos et nanas et moriones et vocales exsoletos et omnia acroamata et pantomimos populo donavit; qui autem usui non erant, singulis civitatibus putavit alendos singulos, ne gravarentur specie mendicorum.

${ }^{342}$ Amaia Goñi (2015: 360) cree que la mala situación económica de la familia de Eudaimonis se debe a los efectos de las Guerras Judías.

${ }^{343}$ At, quae fida fuit nulli, post victa senecta ducit inops tremula stamina torta manu firmaque conductis adnectit licia telis tractaque de niveo vellere ducta putat. Hanc animo gaudente vident iuvenumque catervae conmemorant merito tot mala ferre senem.
} 
"Mas ya aquella plenitud laboriosa de la juventud se ha escapado de los miembros y temblorosa vejez está aquí, y cada vez mi arca ligera suministra menos para el gasto de comida. Pues un hombre inútil no tiene salario oficial, ni un anciano encamado puede trabajar en nada que se cambie por oro" (Auson. Ep. 6.30-35) ${ }^{344}$.

Con anterioridad hemos hecho referencia a los roles que las esclavas ancianas podían ocupar dentro de la familia romana. No obstante, el de nutrix no es el único oficio que tuvieron las vetulae esclavas en la antigua Roma. A lo largo de la presente Tesis Doctoral hemos aludido a otras tareas realizadas por esclavas ancianas, algunas de ellas también desempeñadas por mujeres libres. Sin bien parece que alcanzar la vejez no era la norma entre la población esclava (Alföldy, 1972 apud Gardner, 1986: 225), las fuentes nos hablan de vetulae esclavas que cuidaban a las mujeres jóvenes de la familia, que trabajaban la lana, se encargaban de la higiene y el vestido y peinado de sus amas, hacían de porteras, lavaban la vajilla, vigilaban el fuego, proveían a la casa de agua, etc. (Plaut. Aul. 90-95, 270 y 350 y Mostell. 165 y 249-269). La flautista de terracota a la que hacíamos alusión en el capítulo anterior fue también probablemente una esclava. Sira cargaba con el cuantioso equipaje de su domina:

"DORIPA - Como mi marido me mandó aviso al campo de que no iría él allí, he actuado yo por mi cuenta, me he venido, para perseguir a quien me huye. Pero no veo a nuestra vieja Sira, que venía conmigo. ¡Ah, sí!, ahí viene por fin. ¡Un poco más deprisa!

SIRA - Si es que no puedo, con esta carga tan pesada encima.

DOR. - ¿Qué carga?

SI. - Mis 84 años; échale encima la esclavitud, el sudor, la sed; éstas son las cargas que llevo todas juntas y que me agobian." (Plaut. Merc. 670-675) ${ }^{345}$.

Otras alusiones, si bien están en masculino y no puede saberse si se referían también a las mujeres, nos presentan oficios, como el de portero o cocinero, que bien pudieron ejercer las esclavas ancianas, al tiempo que nos informan de que estos senes y vetulae seguían trabajando incluso en condiciones de debilidad extrema (Cic. Pis. 27.67; Luc. A. 10; Phaed. 2.19; Sen. Ep. 12.1-5).

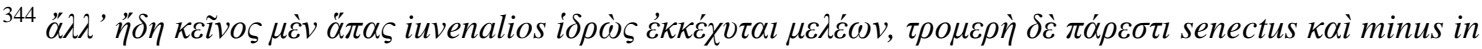

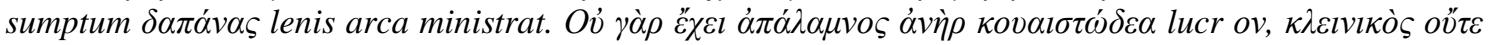

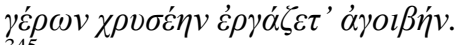

${ }_{345}$ DORIPPA Quoniam a viro ad me rus advenit nuntius, rus non iturum, feci ego ingenium meum, reveni, ut illum persequar qui me fugit. Sed anum non video consequi nostram Syram. Atque eccam incedit tandem. Quin is ocius? SYRA nequeo mecastor, tantum hoc onerist quod fero. DOR. Quid oneris? SYR. Annos octoginta et quattuor; et eodem accedit servitus, sudor, sitis: simul haec quae porto deprimunt.
} 
Robert Knapp (2011: 149), quien piensa que la principal utilidad de una esclava era la reproducción, cree que en la vejez estas mujeres no serían útiles a sus dueños y por lo tanto se tendería a su manumisión. De la misma opinión es Tom Payne (2015: 966), quien cree que la mayoría de los esclavos urbanos de ambos sexos serían manumitidos en su vejez. Manumisión que, por otro lado, no tenía que resultar obligatoriamente positiva, ya que la situación de una mujer liberada en la vejez y que no hubiera sido capaz de ahorrar dinero durante sus años de esclavitud sería bastante precaria, a no ser que tuviera un soporte familiar. No obstante, ya hemos hecho alusión a todas las tareas que podían seguir desempeñando estas mujeres, por lo que la manumisión en la vejez no puede considerarse como una norma generalizada. En ocasiones las patologías derivadas del envejecimiento podían ser incluso vistas como un motivo para retener a una esclava anciana; así, por ejemplo, la sordera podía ser útil para trabajar en ciertos entornos en los que debían evitarse las indiscreciones (Mart. 11.38).

En lo que respecta a su valor económico, las fuentes hacen alguna referencia a la existencia de un mercado de vetulae y senes (Cato Agr. 2.7; Plaut. Bacch. 816-820). Plutarco califica a Catón el Viejo de inhumano por participar de él:

"Solamente aquello de valerese de los esclavos como de acémilas y deshacerse luego de ellos y venderlos a la vejez, para mí no puede ser sino de un hombre cruel, que no se cree enlazado a otro hombre sino con el vínculo de la utilidad. Pues en verdad que la la humanidad y la dulzura tienen todavía más latitud que la justicia, pues de la ley y de la justicia sólo podemos usar con los otros hombres, pero la beneficencia y la gratitud se emplean aun con los animales irracionales, dimanando de la bondad como de una fuente copiosa, porque es propio del hombre de probidad no dejar sin alimento al caballo desfallecido ya por los años y el mantener y cuidar los perros, no sólo de cachorritos, sino aun cuando se han hecho viejos. El pueblo de Atenas, cuando se construyó el Hecatómpedo, a cuantas acémilas llegó a entender haber concurrido constantemente a los trabajos de la obra, a todas las echó a pacer libres y sueltas; y aun se refiere de una de ellas que por sí misma se bajaba al lugar de la obra, y agregándose a las yuntas que subían los carros al alcázar las ayudaba yendo delante, como si las animara y alentara, por lo que se decretó que hasta que muriese se proveyera de los fondos públicos para su manutención. Los sepulcros de las yeguas con que Cimón venció tres veces en Olimpia están inmediatos a los monumentos que a éste se erigieron. Muchos cuidaron de sepultar a los perros que se les habían hecho como comensales y amigos, y entre ellos 
Jantipo el mayor, al perro que nadando junto a su galera le siguió a Salamina, cuando el pueblo abandonó la ciudad, lo hizo sepultar en un promontorio, que todavía se llama la sepultura del perro. En efecto, no hemos de usar de cosas que tienen vida y alma como de los zapatos o de los muebles, echándolos a un rincón cuando ya están rotos y gastados, sino que es razón que en cuanto a aquellas nos mostremos cuidadosos y benignos, aunque no sea más que por excitar a la humanidad. Por tanto, yo ni siquiera a un buey de labor lo vendería por viejo, mucho menos a un hombre anciano, desterrándolo como de su patria de una tierra y de una mansión a que estaba ya habituado, en cambio de una friolera que podrían dar por él, pues que siendo inútil al que lo vendía lo sería también al comprador." (Plut. Cat. Mai. 5$)^{346}$.

Vemos por lo tanto que vender a una vetula esclava perjudicaba tanto a la vendida, a quien no se agradecía los años de servicio prestados proporcionándole soporte en la vejez, como a quien la compraba, porque era poca la utilidad que podía sacarle; si bien podemos pensar que algún uso le encontraría cuando se había molestado en pagar un precio por ella. En el Capítulo II aludíamos al Edicto de Precios de Diocleciano, según el cual se fijaban los precios máximos a los que podían venderse las personas esclavizadas, los cuales variaban en relación con el sexo y la edad, siendo casi siempre menores en el caso de las mujeres -excepto entre los 8 y 16 años, en los que se equiparan en ambos sexos-, y con los precios más bajos por debajo de 8 años y por encima de 60. El que en este edicto los rangos de edad sean comunes para mujeres y hombres y la vejez comience en ambos a los 60 puede deberse tanto a la aplicación del masculino universal, como a la poca importancia que esta ley daba a la edad reproductora, siendo de más relevancia el estado físico de la persona a vender. Tenemos

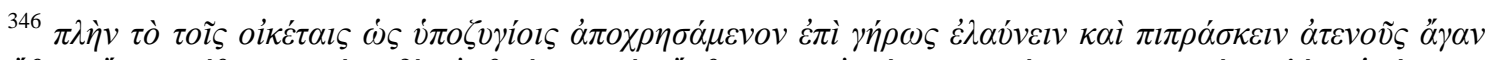

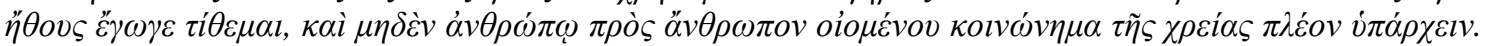

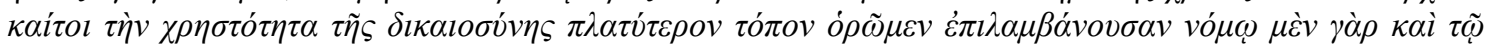

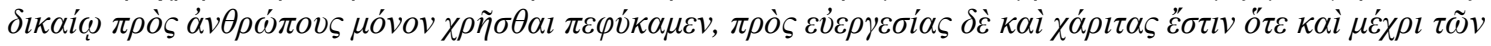

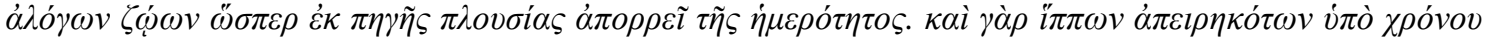

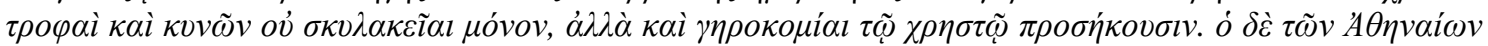

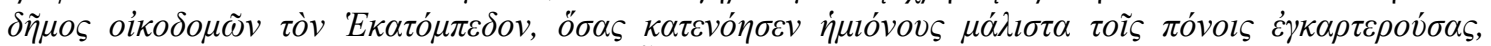

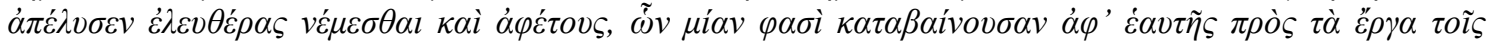

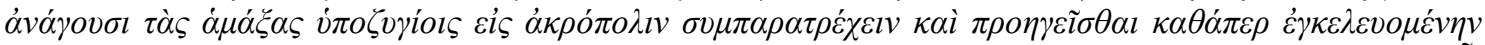

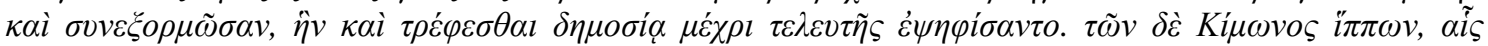

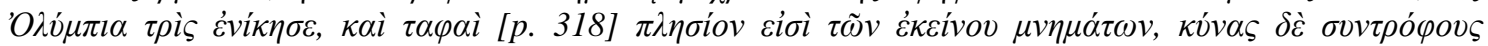

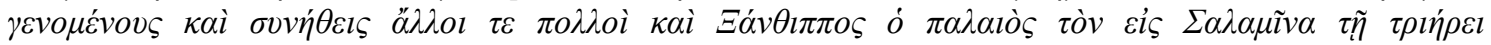

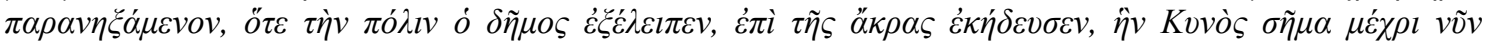

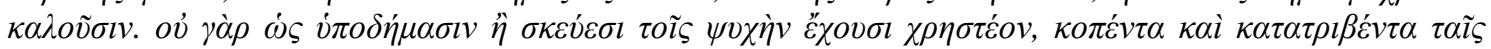

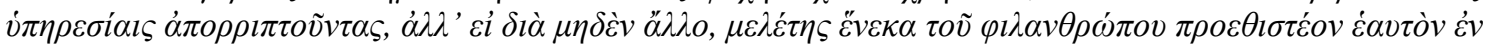

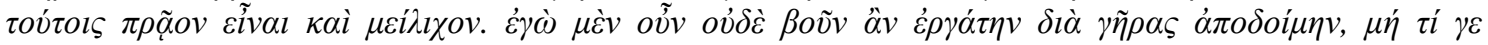

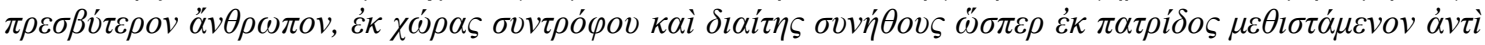

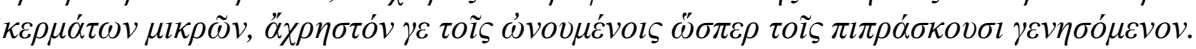


que tener también en cuenta que se están fijando precios máximos, y es probable que en el rango de edad de 40-60 el precio de una mujer dependiese de si todavía podía o no tener hijos; ya se ha visto cómo hay otra ley que obliga a informar de si la esclava es fértil o tiene más de 50 años (Dig. 19.1.21.1).

En relación a la existencia de vetulae y senes esclavizados, contamos también con un documento del siglo IV d.C., proveniente de Thera, en Grecia, en el cual están registradas 152 personas que pertenecen a un mismo dueño (Harper, 2008 y 2011: 75). Sólo conservamos el sexo y la edad de 76 de ellas. Hay 47 mujeres, de las cuales 10 tienen 50 años o más (4 entre 50-54 años, 4 entre 55-59, y 2 de 60 años). La edad más alta es la de un hombre de 66 años. A pesar de que la información está incompleta y que se refiere a un solo propietario, pueden inferirse varios hechos. Por un lado, que entre las personas de quienes conservamos el sexo y la edad, el 61\% son mujeres. Por otro lado, que de las 47 mujeres identificadas, el 21\% tenía 50 años o más. Si añadimos que se trata de esclavas agrícolas podemos ver cómo, al menos en época tardía, las esclavas ancianas no parecen ser liberadas ni excluidas de los trabajos más duros, como son los del campo. Una teoría que ya postuló Thomas Wiedemann (1996: 276 y 288), quien apuesta porque, de común, se les asignaría tareas acondicionadas a sus capacidades.

En lo que respecta a las vetulae de la élite, su economía estaba basada en dos actividades principales: la posesión de tierras, negocios y población esclava, y la realización de actos de evergetismo. Se trata de dos actividades relacionadas entre sí, ya que los beneficios de la primera, junto con el patrimonio familiar, servirían para costear la segunda. A algunas de estas mujeres ya las hemos presentado en las anteriores páginas. Así, hemos hecho alusión al negocio de ladrillos de Antonia Minor y a la enorme fortuna de Livia, quien recompensó con un millón de sestercios a Numerio Ático, el senador que afirmó haber visto a Augusto ascender al cielo (Barrett, 2002: 76). Junto a la herencia de su familia y de Augusto, Livia recibió diversos legados de amistades y clientes, entre ellos Herodes el Grande y su hermana Salomé (Joseph. AJ 18.31). Tenía además numerosos esclavos, como muestran las excavaciones realizadas en el Monumentum Liviae, el cual cuenta con 550 nichos (Barrett, 2002: 180). Pompeya Celerina poseía múltiples propiedades y una gran cantidad de esclavos, y Umidia Cuadratila sufragó la construcción del anfiteatro y de un templo en Casinum, así como la reconstrucción del teatro, donde actuó su compañía de pantomimas ( $A E$ 1992, 244; CIL 10.5183). En el último caso, resalta el hecho de que, entre las personas beneficiarias 
del evergetismo de Umidia, se menciona explícitamente a las mujeres. Conocemos también a dos de los actores que pertenecieron a Umidia, Dionisio y Restituto, que dedican epitafios a su esposa y su verna, respectivamente (AE 1985, 189; EDCS 292). Poco antes de casarse, Pudentila había realizado distribuciones por valor de 50.000 sestercios (Apul. Apol. 87.7-11). Además, donó a sus hijos tierras, rebaños, y más de 400 esclavos. Poseía extensas propiedades destinadas a la explotación agropecuaria, trabajadas por personal libre y esclavo y dirigidas por capataces supervisados por ella (Harlow, 2007: 203; Hidalgo, 2011: 205-207). Contamos también con el ejemplo de Taedia Secunda (CIL 4.7469) y el apoyo electoral prestado a su nieto, otra de las formas que las mujeres poderosas tendrían de incidir en el ámbito público, y cuyo éxito dependería tanto del patrimonio de la vetulae en cuestión como de su prestigio social.

Mediante las acciones evergéticas, estas mujeres modelaron ciudades a lo largo de todo el territorio romano, visibilizándose como personajes de relevancia no sólo a través de las construcciones que costearon y las inscripciones que recuerdan sus donaciones, sino también mediante su presencia en las inauguraciones de los edificios, en los espectáculos que sufragaban, y en los banquetes que organizaban. En palabras de Cándida Martínez:

"Estas mujeres encontraron en las acciones evergéticas un medio que les procuraba la celebridad, el poder y la gloria públicas antes negados, aun sin llegar a detentar cargos políticos. Lo pudieron hacer porque disponían de recursos económicos y podían gestionarlos, porque conocían el funcionamiento de las redes y mecanismos de poder de sus sociedades, porque el culto imperial les proporcionó una influyente proyección social, porque tenían modelos femeninos de referencia en la casa imperial, porque sus acciones convenían a las ciudades en fase de transformación y monumentalización urbana y porque, además, se convirtieron, en muchos casos, en un medio más para enaltecer el grupo familiar y reforzar sus redes sociales" (Martínez, 2011: 285-286).

Ese prestigio que poseían estas mujeres se materializa en época imperial con el nombramiento honorífico de algunas de ellas como madres de ciudades. Diferentes municipios agradecieron mediante este nombramiento a diversas mujeres los favores que habían hecho por ellos. Emily Hemelrijk (2012: 204) sugiere que estas madres de ciudades eran mujeres maduras, que ya habían sido madres biológicas. Un ejemplo lo encontramos en Lucia Fonteia, fallecida con 70 años, quem semper cives matrem appellaverunt (CIL 11.2538). 
En definitiva, vemos cómo las ancianas romanas incidieron en la economía de diversas formas, las cuales dependieron principalmente de su estatus social y su patrimonio. Como esclavas, retirarse en la vejez no era una decisión que estuviera al alcance de las vetulae; algunas serían manumitidas, mientras que a otras se les encomendarían tareas adecuadas a sus capacidades físicas. Como trabajadoras libres, abandonar su oficio dependería tanto del patrimonio que hubiesen acumulado a lo largo de los años como de que su salud no les impidiese trabajar. Como mujeres de la élite, a no ser que sufrieran demencia, pudieron dirigir negocios y encargarse del buen funcionamiento de la economía doméstica.

\section{IV.3. ESTEREOTIPOS CREADORES DE UNA IDENTIDAD COMÚN}

A lo largo de los anteriores apartados hemos visto cómo la vida de las vetulae variaba dependiendo de diversos factores, como su situación económica o su rol familiar. No obstante, por encima de las particularidades individuales de la vejez de cada romana, la literatura y el arte presentan varios estereotipos de vetula que resulta importante analizar para obtener una visión de conjunto de la percepción social de la vejez femenina en la antigua Roma. Por ello, en este apartado pretendemos analizar cinco estereotipos de vetula, a los que debe añadirse el personaje de la anus libidinosa comentado en el Capítulo III, los cuales en ocasiones comparten características o se mezclan, ayudando a crear una identidad de anciana repulsiva y peligrosa que en la literatura romana encarna todos los rasgos negativos de la vejez y la feminidad.

Comenzamos analizando a la anus ebria, la vieja aficionada al vino que resulta un personaje recurrente en la comedia y la sátira, pero que al mismo tiempo parece tener connotaciones religiosas que podemos rastrear tanto en los mitos como en la iconografía. A continuación presentamos la relación entre la vetula y la magia, analizando a personajes literarios tan conocidos como las brujas Canidia y Meroe. Un tercer estereotipo es el de la lena, la prostituta envejecida o la guardiana de la virginidad de las doncellas. Finalmente, el final del presente apartado está dedicado a dos imágenes positivas de la vetula como mujer bondadosa y como transmisora de sabiduría; una sabiduría que, como veremos, en ocasiones podía resultar peligrosa. 


\section{IV.3.1. Anus ebria}

El tópico de la anciana que abusa del alcohol, especialmente del vino, resulta frecuente en la literatura de todas las épocas, convirtiendo a esta figura en una prácticamente atemporal (García Soler, 2010; Pollard, 2008: 124). Este estereotipo parte de la idea de la relación que las sociedades patriarcales establecen entre mujer, bebida y adulterio. En la antigua Roma, la ingesta de vino estaba prohibida para las mujeres y era considerada síntoma de impudicitia. La excepción la suponía un tipo de vino de mala calidad y sin fermentar, llamado lora, que se consideraba apto para las mujeres y los esclavos (Real, 1992: 308).

Si bien parece que esta restricción no se daba en los inicios de la historia de la ciudad, a juzgar por los enterramientos femeninos con ajuar relacionados con el banquete y la bebida encontrados en yacimientos del Lacio fechados en el siglo VIII a.C. (Ford, 2003: 80), en época clásica la prohibición era tan relevante en la mentalidad romana que se ilustraba mediante una historia legendaria, la de Bona Dea. Existen dos versiones de la historia de esta la diosa, esposa o hija de Fauno y paradigma de pudicitia. En la primera de ellas Bona Dea se resiste a ser violada incluso tras ser emborrachada (Macrob. Sat. 1.12.20-29), mientras que en la segunda la diosa habría aprovechado un momento de soledad para beber vino a escondidas (Plut. Quaest. Rom. 20). En ambas versiones Fauno la flagela con una rama de mirto, en la segunda de ellas hasta matarla, tras lo cual se arrepiente y decide dedicarle honores divinos. El tabú de la consumición del alcohol por parte de las romanas, el cual se subraya en ambas versiones del mito, era tan importante que el vino que se bebía durante el festival de la Bona Dea era llamado "leche" (Macrob. Sat. 1.12.25).

Lo inadecuado de beber vino lo señala Valerio Máximo cuando escribe que "antiguamente las mujeres romanas no bebían vino, para no verse obligadas a cometer ningún acto indecoroso, porque no suele haber más que un paso entre la incontinencia y el placer prohibido, y aquella tiene su origen en el padre Baco" (Val. Max. 2.1.5) ${ }^{347}$, a lo que añade que "toda mujer, que bebe vino sin medida, cierra las puertas de su corazón a toda clase de virtudes y las abre a todos los vicios" (Val. Max. 6.3.9) ) $^{348}$. No obstante, de la lectura de estos textos se desprende que la prohibición afectaba principalmente a las romanas respetables, y no son infrecuentes los episodios en los que prostitutas y otros

\footnotetext{
347 Vini usus olim Romanis feminis ignotus fuit, ne scilicet in aliquod dedecus prolaberentur, quia proximus a Libero patre intemperantiae gradus ad inconcessam uenerem esse consueuit.

${ }^{348}$ quaecumque femina uini usum immoderate appetit, omnibus et uirtutibus ianuam claudit et delictis aperit.
} 
personajes femeninos marginales aparecen bebiendo vino, acción que sirve como indicadora de su identidad, contraria a la de la matrona.

En el caso de las vetulae, se esperaría que el consumo de vino fuese especialmente reducido, tanto por su condición de mujeres como por el hecho, ya señalado en el Capítulo II, de que la ingesta de alcohol debía moderarse en la vejez. A pesar de ello, hemos aludido a que la afición de Livia por el vino favoreció su larga vida, y contamos con textos que señalan la dificultad de las mujeres para emborracharse:

"Recuerdo haber leído en un filósofo griego (si no me equivoco era Aristóteles en el libro que redactó sobre la ebriedad) que las mujeres rara vez se emborrachan, los viejos, en cambio, con frecuencia; pero no añadió el motivo ni de la frecuencia de éstos, ni de la escasez de ocasiones de aquéllas. (...) De hecho, el cuerpo de la mujer y el del viejo están dotados de naturalezas opuestas. La mujer tiene un cuerpo muy húmedo. Lo prueba su piel lisa y reluciente, lo prueban sobre todo las continuas menstruaciones que descargan al cuerpo del líquido superfluo. Por tanto, cuando el vino bebido ha venido a parar a tan gran abundancia de líquido, pierde su fuerza, se diluye, y no le resulta fácil golpear la sede del cerebro, agotado ya su vigor. Pero hay otra consideración que corrobora la verdad de la aseveración: el cuerpo femenino, predispuesto a periódicas menstruaciones, está perforado por muchas aberturas, a fin de abrir pasajes y procurar cauces al líquido que confluye hacia la salida de evacuación; a través de estas aberturas el vapor del vino se desvanece rápidamente. Por el contrario, los viejos tienen el cuerpo seco; prueba de ello es la piel áspera y rugosa. Por eso esta edad se toma también bastante difícil para flexionar los miembros, lo cual es indicio de sequedad. Dentro de sus cuerpos el vino no sufre la acción contraria de un líquido incompatible y se adhiere con su fuerza intacta al cuerpo árido, y luego ocupa la región que procura al hombre la inteligencia. No hay duda de que el cuerpo de los viejos es también duro, y por ello incluso los conductos naturales se cierran al tratarse de miembros bastante duros, y cuando se bebe vino, no se produce ninguna evaporación, sino que asciende todo hasta la sede misma de propios de los borrachos: miembros temblorosos, habla titubeante, locuacidad excesiva, arrebatos de cólera; a tales síntomas están supeditados tanto los jóvenes ebrios como los ancianos sobrios. Por tanto, si experimentan un ligero estímulo del vino, no contraen tales achaques, sino que

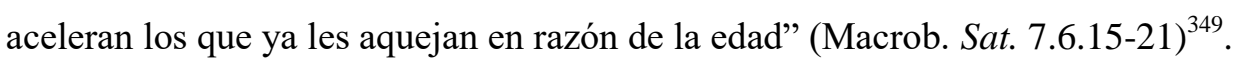

\footnotetext{
${ }^{349}$ Legisse apud philosophum Graecum memini (ni fallor, ille Aristoteles fuit in libro quem de ebrietate
} conposuit) mulieres raro in ebrietatem cadere, crebro senes: nec causam vel huius frequentiae vel illius 
Otro texto al respecto nos lo proporciona Plutarco (Mor. 650). Ambos tienen como fuente a Aristóteles, y su contenido es prácticamente el mismo. Los dos autores señalan la especial tolerancia que las mujeres tienen con el vino, la cual se debe a su naturaleza húmeda. Por el contrario, la vejez se presenta como una etapa seca -aunque ya hemos señalado en el Capítulo II que hay diversas teorías a este respecto-, y por lo tanto las personas ancianas se embriagan con facilidad. Además, los síntomas de la borrachera se identifican con otros que presenta la vejez de forma natural, como la falta de equilibrio, las dificultades en el habla, la desorientación, o los accesos de ira. Por otro lado, nos encontramos con autores como Galeno (Anim. 10) o Platón (R. 2.666b), que recomiendan beber vino en la vejez para contrarrestar el frío del cuerpo, así como el carácter agrio propio de los ancianos, aunque como ya hemos visto debía hacerse con moderación. Las vetulae se sitúan aquí en una posición intermedia, ya que como mujeres parecen tolerar la ingesta de vino, pero como viejas serían más propensas a la borrachera.

De la lectura de los textos literarios se desprende que la prohibición de beber vino se relajaba en el caso de las vetulae. Las ancianas aparecen como bebedoras habituales, e incluso algunas de ellas se nos presentan como alcohólicas, convirtiéndose la bebida en su mayor necesidad ${ }^{350}$. Ello puede deberse a tres causas. Por un lado, porque en las ancianas ya no había peligro de adulterio -dado su escaso atractivo sexual- ni de embarazo en el caso de que tuviesen relaciones sexuales, desapareciendo así el miedo a la descendencia ilegítima. Por otro lado, porque la afición a la bebida se veía, en los ancianos de ambos sexos, como una forma de encontrar consuelo a los males de la vejez, aunque no por ello dejaba de considerarse un defecto (Apul. Met. 4.7; Gal. Anim.

raritatis adiecit (...) contrariam enim sortita naturam sunt muliebre corpus et corpus senile. Mulier humectissimo est corpore. Docet hoc et levitas cutis et splendor, docent praecipue adsiduae purgationes superfluo exonerantes corpus humore. Cum ergo epotum vinum in tam largum ceciderit humorem, vim suam perdit et fit dilutius, nec facile crebri sedem ferit fortitudine eius extincta. Sed et haec ratio iuvat sententiae veritatem: Quod muliebre corpus crebris purgationibus deputatum pluribus consertum est foraminibus, ut pateat in meatus et vias praebeat humori in egestionis exitium confluenti, per haec foramina vapor vini celeriter evanescit. Contra senibus siccum corpus est, quod probat asperitas et squalor cutis. Unde et haec aetas ad flexum fit difficilior, quod est indicium siccitatis. Intra hos vinum nec patitur contrarietatem repugnantis humoris, et integra vi sua adhaeret corpori arido, et mox loca tenet quae sapere homini ministrant. Dura quoque esse senum corpora nulla dubitatio est: et ideo ipsi etiam naturales meatus in membris durioribus obserantur, et hausto vino exhalatio nulla contingit, sed totum ad ipsam sedem mentis ascendit. Hinc fit ut et sani senes malis ebriorum laborent, tremore membrorum, linguae titubantia, abundantia loquendi, iracundiae concitatione: quibus tam subiacent iuvenes ebrii quam senes sobrii. Si ergo levem pertulerint inpulsum vini, non accipiunt haec mala, sed incitant quibus aetatis ratione iam capti sunt.

${ }^{350}$ Sobre el alcoholismo en la Antigüedad, vid. Gourevitch, 2013. 
10; Ov. Met. 4.25-26; Pl. R. 2.666b; Plaut. Cist. 149). Finalmente, porque muchas de estas fuentes se refieren a prostitutas, magas y otras mujeres de las clases bajas, y ya hemos señalado que la prohibición afectaba principalmente a las mujeres de la élite.

La estrecha relación entre vino y ancianas está presente tanto en la literatura como en el arte. En el caso de las fuentes escritas, la vetula ebria aparece sobre todo en contextos humorísticos como el teatro o la sátira, pero también en episodios míticos y religiosos. Marcial, Petronio y Apuleyo, entre otros escritores, recurren en numerosas ocasiones a la anus ebria sin mostrar sorpresa alguna por encontrarse a una anciana borracha, por lo que sería una situación que formaría parte de la cotidianeidad:

"Vieja cocida en vino, de labios temblorosos" (Petron. Sat. fr. 21) ${ }^{351}$.

"Quien crea que Acerra apesta a vino de ayer se equivoca; Acerra bebe siempre hasta el alba" (Mart. 1.28) ${ }^{352}$.

"Para no oler demasiado, Fescennia, cargada del vino de ayer, devoras con avaricia caramelos de Cosmo. Estos desayunos limpian los dientes, pero no son ningún obstáculo cuando brota un eructo desde profundidades abisales. ¿Y qué me dices sobre que huele peor el veneno mezclado con los perfumes y sobre que el doble olor del aliento llega más lejos? Así pues, deja ya esos engaños demasiado conocidos y esos subterfugios descubiertos y preséntate borracha simplemente" (Mart. 1.87) $)^{353}$.

"Tal era el relato que hacía aquella pobre vieja chiflada y borracha a la joven cautiva" (Apul. Met. 6.25.1) ) $^{354}$.

"Como la hermosa Filis se me había entregado sin reparos una noche entera de todas las maneras, y a la mañana andaba yo pensando qué regalo le daría -si una libra de perfume de Cosmo o de Níceros, o un espléndido copo de lana bética, o diez áureos de la ceca del César-, se abrazó a mi cuello y, engatusándome con un beso tan largo como son los arrullos de las palomas, empezó Filis a pedirme un ánfora de vino" (Mart. 12.65)

\footnotetext{
${ }^{351}$ Anus recocta vino trementibus labellis.

${ }_{352}^{352}$ Hesterno fetere mero qui credit Acerram, fallitur: in lucem semper Acerra bibit.

${ }^{353}$ Ne grauis hesterno fragres, Fescennia, uino, pastillos Cosmi luxuriosa uoras. Ista linunt dentes iantacula, sed nihil obstant, extremo ructus cum redit a barathro. Quid quod olet grauius mixtum diapasmate uirus atque duplex animae longius exit odor? Notas ergo nimis fraudes deprensaque furta iam tollas et sis ebria simpliciter.

${ }^{354}$ Sic captivae puellae delira et temulenta illa narrabat anicula.

${ }^{355}$ Formosa Phyllis nocte cum mihi tota se praestitisset omnibus modis largam, et cogitarem mane quod darem munus, utrumne Cosmi, Nicerotis an libram, an Baeticarum pondus acre lanarum, an de moneta
} 
El abuso del vino va asociado en estos textos a otras características como el mal olor, una sexualidad exagerada -Filis podría ser tanto una vetula como las presentadas en el capítulo anterior como una prostituta-, actitudes inadecuadas en una romana como eructar o trasnochar, y la locura; en definitiva, se trata de diferentes maneras de remarcar la marginalidad de estas ancianas. Además, las vetulae aparecen como consumidoras de vino puro, un hábito considerado propio de pueblos bárbaros:

"El primero en darte nombre, Meroe, debió ser el mismo que compuso el de Hipólito, hijo de Teseo. Pues es arte profético dar un nombre que revele el destino y el carácter o la muerte de alguien. (...) Lo mismo te pasa ti, Meroe, no porque seas negra de color como la que nace en la Meroe del Nilo, sino porque no disuelves en agua el vino vertido, acostumbrada como estás a beber sin mezcla y puro el vino" (Auson. Ep. 41) ${ }^{356}$.

En el teatro la anus ebria es, al igual que en los ejemplos ya mostrados, una mujer de baja extracción social, normalmente una esclava o una lena. Leona, personaje de Plauto, se nos presenta como una vetula alcoholizada cuyas acciones pretendían provocar la risa del público, si bien desde nuestro presente se trata de una figura cuya situación inspira compasión:

"LEONA - ¡A vino rancio me huele! Levada de tu amor, salgo ansiosa a oscuras en pos de ti. Esté donde esté, muy lejos no es. ¡Viva, lo encontré! ¡Salve de mi alma, delicia de Baco! Viejo eres tú, vieja soy yo, ¡qué ansias de amor! El olor de todos los perfumes ante ti no es más que heces para mí. Mirra eres, cinamomo, rosa y azafrán, canela, tragacanto, para qué más. Bajo la tierra empapada de ti quisiera reposar. Sólo tu olor ha llegado hasta ahora a mi nariz, al gaznate le toca la vez, no le hagas sufrir. ¿Quita tú! ¿Dónde está la jarrita? No puedo esperar a echarte una mano y a tirárteme al coleto de un solo trago. Por aquí es, ¡adelante!

FÉDROMO - ¡No tiene sed la vieja!

PALINURO - ¿De cuándo crees tú?

F- Es modesta, se toma unos cincuenta cuartillos.

P- Caray, entonces la vendimia de hogaño no sería bastante para ella sola. Hubiera estado mejor de perro, tiene un olfato muy fino.

L- ¡Eh! ¿De quién es esa voz que suena a lo lejos?

Caesaris decem flavos: amplexa collum basioque tam longo blandita, quam sunt nuptiae columbarum, rogare coepit Phyllis amphoram vini.

${ }^{356}$ Qui primus, Meroe, nomen tibi condidit, ille Thesidae nomen condidit Hippolyto, nam divinare est, nomen componere, quod sit fortunae et morum vel necis indicium (...) et tu sic Meroe, non quod sis atra colore, ut quae Niliaea nascitur in Meroe; infusum sed quod vinum non diluis undis, potare imnixtum sueta merumque merum. 
F - (A Palinuro) Me parece que debemos hablarle. Voy allá. ¡Vuélvete y mira para acá, Leona!

L- ¿Quién es el jefe?

F- Baco, el amable dios del vino, que sabiéndote carrasposa, sedienta y somnolienta, te trae de beber, para calmarte la sed.

L- ¿Cómo está de lejos?

F- Mira esta luz.

L - Alarga, pues, tus pasos hacia mí, por favor.

F- ¡Salud!

L- ¿Salud estando muerta de sed?

F- Ahora ya vas a beber en seguida.

L- Se me hace muy largo.

F- Toma, encanto.

L- Salud, pupila de mis ojos.

P- ¡Hala, vacía la jarra en ese abismo, deprisa, a limpiar esa cloaca!

F- Calla, no quiero que se le digan cosas desagradables.

P- Bueno, entonces se las haré, en vez de decírselas.

L- (Volviéndose al altar de Venus) Venus, aunque a desgana, aquí un poquillo de lo poco que tengo, que los enamorados te ofrecen siemore vino cuando beben para congraciarse contigo, pero a mí rara vez me caen tales herencias.

P- Fíjate con qué ansia se traga la asquerosa el vino a todo tragar.

F- ¡Ay de mí, estoy perdido, no sé lo que decirle para empezar!

P- Pues dile eso que acabas de decirme a mí.

F- ¿El qué?

P- Eso, que estás perdido.

F- ¡Maldito seas!

P- Yo no, sino la vieja.

$L_{¡}$ Aaaaah!

P- ¿Qué pasa?, te da gusto ¿eh?

P- A mí también me daría gusto atravesarte a golpes de aguijón.

F- Calla, eso no.

P- Me callo (Señalando a la vieja que se pone a beber) ¡Mira, el arco iris bebiendo, seguro que hoy va a llover!

F- ¿Se lo digo ya?

P- ¿El qué?

F- Que estoy perdido.

P- Venga, díselo. 
F- Escucha, abuela: ¿sabes?, soy un desgraciado y estoy perdido.

L- Y yo te juro que más que salvada. Pero, ¿qué es lo que pasa? ¿A santo de qué viene decir que estás perdido?

F- No tengo lo que amo.

L- Querido Fédromo, por favor, no sufras. Tú ocúpate de que yo no padezca sed, que ya te traeré yo aquí al objeto de tus amores.

F- Yo te prometo que, si guardas tus palabras, te voy a dedicar una estatua de vino en vez de oro como monumento a tu gaznate" (Plaut. Curc. 96-140) ${ }^{357}$.

Encontramos también referencias a la anciana que abusa del vino en contextos míticos y religiosos. Es el caso, por ejemplo, de la protagonista de un ritual en honor a Tacita Muta que nos presenta Ovidio:

"He aquí que una vieja cargada de años se sienta entre las muchachas y cumple con el rito de Tacita aunque ella misma no se está callada, y coloca en la parte de atrás del umbral tres granos de incienso con tres dedos, en el punto donde un minúsculo ratón se ha abierto un camino oculto. A continuación ata un trompo encantado a un trozo de plomo oscuro, y remueve en la boca siete habas negras, y quema al fuego la cabeza de un pececillo que ha untado de alquitrán y cosido atravesándolo con una aguja de cobre. También vierte vino; el vino que queda se lo bebe o ella misma o las acompañantes, aunque ella más. «Hemos amordazado las lenguas de los

\footnotetext{
${ }^{357}$ Leaena. Flos veteris vini meis naribus obiectust, eius amor cupidam me huc prolicit per tenebras. Ubi ubi est, prope me est. euax, habeo. Salve, anime mi, Liberi lepos. Ut veteris vetus tui cupida sum. Nam omnium unguentum odor prae tuo nautea est, tu mihi stacta, tu cinnamum, tu rosa, tu crocinum et casia es, tu telinum, nam ubi tu profusu's, ibi ego me pervelim sepultam. Sed quom adhuc naso odos obsecutust meo, da vicissim meo gutturi gaudium. Nil ago tecum: ubi est ipsus? Ipsum expeto tangere, invergere in me liquores tuos, sine, ductim. Sed hac abiit, hac persequar. Phaed. Sitit haec anus. Pal. Quantillum sitit? Phaed. Modica est, capit quadrantal. Pal. Pol ut praedicas, vindemia [haec] huic anui non sat est soli. Canem esse hanc quidem magis par fuit: sagax nasum habet. Leaena Amabo, cuia vox sonat procul? Phaed. Censeo hanc appellandam anum. Adibo. Redi et respice ad me, Leaena. Leaena Imperator quis est? Phaed. Vinipollens lepidus Liber, tibi qui screanti, siccae, semisomnae adfert potionem et sitim sedatum it. Leaena Quam longe a me abest? Phaed. Lumen hoc vide. Leaena Grandiorem gradum ergo fac ad me, obsecro. Ph. Salve. Le. Egon salva sim, quae siti sicca sum? Ph. At iam bibes. Leaena Diu fit. Phaed. Em tibi anus lepida. Leaena Salve, oculissime homo. Pal. Age, effunde hoc cito in barathrum, propere prolue cloacam. Phaed. Tace. Nolo huic male dici. Pal. Faciam igitur male potius. Le. Venus, de paulo paululum hoc tibi dabo haud lubenter. Nam tibi amantes propitiantes vinum potantes danunt omnes, mihi haud saepe evenunt tales hereditates. Pal. Hoc vide ut ingurgitat impura in se merum avariter, faucibus plenis. Phaed. Perii hercle, huic quid primum dicam nescio. Pal. Em istuc, quod mihi dixti. Phaed. Quid id est? Pal. Periisse ut te dicas. Phaed. Male tibi difaciant. Pal. Dicisti. Le. Ah. Pal. Quid est? Ecquid lubet? Le. Lubet. Pal. Etiam mihi quoque stimulo fodere lubet te. Phaed. Tace. Pal. Noli, taceo. ecce autem bibit arcus, pluet credo hercle hodie. Phaed. Iamne ego huic dico? Pal. Quid dices? Phaed. Me periisse. Pal. Age dice. Phaed. Anus, audi. Hoc volo scire te: perditus sum miser. Leaena At pol ego oppido servata. Sed quid est? Quid lubet perditum dicere te esse? Phaed. Quia id quod amo careo. Leaena Phaedrome mi, ne plora amabo. Tu me curato ne sitiam, ego tibi quod amas iam huc adducam. Phaed. Tibine ego, si fidem servas mecum, vineam pro aurea statua statuam, quae tuo gutturi sit monumentum.
} 
enemigos y las bocas hostiles», dice la vieja conforme se va, saliendo borracha" (Ov. Fast. 2.570-580) ${ }^{358}$.

Dado que Tacita Muta es la divinidad que personifica el silencio femenino, la ausencia de palabras resulta fundamental en la realización del ritual, por lo que se emplea a un pez, animal que no emite sonidos, y además se le cose la boca; sin embargo, la vetula hace honor al estereotipo de vieja charlatana y es incapaz de contener la lengua. Es ella quien dirige el rito, lo que puede deberse a su mayor conocimiento del mismo o, para Matthew Dickie (2001: 188-189), a que las mujeres descritas por Ovidio son una lena y sus prostitutas y por lo tanto la vetula tiene autoridad sobre las jóvenes. Sin embargo, Miriam Blanco (2015: 37) identifica a la anciana como una bruja que instruye a las iniciadas en los rituales mágicos. Se trata, no obstante, de dos interpretaciones que no son excluyentes, ya que como iremos mostrando a lo largo del presente capítulo los diversos estereotipos de vetula se entrecruzan para crear una identidad que condensa diversos rasgos, eminentemente negativos.

Es también Ovidio quien nos da información acerca de otra vetula situada en un contexto religioso. En el libro tercero de los Fastos, podemos leer lo siguiente: "No hace mucho me tropecé con una romería (me ha parecido digno de referir). Una vieja borracha llevaba a rastras a un viejo borracho" $(3.541-543)^{359}$. El escritor señala a continuación que la diosa a la que está dedicada la festividad que describe, Anna Perenna, tiene una atribución un tanto dudosa, y cuenta las diversas historias que pudieron dar origen a su veneración. En la primera versión (Ov. Fast. 3.545-655), Anna es la hermana de Dido, quien huye de Cartago tras la muerte de ésta. El barco en el que viaja naufraga en las costas de Italia y Anna se encuentra allí con un viejo conocido, Eneas, quien la acoge en su casa. Pero la esposa del héroe troyano, Lavinia, desconfía de Anna y quiere asesinarla, por lo que a ésta no le queda más remedio que huir en medio de la noche, y acaba cayendo al río Numicio, de cuyas aguas surge una voz que dice: "Soy la ninfa del apacible Numicio; oculta perennemente en el río me llamo Anna Perenna" (Ov. Fast. 3.654-655) ${ }^{360}$.

\footnotetext{
${ }^{358}$ Ecce anus in mediis residens annosa puellis sacra facit Tacitae (vix tamen ipsa tacet), et digitis tria tura tribus sub limine ponit, qua brevis occultum mus sibi fecit iter: tum cantata ligat cum fusco licia plumbo, et septem nigras versat in ore fabas, quodque pice adstrinxit, quod acu traiecit aena, obsutum maenae torret in igne caput; vina quoque instillat: vini quodcumque relictum est, aut ipsa aut comites, plus tamen ipsa, bibit. 'Hostiles linguas inimicaque vinximus ora' dicit discedens ebriaque exit anus.

${ }_{359}$ Occurrit nuper (visa est mihi digna relatu) pompa: senem potum pota trahebat anus.

360 'Placidi sum nympha Numici: amne perenne latens Anna Perenna vocor'.
} 
Además de la hermana de Dido, Anna Perenna también podría ser una personificación del ciclo de la luna, la novilla de Ínaco, u otra forma de llamar a Azánida, la ninfa nodriza de Júpiter. Finalmente, Ovidio narra otra historia que acontece durante el conflicto patricio-plebeyo (siglos V-III a.C.), concretamente durante la secessio del 494 a.C., y en la que Anna Perenna es identificada con una vetula:

"La plebe antigua, cuando aún no tenía la garantía de los tribunos, escapó y se instaló en la cima del Monte Sacro. Ya les faltaba también el alimento que habían llevado consigo y el trigo apropiado para las necesidades humanas. De las Bovillas, un arrabal de la ciudad, era originaria una tal Ana, una vieja pobre, pero de grandes recursos. Con el pelo canoso ceñido por una mitra de poco peso, aderezaba tortas rústicas con sus manos temblorosas, y de este modo, humeantes todavía, solía repartirlas entre el pueblo por la mañana. Tal abastecimiento resultaba grato a la gente. Cuando se hizo la paz en la cuidad, levantaron una estatua a Perenna por haberles ayudado cuando estuvieron necesitados" (Ov. Fast. 3.663-674) ${ }^{361}$.

No obstante, ésta no es la única aparición de la vetula Anna, ya que poco tiempo después de convertirse en divinidad es visitada por Marte:

"Gradivo se llegó a Anna y, llamándola aparte, tuvo con ella el siguiente coloquio: «Se te venera durante mi mes; he unido mi estación contigo; tengo grandes esperanzas en el servicio que puedes hacerme. Portador de armas como soy, me abraso absorto en el amor de Minerva, portadora de armas, y desde largo tiempo alimento esta herida. Haz que ella y yo, dioses de funciones parejas, podamos unirnos. Esta misión te cuadra bien a ti, amable vieja». Esto dijo. Ella engañó al dios con una promesa vana y con sospechosas tardanzas daba largas a su necia esperanza. Ante la insistencia del dios, le dijo: «He realizado tu encargo; ella ha sido conquistada y al fin ha respondido a tus ruegos». El enamorado lo creyó y preparó la alcoba. A ella acudió Anna, como la novia que iba a casarse, con la cara cubierta. Al ir a darle un beso, Marte vio de pronto a Anna: ya la verguienza de haber sido engañado, ya la rabia, le entró al dios. La nueva diosa se rió del enamorado de su querida Minerva, y ninguna otra cosa fue más agradable a Venus que ésta. A partir de entonces se cantan chanzas antiguas y palabras obscenas y

\footnotetext{
${ }^{361}$ Plebs vetus et nullis etiam nunc tuta tribunis fugit et in Sacri vertice Montis erat; iam quoque quem secum tulerant defecerat illos victus et humanis usibus apta Ceres. Orta suburbanis quaedam fuit Anna Bovillis, pauper, sed multae sedulitatis anus; illa, levi mitra canos incincta capillos, fingebat tremula rustica liba manu, atque ita per populum fumantia mane solebat dividere: haec populo copia grata fuit. Pace domi facta signum posuere Perennae, quod sibi defectis illa ferebat opem.
} 
produce regocijo que Anna hubiese engañado a un gran dios" (Ov. Fast. 3.675$695)^{362}$

La Anna anciana es tan inteligente que no sólo consigue distribuir la poca comida que queda en el Aventino de forma que todas las personas tengan su ración, sino que además es capaz de engañar a un dios, y no parece que lo haga solamente por ayudar a la diosa, sino también por puro divertimento. Vemos aquí como la vetula usa su inteligencia para engañar, un rasgo característico de las ancianas en la literatura.

En cuanto a la romería que describe Ovidio, se trata de la procesión que tenía lugar dentro de la festividad de Anna Perenna, la cual se celebraba el 15 de marzo (Ov. Fast. 3.145) -Marte ya señala en los Fastos que comparte mes con la vetula-, y cuyas características se resumen a continuación:

"El día de los Idus es el festival del genio de Ana Perenna, no lejos de tus riberas, Tíber, advenedizo. Se reúne la plebe, y echándose por doquier en la hierba verde, se pone a beber, y cada cual se recuesta con su pareja. Algunos aguantan a cielo raso; unos pocos ponen tiendas; otros levantan una chabola de hojas y ramas; otra parte, así que han levantado cañas a manera de rígidas columnas, colocan encima las togas extendidas. Sin embargo entran en calor con el sol y el vino, y se desean tantos años como copas toman, y beben contándolas. Allí podrás encontrar al que se bebe los años de Néstor y la que se convierte en la Sibila con las copas que se toma. Allí también cantan lo que aprenden en el teatro y baten hábilmente las palmas siguiendo la letra; colocan un cráter en el suelo y ejecutan duras danzas, y una muchacha ataviada baila con el pelo suelto. Cuando viene de vuelta, van haciendo eses y son el espectáculo de la gente, y los grupos con que se topan los llaman afortunados. No hace mucho me tropecé con una romería (me ha parecido digno de referir). Una vieja borracha llevaba a rastras a un viejo borracho. Pero cuál sea esta diosa, puesto que anda extraviada entre rumores, no es mi propósito que lo oculte mi narración" (Ov. Fast. 3.525-545) ${ }^{363}$.

\footnotetext{
362 venit Gradivus ad Annam, et cum seducta talia verba facit: 'mense meo coleris, iunxi mea tempora tecum; pendet ab officio spes mihi magna tuo. Armifer armiferae correptus amore Minervae uror, et hoc longo tempore volnus alo. Effice, di studio similes coeamus in unum: conveniunt partes hae tibi, comis anus.' dixerat; illa deum promisso ludit inani, et stultam dubia spem trahit usque mora. Saepius instanti 'mandata peregimus' inquit; 'evicta est: precibus vix dedit illa manus.' Credit amans thalamosque parat. Deducitur illuc Anna tegens voltus, ut nova nupta, suos. Oscula sumpturus subito Mars aspicit Annam: nunc pudor elusum, nunc subit ira, deum. Ridet amatorem carae nova diva Minervae, nec res hac Veneri gratior ulla fuit. Inde ioci veteres obscenaque dicta canuntur, et iuvat hanc magno verba dedisse deo.

${ }^{363}$ Idibus est Annae festum geniale Perennae non procul a ripis, advena Thybri, tuis. Plebs venit ac virides passim disiecta per herbas potat, et accumbit cum pare quisque sua. Sub Iove pars durat, pauci tentoria ponunt, sunt quibus e ramis frondea facta casa est; pars, ubi pro rigidis calamos statuere columnis, desuper extentas imposuere togas. Sole tamen vinoque calent annosque precantur quot sumant cyathos, ad numerumque bibunt. Invenies illic qui Nestoris ebibat annos, quae sit per calices facta Sibylla
} 
Se trata de una festividad de gran antigüedad según los expertos (Alton, 1920: 102 n. 1; Perea, 1998: 186), si bien la primera información escrita que tenemos data del siglo I a.C. y nos la proporciona Varrón (Sat. Men. 506). Sabino Perea (1998: 195-198) sugiere que el origen de las celebraciones es helenístico, aunque el nombre de la divinidad sería propiamente romano. Contamos con diversos materiales relativos al culto, los más antiguos del siglo III a.C., aunque cuando comienzan a abundar es en época altoimperial, localizados en una cueva siciliana donde se rendía culto a una divinidad de nombre Anna (Perea, 1998: 195). A comienzos del presente siglo, una excavación de urgencia en Roma sacó a la luz una estructura del siglo II d.C. dedicada a Anna Perenna que contaba con un altar y dos basas de mármol, además de una cisterna colmatada entre los siglos V y VI d.C. que contenía 549 monedas, 70 lucernas sin usar, figurillas, y restos orgánicos indicativos de la realización sacrificios y libaciones (Piranomonte, 2002 apud Eglehaaf-Gaiser, 2007: 212-213). Todas estas dataciones demuestran la longevidad del culto, al menos desde mediados del periodo republicano hasta época tardorromana. Varias inscripciones atestiguan también la devoción hacia la diosa ( $A E$ 1925, 82 y 2003, 253; CIL 6.2299 y 6.2301), como es el caso de un epígrafe realizado en el año 156 d.C. en Roma en el que Suetonio Germano y su esposa Licinia agradecen a Anna Perenna mediante la erección de un ara de mármol el haber atendido su petición (AE 2003,252).

Se trataría de un culto exclusivo de Italia, ya que no se encuentran vestigios del mismo en las provincias (Perea, 1998: 194), y plebeyo, lo que encaja con el hecho de que las mujeres representadas como ancianas borrachas en los textos literarios pertenezcan a las clases bajas. Parece que se trataba de una divinidad bastante popular, suficiente como para aparecer representada en un denario de Annius Luscus del 81 a.C. ${ }^{364}$, y cuyo festival generaba un revuelo y una acumulación de gente tan grande que se ha dicho que los asesinos de César lo habrían empleado como distracción para cometer el crimen (Perea, 1998: 206). Presenta además otros rasgos atribuidos a la vetula estereotipada, como la afición por el vino, la inteligencia mal empleada, la adivinación, o la obscenidad, tanto la expresada mediante el cuerpo como con el uso de

suos. Illic et cantant quicquid didicere theatris, et iactant faciles ad sua verba manus, et ducunt posito duras cratere choreas, cultaque diffusis saltat amica comis. Cum redeunt, titubant et sunt spectacula volgi, et fortunatos obvia turba vocat. Occurrit nuper (visa est mihi digna relatu) pompa: senem potum pota trahebat anus. Quae tamen haec dea sit quoniam rumoribus errat, fabula proposito nulla tegenda meo.

${ }^{364}$ Existe cierta controversia acerca de si la figura representada en el anverso del denario es o no Anna Perenna (Perea, 1998: 215-216). En todo caso, la imagen muestra a la Anna Perenna que cayó al río Numicio, y no a la vetula, y sería la deidad protectora de la gens Annia. 
la palabra. Algunos de estos rasgos (la torpeza, ser cotilla, la traición) también caracterizan en las fuentes a la hermana de Dido, aunque no sea una anciana. En Anna encontramos también atribuciones positivas. Es bondadosa, cuida de quienes están a su alrededor -en este caso, repartiendo el alimento-, y ayuda a otras mujeres a enfrentarse a los hombres, librando a Minerva de Marte.

Ernest Alton (1920) interpreta a la pareja de ancianos borrachos de Ovidio como las efigies de Anna Perenna y Mamurio Veturio, dios asociado a los Salios (Ov. Fast. $3.260)^{365}$. La unión de ambas divinidades tiene sentido no sólo porque se trata de ancianos, sino también porque Mamurio Veturio personificaba el final del año, mientras que Anna Perenna simbolizaría el comienzo del año nuevo, aunque también el ciclo vital en cuanto que agua del río que corre, la nocturnidad y la muerte en su caracterización como diosa de la luna; tampoco podemos olvidar en este sentido la percepción de la vejez como etapa final de la vida, antecesora de la muerte. Para Sabino Perea señala "Anna Perenna participa de los conceptos de vida y muerte, pero no de forma absoluta, ni formalmente estáticas, sino del movimiento en la vida y en la muerte, el «tránsito hacia »" (Perea, 1998: 191). Ovidio también refiere que "cada cual se recuesta con su pareja", lo que daría al festival connotaciones sexuales y báquicas, reforzadas por la relación que parece existir entre Anna Perenna y Liber (Perea, 1998: 203).

Dos días después de la festividad en honor a Anna, el 17 de marzo, se celebraban las Liberalia, de las cuales Varrón nos dice lo siguiente: "Denomínanse así las Liberalia porque ese día las viejas, al igual que las sacerdotisas de Liber, se sientan por toda la ciudad coronadas de hiedra haciendo ofrendas con pasteles (libum) a cuenta del comprador en un hornillo portátil” (Var. L 6.14) ${ }^{366}$. De nuevo nos aparecen vetulae repartiendo pasteles, asociadas además a la hiedra, planta de Baco, y al vino, si bien en este caso las mujeres no lo consumen directamente. Según Danuta Musial (2013), las Liberalia se celebraban dentro de la ciudad, al contrario de lo que ocurría con el festival de Anna Perenna; no obstante, se trata también de un culto relacionado con el ciclo vital, por lo que podríamos estar ante un origen común.

\footnotetext{
${ }^{365}$ Sobre Mamurio Veturio, vid. Alton, 1920 y Loicq, 1964.

${ }^{366}$ Liberalia dicta, quod per totum oppidum eo die sedent, ut sacerdotes Liberi, anus hedera coronatae cum libis in fóculo pro emptore sacrificantes.
} 
Nos encontramos, en resumen, con que el estereotipo de anus ebria estaba extendido en la sociedad romana. Las vetulae aficionadas al vino se documentan tanto en el arte como la sátira, el teatro y la religión, y son un recurso literario e iconográfico prácticamente atemporal, que ya parece existir en los primeros tiempos de la República y que seguirá presente en época medieval y moderna, llegando hasta la actualidad (Pollard, 2008).

El recurso a la borrachera nos es descrito como única forma de aliviar las penurias que conlleva una vejez pobre, aunque la estatuaria muestra cómo las vetulae cuyos ropajes señalan como mujeres pudientes también disfrutan del vino. Para Plinio el Viejo el vino ayudó a Livia a tener una larga vida; el que un moralista como él no se escandalice ante una mujer que consume alcohol de forma habitual nos permite suponer que la prohibición de beber vino que afectaba a las mujeres se relajó con el tiempo o era más un ideal moral que una realidad. Algunas de las interpretaciones que se han hecho de estas mujeres y de sus actitudes las relacionan, como hemos visto, con los rituales religiosos, pero también con la superstición y la magia. Es por ello que a continuación pasamos a analizar el estereotipo de la vetula como bruja.

\section{IV.3.2. La bruja}

Desde la Antigüedad hasta la actualidad, una de las identidades que se atribuye a la anciana es la de bruja; de hecho, tal y como indica Pilar Pedraza, "brujas y viejas son casi sinónimos en el habla popular" (Pedraza, 2001: 7). La idonedad de la vieja para cumplir con este papel viene dada por diversos factores. El primero de ellos está determinado por su identidad de género, ya que, en cuanto que mujer, la vetula era conocedora de todo tipo de plantas medicinales y remedios naturales, especialmente los venenos (Apul. Met. 9.29; Ov. Medic. 35-40) ${ }^{367}$. En este sentido, la referencia a las prácticas mágicas como eminentemente femeninas servía para resaltar la naturaleza descontrolada de la mujer, alertando de los peligros que entrañaba la libertad de actuación femenina (Corsi, 2006). El segundo factor está relacionado con las normas de edad, al considerar a las personas ancianas como especialmente sabias, como veremos más adelante en este mismo capítulo. En tercer lugar, en la antigua Roma la magia se presentaba como propia de las clases populares y las personas marginales, donde a menudo se sitúa a la vetula. Además, la vieja encaja en el tipo de personaje literario que

\footnotetext{
${ }^{367}$ Para un análisis en profundidad de la relación entre magia y mujer en la Antigüedad, vid. Stratton, 2007 y Stratton y Kalleres, 2014.
} 
en principio parece inofensivo -no es más que una anciana débil, encorvada y demente, de la que el héroe podría deshacerse fácilmente-, pero cuyos poderes, una vez son decubiertos al público, son capaces de desafiar las leyes naturales y sociales (Apul. Met. 6.26.8). Y, finalmente, contamos con la noche como factor. El ámbito de actuación de las magas en el imaginario romano era marginal, nocturno, asociado a la muerte, el miedo y la crueldad, en el que más que vivir se sobrevivía (Hidalgo, 2008: 34); un ambiente necrológico y de pobreza que ya hemos visto que estaba íntimamente relacionado con las personas ancianas, especialmente las vetulae.

El vocabulario latino contaba más de una decena de palabras para nombrar a una bruja $^{368}$. Sus actuaciones suelen calificarse de malignas, si bien en ocasiones sus poderes están encaminados hacia el bien. En el siglo IV d.C., Amiamo Marcelino ilustraba la crueldad de Festo, procónsul de Asia, mediante el siguiente episodio en el que una curandera es acusada de hacer magia:

"O a cierta anciana sencilla que solía curar unas fiebres intermitentes mediante un ritual inofensivo, ordenó que la ejecutaran, cuando había sido ella la que curó a su hija en una ocasión en que la llamaron con su propio consentimiento" (Amm. Marc. 29.2.26) ${ }^{369}$.

Si bien en Grecia existía la figura de la bruja joven y bella, con el paso a Roma la magia femenina adquirió un tinte grotesco (Stratton, 2007: 71; Wagner-Hasel, 2011: 12). La figura de la bruja vieja comenzó a tomar fuerza durante época tardorrepublicana y el principado de Augusto, lo que se ha interpretado como un intento masculino por contrarrestar la independencia que estaban adquiriendo algunas mujeres. De esta forma, los ataques a las brujas forman parte de un discurso

"about gender and social order that operates already in republican Rome but was amplified by Augustus as part of his moral and religious reforms following the civil wars. (...) I suggest that while Augustus was promoting domesticity and an idealized and politicized vision of female behavior as part of his imperial ideology, the image of the witch emerged as the antithesis. Her uncontrolled libido, masculine behavior, and independence signified chaos, a reversal of natural order, and social evils such as murders and infanticide. This witch thus functions as a fall foil for the symbol of imperial order, peace, and domestic harmony embodied in

\footnotetext{
${ }^{368}$ Por ejemplo: maga, cantatrix, conietrix, praecantatrix, saga, vates, hariola, lupula, strix, striga, lamia y malefica. No obstante, como indica Maxwell Paule (2017: 8), no parece haber una distinción de tipo funcional en el nombre que se escoja en cada ocasión. Para las diferentes funciones que cumplían las brujas romanas, vid. Dickie, 2001: 162.

${ }^{369}$ Anum quandam simplicem, intervallatis febribus mederi leni carmine consuetam, occidit ut noxiam, postquam filiam suam ipso conscio curavit accita.
} 
the chaste women of the imperial house, who were prominent icons of Augustus's civic renewal" (Sttraton, 2007: 97-99; vid. también Johnson, 2012: 11 y Spaeth, 2014: 54).

Es por ello que, como veremos, en muchas ocasiones las magas aparecen usando sus conocimientos para socavar el poder masculino y romper con el mos maiorum.

Una de las brujas romanas que más interés ha despertado en la historiografía y que además reúne todos los rasgos definitorios de la vieja hechicera es Canidia, protagonista de varios textos de Horacio. La historiografía se ha cuestionado si se trata de una mujer real -o varias mujeres reales-, o si es un personaje inventado por Horacio (Dickie, 2001: 179; Stratton, 2007: 83). Existen dudas incluso con el significado de su nombre, ya que mientras para algunos autores está relacionado con el perro, para otros tiene que ver con sus canas y sirve para subrayar su vejez (Corsi, 2006; Lillo, 2011: 152; Oliensis, 1991: 111). La primera teoría está respaldada por la relación que otra hechicera famosa, Hécate, tenía con los perros, así como con la posibilidad de que estos animales acompañasen a las brujas cuando realizaban sus incursiones nocturnas para protegerlas y avisar de la presencia de personas que pudieran pillarlas in fraganti. Por su parte, la segunda teoría se relaciona directamente con el estereotipo al que dedicamos este apartado, el de la vetula hechicera. Bien puede ser también que Horacio tuviera en mente ambos presupuestos cuando escogió el nombre de su personaje.

Al margen de estas cuestiones, lo que aquí nos interesa son sus poderes, tan grandes que ha conseguido hacer la vida imposible al poeta:

“«Ya, ya me rindo a tu ciencia poderosa, y suplicante te ruego por los reinos de Prosérpina, por los poderes intocables de Diana y por esos libros de ensalmos, capaces de apear los astros, desclavándolos del cielo, Canidia: cesa de una vez en tus invocaciones mágicas y suelta, suelta la peonza, dejándola que gire al otro aire. (...) Yo ya te he pagado con bastantes y sobradas penas a ti, a quien tanto quieren buhoneros y marinos: mi juventud se ha ido, y el color sonrosado ha dejado tras de sí unos huesos cubiertos de piel amarillenta; mi cabello lo han encanecido tus ungüentos, no hay descanso que calme mis fatigas. La noche acosa al día, el día a la noche, y no es posible aliviar la angustia de mi pecho jadeante. Así, pues, pobre de mí, me veo obligado a creer lo que he negado: que los ensalmos sabélicos aturden el alma y que con las cantinelas marsas estalla la cabeza. ¿Qué más quieres? (...) ¿Qué final o qué tributo me esperan todavía? Habla, que cumpliré fielmente los castigos que me impongas, presto a la expiación; tanto si me pides 
cien novillos, como si quieres que con mentirosa lira así te cante (...) líbrame a mí de la demencia; tú, que ni estás manchada por la deshonra de tus padres, ni eres una vieja ducha en esparcir cenizas de nueve días por los sepulcros de los pobres. Tienes un corazón hospitalario y manos puras; hijo de tu vientre es Pactumeyo, y lava la comadrona ropas enrojecidas por tu sangre cada vez que, llena de valor, saltas recién parida de tu lecho». «¿Por qué diriges ruegos a oídos que se cierran? No son más sordas para los desnudos marineros las peñas que en invierno Neptuno bate con sus hondas aguas. ¿Es que tú vas a quedarte sin castigo, (...) vas a quedar impune tras esparcir por toda la ciudad mi nombre? ¿De qué me aprovecharía el haber enriquecido a las viejas pelignas, y el haber compuesto el más rápido veneno? Pero a ti te esperan unos hados más lentos de lo que deseas: arrastrarás una vida ingrata, desdichado, para esto: para que siempre estés a merced de nuevos sufrimientos. (...) Unas veces querrás arrojarte desde lo alto de una torre, otras abrirte el pecho con una espada nórica, y en vano echarás lazos a tu cuello, abatido por el hastío y la tristeza. Entonces cabalgaré yo sobre tus hombros enemigos, y a mi altivez ha de ceder la tierra. ¿O es que yo, que puedo hacer que se muevan las imágenes de cera, según tú mismo sabes por curioso, y arrancar del cielo la luna con mis voces, y que puedo resucitar a muertos reducidos a cenizas, y preparar las copas del deseo, he de llorar el fracaso de mi arte, viendo que contra ti no puede nada?»" (Hor. Epod. 17) ${ }^{370}$.

Canidia es capaz de alterar el orden natural, tanto en lo que concierne al espacio mover la luna y las estrellas- como al tiempo -alterar la noción de día y noche y arrebatar la juventud a su víctima. Además, lleva a cabo prácticas de vudú y resurrecciones. Pero no sólo gobierna a los muertos, sino también a los vivos, pudiendo

\footnotetext{
370 Iam iam efficaci do manus scientiae, supplex et oro regna per Proserpinae, per et Dianae non movenda numina, per atque libros carminum valentium refixa caelo devocare sidera, Canidia: parce vocibus tandem sacris citumque retro solve, solve turbinem. (...) Dedi satis superque poenarum tibi, amata nautis multum et institoribus. Fugit iuventas et verecundus color reliquit ossa pelle amicta lurida, tuis capillus albus est odoribus, nullum a labore me reclinat otium; urget diem nox et dies noctem neque est levare tenta spiritu praecordia. Ergo negatum vincor ut credam miser, Sabella pectus increpare carmina caputque Marsa dissilire nenia. Quid amplius vis? (...) Quae finis aut quod me manet stipendium? Effare; iussas cum fide poenas luam, paratus expiare, seu poposceris centum iuvencos sive mendaci lyra voles sonare (...) solve me dementia, o nec paternis obsoleta sordibus neque in sepulcris pauperum prudens anus novendialis dissipare pulveres. Tibi hospitale pectus et purae manus tuosque venter Pactumeius et tuo cruore rubros obstetrix pannos lavit, utcumque fortis exsilis puerpera'. 'Quid obseratis auribus fundis preces? Non saxa nudis surdiora navitis Neptunus alto tundit hibernus salo. Inultus ut (...) Vrbem nomine inpleris meo? Quid proderat ditasse Paelignas anus velociusve miscuisse toxicum? Sed tardiora fata te votis manent: ingrata misero vita ducenda est in hoc, novis ut usque suppetas laboribus. (...) Voles modo altis desilire turribus, frustraque vincla gutturi innectes tuo modo ense pectus Norico recludere fastidiosa tristis aegrimonia. Vectabor umeris tunc ego inimicis eques meaeque terra cedet insolentiae. An quae movere cereas imagines, ut ipse nosti curiosus, et polo deripere lunam vocibus possim meis, possim crematos excitare mortuos desiderique temperare pocula, plorem artis in te nil agentis exitus?'
} 
provocar en ellos la locura, la lujuria, o el deseo de suicidarse. Altera el orden social, situando su poder por encima del vir; bajo su influencia, Horacio realiza todo tipo de acciones contrarias a su voluntad, de forma que Canidia no sólo supone un peligro para quien somete de forma individual, sino también para el orden cívico en su conjunto. Para ello emplea tanto ungüentos y venenos, lo que evidencia un amplio conocimiento de las propiedades de plantas y animales, como la invocación y el canto, acciones que, junto con la narración suponen como veremos más adelante una de las formas más referidas de subversión femenina del orden patriarcal.

La conversación entre hechicera y hechizado se produce después de que Horacio haya arremetido contra Canidia en tres ocasiones anteriores. En una de ellas alude a cómo emplea el veneno para sus fines (Hor. Sat. 2.1.45), mientras que en las otras dos aparece practicando la magia en compañía de otras brujas:

"Yo era antaño un tronco de higuera, inútil madero, cuando un artesano que no sabía si hacer un escaño o un Príapo prefirió que yo fuera un dios. Y un dios es lo que soy desde entonces, el mayor espanto de ladrones y pájaros; pues a los ladrones los tienen a raya mi diestra y la bermeja estaca que sale de mi indecente entrepierna; y a los pájaros inoportunos los ahuyentan las cañas hincadas en lo alto de mi testa, y les prohibe posarse en los jardines nuevos. Tiempo atrás, a los muertos arrojados de las angostas chozas un compañero de servidumbre los metía en un pobre cajón para traerlos aquí, aquí estaba la fosa común de la mísera plebe, para el bufón Pantólabo y para Nomentano, el perdulario. Les daba mil pies al frente y trescientos al fondo una lauda que aquí había, prohibiendo que el monumento pasara a un heredero. Ahora se puede vivir en unas Esquilas saneadas y pasear por su muro soleado, donde hace poco la gente veía con pena un campo que los huesos blanquecinos afeaban; aunque a mí los ladrones y las bestias que solían revolver por este sitio no me preocupan ni me inquietan tanto como esas mujeres que con ensalmos y pócimas trastornan las almas de los hombres. Con éstas no logro acabar de ningún modo, ni impedir que, tan pronto la vagante Luna su hermoso rostro exhibe, recojan huesos y hierbas dañinas. Yo he visto cómo iba Canidia, ceñida de negro manto, desnudos los pies y sueltos los pelos, aullando con la mayor de las Saganas. La palidez había dado a la una y a la otra un aspecto espantoso. Con sus uñas escarbaron en la tierra, y a mordiscos se pusieron a despedazar una cordera negra; la sangre la vertieron en la fosa, para hacer salir a las almas de los muertos que habían de dar respuesta a sus consultas. Había también una efigie de lana y otra hecha de cera. La de cera se mostraba suplicante, como a punto de perecer como perecen los esclavos. Invoca la una a Hécate, la otra 
a la sañuda Tisífone. Además, se podía ver errando por allí serpientes y perras infernales, y cómo la Luna, ruborizada, se escondía tras los grandes sepulcros, por no ser testigo de semejantes cosas. Y si en algo miento, que manchen mi cabeza de blancas mierdas los ciervos, y que vengan a mearme y a cagarme encima Julio y ese Pediacia, que es tan delicado, y también el ladrón de Vorano. ¿Para qué contar con todos los detalles cómo las sombras, dialogando con Sagana, resonaban con un tono siniestro y chirriante; cómo a escondidas ocultaron en tierra una barba de lobo, con un diente de culebra moteada; cómo de la imagen de cera surgió un fuego enorme, y cómo, cual testigo que no renuncia a la venganza, expresé mi horror por las voces y el proceder de aquellas furias? Y es que, con el mismo estruendo con que una vejiga revienta, solté un pedo que, al ser yo de higuera, me rajó el trasero. Corrieron ellas hacia la ciudad; y cómo a Canidia se le caían los dientes, a Sagana la alta peluca y las hierbas, y las mágicas ataduras de los brazos, es cosa que, de haberla visto, te hubiera provocado gran risa y jolgorio" (Hor. Sat. 1.8) ${ }^{371}$.

“«Pero -ipor cuántos dioses desde el cielo rigen la tierra y el linaje humano!-, ¿qué significa ese tumulto?; ¿y las miradas de todas, que en mí solo feroces se concentran? Te lo ruego por tus hijos, si es que Lucina, cuando la invocaste, te dio su ayuda en partos verdaderos; por este vano adorno de mi púrpura; por Júpiter, que no ha de aprobar esto: ¿por qué me miras como una madrastra o como una fiera atacada con la espada?». Una vez que con voz temblorosa profirió estas quejas, quieto se quedó el muchacho, despojado de atributos; impúber cuerpo, capaz de ablandar hasta los impíos corazones de los tracios. Canidia, con menudas

\footnotetext{
${ }^{371}$ Olim truncus eram ficulnus, inutile lignum, cum faber, incertus scamnum faceretne Priapum, maluit esse deum. Deus inde ego, furum aviumque maxima formido; nam fures dextra coercet obscaenoque ruber porrectus ab inguine palus, ast inportunas volucres in vertice harundo terret fixa vetatque novis considere in hortis. Huc prius angustis eiecta cadavera cellis conservus vili portanda locabat in arca; hoc miserae plebi stabat commune sepulcrum; Pantolabo scurrae Nomentanoque nepoti mille pedes in fronte, trecentos cippus in agrum hic dabat, heredes monumentum ne sequeretur. Nunc licet Esquiliis habitare salubribus atque aggere in aprico spatiari, quo modo tristes albis informem spectabant ossibus agrum, cum mihi non tantum furesque feraeque suetae hunc vexare locum curae sunt atque labori quantum carminibus quae versant atque venenis humanos animos: has nullo perdere possum nec prohibere modo, simul ac vaga luna decorum protulit os, quin ossa legant herbasque nocentis. Vidi egomet nigra succinctam vadere palla Canidiam pedibus nudis passoque capillo, cum Sagana maiore ululantem: pallor utrasque fecerat horrendas adspectu. scalpere terram unguibus et pullam divellere mordicus agnam coeperunt; cruor in fossam confusus, ut inde manis elicerent animas responsa daturas. Lanea et effigies erat altera cerea: maior lanea, quae poenis conpesceret inferiorem; cerea suppliciter stabat, servilibus ut quae iam peritura modis. Hecaten vocat altera, saevam altera Tisiphonen: serpentes atque videres infernas errare canes Lunamque rubentem, ne foret his testis, post magna latere sepulcra. Mentior at siquid, merdis caput inquiner albis corvorum atque in me veniat mictum atque cacatum ÄIulius et fragilis Pediatia furque Voranus. Singula quid memorem, quo pacto alterna loquentes umbrae cum Sagana resonarint triste et acutum utque lupi barbam variae cum dente colubrae abdiderint furtim terris et imagine cerea largior arserit ignis et ut non testis inultus horruerim voces furiarum et facta duarum? Nam, displosa sonat quantum vesica, pepedi diffissa nate ficus; at illae currere in urbem. Canidiae dentis, altum Saganae caliendrum excidere atque herbas atque incantata lacertis vincula cum magno risuque iocoque videres.
} 
víboras enredadas en los pelos de su cabeza despeinada, manda que cabrahígos arrancados de sepulcros, manda que fúnebres cipreses y huevos untados con sangre de asqueroso sapo, y una pluma de nocturno búho, y hierbas llegadas de Yolco y de la Hiberia, fértil en venenos, y huesos arrancados de la boca de una perra ayuna, sean quemados en las llamas de la Cólquide. Y Sagana, que, remangada, va aspergiendo toda la casa con aguas del Averno, tiene de punta sus ásperos cabellos, como el erizo de mar o el jabalí que escapa a la carrera. Sin que la echara atrás ningún escrúpulo, Veya cavaba la tierra con una dura azada, resollando de fatiga, para que el muchacho, allí enterrado, pudiera morirse viendo el espectáculo de la comida cambiada tres y cuatro veces en el largo día, asomando su cara, como asoman el mentón los cuerpos que flotan en el agua; y todo para que sirvieran de pócima amorosa su médula extirpada y su hígado reseco, una vez que sus pupilas se hubieran embotado, clavadas en el manjar prohibido. Que allí no faltaba Folia la de Arímino, la de las pasiones masculinas, lo creía la ociosa Nápoles y todas las ciudades circundantes; esa mujer que con la voz de sus hechizos tesalios arranca del cielo las estrellas y la luna. Entonces, mientras con su negro diente roía la uña de su pulgar, nunca cortada, ¿qué dijo o qué calló Canidia la sañuda? «iOh confidentes, y no infieles, de mis obras, Noche y tú, Diana, que en el silencio reinas cuando se hacen los arcanos ritos: ahora, asistidme ahora, y ahora vuestra ira y poder volvedlos contra las casas enemigas! Mientras se esconden las fieras en los bosques temerosos, de dulce sopor languideciendo, que las perras de la Subura -y que de ello todo el mundo ría- le ladren a ese viejo mujeriego, empapado en un perfume de nardo tal que uno mejor no lo han podido elaborar mis manos. ¿Qué ocurre? ¿Por qué tienen menos fuerza las siniestras pócimas de la bárbara Medea, con las que pudo escapar, no sin vengarse de la soberbia amante, hija del gran Creonte, cuando aquel manto, don impregnado de ponzoña, aniquiló a la recién casada con su fuego? Y eso que ni hierba ni raíz escondidas en ásperos lugares han burlado mis pesquisas: él duerme en lechos impregnados del olvido de todas mis rivales. ¡Ay, ay!, anda libre gracias al ensalmo de una hechicera más experta. No por la fuerza de pócimas sabidas, ;oh Varo, hombre destinado a tantos llantos!, has de acudir a mí de nuevo, ni a mí volverá tu pensamiento llamado por invocaciones marsas. Voy a preparar algo más grande, una poción más potente le voy a administrar a tus desdenes; y el cielo quedará debajo de los mares, y por encima se extenderá la tierra, si no ardes tú en mi amor, como arde el betún en negros fuegos». A esas alturas el muchacho ya no intentaba, como antes, aplacar a aquellas impías con palabras tiernas; sino que, tras dudar de por dónde rompería su silencio, las imprecó como lo haría Tiestes: «Las pócimas pueden trastocar algo tan 
grande como la justicia y la injusticia, mas no la ley de la venganza humana. Mis maldiciones os han de perseguir; y la maldición que pone a los dioses por testigos no hay sacrificio que la expíe. Más aún: una vez que, obligado a morir, haya expirado, me apareceré a vosotras cual nocturna pesadilla, y en las sombras me echaré a vuestras caras con curvadas uñas, que tal es el poder de los divinos manes; y acosando vuestros angustiados corazones, con el pavor os privaré del sueño. A vosotras la turba os aplastará tras perseguiros a pedradas, por aquí y por allá, de calle en calle, obscenas viejas; y luego descuartizarán vuestros miembros insepultos los lobos y las aves esquilmas; y mis padres, que -jay!- me van a sobrevivir, no se han de perder el espectáculo»" (Hor. Epod. 5$)^{372}$.

La identidad de las vetulae de estos textos viene marcada en su mismo nombre. Las compañeras de Canidia se llaman Sagana -de saga, bruja-, Veya -que comparte raíz con vetula- y Folia -que podría estar relacionado con follis, odre, y por lo tanto con el vino, pero también con folium, hoja en la que la Sibila escribía sus oráculos. La construcción que Horacio hace del tiempo -la noche- y del espacio sirve también para dotar de un halo de terror y marginalidad a la narración. El primero de los episodios mostrados tiene lugar en los jardines de Mecenas, ubicados en el Esquilino. Parte del

\footnotetext{
372 'At o deorum quidquid in caelo regit terras et humanum genus, quid iste fert tumultus aut quid ómnium voltus in unum me truces? Per liberos te, si vocata partubus Lucina veris adfuit, per hoc inane purpurae decus precor, per inprobaturum haec Iovem, quid ut noverca me intueris aut uti petita ferro belua?' Ut haec trementi questus ore constitit insignibus raptis puer, inpube corpus, quale posset inpia mollire Thracum pectora: Canidia, brevibus illigata viperis crinis et incomptum caput, iubet sepulcris caprificos erutas, iubet cupressos funebris et uncta turpis ova ranae Sanguine plumamque nocturnae strigis herbasque, quas Iolcos atque Hiberia mittit venenorum ferax, et ossa ab ore rapta ieiunae canis flammis aduri Colchicis. At expedita Sagana, per totam domum spargens Avernalis aquas, horret capillis ut marinus asperis echinus aut Laurens aper. Abacta nulla Veia conscientia ligonibus duris humum exhauriebat, ingemens laboribus, quo posset infossus puer longo die bis terque mutatae dapis inemori spectaculo, cum promineret ore, quantum exstant aqua suspensa mento corpora; exsucta uti medulla et aridum iecur amoris esset poculum, interminato cum semel fixae cibo intabuissent pupulae. Non defuisse masculae libidinis Ariminensem Foliam et otiosa credidit Neapolis et omne vicinum oppidum, quae sidera excantata voce Thessala lunamque caelo deripit. Hic inresectum saeva dente livido Canidia rodens pollicem quid dixit aut quid tacuit? 'O rebus meis non infideles arbitrae, Nox et Diana, quae silentium regis, arcana cum fiunt sacra, nunc, nunc adeste, nunc in hostilis domos iram atque numen vertite. Formidulosis cum latent silvis ferae dulci sopore languidae, senem, quod omnes rideant, adulterum latrent Suburanae canes nardo perunctum, quale non perfectius meae laborarint manus. Quid accidit? Cur dira barbarae minus venena Medeae valent, quibus Superbam fugit ulta paelicem, magni Creontis filiam, cum palla, tabo munus imbutum, novam incendio nuptam abstulit? Atqui nec herba nec latens in asperis radix fefellit me locis. Indormit unctis omnium cubilibus oblivione paelicum? A, a, solutus ambulat veneficae scientioris carmine. Non usitatis, Vare, potionibus, o multa fleturum caput, ad me recurres nec vocata mens tua Marsis redibit vocibus. Maius parabo, maius infundam tibi fastidienti poculum priusque caelum Sidet inferius mari tellure porrecta super quam non amore sic meo flagres uti bitumen atris ignibus'. Sub haec puer iam non, ut ante, mollibus lenire verbis inpias, sed dubius unde rumperet silentium, misit Thyesteas preces: 'venena maga non fas nefasque, non valent convertere humanam vicem. Diris agam vos: dira detestatio nulla expiatur victima. Quin, ubi perire iussus exspiravero, nocturnus occurram Furor petamque voltus umbra curvis unguibus, quae vis deorum est Manium, et inquietis adsidens praecordiis pavore somnos auferam. Vos turba vicatim hinc et hinc saxis petens contundet obscaenas anus; post insepulta membra different lupi et Esquilinae alites neque hoc parentes, heu mihi superstites, effugerit spectaculum'.
} 
programa de urbanismo de época augustea, los jardines se ubicaban sobre lo que había sido un cementerio para personas de escasos recursos y criminales; de ahí las alusiones que hace el dios Príapo, narrador y personaje del fragmento. Se trata, por lo tanto, de un espacio natural encajado dentro del tejido urbano, al mismo tiempo que un lugar en el que se difuminan los límites de lo vivo y lo muerto. Además, sería conocido por todos los habitantes de Roma en la época, de forma que el poeta consigue dar realidad a su narración (Jonhson, 2012: 12). En el segundo caso, nos encontramos con un niño enterrado hasta el cuello, y Horacio hace alusión a cadáveres y perras callejeras, referencia a Hécate y a la compañía a la que ya hemos aludido. Éstas también aparecen en la Sátira 8, junto a los ladrones.

Las acciones de las cuatro brujas son variadas y coinciden con otras muchas referencias literarias. Recogen huesos, hierbas y plumas con el fin de realizar sus pócimas y hechizos (Ov. Met. 7.269-294 y 10.382; Prop. 4.5). Emplean cánticos, hacen preguntas a los muertos, controlan la naturaleza y fabrican muñecos vudú (Amm. Marc. 29.2.26; Apul. Met. 1.8.4 y 1.9; Luc. Dial. Meret. 1; Ov. Met. 7.269; Petron. Sat. 134.12; Prop. 4.5; Tib. 1.5). No obstante, en ambos textos sus poderes se ven perturbados. En el primer caso por la reacción de Príapo, que provoca la huida de Canidia y Sagana; en el segundo porque existe una maga más poderosa que Canidia que bloquea los encantamientos que ella lanza sobre Varo. Además, es el poder masculino el encargado de restaurar el orden en las dos ocasiones, encarnado en el dios ictifálico y en el niño que promete venganza. Por otro lado, como señala Fernando Lillo,

"[la] visión satírica y burlesca de las brujas que observamos en Horacio sería del agrado de los destinatarios de sus poemas, la alta sociedad romana, que miraba con desdén a las hechiceras de poca monta. Agripa había expulsado a magos y astrólogos de Roma en el 33 a.C., algunos años después de la composición de estos poemas horacianos, y en el 16 a.C. volvió a producirse una expulsión similar. Horacio podría estar apoyando la política de Augusto consiguiendo que su público no tuviera miedo de las hechiceras al presentarlas de un modo satírico y burlesco ejecutando acciones que llenarían de horror a cualquiera" (Lillo, 2011: 151).

En cuanto su aspeto físico, sirve al igual que el resto de características para subrayar la marginalidad de las brujas: visten de negro, van descalzas, llevan el pelo suelto o alborotado, tienen las uñas sucias y descuidadas, y llevan postizos. Vemos en estos textos cómo el cuerpo en general, y el pelo en particular, se convierte en recurrente a la hora de mencionar a las brujas. Ello se debe, según Barbette Spaeth 
(2014: 45), a que diversas partes y deshechos corporales son parte esencial de las actividades de las brujas; además, como ya hemos visto en el Capítulo III, el cuerpo de las vetulae se convierte en hipersensible al emplearlo como recurso denigratorio, subrayando su cercanía con la muerte y el desagrado que contemplarlo provoca en el vir.

Una saga con poderes parecidos a los de Canidia es Dipsas, personaje de Ovidio. En este caso, destaca la capacidad de la vetula para someter la naturaleza:

"Hay una... (todo aquel que quiera conocer a una alcahueta, que preste oídos)... hay una vieja llamada Dipsas. De su modo de ser le viene el nombre. Ella nunca contempló, estando sobria, a la madre del negro Memnón sobre sus rosados caballos. Ella conoce las artes mágicas y los conjuros de Eea, y hace volver por medio de su arte las aguas corrientes a su manantial. Sabe bien cuál es la virtud de las hierbas, cuál la de las cintas movidas por la rueda sinuosa, cuál la del veneno de una yegua en celo. Con su sola voluntad, se aglomeran las nubes en toda la extensión del cielo; con su sola voluntad, brilla la luz en la límpida bóveda celeste. He visto, creedme, los astros centelleantes con el color de la sangre, y el rostro de la luna estaba purpúreo por la sangre. Tengo la sospecha de que, convertida en pájaro, revolotea a través de las sombras de la noche, y que su cuerpo de anciana se recubre de plumas. Tengo la sospecha y es lo que se dice. Además, la doble pupila de sus ojos despide rayos, y una luz centelleante surge de ambos globos oculares. Hace surgir de sus antiguas sepulturas a sus bisabuelos y tatarabuelos, y con prolongado ensalmo hiende el suelo compacto" (Ov. Am. 1.8) ${ }^{373}$.

Dipsas ha sido bautizada debido a su afición por la bebida. Comparte métodos con las brujas ya presentadas, entre ellos el de resucitar muertos. Además, tiene la capacidad de convertirse en un ave. Las brujas, al igual que ya hemos señalado para las vetulae en general, aparecen en la literatura estrechamente ligadas a lo animal. Perras, serpientes, y aves nocturnas aparecen como sus compañeras de aquelarre. Las brujas son animalizadas tanto en su aspecto físico, especialmente su cabello, como en sus acciones, ya que aúllan, escarban, y despedazan (Ov. Met. 7.259-300; Prop. 4.5). Pero Dipsas,

\footnotetext{
${ }^{373}$ Est quaedam -quicumque volet cognoscere lenam, audiat!- est quaedam nomine Dipsas anus. Ex re nomen habet -nigri non illa parentem Memnonis in roseis sobria vidit equis. Illa magas artes Aeaeaque carmina novit inque caput liquidas arte recurvat aquas; scit bene, quid gramen, quid torto concita rhombo licia, quid valeat virus amantis equae. Cum voluit, toto glomerantur nubila caelo; cum voluit, puro fulget in orbe dies. Sanguine, siqua fides, stillantia sidera vidi; purpureus Lunae sanguine vultus erat. Hanc ego nocturnas versam volitare per umbras suspicor et pluma corpus anile tegi. Suspicor, et fama est. Oculis quoque pupula dúplex fulminat, et gemino lumen ab orbe venit. Evocat antiquis proavos atavosque sepulcris et solidam longo carmine findit humum.
} 
además, es capaz de transformarse en un ave. Dipsas es una strix, una mujer maligna, un personaje del folklore greco-romano que puede convertirse en un búho o una lechuza para engatusar y devorar jóvenes hermosos, o bien robar cadáveres, con especial gusto por los de los niños (Apul. Met. 2.20.3, 2.22.2-4 y 2.30.2; Luc. Asin. 12; Petron. Sat. 6364). Estos ataques han dejado huella no sólo en la literatura, sino también en el registro epigráfico; en la primera mitad del siglo I d.C., el niño Iucundus fallecía tras el ataque nocturno de una cruel bruja (saga manus crudelis) (CIL 6.19747). Así describía Ovidio a las striges:

"Hay unos; pajaros voraces, no los que engañaban las fauces de Fineo con los manjares, pero tienen la descendencia de ellos. Tienen una cabeza grande, ojos fijos, picos aptos para la rapiña, las plumas blancas y anzuelos por uñas. Vuelan de noche y atacan a los niños, desamparados de nodriza, y maltratan sus cuerpos, que desgarran en la cuna. Dicen que desgarran con el pico las vísceras de quien todavía es lactante y tienen las fauces llenas de la sangre que beben. Su nombre es «vampiro» [strix]; pero la razón de este nombre es que acostumbra a graznar de noche en forma escalofriante. Así pues, tanto si estos pájaros nacen, como si los engendra el encantamiento y son viejas brujas que un maleficio marso transforma en pájaros, llegaron a meterse en la habitación de Proca. Éste, que había nacido en dicha habitación, era con sus cinco años de edad un botín fresco para los pájaros, que chuparon el pecho del niño con sus lenguas voraces; el desgraciado muchacho daba vagidos y pedía socorro. Asustada por la voz de su pupilo acudió corriendo la nodriza y halló sus mejillas arafiadas por las aceradas uñas. ¿Qué podía hacer? El color de su cara era el que suelen tener las hojas tardías a las que ha marchitado el recién llegado invierno. Fue en busca de Crane y le contó lo sucedido. Crane le dijo: «Abandona tu temor, tu pupilo se salvará». Se llegó a la cuna; el padre y la madre lloraban. Ella les dijo: «Contened vuestras 1ágrimas, yo lo voy a curar». Inmediatamente tocó tres veces consecutivas las jambas de la puerta con hojas de madroño; tres veces con hojas de madroño señaló el umbral. Salpicó con agua la entrada (el agua también era medicinal) y sostenía las entrañas crudas de una marrana de dos meses. Y dijo del siguente modo: «Pájaros nocturnos, respetad el cuerpo del niño; por un pequefio es sacrificada una víctima pequeña. Tomad, os lo ruego, corazón por corazón y entrañas por entrañas. Esta vida os entregamos por otra mejor». Cuando hubo sacrificado de esta manera, colocó al aire libre las entrafías partidas y prohibió a los que estaban presentes en la ceremonia volver la vista atrás. Colocó una vara de Jano, tomada de la espina blanca, donde una pequeña ventana diiba luz a la habitación. Cuentan que, con posterioridad a aquel 
rito, los pájaros no ultrajaron la cuna, y el niño recobró el color que antes tenía" (Ov. Fast. 6.130-168) ${ }^{374}$.

Para conseguir robar al niño o al muerto, las striges literarias suelen recurrir a paralizar o dormir a quienes pretender impedir su trabajo. Este tipo de episodios de parálisis nocturna han sido identificados por Barbette Spaeth (2010) como la versión antigua de lo que hoy en día se conoce como Night Hag Attack, o ataque nocturno de la bruja. Las características comunes de este tipo de experiencias son: despertarse en mitad del sueño, escuchar o ver algo que entra en la habitación y se acerca, sentir que te aprietan la garganta o te estrangulan, y la incapacidad para moverse y emitir sonidos. Para Barbette Spaeth, este tipo de episodios servían en la literatura romana para representar la antítesis de la mujer activa que ataca al hombre pasivo, incapaz de moverse: "The attack of the night hags drastically reduces the social status of their victims, making them unfit for their appropiate male roles, and hence lowering their social status and opening them to ridicule" (Spaeth, 2010: 255). Una referencia histórica que encontramos acerca de estos ataques nos la propociona Tácito. En el año 24 d.C., después de que Plaucio Silvano asesinase a Apronia, acusó a su anterior esposa, Numantina, "de haber causado con encantamientos y bebedizos la locura de su marido"

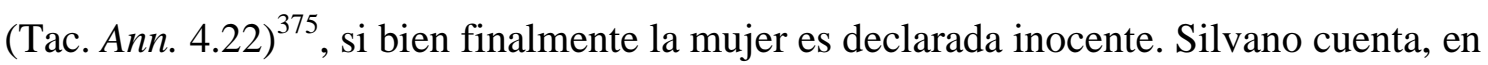
“términos incoherentes algo así como que él estaba profundamente dormido y por ello no se había dado cuenta, y que su esposa había buscado voluntariamente la muerte" (Tac. Ann. 4.22) ${ }^{376}$. Podríamos ver aquí la influencia de la magia de Numantina, que maneja a su exmarido dormido a su antojo, haciéndole asesinar a Apronia en medio de una pesadilla, o paralizándolo mientras insta a la mujer a suicidarse.

\footnotetext{
${ }^{374}$ Sunt avidae volucres, non quae Phineia mensis guttura fraudabant, sed genus inde trahunt: grande caput, stantes oculi, rostra apta rapinis; canities pennis, unguibus hamus inest; nocte volant puerosque petunt nutricis egentes, et vitiant cunis corpora rapta suis; carpere dicuntur lactentia viscera rostris, et plenum poto sanguine guttur habent. Est illis strigibus nomen; sed nominis huius causa quod horrenda stridere nocte solent. Sive igitur nascuntur aves, seu carmine fiunt neniaque in volucres Marsa figurat anus, in thalamos venere Procae: Proca natus in illis praeda recens avium quinque diebus erat, pectoraque exsorbent avidis infantia linguis; at puer infelix vagit opemque petit. Territa voce sui nutrix accurrit alumni, et rigido sectas invenit ungue genas. Quid faceret? Color oris erat qui frondibus olim esse solet seris, quas nova laesit hiems. Pervenit ad Cranaen, et rem docet. illa 'timorem pone: tuus sospes' dixit 'alumnus erit.' Venerat ad cunas; flebant materque paterque: 'sistite vos lacrimas, ipsa medebor' ait. Protinus arbutea postes ter in ordine tangit fronde, ter arbutea limina fronde notat, spargit aquis aditus (et aquae medicamen habebant) extaque de porca cruda bimenstre tenet, atque ita 'noctis aves, extis puerilibus' inquit 'parcite: pro parvo victima parva cadit. Cor pro corde, precor, pro fibris sumite fibras: hanc animam vobis pro meliore damus.' Sic ubi libavit, prosecta sub aethere ponit, quique adsint sacris respicere illa vetat: virgaque Ianalis de spina subditur alba, qua lumen thalamis parva fenestra dabat. Post illud nec aves cunas violasse feruntur, et rediit puero qui fuit ante color. 375 accusata iniecisse carminibus et veneficiis vaecordiam marito.

376 turbata mente respondit, tamquam ipse somno gravis atque eo ignarus, et uxor sponte mortem sumpsisset.
} 
La relación entre muerte, resurrección y brujería se aprecia también en Heliodoro, autor de época tardía ${ }^{377}$. En un momento dado de sus Etiópicas, los viajeros protagonistas se encuentran con los restos de una batalla. Entre los cadáveres de los soldados, una anciana busca a su hijo fallecido (Heliod. Aeth. 6.12.2-12.3). La vieja les promete que, cuando termine de velar el cadáver, los conducirá al pueblo. Los viajeros se van a dormir; una de ellos, Cariclea, se desvela y presencia cómo la vetula realiza actos mágicos:

"En efecto, la vieja, creyendo que nadie la molestaría y que podría actuar con tranquilidad porque nadie la observaba, cavó primero una hoya y luego prendió dos piras, en medio de las cuales colocó el cadáver de su hijo. Sacó a continuación de una trébede que había a su lado una copa de arcilla llena de miel y la vertió sobre la hoya; hizo luego otra libación con otra de leche y finalmente una tercera de vino. Después cogió un pastel de manteca que tenía forma de hombre y tras coronarlo con laurel e hinojo lo echó también en la hoya. Acto seguido, tomó una espada y entre convulsiones frenéticas, propias de un poseso, dirigió a la luna ciertos hechizos en lengua bárbara y extranjera, se hizo una incisión en el brazo, se enjugó la sangre con una rama de laurel y roció con ella la pira. Después de algunas otras prácticas, igualmente portentosas, se inclinó sobre el cadáver de su hijo, lo conjuró con ciertas fórmulas mágicas pronunciadas al oído, le despertó y le obligó con sus brujerías a ponerse de pie. Cariclea, que ni al principio había estado espiando sin temor, sintió entonces un estremecimiento de terror y, espantada ante tales prodigios extraordinarios, despertó a Calasiris, para que también él pudiera presenciar estos hechos. Como estaban en la oscuridad, no podían ser vistos, pero observaban con claridad lo que ocurría a la luz de la luna y de la pira; tampoco estaban lejos, de manera que podían oír lo que la vieja decía, pues ahora preguntaba en voz más alta al cadáver. Y lo que le preguntaba era si su hermano, el hijo que todavía le quedaba a ella, regresaría sano y salvo. Él no respondió nada, pero hizo una señal de asentimiento con la cabeza, que su madre podría interpretar de acuerdo con sus esperanzas; seguidamente, se desplomó tendido de bruces" (Heliod. Aeth. 6.14.2-7) $)^{378}$.

\footnotetext{
${ }^{377}$ Sobre de la magia en la novela de Heliodoro, vid. Hidalgo, 1988.

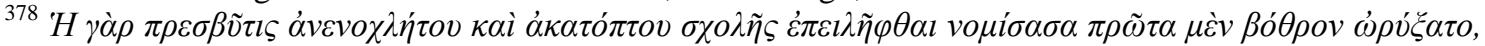

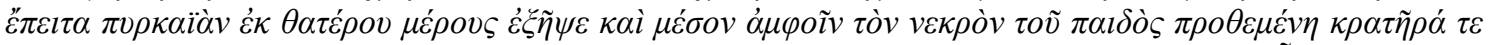

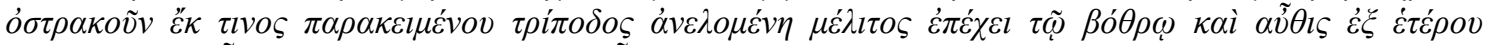

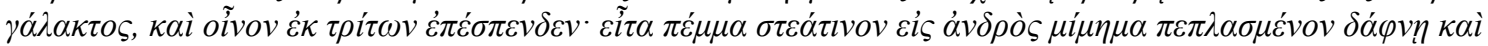

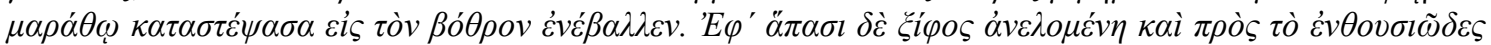

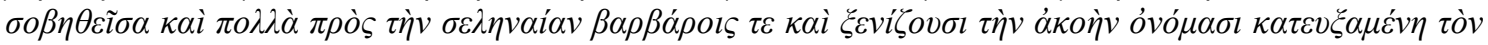

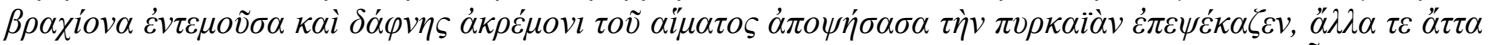

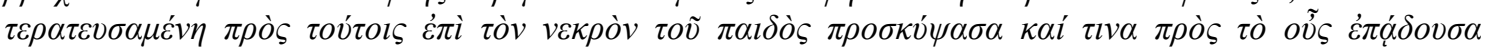


No contenta con la respuesta de su hijo, la bruja insiste y lo resucita de nuevo. El muerto entra en cólera y le dice a su madre que, si bien en un primer momento se ha sentido obligado a acudir a su llamada para cumplir con la pietas, la bruja está quebrantando demasiado las normas naturales al revivirlo de nuevo (Heliod. Aeth. 6.15.1-2). Entonces el hijo regresa al mundo de los muertos, no sin antes informar a la vetula de que la han estado observando. La bruja comienza a perseguir a los viajeros, pero acaba sufriendo un accidente: se clava una punta de lanza rota en la ingle y muere (Heliod. Aeth. 6.15.5). Como vemos, al igual que ocurría con los episodios de Canidia, la fuerza masculina, personificada en la lanza, es la encargada de poner fin a las andanzas de la bruja.

Las brujas romanas también son capaces de provocar o alejar el aojamiento, así como de realizar predicciones y desvelar todo tipo de secretos (Apul. Met. 1.11.2; Cic. Div. 1.65; Col. Rust. 1.8.6; Hor. Sat. 1.9.30-34; Ov. Met. 10.382; Pers. 2.30-34). Además, aparecen como expertas en magia amorosa:

"Después de dar unas vueltas, acababa de sentarme donde lo había hecho el día anterior, cuando se presentó Crisis arrastrando con ella a una viejecita. Cuando me hubo saludado, dijo: «¿Y qué, desabrido, te sientes ya más animado?». La vieja sacó de su seno una red tejida con hilos de varios colores y me la echó al cuello. Luego amasó con saliva un poco de polvo y, colocando la pasta en su dedo cordial, me marcó la frente a pesar de mi repugnancia. (...) Concluido este encantamiento, me mandó escupir tres veces y echarme tres veces al bolsillo unas piedrecitas previamente encantadas por ella y envueltas en púrpura; luego, palpándome, se puso a tantear mi vigor. Sin dar tiempo a decirlo, mis fuerzas obedecieron a la orden de mando, encontrándose la vieja con las manos llenas por mi enorme sobresalto. Ella entonces, saltando de alegría, dijo: «¿Lo ves, querida Crisis, ves cómo he levantado la liebre para que otros la cobren?»" (Petron. Sat. 131) ${ }^{379}$.

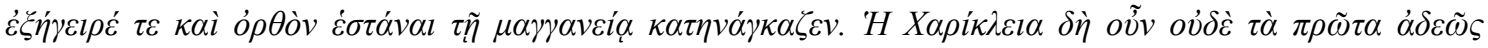

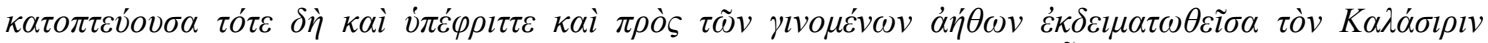

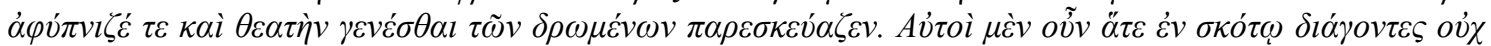

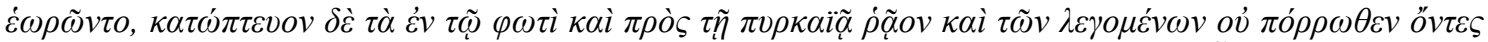

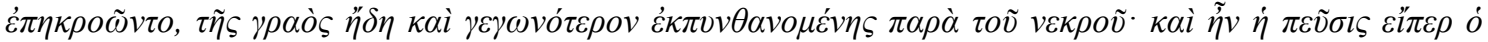

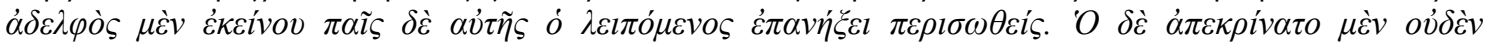

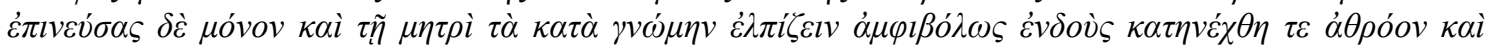

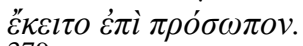

${ }^{379}$ Postero die, cum sine offensa corporis animique consurrexissem, in eundem platanona descendi, etiam si locum inauspicatum timebam, coepique inter arbores ducem itineris expectare Chrysidem. Nec diu spatiatus consederam, ubi hesterno die fueram, cum illa intervenit comitem aniculam trahens. Atque ut me consalutavit: "Quid est, inquit, fastose, ecquid bonam mentem habere coepisti?" Illa de sinu licium 
En un episodio que continúa a este, Petronio nos muestra a dos vetulae aficionadas al vino realizando rituales mágicos para que el protagonista de la historia recupere el vigor sexual (Petron. Sat. 133-138.4). Una de estas mujeres, Oenotea, sacerdotisa de Príapo, promete al joven que pondrá solución a sus problemas si pasa una noche con ella. Él acepta y la bruja comienza a realizar un ritual que se ve interrumpido cuando se le apagan las brasas que calentaban el caldero. Oenotea sale a por brasas y vuelve borracha. Aparece entonces Proseleno, la otra vetula, y los tres beben mientras continúan con el hechizo, el cual subvierte los roles de género al convertir a la vieja en sexualmente activa:

“Oenotea saca un falo de cuero y, después de frotarlo con una mezcla de aceite, pimienta molida y semilla de ortigas trituradas, me lo introduce suavemente por el ano. Luego, la despiadada vieja me unta una y otra vez las piernas con la misma sustancia. Mezcla un poco de jugo de mastuerzo con abrótano y, rociándome las partes, coge un puñado de ortigas verdes y se pone a golpearme suavemente todo el cuerpo hasta la altura del ombligo" (Petron. Sat. 138.1-2) ${ }^{380}$.

La víctima intenta escapar de las vetulae y de sus hechizos, poniendo fin al episodio de forma cómica, como ya hemos visto que hace Horacio con Canidia y Sagana: "Las dos viejecitas, aunque ebrias de vino y lujuria, intentan seguir mis pasos y corren tras de mí por algunas calles gritando: «iAl ladrón, detenedlo!». Logré escapar, sin embargo, pero con los pies todos ensangrentados en mi precipitada evasión" (Petron. Sat. 138.3-4) $)^{381}$. De nuevo, el hombre consigue salir airoso de la influencia mágica de la vetula.

Pero no sólo los hombres recurren a la magia amorosa. Apuleyo nos presenta a una mujer que emplea a una hechicera para solucionar sus problemas maritales:

"Mas ella, aparte de que era mala por naturaleza, profundamente resentida y exasperada además por semejante afrenta, por justa que ésta fuese, volvió a las andadas y se entregó, llena de frenesí, a los artificios habituales en las mujeres.

Buscó con todo cuidado y encontró una vieja taimada que, según creencia general,

prolulit varii coloris filis intortum, cervicemque vinxit meam. Mox turbatum sputo pulverem medio sustulit digito, frontemque repugnantis signavit (...) Hoc peracto carmine ter me iussit expuere terque lapillos conicere in sinum, quos ipsa praecantatos purpura involuerat, admotisque manibus temptare coepit inguinum vires. Dicto citius nervi paruerunt imperio, manusque aniculae ingenti motu repleverunt. At illa gaudio exultans: "Vides, inquit, Chrysis mea, vides, quod aliis leporem excitavi?".

${ }^{380}$ Profert Oenothea scorteum fascinum, quod ut oleo et minuto pipere atque urticae trito circumdedit semine, paulatim coepit inserere ano meo. Hoc crudelissima anus spargit subinde umore femina mea. Nasturcii sucum cum habrotono miscet, perfusisque inguinibus meis, viridis urticae fascem comprehendit, omniaque infra umbilicum coepit lenta manu caedere.

${ }^{381}$ Aniculae quamvis solutae mero ac libidine essent, eandem viam tentant et per aliquot vicos secutae fugientem "Prende furem!" clamant. Evasi tamen omnibus digitis inter praecipitem decursum cruentatis. 
podía conseguir todo lo que se propusiera mediante sortilegio y maleficios. Se asegura su cooperación a fuerza de súplicas y de cargarla de presentes. Luego le pide una de estas dos cosas, que aplaque a su marido y los reconcilie a ambos, o que, si no le es posible esto, suscite al menos contra él un espectro o alguna potencia infernal, que le quite la vida de una manera violenta. Entonces la hechicera, domeñadora incluso de las potencias divinas, ensaya, para comenzar, las armas más elementales de su arte criminal; se esfuerza, pues, en doblegar el ánimo gravemente ofendido del marido y en inducirlo hacia el amor. Como este intento no le saliera tal como había pensado, indignada contra las potencias divinas y aguijoneada, no sólo por la ganancia de la recompensa prometida, sino también por el desprecio a sus poderes mágicos, comienza ahora a maquinar amenazas contra la vida del desdichado marido y a instigar contra él, para causar su pérdida, la sombra de una mujer que ha perecido de muerte violenta" (Apul. Met. 9.29) ${ }^{382}$.

$\mathrm{Si}$ bien en ocasiones las brujas viejas emplean la magia para ayudar a otras mujeres, también la usan en beneficio propio, ya que las vetulae brujas, como hemos visto que ocurre con Canidia, son representadas como depredadoras sexuales. Como dominadora de la magia amorosa destaca Meroe, personaje de Apuleyo:

\begin{abstract}
"Reducido como estaba a una necesidad extrema, busco alojamiento en la posada de una tal Meroe, vieja pero aún de bastante buen ver, y le cuento los motivos de mi largo viaje, y las incidencias del angustioso regreso a mi hogar y del malhadado robo. La posadera me trató desde el primer momento con la mayor amabilidad que darse puede, me ofreció una cena grata y gratuita y después, excitada por el fuego del deseo, me llevó a su alcoba. Y, pobre de mí, en cuanto pasé una noche con ella, como consecuencia de aquel único encuentro, me inflamé de una pasión amorosa inextinguible y abyecta. Le di hasta las vestiduras mismas que los bandidos, en un arranque de generosidad, me habían dejado, para que cubriese mis desnudeces. Le entregaba incluso el pequeño salario que ganaba como mozo de cuerda, mientras
\end{abstract}

\footnotetext{
${ }^{382}$ At illa praeter genuinam nequitiam contumelia etiam, quamvis iusta, tamen altius commota atque exasperata ad armillum revertit et ad familiares feminarum artes accenditur magnaque cura requisitam veteratricem quandam feminam, quae devotionibus ac maleficiis quiduis efficere posse credebatur, multis exorat precibus multisque suffarcinat muneribus, alterum de duobus postulans, vel rursum mitigato conciliari marito vel, si id nequiverit, certe larva vel aliquo diro numine immisso violenter eius expugnari spiritum. Tunc saga illa et divini potens primis adhuc armis facinerosae disciplinae suae velitatur et vehementer offensum mariti flectere atque in amorem impellere conatur animum. Quae res cum ei sequius ac rata fuerat proveniret, indignata numinibus et praeter praemii destinatum compendium contemptione etiam stimulata ipsi iam miserrimi mariti incipit imminere capiti umbramque violenter peremptae mulieris ad exitium eius instigare.
} 
aún tenía vigor para ello. Hasta que esta buena prenda y mi mala fortuna me redujeron al lastimoso aspecto que hace poco has visto" (Apul. Met. 1.7.7) ${ }^{383}$.

Meroe, que al igual que Dipsas abusa del vino (Apul. Met. 1.10.3), consigue que el narrador, Sócratres, se enamore locamente de ella, a pesar de que es consciente de que actúa en contra de su voluntad. Cuando la víctima decide abandonar a la bruja, se encuentra con su amigo Aristomenes, quien se ofrece a ayudarle. Al llegar la noche, empiezan a oírse ruidos en la habitación que comparten Sócrates y Aristomedes:

"Mientras tanto, revolcado en el fangoso suelo y bajo la oportuna protección de mi camastro, miro de reojo en espera de saber de qué se trata, y veo a dos mujeres de edad bastante avanzada. Una de ellas llevaba una lámpara encendida, la otra una esponja y una espada desnuda. Equipadas de esta guisa rodearon a Sócrates, que dormía plácidamente. La que llevaba la espada comenzó a hablar así: «Hermana Pantia, aquí tienes a mi querido Endimión, éste es mi amado Ganímedes, el hombre que durante días y noches se ha burlado de una jovencita tan tierna como yo. Ahora, menospreciando mi amor, no sólo me difama con sus calumnias, sino que incluso se dispone a huir de mi lado. Mientras tanto yo, convertida sin duda en una nueva Calipso, abandonada por la astucia de este Ulises, lloraré mi eterna soledad»"(Apul. Met. 1.12) ${ }^{384}$.

A continuación Meroe y Pantia se vengan asesinando a Sócrates, sacándole el corazón y meando sobre Aristómenes, escondido bajo la cama.

En resumen, vemos cómo Canidia y el resto de vetulae brujas a las que hemos hecho referencia suscitan la ansiedad y el miedo del público, especialmente el de los varones. Ello se debe a que sus acciones pueden ser empleadas para hacer justicia y vengarse del poder masculino, sometiendo a los hombres y poniendo fin a su autonomía. La figura de la bruja anciana simboliza por lo tanto cómo la magia y la

\footnotetext{
${ }^{383}$ Et utpote ultime adfectus ad quandam cauponam Meroen, anum sed admodum scitulam, devorto, eique causas et peregrinationis diuturnae et domuitionis anxiae et spoliationis [diuturnae et dum] miserae refero; quae me nimis quam humane tractare adorta cenae gratae atque gratuitae ac mox urigine percita cubili suo adplicat. Et statim miser, ut cum illa adquievi, ab unico congressu annosam ac pestilentem con<suetudinem> contraho et ipsas etiam lacinias quas boni latrones contegendo mihi concesserant in eam contuli, operulas etiam quas adhuc vegetus saccariam faciens merebam, quoad me ad istam faciem quam paulo ante vidisti bona uxor et mala fortuna perduxit.

${ }^{384}$ Ac dum in fimum deiectus obliquo aspectu quid rei sit grabatuli sollertia munitus opperior, video mulieres duas altioris aetatis; lucernam lucidam gerebat una, spongiam et nudum gladium altera. Hoc habitu Socratem bene quietum circumstetere. Infit illa cum gladio: "Hic est, soror Panthia, carus Endymion, hic Catamitus meus, qui diebus ac noctibus inlusit aetatulam meam, hic qui meis amoribus subterhabitis non solum me diffamat probris verum etiam fugam instruit. At ego scilicet Ulixi astu deserta vice Calypsonis aeternam solitudinem flebo".
} 
sabiduría femenina en general -como veremos más adelante- sirvieron en la antigua Roma como medio de transmisión de saberes femeninos alternativos a los del varón.

\section{IV.3.3. La lena}

Las lenae son aquellas mujeres viejas que se dedican a prostituir a mujeres jóvenes. La mayoría de las veces ellas también fueron prostitutas en su juventud, y llegada la vejez se dedican a guardar las puertas de los prostíbulos y a restringir el acceso de los hombres. En muchas ocasiones, la lena aparece caracterizada como bruja, anus ebria, o ambas al mismo tiempo. Ocurre así con la ya conocida Dipsas (Ov. Am. 1.8), Filenis, a quien Marcial recuerda una vez muerta (9.29), y con Acántide, lena de quien Propercio habla así:

"Que la tierra, alcahueta, cubra tu sepulcro de abrojos y que tu sombra, cosa que tú no deseas, sienta sed, no descansen tus Manes en sus cenizas y Cerbero, vengador, aterrorice tus huesos repugnantes oon ladridos de hambre. Experta en ablandar incluso a Hipólito reacio a Venus y ave siempre siniestra para el tálamo bien avenido, a Penélope incluso, sin hacer caso de las habladurías sobre su marido, obligaría a casarse con el rijoso Antínoo. Si ella quisiera, el imán no atraería al hierro y el ave se convertiría en madrastra en su propio nido. Más todavía: si acercara a una tumba hierbas de Colina, el firme se diluiría en agua corriente. Se ha atrevido a imponer condiciones a la luna hechizada y a disfrazar sus espaldas de nocturno lobo; para conseguir cegar a los maridos recelosos de engaño, arrancó con sus uñas los inocentes ojos de las cornejas; ha consultado a vampiros sobre mi muerte y contra mí ha recogido el flujo de una yegua preñada. Acompañaba su obra con ensalmos, igual que una gota vaga suave hasta horadar con su constancia un camino de rocas. (...) Mientras Acántide pervierte así el alma de mi enamorada, por mi fina piel llego a untar mis huesos. Pero acepta, oh reina Venus, la garganta de esta paloma torcaz sacrificada ante tus altares por tus beneficios. Yo vi que su rugoso cuello se hinchaba con la tos y pasar sangrientos esputos entre sus dientes cariados, y exhalar su alma podrida en las esteras paternas: la curvada choza se estremeció ante el frío del hogar. Sean su mortaja los lazos hurtados para recoger sus cuatro pelos, un gorro descolorido por la mugre del lugar, una perra, demasiado alerta para nuestro pesar, cuando yo tenía que burlar los cerrojos con mi pulgar. Sea la tumba de la alcahueta un ánfora vieja de cuello roto: tu fuerza, cabrahígo, la 
oprima desde arriba. ¡Quienes estéis enamorados, tirad afiladas piedras sobre esta tumba y a las piedras añadid maldiciones!" (Prop. 4.5) ${ }^{385}$.

La lena aparece como experta en magia erótico-amorosa debido a los conocimientos que habría ido adquiriendo con su profesión. Santiago Montero (1999: 337-338) y Matthew Dickie (2001: 164-165) se muestran convencidos de que muchas de las hechiceras serían también lenae, ya que la mayoría del dinero que les pagarían sus clientes por las pociones/conjuros los emplearían en sufragar el coste del ritual y por ello necesitarían más ingresos para poder sobrevivir en la pobreza, con el vino como consuelo. Una vieja hechicera a la que hace referencia Luciano (Dial. Meret. 4), experta en magia amorosa, cobra una dracma y un pan, además de lo necesario para llevar a cabo sus pociones, lo que junto a su afición al vino resalta su pobreza.

Para otras lenae, en cambio, el precio a pagar por burlar su vigilancia es el vino. Ya hemos hecho referencia a Leona, personaje de Plauto que debe su nombre tanto a su oficio como a la fiereza con la que cuida de las jóvenes a su cargo, quien abandona su puesto para satisfacer su alcoholismo (Plaut Curc. 96-140). En ella vemos cómo se recurre a la animalización para, al igual que hemos mostrado con otros ejemplos, resaltar su falta de humanidad. En este caso, la animalización se aprecia también en el ansia con que la vetula se abalanza sobre el vino. Los jóvenes que comparten escena con ella parecen actuar como quien lanza un trozo de carne a un perro guardián para distraerlo y poder entrar a robar en una propiedad; la falta de racionalidad de Leona hace que sólo piense en satisfacer su sed, y no en las consecuencias de ayudar al amante a reunirse con la joven.

\footnotetext{
${ }^{385}$ Terra tuum spinis obducat, lena, sepulcrum, et tua, quod non uis, sentiat umbra sitim; nec sedeant cineri Manes, et Cerberus ultor turpia ieiuno terreat ossa sono! Docta uel Hippolytum Veneri mollire negantem, concordique toro pessima semper auis, Penelopen quoque neglecto rumore mariti nubere lasciuo cogeret Antinoo. Illa uelit, poterit magnes non ducere ferrum, et uolucris nidis esse nouerca suis. Quippe et, Collinas ad fossam mouerit herbas, stantia currenti diluerentur aqua: audax cantatae leges imponere lunae et sua nocturno fallere terga lupo, posset ut intentos astu caecare maritos, cornicum immeritas eruit ungue genas; consuluitque striges nostro de sanguine, et in me hippomanes fetae semina legit equae. Exorabat opus uerbis, ceu blanda perure saxosamque ferat sedula culpa uiam (...) Sed (cape torquatae, Venus o regina, columbae ob meritum ante tuos guttura secta focos) his animum nostrae dum uersat Acanthis amicae, per tenuem ossa sunt numerata cutem. Uidi ego rugoso tussim concrescere collo, sputaque per dentis ire cruenta cauos, atque animam in tegetes putrem exspirare paternas: horruit algenti pergula curua foco. Exsequiae fuerint rari furtiua capilli uincula et immundo pallida mitra situ, et canis, in nostros nimis experrecta dolores, cum fallenda meo pollice clatra forent. Sit tumulus lenae curto uetus amphora collo: urgeat hunc supra uis, caprifice, tua. Quisquis amas, scabris hoc bustum caedite saxis, mixtaque cum saxis addite uerba mala!
} 
En las fuentes literarias las lenae a menudo aparecen como pobres, solitarias e iletradas (Apul. Met. 9.15; Luc. Dial. Meret. 3 y 6; Lucil. 9.256-258; Plaut. Asin. 140160 y 800). Salustio cuenta cómo algunas de estas mujeres acompañaron en el siglo I a.C. a Catilina en su golpe de estado:

"Se dice que por aquella época atrajo a sí a muchísimos hombres de todo tipo, y a algunas mujeres también, que primero habían sobrellevado enormes gastos con el comercio sexual y que luego, cuando la edad había puesto límite a las ganancias sólo, y no a sus despilfarros, habían contraído grandes deudas. Catilina confiaba en que por medio de ellas podría soliviantar a los esclavos de la ciudad, incendiar a ésta y unir a él o asesinar a sus maridos" (Sall. Cat. 24.3-4) ${ }^{386}$.

La pobreza, junto a la astucia que se les atribuye a estas mujeres en cuanto que ancianas, hace que algunos hombres incautos caigan en sus engaños:

"No hacía más que ir y venir sobre mis propios pasos hasta que, harto de correr y bañado de sudor, me dirijo a cierta anciana que vendía legumbres silvestres y le pregunto: «Por favor, abuela, ¿sabrías acaso decirme dónde está mi casa?». Le hizo gracia el chiste tan insulso, y me contestó: «¿Cómo no lo voy a saber?». Se puso de pie y echó a andar adelantándoseme. La tomé por una adivina y... Al poco rato, cuando habíamos llegado a un barrio bastante apartado, la amable vieja retiró la cortina de una puerta y dijo: «Esta debe ser tu morada». Yo protestaba que no reconocía la casa, cuando veo a ciertos individuos paseándose misteriosamente entre dos hileras de letreros y de prostitutas desnudas. Tarde, demasiado tarde ya, comprendí que se me había llevado a un burdel. Maldiciendo, pues, la emboscada que me había tendido la vieja, me cubro la cabeza y echo a correr por el centro del lupanar hasta la salida de enfrente En el mismo umbral de la puerta me cruzo con Ascilto, tan extenuado y moribundo como yo: se diría que lo había llevado allí la misma vieja. Después de saludarlo amablemente, le pregunté qué hacía en un sitio tan poco recomendable. Llevándose las manos a la cabeza para secarse el sudor, dice: «iSi supieras lo que me ha ocurrido!». «QQué pasa?», pregunto. Y él, desfallecido, contesta: «Como andaba desorientado por toda la ciudad, sin saber dónde estaba mi paradero, se me acercó un buen padre de familia que se ofreció muy cortesmente para acompañarme. Luego, por unos callejones tortuosos y muy oscuros, me trajo a este lugar y, con el dinero en la mano, me hizo una propuesta

\footnotetext{
${ }^{386}$ Ea tempestate plurumos cuiusque generis homines adscivisse sibi dicitur, mulieres etiam aliquot, quae primo ingentis sumptus stupro corporis toleraverant, post, ubi aetas tantummodo quaestui neque luxuriae modum fecerat, aes alienum grande conflaverant. Per eas se Catilina credebat posse servitia urbana sollicitare, urbem incendere, viros earum vel adiungere sibi vel interficere.
} 
deshonrosa. La alcahueta ya había cobrado un as como precio de la habitación»" (Petron. Sat. 6-8) ${ }^{387}$.

Las lenae son avariciosas y malvadas. Continuamente imaginan formas de engañar a los hombres que alquilan a las prostitutas que están a su cargo (Plaut. Asin. 150-185 y 205-210). Así, Cleéreta reprende a Filenis porque ésta se ha enamorado de un cliente y el negocio se resiente:

CLEÉRETA - (Saliendo de su casa con la hija.) Pero bueno, ¿es que no va a ser posible que me obedezcas cuando te prohíbo algo? ¿Es que estás dispuesta a hacer caso omiso de la autoridad de tu madre?

FILENIS - Pero, ¿cómo me iba a ser posible guardar mis sentimientos de fidelidad, si quisiera complacerte conduciéndome en la forma que tú me mandas?

CL. — ¿Es que está acaso bonito el hacer la contra a lo que yo te mando?

FI. — ¿Pero qué es lo que pasa?

CL. - ¿Eso se llama guardar los sentimientos de fidelidad, el menoscabar la autoridad materna?

FI. - Yo ni condeno a las que obran bien ni apruebo a las que se portan mal.

CL. - Anda, que estás hecha una enamorada con muy buen pico.

FI. - Madre, así es mi oficio: la lengua pide, el cuerpo desea, el corazón habla, los hechos te dan la pauta.

CL. - Yo quería corregirte y tú te pones ahora a hacerme reproches.

FI. - Por Dios, madre, yo ni te hago reproches ni pienso que me sería lícito el hacerlo; sólo que me lamento de mi suerte al verme separada de aquel a quien amo. CL. - ¿Me va a ser posible coger yo también la palabra en todo el santo día?

FI. - Habla tú, por ti y por mí; tú eres la que das la pauta para hablar y para callar; pero si suelto yo el remo y me dedico a no hacer nada en cubierta, no funciona nada en tu casa.

\footnotetext{
${ }^{387}$ Itaque quocumque ieram, eodem revertabar, donec et cursu fatigatus et sudore iam madens accedo aniculam quandam, quae agreste holus vendebat et: "Rogo, inquam, mater, numquid scis ubi ego habitem?" Delectata est illa urbanitate tam stulta et: "Quidni sciam?" inquit, consurrexitque et coepit me praecedere. Divinam ego putabam et subinde ut in locum secretiorem venimus, centonem anus urbana reiecit et: "Hic, inquit, debes habitare." Cum ego negarem me agnoscere domum, video quosdam inter titulos nudasque meretrices furtim spatiantes. Tarde, immo iam sero intellexi me in fornicem esse deductum. Execratus itaque aniculae insidias operui caput et per medium lupanar fugere coepi in alteram partem, cum ecce in ipso aditu occurrit mihi aeque lassus ac moriens Ascyltos: putares ab eadem anicula esse deductum. Itaque ut ridens eum consalutavi, quid in loco tam deformi faceret quaesivi. Sudorem ille manibus detersit et: "Si scires, inquit, quae mihi acciderunt. — Quid novi?" inquam ego. At ille deficiens: "Cum errarem, inquit, per totam civitatem nec invenirem quo loco stabulum reliquissem, accessit ad me pater familiae et ducem se itineris humanissime promisit. Per anfractus deinde obscurissimos egressus in hunc locum me perduxit, prolatoque peculis coepit rogare stuprum. Iam pro cella meretrix assem exegerat.
} 
CL. - ¿Qué es lo que dices, descarada, más que descarada? ¿Cuántas veces te he prohibido dirigir la palabra a Argiripo el de Deméneto, hacerle carantoñas, charlar con él, ni siquiera mirarle? A ver, ¿qué es lo que nos ha dado, qué los regalos que nos ha mandado? ¿Es que acaso piensas que las palabras zalameras son oro y las cosas bien dichas sustituyen a las dádivas? Tú eres la primera en quererle, la primera en buscarle, la primera en hacerle venir. De los que te dan, te burlas; los que se burlan de ti, por esos te mueres. ¿O es que te parece bien estar esperando, si alguno te promete que te hará rica, cuando se vaya su madre al otro barrio? ¡Por Dios!, que corremos nosotras y toda nuestra casa el gran peligro de morirnos de hambre mientras estamos esperando la muerte de la otra. Yo te digo, que si no me trae aquí las veinte minas dichas, que te juro que se le pondrá de patitas en la calle, a ése, que no sabe dar otra cosa más que lloriqueos. Este es el último día en el que acepto la excusa de que no tiene.

FI. - Madre, si me privas de la comida, me aguantaré.

CL. - Yo no te prohíbo amar a los que pagan para ser amados.

FI. - Pero madre, mi corazón lo tiene ya otro. ¿Qué voy a hacer? Dime.

CL. - Toma, mira mis canas, si es que quieres obrar en interés propio.

FI. - También el pastor que guarda ovejas a sueldo, madre, tiene alguna propia, con la que se consuela, déjame amar sólo a Argiripo, tal como el corazón me lo pide, él es mi elegido.

CL. - Anda y vete dentro, por Dios, no he visto cosa más descarada que tú.

FI. - Como quieras, madre, tu hija está hecha a obedecerte. (Entran en casa.) (Plaut. Asin. 505-540) ${ }^{388}$.

\footnotetext{
${ }^{388}$ CLEARETA Nequeon ego ted interdictis facere mansuetem meis? An ita tu es animata, ut qui matris expers imperio sies? PHILAENIVM Vbi piem Pietatem, si istoc more moratam tibi postulem placere, mater, mihi quo pacto praecipis? CLEAR. An decorum est adversari meis te praeceptis? PHIL. Quid est? CLEAR. Hocine est pietatem colere, matris imperium minuere? PHIL. Neque quae recte faciunt culpo neque quae delinquont amo. CLEAR. Satis dicacula es amatrix. PHIL. Mater, is quaestus mihi est: lingua poscit, corpus quaerit; animus orat, res monet. CLEAR. Ego te volui castigare, tu mi accusatrix ades. PHIL. Neque edepol te accuso neque id me facere fas existimo. Verum ego meas queror fortunas, cum illo quem amo prohibeor. CLEAR. Ecqua pars orationis de die dabitur mihi? PHIL. Et meam partem loquendi et tuam trado tibi; ad loquendum atque ad tacendum tute habeas portisculum. Quin pol si reposivi remum, sola ego in casteria ubi quiesco, omnis familiae causa consistit tibi. CLEAR. Quid ais tu, quam ego unam vidi mulierem audacissimam? Quotiens te votui Argyrippum filium Demaeneti compellare aut contrectare, conloquive aut contui? Quid dedit? Quid ad nos iussit deportari? An tu tibi verba blanda esse aurum rere, dicta docta pro datis? Ultro amas, ultro expetessis, ultro ad te accersi iubes. Illos qui dant, eos derides; qui deludunt, deperis. An te id exspectare oportet, si quis promittat tibi te facturum divitem, si moriatur mater sua? Ecastor nobis periclum magnum et familiae portenditur, dum eius exspectamus mortem, ne nos moriamur fame. Nunc adeo nisi mi huc argenti adfert viginti minas, ne ille ecastor hinc trudetur largus lacrumarum foras. Hic dies summust quo est apud me inopiae excusatio. PHIL. Patiar, si cibo carere me iubes, mater mea. CLEAR. Non voto ted amare qui dant quoia amentur gratia. PHIL. Quid si hic animus occupatust, mater, quid faciam? Mone. C. Em, meum caput contemples, si quidem ex re consultas tua. PHIL. Etiam opilio qui pascit, mater, alienas ovis, aliquam habet peculiarem, qui spem soletur suam. Sine me amare unum Argyrippum animi causa, quem volo.
} 
Cleéreta y Filenis son madre e hija. Al igual que ocurría con Theodora, y con Sira y Selenio (Plaut. Cist. 49), la situación económica familiar ha conducido a las hijas a la prostitución, siguiendo el oficio de la madre. Esta escena cómica, pensada por Plauto para que los espectadores masculinos imaginasen a una Cleéreta malvada, cuya avaricia la conduce a obstaculizar los deseos del amante, tiene también tintes trágicos, ya que nos acerca a la cruda situación que vivirían muchas vetulae romanas, empobrecidas y dependiendo del dinero que ganasen sus familiares.

\section{IV.3.4. La contadora de historias}

Abordamos a continuación el estereotipo de la contadora de historias o transmisora de sabiduría. A diferencia de las imágenes ya presentadas acerca de la vejez femenina, nos enfrentamos ahora a una visión eminentemente positiva de las ancianas romanas, una que las presenta como mujeres sabias y dignas de confianza; si bien también veremos cómo estas mujeres pueden convertirse en un peligro que amenaza la estructura patriarcal romana.

Una de las formas en las que se manifiesta en la literatura la sabiduría de las vetulae es el fenómeno de las aniles fabulae. En el libro cuarto de El asno de oro de Apuleyo, Lucio se encuentra sirviendo a unos bandidos que han raptado a una muchacha. La tienen retenida en la cueva que emplean como guarida, y la han dejado al cuidado de una vetula, la cual vive permanentemente atemorizada por la violencia a la que puedan someterla los bandidos y encuentra consuelo a su penosa vida en el vino:

"Los bandidos se colaron en su guarida a gastas, uno a uno, encogiendo sus miembros, después de dejarnos atados con una fuerte correa justamente delante de la puerta. Había allí una vieja, encorvada bajo el peso de sus muchos años, que parecía ser la única encargada de velar por el bienestar y el sustento de aquel grupo tan numeroso de jóvenes. Éstos la increpaban groseramente de esta manera: «¿Acaso tú, decrépito cadáver escapado de la pira funeraria, deshonra la más grande de los vivos, único ser a quien no admite el Orco en sus entrañas, vas a estar siempre divirtiéndote a costa nuestra, sentada ociosa en casa, sin ofrecernos siquiera, a hora tan avanzada, algo con que repongamos fuerzas y nos consolemos de tan penosos y arriesgados trabajos? Lo único que sabes hacer día y noche es anegar ávidamente en vino puro tu estómago rabioso e insaciable». Al oírlo, la vieja, temblorosa y llena de miedo, contestó con una vocecilla chillona de este

CLEAR. Intro abi, nam te quidem edepol nihil est impudentius. PHIL. Audientem dicto, mater, produxisti filiam. 
modo: «¡Oh, jóvenes valerosísimos y fidelísimos protectores míos, tenéis copiosamente servidas y a punto todas vuestras viandas, perfectamente cocinadas y de exquisito sabor; tenéis también pan abundante, vino escanciado generosamente en bien bruñidas copas y, como de costumbre, está ya preparada el agua caliente, para que os bañéis cuando queráis!». Al acabar la vieja estas palabras, los ladrones se desvisten al instante y, después de reanimar sus cuerpos desnudos al calor de una gran hoguera, se bañan en agua caliente, se friccionan con aceite y se recuestan ante las mesas copiosamente cargadas de manjares" (Apul. Met. 4.7) ${ }^{389}$.

La muchacha raptada se encuentra desesperada por su circunstancia y no para de llorar. La anciana, que parece vivir en una situación de maltrato constante -recordemos ahora los restos óseos presentados en el capítulo anterior en los que se apreciaba el sufrimiento de reiterados episodios violentos- y no puede liberarla por miedo a las represalias de los bandidos, pero se compadece de ella, decide distraerla contándole “alegres relatos y cuentos de viejas" (Apul. Met. 4.27.8) ${ }^{390}$.

La historia que Apuleyo desgrana a continuación a través de la vetula es la de Psique y Cupido, la cual constituye el mejor ejemplo conservado de esos cuentos de viejas o aniles fabulae, narraciones caracterizadas por su transmisión oral y por contar episodios ficticios, situados en espacios fantásticos o grotescos (Scobie, 1979: 251) ${ }^{391}$. Dentro de las aniles fabulae, las cuales deben su nombre a que suelen ser narradas por ancianas, contamos con temáticas tan dispares como episodios protagonizados por personajes míticos, fantasía, fábulas, o historias de fantasmas y seres dañinos. En la literatura romana, la narración de estas historias se sitúa en dos espacios diferentes: por un lado, reuniones de mujeres para tejer o trabajar, y por el otro entornos infantiles donde estas historias servirían como cuentos para dormir o entretener a los niños. De hecho, se ha sugerido que Apuleyo pudo haber aprendido la historia de Psique y Cupido

\footnotetext{
389 Ibi cum singuli derepissent stipatis artubus, nobis ante ipsas fores loro ualido destinatis anum quamdam curuatam graui senio, cui soli salus atque tutela tot numero iuиenum commissa uidebatur, sic infesti compellant: "Etiamne tu, busti cadauer extremum et vitae dedecus primum et Orci fastidium solum, sic nobis otiosa domi residens lusitabis nec nostris tan magnis tamque periculosis laboribus solacium detam sera refectione tribues? Quae diebus ac noctibus nil quicquam rei quam merum sauienti uentri tuo soles auiditer ingurgitare". Tremens ad haec et stridenti uocula pauida sic anus: "At uobis, fortissimi fidelissimique mei sospitatores iuuenes, adfatim cuncta suaui sapore percocta pulmenta praesto sunt, panis numerosus uinum probe calicibus ecfricatis affluenter immissum et ex more calida tumultuario lauacro uestro praeparata". In fine sermonis huius statim sese deuestiunt nudatique et flammae largissimae uapore recreati calidaque perfusi et oleo peruncti mensas dapibus largiter instructas accumbunt.

${ }^{390}$ narrationibus lepidis anilibusque fabulis.

${ }^{391}$ Diversas formas de nombrar este tipo de narrativa oral son anilibus fabulis (Apul. Met. 4.27.8; Quint. Inst. 1.8.19), neniis anilibus (SHA Clod. 12.12), fabellas aniles (Cic. Nat. D. 3.12), anilibus argumentis (Sen. Ben. 1.4.6) y nutricum cunas sapientiae (Macrob. In. Somn. 1.2.8).
} 
en su Madaura natal, y podría ser incluso que se la contase su abuela, nutrix, u otra mujer madura o anciana de su entorno (Plantade y Plantade, 2014: 174) ${ }^{392}$.

Los escritores de la Antigüedad, tanto paganos como cristianos, despreciaban las aniles fabulae al considerarlas cuentos propios de iletrados y cercanos a la superstición, ya que desde su punto de vista carecían de objetivo instructor y solamente pretendían entretener; un entretenimiento basado además en el engaño, al narrarse situaciones irreales (Auson. Protrept. ad nep. 2.69; Hor. Sat. 2.6.76-77; Pablo 1 Tim. 4:7; Pers. 2.30-34; Philostr. Her. 7; Quint. Inst. 1.8.19; Sen. Ben. 1.4.5-6; SHA Clod. 12.12). Arnobio se expresaba así con respecto a las historias populares procedentes de la tradición pagana: "Cuando leéis historias tales, pregunto, ¿no os parece oír a las jóvenes tejedoras que tratan de hacer pasar el tiempo del tedioso trabajo, o a las viejas añosas que tratan de distraer a los crédulos niños y cuentan cualquier fábula bajo apariencia de verdad?" (Arn. Adv. Nat. 5.14) ${ }^{393}$.

Por otro lado, si bien encontramos autores favorables a su uso, expresan una necesidad de selección; así, para Platón (R. 2.377a-378d) es necesario que se controle qué historias cuentan las madres y las ayas, para determinar cuáles son adecuadas para su instrucción moral y cuáles no lo son.

La marginalidad de estas historias se debía también a otros factores. Por un lado, su carácter oral, y por lo tanto popular, convirtiendo a la persona narradora en autora y reinventora de la historia, ya que podría modificarla o darle los matices que considerase oportunos en cada momento, añadiendo detalles o suprimiendo otros que no fueran de su gusto, lo que al mismo tiempo daría lugar a distintas versiones del mismo cuento. Por otro lado, el carácter femenino de las aniles fabulae, ya que la narradora era una mujer, en ocasiones la audiencia también era femenina, y se daba en espacios de socialización de mujeres, como las reuniones para tejer, durante las cuales eran frecuentes los cuentos, las canciones o la simple charla (Ov. Met. 4.36-41 y $\operatorname{Tr}$. 4.1.13-14; Prop. 3.6.15-18 у 4.3.41-42; Tib. 2.1.63-66; Verg. Aen. 7.10-14 у G. 1.291-294 у 4.333-349; Heath, 2011: 70; Scobie, 1979: 251). Finalmente, el tercer factor es el rol social de los sujetos participantes, tanto quien narra la historia como el público, todos ellos considerados inferiores al vir. Como narradoras, las vetulae eran mujeres y además

\footnotetext{
${ }^{392}$ Para las distintas teorías sobre el origen de la historia de Psique, vid. Hidalgo, 1986: 104 y ss.

${ }^{393}$ Cum historias, quaeso, perlegitis tales, nonne vobis videmini aut textriculas puellas audire taedosi operis circumscribentes moras aut infantibus credulis avocamenta quaeritantes anus longaevas et varias fictiones sub imagine veritatis expromere?
} 
viejas, y eran consideradas, tanto por los autores de la época (Cic. Nat. D. 3.12; Hor. Sat. 1.9.30-34) como por parte de la historiografía (Graverini, 2006: 93; Reeves, 1999), como personas iletradas y guiadas por la superstición, la cual se relaciona con el uso de la magia ${ }^{394}$ :

"Mira cómo una abuela o una tía materna llena de supersticiones levanta de su cuna a un niño y con el dedo infame y saliva lustral empieza por purificarle la frente y los húmedos labios, pues es experta en conjuros contra el aojamiento" (Pers. 2.30$34)^{395}$

Filóstrato, al considerar la valía de los mitos y las fábulas y describir las segundas como historias insustanciales y sin credibilidad, las define como "ranas, asnos y charlatanerías aptos para que los devoren viejas y niños" (Philostr. V. A. 5.14.1) ${ }^{396}$. De la misma forma, cuando la vieja nutrix de Filinion acude a sus amos para contarles que su hija, que había fallecido, se aparece en forma de fantasma para acostarse con el joven al que han acogido en su casa, la toman por loca debido a la fama que tienen las ancianas de inventarse historias y de creer en fenómenos sobrenaturales (Phl. Mir. 1). La vetula no recobra la credibilidad hasta que Filinion se aparece ante sus progenitores.

El puesto de las vetulae podían ocuparlo también los circulatores o cuentacuentos ambulantes, hombres de baja extracción social (Booth, 1980; Escámez, 2015: 180-181; Scobie, 1979: 233-234). Por su parte, como público, tanto los bebés y los niños como las mujeres eran considerados seres mentalmente inferiores al varón romano.

Las aniles fabulae tenían en la antigua Roma una funcionalidad cuádruple: entretener, asustar/prevenir, ayudar a dormir y enseñar. Como historias para entretener, ya fuera narradas o cantadas, servían para acompañar labores femeninas cotidianas y divertir a los miembros más jóvenes de la familia. En el caso del episodio de Metamorfosis, la vetula pretende calmar a la joven con sus palabras y hacerle olvidar la pesadilla soñada ${ }^{397}$. El cuidado infantil se refleja también en la función de las aniles fabulae como cuentos que ayudan a dormir. Para Macrobio, el lugar de este tipo de

\footnotetext{
${ }^{394}$ En contra, vid. Scobie, 1979: 232, para quien los habitantes del imperio romano, incluidas las vetulae, tendrían en general un alto grado de alfabetización. No obstante, este mismo autor señala que es de esperar que hubiera más personas iletradas en el ámbito rural, precisamente donde las aniles fabulae tendrían para él mayor influencia. La especial relevancia de los cuentos en el ámbito rural la señala también Cristina Segura (2014: 222).

${ }^{395}$ Ecce auia aut metuens diuum matertera cunis exemit puerum frontemque atque uda labella infami digito et lustralibus ante saliuis expiat, urentis oculos inhibere perita.

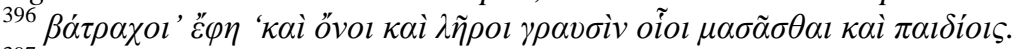

${ }^{397}$ Para el simbolismo de la historia de Psique y Cupido dentro de la novela de Apuleyo, vid. Hidalgo, 1985, 1986: 101 y ss. y 2014.
} 
historias no es otro que "nutricum cunas" (Macrob. In. Somn. 1.2.8), las cunas de las nodrizas. Por su parte, Filóstrato escribe lo siguiente en referencia a la historia de Teseo y Ariadna: "Seguro que se lo habrás oído contar a tu nodriza, pues las nodrizas son sabias en este tipo de historias y pueden incluso llorar mientras las cuentan, si así lo desean" (Philostr. Imag. 1.15) 398 . La importancia que en los individuos ya adultos podía jugar el haber tenido este tipo de experiencias se aprecia, por ejemplo, en el caso de Augusto, quien según Suetonio (Aug. 78) gustaba de estas historias siendo adulto y recurría a ellas para combatir el insomnio. Al ser un medio temprano de socialización, las historias con connotaciones terroríficas servían también para que la audiencia aprendiese ciertos comportamientos y evitase otros muchos, so pena de consecuencias desagradables.

Finalmente, las aniles fabulae contenían una fuerte carga didáctica; no en vano, sabemos que los cuentos infantiles no son algo inocuo, sino un medio de socialización mediante la reproducción de relatos estereotipados mediante los que la audiencia adquiere valores y conceptos sociales básicos, al tiempo que interioriza modelos de comportamiento y aprende cómo enfrentarse a diversas situaciones (Ros, 2016: 10). Así, las mujeres que narraban estas historias a quienes estaban a su cargo contribuían a crear su universo simbólico a través de animalizaciones, personajes y situaciones con las que pudieran identificarse y sentimientos básicos como el miedo o el amor (Ros, 2016: 129; Segura Graíño, 2014; Warner, 1999: 314). En este sentido, las aniles fabulae "partecipano della dimensione della oralità; funzionali al mondo della prima infanzia, sono rivolte ad un uditorio non scolarizzato, non ancora inserito nel processo di alfabetizzazione" (Pugliarello, 2002: 48).

Las aniles fabulae son por otro lado una muestra del papel que las vetulae jugaban en la crianza de los miembros más jóvenes de la familia, una tarea analizada en este mismo capítulo: "La nodriza pequeña, seca y vieja enseña a los pequeñines” (Lucil. Fr. $955)^{399}$. Estas mujeres que se encargaban del cuidado y de la socialización en la infancia, y que por lo tanto tenían una gran influencia en el carácter y el comportamiento de los niños, podían sin embargo convertirse en figuras peligrosas al suponer una fuente de sabiduría/autoridad distinta de la del paterfamilias (Joshel, 1986: 11). Así, para Luca Graverini, el desprecio que los autores clásicos muestran hacia historias del tipo aniles fabulae se deben a que las vetulae

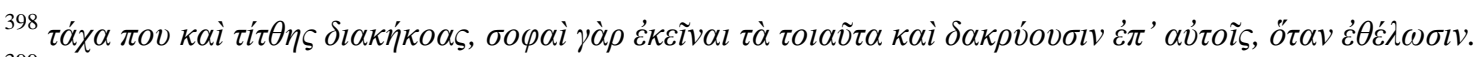
399 Nutricula sicca vetusta infantibus monstrat.
} 
"played a major role in the formation of young men before their schooling. To establish authority in the face of this female formation, male pedagogues $(\ldots)$ had to eradicate thinking that had been inculcated in children through old wives' tales before their formal education began" (Graverini, 2006: 96).

Si nos centramos en el otro de los escenarios que hemos presentado como propicio para la narración de aniles fabulae, como ocurría en el caso de la escena descrita por Apuleyo, se trata de espacios de trabajo y socialización de mujeres en los que frecuentemente tiene protagonismo el tejer, tarea femenina por excelencia y metáfora del contar historias (Ov. Met. 4.50-54 y 4.275). En ocasiones ambas labores se mezclan; ocurre así en la historia de Procne y Filomela (Ov. Met. 6.415-465), donde la hermana mutilada transmite lo sucedido plasmándolo en un tejido.

Las ancianas aparecen en los textos como avezadas en tejer (Juv. 6.495-500; Ov. Met. 6.25-45; Tib. 1.6.65-85). Lo hacen mientras cuidan de mujeres jóvenes, o para pasar el tiempo, en ocasiones tedioso por las cargas físicas y económicas que comportaba la vejez, por lo que este tipo de escenas formarían parte del día a día de las romanas de todas las edades:

"Tú consérvate casta, por favor, y guardiana de tu sagrado pudor siéntese a tu lado una vieja siempre solícita. Que te cuente ella anécdotas fabulosas y, con la lámpara en medio, saque interminables hilos del abultado copo de la rueca; pero a su costado, atenta la joven a la dura tarea, poco a poco, fatigada de sueño, deje caer la labor" (Tib. 1.3.85-90) ${ }^{400}$.

Vemos entonces que las aniles fabulae cumplen con las características del storytelling femenino, popularmente conocido como cotilleo, "a way of talking between women in their roles as women, intimate in style, personal and domestic in topic and setting, a female cultural event which springs from and perpetuates the restrictions of the female role, but also gives the comfort of validation" (Jones, 1980: 194). Este tipo de narraciones femeninas se caracterizan por ocupar un espacio privado asociado a lo femenino y acontecer dentro del tiempo destinado por las mujeres al trabajo y al ocio. Sus participantes son mujeres, ya sea en intimidad o acompañadas por quienes dependen de ellas (niñas y niños, personas dependientes o enfermas). El tema principal

\footnotetext{
${ }^{400}$ At tu casta precor maneas, sanctique pudoris adsideat custos sedula semper anus. Haec tibi fabellas referat positaque lucerna deducat plena stamina longa colu, at circa gravibus pensis adfixa puella paulatim somno fessa remittat opus.
} 
suele ser de carácter femenino, normalmente basado en experiencias propias, y es narrado de forma alusiva, empleando conocimientos y valores comunes a todas las participantes, acompañando el lenguaje verbal con mensajes gestuales. Deborah Jones (1980: 197) y Jennifer Coates (2013: 11) identifican este tipo de narrativas con una forma de subcultura femenina que permite perpetuar los valores de una comunidad, de crear la propia identidad y de señalar a quienes se salen de la norma.

A diferencia de lo que ocurre con las historias que se narran en contextos masculinos, en ocasiones en las historias entre mujeres no ocurre nada, pero se relata de forma implícita lo que sí podría haber ocurrido, demostrando lo peligroso que es el mundo. A veces son historias sin final feliz y carecen de un personaje heroico, al contrario de las narraciones masculinas, que giran en torno al triunfo tras haber superado algún obstáculo. Cuando aparece un personaje heroico, suele ser una mujer que demuestra su capacidad de acción, que toma el control e invierte el orden natural de las cosas (Coates, 2013: 14-17). Además, muchas veces estas historias sirven para expresar quejas hacia el comportamiento de los hombres, así como para hacer confesiones personales sobre asuntos que no pueden abordarse en otros espacios.

Las vetulae se constituyen en narradoras perfectas para historias del tipo anilis fabula, ya que las características que les atribuía la sociedad romana por mujeres y ancianas se ajustan a la concepción de las aniles fabulae como narraciones triviales e insustanciales. En cuanto que ancianas, comparten con los senes el gusto por rememorar tiempos pasados y contar historias antiguas a cualquier persona interesada en escucharlas, especialmente si se trata de un público infantil (Macrob. Sat. 7.2.14; Tib. 1.10.45 y 3.5.15). Además poseen la charlatanería y el carácter chismoso asociado a la mujer, las ganas de hablar por hablar empleando muchas palabras para decir muy poco, con discursos caracterizados por la rapidez y la emoción (Krusckwitz, 2012: 223 y ss.). Se trata de un estereotipo de discurso femenino muy presente en la literatura romana (Apul. Met. 9.17.3; Juv. 6.435-455; Plaut. Aul. 123-126, Cist. 149 y Trin. 800; Val. Max. 7.2), de forma que las vetulae en ocasiones no hablan sino que graznan, aúllan, croan... expresándose no como los seres humanos sino como los animales (Apul. Met. 4.7; Mart. 3.93) y mostrando su falta de decoro y saber estar (Laglands, 2000: 176). Por otro lado, las ancianas eran presentadas en Roma como mujeres aficionadas a las supersticiones y la magia, faltas de cultura y dispuestas al engaño (Apul. Met. 1.11.2 y 9.22.1; Hor. Sat. 1.9.30-34; Pers. 2.30-34; Petron. Sat. 6.4-8.3). Aulo Gelio (NA 12.1.17) sugiere también que las cuidadoras tenían afición por la bebida, completando 
así la imagen de vetula repulsiva y señalando lo poco que podía confiarse en estas mujeres para la crianza ${ }^{401}$.

Esta caracterización de la vetula coincide así con la descripción que Dolores Juliano hace de la expresión femenina desde el punto de vista patriarcal:

"Hablar del saber de las mujeres, de los saberes de las mujeres y de su transmisión, es un desafío en la medida en que la experiencia femenina se conceptualiza normalmente como un no saber, es decir, lo que las mujeres saben y se transmiten por vías no académicas, por el contacto cotidiano, se considera no especializado, se considera no significativo $\mathrm{y}$, normalmente, se asigna no al campo del conocimiento, sino al campo de la naturaleza" (Juliano, 2005: 15).

No obstante, si bien el estereotipo de vetula repulsiva condensa todos los rasgos negativos que los romanos veían en lo femenino, nos encontramos con que también es representada como una persona sabia. Una sabiduría que se relacionaba con la experiencia vivida y que en la literatura aparece como característica de la vejez (Cic. Sen. 2.5 y 7.21; Plaut. Bacch. 690; Sen. Ep. 68.14). Escribe Cicerón que

"Por eso se dice que tienen olfato las ancianas, porque saben, según creen ellas, muchas cosas, y por eso se dice que los perros tienen olfato. Por tanto, se dice que 'presagia' el que es capaz de 'oler' una cosa antes de producirse, esto es, el que presiente el futuro" (Cic. Div. 1.65) ${ }^{402}$.

Es por ello que no seguir el consejo dado por una anciana podía traer funestas consecuencias, como le ocurre a Aracne, quien niega que su habilidad en el tejer provenga de su maestra Minerva, por lo que ésta decide castigarla:

"Palas finge ser una vieja y añade a sus sienes falsas canas y unos débiles miembros que afianza con un bastón. Luego comienza a hablar así: «No todo lo que la edad avanzada trae consigo se ha de evitar; de los años tardíos procede la experiencia. No desdeñes mis consejos: busca la máxima gloria en el arte de la lana, pero sólo entre los mortales. Cede ante una diosa y pídele perdón suplicante por tus atrevidas palabras; si se lo pides, te perdonará». Ella la mira torvamente, abandona los hilos ya empezados, y sin apenas contener sus manos, con la ira reflejada en su semblante, replicó a la irreconocible Palas con tales palabras: «Tu

\footnotetext{
${ }^{401}$ Para Teresa Molinos (2005: 78), esta idea proviene de la creencia de que el vino fomentaba la producción de leche (Sor. Gyn. 2.19), por lo que las nutrices tendrían cierta "licencia" para tomarlo. Puede que esa libertad las llevase a convertirse en consumidoras habituales cuando ya no amamantaban, actitud socialmente reprobable.

${ }_{402}$ Sagire enim sentire acute est; ex quo sagae anus, quia multa scire volunt, et sagaces dicti canes. Is igitur qui ante sagit quam oblata res est, dicitur praesagire, id est futura ante sentire.
} 
entendimiento flaquea, llegas agotada por una vejez y te hace daño haber vivido tanto. Que te escuchen esos consejos tuyos tus nueras o tus hijas, si es que las tienes. A mí me basta con mi propia sensatez; y para que no creas que has conseguido algo con tus recomendaciones, persisto en la misma resolución. ¿Por qué no viene ella en persona? ¿Por qué evita esta contienda?». «iHa venido!», dijo la diosa, y dejando su figura de vieja se mostró como Palas" (Ov. Met. 6.25-45) ${ }^{403}$.

Aracne se atreve a ignorar las sugerencias que le hace la anciana y entonces ésta decide retarla a una competición de hilado; la joven gana y Minerva, ofendida, la convierte en araña como castigo.

Las vetulae conocen lugares que ya no existen y acontecimientos pasados (Ov. Fast. 6.399; Var. L. 7.28), pero también están relacionadas con la magia y son capaces de saber hechos que aún no han acontecido o secretos que no les han contado (Apul. Met. 1.11.2; Hor. Sat. 1.9.30-34). En este sentido, si al senex le correspondía la transmisión del conocimiento escrito, a la vetula se la representa como depositaria de la tradición oral, del folklore, de los elementos fundamentales del mos maiorum, y de la memoria familiar y colectiva (Heath, 2011: 86; Ramos Palomo, 2003: 19; Scobie, 1979: 244). Ya hemos visto cómo de ello se encargaron vetulae como Cornelia y Arria (Plin. Ep. 3.16.2-3; Plut. C. Gracch. 19). Tal y como señala Mariarosaria Pugliarello,

"una delle funzioni specifiche attribuite alla vecchiaia al femminile nel mondo antico: depositarie del patrimonio culturale della collettività e della memoria individuale della famiglia, le vecchie trasmettevano la tradizione, sotto forma di racconti popolari e ricordi, contribuendo a preservare la specifità e l'identità sociale" (Pugliarello, 2002: 50).

Pero, además de sabias, en la literatura de la Antigüedad las viejas son astutas, de forma que aplican sus conocimientos en su beneficio o en el de otras personas a su cargo (Apul. Met. 4.12.3-7). En La vieja y el médico, Esopo narra la historia de una anciana a quien intentan engañar, sin resultado:

"Una anciana enferma de los ojos mandó llamar a un médico a sueldo. Éste fue a su casa y cada vez que le daba un ungüento se dedicaba, mientras ella tenía los ojos

\footnotetext{
403 Pallas anum simulat: falsosque in tempora canos addit et infirmos, baculo quos sustinet, artus. Tum sic orsa loqui 'non omnia grandior aetas, quae fugiamus, habet: seris venit usus ab annis. Consilium ne sperne meum: tibi fama petatur inter mortales faciendae maxima lanae; cede deae veniamque tuis, temeraria, dictis supplice voce roga: veniam dabit illa roganti'. Adspicit hanc torvis inceptaque fila relinquit vixque manum retinens confessaque vultibus iram talibus obscuram resecuta est Pallada dictis: 'mentis inops longaque venis confecta senecta, et nimium vixisse diu nocet. Audiat istas, si qua tibi nurus est, si qua est tibi filia, voces; consilii satis est in me mihi, neve monendo profecisse putes, eadem est sententia nobis. Cur non ipsa venit? Cur haec certamina vitat?' tum dea 'venit!' ait formamque removit anilem Palladaque exhibuit.
} 
cerrados, a sustraerle los enseres uno por uno. Cuando se llevó todo y aquélla quedó curada, reclamó el salario convenido. Como ella se negó a pagar, la condujo ante los magistrados. Ella dijo que había prometido el salario si curaba la vista, pero que ahora, después de la cura, había quedado peor que antes, y afirmó: «Antes veía todos los enseres que había en casa, pero ahora soy incapaz de ver ninguno». Así, los canallas por ansia no se dan cuenta de que atraen contra ellos la prueba de su culpa" (Aesop. 57) ${ }^{404}$.

En su papel de narradora, hemos visto cómo la vetula transmite una serie de conocimientos que en ocasiones se ubican en los márgenes del discurso del vir. Así, por ejemplo, la nutrix del niño Proca consigue salvarle la vida tras un ataque de striges gracias a sus conocimientos, basados en antiguas supersticiones. La nutrix de esta historia emplea sus conocimientos de las hierbas medicinales y su relación con seres fantásticos para librar a Proca del ataque de las striges. En su tarea de cuidadora, a la que hemos aludido con anterioridad, se preocupa por el bienestar del niño, y lo hace aplicando una sabiduría que no se encuentra en los tratados médicos, sino que está basada en la transmisión oral y es cercana a la superstición. De la misma forma, la Dipsas de Ovidio (Am. 1.8), a quien ya nos hemos referido, basa sus poderes en el conocimiento que tiene de la naturaleza, la cual emplea para fines funestos. Se trata, como señala Montserrat Camps (2000: 339-340), de un tipo de sabiduría femenina que incide en el entorno mediante un conocimiento práctico, doméstico, privado, de las enfermedades y dolencias, la cual se mueve entre la ciencia y la creencia, y por ello suscita el recelo masculino en cuanto que fuente de poder alternativa a la regulada por la norma patriarcal.

Estos discursos trasgresores no sólo se daban es espacios infantiles, sino también en aquellos típicamente femeninos. Las ancianas aparecen aconsejando a otras mujeres sobre asuntos cotidianos como el amor o los negocios (Ov. Met. 3.271-285; Plaut. Cist. 49-50 y Mostell. 185-194). Resulta frecuente también la figura de la madre o la vieja esclava que instruye a las mujeres jóvenes acerca de cómo engañar al esposo y facilita el adulterio (Apul. Met. 9.15.4; Juv. 6.230-240, 6.495-500 y 15.25). La suegra de

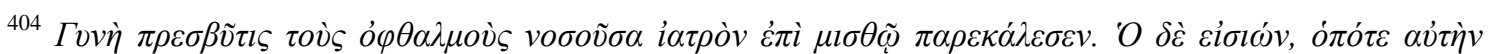
Éर

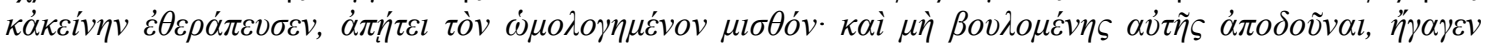

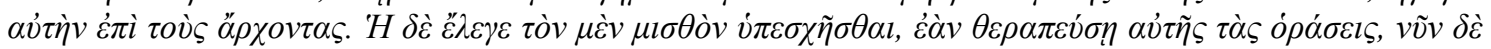

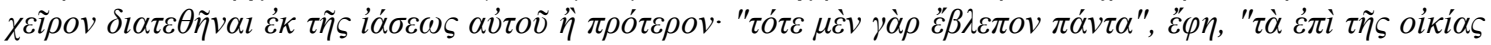

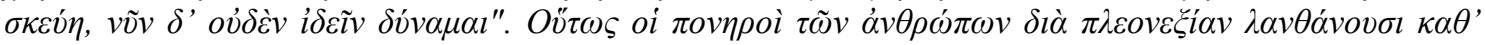

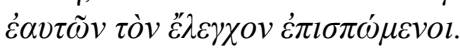


Ponciano, hijo de Pudentila y amigo de Apuleyo, entregó a su hija a la prostitución cuando ella misma ya era demasiado vieja para ejercerla:

"[Esta] mujer, como ya estaba bastante vieja y agotada tuvo que renunciar a mantener la casa entera con sus escándalos. En cuanto a su hija, tras haber sido brindada, sin éxito alguno, mediante la alcahuetería de su propia madre, a todos los jovenzuelos más ricos e incluso prestada a prueba a algunos pretendientes, seguramente estaría aún esperando sentada en casa de sus padres, viuda antes de su boda, si no hubiera ido a parar al carácter acomodaticio de Ponciano" (Apul. Apol. $76.1-2)^{405}$.

Plutarco previene a las mujeres de mantener amistades con otras de su mismo sexo, ya que intentarán ponerles en contra de sus maridos:

"Hermíone parece que dice la verdad, cuando exclama: las visitas de malas mujeres me han matado. Esto no sucece de una manera tan simple, sino cuando las diferencias y celos hacia sus maridos abren a tales mujeres no sólo las puertas sino también los oídos. Por tanto, conviene entonces, sobre todo, que la mujer sensata cierre sus oídos y se guarde de la murmuración, para no añadir fuego al fuego, y tenga presente aquel dicho de Filipo. En efecto, se dice .que éste, animado por sus amigos contra los griegos, porque, a pesar de ser bien tratados, hablaban aún mal de él, les respondió: «¿Qué sucedería entonces si los tratásemos mal?» Así pues, cuando las amigas chismosas le digan: «Tu marido te hace sufrir, aunque tu lo amas y eres una mujer honrada». Ella les debe restsponder: «¿Qué sucedería, entonces, si yo lo odiara y me portase mal con él?»” (Plut. Mor. 143F-144A) ${ }^{406}$.

Dipsas, quien como ya hemos dicho además de lena era bruja, daba el siguiente consejo a una muchacha:

"Se ha propuesto profanar los tálamos honorables, y no le falta elocuencia a pesar de lo maligno de su lengua. La casualidad me hizo ser testigo de su palabrería; ella daba tales consejos (a mí me mantenían oculto unas puertas dobles): «¿Sabes, lucero mío, que ayer fuiste del agrado de un rico mancebo? Quedóse parado y

405 Ceterum uxor iam propemodum uetula et effeta totam domum contumeliis adnuit. Filia autem per adulescentulos ditiores inuitamento matris suae nequicquam circumlata, quibusdam etiam procis ad experiundum permissa, nisi in facilitatem Pontiani incidisset, fortasse an adhuc uidua ante quam nubta domi sedisset.

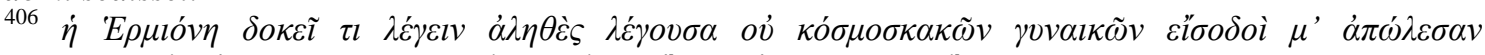

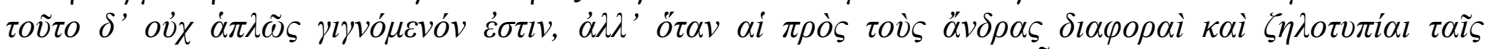

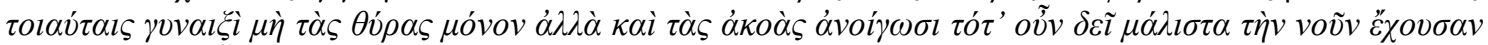

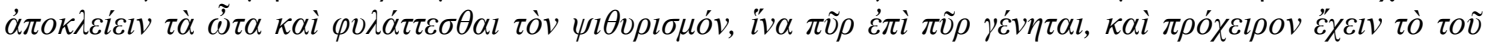

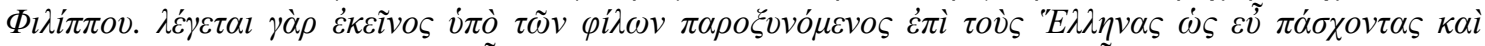

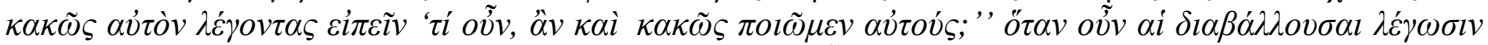

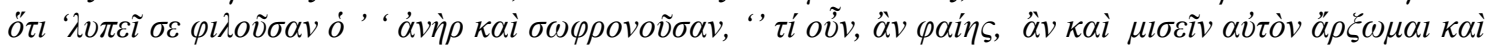
$\dot{\alpha} \delta \iota \kappa \varepsilon \tilde{\imath} v^{\prime}$. 
estuvo pendiente no más que de tu rostro. ¿Y por que no le ibas a gustar tú? Tu hermosura no le es inferior a ninguna, ¡ay de mí, lástima!, a tu cuerpo le falta el cuidado preciso. iOjalá seas tan feliz como hermosísima! Si te haces rica, no seré yo pobre. La estrella contraria de Marte desfavorable te ha perjudicado. Marte se ha alejado; ahora Venus es propicia en un signo suyo. Mira cómo te favorece nada más llegar: un amante rico te ha deseado; él se preocupa de lo que a ti te falta. Su rostro es, asimismo, comparable al tuyo. Aunque no quisiera él comprarte a ti, merecía que tú lo compraras.» (Se sonrojó). Sienta bien a una tez pálida un cierto pudor, pero éste, si es simulado, tiene utilidad; si es verdadero, suele ser un obstáculo. Cuando, con los ojos oportunamente bajados, te contemples el regazo, no debes subirlos para mirar a nadie sino según lo que te ofrezca. Quizá las rudas sabinas, cuando Tacio reinaba, no habrían querido prestarse a tener muchos maridos; ahora Marte ejerce su cólera en naciones extranjeras, mientras que Venus impera en la ciudad de su querido Eneas. Diviértense las que son hermosas: casta es aquella a la que nadie ha solicitado; o incluso, si su impericia no se lo impide, es ella misma la que solicita. A esas también que tienen arrugas en lo alto de su frente zarandéalas y de entre sus arrugas caerán muchas culpas. Penélope ponía a prueba con un arco el vigor de los jóvenes; se trataba de un arco de cuerno, que demostraba el vigor de quien lo empuñaba. Pasa el tiempo sin que nos demos cuenta, volando nos engaña, y el año transcurre rápidamente sobre sus caballos de sueltas bridas; el dinero brilla con el uso, un buen vestido pide que se le lleve puesto, las casas abandonadas encanecen con el feo moho: la hermosura, a no ser que la pongas en juego, envejece si nadie la cultiva. Dos amantes no dan suficiente provecho; más seguro, y sin que provoque ya celos, es el botín que se obtiene de muchos: a los lobos de canosa piel, la presa les llega de un rebaño nutrido. Ea, ¿qué regalos te hace, a no ser versos recién escritos, ese tu amigo poeta? Muchos miles recogerás de tu amante. El dios mismo de los vates aparece vestido con túnica dorada y pulsa las armoniosas cuerdas de una lira recubierta de oro. El que te ofrezca regalos, ése sea para ti más grande que el gran Homero. Hazme caso: el dar es signo de inteligencia y si alguno ha vuelto a la libertad tras haber pagado el precio de su persona, no lo desdeñes: fútil es el delito de tener el pie marcado con yeso. No te engañen las ancestrales imágenes de cera en derredor del atrio: si eres un amante pobre, llévate contigo a tus antepasados. ¿Que, porque es apuesto, solicita de ti una noche sin pagar? ¿Que pida antes a su amante algo para dártelo a ti! Con cierta parquedad debes reclamar el precio, mientras tiendes las redes, no vaya a ser que escapen; pero cuando los hayas cazado, atosígalos con tus condiciones. Tampoco es perjudicial un amor fingido; deja que crea que lo amas, 
pero ten cuidado de que ese amor no se te mantenga gratis. Niégate a menudo a pasar con él la noche: simula unas veces dolor de cabeza, y otras, Isis será quien te dé motivos. Luego recíbelo para que no se acostumbre a la paciencia y para que su amor no se enfríe por ser rechazado una y otra vez. Que tu puerta sea sorda al suplicante, abierta para el que te trae regalos. Que el amante que hayas recibido oiga la voz del que hayas rechazado y, si le has traicionado enfádate alguna vez con él, tu primera, como si te hubiera traicionado él. Se borra tu culpa, compensada con su culpa. Pero no concedas mucho tiempo a tu enfado. A menudo un prolongado enfado es causa de rivalidades. También aprendan incluso tus ojos a llorar forzados, y que éste o aquél sean motivo para que tus mejillas se humedezcan. Y no temas jurar en falso, si engañas a alguno. Venus vuelve sordas a las divinidades en estos juegos eróticos. Procúrate un esclavo y una criada conocedora de su oficio, para que enseñen convenientemente qué se te puede comprar; y que para si mismos reclamen alguna cosilla: si piden a muchos alguna cosilla, con el tiempo, de una espiga tras otra, se formará una gran parva. Que tu hermana y tu madre, también tu nodriza, saquen provecho de tu amante. Se hace rápidamente botín, cuando muchas manos colaboran para alcanzarlo. Cuando te falten motivos para pedir regalos, atestigua con un pastel que es tu cumpleaños. Cuídate de que no ame confiado, sin ningún rival: no dura mucho el amor si le privas de luchas. Que él vea por todas partes en tu lecho huellas de varón y tu cuello amoratado con señales de caricias. Ante todo, que vea los regalos que el otro te haya enviado: si nadie te ha regalado nada, hay que procurárselos en la Vía Sacra. Cuando hayas conseguido de él muchos regalos, para que, no obstante, no sea todo dar, pídele tú misma que te preste algo que nunca le devolverás. Que la lengua te ayude y oculte lo que piensas: acarícialo y perjudícalo; el funesto veneno se esconde bajo dulce miel. Si sigues estas normas, que yo conozco como fruto de una larga experiencia, y el viento y la brisa no se llevan mis palabras, muchas veces me bendecirás, mientras esté viva, y cuando muerta, pedirás muchas veces que mis huesos descansen en paz». Su voz estaba aún en el aire, cuando mi sombra me delató, y apenas se contuvieron mis manos de arrancarle su canosa y rala cabellera, de sacarle sus ojos, llorosos de tanto vino, y destrozarle sus mejillas llenas de arrugas. ¡Que los dioses te priven de todo hogar, y te den una vejez sin recursos, largos inviernos y eterna sed!" (Ov. Am. 1.8.20-110) ${ }^{407}$.

\footnotetext{
${ }^{407}$ Haec sibi proposuit thalamos temerare pudicos; nec tamen eloquio lingua nocente caret. Fors me sermoni testem dedit; illa monebat talia - me duplices occuluere fores: 'scis here te, mea lux, iuveni placuisse beato? Haesit et in vultu constitit usque tuo. Et cur non placeas? Nulli tua forma secunda est; me miseram, dignus corpore cultus abest! Tam felix esses quam formosissima, vellem - non ego, te facta divite, pauper ero. Stella tibi oppositi nocuit contraria Martis. Mars abiit; signo nunc Venus apta
} 
La actitud de Dipsas enfurece a Ovidio, quien desea emplear la violencia contra ella y le augura una vejez llena de necesidad. Al espía no le molesta sólo que la vetula esté corrompiendo a la joven con sus consejos, sino también el mensaje que le transmite. Con su discurso, Dipsas desea su beneficio, el de la muchacha y el de las mujeres que le rodean, y le insta a obtenerlo engañando a los hombres.

De la misma forma, hemos visto cómo Propercio dirige su ira hacia la tumba de la

lena Acántide, que daba consejos a las jóvenes acerca de cómo comportarse con sus amantes:

"Si te agrada la dorada ribera oriental de los Dorozantes y la perla que se enorgullece bajo las aguas tirias, si te encantan las telas de Eurípilo y de la Minerva de Cos y los delicados relieves arrancados de los lechos atálicos, o los productos que envía para su venta la palmífera Tebas o los vasos de cristal cocidos en los hornos de Partia, desprecia la fidelidad, derriba las estatuas de los dioses, triunfe la mentira y rompe las promesas de un nocivo pudor. Inventarse un marido aumenta

suo. Prosit ut adveniens, en adspice! Dives amator te cupiit; curae, quid tibi desit, habet. Est etiam facies, qua se tibi conparet, illi; si te non emptam vellet, emendus erat'. Erubuit. 'Decet alba quidem pudor ora, sed iste, si simules, prodest; verus obesse solet. Cum bene deiectis gremium spectabis ocellis, quantum quisque ferat, respiciendus erit. Forsitan inmundae Tatio regnante Sabinae noluerint habiles pluribus esse viris; nunc Mars externis animos exercet in armis, at Venus Aeneae regnat in urbe sui. Ludunt formosae; casta est, quam nemo rogavit - aut, si rusticitas non vetat, ipsa rogat. Has quoque, quae frontis rugas in vertice portant, excute; de rugis crimina multa cadent. Penelope iuvenum vires temptabat in arcu; qui latus argueret, corneus arcus erat. Labitur occulte fallitque volubilis aetas, ut celer admissis labitur amnis aquis. Aera nitent usu, vestis bona quaerit haberi, canescunt turpi tecta relicta situ - forma, nisi admittas, nullo exercente senescit. Nec satis effectus unus et alter habent; certior e multis nec tam invidiosa rapina est. Plena venit canis de grege praeda lupis. Ecce, quid iste tuus praeter nova carmina vates donat? Amatoris milia multa leges. Ipse deus vatum palla spectabilis aurea tractat inauratae consona fila lyrae. Qui dabit, ille tibi magno sit maior Homero; crede mihi, res est ingeniosa dare. Nec tu, siquis erit capitis mercede redemptus, despice; gypsati crimen inane pedis. Nec te decipiant veteres circum atria cerae. Tolle tuos tecum, pauper amator, avos! Qui, quia pulcher erit, poscet sine munere noctem, quod det, amatorem flagitet ante suum! Parcius exigito pretium, dum retia tendis, ne fugiant; captos legibus ure tuis! Nec nocuit simulatus amor; sine, credat amari, et cave ne gratis hic tibi constet amor! Saepe nega noctes. capitis modo finge dolorem, et modo, quae causas praebeat, Isis erit. Mox recipe, ut nullum patiendi colligat usum, neve relentescat saepe repulsus amor. Surda sit oranti tua ianua, laxa ferenti; audiat exclusi verba receptus amans; et, quasi laesa prior, nonnumquam irascere laeso - vanescit culpa culpa repensa tua. Sed numquam dederis spatiosum tempus in iram: saepe simultates ira morata facit. Quin etiam discant oculi lacrimare coacti, et faciant udas illa vel ille genas; nec, siquem falles, tu periurare timeto - commodat in lusus numina surda Venus. Servus et ad partes sollers ancilla parentur, qui doceant, apte quid tibi possit emi; et sibi pauca rogent - multos si pauca rogabunt, postmodo de stipula grandis acervus erit. Et soror et mater, nutrix quoque carpat amantem; fit cito per multas praeda petita manus. Cum te deficient poscendi munera causae, natalem libo testificare tuum! Ne securus amet nullo rivale, caveto; non bene, si tollas proelia, durat amor. Ille viri videat toto vestigia lecto factaque lascivis livida colla notis. Munera praecipue videat, quae miserit alter. Si dederit nemo, Sacra roganda Via est. Cum multa abstuleris, ut non tamen omnia donet, quod numquam reddas, commodet, ipsa roga! Lingua iuvet mentemque tegat - blandire noceque; inpia sub dulci melle venena latent. Haec si praestiteris usu mihi cognita longo, nec tulerint voces ventus et aura meas, saepe mihi dices vivae bene, saepe rogabis, ut mea defunctae molliter ossa cubent'. Vox erat in cursu, cum me mea prodidit umbra, at nostrae vix se continuere manus, quin albam raramque comam lacrimosaque vino lumina rugosas distraherentque genas. Di tibi dent nullosque Lares inopemque senectam, et longas hiemes perpetuamque sitim! 
la cotización: ten a mano excusas. Negando una noche el amor volverá con más fuerza. $\mathrm{Si}$ acaso te estropeara el cabello, te será útil enfadarte: poco después quedará dominado cuando compre las paces. Al fin, cuando le prometas sexo en medio de abrazos pagados, excúsate con que estás en las festividades castas de Isis. Que Yole deje caer que es abril, que Amicle le golpee con que tu cumpleaños es el quince de mayo. Suplicante tome él asiento, tú en acomodado sillón escribe cualquier cosa: si él teme tretas, ¡tuyo es! Ten siempre mordiscos recientes alrededor de tu cuello, para que se figure que los has recibido en escarceos con otro. No te agraden las afrentas de la rendida Medea (sin duda sufrió los desdenes de haberse atrevido a declararse primero), sino mejor la interesada Taide del elegante Menandro, cuando como amante de las comedias engaña a los astutos getas. Adáptate a las costumbres de tu amante: si le da por berrear canciones, acompáñale y, ebria, une tu voz a él. Tu portero esté despierto para los espléndidos: si llama uno sin blanca, sordo duerma sobre el cerrojo bien echado. No le hagas ascos a un soldado no hecho para el amor, ni a un marinero si trae pasta en su callosa mano, ni a quienes colgaron un cartel de su cuello extranjero, cuando, untados de greda, saludaron en medio del foro. ¡Fíjate en el oro, no en las manos que lleven el oro! ¿Qué sacarás de oír versos sino palabras? ¿De qué te sirve, vida mía, ir con un peinado sofisticado y ondear los delicados pliegues de un vestido de Cos? Quien te regale versos, pero no vestidos de Cos, haz oídos sordos a su lira, que no vale un duro. Mientras hierve la sangre y la edad esté libre de arrugas, disfruta, no sea que el mañana se tome algo de tu belleza. Yo vi los rosales del oloroso Pesto, que vida prometían, yacer mustios bajo el viento sur de una mañana" (Prop. 4.5) ${ }^{408}$.

La razón de su odio es la misma que la de Ovidio; las palabras de la vetula pueden hacer que la puella se convierta en una mujer que busca su propio beneficio, menos

\footnotetext{
408 "si te Eoa Dorozantum iunat aurea ripa et quae sub Tyria concha superbit aqua, Eurypylique placet Coae textura Mineruae, sectaque ab Attalicis putria signa toris, seu quae palmiferae mittunt uenalia Thebae, murreaque in Parthis pocula cocta focis; sperne fidem, prouolue deos, mendacia uincant, frange et damnosae iura pudicitiae! Et simulare uirum pretium facit: utere causis! Maior dilata nocte recurret amor. Si tibi forte comas uexauerit, utilis ira: post modo mercata pace premendus erit. Denique ubi amplexu Venerem promiseris empto, fac simules puros Isidis esse dies. Ingerat Aprilis Iole tibi, tundat Amycle natalem Mais Idibus esse tuum. Supplex ille sedet posita tu scribe cathedra quidlibet! Has artis si pauet ille, tenes! Semper habe morsus circa tua colla recentis, litibus alternis quos putet esse datos. Nec te Medeae delectent probra sequacis (nempe tulit fastus ausa rogare prior), sed potius mundi Thais pretiosa Menandri, cum ferit astutos comica moecha Getas. In mores te uerte uiri: si cantica iactat, $i$ comes et uoces ebria iunge tuas. Ianitor ad dantis uigilet: si pulset inanis, surdus in obductam somniet usque seram. Nec tibi displiceat miles non factus amori, nauta nec attrita si ferat aera manu, aut quorum titulus per barbara colla pependit, cretati medio cum saluere foro. Aurum spectato, non quae manus afferat aurum! Uersibus auditis quid nisi uerba feres? [quid iunat ornato procedere, uita, capillo et tenuis Coa ueste monere sinus?] Qui uersus, Coae dederit nec munera uestis, istius tibi sit surda sine arte lyra. Dum uernat sanguis, dum rugis integer annus, utere, ne quid cras libet ab ore dies! Uidi ego odorati uictura rosaria Paesti sub matutino cocta iacere Noto".
} 
manejable, menos sumisa, y por lo tanto menos deseable. Se trata de un discurso que también aparece en Tibulo: "Pero tú, los consejos de una bruja ladrona, olvídalos cuanto antes. Es que con regalos se vence todo amor. Un amante pobre estará listo siempre" (Tib. 1.5.60) ${ }^{409}$.

Otro caso parecido es el de la esposa del molinero, uno de los amos del asno Lucio, quien se pasa el día bebiendo junto a una vetula y hablando acerca de sus amantes: "Empezaban por desayunar juntas; luego, competían en servirse mutuamente copas de vino puro y acababan montando el escenario infernal de las malas pasadas que harían al pobre marido" (Apul. Met. 9.15) ${ }^{410}$. Se trata de féminas que actúan en intimidad y que además presentan comportamientos masculinos como abusar del vino y mostrarse sexualmente activas y dominantes. En una de sus reuniones, la mayor cuenta una historia que podría identificarse con una anilis fabula, o al menos con un ejemplo del story-telling femenino, en la que una adúltera a punto está de verse descubierta por su esposo, si bien el amante consigue enderezar la situación en el último momento (Apul. Met. 9.17-21). El objetivo de esta historia no es mostrar el triunfo de un héroe, como es el caso de las narraciones masculinas, sino hacer ver a la molinera cuán estupendo amante es Filesitero y convencerla de que necesita uno igual de bueno.

En este sentido, hemos hecho referencia también a la vieja nutrix de Mirra, quien la ayuda a cometer incesto con su padre. Esta vetula es además presentada como experta en el manejo de hierbas y en rituales mágicos, al tiempo que como confidente y consuelo de la joven Mirra.

Estos pasajes nos sirven para ilustrar cómo las vetulae aprovecharían los momentos de socialización femenina para transmitir a las mujeres jóvenes, en ocasiones en forma de cuentos, ciertos conocimientos que podían ser subversivos. Se aprecia entonces, como muestran historias como la de Procne y Filomela o la de Tacita Muta entre muchas otras, que las mujeres que acceden al conocimiento y que lo usan para realizar actos de sororidad suponen un peligro para el poder patriarcal, lo que genera el rechazo de los hombres que observan la transgresión, como Ovidio, Propercio y Lucio.

Vemos de ésta forma cómo la literatura de época romana nos presenta a las ancianas como depositarias y garantes de una sabiduría oral, popular y estrechamente

\footnotetext{
409 At tu quam primum sagae praecepta rapacis desere, nam donis vincitur omnis amor. Pauper erit praesto semper, te pauper adibit.

${ }^{410}$ Cum qua protinus ientaculo ac dehinc vino mero mutuis vicibus velitata scaenas fraudulentas in exitium miserrimi mariti subdolis ambagibus construebat.
} 
relacionada con lo femenino. Lo que saben y lo que dicen las ancianas, ya sea de forma directa o a través de cuentos, sirve para moldear las mentes jóvenes y supone una primera interiorización del código moral de la sociedad romana. Para ello, resulta necesaria la representación de la vetula como una figura severa, pero también afectiva, capaz de ganarse el afecto y la obediencia de quienes están a su cuidado.

Para poder cumplir con su cometido, la vetula debía poseer un amplio conocimiento de multitud de temas, el cual habría ido adquiriendo a través de sus experiencias vitales pero también con una sabiduría que probablemente le fue transmitida por otras mujeres mediante los mismos mecanismos que ella empleará después. La anciana romana se constituye así en importante agente de transmisión de la cultura oral, tanto en lo que respecta a asuntos cotidianos como a conocimientos más complejos, ya sea de tipo religioso, médico, o familiar.

\section{IV.3.5. La vetula bondadosa}

Las ancianas además de sabias son bondadosas, mujeres en las que se puede confiar. Ya hemos visto cómo esta bondad se encuentra relacionada con las tareas de cuidado que les son asignadas. Al encargarse de las necesidades básicas en la infancia, se forja entre la vetula y quien está a su cargo, especialmente en el caso de las niñas, una relación de afecto y confianza que hace que se recurra a ellas cuando se necesita ayuda y consejo. La joven secuestrada por los ladrones en Metamorfosis confía pronto en la vieja que la custodia, y se deja reconfortar por ella. Gracias a los años vividos, las vetulae han adquirido una sabiduría que propicia que sus consejos sean certeros, y son vistas además como fuente de cariño y como aliadas, incluso en situaciones extremas como la ya aludida de la incestuosa Mirra.

Las vetulae, por la confianza que inspiran, son presentadas en la literatura como buenas anfitrionas, al igual que ocurre con los senes. Baucis y Filemón son buen ejemplo de ello. En el ámbito familiar, esta característica se manifiesta por un lado en cómo los miembros más jóvenes de la familia son dejados bajo su cuidado, y también en cómo son bondadosas e incluso transigentes con ellos ( $A E$ 2007, 298; Auson. Par. 5; Cass. Dio 60.2.4-5; Plin. Ep. 4.19). Las jóvenes acuden a las ancianas en busca de consejo y las vetulae se muestran con ellas solícitas y afectuosas, siempre dispuestas ayudar (Juv. 6.495-500; Ov. Met. 10.382-464; Tib. 1.3.85-90). 
En el caso de las ancianas de la élite, la bondad se manifestaría a través de los actos evergéticos, a los que ya hemos aludido, así como mediante la muestra pública de apoyo a la ciudadanía ante situaciones críticas. Cuando Veturia acude ante su hijo no sólo le ruega por ella, sino también por el Estado romano y todas las personas que viven bajo él (Cass. Dio 5.18.8-11). Precisamente son la bondad y la empatía de Veturia lo que hace que Valeria acuda a ella en busca de ayuda (Dion. Hal. Ant. Rom. 8.40-54.2). Siendo una vetula, Livia siguió preocupándose por el bienestar del pueblo romano: “en un incendio que se había declarado junto al templo de Vesta, se había personado en el lugar del siniestro y había exhortado al pueblo y a los soldados a prestar auxilio con todas sus fuerzas, como solía hacerlo en vida de su marido" (Suet. Tib. 50-51).

No obstante, confiar en la supuesta bondad de una vetula desconocida podía tener consecuencias indeseadas. Ya hemos aludido a la lena del Satiricón que conduce al personaje que se ha perdido al burdel que regenta. De igual forma, la bruja de Heliodoro a punto está de asesinar a los viajeros que habían confiado en ella para que les procurase el buen acogimiento de los habitantes de su pueblo. Meroe se presenta en un primer momento como una posadera solícita que acoge al cansado viajero, si bien más adelante descubrimos que se trata de una bruja que busca satisfacer su deseo sexual (Apul. Met. 1.7.7).

En ocasiones, las divinidades aprovechan la bondad que se atribuye a las ancianas y la confianza que tienen, especialmente con las mujeres jóvenes, para el engaño. Ovidio narra cómo Vertumno se transforma en vetula para violar a Pomona:

“Incluso llegó a ceñirse las sienes con un pañuelo de colores y apoyándose en un bastón y colocándose canas en las sienes fingió ser una vieja y entró en aquel jardín bien cultivado, y admirando los frutos dijo: «iEres más atractiva aún!», y tras piropearla le dio besos como nunca se los hubiera dado una vieja de verdad, y se sentó, encorvada, sobre el terruño, contemplando las ramas inclinadas por el peso del otoño. (...) «Pero si eres lista, si quieres casarte bien y hacer caso de esta vieja, que más que todos éstos, más de lo que tú te piensas, te amo, rechaza un matrimonio vulgar y escoge a Vertumno por compañero de tu lecho»" (Ov. Met. $14.654-678)^{411}$.

\footnotetext{
411 Ille etiam picta redimitus tempora mitra, innitens baculo, positis per tempora canis, adsimulavit anum: cultosque intravit in hortos pomaque mirata est 'tanto' que 'potentior!' inquit paucaque laudatae dedit oscula, qualia numquam vera dedisset anus, glaebaque incurva resedit suspiciens pandos autumni pondere ramos (...) "Sed tu si sapies, si te bene iungere anumque hanc audire voles, quae te plus omnibus illis, plus, quam credis, amo: vulgares reice taedas Vertumnumque tori socium tibi selige!"
} 
La vetula falsa halaga a la joven y le aconseja que escoja a Vertumno entre todos sus pretendientes, "pues la vejez me ha dado el saber muchas cosas" (Ov. Met. $14.695)^{412}$. La vetula-Vertumno utiliza también una anilis fabula para convencer a Pomona, en concreto la historia de Ifis y Anaxárete (Ov. Met. 14.700-764), y después descubre el engaño: "Dicho esto sin éxito el dios disfrazado de vieja recobró su aspecto juvenil, se quitó los abalorios propios de vieja y se mostró a Pomona" (Ov. Met. 14.766). En este caso la treta de Vertumno tiene buen final para él: se dispone a violar a Pomona, pero para entonces ésta se ha rendido a los halagos que el dios le hacía disfrazado de vieja y se entrega a él.

Vemos por lo tanto cómo aquí también se refleja la actitud ambigua que la sociedad tenía hacia las vetulae. Aunque eran consideradas como personas buenas y de fiar, en cuanto que mujeres siempre estaban dispuestas al engaño, sobre todo si la víctima del mismo era un hombre, por lo que conveía acercarse a ellas con cautela.

\section{IV.3.6. Estereotipos que se solapan para crear una identidad común}

A lo largo de los anteriores apartados hemos analizado los diversos estereotipos de vejez femenina presentes en el imaginario romano. Estereotipos que en ocasiones se mezclan y que, incluso cuando muestran una imagen positiva de la vejez femenina, resulta fácil convertirlos en atributos negativos.

Partiendo de Dipsas y Canidia, pasando por Trotaconventos y Celestina, hasta llegar a la actualizada versión de Fiona Goodey en American Horror Story: Coven $^{413}$, la vieja sabia y poderosa -y por lo tanto peligrosa-, adicta a la bebida y/o al sexo, íntimamante ligada con la muerte y deseosa de dañar al hombre, aparece en la literatura y el arte de todas las épocas históricas, adaptada al público que la contempla en cada momento. Podría decirse entonces, como señala Margarita Ortega (2002: 403), que históricamente la vieja se ha configurado como un sujeto bajo continua sospecha.

En este sentido, una postura interesante desde la que estudiar a estas vetulae la proponen Michael Ostling y Laura Kounine (2016: 2), quienes señalan que, en algunos casos, es el trato que la sociedad da a la mujer en cuestión lo que la lleva a adoptar la

\footnotetext{
412 etenim mihi multa vetustas scire dedit.

${ }^{413}$ Tercera temporada de la serie de la FOX American Horror Story, que gira en torno a las vicisitudes de un aquelarre del siglo XXI. Una de sus protagonistas, Fiona Goodey -encarnada por Jessica Lange-, jefa del aquelarre, es una anciana alcohólica con tremendos poderes mágicos y de seducción que, no obstante, menguan a medida que avanza en la vejez y se acerca el momento de su muerte.
} 
identidad que ya se le adjudica socialmente. Al ir atribuyéndole los demás las características de la vetula marginada -evitando el trato con ella, expandiendo rumores sobre sus actividades y sus aficiones, previniendo a niñas y niños para que no se acerquen a ella, trayendo a la mente historias populares protagonizadas por viejas que asesinan, engañan, reviven muertos y secuestran bebés, etc.-, la propia anciana pudo interiorizar y asumir cada vez más y más rasgos estereotipados, hasta convertirse en lo que ya se esperaba de ella.

Esta relación bidireccional entre lo que la sociedad piensa que es la vetula y lo que la vetula percibe que la sociedad siente hacia ella, de forma que proyecta su odio hacia los demás empleando precisamente los mismos mecanismos que se le atribuyen de forma "natural", ha sido percibida por María José Hidalgo en el caso de las vetulae que practican la magia:

"Esta característica de la vejez como elemento común de todas las brujas profesionales, según la documentación literaria, podía estar relacionada (...) con un fenómeno de fobias recíprocas. Por un lado, el rechazo que la sociedad proyecta sobre las mujeres viejas y, por otro, la actitud de estas viejas contra la propia sociedad que las margina y sobre la que pretenden ejercer sus venganzas, como medio único a su alcance de actuar contra tal situación” (Hidalgo, 1994: 504).

La elaboración y posterior venta de cosméticos y remedios medicinales, la magia, la prostitución, y el oficio de cuidadora, pudieron ser soluciones que algunas vetulae buscaron para su pobreza. Se trata además de actividades que podían complementarse, lo que propicia que en ocasiones varias de ellas se atribuyan a una misma vetula.

En definitiva, en este apartado hemos presentado cómo en la sociedad romana existieron diversos estereotipos de vetula, los cuales en ocasiones se combinan para crear una identidad común, una figura marginal y peligrosa. Tras ella se esconden vetulae sabias, encargadas de transmitir a la comunidad el folklore y la memoria de los antepasados, así como ancianas que realizan actos de sororidad y suponen un apoyo para féminas más jóvenes, y también mujeres que tratan de sobrevivir a la pobreza extrema y cuyas penurias las avocan al alcoholismo. Todas ellas son vetulae que no encajaban en el rol genérico que se les asignaba en cuanto que mujeres y viejas y cuyo peligro los varones intentaban anular mediante la creación de personajes abyectos y ridículos, sobre los que aplican la violencia. 


\section{IV.4. LA VEJEZ SENTIDA DE LAS VETULAE: UN ACERCAMIENTO A LAS EMOCIONES DE LA VEJEZ FEMENINA EN LA ANTIGUA ROMA}

A lo largo de este capítulo y del anterior hemos abordado las dimensiones cronológica, física y social de la vejez femenina en la antigua Roma. Hemos hecho referencia también a los cambios psicológicos y psiquiátricos que acompañan al proceso de envejecer. Resta, por lo tanto, abordar la vejez sentida o percepción del sí como personas viejas de las vetulae.

Conocer la idea que las personas ancianas tienen de sí mismas y saber cómo sienten su vejez y cómo perciben su entorno en relación con su momento vital se ha convertido en uno de los objetivos principales de la Gerontología Social en la actualidad. Con ello pretende no sólo mejorar la calidad de vida en la vejez a través de la inclusión en los planes médicos y sociales de los intereses, miedos, opiniones y percepciones de ancianas y ancianos, sino también integrar a éstas personas como parte activa de la sociedad y darles voz y espacio propios. La forma reunir estos datos es mediante la recopilación de lo que se conoce como "historias de vida"; es decir, relatos autobiográficos acerca de la propia vida en los que se expresan sentimientos sobre los hechos pasados y presentes y se pregunta a los sujetos a estudiar acerca de cómo se sienten en ese momento en relación con su vejez y cómo creen que son percibidos por la sociedad.

Cuando intentamos acceder a estas historias de vida y a la percepción del sí en el pasado, nos enfrentamos a diversas dificultades. Entre ellas la principal es una aparente falta de fuentes adecuadas que contesten a las preguntas que se plantea la investigación, sobre todo cuando abordamos periodos para los que no podemos contar con testimonios de primera mano. Desde su nacimiento, y especialmente desde su resurgimiento a principios del siglo XXI, la Historia de las Emociones se ha planteado si solamente podemos conocer qué sentían personas de diversas épocas históricas a través de diarios y relatos en primera persona, o si las referencias en tercera persona, el arte y la materialidad pueden considerarse en este caso fuentes también fiables (Zaragoza, 2013).

Otro de los obstáculos que debemos tener en cuenta proviene de la propia definición de palabras como "emoción", "sentimiento", etc., y de si deben considerarse como un mismo concepto o como elementos distintos a la hora de abordar la investigación (Zaragoza, 2013: 2). A ello se le une el debate sobre si las emociones son universales y naturales, o si están condicionadas social, temporal y espacialmente. 
Además, cuando pretendemos ahondar en las afectividades de sociedades distantes en el tiempo y con un idioma diferente al nuestro, no podemos olvidar que en ocasiones no existen equivalencias entre las palabras de nuestro vocabulario y aquellas que queremos historiar. De la misma forma, cabe preguntarse si hay emociones que han desaparecido con el tiempo o si todas las emociones que identificamos en el presente son ahistóricas o tienen un origen concreto. Especialmente conscientes de estos hechos se muestran, para el periodo que concierne a nuestra Tesis Doctoral, Rebecca Langlands (2006: 29 y ss.) en su estudio sobre la pudicitia y Robert Kaster (2005: 6 y ss.) en su libro acerca de las emociones en la sociedad romana.

Finalmente, debemos cuestionarnos si, en aquellos casos en los que nuestra fuente no explicita cuáles son sus emociones, realmente estamos historiando sentimientos o interpretamos desde nuestra subjetividad aquello que nos parece que sintieron las personas analizadas. Cuando Séneca el Viejo (Contr. 1) escribe que encuentra felicidad en rememorar los años pasados, podemos creerle dado que no hay indicios en el resto del pasaje que nos hagan sospechar que miente; sin embargo, no podemos saber cuáles eran las motivaciones de la esposa de Domicio Tulo al cuidar de él en su dependencia, si el afecto por su cónyuge, la resignación de cumplir con el cometido que se esperaba de ella en cuanto que mujer casada, o la esperanza de recibir una buena porción de la herencia del senex una vez éste falleciese. Por mucho que Apuleyo se esfuerce por declarar que fue su amor por Pudentila lo que le incitó a casarse con ella a pesar de que no era una mujer joven ni atractiva, bien podían tener también razón quienes lo acusaban de haber celebrado un matrimonio basado en el interés económico. De la misma forma, sabemos cuáles son las emociones que nos provoca la contemplación de obras como las del tipo anus ebria, pero no qué sentían los romanos y romanas que las veían o cuáles eran sus motivaciones a la hora de encargarlas o adquirirlas.

Norma Hernández (2014) ha realizado un intento de acercarse a la vejez sentida en la antigua Roma. Aborda desde una perspectiva filosófica los escritos de varones como Marco Aurelio y Plinio el Joven para tratar de averiguar qué percepción tenían de sí mismos en cuanto que ancianos. Si bien se trata de un estudio limitado en lo que respecta a la cantidad de autores que analiza y a que habla en exclusiva de varones de la élite, supone un excepcional ejemplo de cómo podemos acercarnos a la vejez sentida en la Antigüedad. 
Intentar analizar la vejez sentida de las vetulae resulta un trabajo arduo, ya que en cuanto que mujeres y ancianas son pocos los testimonios en primera persona que tenemos. A pesar de que poseemos cartas e inscripciones en las que diversas vetulae expresan sus sentimientos, en muchos casos no podemos saber si realmente fueron hechas por mujeres o se trata de interpretaciones que otras personas hicieron de sus pensamientos y sentimientos, o bien la expresión escrita de las convenciones sociales. Somos conscientes de la dificultad que entraña tratar de acceder a los sentimientos de las ancianas romanas, por lo que en este apartado de nuestra investigación pretendemos realizar un primer intento de comprender las emociones de mujeres que vivieron hacer dos milenios.

Una de las conclusiones a las que llega Norma Hernández en el trabajo ya citado es que "entre los romanos cultivados la atención hacia sí mismo se incrementa en la edad avanzada" (Hernández, 2014: 106), y que este hecho se debe a las exigencias del propio cuerpo. Se trata de un hecho bien estudiado por la Gerontología (Castellanos y López, 2010) y que puede aplicarse no sólo a los varones de la élite, sino a todas las personas viejas. A medida que la vejez acarrea enfermedades -ya sean puntuales o crónicas-, dependencia progresiva, cambios físicos, dificultades para realizar tareas cotidianas, etc., las personas ancianas son cada vez más conscientes de su corporeidad. El cuerpo reacciona de forma distinta a como lo hacía antes, ha cambiado con respecto a los años de juventud y madurez, ni siquiera el aspecto físico es el mismo, y todos estos cambios sirven para que la sociedad identifique a alguien como viejo. Las personas ancianas comienzan entonces a comparar su situación actual con la pasada, reconociendo una pérdida de posibilidades y capacidades (Castellanos y López, 2010: $44)$.

La esclava Sira (Plaut. Merc. 675) es consciente de cómo la vejez ha afectado a su motricidad, y ese pensamiento le provoca agobio (deprimunt). Una prostituta del mismo nombre da consejos a su hija, de forma que "no te pondrás nunca vieja como yo" (Plaut. Cist. 49) ${ }^{414}$, haciendo alusión a cómo el cuerpo envejecido no es del agrado de sus clientes. Con anterioridad ha hecho referencia a cómo su condición social no le dejó otra opción que convertirse en prostituta, y a la importancia que los lazos de afecto y de solidaridad tienen para quienes se dedican a su misma labor, expresando el cariño que siente por Selenio. Escafa es consciente de que han sido los cambios que la vejez ha

\footnotetext{
${ }^{414}$ numquam senecta fies.
} 
provocado en su físico los que han hecho que su amante la abandonase (Plaut. Mostell. 200-203). Por su parte, Haynchis declara que necesita la ayuda de su hija en el negocio porque es vieja, y expresa ansiedad por su ausencia (P.Lond. 7.1976). Julia sentía rechazo por las canas que preconizaban su vejez, y por ello se las hacía arrancar (Macrob. Sat. 2.5.7). Este sentimiento lo comparte con aquellas vetulae que tratan de disimular arrugas, alopecia y falta de dientes mediante diversos remedios (Luc. Am. 3942; Mart. 3.43 y 5.43; Ov. Ars am. 2.665-700).

Percibimos en estos testimonios un patrón que han señalado para la actualidad Fabiola Castellanos y Alba López (2010: 47). En un estudio realizado entre población anciana en contexto de pobreza, han constatado cómo en el caso de las personas con menos recursos, los cambios corporales percibidos no están asociados a la belleza o a la estética, sino a la imposibilidad de trabajar y a la pérdida de funcionalidad corporal. Sira y Haynchis, que dependen de su físico, lamentan la disminución de vigor corporal. Sin embargo, mujeres como las descritas por Luciano (Am. 39-42) centran su ansiedad en la pérdida de atractivo y los cambios en su aspecto. Una visión intermedia la encontramos en las prostitutas; se quejan por no resultar hermosas, pero lo hacen porque la belleza es parte fundamental de su medio de vida.

Por el contrario, contamos también con ejemplos de vetulae que parecen encontrarse cómodas con su cuerpo. Es el caso de las mujeres que escogen ser representadas en su vejez, ya sea en bustos o con imágenes asociadas a sus epitafios, que debieron sentirse a gusto con los signos exteriores del envejecimiento o que al menos eran conscientes del prestigio que les otorgaba ser representadas de esa forma.

En ocasiones, la propia vejez puede percibirse como una carga, ya sea por las condiciones concretas en las que se encuentra la persona anciana o por cómo es tratada por su entorno. Es el caso de una anciana pobre que menciona Tibulo (1.6) y de la longeva Sibila (Ov. Met. 14.130-154). Sóstrata, a quien nos hemos referido en el apartado correspondiente a las suegras, manifiesta que no desea convertirse en una carga para nadie debido a su avanzada edad, y por ello se retira al campo (Ter. Hec. 590-595). El marido de Sóstrata, hablando de sí mismo y de su esposa, declara a su hijo que "a fin de cuentas, Pánfilo, nosotros ya valemos sólo para hacer chistes: "Érase un viejo y una vieja..." (Ter. Hec. 620) ${ }^{415}$.

\footnotetext{
${ }^{415}$ postremo nos iam fabulae sumu', Pamphile, "senex atque anus".
} 
La vejez también es percibida como una carga en el caso de las madres que pierden a su descendencia o cuando ésta se comporta de forma indigna. Así, Vicia (Tac. Ann. 6.10) y la bruja de las Etiópicas (Heliod. Aeth. 6.12) se nos presentan lamentando la muerte de sus hijos, y Veturia (Val. Max. 5.4.1) llora por las acciones de Coriolano. La pérdida de seres queridos intrínseca a una vida longeva se manifiesta en el epitafio de Papiria Tertia, fallecida a una edad desconocida entre los años 30 y 70 de nuestra era:

“Titus Truppicus hijo de Titus, Papiria Tertia hija de Titus. Mira extraño este monumento que he erigido para los míos y cómo triste, vieja y miserable necesito a mi descendencia. Que mi vejez solitaria sea ejemplo de que la esterilidad es una alegría para las esposas. Titus Truppicus hijo de Titus lo hizo" (CIL 5.2435 $)^{416}$.

La inscripción, en la que aparece representada Papiria junto a los que podrían ser su esposo y su hijo, parece haber sido encargada en vida por la vetula de forma que al morir fuese conmemorada junto a su familia. No sabemos cuántos hijos e hijas tuvo Papiria, ni con qué edad fallecieron, pero sí que dejaron un vacío emocional que se hizo insoportable en la vejez.

Por otro lado, nos encontramos con ejemplos en los que la propia vejez es empleada como un recurso para conmover al interlocutor. En la carta de Cornelia a la que ya hemos aludido, esta vetula ve cercana su vejez y la emplea como un modo de convencer a su hijo de que siga sus consejos (Nep. Fr. 2). Expresa además su queja por la ingratidud de su hijo, quien siente que rompe con la pietas que le debe en cuanto que madre y vieja. Una actitud que también se aprecia en el discurso de Veturia, en las exigencias que Eudaimonis hace a su nuera -e implícitamente a su hijo Apolonios- y en las conversaciones entre las madres ancianas y sus hijas prostitutas (Dion. Hal. Ant. Rom. 8.51.2-52.2; Luc. Dial. Meret. 6.1-2; P. Brem. 63; Plaut. Cist. 105 y 120-145).

En estos casos, la vejez se convierte en un arma de doble filo, ya que puede ser usada tanto para resaltar la autoridad que aportan los años como para aludir a la debilidad física y al desamparo económico que en Roma se asociaban a la vejez, y conseguir así los objetivos propuestos.

Los textos clásicos también aluden a otras emociones sentidas por vetulae. La abuela que en el 143 a.C. asesinó a sus nietos lo hizo movida por el odio que sentía

\footnotetext{
${ }^{416} T$ (itus) Truppicus T(iti) f(ilius) Papiria T(iti) f(ilia) Tertia / cernis ut orba meis hospes monumenta locavi / et tristis senior natos miseranda requiro / exemplis referenda mea est deserta senectus / ut steriles vere possint gaudere maritae / T(itus) Truppicus T(iti) f(ilius) f(ecit).
} 
hacia su hija (Val. Max. 8.1). El odio es también la emoción que caracteriza a las suegras, centrado en este caso en sus nueras (Ter. Hec. 230 y 240). Calpurnia Hispula profesa a su sobrina un amor comparable al de una madre (Plin. Ep. 8.11). La anciana que narra la historia de Psique y Cupido siente miedo por el daño que puedan hacerle los ladrones (Apul. Met. 4.7). Meroe se siente despechada y sola por cómo la trata su amante: "Ahora, menospreciando mi amor, no sólo me difama con sus calumnias, sino que incluso se dispone a huir de mi lado. Mientras tanto yo, convertida sin duda en una nueva Calipso, abandonada por la astucia de Ulises, lloraré mi eterna soledad" (Apul. Met. 1.12 $)^{417}$. La nodriza de Mirra, que impide su suicidio, se horroriza ante su deseo incestuoso, pero también siente un amor incondicional que hace que la ayude en su propósito (Ov. Met. 10.382-401). La liberta Teeus escribe una carta a Apolonios, hermano de su yerno, en la que expresa su afecto por él y la ansiedad que le produce su ausencia (P. Giss 17).

En algunos pasajes podemos acceder a los deseos de las vetulae. Matrinia, Vetustila, y otras ancianas a las que hemos hecho referencia a lo largo de las anteriores páginas expresan sus deseos sexuales, despertando el rechazo de los varones con quienes desean relacionarse (Mart. 3.32, 3.93 y 7.75; Priap. 12). De la misma forma, durante el juicio a Apuleyo se hace alusión a la sexualidad de Pudentila, cuestionándose su legitimidad: "luego se han presentado contra mí (...) el hecho de que se ha casado, a pesar de tener sesenta años, para satisfacer su sensualidad" (Apul. Apol. 67) ${ }^{418}$. En este mismo contexto se hace referencia a una carta escrita por Pudentila, en la que manifiesta su amor por Apuleyo (Apul. Apol. 81). No podemos saber qué pensaba la aludida respecto a esta exposición pública a sus sentimientos, la cual como señala María José Hidalgo (2011: 215) es cuanto menos desconsiderada, pero probablemente el juicio en general, y la alusión a sus asuntos más íntimos en particular, no fueran de su agrado.

Nos encontramos, en definitiva, con que las vetulae percibían su propia vejez y la forma en la que la sociedad las veía de formas muy distintas, que varían según las circunstancias personales. El cuerpo envejecido se convertía en fuente de preocupación, como ocurre en todas las sociedades patriarcales, ya que a medida que las romanas cumplían años su aspecto comenzaba a alejarse del ideal establecido y generaba la

\footnotetext{
${ }^{417}$ hic qui meis amoribus subterhabitis non solum me diffamat probris verum etiam fugam instruit. At ego scilicet Ulixi astu deserta vice Calypsonis aeternam solitudinem flebo.

${ }^{418}$ deinde sexagesimo anno aetatis ad lubidinem nubsisse.
} 
repulsa masculina. En algunos casos, al erotismo se sumaba la posible pérdida económica, que angustiaría a las vetulae más pobres. De la misma forma, es probable que una esclava que viera cómo la edad y el trabajo comenzaban a modelar su cuerpo se sintiera preocupada por qué le depararía el futuro si en algún momento ya no era capaz de desempeñar un oficio. Otras vetulae, por el contrario, convirtieron su vejez en una ventaja, tanto para ganar prestigio como para exigir obediencia o cumplir con sus objetivos.

\section{IV.5. CONCLUSIONES}

A lo largo de este Capítulo IV hemos analizado las dos dimensiones eminentemente subjetivas de la vejez: la dimensión social y la sentida. Se ha visto cómo en la literatura, la mayoría de las veces las vetulae aparecen mencionadas ocupando papeles secundarios, siempre en relación con otros personajes, generalmente masculinos: esposas, madres, abuelas, servidoras fieles, cómplices de los jóvenes amantes... En el ámbito familiar, son figuras en quienes se mezclan el afecto y la severidad. La ancianidad no las exime de encargarse de las tareas de cuidado y del mantenimiento doméstico, sean esclavas o libres, pobres o ricas. Ello comporta una tarea que tiene contrapartidas positivas, como la reverencia que las abuelas y las nutrices reciben de quienes están bajo su vigilancia, pero también negativas, como la enfermedad mortal Fania.

Fuera del espacio doméstico, hemos visto cómo las vetulae ejercían todo tipo de oficios, desde la tenencia de propiedades agrícolas y negocios, hasta otros que pasarían factura al cuerpo envejecido, como la prostitución y la minería. Algunas, aquellas que pertenecían a la élite propietaria, podían incidir incluso en la trama urbana mediante acciones evergéticas que les harían ganarse el favor del pueblo, al que también contentarían a través de donaciones. Incluso hemos visto a vetulae influyendo en política, ya sea a través de sus familiares, como Vetustila y Sulpicia, o de forma autónoma, como Umidia Cuadratila. Para otras, en cambio, la vejez no tuvo un cariz tan positivo, obligándolas a ejercer la mendicidad o a prostituir a sus propias hijas. Las fuentes nos muestran así dos caras opuestas de la vejez, demostrando cómo ésta no sólo se ve condicionada por el género, sino también por la clase social.

La experiencia ganada, tanto en lo privado como en lo público, revestía a las ancianas con el halo de la gravitas y las convertía en fuente de auctoritas, otorgándoles 
una enorme influencia sobre sus familiares, pero también en aquellos casos en los que la posición social lo permitiese sobre el propio Estado. Incluso Tiberio se vio obligado a aceptar la autoridad de su madre Livia. En general, se percibe que las vetulae tenían una alta capacidad de decisión en el seno familiar y gran libertad de movimiento y actuación, lo cual podría deberse tanto al prestigio propio de la vejez como a que la sociedad ya no necesitaba controlarlas en cuanto que cuerpos no reproductores.

En el presente capítulo hemos visto también cómo en la antigua Roma existieron diversos estereotipos negativos -bruja, lena, anus ebria, esposa dominante, vetula astuta-, la conjunción de los cuales consigue crear un tipo de personaje que Yolanda Beteta ha denominado "monstruo femenino":

"La carencia de instinto maternal, la atracción por la muerte, la nocturnidad y los conocimientos guerreros convierten a los monstruos femeninos en símbolos transgresores. Los monstruos femeninos representan los valores opuestos al ideal patriarcal de feminidad y proyectan las supuestas debilidades y maldades que las mujeres pueden desatar de manera consciente o inconsciente" (Beteta, 2014: 294).

Se trata de un personaje arquetípico que al varón romano le resulta desconcertante y preocupante, ya que, en cuanto que mujer poderosa, "representa la inversión de los roles de género, (...) genera desórdenes sociales; es decir, actúa como agente desestabilizador" (Cid, 2014: 181). De esta forma, al no cumplir con el rol que se les asignó en sociedad en cuanto que mujeres, las vetulae se situaban en una especie de limbo, ya que los hombres no sabían dónde ubicarlas, lo que a su vez provocaba el miedo a la independencia que habían adquirido algunas de estas mujeres, solteras, viudas o divorciadas que manejaban un gran patrimonio y que no dependían para ello de ningún hombre (LaFosse, 2011: 133; Pudsey, 2012: 158). Mujeres que controlaban a su familia, atentando de esta forma contra uno de los pilares de la sociedad romana.

La forma que el romano tenía de combatir el poder de las vetulae era recurrir a la violencia, legitimada en cuanto que las ancianas suponían una amenaza para la jerarquía patriarcal. Esta violencia se ejerció tanto de forma directa, recurriendo a la agresión física, como de forma simbólica, mediante la creación de los estereotipos ya mencionados y el ataque a los mismos en la literatura. Vemos por ejemplo cómo el personaje de la bruja repulsiva que altera el orden natural aparece en época augustea, lo que puede interpretarse como una reacción masculina a una situación, que se venía fraguando desde época tardorrepublicana y se aprecia con claridad durante el Imperio, 
en la cual las mujeres de la élite adquieren autonomía y entidad propias y se convierten en agentes en el ámbito público. Si bien la familia a la que pertenecen sigue siendo clave en la imagen pública que proyectan, les son concedidos honores exclusivos que muchas veces provienen de sus acciones individuales, como ocurre con las madres de ciudades. Honores que además están ligados al ciclo vital, a la sabiduría y la auctoritas que se ganan con el paso del tiempo; de ahí que la vetula sea vista como especialmente peligrosa.

Tanto en el ámbito privado como en el público, las vetulae ostentaban ese "poder integrador" que Cándida Martínez atribuye a la materfamilias, entendido como la "capacidad de construir organizaciones, de formar familias y grupos, de inspirar lealtad y de unir gente a través del respeto, el amor, la compasión, etc. hacia el grupo familiar, los hijos, la patria o cualquier manifestación social o cultural” (Martínez, 2012: 157). Vetulae como Veturia, Sulpicia o la anciana que vive con los ladrones en Metamorfosis, se nos presentan como mujeres serenas, que ponen freno a la agresividad masculina mediante su actitud calmada y su auctoritas, al tiempo que tratan de favorecer a otras mujeres, tanto si éstas son conocidas, como Valeria y el resto de matronae que forman la comitiva contra Coriolano, como desconocidas, como Hispula y la joven secuestrada. Además, a lo largo de las anteriores páginas hemos visto cómo las fuentes literarias dejan entrever el papel de las vetulae como transmisoras de sabiduría. Una transmisión empleada con dos fines. Por un lado, el cuidado de los niños y las jóvenes. Las familias depositarían su confianza en las ancianas para la educación de sus hijos, encargándose éstas de las primeras etapas del aprendizaje infantil.

Por otro lado, la enseñanza de saberes que podían resultar peligrosos. La figura de la mala cuidadora se convirtió en un recurso literario que servía para señalar la corrupción de los tiempos, dejando las madres el cuidado de la descendencia a otras mujeres, a las que se asociaba con la magia, lo grotesco y lo marginal. Las ancianas enseñaban a las mujeres a cuidarse entre ellas, a enfrentarse a las amenazas que en ocasiones suponían los hombres, y a enfrentarse a las normas que les imponía el patriarcado, pervirtiéndolas e impidiendo que se comportasen como perfectas matronae. A este respecto, hemos visto cómo los poetas atacaban a las ancianas que daban consejos amorosos a las mujeres jóvenes, haciéndolas menos dóciles a las manipulaciones masculinas. La vetula se erige en la antigua Roma como una figura transmisora del folklore y las costumbres, así como depositaria de la sabiduría femenina 
y la memoria familiar. La anciana guarda las tradiciones y se las inculca a las generaciones futuras, pero al mismo tiempo es capaz de romperlas con sus conocimientos subversivos.

Además de analizar la imagen de la vejez femenina existente en la sociedad romana, el presente capítulo tenía como objetivo acercarse a la percepción que de sí mismas tenían las vetulae. Una tarea que nos ha resultado dificultosa por la naturaleza de las fuentes a nuestra disposición. Hemos visto cómo las ancianas romanas sentían su vejez de muy diversas formas, y cómo esta percepción se veía alterada por las circunstancias personales de cada vetula. A pesar de que el nuestro ha sido un acercamiento preliminar al estudio de la vejez sentida en las sociedades pasadas, necesario para completar las cuatro perspectivas o dimensiones desde las que hemos abordado la vejez femenina de la antigua Roma, creemos que se trata de un área de estudio en la que debe profundizar la historiografía. 


\section{CONCLUSIONES}

Las anteriores páginas han supuesto un viaje que hemos realizado en compañía de más de 300 vetulae. A ellas, y a las fuentes que nos las presentan, les hemos planteado diversas preguntas que nos han permitido ahondar en el conocimiento de la vejez femenina en la antigua Roma: ¿Quiénes eran las vetulae? ¿Cómo afectaba a una mujer romana alcanzar la vejez? ¿Qué cambios se producían en su identidad como mujer, como esposa, como madre...? ¿De qué manera eran percibidos esos cambios en el conjunto de la sociedad? ¿Cómo era el día a día de las vetulae? ¿Cómo se sentían con respecto a su vida?

En este largo proceso, hemos contado con la ayuda de las directrices metodológicas proporcionadas por la historiografía, la gerontología y el feminismo. La más que asentada Historia de las Mujeres y de las Relaciones de Género, y la incipiente Historia de la Vejez, así como la Gerontología Feminista, han sido los cimientos desde los que hemos construido nuestra Tesis Doctoral. De ello hemos dejado constancia en el recorrido historiográfico y en el apartado metodológico del Capítulo I. Puntualmente, hemos acudido también a la Historia de las Emociones.

Con todas estas herramientas a nuestra disposición, nos hemos propuesto encontrar en las fuentes respuestas a las preguntas planteadas unas líneas más arriba. Los documentos literarios, epigráficos, materiales e iconográficos en los que hemos rastreado la presencia de vetulae abarcan un marco cronológico amplio. Analizar la imagen que los escritores antiguos transmiten de la vejez femenina y la intencionalidad con que lo hacen sirve para adentrarnos en las normas de edad y de género de la sociedad romana. Así, las fuentes literarias nos han posibilitado conocer a las mujeres de la Roma antigua, pero también a los hombres de la élite romana. De la misma forma, los aparentes errores o falsedades en las edades de fallecimiento del registro epigráfico, junto a los fragmentos literarios en los que aparecen cifras que resultan sospechosas, nos han llevado a cuestionarnos cómo medían el tiempo las sociedades antiguas y cómo nuestro propio edadismo nos empuja a descartar posibilidades que no por estadísticamente improbables son imposibles. 
Previamente al análisis de las vetulae, consideramos necesario plantear un capítulo en el que se conceptualizase la vejez romana y se apuntasen algunos de los aspectos en los que íbamos a profundizar en los siguientes apartados. Además, hemos definido las cuatro dimensiones que para la Sociología Gerontológica tiene la vejez cronológica, física, psicológica y social-, las cuales nos han servido de eje articulador de nuestra investigación, no sin alguna leve modificación.

Por otro lado, el Capítulo II ya plantea aspectos como la centralidad del cuerpo como definitorio de la ancianidad en la antigua Roma, la importancia de la familia como foco de cuidados y socialización, la relevancia otorgada a la autonomía, y la estrecha relación simbólica que guardaban vejez y muerte. Además, se muestra cómo en Roma no era lo mismo envejecer siendo hombre o mujer, rico propietario o esclava, teniendo una salud de hierro o padeciendo demencia.

El grueso de nuestra investigación comienza en el Capítulo III. En él hemos señalado cómo la biología, y en concreto la capacidad de procreación y la función que ésta cumplía en el Estado romano, servía para organizar el ciclo vital de las romanas en tres etapas fundamentales: antes, durante y después de la fertilidad. Por ello a continuación hemos abordado el cuerpo de la vetula partiendo de la menopausia como fenómeno intrínsecamente relacionado con la vejez femenina. Hemos elaborado también un catálogo de las diversas patologías y condiciones físicas y mentales que afectaron a las vetulae, combinando las fuentes escritas con los restos óseos.

Siendo conscientes de que la vejez es también un fenómeno visual, hemos acudido a los textos y a la iconografía para analizar cómo era mostrado el aspecto físico de las viejas romanas, y cómo los mismos rasgos físicos podían ser interpretados como signo de dignidad y de marginalidad. El cuerpo de las vetulae se transformaba en abyecto, en fuente de repulsa, cuando era visto en situaciones de transgresión, sobre todo si ésta tenía tintes eróticos. Un cuerpo que debía se aséptico, tan alejado del atractivo sexual de las mujeres jóvenes, sufría un horrible castigo cuando se mostraba sensual, atacado al transgredir tanto las normas de género como las de edad.

El Capítulo IV nos ha permitido observar a las vetulae desde múltiples perspectivas: como mujeres viejas, como parte de una familia, como trabajadoras, como personas que se movían en los márgenes de lo establecido, y como entes individuales que se veían afectados por su entorno. En la familia romana, las vetulae ocupaban roles diversos y establecían todo tipo de relaciones que estaban marcadas por su edad, pero también por las condiciones en las que se había desarrollado su ciclo vital. Como 
encargadas de mantener la armonía familiar por ser mujeres y por la experiencia adquirida, las madres, abuelas, tías, etc. poseían un poder integrador capaz de contener la violencia masculina y garantizar el correcto funcionamiento social. Pero al mismo tiempo, como seres distintos al varón de la élite y situados al margen de los conocimientos oficiales, eran capaces de poner en peligro el orden establecido mediante sus actuaciones, empleando tanto los cauces socialmente aceptados, como el evergetismo, como otros que no lo estaban, como la magia.

Desde el punto de vista historiográfico, tratar de conocer la vejez sentida de las vetulae nos ha supuesto un ejercicio estimulante. Siendo conscientes de las limitaciones de las fuentes disponibles para acceder a los sentimientos y pensamientos de las vetulae, especialmente la falta de noticias en primera persona, salvo algunas excepciones hemos tenido que conformarnos con analizar las emociones que los escritores antiguos adjudicaron a estas mujeres. Emociones que se nutrirían de la experiencia de estos hombres y de las relaciones que tuvieran con vetulae, pero que también están marcadas por estereotipos de género y edad.

Las fuentes literarias nos han permitido constatar la existencia en la Roma antigua de los 8 mitos sobre la vejez que permanecen en las sociedades actuales. El mito de la edad biológica se aprecia tanto en los textos médicos y filosóficos como en el epistolario y la poesía. En general, y salvo excepciones como Cicerón, la sociedad romana veía la vejez como una enfermedad incurable e inevitable, que padecía todo ser humano como consecuencia del paso del tiempo. Esta visión de la ancianidad propicia la existencia del segundo mito, el de la mala salud, la cual conducía a una progresiva dependencia que en ocasiones era mejor evitar recurriendo al suicidio. Hemos visto también cómo la literatura caracteriza a vetulae y senes como personas egoístas, avariciosas, mezquinas, difíciles de aguantar, viviendo una segunda infancia que se remarca empleando un vocabulario común para ambas etapas vitales, cumpliendo así con el mito de la senilidad. Algunos escritores, como Cicerón, trataron de combatir el mito del declive intelectual demostrando que en la vejez podían aprenderse cosas nuevas, y hemos visto cómo a menudo las vetulae son descritas como mujeres sabias. No obstante, también son frecuentes las alusiones a la pérdida de facultades mentales y a la afición por la conversación sin sentido. El mito de la pobreza lo personifican varias de las vetulae que se han presentado a lo largo del texto. Se trata de mujeres que ya no son económicamente productivas y que dependen de su familia para obtener un 
sustento, pudiendo caer en la mendicidad. Algunas ancianas, pertenecientes a todos los estratos sociales, recuerdan a sus descendientes que haberlos criado exige en contrapartida que éstos les proporcionen una vejez tranquila, un seguro que en el Egipto romano llegó a ponerse por escrito. En cuanto al mito de la jubilación, hemos señalado cómo para la antigua Roma éste sólo podía aplicarse a las personas económicamente pudientes, especialmente a los varones que decidían apartarse de los asuntos públicos retirándose a sus villas campestres, como también hicieron algunas viudas como Cornelia. Si bien el mito del aislamiento social se cumple en cuanto que en la sociedad romana existían comportamientos edadistas que marginaban a las personas ancianas, la costumbre de mantener relaciones de amistad intergeneracionales y la importancia de la familia, en la que convivirían personas de diferentes edades, propició que este mito tuviera una incidencia menor que la que tiene en la actualidad. Finalmente, el mito del conservadurismo se aprecia en la existencia de conflictos generacionales, y sería probablemente visible en debates políticos como los del Senado, los cuales no tienen cabida en nuestra investigación por estar las mujeres excluidos de ellos.

El teatro, la sátira, la poesía, incluso en ocasiones las cartas personales, consideraban la vejez y las características que le atribuían objeto de burla. En una sociedad en la que ser vieja, alcohólica, o padecer algún tipo de enfermedad incapacitante podía ser considerado un hecho gracioso, cabe esperar que la situación de las vetulae más económica y socialmente desfavorecidas fuera marginal. De ahí que se considerase habitual intentar ocultar la edad que se tenía mintiendo sobre la cifra o aplicando cosméticos sobre el cuerpo envejecido. Una vez marginadas, resultaba fácil deshumanizarlas, lo que posibilitaba el empleo de la violencia como estrategia de control e imposición de un modelo de vejez asexual, dedicada al cuidado de los integrantes más jóvenes de la familia en el hogar.

A lo largo de nuestra investigación hemos comprobado cómo entre las vetulae existía una variedad de situaciones comparable a la diversidad de vejeces de las mujeres actuales. Nos hemos encontrado con vetulae muy ricas a quienes la vejez parece condicionar más bien poco, si no es porque van ganando en autoridad y libertad, ya que continúan realizando las mismas actividades económicas, familiares y de ocio que hacían siendo adultas. Al disfrutar de una buena salud, el día a día de mujeres como Cornelia, Livia o Cuadratila no se vio alterado en la ancianidad y conservaron el reconocimiento de la comunidad. Si la salud fallaba, podían sufragar los gastos médicos 
y recurrir al personal esclavo para trasladarse, vestirse, alimentarse, etc. En el caso de las vetulae de la clase trabajadora, su situación dependía no sólo de su estado de salud, el cual les permitiría o les impediría seguir desempeñando su oficio -o cambiando a otro más adecuado a sus capacidades físicas-, sino también del apoyo familiar, factor clave tanto para proveer de cuidados médicos como para evitar la pobreza. En lo que respecta a las esclavas, las condiciones en las que vivieron su vejez dependían de sus propietarios, y estaban expuestas a posibles ventas y al abandono. Si bien la pietas y algunas disposiones legales proporcionaban cierta seguridad en la vejez, hemos presentado casos de vetulae que vivieron situaciones de extrema pobreza $\mathrm{y}$ marginalidad, las cuales podían conducir a la muerte.

La mayoría de las veces, en la literatura las vetulae aparecen como personajes secundarios: madres, abuelas, nutrices... Si conocemos a Veturia es porque es una pieza clave en el fin del conflicto entre Coriolano y Roma, y si Plinio hace referencia a Umidia Cuadratila es porque quiere resaltar las cualidades morales de su amigo Umidio, como también hace con Serrana Prócula. Las vetulae presentadas en otros textos no dependen de un personaje principal, pero se trata de mujeres que, al contrario de las anteriores, no son respetables, sino seres grotescos y peligrosos. Las convenciones epigráficas no permiten individualizar en demasía a las vetulae que aparecen en ellas, si bien epitafios como los de Julia Agele y Papiria Tertia nos han ayudado a profundizar en el papel económico y en los sentimientos de las ancianas romanas.

En todos los periodos de la historia romana existió un estereotipo de vetula en el que confluyen diversos rasgos, tanto negativos como, en menor medida, positivos, que podemos rastrear en la literatura y en el arte. Si bien la figura de la bruja vieja vive su momento más popular a finales del siglo I a.C. y principios del siglo I d.C., lo que puede interpretarse como una reacción masculina a la mayor libertad que adquirieron las romanas a partir de época tardorrepublicana, el rechazo hacia determinados comportamientos de las vetulae se repite a lo largo del tiempo. Esposa y suegra molesta, maga, alcohólica, charlatana, avariciosa, sexualmente insaciable... la vieja que aparece en las fuentes tiene tanto una dimensión real como otra simbólica. Percibimos a vetulae trabajadoras, tanto libres como esclavas, algunas de ellas extremadamente pobres, junto a otras que poseen un rico patrimonio que les permite obtener una posición socialmente preeminente para sí mismas y para sus familiares y amistades, participando de la vida pública de su comunidad. La suegra del teatro y la sátira, dispuesta a hacer el mal, poco 
parece tener en común con Pompeya Celerina, cuya relación con su yerno Plinio era especialmente estrecha; del mismo modo, la armonía matrimonial que se percibe en parejas como la de Livia y Augusto o Baucis y Filemón tiene su contrapunto en los senes que deseaban asesinar a sus esposas o en las hermanas de Psique, que odiaban a sus ancianos maridos. De la misma forma, el consumo de vino por parte de las vetulae adquiere en las fuentes diversos matices; asociado al ámbito religioso o consumido como consuelo a una mala vejez, no obstante casi siempre conduce a la ruptura con la feminidad normativizada por el patriarcado romano.

Junto a vetulae que realizaban acciones imposibles, como controlar las estrellas y resucitar cadáveres, las fuentes nos muestran a otras ancianas más reales, que emplearon la sabiduría con diversos fines. Una sabiduría que habían adquirido gracias a la experiencia dada por los años vividos y a los conocimientos transmitidos por otras mujeres. La Loba/Huesera de la leyenda con la que abríamos esta Tesis Doctoral bien pudo vivir en la Roma del siglo I a.C. o el África romana del siglo II d.C. y llamarse Canidia, Dipsas, o avia Tértula. La Loba recoge huesos -conocimientos, leyendas, ingredientes, jóvenes inexpertas-, piezas del pasado o mujeres del presente hechas metafóricamente añicos, y los reconstruye -memoriza, mezcla, cuida- mediante canciones -palabras, narraciones, tejidos, enseñanzas, consejos. Esos huesos reconstruidos y convertidos en una loba-mujer se transforman, tras pasar por la magia de la vieja, en seres libres, poderosos, que han adquirido una identidad propia, en ocasiones no normativa y con la capacidad de transgredir el orden patriarcal. Huesos, metamorfosis animales, muerte y liminalidad son constantemente aludidos en las fuentes que nos hablan de las vetulae, simbolizando cómo estas ancianas, y las mujeres sobre las que intervinieron, traspasaron las fronteras de lo admitido por el mos maiorum, de su identidad genérica y etaria, para convertirse en seres peligrosos que amenazaban la hegemonía masculina empleando sus artes femeninas; en definitiva, su inteligencia.

Para contrarrestar este poder, hemos visto cómo los varones se servían de la violencia -verbal, física y simbólica- contra las vetulae. Una violencia que debía ser normalizada, de forma que fuera interiorizada por el conjunto de la sociedad, incluidas las propias ancianas, entrando a formar parte del subconsciente colectivo.

Presentadas las conclusiones a las que hemos llegado en nuestra investigación, nos gustaría poner punto y final a esta Tesis Doctoral haciendo referencia a las vías de futuro que parten de la misma. El objetivo de nuestro trabajo ha sido tratar de 
conceptualizar la vejez femenina en la antigua Roma atendiendo a cuatro dimensiones cronológica, física, social y sentida-, las cuales a su vez abarcan aspectos dispares y amplios. Ello nos ha obligado a abordar algunos temas de forma general, favoreciendo la visión de conjunto que buscábamos para la investigación. Por ello, somos conscientes de que algunos aspectos de la vejez femenina que se han tratado en las páginas anteriores son en sí mismos temas que podrían ser fruto de un trabajo de doctorado.

Es el caso del cuerpo de la vetula, que debe ser estudiado en mayor profundidad tanto desde el punto de vista médico como simbólico, incidiendo en cómo le afectan las variables de género -comparándolo con el cuerpo de los senes- y edad -comparándolo con el cuerpo de las romanas de otras edades. La cuestión de la dependencia y de cómo ésta afectaba a las vetulae supone también un campo de estudio con grandes posibilidades.

En lo que respecta a la dimensión social, tanto el papel de la vetula en el ámbito familiar como su injerencia económica son temas con amplia proyección de futuro, sobre todo si, intuimos, se ahonda en las fuentes epigráficas. En este sentido, resulta necesario establecer las diferencias y similitudes existentes entre las ancianas provenientes de diversos estratos sociales. De la misma forma, un repaso a los estereotipos de ancianidad, en el que se pongan en relación las fuentes escritas y el arte, nos parece prometedor.

Vemos por lo tanto como la presente investigación ha supuesto un viaje que lejos de haber llegado a su final promete ampliaciones futuras. 


\section{ANEXOS}

\section{ANEXo 1: FiCHAS DE LAS VETULAE MENCIONADAS EN EL TEXTO}

A continuación presentamos a las vetulae mencionadas a lo largo del texto. Hemos optado por ordenar los registros alfabéticamente, por lo que aparecen intercaladas mujeres de distintas épocas. En caso de no conocer la edad de la muerte, ya sea exacta o aproximada, reflejamos el número más alto de años vividos que mencionan las fuentes. En cuanto a la cronología, cuando no se conoce de forma exacta hemos tratado de inferirla a partir del texto, o bien hemos tomado como referencia la época de la fuente. Incluimos además las páginas de la Tesis Doctoral en las que aparece cada vetula.

En la siguiente lista mencionamos tanto a mujeres históricas como a otras puramente literarias. Hemos optado por presentarlas juntas porque en ocasiones es difícil distinguir si una vetula perteneció a una categoría u otra. Canidia pudo haber sido una mujer real o un personaje inventado por Ovidio; de la misma forma, la historicidad de ancianas como Veturia no es segura.

\begin{tabular}{|c|l|l|l|l|}
\hline NOMBRE & FECHA & EDAD & \multicolumn{1}{|c|}{ FUENTE(S) } & PÁGINAS \\
\hline 2481B & s. I d.C. & Senil & $\begin{array}{l}\text { García Prósper y Polo, } \\
\text { 2003: 305 }\end{array}$ & 153 \\
\hline Acántide & s. I a.C. & - & Prop. 4.5 & $\begin{array}{l}314, \quad 315, \\
323,341\end{array}$ \\
\hline Acerra & s. I d.C. & - & Mart. 1.28 & 297 \\
\hline Aelia Secundula & 299 d.C. & 75 & CIL 8.20277 & 229 \\
\hline Albatia Sabina & $27 / 26$ a.C. - & 100 & Phl. 44 & 383 \\
\hline Alejandra & s. I d.C. & - & Suet. Ner. 42? y 50 & 272 \\
\hline Anna Calediga & - & 80 & CIL 2.6299 & 252 \\
\hline Anna Perenna & - & - & $\begin{array}{l}\text { AE 1925, 82, 2003, 252 } \\
\text { y 2003, 253; CIL } \\
6.2299 \text { y 6.2301; Ov. } \\
\text { Fast. 3.135, 3.525-655 }\end{array}$ & 165,301 \\
\hline
\end{tabular}




\begin{tabular}{|c|c|c|c|c|}
\hline & & & $\begin{array}{l}\text { y 3.663-695; Var. Sat. } \\
\text { Men. } 506\end{array}$ & \\
\hline Anónima & - & - & Cod. Iust. 5.12 .6 & 240 \\
\hline Anónima & - & - & Cod. Iust. 7.60 .2 & 240 \\
\hline Anónima & - & - & Hor. Sat. 2.5.25-105 & 264 \\
\hline Anónima & - & - & Priap. 12 & $\begin{array}{l}142, \quad 146, \\
169, \quad 186, \\
283,253\end{array}$ \\
\hline Anónima & - & - & Priap. 57 & $\begin{array}{l}60, \\
171\end{array}$ \\
\hline $\begin{array}{l}\text { Anónimas (devotas de } \\
\text { Liber) }\end{array}$ & - & - & Var. $L 6.14$ & 305 \\
\hline Anónima & s. IV a.C. & - & Aesop. 57 & 337 \\
\hline Anónima & ss. III - II a.C. & - & Plaut. Aul. 162-165 & 186 \\
\hline Anónimas & ss. III - II a.C. & - & Plaut. Mostell. 275-280 & $\begin{array}{l}142, \quad 171, \\
259\end{array}$ \\
\hline Anónima & 150 a.C. & - & $\begin{array}{lrrr}\text { Plin. } & N H \quad 7.36 ; & \text { Val. } \\
\text { Max. 5.4.7 } & \end{array}$ & 225 \\
\hline Anónima & 143 a.C. & - & Val. Max. 8.1.c1 & 242 \\
\hline Anónima & s. II a.C. & - & Lucil. 7.196 & 151,212 \\
\hline Anónima (nutrix) & s. II a.C. & - & Lucil. Fr. 955 & 271,332 \\
\hline Anónima (prostituta) & s. II a.C. & - & Lucil. 9.256-258 & $\begin{array}{l}151, \quad 190, \\
325\end{array}$ \\
\hline Anónima & 59/58 a.C. - & 132 & Plin. NH 7.49.162-164 & 59,71 \\
\hline Anónima & 47/46 a.C. - & 120 & Phl. 95 & 383 \\
\hline Anónima & -18 a.C. & - & Val. Max. 2.6.8 & 119 \\
\hline Anónima & s. I a.C. & - & Cic. Scaur. 5-6 & 187 \\
\hline Anónima & s. I a.C. & - & Hor. Epod. 8 & $\begin{array}{ll}142, & 143, \\
166, & 167, \\
170, & 188, \\
189 & \end{array}$ \\
\hline
\end{tabular}




\begin{tabular}{|c|c|c|c|c|}
\hline Anónima & s. I a.C. & - & Hor. Epod. 12 & $\begin{array}{l}173, \quad 188, \\
190\end{array}$ \\
\hline Anónima & s. I a.C. & - & Hor. Sat. 2.1.54-57 & 267 \\
\hline Anónima & s. I a.C. & - & Prop. 2.18 .20 & $\begin{array}{l}91, \quad 146, \\
170,184\end{array}$ \\
\hline Anónima & s. I a.C. & - & Tib. $1.3 .85-90$ & $\begin{array}{l}100, \quad 273, \\
333,344\end{array}$ \\
\hline $\begin{array}{c}\text { Anónima (abuela de } \\
\text { Ático) }\end{array}$ & s. I a.C. & - & Cic. Att. 1.3 & 115,234 \\
\hline Anónima (bruja) & s. I a.C. & - & Tib. 1.5 & 314,343 \\
\hline $\begin{array}{l}\text { Anónima (bruja } \\
\text { sabelia) }\end{array}$ & s. I a.C. & - & Hor. Sat. 1.9.30-34 & $\begin{array}{l}319, \quad 331, \\
334,336\end{array}$ \\
\hline $\begin{array}{c}\text { Anónima (madre de } \\
\text { Delia) }\end{array}$ & s. I a.C. & - & Tib. $1.6 .57-65$ & 247 \\
\hline Anónima (tejedora) & s. I a.C. & - & Tib. $1.6 .75-85$ & 91,287 \\
\hline Anónimas (prostitutas) & s. I a.C. & - & Sall. Cat. 24.3-4 & 325 \\
\hline Anónima & ss. I a.C. - I d.C. & - & Ov. Ars am. 3.243-250 & 169 \\
\hline Anónima & ss. I a.C. - I d.C. & - & Ov. Fast. 6.399 & 336 \\
\hline Anónima & ss. I a.C. - I d.C. & - & Phaed. 2.2 & 216 \\
\hline Anónima (ciega) & ss. I a.C. - I d.C. & - & Sen. Contr. 7.4 & 150,279 \\
\hline $\begin{array}{l}\text { Anónima (nutrix de } \\
\text { Mirra) }\end{array}$ & ss. I a.C. - I d.C. & - & Ov. Met. 10.382-464 & $\begin{array}{l}273, \quad 343, \\
344\end{array}$ \\
\hline $\begin{array}{c}\text { Anónima (sacerdotisa } \\
\text { de Tacita Muta) }\end{array}$ & ss. I a.C. - I d.C. & - & Ov. Fast. 2.570-580 & 200 \\
\hline Anónima (suegra) & ss. I a.C. - I d.C. & - & Val. Max. 7.2 & 334 \\
\hline $\begin{array}{l}\text { Anónima (tía de } \\
\text { Séneca) }\end{array}$ & ss. I a.C. - I d.C. & - & Sen. Helv. 19.1-2 & 246 \\
\hline Anónimas & ss. I a.C. - I d.C. & - & Ov. Ars am. 2.665-700 & 191,351 \\
\hline Anónima & ss. I a.C. - III d.C. & +50 & $\begin{array}{l}\text { Minozzi et al., 2012: } \\
271\end{array}$ & 141,390 \\
\hline
\end{tabular}




\begin{tabular}{|c|c|c|c|c|}
\hline Anónima & s. I d.C. & - & Mart. 7.75 & 187 \\
\hline Anónima & s. I d.C. & - & Petron. Sat. fr. 21 & 297 \\
\hline Anónima (abuela o tía) & s. I d.C. & - & Pers. 2.30-34 & $\begin{array}{ll}243, & 319, \\
330, & 331, \\
334 & \end{array}$ \\
\hline Anónima (lena) & s. I d.C. & - & Petron. Sat. 6-8 & 325 \\
\hline Anónima (bruja) & s. I d.C. & - & Petron. Sat. 131 & 319 \\
\hline $\begin{array}{c}\text { Anónima (esposa de } \\
\text { Gelio) }\end{array}$ & s. I d.C. & - & Mart. 9.80 & 150,217 \\
\hline $\begin{array}{c}\text { Anónima (madre de } \\
\text { Vacerra) }\end{array}$ & s. I d.C. & - & Mart. 12.32 & 168,170 \\
\hline $\begin{array}{c}\text { Anónimas (abuela y } \\
\text { tía) }\end{array}$ & s. I d.C. & - & Pers. 2.30-34 & $\begin{array}{l}100, \quad 243, \\
319, \quad 330, \\
331,334\end{array}$ \\
\hline $\begin{array}{c}\text { Anónimas (amantes de } \\
\text { Baso) }\end{array}$ & s. I d.C. & - & Mart. 3.76 & 60,190 \\
\hline $\begin{array}{c}\text { Anónimas (amigas de } \\
\text { Fabula) }\end{array}$ & s. I d.C. & - & Mart. 8.79 & 172 \\
\hline Anónima & ss. I - II d.C. & - & Juv. $1.37-40$ & 259 \\
\hline Anónima & ss. I - II d.C. & - & Juv. 3.109-114 & 190 \\
\hline Anónima & ss. I - II d.C. & 86 & Juv. 6.190-199 & 188 \\
\hline Anónima (esclava) & ss. I - II d.C. & - & Juv. 6.495-500 & $\begin{array}{l}274, \quad 333, \\
337,344\end{array}$ \\
\hline $\begin{array}{l}\text { Anónima (esposa de } \\
\text { Domicio Tulo) }\end{array}$ & ss. I - II d.C. & - & Plin. Ep. 8.18 & $\begin{array}{l}107, \quad 214, \\
349\end{array}$ \\
\hline $\begin{array}{c}\text { Anónima (nutrix de } \\
\text { Plinio) }\end{array}$ & ss. I - II d.C. & - & Plin. Ep. 6.3 & 273 \\
\hline Anónima (suegra) & ss. I - II d.C. & - & Juv. $6.230-240$ & 246,337 \\
\hline Anónimas (familiares) & ss. I - II d.C. & - & Tac. Dial. 28.5-6 & 197,272 \\
\hline $\begin{array}{l}\text { Anónima (hija de } \\
\text { Tasoucharion) }\end{array}$ & s. III d.C. & 56 & BF 201-Ar-9 & 229 \\
\hline
\end{tabular}




\begin{tabular}{|c|c|c|c|c|}
\hline Anónima & ss. I - III d.C. & +50 & $\begin{array}{l}\text { Minozzi et al., 2012: } \\
271\end{array}$ & 141,390 \\
\hline Anónima & ss. I - III d.C. & +50 & $\begin{array}{l}\text { Minozzi et al., 2012: } \\
274\end{array}$ & 153,390 \\
\hline Anónima & s. II d.C. & \pm 74 & Luc. Rhet. p. 24 & 190,262 \\
\hline Anónima (molinera) & s. II d.C. & - & Apul. Met. 9.15-31 & $\begin{array}{l}325, \quad 337, \\
343\end{array}$ \\
\hline $\begin{array}{l}\text { Anónima (nutrix de } \\
\text { Filinion) }\end{array}$ & s. II d.C. & - & Phl. Mir. 1 & 331 \\
\hline Anónima (bruja) & s. II d.C. & - & Apul. Met. 9.17-31 & 334,343 \\
\hline Anónima (bruja) & s. II d. C. & - & Luc. Dial. Meret. 4 & 324 \\
\hline $\begin{array}{l}\text { Anónima (esposa de } \\
\text { Herennio Rufo) }\end{array}$ & s. II d.C. & - & Apul. Apol. 74-76.2 & 265,287 \\
\hline Anónima (madrastra) & s. II d.C. & - & Apul. Met. 9.30-31 & 232 \\
\hline Anónima (posadera) & s. II d.C. & - & Apul. Met. 1.21 & 284 \\
\hline $\begin{array}{c}\text { Anónima (vetula que } \\
\text { convive con los } \\
\text { ladrones) }\end{array}$ & s. II d.C. & - & 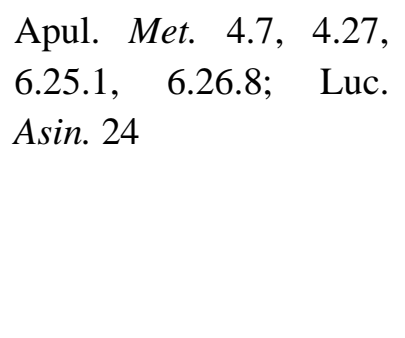 & $\begin{array}{ll}100, & 119, \\
124, & 146, \\
170, & 171, \\
193, & 296, \\
297, & 307, \\
328, & 334, \\
353 & \end{array}$ \\
\hline Anónimas & s. II d.C. & - & Luc. Am. 39-41 & 176 \\
\hline Anónimas (brujas) & s. II d.C. & - & $\begin{array}{l}\text { Apul. Met. 2.20-22 у } \\
2.30 .2\end{array}$ & $\begin{array}{l}124, \quad 176, \\
316\end{array}$ \\
\hline $\begin{array}{l}\text { Anónima (madre de } \\
\text { Isidoro) }\end{array}$ & 211 d.C. & - & P. Lond. 3.932 & 277 \\
\hline Anónima (bruja) & ss. III - IV d.C. & - & Heliod. Aeth. 6.12-15 & $\begin{array}{l}318, \quad 319, \\
352\end{array}$ \\
\hline Anónimas & ss. III - IV d.C. & - & Arn. Adv. Nat. 5.14 & 330 \\
\hline Anónima & s. IV d.C. & - & Amm. Marc. 29.2.26 & 307,314 \\
\hline Anónima & s. IV d.C. & - & $\begin{array}{l}\text { Auson. Protrept. ad } \\
\text { nep. } 2.18-20\end{array}$ & 272 \\
\hline
\end{tabular}




\begin{tabular}{|c|c|c|c|c|}
\hline Anónimas & 89 d.C. & - & Tac. Hist. 3.33 & 152 \\
\hline Antistia Plutia & - & - & CIL 6.2170 & 158 \\
\hline Antonia Caenis & s. I d.C. & - & $\begin{array}{l}\text { Cass. Dio 66.14; Suet. } \\
\text { Dom. } 13 \text { y Vesp. } 3 \text { y } 21\end{array}$ & 274 \\
\hline Antonia Máxima & - & 70 & $A E 1967,630$ & 252 \\
\hline Antonia Minor & 36 a.C. -37 d.C. & 73 & $\begin{array}{l}\text { Cass. Dio 60.2.4-5; } \\
\text { Suet. Calig. 10, } 15.2 \text { y } \\
\text { 23.2; Val. Max. 4.3.3 }\end{array}$ & $\begin{array}{ll}157, & 200, \\
234, & 243, \\
254, & 274, \\
279, & 291, \\
393 & \end{array}$ \\
\hline Antonia Secunda & 27/26 a.C. - & 100 & Phl. 43 & 383 \\
\hline Aquilia Julia & - & 75 & $A S P 2004,117,5$ & 234 \\
\hline Arelia Saturnina & - & 72 & $A E 1972,776$ & 204 \\
\hline Argentaria Verana & - & 65 & $A E 1993,903$ & 251,270 \\
\hline Arquilis & s. II a.C. & - & Ter. An. 227-235 & 284 \\
\hline Arria & -42 d.C. & - & Plin. Ep. 3.16.2-10 & $\begin{array}{l}204, \quad 242, \\
336\end{array}$ \\
\hline Artemona & ss. III - II a.C. & - & $\begin{array}{l}\text { Plaut. Asin. } 95 \text { y } 855- \\
895\end{array}$ & 209 \\
\hline Aucxina & ss. I - III d.C. & 100 & CIL 8.26736 & 234 \\
\hline Audiena & - & - & CIL 2.6188 & 251 \\
\hline Aurelia & - & - & CIL 5.1880 & 204 \\
\hline Aurelia Placentina & - & 60 & CIL 3.1229 & 270 \\
\hline Aurelia Rufina & - & \pm 70 & CIL 3.8936 & 74 \\
\hline Aurelia Titula & - & 70 & $A E 1986,548$ & 252 \\
\hline Aurelia Valentina & s. III d.C. & 77 & CIL 6.2774 & 251 \\
\hline Avita & - & - & CIL 2.813 & 234 \\
\hline Bascia & 27/26 a.C. - & 100 & Phl. 47 & 383 \\
\hline Baucis & - & - & Ov. Met. $8.630-720$ & $\begin{array}{l}201, \quad 344, \\
364\end{array}$ \\
\hline
\end{tabular}




\begin{tabular}{|c|c|c|c|c|}
\hline Baubo & - & - & $\begin{array}{l}\text { Arn. Adv. nat. 5.25-26; } \\
\text { Clem. Al. Protp. } 2.20\end{array}$ & 163,165 \\
\hline Bebia Marcella & 27/26 a.C. - & 100 & $\mathrm{Phl} .46$ & 383 \\
\hline Birria & s. I d.C. & 60 & $A E 1980,326$ & 271 \\
\hline Bonita & - & 71 & CIL 8.2906 & 252 \\
\hline Bourne 135 & ss. I - IV d.C. & +50 & Gowland 2017b & 152 \\
\hline Buria Lychnainis & 28/27 a.C. - & 101 & Phl. 74 & 383 \\
\hline Caesia Celsa & s. I d.C. & 75 & CIL 2.1699 & 284 \\
\hline Caiantia Sumaria & - & 80 & CIL 3.4755 & 204 \\
\hline Calpurnia Hispula & ss. I - II d.C. & - & $\begin{array}{l}\text { Plin. Ep. 4.19, } 8.11 \text { y } \\
10.120-121\end{array}$ & $\begin{array}{l}244, \quad 268, \\
353\end{array}$ \\
\hline Calvia Fortunata & s. III d.C. & 81 & $A E$ 1994, 466 & 70 \\
\hline Canidia & s. I a.C. & - & $\begin{array}{l}\text { Hor. Epod. } 5 \text { y } 17 \text { y Sat. } \\
1.8 \text { y } 2.1 .45\end{array}$ & $\begin{array}{ll}124, & 164, \\
175, & 293, \\
308, & 315, \\
319, & 320, \\
321, & 346, \\
364 & \end{array}$ \\
\hline Canuleia Tyche & - & - & CIL 6.20938 & 235 \\
\hline Casidia Clementina & s. II d.C. & - & $A E 1983,376$ & 252 \\
\hline Catia & 27/26 a.C. - & 100 & Phl. 18 & 383 \\
\hline Cecilia & $152-42$ a.C. & 90 & $\begin{array}{l}\text { Cic. Att. } 1.5 .8,1.7,1.8 \\
\text { у } 2.3 ; \text { Nep. Att. } 17\end{array}$ & 224,268 \\
\hline Cerelia & s. I a.C. & \pm 80 & $\begin{array}{l}\text { Cass. Dio 46.18.3-4; } \\
\text { Cic. Att. 12.51, 13.21a, } \\
\text { 13.22, 14.19, } 15.1 \text { y } \\
\text { 15.26 у Fam. } 13.72\end{array}$ & 186,214 \\
\hline Cereonia Verecunda & 28/27 a.C. - & 101 & Phl. 72 & 383 \\
\hline Chreste & 27/26 a.C. - & 100 & Phl. 57 & 383 \\
\hline Chrysion & 27/26 a.C. - & 100 & Phl. 58 & 383 \\
\hline Claudia & - & 75 & CIL 6.9720 & 234 \\
\hline
\end{tabular}




\begin{tabular}{|c|c|c|c|c|}
\hline Claudia Berus & s. I d.C. & 70 & $A E 2007,298$ & $\begin{array}{l}44, \quad 234, \\
344\end{array}$ \\
\hline Claudia Rogata & - & 75 & $A E 1981,934$ & 229 \\
\hline Cleéreta & ss. III - II a.C. & - & $\begin{array}{l}\text { Plaut. Asin. } 150-185, \\
205-210 \text { y } 505-540\end{array}$ & 326 \\
\hline Cleústrata & ss. III - II a.C. & - & Plaut. Cas. 171-196 & 269 \\
\hline Clodia & ss. II - I a.C. & 115 & Plin. $N H$ 7.48.158-159 & 59 \\
\hline Clodia Potestas & 28/27 a.C. - & 101 & Phl. 70 & 383 \\
\hline Clodia Rufina & - & - & CIL 2.4352 & 234,251 \\
\hline Cloris & s. I a.C. & - & Hor. Carm. 3.15 & 184 \\
\hline Cocnania Musa & 30/29 a.C. - & 103 & Phl. 78 & 383 \\
\hline Concordia & - & 80 & $A E 1906,117$ & 229 \\
\hline Corelia & ss. I - II d.C. & - & Plin. Ep. 7.11 & 268 \\
\hline Cornelia Escipión & $\begin{array}{l}\text { c. } 190 \text { a.C. }- \text { c. } \\
102 \text { a.C. }\end{array}$ & \pm 90 & $\begin{array}{l}\text { Nep. Fr. 2; Plut. } C \text {. } \\
\text { Gracch. } 19 \text { y Ti. } \\
\text { Gracch. 1.7; Val. Max. } \\
4.4\end{array}$ & $\begin{array}{ll}270, & 278, \\
280, & 282, \\
336, & 352, \\
362 & \end{array}$ \\
\hline Cornelia Publiana & s. III d.C. & - & CIL 6.1478 & 235 \\
\hline Cornelia Soteria & s. II d.C. & 85 & $A E 1980,518$ & 251 \\
\hline Crascentila & - & - & CIL 3.7458 & 252 \\
\hline Crisarion & s. II d.C. & - & Luc. Dial. Meret. 1 & 314 \\
\hline Cróbile & s. II d.C. & - & Luc. Dial. Meret. 6.1-2 & 227,352 \\
\hline Cusinia Moschis & 28/27 a.C. - & 101 & Phl. 71 & 383 \\
\hline Di() Anadri & - & $62 ?$ & CIL 3.10038 & 251 \\
\hline Dipsas & ss. I a.C. - I d.C. & - & Ov. Am. 1.8 & $\begin{array}{ll}166, & 168, \\
170, & 315, \\
323, & 337, \\
338 & \end{array}$ \\
\hline Domicia Longina & $\begin{array}{l}\text { c. } 50-60 \text { d.C. }- \\
126-140 \text { d.C. }\end{array}$ & \pm 80 & $\begin{array}{l}\text { Cass. Dio 67.15; CIL } \\
14.2795 \text { y } 15.548 .1- \\
15.550 .24 ; \text { Joseph. Vit. }\end{array}$ & 255,282 \\
\hline
\end{tabular}




\begin{tabular}{|c|c|c|c|c|}
\hline & & & 76; Suet. Dom. 14.1 & \\
\hline Doripa & ss. III - II a.C. & - & Plaut. Merc. 670-675 & 146,288 \\
\hline Duronia & s. II a.C. & - & Liv. 39.9-14 & 249 \\
\hline Dydimarion & s. II d.C. & - & P. Petaus 29 & 248 \\
\hline Ebucia & s. II a.C. & - & Liv. 39.9-14 & 249 \\
\hline Eclogea & s. I d.C. & - & Suet. Ner. 42 ? y 50 & 272 \\
\hline Elia Catela & c. 20 a.C. - & \pm 80 & Cass. Dio 62.19.1-2 & 285 \\
\hline Emilia Corintia Maura & s. IV d.C. & - & Auson. Par. 2 y 5 & 237 \\
\hline Emilia Hilaria & s. IV d.C. & 63 & Auson. Par. 6 & 244 \\
\hline Emilia Pudentila & s. II d.C. & $35-60$ & $\begin{array}{l}\text { Apul. Apol. 27.10, 66.1- } \\
2,67.3,68.2-69.3,73.3- \\
8, \quad 75.8,80.1,82-84, \\
85.4-7,87.689 .1-5, \\
92.3-7,98.1 \text { у } 99.3\end{array}$ & $\begin{array}{ll}217, & 219, \\
256, & 292, \\
338, & 349, \\
353 & \end{array}$ \\
\hline Escafa & ss. III - II a.C. & - & $\begin{array}{l}\text { Plaut. Mostell. 165-194, } \\
200-203, \quad 249-269 \text { у } \\
275-280\end{array}$ & $\begin{array}{l}151, \quad 166, \\
171,350\end{array}$ \\
\hline Escribonia & ss. I a.C. - I d.C. & \pm 80 & $\begin{array}{l}\text { Sen. Ep. 70.10; Tac. } \\
\text { Ann. } 2.27 .2\end{array}$ & 241,257 \\
\hline Esersythis & s. I d.C. & 70 & $B F 11-A r-1$ & 229 \\
\hline Estáfila & ss. III - II a.C. & - & $\begin{array}{l}\text { Plaut. Aul. 43, 90-95 y } \\
350\end{array}$ & 151,288 \\
\hline Estatilia & s. I a.C. & 99 & Plin. $N H$ 7.48.158-159 & 59 \\
\hline Eudaimonis & 117 d.C. & - & $\begin{array}{l}\text { P. Brem. 63; P. Giss. } \\
21,23 \text { у } 78\end{array}$ & $\begin{array}{l}235, \quad 249, \\
287,352\end{array}$ \\
\hline Fescennia & s. I d.C. & - & Mart. 1.87 & 297 \\
\hline Filenis & s. I d.C. & - & Mart. 2.33 y 9.62 & $\begin{array}{ll}168, & 170, \\
323 & \end{array}$ \\
\hline Filis & s. I d.C. & - & Mart. 11.29 y 12.65 & 192,297 \\
\hline $\begin{array}{l}\text { Filis (nutrix de } \\
\text { Domiciano) }\end{array}$ & s. I d.C. & - & Suet. Dom. 17 & 272 \\
\hline
\end{tabular}




\begin{tabular}{|c|c|c|c|c|}
\hline Filomena & s. I d.C. & - & Petron. Sat. 140 & 263 \\
\hline Flavia & - & 50 & CIL 3.8350 & 271 \\
\hline Flavia Apama & - & 50 & $A E 1985,920$ & 253 \\
\hline Flavia Dativa & - & 60 & CIL 8.11586 & 271 \\
\hline Flavia Venusta & - & 123 & CIL 8.11494 & 229 \\
\hline Folia & s. I a.C. & - & Hor. Epod. 5 & 312 \\
\hline Fortunata & - & 61 & CIA 28 & 270 \\
\hline Gala & s. I d.C. & - & Mart. 2.34 y 9.37 & $\begin{array}{l}186, \quad 170, \\
172,186\end{array}$ \\
\hline Galeria & - & 97 & CIL 6.18860 & 270 \\
\hline Galeria Copiola & 95 a.C. -9 d.C. & +104 & Plin. NH 7.48.158-159 & 284 \\
\hline Garcilia & - & 80 & CIL 8.1213 & 252 \\
\hline Gaza & 27/26 a.C. - & 100 & Phl. 56 & 383 \\
\hline Haynchis & s. III d.C. & - & P.Lond. 7.1976 & 351 \\
\hline Heliodora & s. III d.C. & - & P. Mich. III 217 & 248 \\
\hline Helvia & ss. I a.C. - I d.C. & - & Sen. Helv. 18 & 234 \\
\hline Isarous & s. II d.C. & 70 & BF 117-Ar-1 & 257 \\
\hline Julia Agele & - & 80 & CIL 6.9855 & 270,284 \\
\hline Julia Catafronia & s. IV d.C. & - & Auson. Par. 26 & 244 \\
\hline Julia Driadia & s. IV d.C. & 60 & Auson. Par. 12 & 256 \\
\hline Julia Modestina & 27/36 a.C. - & $\begin{array}{c}110- \\
120\end{array}$ & Phl. 94 & 383 \\
\hline Julia Pistrix & - & $100 ?$ & CIL 8.2889 & 272 \\
\hline Julia Soteridi & - & 80 & CIL 6.9498 & 284 \\
\hline Julia Tyche & - & 70 & ERAE 294 & 229 \\
\hline Junia Silana & 55 d.C. & - & $\begin{array}{l}\text { Tac. Ann. 13.19.1-2 y } \\
13.21 .2\end{array}$ & 259,263 \\
\hline
\end{tabular}




\begin{tabular}{|c|c|c|c|c|}
\hline Junia Silana Tertia & $\begin{array}{c}\text { c. } 73 \text { a.C. }-22 \\
\text { d.C. }\end{array}$ & \pm 95 & Tac. Ann. 3.76 & 255 \\
\hline Juno/Beroe & - & - & Ov. Met. 3.271-285 & 337 \\
\hline Kronous & s. II d.C. & 78 & $\begin{array}{l}B F 117-A r-12 \text { y } 131-A r- \\
12\end{array}$ & 229 \\
\hline Lecania & s. I d.C. & - & Mart. 5.43 & 351 \\
\hline Lelia & s. I d.C. & - & Mart. 12.23 & $\begin{array}{l}95, \quad 144, \\
168\end{array}$ \\
\hline Leona & ss. III - II a.C. & - & Plaut. Curc. 96-140 & 298,324 \\
\hline Lesbia & s. II a.C. & - & Ter. An. 227-235 & 284 \\
\hline Lesbia & ss. I a.C. - I d.C. & - & Mart. 10.39 & 75 \\
\hline Lice & s. I a.C. & - & Hor. Carm. 4.13 & 111,184 \\
\hline Licinia Primigenia & s. II d.C. & 71 & CIL 10.1965 & 284 \\
\hline Lícoris & s. I d.C. & - & Mart. 1.72 & $\begin{array}{l}91, \quad 95, \\
168,170\end{array}$ \\
\hline Ligeya & s. I d.C. & - & Mart. 12.6 & 168,187 \\
\hline Livia & s. I a.C. & 97 & Plin. $N H$ 7.48.158-159 & 59 \\
\hline Livia & $\begin{array}{c}59 / 58 \text { a.C. }-29 \\
\text { d.C. }\end{array}$ & $87 / 88$ & $\begin{array}{l}\text { Cass. Dio 60.2.4-5; } \\
\text { Joseph. AJ 18.31; Ov. } \\
\text { Fast. 1.649 y Pont. } \\
\text { 3.1.117 y 3.1.145; Plin. } \\
\text { NH 14.8.60; RIC 1(2), } \\
\text { 97, no } 47 \text {; Suet. Aug. 62- } \\
\text { 63, } 69 \text { y 71, Calig. 23.2, } \\
\text { Claud. } 4 \text { y Tib. 50-51; } \\
\text { Tac. Ann. 1.14, 2.71.2, } \\
\text { 3.71, } 4.57 \text { y 5.1-3 }\end{array}$ & 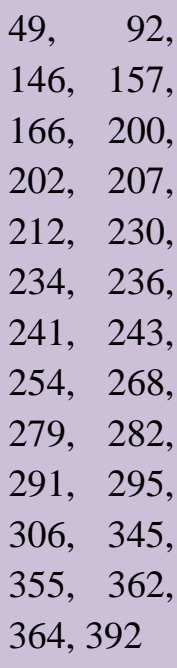 \\
\hline Livia Attica & 28/27 a.C. - & 101 & Phl. 73 & 383 \\
\hline Luceya & - & +100 & Plin. $N H 7.48 .158-159$ & 59 \\
\hline Lucia Fonteia & - & 70 & CIL 11.2538 & 292 \\
\hline
\end{tabular}




\begin{tabular}{|c|c|c|c|c|}
\hline Mamma Donata & - & \pm 70 & CIL 8.23060 & 74 \\
\hline Marcia & ss. I a.C. - I d.C. & - & Sen. Marc. 16 & 220,234 \\
\hline María Faustina & s. II d.C. & 75 & $A E 2013,1925$ & 234 \\
\hline Maronila & s. I d.C. & - & Mart. 1.10 & 216 \\
\hline Matrinia & s. I d.C. & - & Mart. 3.32 & $\begin{array}{l}124,171, \\
187,353\end{array}$ \\
\hline Maurentia & - & - & CIL 3.14524 & 204 \\
\hline Meroe & s. II d.C. & - & $\begin{array}{l}\text { Apul. Met. } 1.7 .7,1.8-9, \\
1.10 .3,1.11 .2 \text { y } 1.12\end{array}$ & $\begin{array}{l}164, \\
179, \\
290, \\
284, \\
322, \\
345,\end{array}$ \\
\hline Meroe & s. IV d.C. & - & Auson. Ep. 41 & 298 \\
\hline Merula & s. V d.C. & \pm 80 & ILSard 1.115 & 74 \\
\hline Minerva & - & - & Ov. Met. 6.25-45 & 333,335 \\
\hline Minucia & - & 97 & CIL 6.2281 & 270 \\
\hline Mount 4255 & - & +50 & Gowland, 2017b & 153 \\
\hline Munantia Procula & 37/37 a.C. - & 110 & Phl. 90 & 383 \\
\hline Occia & s. I d.C. & +60 & Tac. Ann. 2.86 & 258 \\
\hline Octavia Fortunata & - & 61 & $A E 1968,570$ & 270 \\
\hline Octavia Lochias & - & 65 & CIL 8.13092 & 252 \\
\hline Octavia Rufina & - & 95 & CIL 8.3944 & 234 \\
\hline Oenotea & s. I d.C. & - & Petron. Sat.133-138.4 & 283,320 \\
\hline Pantia & s. II d.C. & - & Apul. Met. 1.12 & 321 \\
\hline Papiria Tertia & $\begin{array}{l}\text { s. I a.C. }-30 / 70 \\
\text { d.C. }\end{array}$ & - & CIL 5.2435 & 352 \\
\hline Paula & s. I d.C. & - & Mart. 10.8 & 263 \\
\hline Paula & s. V d.C. & \pm 90 & $A E 1971,138$ & 74 \\
\hline
\end{tabular}




\begin{tabular}{|c|c|c|c|c|}
\hline Pekeis & s. II d.C. & 53 & $B F$ 117-Ar-6 & 229,249 \\
\hline Petronia & 27/26 a.C. - & 100 & Phl. 22 & 383 \\
\hline Philtates & - & 68 & $A E 1976,311$ & 284 \\
\hline Plinia & s. I d.C. & +50 & Plin. Ep. 6.20.11-13 & 278 \\
\hline Plucia & s. I d.C. & - & Mart. 10.67 & 60,187 \\
\hline Pola & s. I d.C. & - & Mart. 3.42 & 166,167 \\
\hline Polla Donata & 37/37 a.C. - & 110 & Phl. 89 & 383 \\
\hline Pollia Pola & 27/26 a.C. - & 100 & Phl. 23 & 383 \\
\hline Pompeya Ammia & - & 60 & CIL 6.5280 & 200 \\
\hline Pompeya Celerina & ss. I - II d.C. & - & $\begin{array}{l}\text { Plin. Ep. 1.4, } 1.18, \\
3.19 .8 \text { у } 6.10 .1\end{array}$ & $\begin{array}{l}102, \quad 250 \\
291,364\end{array}$ \\
\hline Pomponia Gala & ss. I - II d.C. & - & Plin. Ep. 5.1 & 262 \\
\hline Postumia Matronila & - & 53 & CIL 8.11294 & 205 \\
\hline Postumia Paulina & - & - & CIL 5.3710 & 208,235 \\
\hline Proseleno & s. I d.C. & - & Petron. Sat.133-138.4 & 320 \\
\hline Publicia Martia & - & 71 & CIL 2-7.522 & 251 \\
\hline Rubria & - & 50 & CIL 6.9245 & 271 \\
\hline Rufia & - & 70 & $A E 1975,388$ & 234 \\
\hline Sabina & ss. II - III d.C. & $61 ?$ & $\begin{array}{l}\text { CIL } 8.1542,8.15511 \mathrm{y} \\
8.26673\end{array}$ & 132 \\
\hline Sabina & ss. I a.C. - I d.C. & - & $\begin{array}{l}\text { AE 1996,468; Paestum } \\
158\end{array}$ & 242 \\
\hline Sagana & s. I a.C. & - & Hor. Epod. 5 y Sat. 1.8 & $\begin{array}{l}41, \quad 124, \\
174, \quad 175, \\
310,320\end{array}$ \\
\hline Salvia & s. I a.C. & - & CIL 1.1220 & 207 \\
\hline Salvia Varena & 27/26 a.C. - & 100 & Phl. 45 & 383 \\
\hline Sámula & - & 110 & Plin. $N H 7.48 .158-159$ & 59,62 \\
\hline
\end{tabular}




\begin{tabular}{|c|c|c|c|c|}
\hline Sarke & 27/26 a.C. - & 100 & Phl. 50 & 383 \\
\hline Seccia & - & 60 & CIL 3.1243 & 229 \\
\hline Sentaos & s. II d.C. & 75 & $B F$ 117-Ar-6 & 229 \\
\hline Serrana Prócula & 97 d.C. & - & Plin. Ep. 14.6 & 241,363 \\
\hline Serva Cleopatra & s. I d.C. & 65 & $A E 1978,232$ & 229 \\
\hline Sextia Treptes & s. II d.C. & 75 & NSA-1919-338 & 204 \\
\hline Sextilia & -69 d.C. & - & $\begin{array}{l}\text { Suet. Vit. 14.5; Tac. } \\
\text { Hist. } 67\end{array}$ & 116 \\
\hline Sira & ss. III - II a.C. & - & $\begin{array}{l}\text { Plaut. Cist. } 49-50,105 \text {, } \\
120-145 \text { y } 149\end{array}$ & $\begin{array}{l}277, \quad 297 \\
328, \quad 334 \\
337,350\end{array}$ \\
\hline Sira & ss. III - II a.C. & 84 & Plaut. Merc. 670-675 & 288,350 \\
\hline Sibila & - & 1000 & $\begin{array}{l}\text { Ov. Met. 14.130-154; } \\
\text { Phl. } 99\end{array}$ & $\begin{array}{ll}42, & 121 \\
142, & 351 \\
383 & \end{array}$ \\
\hline Striges & ss. I a.C. - I d.C. & - & Ov. Fast. 6.130-168 & 316 \\
\hline Sóstrata & s. II a.C. & - & $\begin{array}{l}\text { Ter. Her. } 230,275-280 \text {, } \\
590-595 \text { у } 620\end{array}$ & $\begin{array}{l}247, \quad 248 \\
351,353\end{array}$ \\
\hline Sulpicia & s. II a.C. & - & Liv. 39.9-14 & 249 \\
\hline Sura & - & \pm 60 & CIL 3.2800 & 229 \\
\hline T.237 & ss. III-IV d.C. & +65 & $\begin{array}{l}\text { Baxarías, 2002: 102- } \\
103\end{array}$ & 141 \\
\hline Taedia Secunda & s. I d.C. & - & CIL 4.7469 & 240 \\
\hline Tais & s. I d.C. & - & Mart. 5.43 & $\begin{array}{ll}91, & 141 \\
351 & \end{array}$ \\
\hline Tasoucharion & s. III d.C. & 74 & BF 201-Ar-9 & 229 \\
\hline Tatithoes & s. II d.C. & 60 & $B F 11-A r-1$ & 229 \\
\hline Teeus & s. II d.C. & - & P. Giss 17 & 353 \\
\hline Teodora & s. IV d.C. & - & $B G U$ 4.1024, 2.6-8 & 228 \\
\hline
\end{tabular}




\begin{tabular}{|c|c|c|c|c|}
\hline Theogiton & s. II d.C. & - & P. Fay. 124 & 278 \\
\hline Thephrokos & s. II d.C. & +50 & BF 131-He-2 & 249 \\
\hline Terencia & ss. II - I a.C. & 103 & $\begin{array}{l}\text { Cic. Att. 1.5.8, 1.18.1, } \\
2.3,2.4 .5,3.19 .3 \text { y } \\
13.46 \text { y Fam. 5.6.1, } \\
\text { 14.2, 14.3, 14.4.1, 14.5, } \\
\text { 14.7, 14.8 y 14.14; Plin. } \\
\text { NH 7.48.158-159; Plut. } \\
\text { Cic. } 8 \text { y 46; Val. Max. } \\
8.13 .6\end{array}$ & $\begin{array}{l}59, \quad 207, \\
215, \quad 257, \\
268,270\end{array}$ \\
\hline Tértula & 64/63 a.C. - & 137 & Plin. NH 7.49.162-164 & 59 \\
\hline Tértula & ss. I a.C. - I d.C. & - & Suet. Vesp. 2 & $\begin{array}{l}236, \quad 241, \\
364\end{array}$ \\
\hline Tetoeus & s. II d.C. & - & BF 117-Ox-2 & 246 \\
\hline Torcuata & 22 d.C. & 64 & $\begin{array}{l}\text { CIL } 6.2127 \text { y } 6.2128 ; \\
\text { Tac. Ann. } 3.69 .6\end{array}$ & 258,270 \\
\hline Turellia Forensis & 27/26 a.C. - & 100 & Phl. 39 & 383 \\
\hline Ulpia Martina & ss. II - II d.C. & 80 & CIL 3.4336 & 44,234 \\
\hline Umidia Cuadratila & 28 d.C. -107 d.C. & 79 & $\begin{array}{l}A E \text { 1992, } 244 \text { y } 1985, \\
\text { 189; EAOR } 4.47 ; \text { EDCS } \\
292 ; \quad C I L \quad 6.28526, \\
10.5183 \text { y } 15.7567 ; \\
\text { Plin. Ep. } 7.24\end{array}$ & 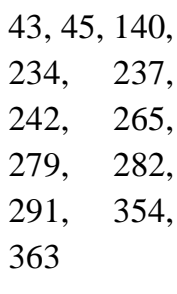 \\
\hline Urbana & - & - & CIL 6.6346 & 284 \\
\hline Urgulania & ss. I a.C. -33 d.C. & - & Tac. Ann. 2.71 .2 y 4.22 & 241,268 \\
\hline Valeria Justina & ss. I - II d.C. & - & CIL 11.4483 & 204 \\
\hline Valeria Prisca & - & 60 & CIL 2.3970 & 270 \\
\hline Verania & ss. I - II d.C. & - & Plin. Ep. 2.20 .3 & 261 \\
\hline $\begin{array}{c}\text { Vertumno } \\
\text { (transformado en } \\
\text { vetula) }\end{array}$ & - & - & Ov. Met. 14.654-766 & 345 \\
\hline Veturia & 488 a.C. & - & $\begin{array}{l}\text { Cass. Dio 5.18.8-11; } \\
\text { Dion. Hal. Ant. Rom. }\end{array}$ & $\begin{array}{ll}23, & 221, \\
278, & 282,\end{array}$ \\
\hline
\end{tabular}




\begin{tabular}{|c|c|c|c|c|}
\hline & & & $\begin{array}{l}\text { 8.40-54.2 Liv. 2.40.1- } \\
\text { 12; Plut. Cor. } 4 \text { y 23- } \\
\text { 37; Val. Max. 1.8.4, } \\
\text { 5.2.1 y 5.4.1 }\end{array}$ & $\begin{array}{l}345, \quad 352, \\
356,363\end{array}$ \\
\hline Veturia Daphne & - & 72 & CIL 6.5047 & 270 \\
\hline Vetustila & s. I d.C. & - & Mart. 3.93 & $\begin{array}{ll}91, & 122, \\
123, & 142, \\
166, & 167, \\
170, & 171, \\
172, & 334, \\
353 & \end{array}$ \\
\hline Veya & s. I a.C. & - & Hor. Epod. 5 & 312,313 \\
\hline Vicia & ss. I a.C. - I d.C. & - & Tac. Ann. 6.10 & 352 \\
\hline Vibia & 52 d.C. & - & Tac. Ann. 12.52.1 & 230 \\
\hline Vibia Crispa & - & 67 & CIL 2.967 & 284 \\
\hline Vibidia & 48 d.C. & - & Tac. Ann. 11.32.2 & 283 \\
\hline Volumnia & - & 105 & CIL 6.29497 & 271 \\
\hline Watersmeet 2265 & - & Senil & Gowland 2017b & 152 \\
\hline Zois & s. II d.C. & 53 & $B F$ 117-Ar-1 & 257 \\
\hline
\end{tabular}




\section{ANEXo 2: TABLAS}

\section{Nombre}

Edad

L. Cornelius; L. Glaucius Verus; L. Vetustius Secundus; L. Licinius Palus; L. Acilius Marcellus; L. Vettius; L. Cusonius; L. Gabinius; G. Hortensius Fronto; G. Nonius Maximus; G. Amurius Tiro; G. Cassius Pudes; G. Titius Communis; G. Vatius Tertius; G. Iulius Pothus; G. Valerius Primus; Caesellius Cyrus; Catia; P. Fulvius Phryx; P. Naevius; P. Deccenius Demosthenes; Petronia; Pollia Polla; M. Vilonius Severus; M. Terentius Albius; M. Antonius; M. Talpius Vitalis; M. Acilius; M. Nirellius; T. Aemilius; T. Veteranius; T. Numerius; T. Servius Secundus; T. Petronius; T. Antonius; T. Aerusius Pollio; T. Camuris Tertius; Turellia Forensis; Q. Cassius Rufus; Q. Lucretius Primus; Q. Velius; Antonia Secunda; Albatia Sabina; Salvia Varena; Bebia Marcella; Bascia; Bronzes; Phronton; Sarke; Aidesios; Bithys; Zaikedenthes; Mantis; Alexander; Gaza; Chreste; Chrysion; Hieron; Mouzakos; Lucius Fidiclanius Nepos; Aloukios Apilioutas; Ambatos; Kamalos; Keltios; Arruntius; Tamphios; Dokkourios

G. Leledius Primus; Clodia Potestas; Cusinia Moschis; Cereonia Verecunda; Livia Attica; Buria Lychnainis G. Samius; Q. Cornelius; T. Antonius Cocnania Musa

Demokritos de Abdera; Ktesibios; Hieronymos

G. Lallias Tionaeus; P. Quisentius Ephyrion; T. Cottinas Chysanthos; M. Pomponius Severus; S. Naevius

\begin{tabular}{l|l} 
L. Aelius Dorotheos & 106
\end{tabular}

\begin{tabular}{|l|l}
\hline G. Pomposius Montianus & 107
\end{tabular}

Polla Donata; Munantia Procula; Anónim@; Anónim@; Anónim@, 110 Anónim@; Anónim@; Anónim@

\begin{tabular}{|l|l}
\hline Titus Purennius Tutus & 111
\end{tabular}

\begin{tabular}{|l|r}
\hline L. Antistius Soterichos & 113
\end{tabular}

\begin{tabular}{l|l}
\hline Lucius & 113 \\
\hline Anónima; Anonim@; Anonin@; Anonim@; Anonim@; Anonim@; & 120
\end{tabular}

Anónima; Anónim@; Anónim@; Anónim@; Anónim@; Anónim@; 120

Anónim@; Anónim@*

\begin{tabular}{l|l}
\hline Anónim@ & 125
\end{tabular}

\begin{tabular}{l|l}
\hline Anónim@; Anónim@; Anónim@ & 130
\end{tabular}

\begin{tabular}{|l|r}
\hline Anónima & 132
\end{tabular}

\begin{tabular}{|l|r}
\hline Lucius Terentius & 135 \\
\hline
\end{tabular}

\begin{tabular}{|l|l}
\hline Faustus & 136 \\
\hline
\end{tabular}

\begin{tabular}{|r|r}
\hline Tertulla & 137
\end{tabular}

\begin{tabular}{|l|r}
\hline L. Terentius; M. Aponius; M. Mucius & 140
\end{tabular}

\begin{tabular}{|l|l}
\hline Argantonio & 150 \\
\hline
\end{tabular}

\begin{tabular}{l|r}
\hline Sibila & 1000
\end{tabular}

Tabla 1 -Personas centenarias mencionadas por Plinio y Flegón de Trales en relación con el censo del siglo I d.C. Las personas calificadas como "anónim@" corresponden a referencias de Plinio en las que no explicita el sexo. Las vetulae aquí mencionadas aparecen también en el Anexo 1. *No podemos saber si alguna de las personas anónimas citadas por Plinio corresponde con la mujer sin nombre de la misma edad a la que hace referencia Flegón. 


\begin{tabular}{|c|c|c|}
\hline $\begin{array}{c}\text { Calendario de Rómulo } \\
\text { (s. VIII a.C. }\end{array}$ & $\begin{array}{c}\text { Calendario de Numa } \\
\text { (s. VII a.C.) }\end{array}$ & $\begin{array}{c}\text { Calendario de César } \\
\text { (46 a.C.) }\end{array}$ \\
\hline $\mathbf{5 0}$ & 42 & 41 \\
\hline $\mathbf{7 5}$ & 64 & 83 \\
\hline $\mathbf{1 0 0}$ & 85 & 48 \\
\hline 58 & $\mathbf{5 0}$ & 72 \\
\hline 87 & $\mathbf{7 5}$ & 97 \\
\hline 116 & $\mathbf{1 0 0}$ & $\mathbf{5 0}$ \\
\hline 60 & 51 & $\mathbf{7 5}$ \\
\hline 90 & 77 & $\mathbf{1 0 0}$ \\
\hline 120 & 102 & \\
\hline
\end{tabular}

Tabla 2 - Equivalencia de edades cronológicas entre los distintos calendarios romanos. Los números en negrita señalan el calendario del que han partido los cálculos en cada caso. Para realizar los cálculos hemos multiplicado la edad (50-75-100) por el número de días que tiene un año en el calendario de referencia, y hemos dividido el resultado entre el número de días que tiene el calendario al que realizamos la conversión. Así, por ejemplo, si deseamos saber qué edad tendría en el calendario juliano una persona de 50 años en el calendario de Rómulo, debemos operar de la siguiente manera: 50 × 304 / $365=41$. Las operaciones matemáticas se han realizado con años de 365 días en el caso juliano, eliminando los años bisiestos para simplificar el proceso. 


\begin{tabular}{|c|c|c|}
\hline Autor & Cronología & División \\
\hline Etruscos & ss. XIII-I a.C. & 12 periodos de 7 años cada uno \\
\hline Solón & ss. VII-VI a.C. & 10 periodos de 7 años cada uno \\
\hline Hipócrates & ss. V-IV a.C. & $\begin{array}{l}7 \text { periodos: } 6 \text { de } 7 \text { años cada uno y el último de los } \\
56 \text { en adelante }\end{array}$ \\
\hline Varrón & ss. II-I a.C. & $\begin{array}{l}5 \text { periodos de } 15 \text { años cada uno: niño, adolescente, } \\
\text { joven, adulto, viejo }\end{array}$ \\
\hline Cicerón & s. I a.C. & 4 etapas: infancia, juventud, edad media, ancianidad \\
\hline Diodoro Sículo & s. I a.C. & $\begin{array}{l}4 \text { etapas: niño, joven adulto, hombre maduro y viejo } \\
\text { / niña, doncella, mujer casada, vieja }\end{array}$ \\
\hline Staseas & s. I a.C. & 12 periodos de 7 años cada uno \\
\hline Filón de Alejandría & ss. I a.C. - I d.C. & $\begin{array}{l}7 \text { periodos: } 6 \text { de } 7 \text { años cada uno y el último de los } \\
56 \text { en adelante }\end{array}$ \\
\hline Ovidio & ss. I a.C. - I d.C. & 4 periodos: niño, joven, maduro, senil \\
\hline Plinio el Viejo & s. I d.C. & $\begin{array}{l}5 \text { etapas: niñez, adolescencia, juventud, madurez y } \\
\text { vejez }\end{array}$ \\
\hline Séneca & s. I d.C. & 4 etapas: infante, niño, adolescente, maduro \\
\hline Plutarco & ss. I-II d.C. & $\begin{array}{l}8 \text { etapas: feto, criatura, niño, muchacho, joven, } \\
\text { hombre, viejo, anciano }\end{array}$ \\
\hline Aulo Gelio & s. II d.C. & 3 etapas: niñez ( -17$)$, juventud (18-45) y vejez (46- ) \\
\hline Galeno & s. II d.C. & $\begin{array}{l}4 \text { etapas: niñez (7-14 ó } 7-18) \text {, adolescencia (14-25, } \\
18-25 \text { ó } 25-35) \text {, juventud (35-48) y vejez (48-) }\end{array}$ \\
\hline Censorino & s. III d.C. & 12 periodos de 7 años cada uno \\
\hline Amiano Marcelino & s. IV d.C. & 4 etapas: niñez, juventud, madurez, vejez \\
\hline Macrobio & s. IV d.C. & $\begin{array}{l}4 \text { etapas: niñez (7-14 ó } 7-18) \text {, adolescencia (14-25, } \\
18-25 \text { ó } 25-35) \text {, juventud (35-48) y vejez (48-) }\end{array}$ \\
\hline Agustín de Hipona & ss. IV-V d.C. & $\begin{array}{l}6 \text { etapas: infancia, niñez, adolescencia, juventud, } \\
\text { madurez y vejez }\end{array}$ \\
\hline Isidoro de Sevilla & ss. VI-VII d.C. & $\begin{array}{l}6 \text { etapas: infancia (0-7), niñez (7-14), adolescencia } \\
\text { (14-28 ó 15-28), juventud ( } 28-49 \text { ó } 28-50) \text {, madurez } \\
\text { (50-70 ó } 50-77) \text { y vejez ( } 70-\text { ) }\end{array}$ \\
\hline
\end{tabular}

Tabla 3 - Divisiones del ciclo vital según diversos autores. 


\begin{tabular}{|c|c|}
\hline Tipo de afección & Patologías \\
\hline Genital & $\begin{array}{l}\text { Menorragia, metrorragia, anemia climatérica, leucorrea, cambios } \\
\text { mamarios, atrofia vaginal }\end{array}$ \\
\hline Metabólica & Obesidad, adiposis localizada, adelgazamiento, caquexia, diabetes \\
\hline Circulatoria & Hipertensión, taquicardia, insuficiencia cardíaca, arritmia, varices \\
\hline Locomotriz & Reumatismo, artrosis, osteoporosis, fracturas \\
\hline Endocrina & Hipertiroidismo, mixidema, síntomas hipofisiarios y suprarrelanes \\
\hline Nerviosa & $\begin{array}{l}\text { Neuralgia, jaqueca, cefalea, dolor óseo, raquialgia, parestesia, dolor } \\
\text { en las piernas, pruritos, trastorno sensorial, vértigo, insomnio }\end{array}$ \\
\hline Digestiva & Glositis, trastorno gástrico, estreñimiento, diarrea, colecistopatía \\
\hline Respiratoria & Asma \\
\hline Urinaria & Cistitis, litiasis renal \\
\hline Dermatológica & Eczema, acné, melanodermia, vitíligo, hipertricosis, calvicie \\
\hline Psicológica & $\begin{array}{l}\text { Inestabilidad emocional, depresión, melancolía, trastornos sexuales, } \\
\text { paranoia, estado maníaco-depresivo }\end{array}$ \\
\hline
\end{tabular}

Tabla 4 - Afecciones asociadas a la menopausia. Realizada a partir de Carmenate y Prado, 2002: 451.

\begin{tabular}{|c|l|l|}
\hline \multicolumn{1}{|c|}{ Hipócrates } & \multicolumn{1}{|c|}{ Celso } & \multicolumn{1}{|c|}{ Celio Aureliano } \\
\hline $\begin{array}{l}\text { Disnea, catarro, tos, dolores } \\
\text { articulares, estraguria, disuria, } \\
\text { nefritis, apoplejía, insomnio, } \\
\text { diarrea, supuración en ojos y } \\
\text { nariz, glaucoma, sordera, } \\
\text { ambliopía }\end{array}$ & $\begin{array}{l}\text { prinarias, coriza, dolores } \\
\text { partisis, caquexia, insomnio, } \\
\text { enfermedades en oídos, ojos y } \\
\text { nariz, disentería, diarrea }\end{array}$ & $\begin{array}{l}\text { Pleuritis, tos, debilidad, asma, } \\
\text { letargo, disnea, apoplejía, } \\
\text { perineumonía }\end{array}$ \\
\hline
\end{tabular}

Tabla 5 - Patologías asociadas a la vejez en la Antigüedad. Realizada a partir de André, 2006:

216-217. 


\section{ANEXo 3: IMÁGENES}

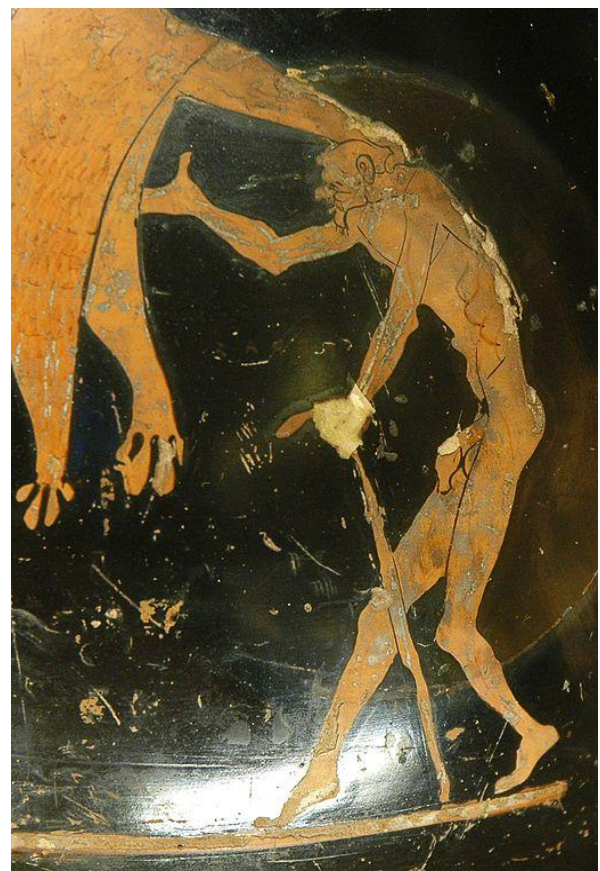

Figura 1 - Geras. Detalle de una cerámica griega (s. V a.C.). Musée du Louvre (París).

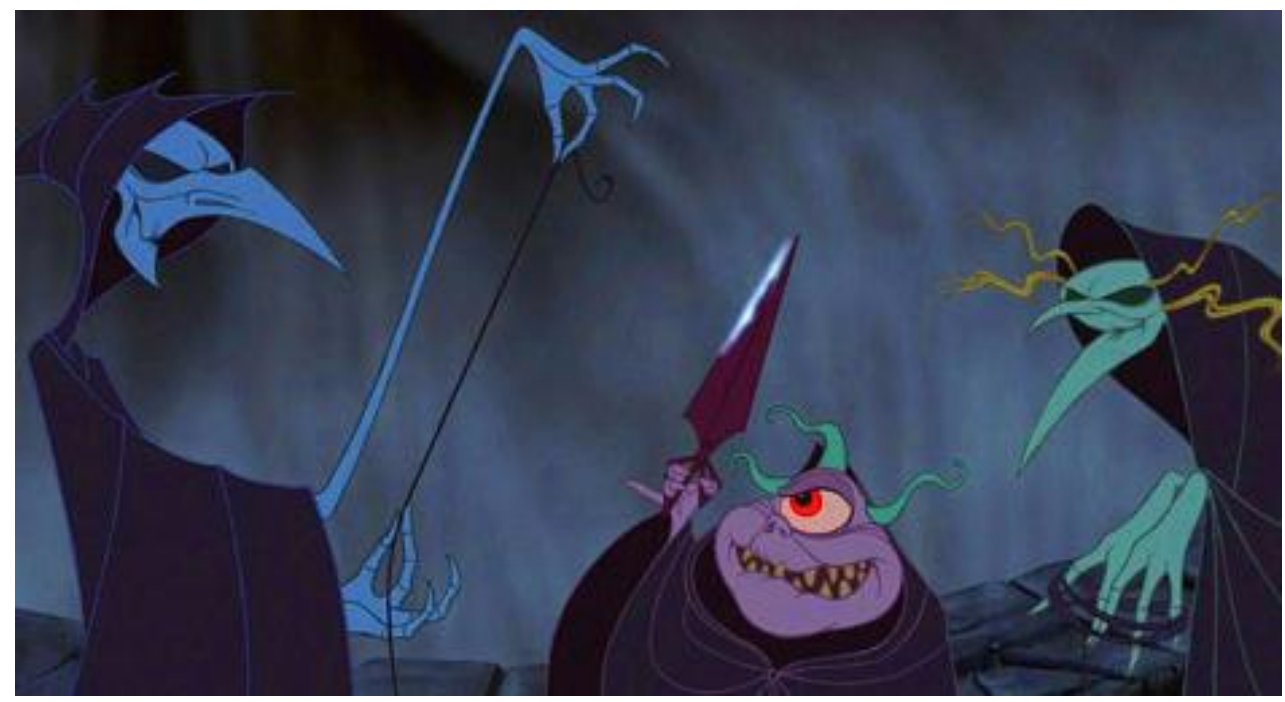

Figura 2 - Las Parcas. Fotograma de la película de animación Hércules (Ron Clemens y John Musker, 1997). Las Parcas han sido aquí asimiladas con las Grayas. 


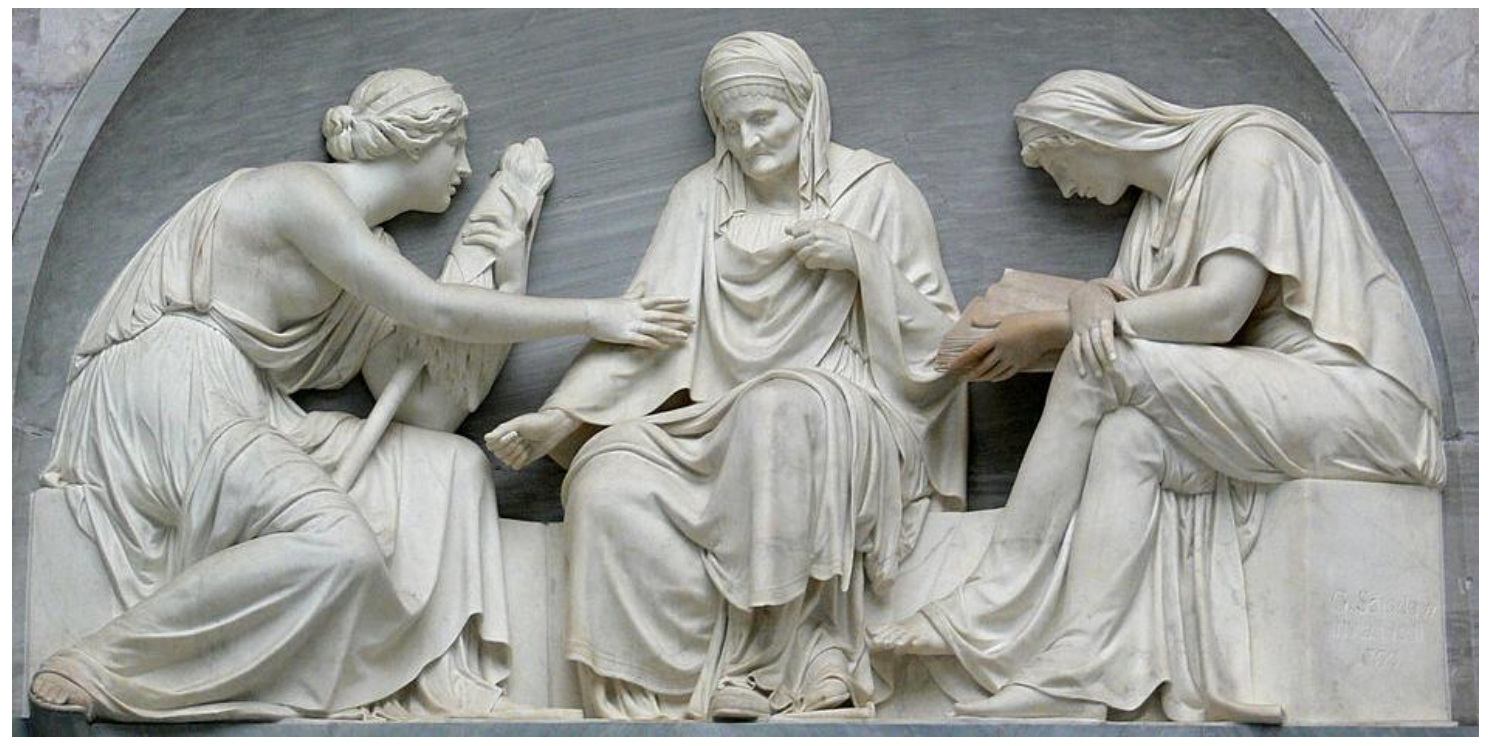

Figura 3 - Las Parcas personificando a la puella, la matrona y la vetula. Detalle de la tumba de Alexander von der Mark en Berlín (Johann Gottfried Schadow, 1789).

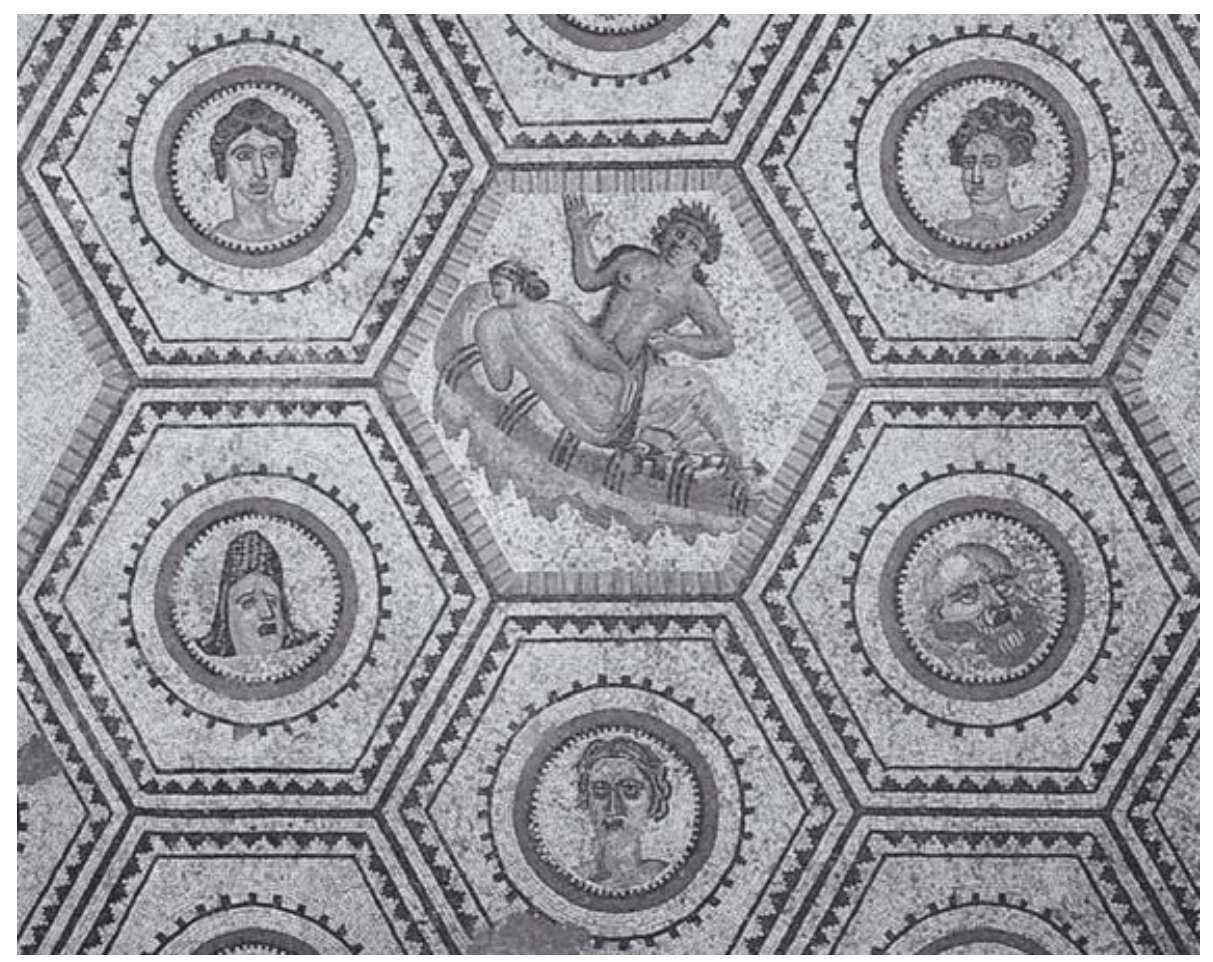

Figura 4 - Ciclo vital femenino. Detalle del mosaico de Baco y Ariadna en Vallon (s. II d.C.) (Fusch, 2008: 73). 


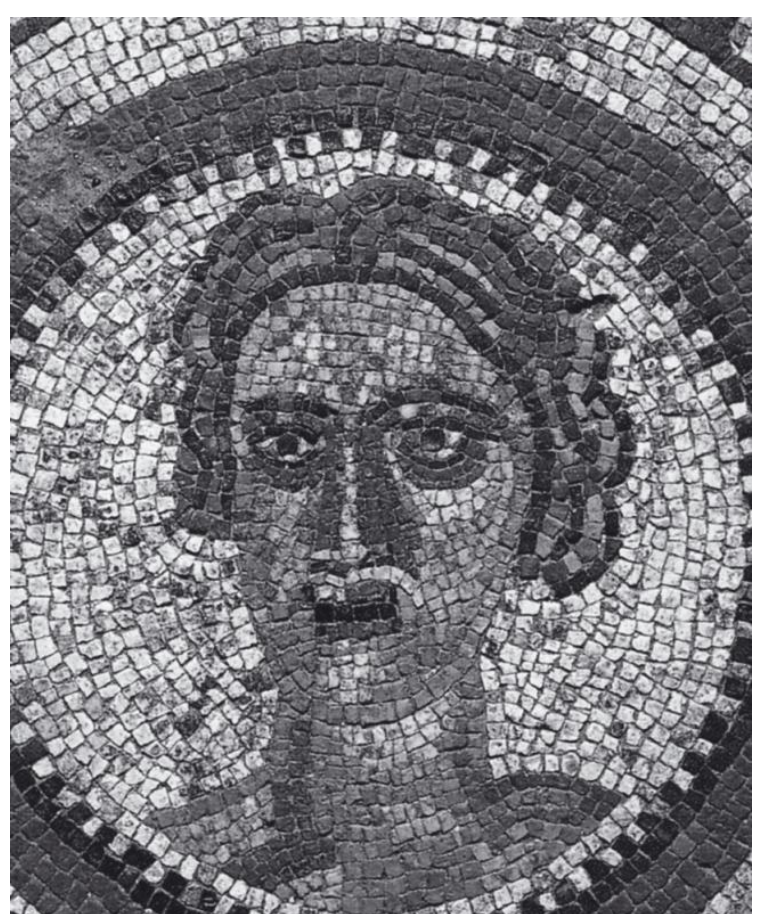

Figura 5 - Vetula del mosaico de Baco y Ariadna en Vallon (s. II d.C.) (Fusch, 2008: 74).
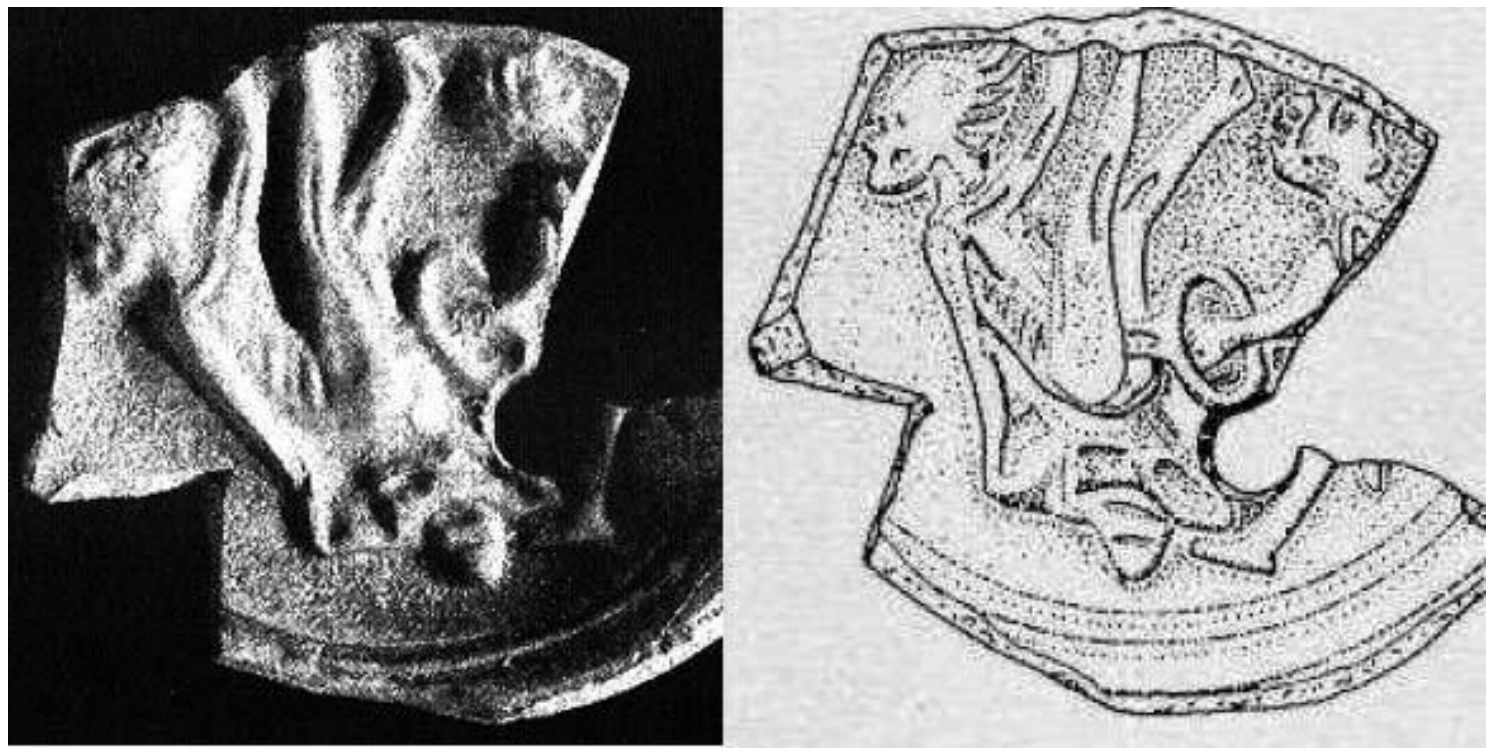

Figura 6 - Lucerna con examen ginecológico a una vetula encontrada en León (s. I d.C.). Fotografía (izquierda) y dibujo (derecha) de la pieza (Morillo, 1999: figs. 51.2 y 141.55; http://www.culturaclasica.com/?q=node/2562). 

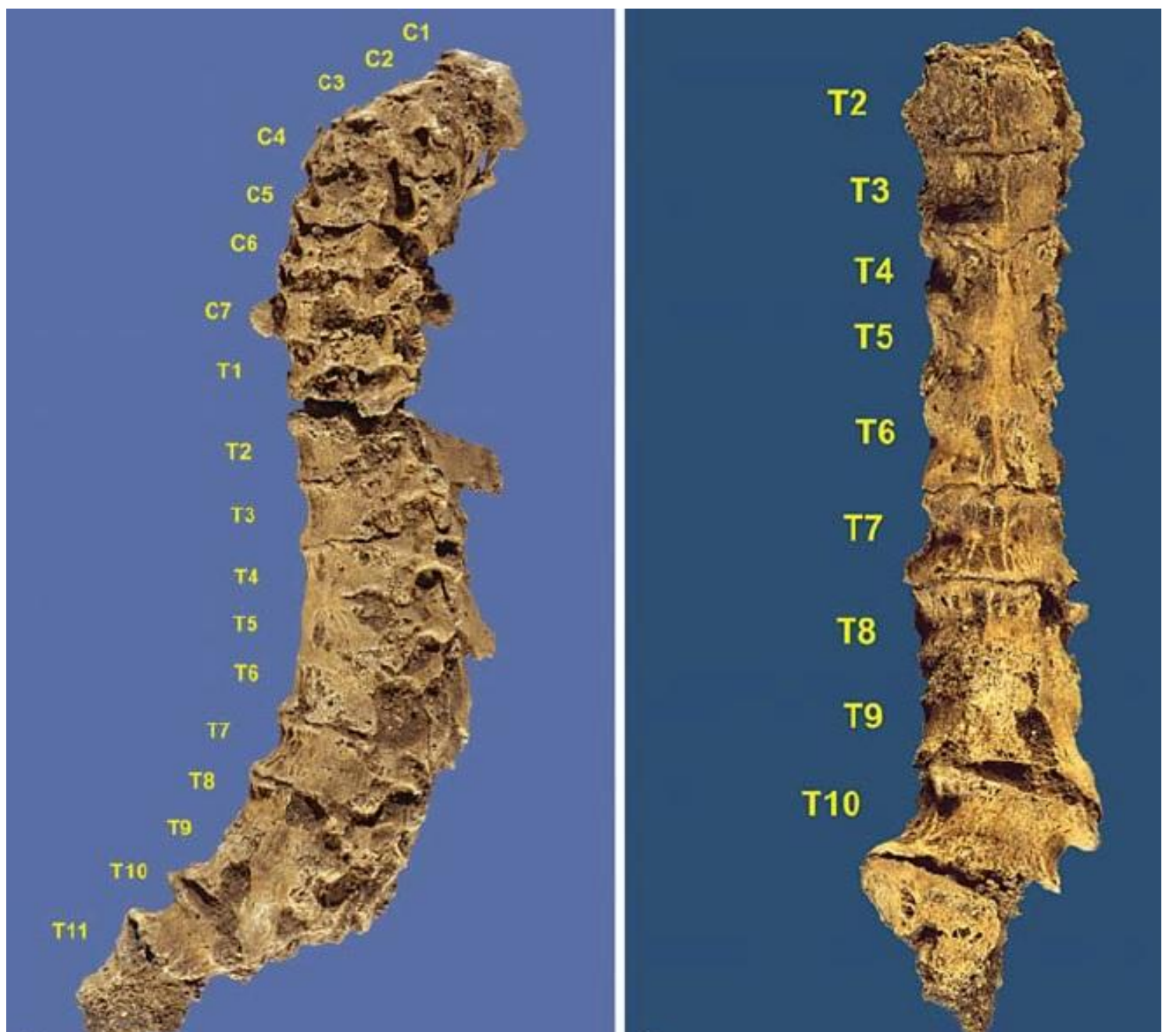

Figura 7 - Espondilitis anquilosante de una mujer de la necrópolis Colatina (Roma) (Minozzi et al., 2012: 271).
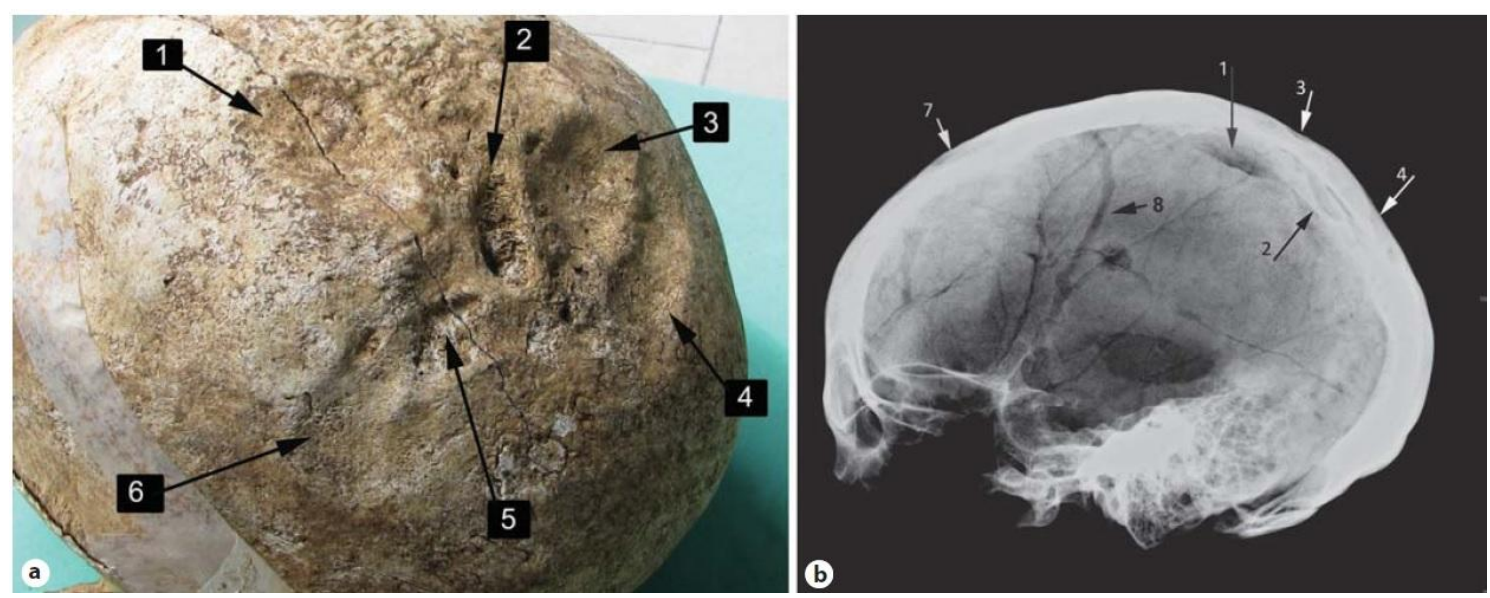

Figura 8 - Múltiples traumatismos en el cráneo de una mujer de la necrópolis Colatina (Roma) (Minozzi et al., 2012: 274). 


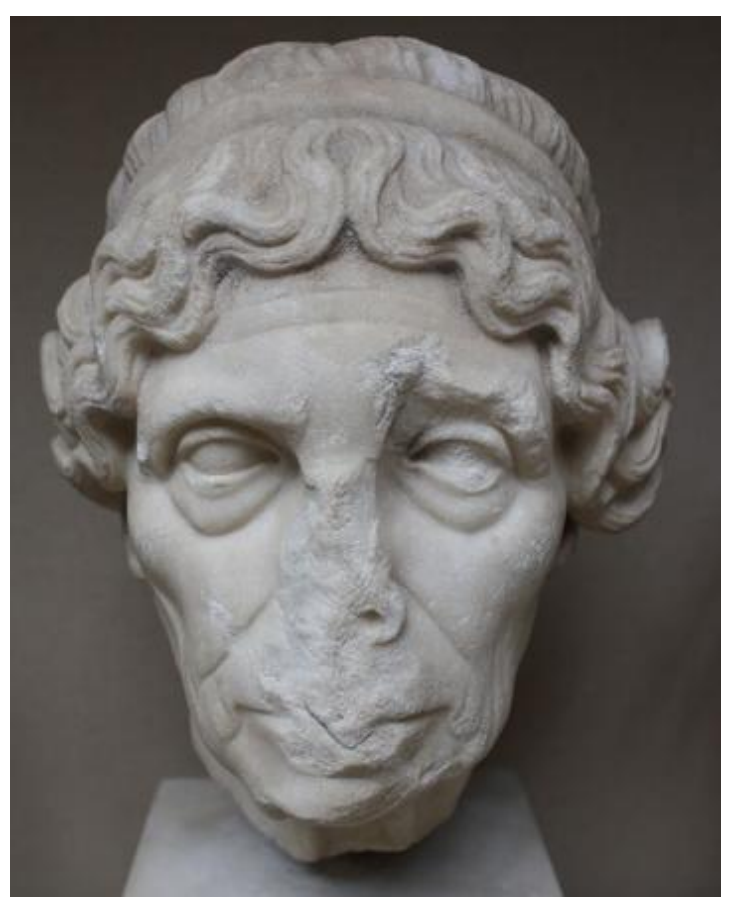

Figura 9 - Busto de vetula (copia romana de original griego del s. IV a.C.). The British Museum (Londres).

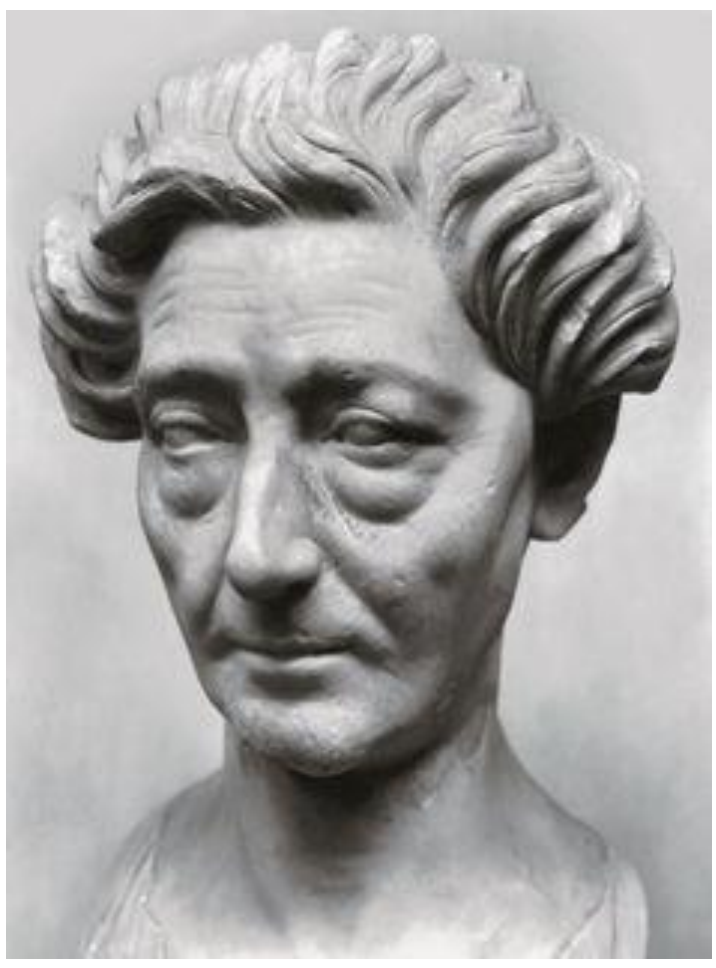

Figura 11 - Busto de vetula (s. I d. C.). Musei Vaticani (Roma).

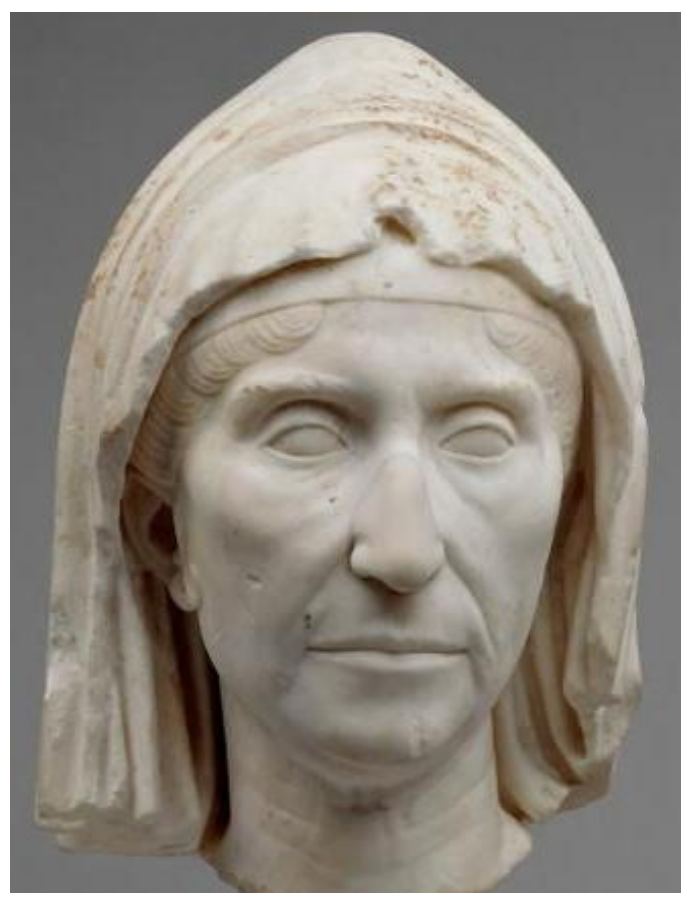

Figura 10 - Busto de vetula (c. 40 a.C.). Kunst Historisches Museum (Viena).

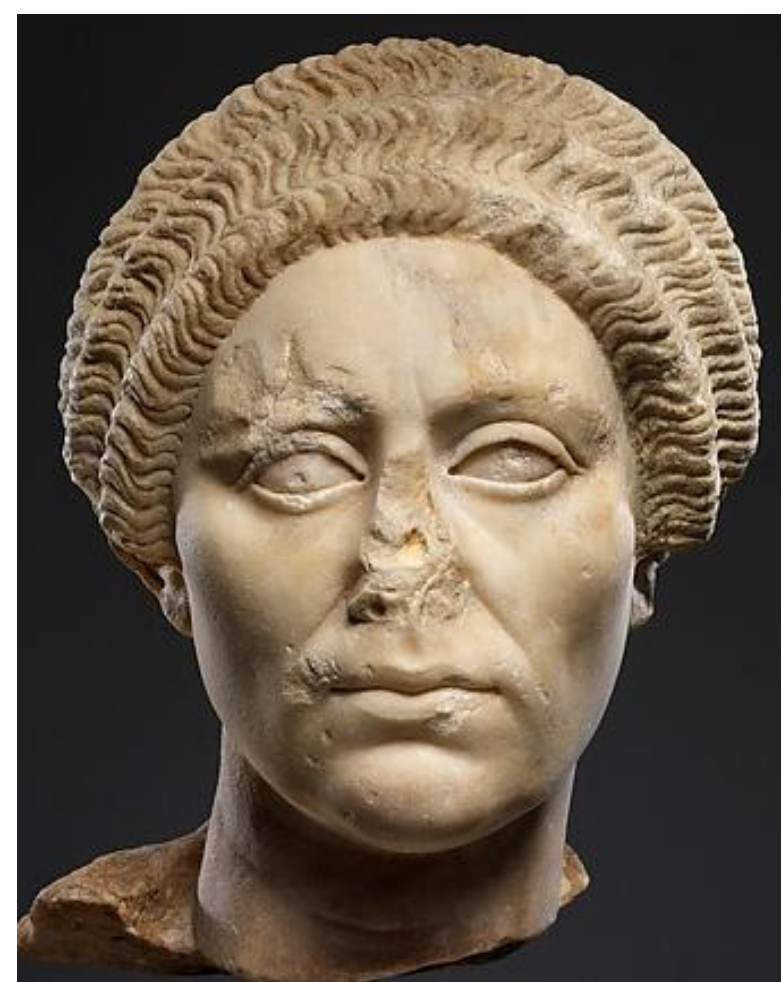

Figura 12 - Busto de vetula (s. II d.C.). The Metropolitan Museum (Nueva York). 


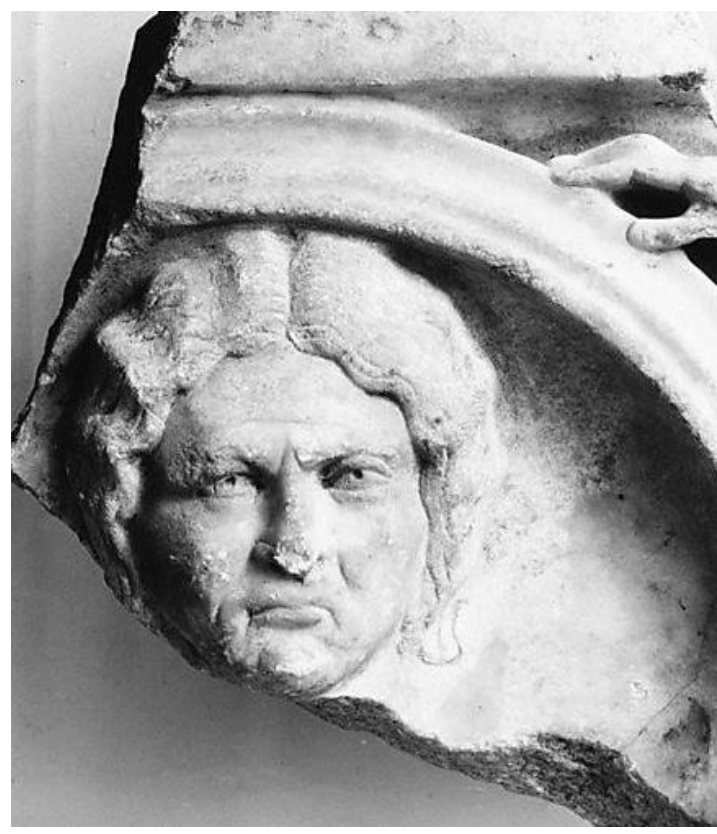

Figura 13 - Fragmento de sarcófago (ss. IIIII d.C.). The Metropolitan Museum (Nueva York).

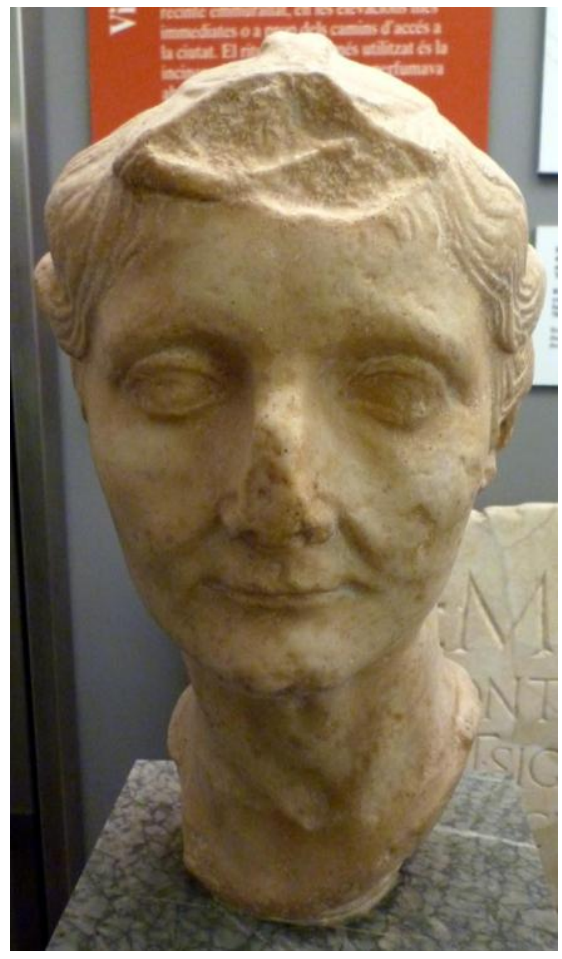

Figura 15 - Busto de Livia (s. I d.C.). Museu d'Arqueologia de Catalunya (Ampurias).

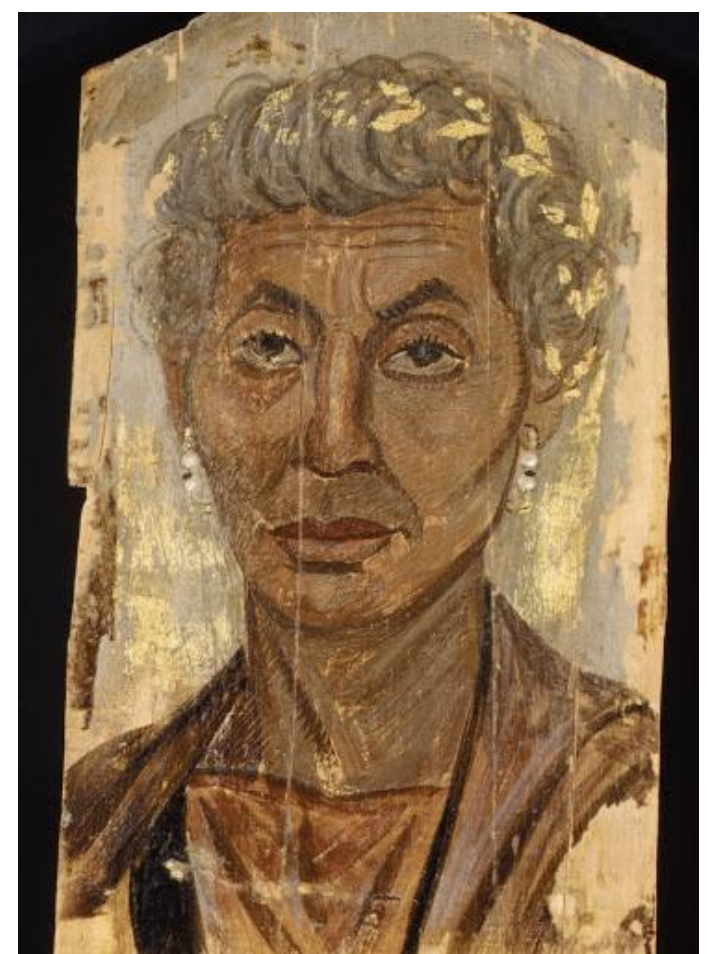

Figura 14 - Retrato de vetula (ss. I-III d.C.). The Metropolitan Museum (Nueva York).

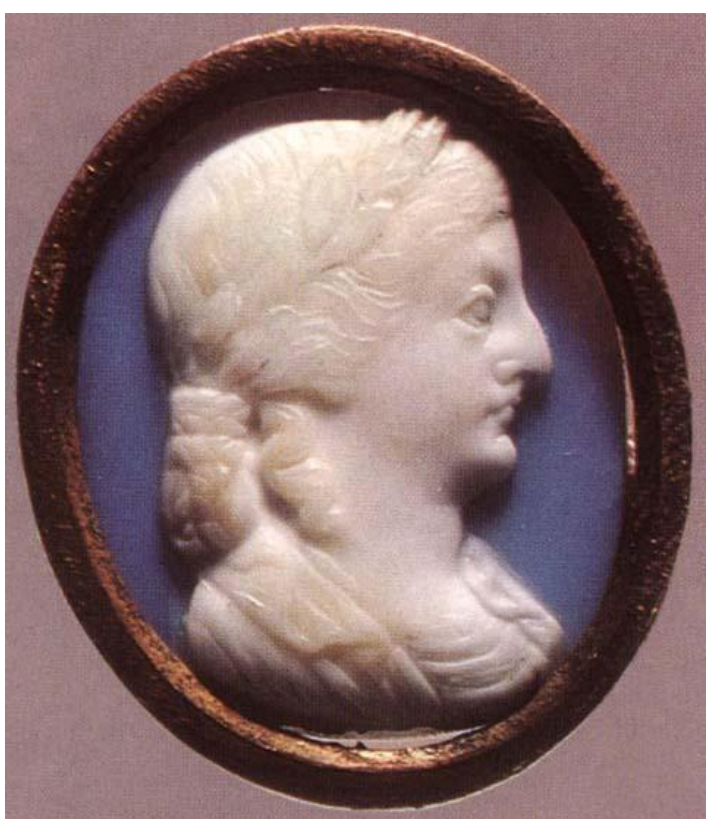

Figura 16 - Camafeo de Livia (s. I d.C.) The State Hermitage Museum (Moscú). 


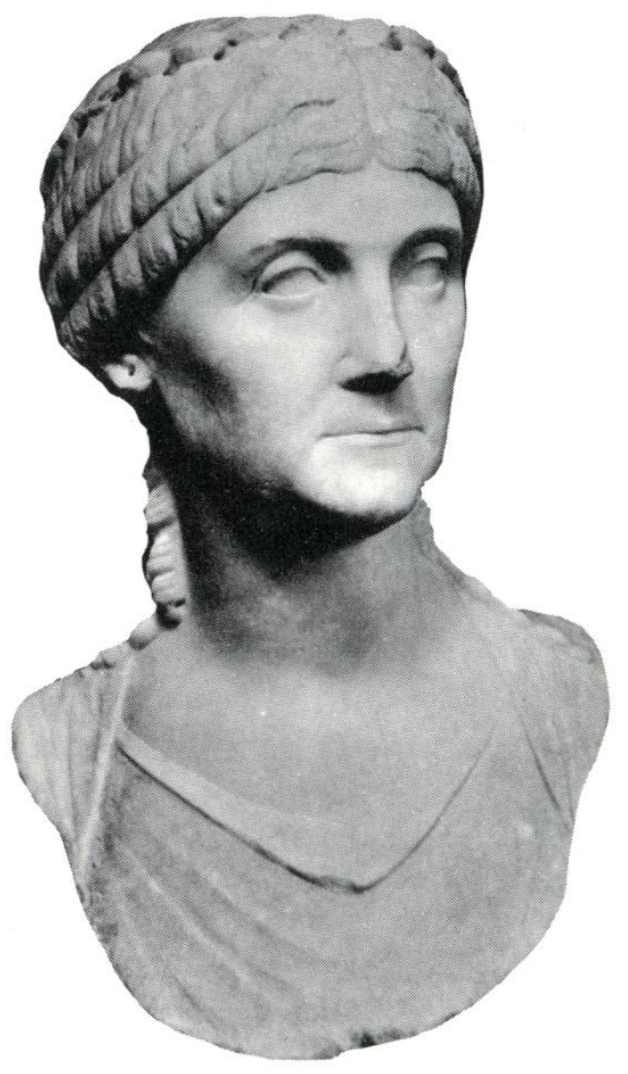

Figura 17 - Busto de Antonia Minor (s. I d.C.). Musei Capitolini (Roma).

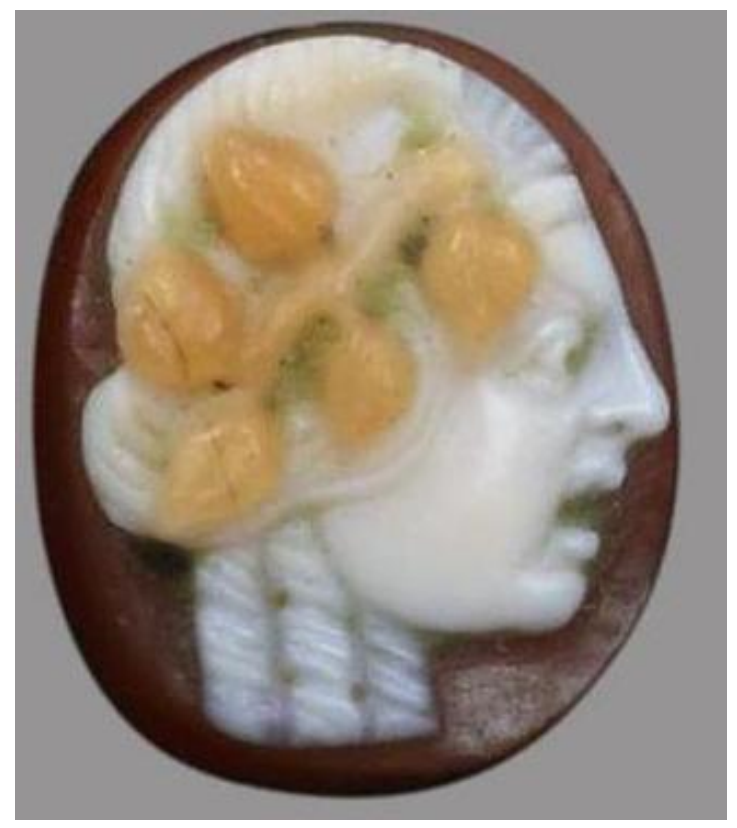

Figura 19 - Camafeo con máscara teatral de vetula (ss. I a.C. - I d.C.). The State Hermitage Museum (Moscú).

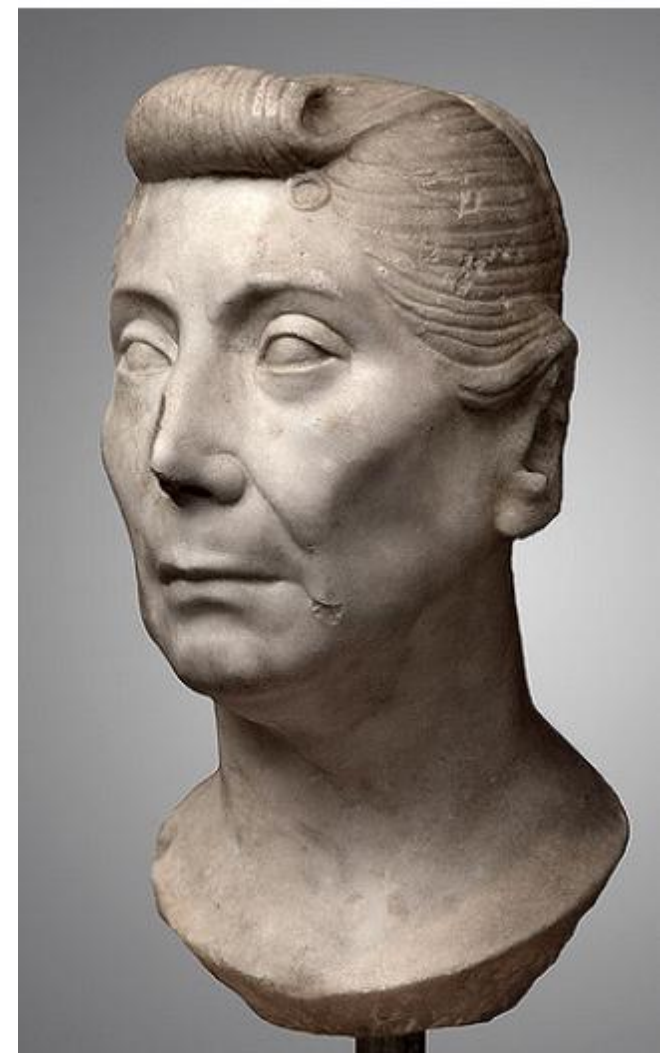

Figura 18 - Busto de vetula (c. 14 d.C.). Palazzo Massimo (Roma).

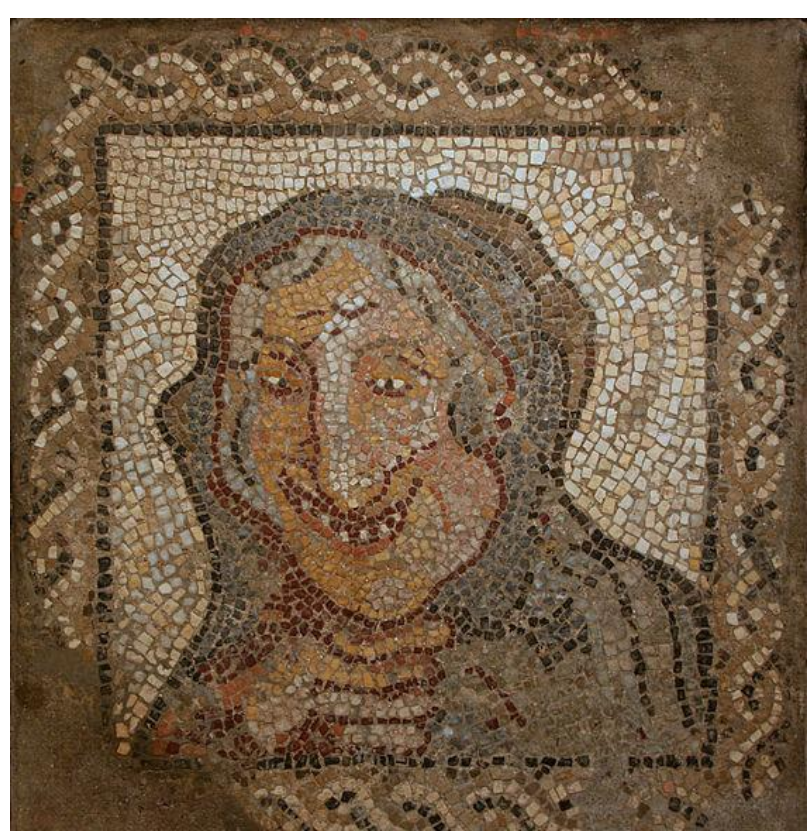

Figura 20 - Mosaico de máscara teatral de vetula (s. III d.C.). Museu d'Arqueologia de Catalunya (Barcelona). 


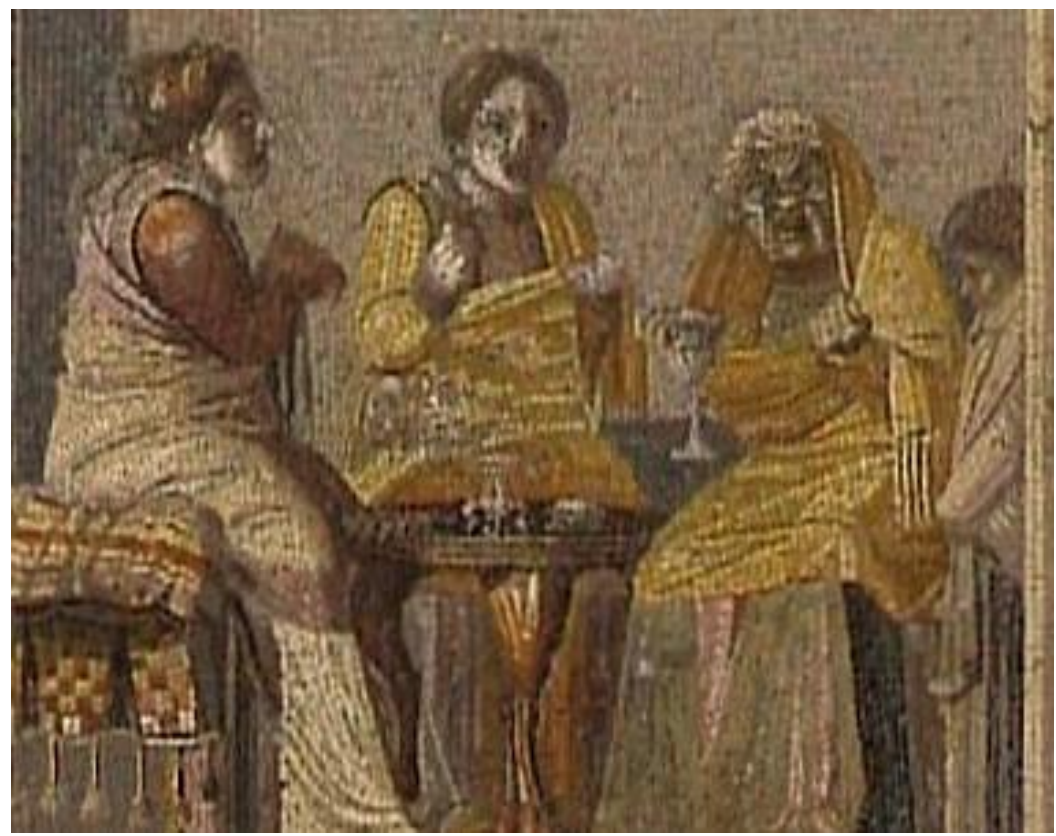

Figura 21 - Mosaico con vetula (s. I a.C.). Museo Archeologico Nazionale (Nápoles).

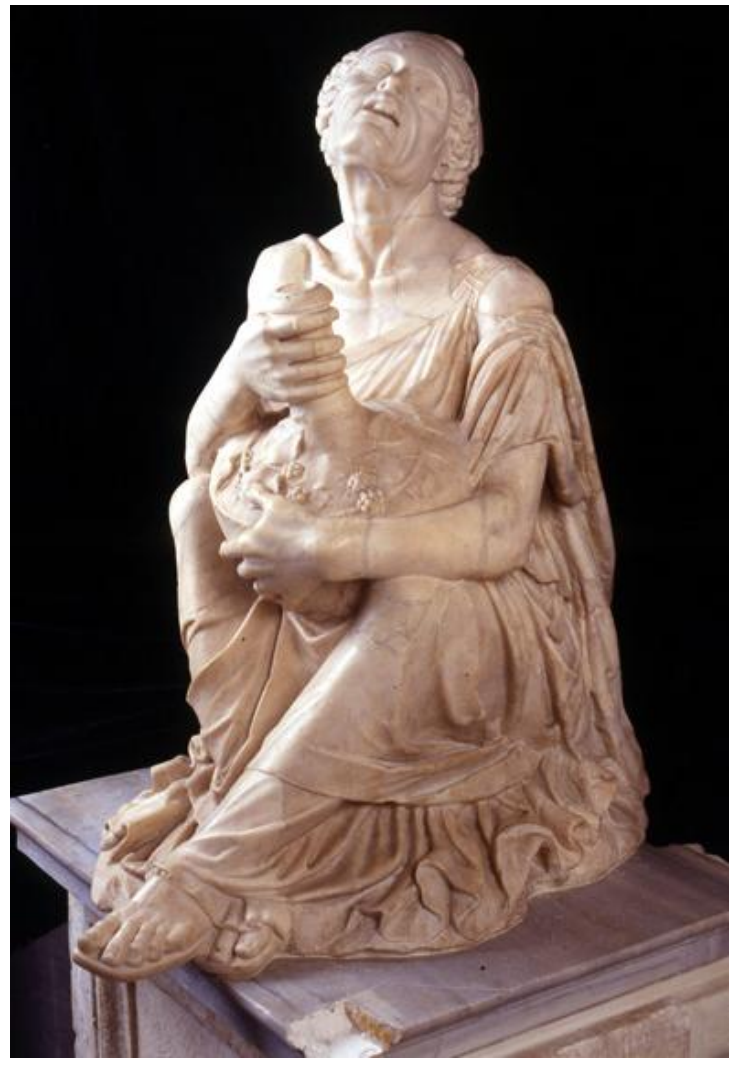

Figura 22 - Escultura de anus ebria (fecha desconocida, posible copia de original helenístico). Musei Capitolini (Roma).

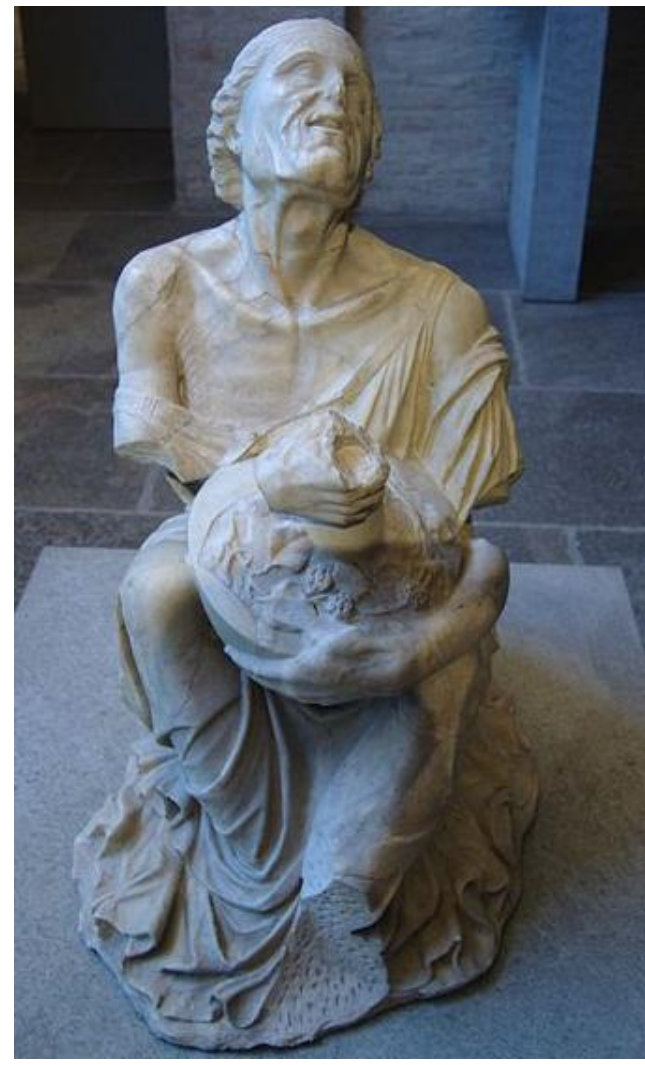

Figura 23 - Escultura de anus ebria (fecha desconocida, posible copia de original helenístico). Glyptothek (Múnich). 


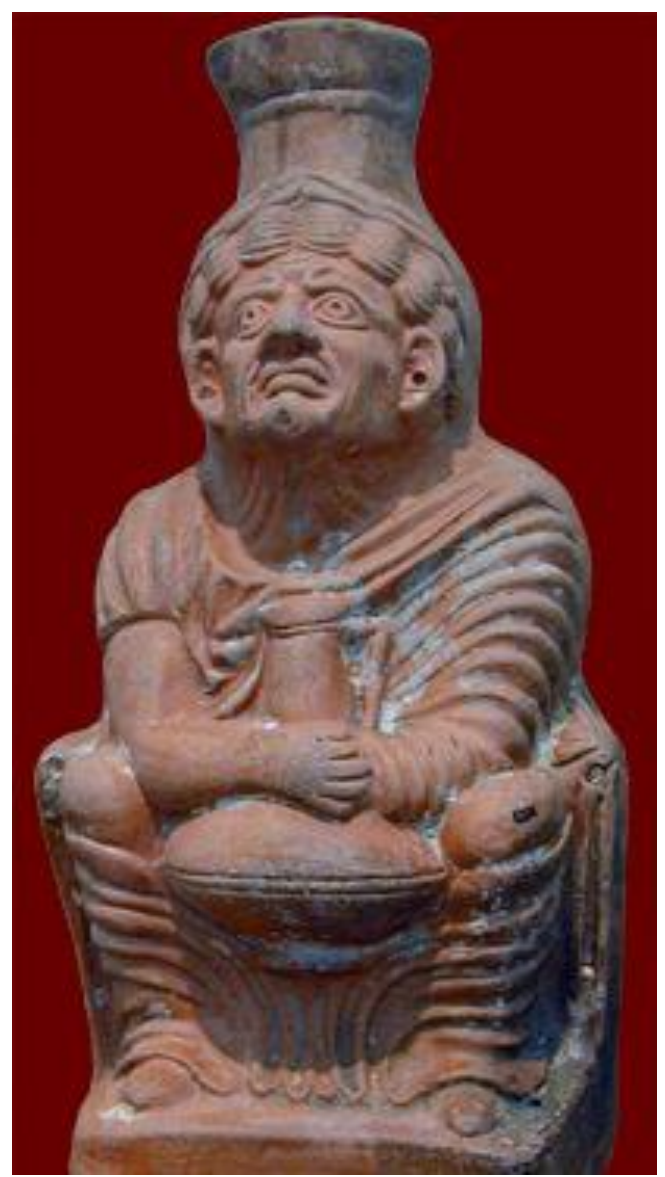

Figura 24 - Botella cerámica tipo anus ebria (s. III d.C.). Museum of Fine Arts (Boston).

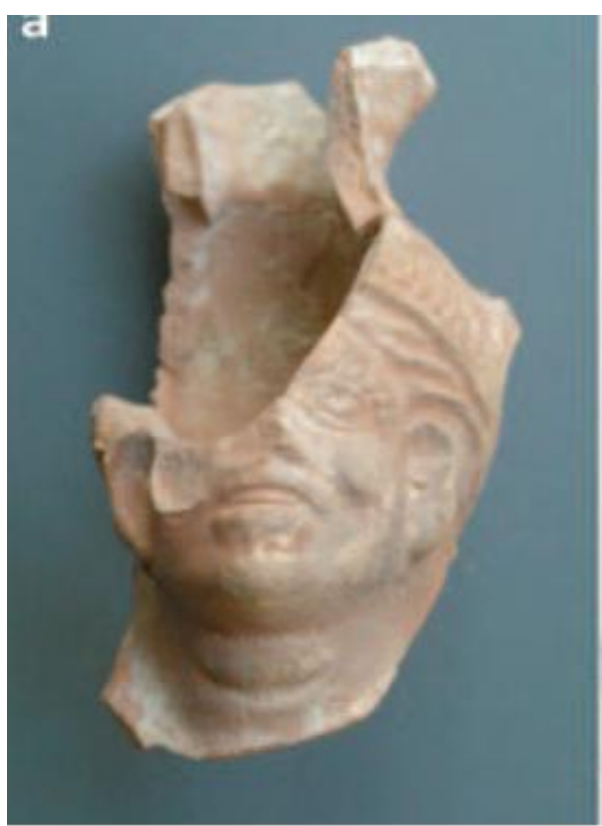

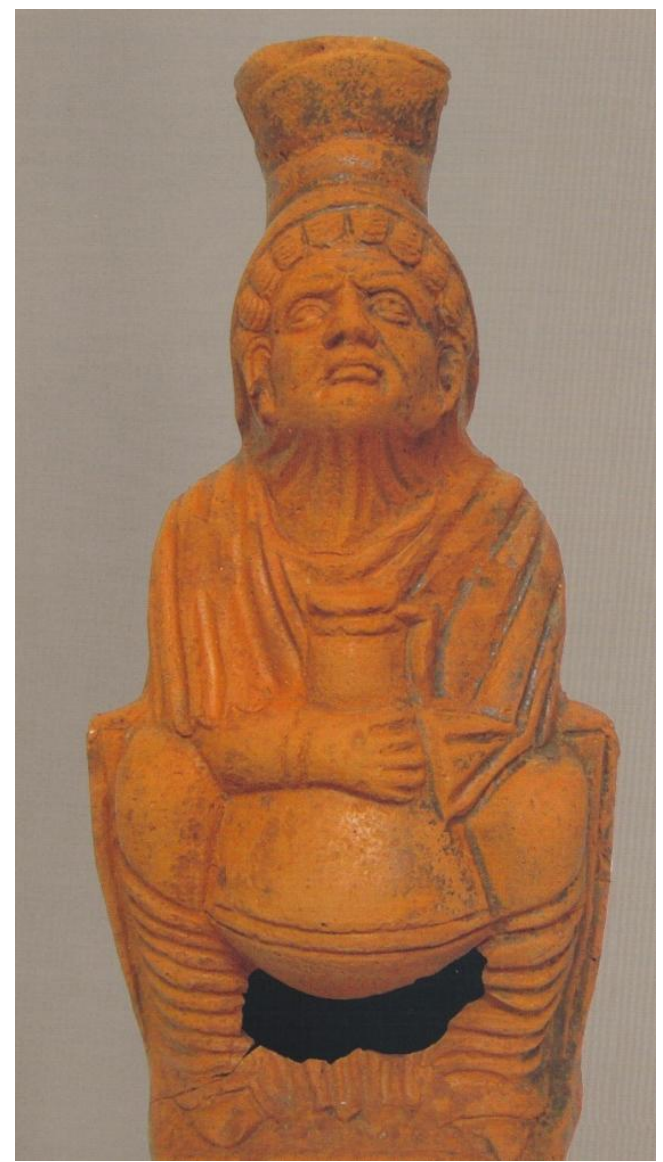

Figura 25 - Botella cerámica tipo anus ebria (ss. II-III d.C.). Palau de Cerveró (Valencia).

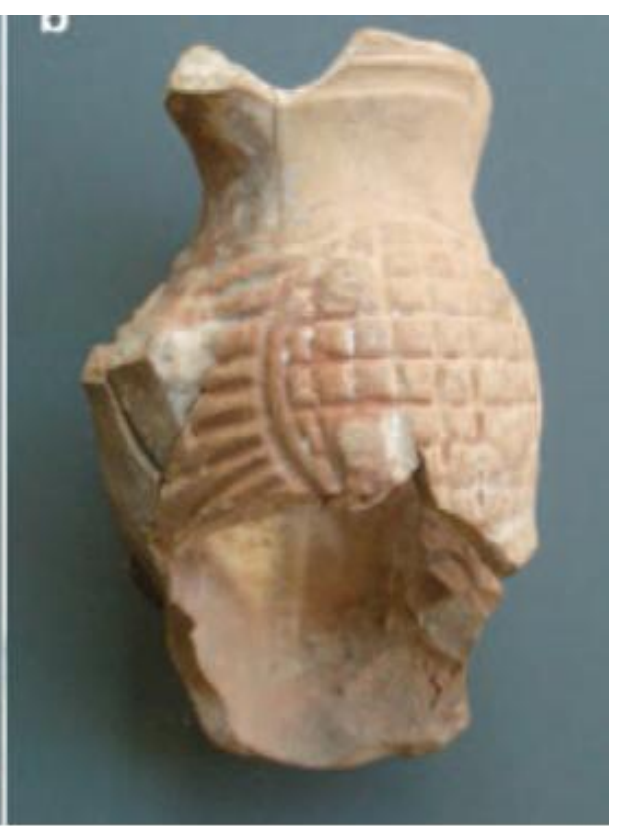

Figura 26 - Botella cerámica tipo anus ebria (s. II d.C.). Museo Arqueológico de Cartagena (Cartagena) 


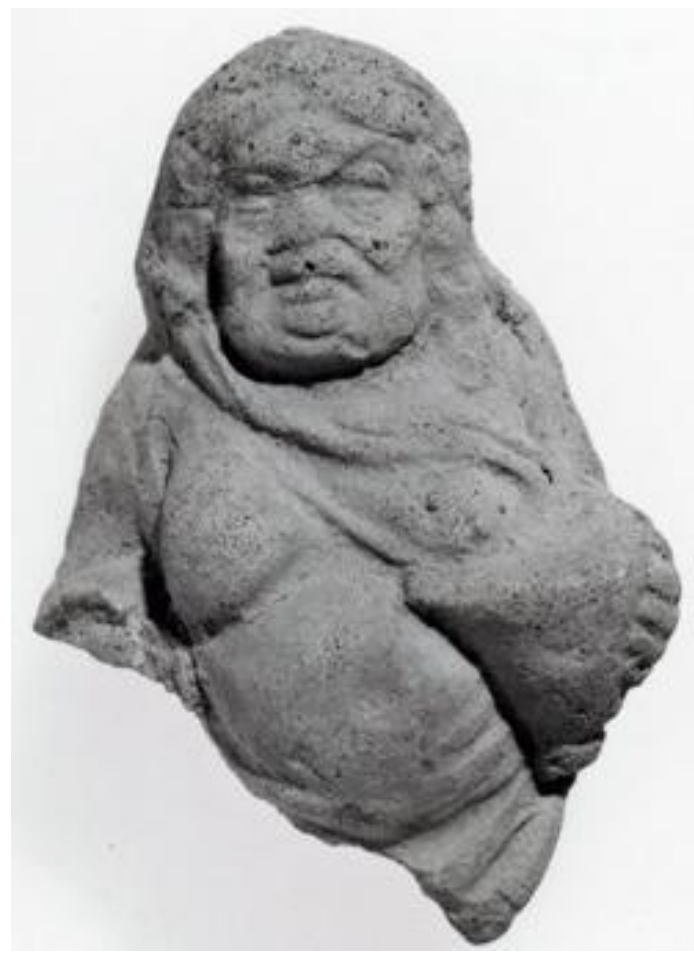

Figura 27 - Figura de terracota del tipo vieja del mercado (ss. III-II a.C.). The British Museum (Londres).

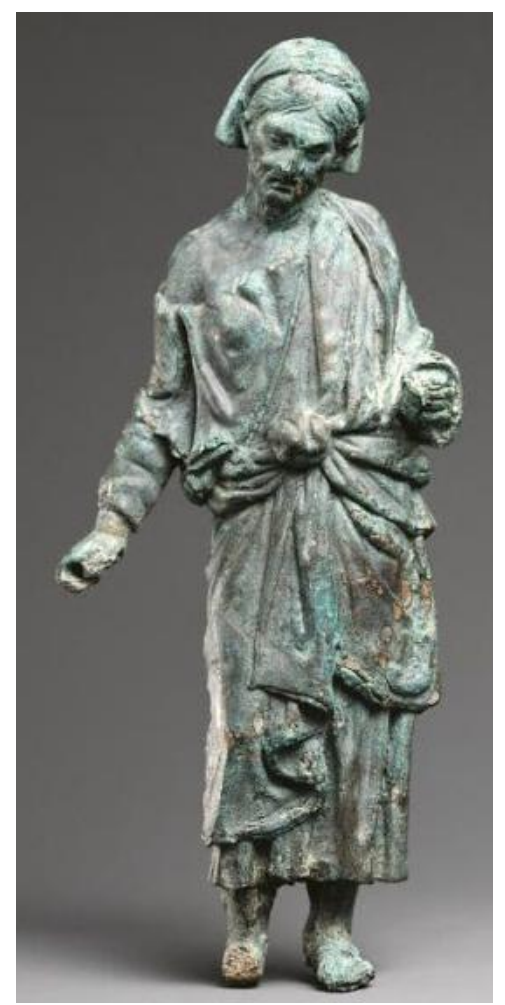

Figura 29 - Escultura del tipo vieja del mercado (s. I a.C.). The J. Paul Getty Museum (Los Ángeles).

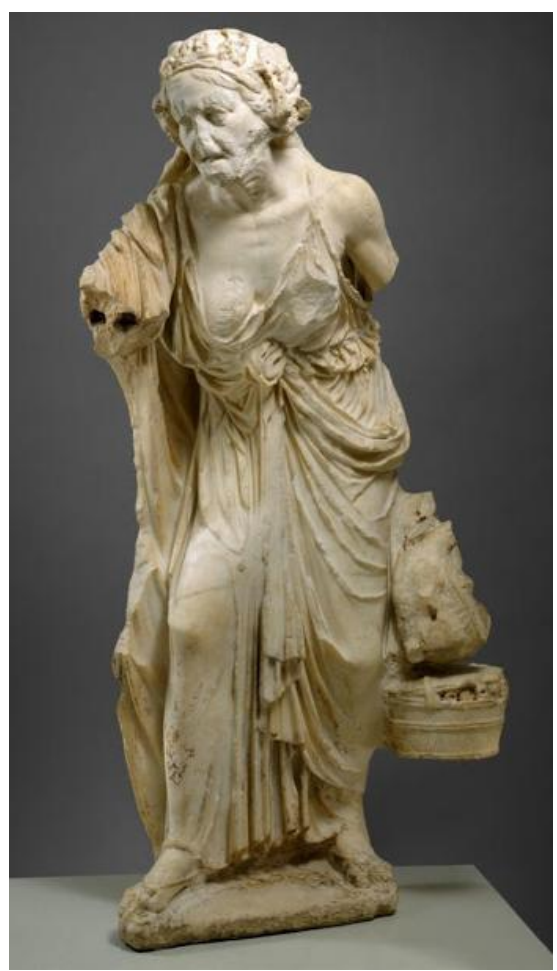

Figura 28 - Escultura del tipo vieja del mercado (s. I d.C.). The Metropolitan Museum (Nueva York).

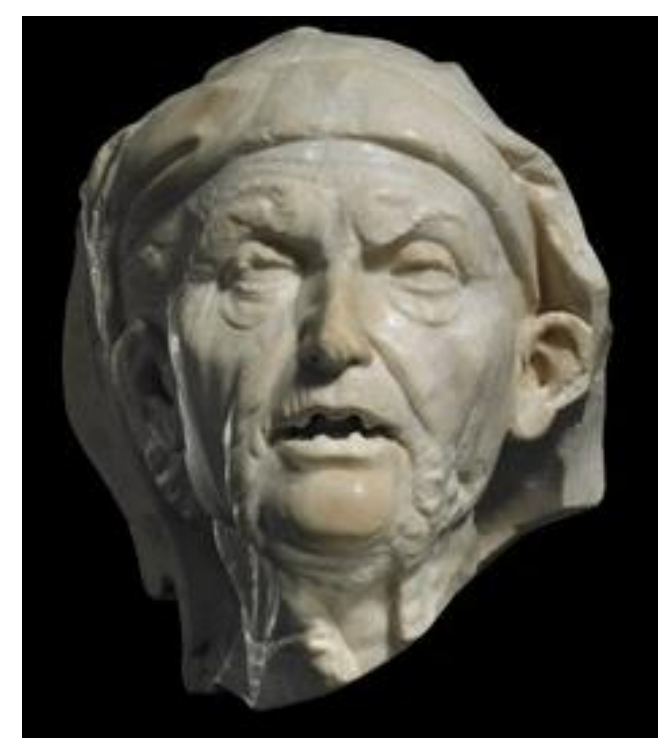

Figura 30 - Cabeza de vetula (posible copia romana de un original helenístico del s. III a.C.). The British Museum (Londres). 


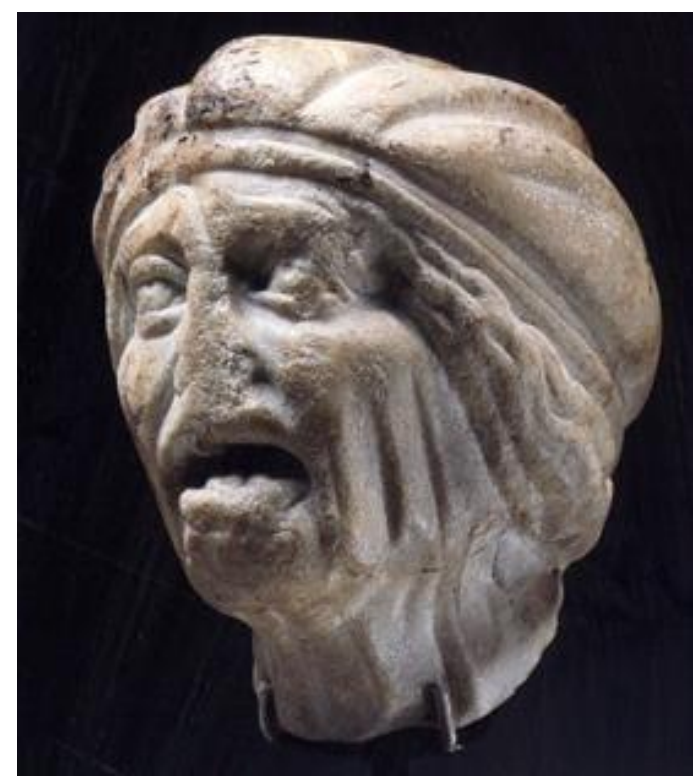

Figura 31 - Cabeza de vetula (s. I d.C.). Colección privada.

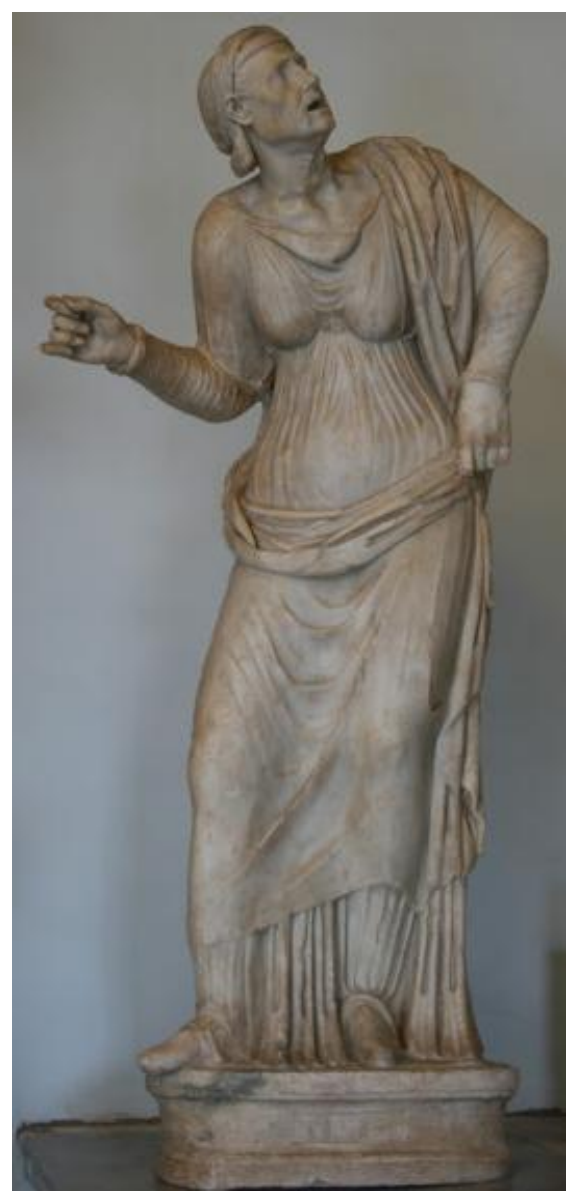

Figura 32 - Escultura de vetula (s. I d.C.). Musei Capitolini (Roma).

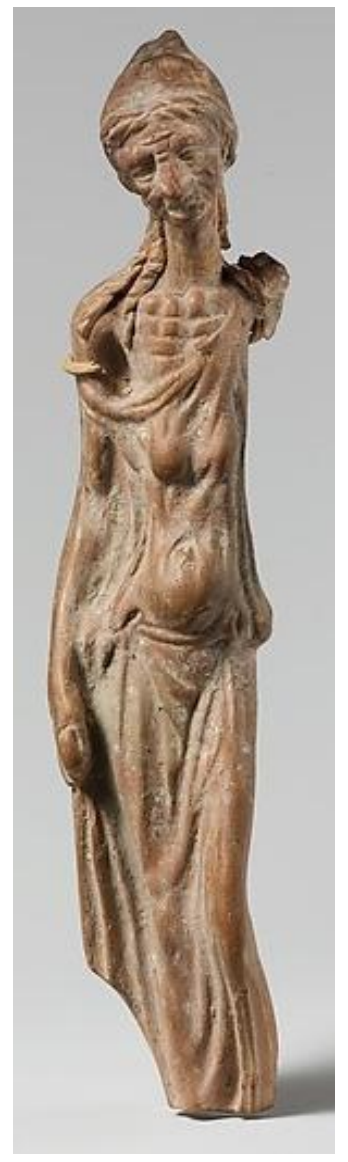

Figura 33 - Figura de terracota de vetula desnuda (s. I a.C.). The Metropolitan Museum (Nueva York). 


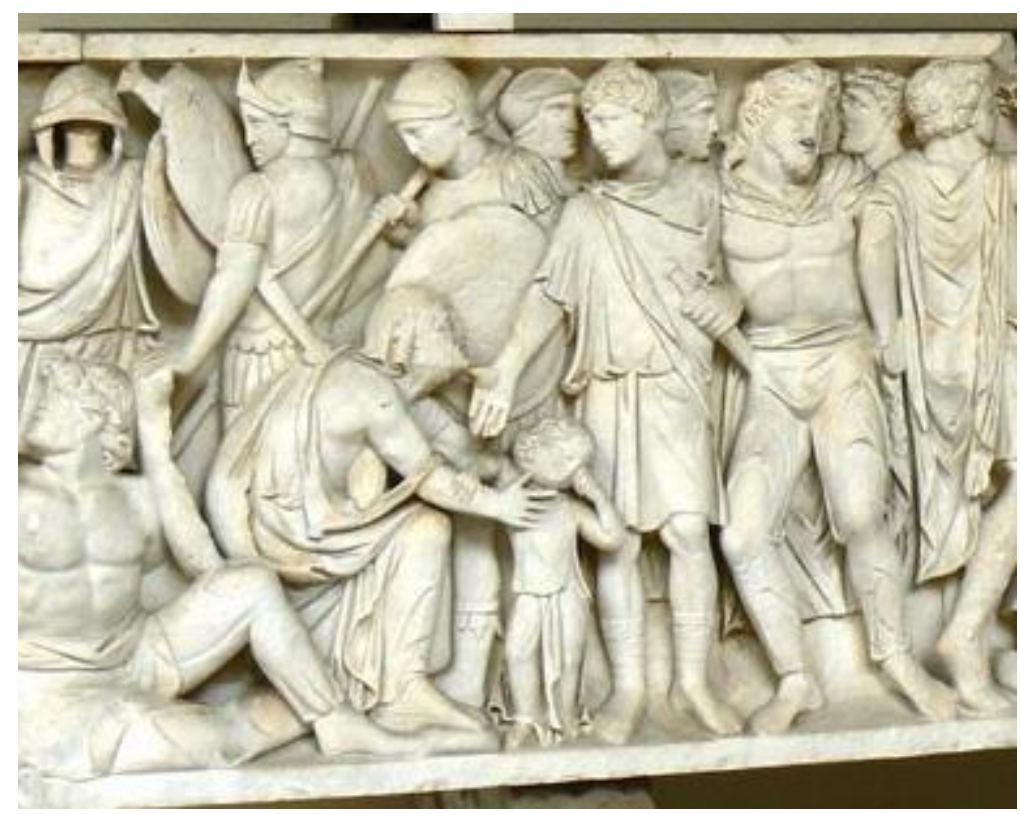

Figura 34 - Detalle del sarcófago en el que aparece una prisionera anciana (s. II d.C.). Musei Vaticani (Roma).

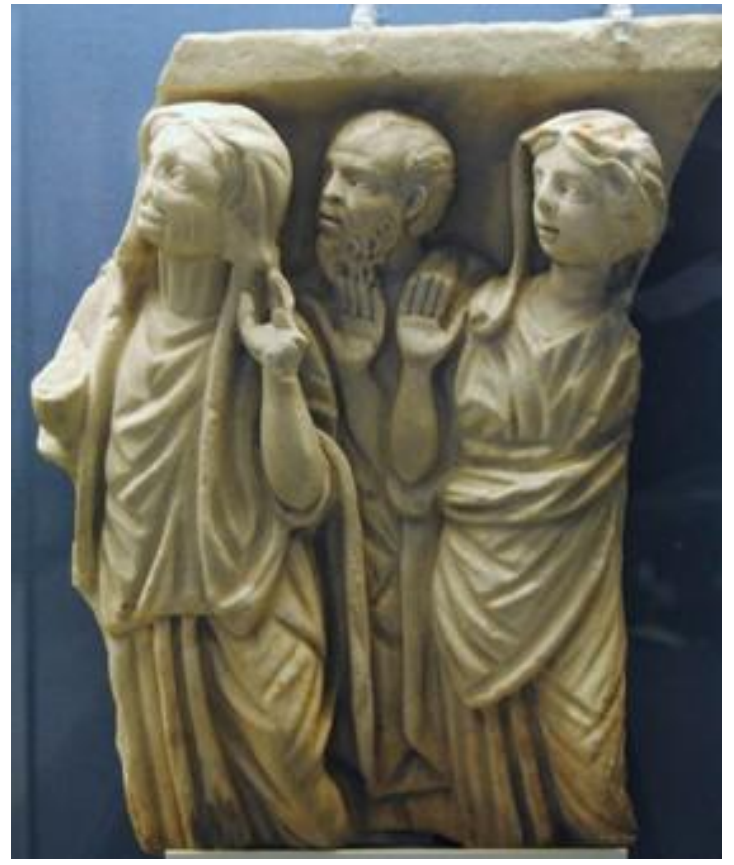

Figura 35 - Sarcófago en el que aparece una vetula (s. III d.C.). The British Museum (Londres).

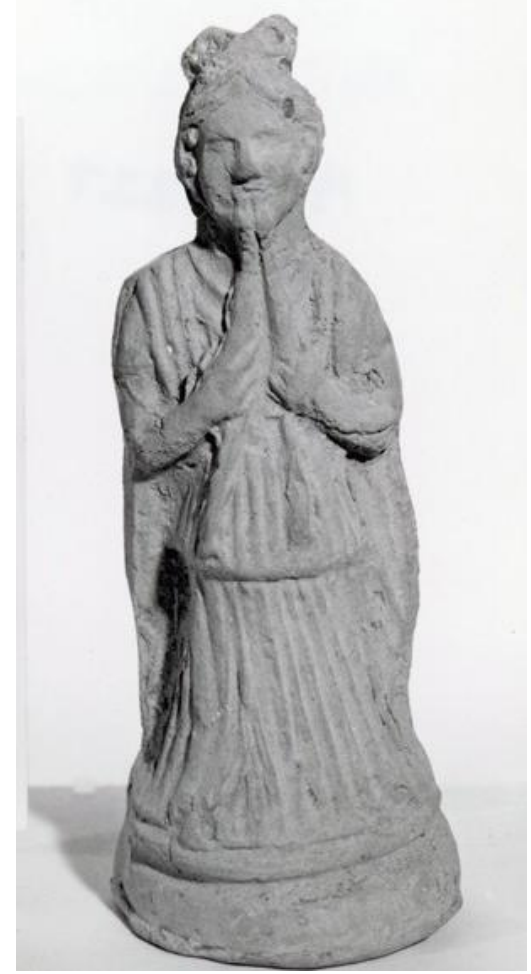

Figura 36 - Figura de terracota de vetula flautista (ss. I a.C. - I d.C.). The British Museum (Londres). 


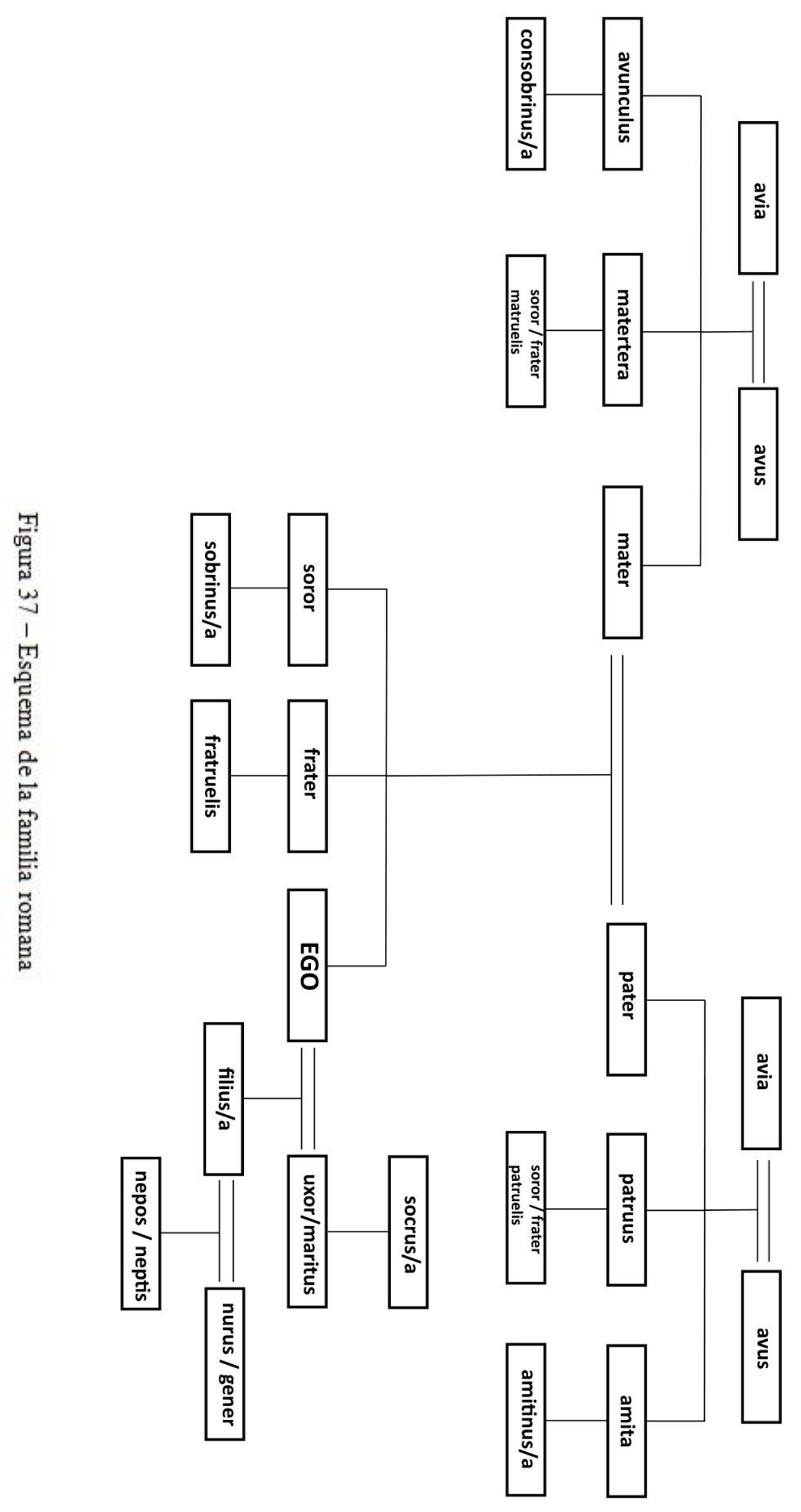




\section{ÍNDICE DE AUTORES CLÁSICOS}

A

Ael.

$N A$

Aesop.

Amm. Marc

Apollod.

Bibl.

Apul.

Apol.

Met.

Aret.

SD

Arist.

$G A$

Iuu.

Long.

Mem.

Aristid

Or.

Arn.

Adv. Nat.

August.

De Civ. D.

Contra Iul.

Div. quaest.
Eliano

Historia de los animales

Esopo

Fábulas

Amiano Marcelino

Historia

Apolodoro

Biblioteca

Apuleyo

Apología

Metamorfosis

Areteo de Capadocia

Sobre las causas y los síntomas de las enfermedades

crónicas

Aristóteles

Historia de los animales

Acerca de la juventud y la vejez, de la vida y de la muerte Acerca de la longevidad y de la brevedad de la vida Acerca de la memoria y la reminiscencia

Elio Arístides

Discursos

Arnobio de Sicca

En pugna con los gentiles

Agustín de Hipona

La ciudad de dios

Réplica a Juliano

Ochenta y tres cuestiones diversas 
Aur.

Auson.

App.

Ecl.

Ep.

Par.

Prof. Burd.

Protrept. ad nep.

C

Cass. Dio

Cato

Agr.

Catull.

Cel.

Med.

Cen.

DN

Cic.

Amic.

Att.

De or.

Div.

Fam.

Fin.

Leg.

Nat. D

Off.

Pis.

Scaur.

Sen.
Marco Aurelio

Meditaciones

Ausonio

Apéndices

Églogas

Cartas

Conmemoración a los familiares

Conmemoración a los profesores de Burdeos

Exhortación a mi nieto

Dión Casio

Historia romana

Catón

Tratado de agricultura

Catulo

Poemas

Celso

Sobre la medicina

Censorino

Del día del nacimiento

Cicerón

Sobre la amistad

Cartas a Ático

Sobre el orador

Sobre la adivinación

Cartas a los familiares

Del supremo bien y del supremo mal

Sobre las leyes

Sobre la naturaleza de los dioses

Los deberes

Contra Lucio Calpurnio Pisón

En defensa de Marco Emilio Escauro

Sobre la vejez 
Tim.

Tusc.

Clem. Al.

Propt.

Cod. Iust.

Col.

Rust.

D

D. Cr.

Dig.

Diod. Sic.

Dion. Hal.

Ant. Rom.

F

Fest.

G

Gai.

Inst.

Gal.

De loc. aff.

De san.

De usu p.

Nat. Fac.

Anim.

Gell.
Timeo

Disputaciones Tusculanas

Clemente de Alejandría

Protéptico

Código de Justiniano

Columela

Los trabajos del campo

Dión Crisóstomo

Discursos

Digesto

Diodoro Sículo

Biblioteca Histórica

Dionisio de Halicarnaso

Historia antigua de Roma

Festo

Sobre el significado de las palabras

Gayo

Instituciones

Galeno

Sobre la localización de las enfermedades

Sobre la higiene

Del uso de las partes

Sobre las facultades naturales

Las facultades del alma siguen los temperamentos del cuerpo

Aulo Gelio

Noches áticas 
Hdn.

Herodiano

Historia del imperio romano después de Marco Aurelio

Heliod.

Heliodoro

Aeth.

Etiópicas

Hes.

Hesíodo

Sc.

Escudo

Th.

Teogonía

Hippoc.

Hipócrates

Aph.

Aforismos

Coac. Pr.

Prenociones de Cos

De di.

Sobre la dieta

Epid.

Epidemias

Morb.

Sobre las enfermedades

Mul.

Sobre las enfermedades de las mujeres

Nat. Mul.

Sobre la naturaleza de la mujer

Hymn. Hom.

Himnos homéricos

Hymn. Hom. Ven.

Himno Homérico a Afrodita

Hom.

Il.

Homero

Ilíada

Hor.

Horacio

Ars $P$.

Ars poética

Carm.

Odas

Epist.

Epístolas

Epod.

Épodos

Sat.

Sátiras

I

Isid.

Isodoro de Sevilla

Diff.

Diferencias

Etym.

Etimologías

Iust.

Justiniano

Cod. Iust.

Código de Justianiano 
Joseph.

AJ

Vit.

Juv.

L

Liv.

Luc.

Am.

Asin.

Dial. Meret.

Dial. Mort.

Pr. Im.

Rhet.p.

Sat.

Tim.

Lucil.

Lucr.

M

Macrob.

In somn.

Sat.

Mart.

$\mathbf{N}$

Nep.

Att.
Flavio Josefo

Antigüedades Judías

Autobiografía

Juvenal

Sátiras

Tito Livio

Historia de Roma desde su fundación

Periocas

Luciano

Amores

Lucio o el asno

Diálogos de las heteras

Diálogos de los muertos

En pro de los retratos

El maestro de retórica

Saturnales

Timón

Lucilio

Sátiras

Lucrecio

La naturaleza

Macrob

Comentario al sueño de Escipión

Saturnales

Marcial

Epigramas

Cornelio Nepote

Vidas - Ático 
O

Orib.

Ec.

Oribasio

Inc.

Égloga

Libros inciertos

Ov.

Am.

Ovidio

Ars am.

Amores

Fast.

Arte de amar

Medic

Fastos

Met.

Pont.

$\operatorname{Tr}$.

Sobre la cosmética del rostro femenino

Metamorfosis

Pónticas

Tristes

$\mathbf{P}$

Paus.

Pausanias

Descripción de Grecia

Pers.

Persio

Sátiras

Petron.

Petronio

Sat.

Satiricón

$\mathrm{Ph}$.

Filón de Alejandría

De op.

Sobre la creación del mundo

Phaed.

Fedro

Fábulas

Philostr.

Filóstrato

Her.

Heroico

Imag.

Descripciones de cuadros

V.A.

Vida de Apolonio de Tiana

Phl.

Flegón de Trales

De los casos de longevidad

Mir.

De las cosas maravillosas 
Pl.

$R$.

Plaut.

Amph.

Asin.

Aul.

Bacch.

Capt.

Cas.

Cist.

Curc.

Men.

Merc

Mil.

Mostell.

Rud.

Trin.

Plin.

Ep.

Pan.

Plin.

NH

Plut.

C. Gracch.

Cat. Mai.

Cic.

Cor.

Luc.

Mor.

Num.

Quaest. Rom.

Ti. Gracch.
Platón

República

Plauto

Anfitrión

Comedia de los asnos

La comedia de la olla

Las dos Báquides

Los cautivos

Cásina

La cestita

Gorgojo

Los dos Menecmos

El mercader

El militar fanfarrón

La comedia del fantasma

La maroma

Tres monedas

Plinio el Joven

Cartas

Panegírico a Trajano

Plinio el Viejo

Historia natural

Plutarco

Vidas paralelas - Cayo Graco

Vidas paralelas - Catón el Viejo

Vidas paralelas - Cicerón

Vidas paralelas - Coriolano

Vidas paralelas - Lúculo

Obras morales y de costumbres

Vidas paralelas: Numa

Cuestiones romanas

Vidas paralelas - Tiberio Graco 
Prop.

Propercio

Elegías

S

Sall.

Salustio

Cat.

Conjuración de Catilina

Sen.

Séneca el Joven

Clem.

Clemencia

Dial.

Diálogos

Ep.

Epístolas

Helv.

Consolación a Helvia

Herc.

Hércules loco

Marc.

Consolación a Marcia

Pol.

Consolación a Polibio

Sen.

Contr.

Séneca el Viejo

Suas.

Controversias

Suasorias

Serv.

Aen.

Servio

Comentarios a la Eneida

SHA

Claud.

Scriptores Historiae Augustae

Clod.

Claudio Gótico

Hadr.

Clodio

Marc.

Adriano

Sev.

Marco Aurelio

Severo

Sor.

Gyn.

Sorano

Ginecología

Suet.

Suetonio

Aug.

Augusto

Calig.

Calígula

Claud.

Claudio

Dom.

Domiciano

Galb.

Galba

Ner.

Nerón 
Tib.

Vesp.

Vit.

$\mathbf{T}$

Tac.

Ann.

Hist.

Ter.

Ad.

An.

Hec.

Phorm.

Tib.

$\mathbf{U}$

Ulp.

V

Val. Max.

Var.

$L$.

Sat. Men.

Verg.

Aen.

G.
Tiberio

Vespasiano

Vitelio

Tácito

Anales

Historias

Terencio

Adelphoe

La muchacha de Andros

La suegra

Phormio

Tibulo

Elegías

Ulpiano

Fragmentos

Valerio Máximo

Hechos y dichos memorables

Varrón

Sobre la lengua latina

Sátiras Menipeas

Virgilio

Eneida

Geórgicas 


\section{REFERENCIAS}

\section{CORPORA}

$A E$ : L'Année épigraphique: Revue des publications épigraphiques relatives à l'antiquité romaine. París, 1888-

ASP: Archivio storico Pugliense. Bari, 1990-

BF: BAGNALL, Robert S. y FRIER, Bruce W. (1994): The Demography of Roman Egypt. Cambridge: Cambridge University Press.

BGU: Aegyptische Urkuden aus den Königlichen Museen zu Berlin. Berlín, 1895-

CEG: Carmina Epigraphica Graeca. Berlín-Nueva York, 1983-1989.

CIA: Corpus des inscriptions latines d'Albanie. Roma, 2009.

CIL: Corpus Inscriptionum Latinarum. Berlín, 1863-

EAOR: Epigrafia anfiteatrale dell'Occidente romano. Roma, 1988-

ERAE: Epigrafía romana de Augusta Emerita. Madrid, 1973.

ILS: Inscriptiones Latinae Selectae. Berlín, 1892-1916.

ILSard: Iscrizioni latine della Sardegna. Padua, 1961.

NSA: Notizie degli scavi di antichità. Roma, 1800-

Paestum: MELO, Mário y VOZA, Giuseppe (1968): Le inscrizioni latine di Parestum. Nápoles: Università Degli Studi di Napoli.

P. Brem.: Die Bremer Papyri. Berlín, 1936.

P. Diog.: Les archives de Marcus Lucretius Diogenes et textes apparentés. Bonn, 1990.

P. Fay.: Fayum Towns and their Papyri. Londres, 1900.

P. Giss: Griechische Papyri im Museum des oberhessischen Geschichtsvereins zu Giessen. Berlín, 1910-1912.

P. Lond.: Greek Papyri in the British Museum. Londres, 1893-

P. Oxy.: The Oxyrhynchus Papyri. Londres, 1898- 
P. Petaus: Das Archiv des Petaus. Opladen, 1969.

RIC: Roman Imperial Coinage. Vol 1. Londres, 1984.

SB: Sammelbuch griechischer Urkunden aus Aegypten. Berlín, 1915-

\section{EDICIONES DE AUTORES CLÁSICOS}

AGUSTÍN DE HIPONA (1985): Réplica a Juliano. Traducción, introducción y notas de Luis Arias. Madrid: Biblioteca de Autores Cristianos.

- (1988): La ciudad de dios. Traducción de Santos Santamarta del Río y Miguel Fuertes Lanero; introducción y notas de Victorino Capánaga. Madrid: Biblioteca de Autores Cristianos.

— (1995): Ochenta y tres cuestiones diversas. Introducciones, versión, notas e índices de Teodoro C. Madrid. Madrid: Biblioteca de Autores Cristianos.

AMIANO MARCELINO (2002): Historia. Edición de M. Luis Harto Trujillo. Madrid: Akal.

APULEYO (1978): Metamorfosis. Introducción, traducción y notas de Lisardo Rubio Fernández. Madrid: Gredos.

- (1998): Apología. Introducción, traducción y notas de Santiago Segura Munguía. Madrid: Gredos.

ARISTÓTELES (1987): Acerca de la juventud y la vejez, de la vida y de la muerte. Acerca de la longevidad y de la brevedad de la vida. Acerca de la memoria y la reminiscencia. Introducciones, traducciones y notas de Ernesto La Croce y Alberto Bernabé Pajares. Madrid: Gredos.

— (1990): Historia de los animales. Edición de José Vara Donado. Madrid: Akal.

ARNOBIO DE SICCA (2003): En pugna con los gentiles. Traducción, introducción y notas por Clara Castroviejo Bolíbar. Madrid: Biblioteca de Autores Cristianos.

AULO GELIO (2009): Noches Áticas. Edición de Santiago López Moreda. Madrid: Akal.

AUSONIO (1990): Apéndices. Cartas. Conmemoración a los familiares. Conmemoración a los profesores de Burdeos. Églogas. Exhortación a mi nieto. Traducción, introducción y notas de Antonio Alvar Ezquerra. Madrid: Gredos. 
CATULO (1993): Poemas. Introducciones, traducciones y notas de Arturo Soler Ruiz. Madrid: Gredos.

CELSO (1971): De Medicina. Translation by William G. Spencer. Cambridge-Londres: Harvard University Press-William Heinemann LDT.

CENSORINO (1900): De die natale. Translated into English by William Maude. Nueva York: The Cambridge Encyclopedia.

CICERÓN (1987): Del supremo bien y del supremo mal. Introducción, traducción y notas de Víctor J. Herrero Llorente. Madrid: Gredos.

- (1996): Cartas a Ático. Introducción, traducción y notas de Miguel RodríguezPantoja Márquez. Madrid: Gredos.

- (1999): Sobre la adivinación. Sobre la naturaleza de los dioses. Timeo. Introducciones, traducciones y notas de Ángel Escobar. Madrid: Gredos.

- (2002): Sobre el orador. Introducción, traducción y notas de José Javier Iso Echegoyen. Madrid: Gredos.

- (2005a): Disputaciones Tusculanas. Traducciones, introducciones y notas de Alberto Medina González. Madrid: Gredos.

— (2005b): Sobre la vejez. Traducción de Rosario Delicado Méndez. Madrid: Tal Vez.

- (2008): Cartas a los familiares. Introducción, traducción y notas de José A. Beltrán. Madrid: Gredos.

- (2009a): Las leyes. Traducción, introducción y notas de Carmen T. Pabón de Acuña. Madrid: Gredos.

- (2009b): Sobre la amistad. Traducción, introducción y notas de M. Esperanza Torrego Salcedo. Madrid: Alianza.

- (2013): Contra Lucio Calpurnio Pisón. En defensa de Marco Emilio Escauro. Traducciones, introducciones y notas de Elena Cuadrado Ramos. Madrid: Gredos.

- (2014): Los deberes. Traducciones, introducciones y notas de Ignacio J. García Pinilla. Madrid: Gredos.

CLEMENTE DE ALEJANDRÍA (1994): Protéptico. Introducción, traducción y notas de M. Consolación Isart Hernández. Madrid: Gredos. 
CORNELIO NEPOTE (1985): Vidas. Introducción, traducción y notas de Manuel Segura Moreno. Madrid: Gredos.

Digesto (1889-1897). Edición de Ildefonso L. García del Corral. Barcelona: Jaime Molinas Editor.

DIODORO SÍCULO (2001): Biblioteca histórica. Introducción, traducción y notas de Francisco Parreu Alasà. Madrid: Gredos.

DION CASIO (2011): Historia romana. Traducción y notas de Juan Pedro Oliver Segura. Madrid: Gredos.

- (2014): Historia romana. Libros LXI a LXX. Traducción de Antonio D. Duarte Sánchez. Disponible en

https://www.academia.edu/23705418/DIÓN_CASIO_Historia_Romana_Epítomes_de_los_Libr os_LXI_a_LXX [Consulta 26/02/2018]

DIONISIO DE HALICARNASO (1984): Historia antigua de Roma. Introducción de Domingo Plácido. Traducción y notas de Elvira Jiménez y Ester Sánchez. Madrid: Gredos.

ELIANO (1989): Historia de los animales. Edición de José Vara Donado. Madrid: Akal.

ELIO ARÍSTIDES (1997): Discursos. Introducción, traducción y notas de Manuel Cortés Copete. Madrid: Gredos.

ESOPO (1985): Fábulas. Introducción general de Carlos García Gual. Introducciones, traducciones y notas de Pedro Bádenas de la Peña y Javier López Facal. Madrid: Gredos.

FEDRO (1998): Fábulas. Edición de Manuel Mañas Núñez. Madrid: Akal.

FESTO (1846): De la signification des mots. Traduit par M. A. Savagner. París: C. L. F. Panckoucke.

FILÓN DE ALEJANDRÍA (1976): Sobre la creación del mundo. Traducción directa, introducción y notas de José M. Triviño. Buenos Aires: Acervo Cultural.

FILÓSTRATO (1979): Vida de Apolonio de Tiana. Edición de Alberto Bernabé Pajares. Madrid: Gredos.

— (1996): Descripciones de cuadros. Heroico. Edición de Francesca Mestre. Madrid: Gredos. 
FLAVIO JOSEFO (1994): Autobiografía. Traducción y notas de Margarita Rodríguez de Sepúlveda. Madrid: Gredos.

— (1997): Antigüedades judías. Edición de José Vara Donado. Madrid: Akal.

FLEGÓN DE TRALES (1996): Book of marvels. Translated with an Introduction and Commentary by William Hansen. Exeter: University of Exeter.

GALENO (1997): Sobre la localización de las enfermedades. Introducciones de Luis García Ballester. Traducción y notas de Salud Andrés Aparicio. Madrid: Gredos.

- (2003): Las facultades del alma siguen los temperamentos del cuerpo. Sobre las facultades naturales. Introducciones, traducción y notas de Juana Zaragoza Gras. Madrid: Gredos.

- (2010): Del uso de las partes. Introducción, traducción y notas de Mercedes López Silva. Madrid: Gredos.

— (2012): Sobre la higiene. Robert Montraville Green (Translator), Henry E. Sigerist Introduction). Whitefish: Literary Licensing.

HELIODORO (1979): Las etiópicas. Introducción, traducción y notas de Emilio Crespo Güemes. Madrid: Gredos.

HERODIANO (1985): Historia del imperio romano después de Marco Aurelio. Traducción, introducción y notas de Juan J. Torres Esbarranch. Madrid: Gredos.

HESÍODO (1978): Escudo. Teogonía. Introducción, traducción y notas de Aurelio Pérez Jiménez y Alfonso Martínez Díez. Madrid: Gredos.

Himnos Homéricos (2005). Edición y traducción de José B. Torres Guerra. Madrid: Cátedra.

HIPÓCRATES (1983): Aforismos. Introducciones, traducciones y notas por Carlos García Gual, María D. Lara Nava, José A. López Férrez y Beatriz Cabellos Álvarez. Madrid: Gredos.

- (1986a): Prenociones de Cos. Introducciones, traducciones y notas de Juan Antonio López Férez y Elsa García Novo. Madrid: Gredos.

- (1986b): Sobre la dieta. Sobre las afecciones. Introducciones, traducciones y notas de Carlos García Gual, José M. Lucas de Dios, Beatriz Cabellos Álvarez e Ignacio Rodríguez Alfageme. Madrid: Gredos. 
- (1988): Sobre la naturaleza de la mujer. Sobre las enfermedades de las mujeres. Traducción y notas por Lourdes Sanz Mingote. Madrid: Gredos.

- (1989): Epidemias. Traducción, introducciones y notas de Alicia Esteban Santos, Elsa García Novo y Beatriz Cabellos Álvarez. Madrid: Gredos.

- (1990): Sobre las enfermedades. Traducciones, introducciones y notas de Assela Alamillo Sanz y M. Dolores Lara Nava. Madrid: Gredos.

HOMERO (2008): Ilíada. Edición de Antonio López Eire. Madrid: Cátedra.

HORACIO (2007): Épodos. Odas. Introducción, traducción y notas de José Luis Moralejo. Madrid: Gredos.

- (2008): Ars poética. Epístolas. Sátiras. Introducciones, traducciones y notas de J. Luis Moralejo. Madrid: Gredos.

ISIDORO DE SEVILLA (1982-1983): Etimologías. Versión española y notas por José Oroz Reta y Manuel A. Marcos Casquero. Madrid: Biblioteca de Autores Cristianos.

JUVENAL (2007): Sátiras. Edición bilingüe y traducción a cargo de Rosario Cortés Tovar. Madrid: Cátedra, 2007.

LUCIANO (1981): Timón. Introducción general de José Alsina. Traducción y notas de Andrés Espinosa. Madrid: Gredos.

- (1988): El maestro de retórica. Lucio o el asno. Traducción y notas de José L. Navarro. Madrid: Gredos.

— (1990): Amores. En pro de los retratos. Las Saturnales. Traducción y notas de Juan Zaragoza Botella. Madrid: Gredos.

— (1992): Diálogos de las heteras. Traducción y notas por José L. Navarro González. Madrid: Gredos.

- (2007): Diálogos de los muertos. Edición de Chantal López y Omar Cortés. Biblioteca Virtual Antorcha. Disponible en http://www.antorcha.net/biblioteca_virtual/literatura/muertos/indice.html [20/03/2018]

LUCILIO (1991): Sátiras. Edición de José Guillén Cabañero. Madrid: Akal.

LUCRECIO (1990): La naturaleza. Edición de Ismael Roca Melia. Madrid: Akal. 
MACROBIO (2005): Comentarios al sueño de Escipión. Edición y traducción de Jordi Raventós Barlam. Madrid: Siruela.

- (2010): Saturnales. Introducción, traducción y notas de Fernando Navarro Antolín. Madrid: Gredos.

MARCIAL (2004): Epigramas. Texto, introducción y notas de José Guillén. Zaragoza: CSIC.

MARCO AURELIO (1977): Meditaciones. Traducción y notas de Ramón Bach Pellicer. Madrid: Gredos.

OVIDIO (1988): Fastos. Introducción, traducción y notas de Bartolomé Segura Ramos. Madrid: Gredos.

- (1989): Amores. Arte de amar. Sobre la cosmética del rostro femenino. Traducción, introducción y notas de Vicente Cristóbal López. Madrid: Gredos.

— (1992): Tristes. Introducción, traducción y notas de José González Vázquez. Madrid: Gredos.

- (2003): Metamorfosis. Traducción de Antonio Ramírez de Verger y Fernando Navarro Antolín. Madrid: Alianza.

— (2008-2012): Metamorfosis. Traducción, introducción y notas de J. Carlos Fernández Corte y Josefa Cantó Llorca. Madrid: Gredos.

PAUSANIAS (1994): Descripción de Grecia. Introducción, traducción y notas de M. Cruz Herrero Ingelmo. Madrid: Gredos.

PERSIO (1991): Sátiras. Introducciones generales de Manuel Balasch y Miquel Dolç. Introducciones particulares, traducción y notas de Manuel Balasch. Madrid: Gredos.

PETRONIO (1978): Satiricón. Introducción, traducción y notas de Lisardo Rubio Fernández. Madrid: Gredos.

PLATÓN (1986): República. Diálogos IV. Introducción, traducción y notas de Conrado Eggers Lan. Madrid: Gredos.

PLAUTO (1992): Anfitrión. Comedia de los asnos. La comedia de la olla. Las dos Báquides. Los cautivos. Introducciones, traducciones y notas de Mercedes González-Haba. Madrid: Gredos. 
- (1996): Gorgojo. El militar fanfarrón. La cestita. La comedia del fantasma. Los dos Menecmos. El mercader. Introducciones, traducción y notas de Mercedes González-Haba. Madrid: Gredos.

- (2002): La maroma. Tres monedas. Introducción, traducción y notas de Mercedes González-Haba. Madrid: Gredos.

PLINIO EL JOVEN (2005): Cartas. Introducción, traducción y notas de Julián González Fernández. Madrid: Gredos.

— (2007): Panegírico a Trajano. Edición y traducción de J. Carlos Martín. Madrid: Cátedra.

PLINIO EL VIEJO (1995-2010): Historia natural. Traducción y notas de Antonio Fontán, Ana M $^{\mathrm{a}}$ Moure Casas, Ignacio García Arribas, Encarnación del Barrio y M ${ }^{\mathrm{a}}$ Luisa Arribas. Madrid: Gredos.

PLUTARCO (1985): Vidas paralelas. Introducción general, traducción y notas por Aurelio Pérez Jiménez. Madrid: Gredos.

- (1989): Obras morales y de costumbres. Introducciones, traducciones y notas por Mercedes López Salvá. Madrid: Gredos.

Priapeos (1990) Introducciones, traducciones y notas de Enrique Montero. Madrid: Gredos.

PROPERCIO (1989): Elegías. Introducción, traducción y notas de Antonio Ramírez de Verger. Madrid: Gredos.

SALUSTIO (1997): Conjuración de Catilina. Introducción, traducción y notas de Bartolomé Segura Ramos. Madrid: Gredos.

SCRIPTORES HISTORIAE AUGUSTAE (1989): Historia Augusta. Edición de Vicente Picón y Antonio Cascón. Madrid: Akal.

SÉNECA (1986): Epístolas. Introducción, traducción y notas de Ismael Roca Meliá. Madrid: Gredos.

— (1987): Hércules loco. Introducciones, traducciones y notas de Jesús Luque Moreno. Madrid: Gredos.

- (1996): Consolación a Helvia. Consolación a Marcia. Introducciones, traducciones y notas de Juan Mariné Isidro. Madrid: Gredos. 
- (2000): Diálogos. Introducciones, traducciones y notas de Juan Mariné Isidro. Madrid: Gredos.

- (2010): Diálogos - Sobre la brevedad de la vida. Traducción, notas y posfacio de Francisco Socas Gavilán. Sevilla: Junta de Andalucía.

SÉNECA EL VIEJO (1996): Suasorias. Introducciones, traducciones y notas de Juan Mariné Isidro. Madrid: Gredos.

- (2005): Controversias. Introducción, traducción y notas de Ignacio J. Adiego Lajara, Esther Artigas Álvarez y Alejandra de Riquer Permanyer. Madrid: Gredos.

SERVIO (2012): Comentarios a la Eneida. Texte établi, traduit et commenté par Emmanuell Jeunet-Mancy. París: Les Belles Lettres.

SORANO (1956): Ginecología. Traslated with and Introduction by Owsei Temkin. Baltimore: The Jonhs Hopkins University Press.

SUETONIO (1992): Vida de los doce césares. Introducción general de Antonio Ramírez de Verger. Traducción de Rosa $\mathrm{M}^{\mathrm{a}}$ Agudo Cubas. Madrid: Gredos.

TÁCITO (1980): Anales. Traducción y notas de José L. Moralejo. Madrid: Gredos.

— (1990): Historias. Edición de José L. Moralejo. Madrid: Akal.

TERENCIO (1987): Phormio. Aurea dicta: dichos y proverbios del mundo clásico. Selección de Eduard Valentí. Traducción de Neus Galí. Barcelona: Crítica.

- (1998): La muchacha de Andros. Edición de Aurora López López y Andrés Pociña Pérez. Madrid: Akal.

- (2008): La suegra. Introducción, traducción y notas de Gonzalo Fontana Elboj. Madrid: Gredos.

TÍBULO (1993): Elegías. Introducciones, traducciones y notas de Arturo Soler Ruiz. Madrid: Gredos.

TITO LIVIO (1993): Historia de Roma desde su fundación. Introducción, traducción y notas de J. Antonio Villar Vidal. Madrid: Gredos.

- (1995): Períocas. Introducción, traducción y notas de J. Antonio Villar Vidal. Madrid: Gredos. 
VALERIO MÁXIMO (1988): Hechos y dichos memorables. Edición de Fernando Martín Acera. Madrid: Akal.

VARRÓN (1974): Sátiras Menipeas. Édition, traduction et commentaire par Jean-Pierre Cèbe. Roma: Ècole Française de Rome.

- (1990): Sobre la lengua latina. Introducción, traducción y notas de Manuel A. Marcos Casquero. Barcelona: Anthropos.

VIRGILIO (1990): Geórgicas. Traducciones, introducciones y notas de Tomás A. Recio García y Arturo Soler Ruiz. Madrid: Gredos.

— (1992): Eneida. Introducción de Vicente Cristóbal. Traducción y notas de Javier de Echave-Sustaeta. Madrid: Gredos.

\section{BIBLIOGRAFÍA}

ABAD CADENAS, Cristina (2016): «Disidentes y visionarias de los nuevos feminismos». Arbor, 778, pp. 1-9.

ACERBI CREMADES, Norma (2013): «Y también la vejez tiene su historia». Revista de Salud Pública, 17, pp. 69-73.

ACHENBAUM, Andrew (2010): «Past as Prologue: Towards a Global History of Ageing». En DANNEFER, Dale y PHILLIPSON, Chris (ed.): The SAGE Handbook of Social Gerontology. Londres: SAGE, pp. 20-32.

AGARWAL, Sabrina C. y BEAUCHESNE, Patrick (2011): «It is Not Carved in Bone. Development and Plasticity of the Aged Skeleton». En AGARWAL, Sabrina C. y GLENCROSS, Bonnie A. (ed.): Social Bioarchaeology. Oxford: Blackwell, pp. 312-332.

AGRONIN, Marc E. (2014): «From Cicero to Cohen: Developmental Theories of Aging, from Antiquity to the Present». The Gerontologist, 54:1, pp. 30-39.

AGUILAR GARCÍA, María L. (2011): «La vestimenta femenina en la sátira latina». En ALFARO GINER, Carmen; MARTÍNEZ GARCÍA, María J. y ORTIZ GARCÍA, Jónatan (ed.): Mujer y vestimenta. Aspectos de la identidad femenina en la Antigüedad. Valencia: SEMA, Universitat de València, pp. 67-104.

ALBA, Víctor (1992): Historia social de la vejez. Barcelona: Laertes. 
ALBERICI, Lisa A. y HARLOW, Mary (2007): «Age and Innocence: Female Transitions to Adulthood in Late Antiquity». En CHOEN, Ada y RUTTER, Jeremy B. (ed.): Constructions of Childhood in Ancient Greece and Italy. Princeton: The American School of Classical Studies at Athens, pp. 193-203.

ALFARO GINER, Carmen (2010): «La mujer y el trabajo en la Hispania prerromana y romana». Mélanges de la Casa de Velázquez, 40:2, pp. 15-38.

ALFÖLDY, Géza (1972): «Die Frellassung von Sklaven und die Struktur der Sklaverei in der römischen Kaiserzeit». Rivista Storica dell'Antichitá, 2, pp. 97-129.

ALLASON-JONES, Lindsay (1989): Women in Roman Britain. Londres: British Museum Publications.

ALTON, Ernest H. (1920): «Anna Perenna and Mamurius Veturius». Hermathena, 19:42, pp. 100-104.

ALVAR NUÑO, Antón (2009): «Nocturnae aves: su simbolismo religioso y función mágica en el mundo romano». Arys, 8, pp. 187-202.

ALVAREZ MELERO, Anthony (2016): «Les parentes féminines de chevaliers romains à l'époque tardo-républicaine (fin IIe s. - 27 a.v.J.-Chr». En CENERINI, Francesa y ROR VIO, Francesca (a cura di): Matronae in domo et in re publica agentes. Spazi e occasioni dell'azione femminile nel mondo romano tra tarda repubblica e primo impero. Atti del Convegno di Venezia 16-17 ottobre 2014. Trieste: Edizioni Università di Trieste, pp. 217-237.

AMOSSY, Ruth y HERRSCHBERG PIERROT, Anne (2011): Estereotipos y clichés. Eudeba: Buenos Aires.

AMUNDSEN, Darrel W. y DIERS, Carol J. (1970): «The Age of Menopause in Classical Greece and Rome». Human Biology, 42, pp. 79-86.

ANDRÉ, Jean-Marie (2006): La médicine à Rome. París: Éditions Tallandier.

ANGELI, Stefano de (1991): «Problemi di iconografía romana: dalle Moire alle Parche». Mélanges de l'Ecole française de Rome, 103, pp. 105-128.

APARISI MIRALLES, Ángela (2016): «Discursos de género: el modelo de la igualdad en la diferencia». Arbor, 778, pp. 1-8.

APPLEBY, Joanna E. P. (2010): «Why We Need an Archaeology of Old Age, and a Suggested Approach». Norwegian Archaeology Review, 43, pp. 145-168. 
ARCAZ POZO, Juan L. (2012): «Senilis amor: postura de los elegíacos latinos frente al amor en la vejez». AnMal Electrónica, 32, pp. 3-28.

ARQUIOLA LLOPIS, Elvira (1995): La vejez a debate. Análisis histórico de la situación sociosanitaria de la vejez en la actualidad. Madrid: CSIC.

AUSTIN, Lucy (1946): «The Caerellia of Cicero's Correspondence». The Classical Journal, 41:7, pp. 305-309.

BALDWIN, Barry (1976): «Young and old in imperial Rome». En BERTMAN, Stephen: The Conflict of Generations in Ancient Greece and Rome. Ámsterdam: Grüner, pp. 221-233.

BALLARÍN DOMINGO, Pilar (2017): «Las fronteras de la docencia universitaria feminista en tiempos revueltos». En GALLEGO FRANCO, Henar y MORENO SECO, Mónica (ed.): Cómo enseñamos la Historia (de las Mujeres). Homenaje a Amparo Pedregal. Barcelona: Icaria, pp. $51-74$

BAROIN, Charlote (2002): «Les cicatrices ou la mémoire du corps». En MOREAU, Phillippe (ed.): Corps romains. Grenoble: Editions Jérôme Millon, pp. 27-46.

BARRETT, Anthony A. (2002): Livia. First Lady of Imperial Rome. New Haven: Yale University Press.

BARTMAN, Elizabeth (1999): Portraits of Livia. Imaging the Imperial Woman in Augustan Rome. Cambridge: Cambridge University Press.

- (2001): «Hair and Artifice of Roman Female Adornment». American Journal of Archaeology, 105:1, pp. 1-25.

BAXARÍAS TIBAU, Joaquín (2002): La enfermedad en la Hispania Romana: estudio de una necrópolis tarraconense. Zaragoza: Libros Pórtico.

BEAUVOIR, Simone de (1996): The coming of age. Londres-Nueva York: Norton.

— (2013): El segundo sexo. Madrid: Cátedra.

BELTRANI, Lucia (2016): «La bellezza femminile nella cultura romana». Storia delle Donne, 12, pp. 141-159.

BENEDETTO, Vincenzo Di (1985): «Il tema della vecchiaia e il fr. 58 di Saffo». Quaderni Urbinati di Cultura Classica, New Series, 19, pp. 145-163. 
BENKE, Nikolaus (2005): «Aemilia Pudentilla - a Landowning Lady». En VAN DEN BERGH, Rena (ed.): Ex iusta causa traditum: Essays in Honour of Eric H. Pool. Pretoria: Fundamina, pp. 19-31.

BENNETT, Judith M. (2006): History Matters. Patriarchy and the Challenge of Feminism. Filadelfia: University of Pensylvania Press.

BENOIT-LAPIERRE, Nicole (1983): «Une histoire de la vieillesse? Entretien avec Philippe Ariès». Communications, 37, pp. 47-54.

BERELSON, Louis J. (1934): Old Age in Ancient Rome. University of Virginia, Tesis Doctoral inédita.

BERG, Ria (2002): «Wearing Wealth. Mundus Muliebris and Ornatus as Status Markers for Women». En SETÄLÄ, Päivi; BERG, Ria; HÄLIKKA, Riika; KELTANEN, Minerva; PÖLÖNEN, Janne y VUOLANTO, Ville: Women, Wealth and Power in the Roman Empire. Roma: Institutum Romanum Finlandiae, pp. 15-73.

BERMEJO BARRERA, J. Carlos. (2009): Introducción a la historia teórica. Madrid: Akal.

BERNAL CASASOLA, Dario (1995): «Cerámicas romanas de tipo figurado en contextos tarraconenses». Boletín de la Asociación Española de Amigos de la Aqueología, 35, pp. $263-$ 268.

BERTMAN, Stephen (1976): The Conflict of Generations in Ancient Greece and Rome. Ámsterdam: Grüner.

- (1989): «The Ashes and the Flame: Passion and Ageing in Classical Poetry». En FALKNER, Thomas M. y LUCE, Judith de (ed.): Old age in Greek and Latin Literature. Nueva York: State University of New York, pp. 157-171.

BERNÁRDEZ RODAL, Asunción (2009): «Transparencia de la vejez y sociedad del espectáculo: pensar a partir de Simone de Beauvoir». Investigaciones Feministas, 0, pp. 29-46.

BETETA MARTÍN, Yolanda (2014): «La sexualidad de las brujas. La deconstrucción y subversión de las representaciones artísticas de la brujería, la perversidad y la castración femenina en el arte feminista del siglo XX». Dossiers Feministes, 18, pp. 293-307.

BLANCO CESTEROS, Miriam (2015): «Haberlas haylas. Redescubriendo a las brujas en el Mundo Greco-Latino». En ROSA CUBO, Cristina de la; VAL VALDIVIESO, María I.; DUEÑAS CEPEDA, María J. y SANTO TOMÁS PÉREZ, Magdalena (coord.): Femina. Mujeres en la Historia. Valladolid: Ediciones Universidad de Valladolid, pp. 29-48. 
BLANCO LÓPEZ, Juan y VALCUENDE DEL RÍO, José M. (coord.) (2003): Hombres: la construcción cultural de las masculinidades. Madrid: Talasa.

BLÁZQUEZ MARTÍNEZ, José M. (1989): «Administración de las minas en época romana. Su evolución». En DOMERGUE, Claude (coord.): Minería y metalurgia en las antiguas civilizaciones mediterráneas y europeas. Tomo II. Madrid: Ministerio de Cultura, pp. 119-132.

- (2000): «Los anticonceptivos en la Antigüedad clásica». En ALFARO GINER, Carmen y TIRADO PASCUAL, Marta (ed.): Actas del Segundo Seminario de Estudios sobre la Mujer en la Antigüedad (Valencia, 26-28 marzo 1998). Valencia: Universitat de València, pp. 135-146.

BOEHRINGER, Sandra y SEBILLOTTE CUCHET, Violaine (2015): «Corps, sexualité et genre dans les mondes grec et romain». En GHERCHANOC, Florence (dir.): L'histoire du corps dans l'Antiquité: bilan historiographique. Journée des printemps de la SOPHAU du 25 mai 2013. Besançon: Presses universitaires de Franche-Comté, pp. 83-108.

BOOTH, Alan D. (1980): «Allusion to the Circulator by Persius and Horace?». Greece \& Rome, 27, pp. 166-169.

BORDO, Susan (1995): Unbearable Weight. Feminism, Western Culture, and the Body. Berkeley: University of California Press.

BOTELHO, Lynn (2014a): «Age and History as Categories of Analysis: Refiguring Old Age». Age, Culture, Humanities. An International Journal, 1.

— (2014b): «Old age and menopause in rural women of early modern Suffolk». En BOTELHO, Lynn y THANE, Pat: Women and Ageing in British Society since 1500. LondresNueva York: Routledge, pp. 43-65.

BOTELHO, Lynn y THANE, Pat (2014): «Introduction». En BOTELHO, Lynn y THANE, Pat: Women and Ageing in British Society Since 1500. Londres-Nueva York: Routledge, pp. 1-12.

BOYMEL KAMPEN, Natalie (1991): «Between Public and Private: Women as Historical Subjects in Roman Art». En POMEROY, Sarah B. (ed.): Women's History \& Ancient History. Chapel Hill: The University of North Carolina Press, pp. 218-248.

BRADLEY, Keith R. (1996): «Remarriage and the Structure of the Upper-Class Roman Family». En RAWSON, Beryl (ed.): Marriage, Divorce, and Children in Ancient Rome. Oxford: Claredon Press, pp. 79-98. 
— (2000): «Animalizing the Slave: The Truth of Fiction». Journal of Roman Studies, 90, pp. 110-125.

BRAUDEL, Fernand (1979): La historia y las ciencias sociales. Madrid: Alianza.

BURKE, Peter (2001): Visto y no visto. El uso de la imagen como documento histórico. Barcelona: Crítica.

BURN, Andrew R. (1953): «Hic breve vivitur. A Study of the Expectation of Life in the Roman Empire». Past \& Present, 4, pp. 2-31.

BURNS, Jasper (2007): Great Women of Imperial Rome. Mothers and Wives of the Caesars. Nueva York: Routledge.

BUTLER, Judith (2007): El género en disputa. Barcelona: Paidós.

BUTLER, Robert N. (1980): «Ageism: A Foreword». Journal of Social Issues, 36:2, pp. 8-11.

BYL, Simon (1988a): «La gérontologie de Galien». History and Philosophy of the Life Sciences, 10, pp. 73-92.

- (1988b): «Rheumatism and Gout in the Corpus Hippocraticum». L'antiquité classique, 57, pp. 89-102.

- (2001): «Les infirmities physiques de la vieillesse dans les épigrammes de l'Anthologie palatine». Revue des Études Grecques, 114, pp. 439-455.

— (2003): «Les faculties mentales du vieillard dans la literature grecque». Bulletin de l'Association Guillaume Budé, 2, pp. 27-49.

CABALLERO WANGÜEMERT, María (2016): «¿Hay mujeres más allá del feminismo? De la lucha por la igualdad al transhumanismo/posthumanismo». Arbor, 778, pp. 1-6.

CABEZAS FERNÁNDEZ DEL CAMPO, José A. (2003): «Algunas interpretaciones históricas acerca de la vejez y el envejecimiento». En Real Academia Nacional de Farmacia: Bioquímica y fisiopatología del envejecimiento. Madrid: RANF, pp. 15-28.

CABRERA BARBERO, Silvia (2009): «Valoración de los factores psicosociales que afectan a la sexualidad en la vejez e influencia percibida en la actividad sexual». Informaciones Psiquiátricas, 195-196, pp. 101-138.

CAIRO, Emilia (2011): «La historia de amor de la Sibila y las dinámicas narrativas de Metamorfosis». En GALÁN, Lía y BLISEL, María D. (ed.) y PEDERNERA, Soledad (coord.): 
$V$ Jornadas de Estudios Clásicos y Medievales, 5 al 7 de octubre de 2011. Juventud y vejez en la Antigüedad y el Medievo. La Plata, Argentina. Buenos Aires: Universidad Nacional de La Plata. Disponible en

http://www.memoria.fahce.unlp.edu.ar/library?a=d\&c=eventos\&d=Jev1221 [Consulta 10/02/2018]

CALDARINI Carla; CATALANO, Paola; PICCIOLI, Andrea; SPINELlI, Maria S. y ZAVARONI, Federica (2015): «Joint Degenerative Pathologies». En PICCIOLI, Andrea; GAZZANIGA, Valentina y CATALANO, Paola: Bones. Orthopaedic Pathologies in Roman Imperial Age. Nueva York: Springer, pp. 83-101.

CAMPILLO IBORRA, Neus (2003): «Ontología y diferencia de los sexos». En TUBERT, Silvia (ed.): Del sexo al género. Los equívocos de un concepto. Madrid: Cátedra, pp. 83-122.

CAMPS GASET, Montserrat (2000): «La sabiduría de las mujeres: magia y medicina». Arenal, 7:2, pp. 323-340.

CANNADINE, David (2008): Making History Now and Then. Discoveries, Controversies and Explanations. Nueva York: Palgrave Macmillan.

CANO LÓPEZ, Santiago (2012): «Consideraciones en torno a la "Vieja Borracha" del Museo de Santaella (Córdoba)». Boletín de la Asociación Provincial de Museos Locales de Córdoba, 13, pp. 295-299.

CANTARELlA, Eva (1995): «La sexualidad de la mujer romana». En PÉREZ JIMÉNEZ, Aurelio y CRUZ ANDREOTTI, Gonzalo (ed.): Hijas de Afrodita. La sexualidad femenina en los pueblos mediterráneos. Madrid: Ediciones Clásicas, pp. 115-130.

CARBAJO PÉREZ, María C. (2008): «La historia de la vejez». Ensayos, 18, pp. 237-254.

CARBÓ GARCÍA, Juan R. y PÉREZ MIRANDA, Iván (2009-2010): «Hijas de la noche (II): El destino de las Parcas entre el pasado y el presente». Arys, 8, pp. 141-154.

CARLON, Jacqueline M. (2009): Pliny's Women. Constructing Virtue and Creating Identity in the Roman World. Cambridge: Cambridge University Press.

CARMENATE, Margarita y PRADO, Consuelo (2002): «Las edades biológicas de la mujer». En PÉREZ CANTÓ, Pilar y ORTEGA LÓPEZ, Margarita (ed.): Las edades de las mujeres. Madrid: Universidad Autónoma de Madrid, pp. 443-453.

CARRERAS MONFORT, César (2014): «Nuevas tendencias y datos sobre la demografía romana en la Península Ibérica». BSAA arqueología, 80, pp. 53-82. 
CASCAJERO GARCÉS, Juan (2000): «Grupos de edad y relaciones de dependencia en la oralidad antigua. La vejez en los restos orales». En MYRO, María M.; CASILLAS, Juan M.; ALVAR EZQUERRA, Jaime y PLÁCIDO SUÁREZ, Domingo (ed.): Las edades de la dependencia durante la Antigüedad. Madrid: Ediciones Clásicas, pp. 1-27.

- (2002): «Feminismo, postmodernidad e Historia Antigua. Entre la igualdad y la diferencia». Gerión, 20, pp. 33-74.

CASTELLANOS SORIANO, Fabiola y LÓPEZ DÍAZ, Alba L. (2010): «Mirando pasar la vida desde la ventana: significados de la vejez y la discapacidad en un grupo de ancianos en un contexto de pobreza». Investigación en Enfermería, 12:2, pp. 37-53.

CAVE, Christine y OXENHAM, Marc (2016): «Identification of the Archaeological 'Invisible Elderly: An Approach Illustrated with an Anglo Saxon Example». International Journal of Osteoarchaeology, 26, pp. 163-175.

CEBERIO, Marcelo R. (2013): El cielo puede esperar. La cuarta edad: ser anciano en el siglo XXI. Madrid: Ediciones Morata.

CENARRO LAGUNAS, Ángela (2014): «Introducción». En CENARRO LAGUNAS, Ángela e ILLION, Régine (ed.): Feminismos: Contribuciones desde la historia. Zaragoza: Prensas de la Universidad de Zaragoza, pp. 9-25.

CENERINI, Francesca (2014): «L'affettività femminile in età romana: una ricerca impossibile?». En CHEMOTTI, Saveria (a cura di): Affettività elettive. Relazioni e costellazioni dis-ordinate. Padua: Il Poligrafo, pp. 15-29.

CENTLIVRES CHALLET, Claude-Emmanuelle (2012): «Pliny the Nephew: Youth and Family Ties across Generations and Genders». En LARSSON LOVÉN, Lena y HARLOW, Mary (ed.): Families in the Imperial and Late Antique Roman World. Londres-Nueva York: Continuum, pp. $7-22$.

CHANDLER, Albert R. (1948a): «Aristotle on Mental Aging». The Journal of Gerontology, 3, pp. 220-224.

— (1948b): «Cicero's Ideal Old Man». The Journal of Gerontology, 3, pp. 285-289.

CHAPARRO GÓMEZ, César (2002): «La mujer en Roma: la trama de la discriminación». En LÓPEZ MOREDA, Santiago (ed.): Ideas. Contemporaneidad de los mitos clásicos. Madrid: Ediciones Clásicas, pp. 69-84. 
CHAUSSON, François (2003): «Domitia Longina: reconsideration d'un destin imperial». Journal des savants, 1, pp. 101-129.

CHERRY, David (2001): The Roman World: A Sourcebook. Malden: Blackwell Publishers.

CID LÓPEZ, Rosa M. (1998): «Livia versus Diva Augusta. La mujer del príncipe y el culto imperial». Arys, 1, pp. 139-156.

— (2010): «Mujeres "poderosas" del Imperio romano en la historiografía moderna. Algunas notas críticas a las visiones de la Ilustración y su influencia». En FORNIS, César; GALLEGO, Julián; LÓPEZ BARJA DE QUIROGA, Pedro y VALDÉS, Miriam (ed.): Dialéctica histórica y compromiso social. Homenaje a Domingo Plácido. Vol. 2. Zaragoza: Libros Pórtico, pp. 685-701.

- (2011): «El discurso religioso y jurídico en la Roma antigua. La matrona y las mujeres de la Roma antigua. Un estereotipo femenino a través de las imágenes religiosas y las normas legales». En HIDALGO RODRÍGUEZ, David; CUBAS MARTÍN, Noemí y MARTÍNEZ QUINTEIRO, M. Esther (eds.): Mujeres en la Historia, el Arte y el Cine. Discursos de género, variantes de contenidos y soportes: de la palabra al audiovisual. Salamanca: Ediciones Universidad de Salamanca, pp. 55-70.

— (2014): «Imágenes del poder femenino en la Roma antigua. Entre Livia y Agripina». Asparkía, 25, pp. 179-201.

- (2015a): «El género y los estudios históricos sobre las mujeres en la Antigüedad. Reflexiones sobre los usos y evolución de un concepto». Revista de Historiografía, 22, pp. 2549.

- (2015b): «Las silenciosas mujeres de la Roma antigua Revisiones desde el género y la historia». En DOMÍNGUEZ ARRANZ, Almudena y MARINA SÁEZ, Rosa M. (ed.): Género y enseñanza de la Historia. Silencios y ausencias en la construcción del pasado. Madrid: Sílex, pp. 187-212.

- (2016): «Madres sustitutas y oficios femeninos. Nodrizas y niñeras en la Roma antigua». En DELGADO HERVÁS, Ana y PICAZO GURINA, Marina (ed.): Los trabajos de las mujeres en el mundo antiguo. Cuidado y mantenimiento de la vida. Tarragona: Institut Català d'Arqueologia Clàssica, pp. 129-138.

- (2018): «Madres poderosas e hijas invisibles en la domus Caesarum. Ortodoxias y heterodoxias del poder femenino» En PÉREZ SÁNCHEZ, Dionisio; RODRÍGUEZ GERVÁS, 
Manuel J.; CARBÓ GARCÍA, Juan R. y PÉREZ MIRANDA, Iván (ed.): Poder y heterodoxia en el mundo greco-romano. Salamanca: Ediciones Universidad de Salamanca, pp. 119-146.

CLEMEAU ESLER, Carol (1989): «Horace's Old Girls: Evolution of a Topos». En FALKNER, Thomas M. y LUCE, Judith de (ed.): Old Age in Greek and Latin Literature. Nueva York: State University of New York, pp. 172-182.

COATES, Jennifer (2013): Women, Men and Everyday Talk. Nueva York: Palgrave Macmillan. COHEN, Leah (1985): Small Expectations. Society's Betrayal of Older Women. Toronto: McClelland and Steart Limited.

COKAYNE, Karen (2003): Experiencing Old Age in Ancient Rome. Londres: Routledge.

- (2007): «Age and the aristocratic self-identity: activities for the elderly». En HARLOW, Mary y LAURENCE, Ray (ed.): Age and ageing in the Roman Empire. Ann Arbor: Journal of Roman Archaeology, pp. 209-220.

COLE, Thomas R. (1992): The Journey of Life. A Cultural History of Aging in America. Cambridge: Cambridge University Press.

COLEMAN-NORTON, Paul R. (1947): «The View of Old Age in Roman Dramas». Classical Bulletin, 23, pp. 33-40.

COOLEY, Alison E. (2013): «Women beyond Rome: trend-setters or dedicated followers of fashion?». En HEMELRIJK, Emily A. y WOOLF, Greg (ed.): Women and the Roman City in the Latin West. Leiden: Brill, pp. 23-46.

COPPIN, Margot y GASPARD, Jean-Luc (2017): «El humor negro frente a la muerte». Desde el Jardín de Freud, 17, pp. 149-160.

CORSI, Marcella y SAMEK LODOVICI, Manuela (2013): «Active Ageing and Gender Equality». En FOLGUERA CRESPO, Pilar; MAQUEIRA D'ANGELO, Virginia; MATILLA QUIZA, María J.; MONTERO LÓPEZ, Pilar y VARA MIRANDA, María J. (ed.): Género y envejecimiento. XIX Jornadas Internacionales de Investigación Interdisciplinar. Madrid: Instituto Universitario de la Mujer - Ediciones de la Universidad Autónoma de Madrid, pp. 347.

CORSI SILVA, Semíramis (2006): «A imagem da mulher feticeira como expressão da diferença de gênero em Roma: os poemas de Horacio e Ovidio». Kelpsidra, 27. Disponible en http://www.klepsidra.net/klepsidra27/feiticaria.htm [Consulta 09/04/2018] 
COTONER CERDÓ, Luisa (2007): «La imagen de la mujer madura y su ingrata representación en los textos literarios». Lectora, 13, pp. 259-266.

COVEY, Herbert C. (1992-1993): «A Return to Infancy: Old Age and the Second Childhood in History». International Journal of Aging and Human Development, 36, pp. 81-90.

CRUZ JENTOFT, Alfonso J. (2001): «¿Qué es envejecer?». En MIGUEL RODRÍGUEZ, Armando de (coord.): Los mayores activos. Madrid: Seniors Españoles para la Cooperación Técnica, pp. 55-78.

CURCHIN, Leonard A. (2000-2001): «The Roman Family: Recent Interpretations». Zephyrus, 53-54, pp. 535-550.

D’AMBRA, Eve (2007): Roman women. Cambridge: Cambridge University Press.

DANNEFER, Dale y SETTERSTEN, Richard A. (2010): «The Study of the Life Course: Implications for Social Gerontology». En DANNEFER, Dale y PHILLIPSON, Chris (ed.): The SAGE Handbook of Social Gerontology. Londres: SAGE, pp. 3-19.

DAVIS, Oliver (2006): Age Rage and Going Gently. Stories of the Senescent Subject in Twentieth Century. Nueva York-Amsterdam: Editions Rodopi.

DEAN-JONES, Lesley A. (1994): Women's Bodies in Classical Greek Science. Oxford: Oxford University Press.

DEROW, Peter S. (1973): «The Roman Calendar, 190-168 B.C.». Phoenix, 27:4, pp. 345-356.

— (1976): «The Roman Calendar, 218-191 B.C.». Phoenix, 30:3, pp. 265-281.

DÍAZ MADERUELO, Rafael (1998): «Los aromas del género. Control social sobre el sentido del olfato y las categorías olfativas relativas a las identidades sexuales». En ORTEGA, Pilar; RODRÍGUEZ MAMPASO, María J. y WAGNER, Carlos G. (ed.): Mujer, Ideología y Población. II Jornadas de roles sexuales y de género. Madrid, 13 al 16 de noviembre de 1995. Madrid: Ediciones Clásicas, pp. 137-152.

DICKIE, Matthew W. (2001): Magic and Magicians in the Greco-Roman World. LondresNueva York: Routledge.

DICKMANN, Jens-Arne (2011): «Space and Social Relations in the Roman West». En RAWSON, Beryl (ed.): A companion to families in the Greek and Roman worlds. Malden: Blackwell, pp. 53-72. 
DIERS, Carol J. (1974): «Historical trends in the age at menarche and menopause». Psychological Reports, 34, pp. 931-937.

DÍEZ, Viviana y PALACIOS, Jimena (2011): «Representaciones de la vejez y discurso ejemplar romano durante el s. I d.C.». En GALÁN, Lía y BLISEL, María D. (ed.) y PEDERNERA, Soledad (coord.): V Jornadas de Estudios Clásicos y Medievales, 5 al 7 de octubre de 2011. Juventud y vejez en la Antigüedad y el Medievo. La Plata, Argentina. Buenos Aires: Universidad Nacional de la Plata. Disponible en http://sedici.unlp.edu.ar/handle/10915/33421 [Consulta 10/02/2018]

DIMARTINO, Alessia (2008): «Anus ebria. Immagini di una donna tra vecchiaia e ubriachezza». Prospettiva: rivista di storia dell'arte antica e moderna, 129, pp. 67-80.

DIXON, Suzanne (1990): The Roman Mother. Londres-Nueva York: Routledge.

— (1992): The Roman Family. Baltimore: The Johns Hopkins University Press.

- (1996): «The Sentimental Ideal of the Roman Family». En RAWSON, Beryl: Marriage, Divorce, and Children in Ancient Rome. Oxford: Claredon Press, pp. 99-113.

— (1999): «Conflict in the Roman Family». En RAWSON, Beryl y WEAVER, Paul (ed.): The Roman Family in Italy: Status, Sentiment, Space. Oxford: Claredon Press, pp. 149167.

— (2001): Reading Roman Women. Londres: Duckworth.

- (2003): «Sex and the Married Woman in Ancient Rome». En BALCH, David L. y OSIEK, Carolyn (ed.): Early Christian Families in context. An interdisciplinary dialogue. Cambridge: B. Eerdemans Publishing, pp. 111-129.

— (2007): Cornelia. Mother of the Gracchi. Nueva York: Routledge.

DOBSON, Elizabeth S. (1981): «Pliny the Younger's Depiction of Women». The Classical Bulletin, 58, pp. 81-85.

DOMÍNGUEZ CONTRERAS, Fermín (2002): «Status jurídico y las edades de las mujeres en el Código de Hammurabi». En PÉREZ CANTÓ, Pilar y ORTEGA LÓPEZ, Margarita (ed.): Las edades de las mujeres. Madrid: Universidad Autónoma de Madrid, pp. 183-196.

DUNCAN-JONES, Richard (1990): Structure \& Scale in the Roman Economy. Cambridge: Cambridge University Press. 
DYSON, Stephen L. (1992): «Age, Sex and Status: The View from the Roman Rotary Club». Echos du monde classique, 36, pp. 369-385.

EDMONDSON, Jonathan (2005): «Family Relations in Roman Lusitania. Social Change in a Roman Province?». En GEORGE, Michele (ed.): The Roman Family in the Empire: Rome, Italy and Beyond. Oxford: Oxford University Press, pp. 183-230.

- (2014): «Roman Family History». En BRUUN, Christer y EDMONDSON, Jonathan: The Oxford Handook of Roman Epigraphy. Oxford: Oxford University Press, pp. 559581.

EGLEHAAF-GAISER, Ulrike (2007): «Roman Cult Sites: A Pragmatic Approach». En RÜPKE, Jörg (ed.): A Companion to Roman Religion. Oxford: Blackwell, pp. 205-221.

EGOSCÓZABAL MARTínEZ-AVIAL, Cristina (2003): «Los animales del «Yambo de las mujeres» de Semónides». Estudios Clásicos, 123, pp. 7-26.

ENGELS, Donald (1980): «The problem of female infanticide in the Greco-Roman World». Classical Philology, 75, pp. 112-120.

- (1984): «The Use of Historical Demography in Ancient History». The Classical Quaterly, 34, pp. 386-393.

ESCÁMEZ DE VERA, Diego M. (2015): «Rumor, prodigia e ideología en época flavia». Studia Historica. Historia Antigua, 33, pp. 169-193.

ESCORIZA MATEU, Trinidad (2008): «Presentación: Trazando nuevas rutas desde una Arqueología Feminista y Materialista». En ESCORIZA MATEU, Trinidad; LÓPEZ MEDINA, Juana y NAVARRO ORTEGA, Ana (ed.): Mujeres y Arqueología. Nuevas aportaciones desde el materialismo histórico. Homenaje al profesor Manuel Carrilero Millán. Granada: Junta de Andalucía, pp. 19-57.

ESDAILE, Katharine A. (1914): «The Aged Livia». The Journal of Roman Studies, 4, pp. 139141.

ESPEJO MURIEL, Carlos (1998): «La Historia Antigua y las nuevas tecnologías: Internet». Florentia iliberritana, 9, pp. 141-152.

EVANS GRUBBS, Judith (2002): Women and the Law in the Roman Empire. A Sourcebook on marriage, divorce and widowhood. Londres-Nueva York: Routledge. 
- (2006): «The Family». En POTTER, David S. (ed.): A Companion to the Roman Empire. Oxford: Blackwell, pp. 312-326.

FALCÓN O’NEILL, Lidia (2000): Los nuevos mitos del feminismo. Madrid: Vindicación Feminista Publicaciones.

FALKNER, Thomas M. (1995): The poetics of old age in Greek epic, lyric, and tragedy. Norman: University of Oklahoma Press.

FALKNER, Thomas M. y LUCE, Judith de (ed.) (1989): Old Age in Greek and Latin Literature. Nueva York: State University of New York.

FANTHAM, Elaine (1995): «Aemilia Pudentilla, or the Wealthy Widow's Choice». En HAWLEY, Richard y LEVICK, Barbara (ed.): Women in Antiquity. New Assessments. LondresNueva York: Routledge, pp. 220-232.

FANTHAM, Elaine; PEET FOLEY, Helene; BOYMEL KAMPEN, Natalie; POMEROY, Sarah B. y SHAPIRO, H. Alan (1994): Women in the Classical World. Image and text. Nueva York: Oxford University Press.

FERNÁNDEZ BALLESTEROS, Rocío (2011): «Limitaciones y posibilidades de la edad». INSTITUTO DE MAYORES Y SERVICIOS SOCIALES - IMSERSO (2011): El libro blanco del envejecimiento activo. Madrid: IMSERSO-Ministerio de Sanidad, Política Social e Igualdad, pp. 105-148.

FERNÁNDEZ URIEL, Pilar (2011): «Obreras y empresarias en el Periodo Romano Altoimperial». Espacio, Tiempo y Forma. Serie II, Historia Antigua, 24, pp. 367-390.

FERNÁNDEZ VALENCIA, Antonia (2014): «Género e Historia: una perspectiva didáctica». En ClAVO SEBASTIÁN, María J. y GOICOECHEA GAONA, María A.: Miradas multidisciplinares para un mundo en igualdad. Ponencias de la I Reunión Científica sobre Igualdad y Género. Logroño: Universidad de La Rioja, pp. 147-176.

FERRER ALCANTUD, Coré (2013): «La mujer romana y el ejercicio del poder a través del control de las finanzas: el caso de Terencia, esposa de Cicerón». Potestas, 7, pp. 5-25.

FIGARI, Carlos E. (2009): «Las emociones de lo abyecto: repugnancia e indignación». En FIGARI, Carlos E. y SCRIBANO, Adrián (comp.): Cuerpo(s), Subjetividad(es) y Conflicto(s): Hacia una sociología de los cuerpos y las emociones en Latinoamérica. Buenos Aires: Ediciones Ciccus, pp. 131-139. 
FINCH, Caleb E. (2009): «Herodotus on Diet and Longevity: How the Persians Fed on Dung and Lived to 80, While the Tall, Handsome Ethiopians Ate Boiled Meat and Lived Beyond 120». Journal of Aging, Humanities, and the Arts, 3:2, pp. 86-96.

- (2010): «Evolving views of Ageing and Longevity from Homer to Hippocrates: Emergence of Natural Factors, Persistence of the Supernatural». Greece and Rome, 57:2, pp. 355-377.

FINLEY, Moses I. (1986): Historia Antigua: problemas metodológicos. Barcelona: Crítica.

— (1989): «Introduction. The Elderly in Classical Antiquity». En FALKNER, Thomas M. y LUCE, Judith de (ed.): Old Age in Greek and Latin Literature. Nueva York: State University of New York, pp. 1-20.

FOLGUERA CRESPO, Pilar (2013): «Bienvenidas a la tercera vida. Actitudes y motivaciones de las mujeres mayores en Europa». En FOLGUERA CRESPO, Pilar; MAQUEIRA D’ANGELO, Virginia; MATILlA QUIZA, María J.; MONTERO LÓPEZ, Pilar y VARA MIRANDA, María J. (ed.): Género y envejecimiento. XIX Jornadas Internacionales de Investigación Interdisciplinar. Madrid: Instituto Universitario de la Mujer - Ediciones de la Universidad Autónoma de Madrid, pp. 51-72.

FONTANILLE, Marie-Thérèse (2004): Vieillir à Rome. Approchr démographique. Bruselas: Éditions Latomus.

FORD RUSSELL, Brigette (2003): «Wine, women, and the polis: gender and the formation of the city-state in archaic Rome». Greece \& Rome, 50, pp. 77-84.

FOUCAULT, Michael (1998): Historia de la sexualidad. 1: La voluntad de saber. Madrid: Siglo veintiuno editores.

FOX, Sherry C. (2005): «Health in Hellenistic and Roman Times. The case studies of Paphos, Cyprus and Corinth, Greece». En KING, Helen: Health in Antiquity. Londres-NY: Routledge, pp. 59-82.

FOXHALL, Lin y SALMON, John (ed.) (1998): When Men Were Men. Masculinity, power and identity in classical antiquity. Londres-Nueva York: Routledge.

FRAISSE, Geneviève (2003): «El concepto filosófico de género». En TUBERT, Silvia (ed.): Del sexo al género. Los equívocos de un concepto. Madrid: Cátedra, pp. 39-46.

- (2016): Los excesos del género. Concepto, imagen, desnudez. Madrid: Ediciones Cátedra. 
FRANCIA SOMALO, Rosa (1995): «Séneca y la posición estoica sobre la mujer». En VERDEJO SÁNCHEZ, M. Dolores (coord.): Comportamientos antagónicos de las mujeres en el mundo antiguo. Málaga: Universidad de Málaga.

FREIXÁS FARRÉ, Anna (1997): «Envejecimiento y género: otras perspectivas necesarias». Anuario de Psicología, 73, pp. 31-42.

— (2008): «La vida de las mujeres mayores a la luz de la investigación gerontológica feminista». Anuario de Psicología, 39, pp. 41-57.

— (2013): «Las «Hijas del Rock and Roll» ya viajan con tarjeta dorada. Las nuevas ancianas del siglo XXI». En FOLGUERA CRESPO, Pilar; MAQUEIRA D'ANGELO, Virginia; MATILLA QUIZA, María J.; MONTERO LÓPEZ, Pilar y VARA MIRANDA, María J. (ed.): Género y envejecimiento. XIX Jornadas Internacionales de Investigación Interdisciplinar. Madrid: Instituto Universitario de la Mujer - Ediciones de la Universidad Autónoma de Madrid, pp. 175-190.

FREIXÁS FARRÉ, Anna y LUQUE SALAS, Bárbara (2009): «El secreto mejor guardado: la sexualidad de las mujeres mayores». Política y Sociedad, 46:1-2, pp. 191-203.

FRIER, Bruce (1982): «Roman Life Expectancy: Ulpian's Evidence». Harvard Studies in Classical Philology, 86, 213-251.

FUCHS, Michel (2008): «Petite vielle ou noble dame: portraits de femmes âgées sous l'Empire romain». En WILGAUX, Jérôme y DASEN, Véronique (dir.): Langages et metaphors du corps dans le monde antique. Rennes: Presses Universitaires de Rennes, pp. 73-89.

GAMBA, Susana B. (2007): Diccionario de estudios de género y feminismos. Buenos Aires: Biblos.

GANNON, Linda R. (2005): Women and Aging. Trascending the myths. Londres: Routledge.

GARCÍA GARCÍA, Margarita (2017): «La(s) menopausia(s). Simbologías y sintomatologías culturales». Femeris, 2, pp. 223-231.

GARCÍA-GELABERT, M. Paz (2002): «Muerte y género en la Antigüedad». En ALFARO GINER, Carmen; GARCÍA SÁNCHEZ, Manel y ALAMAR LAPARRA, Mónica (eds.): Actas del Tercer y Cuarto Seminarios de Estudios Sobre la Mujer en la Antigüedad. Valencia, 28-30 abril, 1999 y 12-14 abril, 2000. Valencia: SEMA, pp. 193-197.

GARCÍA GONZÁLEZ, Francisco (2005): «Introducción: vejez, envejecimiento e historia. La edad como objeto de investigación». En GARCÍA GONZÁLEZ, Francisco: Vejez, 
envejecimiento y sociedad en España, siglos XVI-XXI. Cuenca: Ediciones de la Universidad de Castilla-La-Mancha, pp. 11-34.

GARCÍA HERRERO, María C. (2013): «Mujer, historia e historiografía». En DOMÍNGUEZ ARRANZ, Almudena (ed.): Política y género en la propaganda en la Antigüedad: antecedentes y legado. Gijón: Trea, pp. 27-36.

GARCÍA LEAL, Alfonso (1984): «El amor en la juventud y en la vejez en Tibulo». Archivum, 34, pp. 7-21.

GARCÍA MARTÍNEZ, Alfonso (2001): «La cuestión de la dependencia en la vejez». Pedagogía Social. Segunda época, 8, pp. 255-264.

GARCÍA PRÓSPER, Elisa y POLO CERDÁ, Manuel (2003): «Enterramientos en decúbito prono y un posible preso entre los primeros pobladores de Valencia (siglos II a.C.-III d.C.)». En CAMPO MARTÍN, Manuel y ROBLES RODRÍGUEZ, Francisco J. (ed.): ¿Dónde estamos? Pasado, presente y futuro de la Paleopatología: actas del VI Congreso Nacional de Paleopatología (Madrid, 13 al 16 de septiembre de 2001). Madrid: Asociación Española de Paleopatología, pp. 298-316.

GARCÍA SOLER, María J. (2010): «Mujer y vino en la comedia griega». En GARCÍA SOLER, María J. (ed.): Expresiones del humor desde la Antigüedad hasta nuestros días. Vitoria-Gasteiz: Euskal Herriko Unibertsitatea-Universidad del País Vasco, pp. 75-90.

GARDNER, Jane F. (1986): Women in roman law and society. Londres: Croom Helm.

- (1998): Family and Familia in Roman Law and Life. Nueva York: Claredon Press Oxford.

GARNER, J. Dianne (2013): «Feminism and Feminist Gerontology». En GARNER, J. Dianne (ed.): Fundamentals of Feminist Gerontology. Nueva York: Routledge, pp. 3-12.

GARNSEY, Peter (1999): Food and society in classical antiquity. Cambridge: Cambridge University Press.

GARRIDO GONZÁLEZ, Elisa (2002): «Las mujeres romanas y la muerte». En PÉREZ CANTÓ, Pilar y ORTEGA LÓPEZ, Margarita (ed.): Las edades de las mujeres. Madrid: Universidad Autónoma de Madrid, pp. 351-376.

- (2011) «Las edades de Hipatia». En VÁZQUEZ BERMÚDEZ, Isabel (coord.): Investigación y género. Logros y retos. III Congreso Universitario Nacional. Sevilla: Universidad de Sevilla, pp. 691-699. 
- (2013): «Visión androcéntrica de la vejez femenina en la Antigüedad». En FOLGUERA CRESPO, Pilar; MAQUIEIRA D’ANGELO, Virginia; MATILLA QUIZA, María J.; MONTERO LÓPEZ, Pilar y VARA MIRANDA, María J. (ed.): Género y envejecimiento. XIX Jornadas Internacionales de Investigación Interdisciplinar. Madrid: Instituto Universitario de la Mujer - Ediciones de la Universidad Autónoma de Madrid, pp. 543-567.

GAVILANES, Emilio (1995): «El número nueve en la cultura popular». Revista de Dialectología y Tradiciones Populares, 50, pp. 243-262.

GENTILE, Kristen M. (2009): Reclaiming the Role of the Old Priestess: Ritual Agency and the Post-Menopausal Body in Ancient Greece. Ohio State University, Tesis Doctoral inédita. Disponible en https://etd.ohiolink.edu/pg_10?0::NO:10:P10_ACCESSION_NUM:osu1243982652 [Consulta $10 / 02 / 2018]$

GEORGE, Michele (ed.) (2005): The Roman Family in the Empire: Rome, Italy and Beyond. Oxford: Oxford University Press.

GILCHRIST, Roberta (2004): «Archaeology and the Life Course: a Time and Age for Gender». En MESKELL, Lynn y PREUCEL, Robert W. (ed.): A Companion to Social Archaeology. Oxford: Blackwell, pp. 142-160.

GILLEARD, Chris y HIGGS, Paul (2011): «Ageing abjection and embodiment in the fourth age». Journal of Aging Studies, 25, pp. 135-142.

GINN, Jay y ARBER, Sara (1996): «Mera conexión. Relaciones de género y envejecimiento». En ARBER, Sara y GINN, Jay (ed.): Relación entre género y envejecimiento. Enfoque sociológico. Madrid: Narcea, pp. 17-34.

GIRÓ MIRANDA, Joaquín (2011): «El significado de la vejez». En GIRÓ MIRANDA, Joaquín (coord.) (2011): Envejecimiento y sociedad. Una perspectiva pluridisciplinar. Logroño: Universidad de la Rioja, pp. 19-45.

GLOVER, David y KAPLAN, Cora (2000): Genders. Londres-NY: Routledge.

GOLD, Barbara K. (1993): «"But Ariadne Was Never There in the First Place”: Finding the Female in Roman Poetry». En RABINOWITZ, Nancy S. y RICHLIN, Amy (ed.): Feminist Theory and the Classics. Nueva York-Londres: Routledge, pp. 75-101.

— (2004): «My Sister's Words are Swallowed by The Next Wave». En SKINNER, Marilyn B. (ed.): Gender and Diversity in Place: Proceedings of the Fourth Conference on 
Feminism and Classics. May 27-30, 2004, University of Arizona. Tucson: University of Arizona. Disponible en http://www.stoa.org/diotima/essays/fc04/Gold.html [Consulta
[ $16 / 01 / 2018]$

GÓMEZ BELLARD, Francisco (1996): «El análisis antropológico de las cremaciones». Complutum Extra, 6 (2), pp. 55-64.

GÓMEZ PALLARÈS, Joan (2007): «Humor negro: el diálogo entre los vivos y los muertos en la poesía epigráfica latina». Exemplaria Classica, 11, pp. 167-196.

GÓMEZ SANTA CRUZ, Julio (2013): «La muerte relativizada. Morir y matar en «clave de humor» en la Roma imperial». En BRAVO, Gonzalo y GONZÁLEZ SALINERO, Raúl (ed.): Formas de morir y formas de matar en la Antigüedad romana. Actas del X Coloquio de la Asociación Interdisciplinar de Estudios Romanos. Madrid: Signifer, pp. 35-54.

GÓMEZ-PANTOJA FERNÁNDEZ-SALGUERO, Joaquín L. y LÓPEZ TRUJILLO, M. Ángel (1999): «En las redes de Clío. Historia Antigua e Internet: un caso práctico». Clío: History and History Teaching, 9.

GONZÁLEZ GONZÁLEZ, Marta (2015): «Eudaimones. Dichosos los ancianos del Ática». En IRIARTE GOÑI, Ana y FERREIRA, Luísa N. (coord.): Idades e género na literatura e na arte da Grécia antiga. Coímbra: Impresa da Universidade de Coimbra, pp. 167-191.

GONZÁLEZ GUTIÉRREZ, Patricia (2011): «Maternidad, aborto y ciudadanía femenina en la Antigüedad». El Futuro del Pasado, 2, pp. 425-438.

GOÑI ZABALEGUI, Amaia (2015): Cartas papiráceas de mujeres del Egipto romano: género y sociedad. Universidad de Salamanca, Tesis Doctoral inédita.

GOUREVITCH, Danielle (2004): «Karen COKAYNE, Experiencing Old Age in Ancient Rome». L'Antiquité classique, 73, pp. 465-466.

— (2013): «Two Historical Case Histories of Acute Alcoholism in the Roman Empire». En LAES, Christian; GOODEY, Chris y ROSE, M. Lynn (ed.): Disabilities in Roman Antiquity: disparate bodies, a capite ad calcem. Londres: Brill, pp. 73-88.

GOWERS, Emily (2005): «Talking Trees: Philemon and Baucis Revisited». Arethusa, 38:3, pp. 331-365.

GOWLAND, Rebecca L. (2016): «Elder Abuse: Evaluating the Potentials and Problems of Diagnosis in the Archaeological Record». International Journal of Osteoarchaeology, 26:3, pp. 414-423. 
- (2017a): «Growing Old: Biographies of Disability and Care in Later Life». En TILLEY, Lorna y SCHRENK, Alecia A. (ed.): New Developments in the Bioarchaeology of Care. Further Case Studies and Expanded Theory. Nueva York: Springer, pp. 237-252.

— (2017b): «That 'Tattered Coat Upon a Stick' the Ageing Body: Evidence for Elder Marginalization and Abuse in Roman Britain». En POWELL, Lindsay; SOUTHWELLWRIGHT, William y GOWLAND, Rebecca L. (ed.): Care in the Past. Archaeological \& Interdisciplinary Perspectives. Oxford: Oxbow, pp. 71-90.

GOWLAND, Rebecca L. y CHAMBERLAIN, Andrew T. (2002): «A Bayesian Approach to Ageing Perinatal Skeletal Material from Archaeological Sites: Implications for the Evidence for Infanticide in Roman-Britain». Journal of Archaeological Science, 29, pp. 677-685.

GRAHAM, Emma-Jayne (2008): «Mary Harlow, Ray Laurence (ed.), Age and Ageing in the Roman Empire». Bryn Mawr Classical Review, 2008.09.13.

GRAVERINI, Luca (2006): «An Old Wife's Tale». En KEULEN, Wytse H.; NAUTA, Ruurd R. y PANAYOTAKIS, Stelios (ed.): Lectiones Scrupulosae. Essays on the Text and Interpretation of Apuleius' Metamorphoses in Honour of Maaike Zimmerman. Groningen: Barkhuis Publishing \& Groningen University Library, pp. 86-110.

GRAY-FOW, Michael J. G. (1988): «The Wicked Stepmother in Roman Literature and History: an Evaluation». Latomus, 47:4, pp. 741-757.

GROSZ, Elizabeth (1994): Volatile Bodies. Toward a Corporeal Feminism. Bloomington: Indiana University Press.

GULLETTE, Margaret M. (2003): «Age studies and gender». En CODES, Lorraine (ed.): Encyclopedia of Feminist Theories. Londres: Routledge, pp. 12-14.

— (2015): «Aged by culture». En TWIGG, Julia y MARTIN, Wendy (ed.): Routledge Handbook of Cultural Gerontology. Londres-Nueva York: Routledge, pp. 21-28.

HAENTJENS, Ann M. E. (2000): «Reflections on Female Infanticide in the Greco-Roman World». L'antiquité classique, 69, pp. 261-264.

HALL, Stuart (2000): «The work of representation». En HALL, Stuart (ed.): Representation. Cultural Representations and Signifying Practices. Londres: SAGE, pp. 13-74.

HALLETT, Judith P. (1992): «Heading our Native Informants: The Uses of Latin Literary Texts in recovering the Elite Roman Attitudes toward Age, Gender and Social Status». Echos du monde classique, 36, pp. 333-355. 
- (2004): «Response: Safe as Houses? The Politics and Discourse of Feminism and Classics». En SKINNER, Marilyn B. (ed.): Gender and Diversity in Place: Proceedings of the Fourth Conference on Feminism and Classics. May 27-30, 2004, University of Arizona. Tucson: University of Arizona. Disponible en www.stoa.org/diotima/essays/fc04/Hallett.html [Consulta 09/05/2018]

HANNAH, Robert (2005): Greek and Roman Calendars. Constructions of Time in the Classical World. Londres: Duckworth.

HARDERS, Ann-Cathrin (2012): «Beyond Oikos and Domus: Modern kinship Studies and the Ancient Family». En LAURENCE, Ray y STRÖMBERG, Agneta (ed.): Families in the Graeco-Roman World. Londres: Continuum, pp. 10-26.

HARLOW, Mary (2007): «Blurred visions: male perception of the female life course - the case of Aemilia Pudentilla». En HARLOW, Mary y LAURENCE, Ray (ed.): Age and ageing in the Roman Empire. Ann Arbor: Journal of Roman Archaeology, pp. 195-208.

HARLOW, Mary y LAURENCE, Ray (2002): Growing Up and Growing Old in Ancient Rome. A life course approach. Londres-Nueva York: Routledge.

— (2007): «Introduction: Age and Ageing in the Roman Empire». En HARLOW, Mary y LAURENCE, Ray (ed.): Age and ageing in the Roman Empire. Ann Arbor: Journal of Roman Archaeology.

- (2010): «De Amicitia: The Role of Age». En MUSTAKALlIO, Katarina y KRÖTZL, Christian (ed.): De Amicitia: Friendship and social networks in Antiquity and the Middle Ages. Roma: Institutum Romanum Finlandiae, pp. 21-32.

— (2011): «Viewing the Old: Recording and Respecting the Elderly at Rome and in the Empire». En KRÖTZL, Christian y MUSTAKALLIO, Katariina (ed.): On Old Age: Approaching Death in Antiquity and the Middle Ages. Turnhout: Brepols Publishers, pp. 3-23.

- (2015): «Age, Agency and Disability: Suetonius and the Emperors of the First Century CE». En KRÖTZL, Christian; MUSTAKALLIO, Katariina y KUULIALA, Jenni (ed.): Infirmity in Antiquity and the Middle Ages. Social and Cultural Approaches to Health, Weakness and Care. Farnham-Burlington: Ashgate, pp. 15-27.

- (2017): «Augustus senex: old age and the remaking of the Principate». Greece \& Rome, 64:2, pp. 115-131. 
HARPER, Kyle (2008): «The Greek Census Inscriptions of Late Antiquity». The Journal of Roman Studies, 98, pp. 83-119.

— (2011): Slavery in the Late Roman World. Cambridge: Cambridge University Press.

HARRIS, Rivkah (2000): Gender and Aging in Mesopotamia: The Gilgamesh Epic and Other Ancient Literature. Norman: University of Oklahoma Press.

HARRIS, William (1982): «The Theoretical Possibility of Extensive Infanticide in the GraecoRoman World». The Classical Quaterly, 32, pp. 114-116.

HARTMANN, Elke (2012): «Femmes riches et captateurs d'heritage à Rome Durant le HautEmpire». Annales. Histoire, Sciences Sociales, 67, pp. 431-452.

HAYNES, Maria S. (1963): «The Supposedly Golden Age for the Aged in Ancient Rome (A Study of Literary Concept of Old Age)». The Gerontologist, 3:1, pp. 26-35.

HEATH, John (2011): «Women's Work: Female Transmission of Mythical Narratives». Transactions of the American Philological Association, 141, pp. 69-104.

HEMELRIJK, Emily A. (1999): Matrona docta. Educated women in the Roman élite from Cornelia to Julia Domna. Londres-Nueva York: Routledge.

- (2012): «Fictive Motherhood and Female Authority in Roman Cities». EuGeStA, 2, pp. 201-220.

HENDRICKS, Jon (1993): «Cicero and Social Gerontology: Context and Interpretation of a Classic». Journal of Aging Studies, 7:4, pp. 339-351.

HERNÁNDEZ GARCÍA, Norma H. (2014): «Envejecer como experiencia de sí en la época imperial romana». Revista de Filosofía, 25, pp. 91-110.

HIDALGO DE LA VEGA, María J. (1985): «La "bella fabela” de Eros y Psique y su relación con el libro XI de Las Metamorfosis de Apuleyo». En MARÍN DÍAZ, Nicolás (coord.): In memoriam Agustín Díaz Toledo. Granada: Universidad de Granada, pp. 199-227.

- (1986): Sociedad e ideología en el imperio romano: Apuleyo de Madaura. Salamanca: Ediciones Universidad de Salamanca.

- (1988): «Los misterios y la magia en la Etiópicas de Heliodoro». Studia Historica Historia Antigua, 6, pp. 175-188. 
- (1994): «La imagen de la mujer en la magia como expresión de la diferencia de género». En SÁEZ FERNÁNDEZ, Pedro y ORDÓÑEZ AGULLA, Salvador (ed.): Homenaje al profesor Peredo. Sevilla: Universidad de Sevilla, pp. 495-512.

- (2002): «Los ciclos vitales de las princesas Antoninas a la manera de un cursus honorum». En PÉREZ CANTÓ, Pilar y ORTEGA LÓPEZ, Margarita (ed.): Las edades de las mujeres. Madrid: Universidad Autónoma de Madrid, pp. 137-170.

— (2003): «Esposas, hijas y madres imperiales: el poder de la legitimidad dinástica». Latomus, 62, pp. 47-72.

— (2008): «Voix soumises, pratiques transgressives. Les magiciennes dans le roman gréco-romain». Dialogues d'histoire ancienne, 34, pp. 27-43.

— (2009): «Maternidad y poder político: las princesas julio-claudias». En CID LÓPEZ, Rosa M. (coord.): Madres y maternidades. Construcciones culturales en la civilización clásica. Oviedo: KRK, pp. 187-213.

— (2011): «El sofista Apuleyo de Madaura y la memoria: construcción de la imagen de su esposa, Emilia Pudentila, una aristócrata africana». Studia Historica Historia Antigua, 29, pp. 197-221.

- (2012): Las emperatrices romanas. Sueños de púrpura y poder oculto. Salamanca: Ediciones Universidad de Salamanca.

- (2014): «Libertad, esclavitud y género: el mito de Cupido y Psique (Met. 4.286.24)». En REDUZZI MEROLA, Francesca (coord.): Dipendenza ed emarginazione nel mondo antico e moderno: atti del XXIII Convegno Internazionale G.I.R.E.A. dedicati alla memoria di Franco Salerno. Nápoles: Aracne Editrice, pp. 353-368.

HIN, Saskia; OGÓREK, Bartosz y HEDEFALK, Finn (2016): «An Old Mom Keeps You Young: Mother's Age at Last Birth and Offspring Longevity in Nineteenth-Century Utah». Biodemography and Social Biology, 62:2, pp. 164-181.

HINOJO ANDRÉS, Gregorio (1991): «Concepción y representación de la muerte en el s. I». En RAMOS GUERREIRA, Agustín (ed.): Mnemosynum C. Codoñer a discipulis doblatum. Salamanca: Ediciones Universidad de Salamanca, pp. 145-160.

— (2010): «Las designaciones de la muerte voluntaria en Roma». Hápax, 3, pp. 57-72.

HOLLERAND, Claire y PUDSEY, April (2011): «Introduction. Studies in ancient historical demography». En HOLLERAND, Claire y PUDSEY, April (ed.): Demography and the Graeco- 
Roman World. New Insights and Approaches. Cambridge: Cambridge University Press, pp. 113.

HOLSTEIN, Martha B. (2010): «Sobre cómo envejecemos las mujeres». Debate feminista, 42, pp. 52-78.

HUEBNER, Sabine R. (2013): The Family in Roman Egypt. A Comparative Approach to Intergenerational Solidarity and Conflict. Cambridge: Cambridge University Press.

- (en prensa): «Single Men and Women in Pagan Society - The Case of Roman Egypt». En HUEBNER, Sabine R. y LAES, Christian (ed.): Singles and the Single in the Roman and Later Roman Worlds. Cambridge: Cambridge University Press.

HUEBNER, Sabine R. y NATHAN, Geoffrey (ed.) (2017): Mediterranean Families in Antiquity. Households, Extended Families, and Domestic Space. Malden: John Willey \& Sons.

HÜLSEN, Christian (1905): Il Foro Romano. Storia e Monumenti. Roma: Ermanno Loescher \& Co Editori.

HUNINK, Vincent (1998): «The Enigmatic Lady Pudentilla». The American Journal of Philology, 119:2, pp. 275-291.

HURD CLARKE, Laura C. (1999): «"We're not Old!”: Older Women's Negotiation of Aging and Oldness». Journal of Aging Studies, 13:4, pp. 419-439.

- (2011): Facing Age. Women Growing Older in Anti-Aging Culture. Maryland: Rowman \& Littlefield Publishers.

IACUB, Ricardo (2004): «Erotismo y vejez en la cultura greco-latina». Revista Brasileira de Ciências do Envelhecimiento Humano, 84, pp. 84-103.

- (2005): «La terapéutica estoica con la vejez». Estudos Interdisciplinares sobre o Envelhecimento, 7, pp. 87-100.

— (2009): «Deconstrucción de la erótica de la vejez en Occidente». Kairós, 12, pp. 2343.

INSTITUTO DE MAYORES Y SERVICIOS SOCIALES - IMSERSO (2011): El libro blanco del envejecimiento activo. Madrid: IMSERSO-Ministerio de Sanidad, Política Social e Igualdad. IRIARTE GOÑI, Ana (2015): «Semblanzas de semi-ciudadanías griegas. Sobre críos, ancianos y féminas». En IRIARTE GOÑI, Ana y FERREIRA, Luísa N. (coord.): Idades e género na literatura e na arte da Grécia antiga. Coímbra: Impresa da Universidade de Coimbra, pp. 9-30. 
IRIARTE GOÑI, Ana y FERREIRA, Luísa N. (coord.) (2015): Idades e género na literatura e na arte da Grécia antiga. Coímbra: Impresa da Universidade de Coimbra.

ISAYEV, Elena (2007): «Unruly Youth? The Myth of Generation Conflict in Late Republican Rome». Historia: Zeitschrift für Alte Geschichte, 56, pp. 1-13.

JEPPESEN-WIGELSWORTH, Alison (2010): The Portrayal of Roman Wives in Literature and Inscriptions. Universidad de Calgary, Tesis Doctoral inédita. Disponible en https://prism.ucalgary.ca/bitstream/1880/47797/1/2010_Jeppesen_Wigelsworth.pdf [Consulta 09/05/2018]

JOHNSON, Marguerite (2012): «Witches in Time and Space: Satire 1.8, Epode 5 and landscapes of fear». Hermathema, 192, pp. 5-44.

JOHNSON, Paul (ed.) (1998): Old Age from Antiquity to Post-Modernity. Londres-Nueva York: Routledge.

JONES, Deborah (1980): «Gossip: Notes on Women's Oral Culture». Women's Studies International Quaterly, 3, pp. 193-198.

JOSHEL, Sandra R. (1986): «Nurturing the Master's Child: Slavery and the Roman ChildNurse». Signs, 12, pp. 3-22.

JULIANO CORREGIDO, María D. (2005): «El saber de las mujeres». En FREIXÁS FARRÉ, Anna (ed.): Abuelas, madres, hijas. La transmisión sociocultural del arte de envejecer. Barcelona: Icaria, pp. 15-32.

— (2008): «La construcción social de las jerarquías de género». Asparkía, 19, pp. 1927.

KAMPEN, Natalie B. (1997): «Gender Theory in Roman Art». En KLEINER, Diana E. E. y MATHESON, Susan B. (ed.): I Claudia. Women in Ancient Rome. Austin: University of Texas Press, pp. 14-25.

KAMPMANN, Sabine (2015): «Visual Aging Studies: Exploring Images of Aging in Art History and Other Disciplines». Age, Culture, Humanities, 2, pp. 279-291.

KASTER, Robert A. (2005): Emotion, Restraint, and Community in Ancient Rome. Oxford: Oxford University Press.

KEBRIC, Robert B. (1983): «Aging in Pliny's Letters: A View from the Second Century A.D.». The Gerontologist, 23:5, pp. 538-545. 
KEEGAN, Peter (2014): Roles for Men and Women in Roman Epigraphic Culture and Beyond. Oxford: Archaeopress.

KEITH, Alison (2000): Engendering Rome. Women in Latin Epic. Cambridge: Cambridge University Press.

KENWARD, Harry (1999): «Pubic lice (Pthirus pubis L.) were present in Roman and Medieval Britain». Antiquity, 73, pp. 911-915.

KHANOUSSI, Mustapha y MAURIN, Louis (2002): Mourir a Dougga. Recueil des inscriptions funéraires. Burdeos: Ausonius Publications.

KING, Helen (2001): Hippocrates' Woman: Reading the female body in Ancient Greece. Londres-Nueva York: Routledge.

— (2005): Health in Antiquity. Londres-NY: Routledge.

— (2011): «Galen and the widow: towards a history of therapeutic masturbation in ancient gynecology». EuGeStA: Journal of Gender Studies in Antiquity, 1, pp. 205-235.

KLEINER, Diana E. E. y MATHESON, Susan B. (2000): «Introduction. Her parents gave her the name Claudia». En KLEINER, Diana E. E. y MATHESON, Susan B. (ed.): I Claudia II. Women in Roman Art and Society. Austin: University of Texas Press, pp. 1-16.

KNAPP, Robert (2011): Invisible Romans. Prostitutes, outlaws, slaves, gladiators, ordinary men and women... the Romans that history forgot. Londres: Profile Books.

KNOX, Peter E. (ed.) (2009): A companion to Ovid. Oxford: Blackwell Publishing.

KREKULA, Clary (2007): «The Intersection of Age and Gender. Reworking Gender Theory and Social Gerontology». Current Sociology, 55:2, pp. 155-171.

KOKKINOS, Nikos (1992): Antonia Augusta. Portrait of a Great Roman Lady. Nueva York: Routledge.

KRAFFT-EBING, Richard von (1939): Psychopathia Sexualis. Nueva York: Pioneer Publications.

KRAUSE, Neil (2006): «Social Relationships in Late Life». En BINSTOCK, Robert H. y GEORGE, Linda K. (ed.): Handbook of Aging and the Social Sciences. Londres: Academic Press, pp. 181-200. 
KRISTEVA, Julia (1982): Powers of Horror. An Essay on Abjection. Nueva York: Columbia University Press.

LAES, Christian (2005): «Àla recherché de la vieillesse dans l'Antiquité gréco-romaine». L'Antiquité Classique, 74, pp. 243-255.

- (2007): «Inscriptions from Rome and the history of childhood». En HARLOW, Mary y LAURENCE, Ray (ed.): Age and Ageing in the Roman Empire. Ann Arbor: Journal of Roman Archaeology, pp. 25-37.

- (2012): «Latin inscriptions and the life course. Regio III (Bruttium and Lucania) as a test case». Arctos, 46, pp. 95-113.

- (2015): «Grandmothers in Roman Antiquity: A Note on Avia Nutrix (AE 2007, 298)». Melita Classica, 2, pp. 99-113.

LAFOSSE, Mona (2011): Age Matters: Age, Aging and Intergenerational Relationships in Early Christian Communities, With a Focus on 1 Timothy 5. University of Toronto, Tesis doctoral inédita. Disponible en https://tspace.library.utoronto.ca/handle/1807/35732 [Consulta 22/02/2018]

LANGLANDS, Rebecca (2000): Gender and Exemplarity in Valerius Maximus. University of Cambridge, Tesis Doctoral inédita. Disponible en https://www.repository.cam.ac.uk/handle/1810/245009 [Consulta 17/03/2018]

— (2006): Sexual Morality in Ancient Rome. Cambridge: Cambridge University Press.

LAPI, Barbara y SARKIS FERNÁNDEZ, Diana (2008): «Género y materialismo histórico: ¿Una relación imposible? Algunas reflexiones desde la antropología social y una propuesta teórico-metodológica transdisciplinaria». En ESCORIZA MATEU, Trinidad; LÓPEZ MEDINA, Juana y NAVARRO ORTEGA, Ana (ed.): Mujeres y Arqueología. Nuevas aportaciones desde el materialismo histórico. Homenaje al profesor Manuel Carrilero Millán. Granada: Junta de Andalucía, pp. 105-155.

LAPINI, Novella (2016): «Nuove prospettive per l'azione matronale: l'esempio di Cerellia corrispondente di Cicerone». En CENERINI, Francesca y ROHR VIO, Francesca (a cura di): Matronae in domo et in re publica agentes - spazi e occasioni dell'azione femminile nel mondo romano tra tarda repubblica e primoimpero. Trieste: Edizioni Università di Trieste, pp. 89-107. 
LASLETT, Peter (1977): «The history of aging and the aged». En LASLETT, Peter: Family Life and Illicit Love in Earlier Generations. Essays in Historical Sociology. Cambridge: Cambridge University Press, pp. 174-213.

LAURENCE, Ray (2005): «Health and the Life Course at Herculaneum and Pompeii». En KING, Helen: Health in Antiquity. Londres-Nueva York: Routledge, pp. 83-96.

- (2007): «Gender, age, and identity: the female life course at Pompeii». En HARLOW, Mary y LAURENCE, Ray (ed.): Age and ageing in the Roman Empire. Ann Arbor: Journal of Roman Archaeology, pp. 95-110.

LAURENCE, Ray y STRÖMBERG, Agneta (ed.) (2012): Families in the Greco-Roman World. Londres-Nueva York: Continuum.

LAURENCE, Ray y TRIFILÒ, Francesco (2012): «'Vixit plus minus’. Commemorating the Age of the Dead: Towards a Familial Roman Life Course?». En LARSSON LOVÉN, Lena y HARLOW, Mary (ed.): Families in the Imperial and Late Antique Roman World. LondresNueva York: Continuum, pp. 23-40.

LEON, Ernestine S. (1951): «Scribonia and Her Daughters». Transactions and Proceedings of the American Philological Association, 82, pp. 168-175.

LILJA, Saara (1978): «Descriptions of Human Appearance in Pliny's Letters». Arctos, 12, pp. 55-62.

LILLO REDONET, Fernando (2011): Fantasmas, brujas y magos de Grecia y Roma. Madrid: Evohé.

LINCOLN, Bruce (1979): «The Rape of Persephone: A Greek Scenario of Women's Initiation». The Harvard Theological Review, 72, pp. 223-235.

LIVSON, Florence B. (1983): «Gender Identity». En WEG, Ruth B. (ed.): Sexuality in the Later Years: Roles and Behavior. Nueva York: Academic Press, pp. 104-129.

LO CASCIO, Elio (2000): «Recruitment and the size of the Roman population from the third to the first century BCE». En SCHEIDEL, Walter (ed.): Debating Roman Demography. LeidenBoston-Köln-Brill: Mnemosyme Supplementum, pp. 111-138.

LOICQ, Jean (1964): «Mamurius Veturius et l'ancienne representation italique de l'année». Latomus, 70, pp. 401-426. 
LÓPEZ BARJA DE QUIROGA, Pedro (2007): «Violencia servil en las Metamorfosis de Apuleyo». Studia Historica Historia Antigua, 25, pp. 305-313.

LÓPEZ DE LA PLAZA, Gloria (1993): «Historia de las mujeres: compromiso y método». En SEGURA GRAÍÑ̃, Cristina (ed.): La voz del silencio II. Historia de las mujeres: compromiso y método. Madrid: Al-Mudayna, pp. 7-15.

LÓPEZ LÓPEZ, Aurora (2008): «Cartas de Cornelia y Elegías de Sulpicia». En POCIÑA PÉREZ, Andrés y GARCÍA GONZÁLEZ, Jesús M.: En Grecia y Roma II. Lecturas pendientes. Granada: Universidad de Granada, pp. 139-156.

LÓPEZ MOREDA, Santiago (2003): «Semblanzas de la vejez en la literatura grecolatina». En LÓPEZ MOREDA, Santiago (ed.): Ideas. Conflicto, drama y literatura en el mundo antiguo. Madrid: Ediciones Clásicas, 67-84.

LÓPEZ PULIDO, Alfonso (2008): «Fragmentos literarios sobre la Ancianidad en Roma». Revista de enfermería gerontológica, 12, pp. 6-25.

— (2013): «La vigencia de los clásicos: el ejemplo de Cicerón». Gerokomos, 24:2, pp. $56-62$.

- (2015): La ancianidad en la Antigüedad clásica. Gijón: Sociedad Española de Enfermería Geriátrica y Gerontológica.

— (2017): «Kairotanasia y ancianidad en la antigüedad clásica». Humanidades: Revista de la Escuela de Estudios Generales de la Universidad de Costa Rica, 7, pp. 1-46.

LÓPEZ RODRÍGUEZ, Irene (2009): «La animalización del retrato femenino en el Libro de Buen Amor». Lemir, 13, pp. 53-84.

LÓPEZ SACO, Julio (2009): «Las cosmovisiones matriarcales y patriarcales clásicas: el valor del mito como una fuente histórica». Praesentia, 10, pp. 1-5.

LUCE, Judith de (1993): «Theme and variations in the De Senectute». Journal of Aging Studies, 7:4, pp. 361-371.

LUCY, Sam (2005): «The archaeology of age». En DÍAZ-ANDREU, Margarita (ed.): Archaeology of Identity: Approaches to Gender, Age, Status, Ethnicity and Religion. LondresNueva York: Routledge, pp. 43-66.

LUND, Thomas W. M. (1910): The Lake of Como. Its History, Art, and Archaeology. Londres: Kegan Paul, Trench, Trübner \& Co. 
LUNDGREN, Anna S. (2010): «"In the good old days”: Insidious nostalgia and the constitution of old age identity». Journal of Ageing Studies, 24, pp. 248-256.

MANCHÓN ZORRILLA, Alejandro (2015): «Viudas y rebeldes: Rhea, madre de Quinto Sertorio». En DOMÍNGUEZ ARRANZ, Almudena y MARINA SÁEZ, Rosa M. (ed.): Género y enseñanza de la Historia. Silencios y ausencias en la construcción del pasado. Madrid: Sílex, pp. 213-236.

MANGAS MANJARRÉS, Julio; MARTÍNEZ CABALLERO, Santiago y HOCES DE LA GUARDIA BERMEJO, Ángel L. (2013): «El ara de las Parcae de Termes (Tiermes, Soria): nuevo documento y análisis sobre un posible sincretismo». Gerión, 31, pp. 331-361.

MARRE, Martine E. A. de (2002): The role and position of women in Roman North African society. University of South Africa, Tesis Doctoral inédita. Disponible en http://uir.unisa.ac.za/handle/10500/17967 [Consulta 21/01/2018]

MARTIN, Dale B. (1996): «The Construction of the Ancient Family: Methodological Considerations». The Journal of Roman Studies, 86, pp. 40-60.

MARTÍN MORENO, Jaime (2005): «Los límites de la vida». Sociedad y utopía: Revista de ciencias sociales, 25, pp. 391-406.

MARTÍNEZ LÓPEZ, Cándida (1995): «Las mujeres en la sociedad romana. Una nueva perspectiva desde las relaciones de género». En ALFARO BECH, Virginia y TAILLEFER DE HAYA, Lidia (ed.): Nueva lectura de la mujer: crítica histórica. Málaga: Universidad de Málaga, pp. 41-62.

— (2011): «Amantissima civium suorum: Matronazgo cívico en el Occidente romano». Arenal, 18:2, pp. 277-307.

— (2012): «Poder integrador de la mater familias romana». En DÍAZ SÁNCHEZ, Pilar; FRANCO RUBIO, Gloria y FUENTE PÉREZ, María J. (ed.): Impulsando la historia desde la Historia de las mujeres: la estela de Cristina Segura. Huelva: Editorial Universidad de Huelva, pp. 157-168.

- (2017): «Legitimar la historia de las mujeres: logros, déficits y retos de las sociedades democráticas». En GALLEGO FRANCO, Henar y MORENO SECO, Mónica (ed.): Cómo enseñamos la Historia (de las Mujeres). Homenaje a Amparo Pedregal. Barcelona: Icaria, pp. 19-48. 
MASTERS, William H. y JOHNSON, Virginia E. (1966): Human sexual response. Boston: Little Brown.

MASTERSON, Mark (2004): «Occluding (?) Lens: The Turn to Masculinity in Roman Studies». En SKINNER, Marilyn B. (ed.): Gender and Diversity in Place: Proceedings of the Fourth Conference on Feminism and Classics. May 27-30, 2004, University of Arizona. Tucson: University of Arizona. Disponible en http://www.stoa.org/diotima/essays/fc04/Masterson.html [Consulta 10/02/2018]

MATHESON, Susan B. (2000): «The elder Claudia. Older Women in Roman Art». En KLEINER, Diana E. E. y MATHESON, Susan B.: I Claudia II. Women in Roman Art and Society. Austin: University of Texas Press, pp. 125-138.

MATTIOLI, Umberto (a cura di) (1995): Senectus. La vecchiaia nel mondo classico. Bolonia: Patron editore.

MEDINA-VICENT, María (2015): «Educación moral en la ética de la razón cordial para la emergencia de nuevas masculinidades. Los Men's Studies en la agenda política feminista». Oxímora. Revista Internacional de Ética y Política, 7, pp. 224-239.

MEDINA QUINTANA, Silvia (2011): «El trabajo femenino: utopía y realidad social». En HERNÁNDEZ HUERTA, José L.; SÁNCHEZ BLANCO, Laura; REBORDINOS HERNANDO, Francisco J. y CACHAZO VASALLO, Alexia (ed): Historia y utopía. Estudios y reflexiones. Salamanca: Hergar ediciones Antema, pp. 45-61.

- (2014): Mujeres y economía en la Hispania romana. Oficios, riqueza y promoción social. Oviedo: Trabe.

MENCACCI, Francesca (2006): «"Mala aetas nulla delenimenta invenit»” Donne, uomini e vecchiaia nella letteratura latina». Storia delle donne, 2, pp. 141-158.

MEYER, John C. (2014): «The canines in Horace’s Epodes». Akroterion, 59, pp. 105-122.

MICHAELIDES, Demetrios (2004): «Baubo and Priapos in Cyprus: a note». Mediterranean Archaeology, 17, pp. 307-309.

MIGDAL, Justyna (2014): «Old women: divination and magic or anus in roman literature». Symbolae philologorum posnaniensium graecae et latinae, 24, pp. 57-67.

MILNOR, Kristina (2011): «Women in Roman Society». En PEACHIN, Michael (coord): The Oxford Handbook of Social Relations in the Roman World. Oxford: Oxford University Press, pp. 609-622. 
MINOIS, Georges (1987): Historia de la vejez. De la Antigüedad al Renacimiento. Madrid: Nerea.

MINOZZI, Simona; CATALANO, Paola; CALDARINI, Carla y FORNACIARI, Gino (2012): «Palaeopathology of Human Remains from the Roman Imperial Age». Pathobiology, 79, pp. 268-283.

MIRÓN PÉREZ, M. Dolores (2002): «Niñas y ancianas en la antigua Olimpia». En PÉREZ CANTÓ, Pilar y ORTEGA LÓPEZ, Margarita (ed.): Las edades de las mujeres. Madrid: Universidad Autónoma de Madrid, pp. 53-66.

- (2005): «La desmesura femenina, o por qué es tan importante el autocontrol para una mujer griega». En PEDREGAL RODRÍGUEZ, Amparo y GONZÁLEZ GONZÁLEZ, Marta (ed.): Venus sin espejo. Imágenes de mujeres en la Antigüedad clásica y el cristianismo primitivo. Oviedo: KRK, pp. 81-101.

— (2010): «Mujeres y poder en la Antigüedad clásica: Historia y Teoría Feministas». Saldvie, 10, pp. 113-125.

MITCHELL, Alexandre G. (2013): «Disparate bodies in ancient artefacts: the function of caricature and pathological grotesques among Roman terracotta figurines». En LAES, Christian; GOODEY, Chris F. y ROSE, M. Lynn (ed.): Disabilities in Roman Antiquity: disparate bodies, a capite ad calcem. Londres: Brill, pp. 275-295.

MOLET CHICOT, Carme y BERNAD CAVERO, Olga (2015): «¿Debemos continuar hablando de feminismos?». Oxímora. Revista Internacional de Ética y Política, 7, pp. 1-15.

MOLINA PETIT, Cristina (2003): «Género y poder desde sus metáforas. Apuntes para una topografía del patriarcado». En TUBERT, Silvia (ed.): Del sexo al género. Los equívocos de un concepto. Madrid: Cátedra, pp. 123-159.

MOLINOS TEJADA, M. Teresa (2005): «Madres y nodrizas en la Antigüedad». En PEDREGAL RODRÍGUEZ, Amparo y GONZÁLEZ GONZÁLEZ, Marta (ed.): Venus sin espejo. Imágenes de mujeres en la Antigüedad clásica y el cristianismo primitivo. Oviedo: KRK.

MONTAÑANA CASANÍ, Amparo (2002): «La viuda y la sucesión en la República romana». En ALFARO GINER, Carmen; GARCÍA SÁNCHEZ, Manel y ALAMAR LAPARRA, Mónica (ed.): Actas del Tercer y Cuarto Seminarios de Estudios sobre la Mujer en la Antigüedad. Valencia, 28-30 abril 1999 y 12-14 abril 2000. Valencia: Seminario de Estudios sobre la Mujer en la Antigüedad, pp. 153-175. 
MONTERO HERRERO, Santiago (1999): «La remuneración económica de las adivinas y hechiceras en Roma». Saitabi, 49, pp. 333-340.

MOOG, Peter F. y SCHÄFER, Daniel (2008): «Joannes Stobaios, “On Old Age”: An Important Source for the History of Gerontology». Journal of the American Geriatrics Society, 56:2, pp. 354-358.

MORANT DEUSA, Isabel (2016): «Introducción: Geneviève Fraisse. A contracorriente». En FRAISSE, Geneviève: Los excesos del género. Concepto, imagen, desnudez. Madrid: Ediciones Cátedra, pp. 7-42.

MORENO CONDE, Margarita (2015): «Las edades de la vida: infancia y vejez a través de la iconografía griega». En IRIARTE GOÑI, Ana y FERREIRA, Luísa N. (coord.): Idades $e$ género na literatura e na arte da Grécia antiga. Coímbra: Impresa da Universidade de Coimbra, pp. 31-60.

MORGAN, Leslie A. y KUNKEL, Suzanne R. (2016): Aging, Society, and the Life Course. Nueva York: Springer.

MORILLO CERDÁN, Ángel (1999): Lucernas romanas en la región septentrional de la península ibérica. Montagnac: Éditions Monique Mergoil.

MUELLER, Ilse (2010): «Single Women in the Roman Funerary Inscriptions». Zeitschrift für Papyrologie und Epigraphik, 175, pp. 295-303.

MURNAGHAN, Sheila (2015): «Tragic Realities: Fictional Women and the Writing of Ancient History». EuGeStA, 5, pp. 178-196.

MUSIAL, Danuta (2013): «Divinities of the Roman Liberalia». Przeglad Humanistyczny, 2, pp. 95-100.

MUSTAKALLIO, Katarina (2011): «Representing Older Women: Hersilia, Veturia, Virgo Vestalis Maxima». En KRÖTZL, Christian y MUSTAKALLIO, Katariina (ed.): On Old Age: Approaching Death in Antiquity and the Middle Ages. Turnhout: Brepols Publishers, pp. 41-56.

MYEROWITZ LEVINE, Molly (1995): «The Gendered Grammar of Ancient Mediterranean Hair». En EILBERG-SCHWATZ, Howard y DONIGER, Wendy (ed.): Off with Her Head! The Denial of Women's Identity in Myth, Religion, and Culture. Berkeley: University of California Press, pp. 76-130.

MYERS, K. Sara (1996): «The Poet and the Procuress: The Lena in Latin Love Elegy». The Journal of Roman Studies, 86, pp. 1-21. 
NASH, Mary (2014): «Presentación». En NASH, Mary (ed.): Feminidades y masculinidades. Arquetipos y prácticas de género. Madrid: Alianza, pp. 14-19.

NASTA, Marcela (2011): «Cuerpos repulsivos: invectiva y afirmación genérica en Horacio, Epodos 8 y 12». En SCHNIEBS, Alicia (coord.): Discursos del cuerpo en Roma. Buenos Aires: Editorial de la Facultad de Filosofía y Letras Universidad de Buenos Aires, pp. 231-252.

NICHOLSON, Linda (2003): «La interpretación del concepto género». En TUBERT, Silvia (ed.): Del sexo al género. Los equívocos de un concepto. Madrid: Cátedra, pp. 47-81.

NIKOLOPOULOS, Anastasios D. (2003): «Tremuloque gradu aegra senectus: Old Age in Ovid's "Metamorphoses"». Mnemosyne, 56, pp. 48-60.

OJALA, Hanna; PIETILÄ, Ilkka y NIKANDER, Pirjo (2016): «Immune to ageism? Men's perceptions of age-based discrimination in everyday contexts». Journal of Aging Studies, 39, pp. 44-53.

OLENDER, Maurice (1985): «Aspects de Baubô. Textes et contexts antiques». Revue de l'histoire des religions, 202, pp. 3-55.

OLIENSIS, Ellen (1991): «Canidia, Canicula, and the Decorum of Horace’s Epodes». Arethusa, 24 , pp. 107-138.

OLSON, Kelly (2008): Dress and the Roman Women. Self-presentation and Society. Nueva York: Routledge.

OLSON, Laura K. (1988): «Aging is a Woman's Problem: Issues Faced by the Female Elderly Population». Journal of Aging Studies, 2:2, pp. 97-108.

ORMAND, Kirk (2015): «Toward Iambic Obscenity». En DUTSCH, Dorota y SUTER, Ann (ed.): Ancient Obscenites. Their Nature and Use in the Ancient Greek and Roman World. Ann Arbor: University of Michigan Press, pp. 44-70.

ORTEGA LÓPEZ, Margarita (2002): «Sospechosas, feas o brujas: las ancianas en la sociedad popular española del Antiguo Régimen». En PÉREZ CANTÓ, Pilar y ORTEGA LÓPEZ, Margarita (ed.): Las edades de las mujeres. Madrid: Universidad Autónoma de Madrid, pp. 387403.

OSORIO, Paulina (2010): «La edad mayor como producción sociocultural». Comunicación y medios, 22, pp. 30-35. 
OSTLING, Michael y KOUNINE, Laura (2016): «Introduction: 'Unbridled Passion' and the History of Witchcraft». En KOUNINE, Laura y OSTLING, Michael (ed.): Emotions in the History of Witchcraft. Londres: Macmillan Publishers Ltd., pp. 1-15.

OTERO, Hernán (2013): «La vejez como problema histórico. Una agenda de investigación». Anuario del Centro de Estudios Históricos "Profesor Carlos S. A. Segreti”, 13, pp. 93-108.

PALACIOS, Jimena (2014): «Miradas romanas sobre lo femenino: discurso, estereotipos y representación». Asparkía: Investigación feminista, 25, pp. 92-110.

- (2015): «Identidad y diversidad: estereotipos y representaciones de género en Metamorphoses de Apuleyo». Actas de y comunicaciones del Instituto de Historia Antigua y Medieval, 11, pp. 32-40.

PALOMAR VEREA, Cristina (2015): «El vacío del género». Asparkía, 16, pp. 17-33.

PAPÍ GÁLVEZ, Natalia (2003): «Un nuevo paradigma para el análisis de las relaciones sociales: el enfoque de género». Feminismo/s, 1, pp. 135-148.

PARKIN, Tim G. (1992): Demography and Roman Society. Baltimore: The Johns Hopkins University Press.

— (1998): «Ageing in antiquity. Status and participation». En JOHNSON, Paul (ed.): Old Age from Antiquity to Post-Modernity. Londres-Nueva York: Routledge, pp. 19-42.

- (1999): «Out of Sight, Out of Mind: Elderly Members of the Roman Family». En RAWSON, Beryl y WEAVER, Paul (ed.): The Roman Family in Italy: Status, Sentiment, Space. Oxford: Claredon Press, pp. 123-148.

- (2001): «On becoming a parent in later life. From Augustus to Antonio Agustín via St. Augustine». En DIXON, Suzanne (ed.): Childhood, class and kin in the Roman world. Londres-Nueva York: Routledge, pp. 221-24.

— (2003): Old Age in the Roman World. A Cultural and Social History. Baltimore: The Johns Hopkins University Press.

- (2011a): «From the margins to the centre stage. Some closing reflections on ancient historical demography». En HOLLERAND, Claire y PUDSEY, April (ed.): Demography and the Graeco-Roman World. New Insights and Approaches. Cambridge: Cambridge University Press, 181-188. 
- (2011b): «The Elderly Children of Greece and Rome». En KRÖTZL, Christian y MUSTAKALLIO, Katariina (ed.): On Old Age: Approaching Death in Antiquity and the Middle Ages. Turnhout: Brepols Publishers, pp. 25-40.

— (2011c): «The Roman Life Course and the Family». En RAWSON, Beryl (ed.): A companion to families in the Greek and Roman worlds. Malden: Blackwell, pp. 276-290.

PASCUAL LÓPEZ, Xavier (2015): «Las denominaciones de la mujer anciana en la lengua latina: interpretación etnolingüística». Symbolae Philologorum Posnaensium Graecae et Latinae, 25:1, pp. 15-31.

PAULE, Maxwell T. (2017): Canidia, Rome's First Witch. Londres-Nueva York: Routledge.

PAULIN, Sara (2011): «La bruja y la vieja: un cruce entre dos estereotipos. El caso horaciano». En GALÁN, Lía y BLISEL, María D. (ed.) y PEDERNERA, Soledad (coord.): V Jornadas de Estudios Clásicos y Medievales, 5 al 7 de octubre de 2011. Juventud y vejez en la Antigüedad y el Medievo. La Plata, Argentina. Buenos Aires: Universidad Nacional de La Plata. Disponible en http://jornadasecym.fahce.unlp.edu.ar/v-jornadas/actas/Paulin.pdf/view [Consulta 24/02/2018]

PAVÓN TORREJÓN, Pilar (2015): «La mujer en la religión romana: entre la participación y la marginación». En FERRER ALBELDA, Eduardo y PEREIRA DELGADO, Álvaro (coord.): Hijas de Eva. Mujeres y religión en la Antigüedad. Sevilla: Editorial Universidad de Sevilla, pp. 115-141.

PAYNE, Tom (2015): The Ancient Art of Growing Old. Londres: Vintage Books.

PEDRAZA Y MARTÍNEZ, M. Pilar (2001): «La vieja desnuda. Brujería y abyección». En CANCELLER, Antonella y LONDER, Renata (coord.): Le arti figurattive nelle letterature iberiche e iberoamericane. Atti del XIX Convegno, Roma 16-18 settembre 1999. Padua: Unipress, pp. 5-17.

PEDREGAL RODRÍGUEZ, Amparo (2007): «“Ancilla dei”. El discurso cristiano sobre la sumisión femenina». Studia Historica Historia Antigua, 25, pp. 417-434.

PELLING, Margaret y SMITH, Richard M. (1991): «Introduction». En PELLING, Margaret y SMITH, Richard M. (ed.): Life, death, and the elderly. Historical Perspectives. Londres: Routledge, pp. 1-32.

PEREA YÉBENES, Sabino (1998): «Anna Perenna: Religión y ejemplaridad mítica». Espacio Tiempo y Forma. Serie II Historia Antigua, 11, pp. 185-219. 
PÉREZ CANTÓ, Pilar (2002): «Virtuosas, castas y sumisas». En PÉREZ CANTÓ, Pilar y ORTEGA LÓPEZ, Margarita (ed.): Las edades de las mujeres. Madrid: Universidad Autónoma de Madrid, pp. 171-181.

PÉREZ CANTÓ, Pilar y ORTEGA LÓPEZ, Margarita (ed.) (2002): Las edades de las mujeres. Madrid: Universidad Autónoma de Madrid.

PÉREZ MENDOZA, Sofía (2016): «Una revista del CSIC cuestiona que exista discriminación por género en la ciencia». eldiario.es, 12/09/2016. Disponible en

https://www.eldiario.es/sociedad/revista-CSIC-cuestiona-discriminacion-

cristal 0 558194677.html [Consulta 10/02/2017]

PÉREZ MIRANDA, Iván (2011): Mito y género en la Grecia antigua. Tantálidas, labdácidas y dardánidas. Universidad de Salamanca, Tesis doctoral inédita. Disponible en https://gredos.usal.es/jspui/handle/10366/115595 [Consulta 31/05/2018]

PÉREZ ORTIZ, Lourdes (2003): Envejecer en femenino. Las mujeres mayores en España a comienzos del siglo XXI. Madrid: Instituto de la Mujer.

PHILLIPS, Judith; AJROUCH, Kristine y HILLCOAT-NALLÉTAMBY, Sarah (2010): Key Concepts in Social Gerontology. Londres-Thousand Oaks-Nueva Delhi-Singapur: SAGE.

PICHARDO GALÁN, J. Ignacio (2013): «Vínculos y nuevas formas de vida de las mujeres mayores». En FOLGUERA CRESPO, Pilar; MAQUIEIRA D'ANGELO, Virginia; MATILLA QUIZA, María J.; MONTERO LÓPEZ, Pilar y VARA MIRANDA, María J. (ed.): Género y envejecimiento. XIX Jornadas Internacionales de Investigación Interdisciplinar. Madrid: Instituto Universitario de la Mujer - Ediciones de la Universidad Autónoma de Madrid, pp. 229-244.

PIRANOMONTE, Marina (2002): Il Santuario della Musica e il Bosco Sacro di Anna Perenna. Roma: Mondadori Electa.

PLÁCIDO SUÁREZ, Domingo (2005): «La construcción cultural de lo femenino». En PEDREGAL RODRÍGUEZ, Amparo y GONZÁLEZ GONZÁLEZ, Marta (ed.): Venus sin espejo. Imágenes de Mujeres en la Antigüedad clásica y el cristianismo primitivo. Oviedo: KRK, pp. 17-32.

PLANTADE, Emmanuel y PLANTADE, Nedjima (2014): «Libyca Psyche: Apuleius’ Narrative and Berber Folktales». En LEE, Benjamin T.; FINKELPEARL, Ellen y GRAVERINI, Luca (ed.): Apuleius and Africa. Nueva York: Routledge. 
PLESCIA, Joseph (1976): «Patria potestas and the Roman revolution». En BERTMAN, Stephen: The Conflict of Generations in Ancient Greece and Rome. Ámsterdam: Grüner, pp. 143-169.

POLLARD, Elizabeth A. (2008): «Witch-Crafting in Roman Literature and Art. New Thoughts on an Old Image». Magic, Ritual, and Witchcraft, 3:2, pp. 119-155.

POLO CERDÁ, Manuel y GARCÍA PRÓSPER, Elisa (2002): «Ritual, violencia y enfermedad. Los enterramientos en decúbito prono de la necrópolis fundacional de Valentia». Sagvntvm, 34, pp. $137-148$.

POLO TORIBIO, Gema (2013): «La edad de la mujer en Roma: la perfecta aetas». En RODRÍGUEZ LÓPEZ, Rosalía y BRAVO BOSCH, María J. (ed.): Mulier. Algunas Historias e Instituciones de Derecho Romano. Madrid: Dykinson, pp. 179-198.

POSADAS SÁNCHEZ, Juan L. (2013): «Muertes paralelas: el fin de las Julio-Claudias». En BRAVO, Gonzalo y GONZÁLEZ SALINERO, Raúl (ed.): Formas de morir y formas de matar en la Antigüedad romana. Actas del X Coloquio de la Asociación Interdisciplinar de Estudios Romanos. Madrid: Signifer, pp. 267-280.

POTTER, David S. (2002): «Odor and Power in the Roman Empire». En PORTER, James I. (ed.): Constructions of the Classical Body. Ann Arbor: The University of Michigan Press, pp. 169-189.

PRATT, Louise (2000): «The Old Women of Ancient Greece and the Homeric Hymn to Demeter». Transactions of the American Philological Association, 130, pp. 41-65.

PRICOP, Loredana (2014): «Age rounding and social status in Noricum». Studia Antiqua et Archaeologica, 20, pp. 185-217.

PROWSE, Tracy L. (2011): «Diet and Dental Health through the Life Course in Roman Italy». En AGARWAL, Sabrina C. y GLENCROSS, Bonnie A. (ed.): Social Bioarchaeology. Oxford: Blackwell, pp. 410-437.

PUCHE, Luis (2013): «Imágenes socioculturales sobre el envejecimiento: persistencias, cambios y retos en la representación de las personas mayores en los medios de comunicación». En FOLGUERA CRESPO, Pilar; MAQUIEIRA D’ANGELO, Virginia; MATILLA QUIZA, María J.; MONTERO LÓPEZ, Pilar y VARA MIRANDA, María J. (ed.): Género y envejecimiento. XIX Jornadas Internacionales de Investigación Interdisciplinar. Madrid: Instituto Universitario de la Mujer - Ediciones de la Universidad Autónoma de Madrid, pp. 245-268. 
PUDSEY, April (2012): «Death and the Family: Widows and Divorcées in Roman Egypt». En LARSSON LOVÉN, Lena y HARLOW, Mary (ed.): Families in the Imperial and Late Antique Roman World. Londres-Nueva York: Continuum, pp. 157-180.

PUGLIARELLO, Mariarosaria (2002): «Invecchiare al femminile: i racconti delle nonne (Aniles fabellae) nell' antica Roma». En GUERCI, Antonio y CONSIGLIERE, Stefania (a cura di): La vecchiaia nel tempo. Génova: Erga Edizioni, pp. 45-51.

PULEO GARCÍA, Alicia H. (2007): «El hilo de Ariadna: ecofeminismo, animales y crítica al androcentrismo». VELAYOS CASTELO, Carmen; BARRIOS HERRERO, Olga y FIGUERUELO BURRIEZA, Ángela (ed.): Feminismo ecológico. Estudios multidisciplinares de género. Salamanca: Ediciones de la Universidad de Salamanca, pp. 71-85.

QUEVEDO SÁNCHEZ, Alejandro (2010): «La “vieja borracha”: una nueva pieza minorasiática de época medioimperial en Cartagena». Ex Officina Hispana, 2, pp. 45-50.

RAMOS PALOMO, María D. (2003): «Historia de las mujeres, saber de las mujeres: la interpretación de las fuentes en el marco de la tradición feminista». Femisnismos, 1, pp. 19-32.

RAMOS TORO, Mónica 2013): «Políticas y programa para un nuevo envejecimiento desde la perspectiva de género». En FOLGUERA CRESPO, Pilar; MAQUIEIRA D’ANGELO, Virginia; MATILLA QUIZA, María J.; MONTERO LÓPEZ, Pilar y VARA MIRANDA, María J. (ed.): Género y envejecimiento. XIX Jornadas Internacionales de Investigación Interdisciplinar. Madrid: Instituto Universitario de la Mujer - Ediciones de la Universidad Autónoma de Madrid, pp. 269-286.

- (2017): Envejecer siendo mujer. Dificultades, oportunidades y retos. Barcelona: Edicions Bellaterra.

RAWSON, Beryl (ed.) (2011): A companion to families in the Greek and Roman worlds. Malden: Blackwell.

REAL TORRES, Carolina (1992): «El vino como alimento y medicina en la sociedad romana». Fortunatae, 3, pp. 305-314.

REDONDO-MOYANO, Elena (2016): «El encuentro de Veturia y Coriolano (D.H. Antiquitates Romanae 8.44-53)». Studia Philologica Valentina, 18, pp. 335-342.

REHER, David-Sven (1997): «Vejez y envejecimiento en perspectiva histórica: Retos de un campo en auge». Política y Sociedad, 26, pp. 63-71. 
REINHOLD, Meyer (1970): «The Generation Gap in Antiquity». Proceedings of the American Philosophical Society, 114:5, pp. 347-365.

REEVES, Eileen (1999): «Old Wives» Tales and the New World System: Gilbert, Galileo, and Kepler». Configurations, 7, pp. 301-354.

REOL TEJADA, Juan M. (2003): «Prólogo». En Real Academia Nacional de Farmacia: Bioquímica y fisiopatología del envejecimiento. Madrid: RANF, pp. 11-14.

REVELL, Louise (2005): «The Roman Life Course: A View from the Inscriptions». European Journal of Archaeology, 8, pp. 43-63.

RIBERA CASADO, J. Manuel (2011): «Envejecer con buena salud». En INSTITUTO DE MAYORES Y SERVICIOS SOCIALES - IMSERSO: El libro blanco del envejecimiento activo. Madrid: IMSERSO-Ministerio de Sanidad, Política Social e Igualdad, pp. 225-263.

RICHARDSON, Bessie E. (1933): Old Age Among the Ancient Greeks. The Greek Portrayal of Old Age in Literature, Art, and Inscriptions. Baltimore: The Johns Hopkins University Press.

RICHLIN, Amy (1984): «Invective against women in Roman satire». Arethusa, 17, pp. 67-80.

- (1992): The Garden of Priapus: Sexuality and Aggression in Roman Humor. Oxford: Oxford University Press.

- (2013): «Sexuality and History». En PARTNER, Nancy y FOOT, Sarah (ed.): The SAGE Handbook of Historical Theory. Londres: SAGE, pp. 294-310.

RIGSBY, Andrew M. (2011): «Memoir and Autobiography in Republican Rome». En MARINCOLA, John (ed.): A Companion to Greek and Roman Historiography. Oxford: Blackwell, pp. 266-274.

RIPPIER WHEELER, Helen (1997): Women \& Aging. A Guide to the Literature. Boulder: Lynee Rienner Publishers.

RIVERA DÍAZ, Raquel y GUERRA TAPIA, Aurora (2008): «Manejo de la alopecia androgenética en mujeres posmenopáusicas». Actas Dermo-Sifiliográficas, 99:4, pp. 257-261.

RIVERA GARRETAS, María M. (1994): Nombrar el mundo en femenino. Pensamiento de las mujeres y teoría feminista. Barcelona: Icaria.

ROBERTS, Charlotte (2017): «Preface. Navigating Approaches to Impairment, "Disability" and Care in the Past: The Need for Reflection». En POWELL, Lindsay; SOUTHWELL-WRIGHT, 
William y GOWLAND, Rebecca L. (ed.): Care in the Past. Archaeological \& Interdisciplinary Perspectives. Oxford: Oxbow, pp. xi-xviii.

RODEHEAVER, Dean (1993): «Psychological Adaptation and Virtue: Geropsychological Perspectives on Cicero's De Senectute». Journal of Aging Studies, 7:4, pp. 353-359.

RODRÍGUEZ ALEMÁN, Rosalía (2011): «La persistencia de las desigualdades en la última fase del ciclo vital». En VÁZQUEZ BERMÚDEZ, Isabel: Investigación y género. Logros y retos. III Congreso Universitario Nacional. Sevilla, Universidad de Sevilla, pp. 1692-1706.

RODRÍGUEZ ÁVILA, Nuria (2006): Manual de sociología gerontológica. Barcelona: Publicacions i edicions de la Universitat de Barcelona.

RODRÍGUEZ MAMPASO, María J.; HIDALGO BUENO, Esther y WAGNER, Carlos G. (ed.) (1994): Roles sexuales. La mujer en la historia y la cultura. Madrid: Ediciones Clásicas.

RODRÍGUEZ SOMOLINOS, Helena (2005): «Safo, Titono y la cigarra (PKÖLN.inv.21351re+21376+POXY.1787)». En COSTAS RODRÍGUEZ, Jenaro (coord.): Ad amicam amicissime scripta. Homenaje a la profesora María José López de Ayala y Genovés. Volumen I. Madrid: UNED, pp. 129-138.

ROLDÁN GARCÍA, Clodoaldo; FERRERO CALABUIG, José y MURCIA MASCARÓS, Sonia (2007): «Análisis de materiales de una botella cerámica con forma antropomorfa anus ebria y análisis de residuos orgánicos en muestras del interior de una vasija (\#1CISNAQ/05, VE.3740)». En PIQUERAS SÁNCHEZ, Norberto (ed.): Palau de Cerveró. Instituto de Historia de la Ciencia y Documentación López Piñero. Valencia: Universitat de València, pp. 241-252.

ROS GARCÍA, Esther (2016): Socialización del género a través del cuento infantil en la Comunidad Autónoma de Andalucía. Universidad de Sevilla, Tesis doctoral inédita. Disponible en https://idus.us.es/xmlui/handle/11441/40261 [Consulta 10/12/2017]

ROSE, M. Lynn (2006): «Deaf and Dumb in Ancient Greece». En DAVIS, Lennard J. (ed.): The Disability Studies Reader. Second Edition. Oxford-Nueva York: Routledge, pp. 17-32.

ROSE, Sonya O. (2012): ¿Qué es historia de género? Madrid: Alianza.

RUBIERA CANCELAS, Carla (2014): La esclavitud femenina en la Roma antigua. Famulae, ancillae et servae. Oviedo: Trabe.

RUDMAN, Laurie A. y MESCHER, Kris (2012): «Of Animals and Objects: Men’s Implicit Dehumanization of Women and Likehood of Sexual Aggresion». Personality and Social Psychology Bulletin, 20, pp. 1-13. 
RUIZ DE ELVIRA, Antonio (1976): «Problemas del calendario romano». Cuadernos de filología clásica, 11, pp. 9-52.

RÜPKE, Jörg (2011): The Roman Calendar from Numa to Constantine. Time, History and the Fasti. Oxford: Wiley-Blackwell.

RUSSELL, Cherry (1987): «Ageing as a feminist issue». Women's Studies International Forum, 10:2, pp. 125-132.

SADA CASTILLO, Pilar (2010): «¿Mujeres invisibles? La presencia de las mujeres en los discursos expositivos de la historia». En DOMÍNGUEZ ARRANZ, Almudena (ed.): Mujeres en la Antigüedad Clásica. Género, poder y conflicto. Madrid: Sílex, pp. 229-247.

SALLER, Richard P. (1994): Patriarchy, property and death in the Roman family. Cambridge: Cambridge University Press.

SALLER, Richard P. y SHAW, Brent D. (1984): «Tombstones and Roman Family Relations in the Principate: Civilians, Soldiers and Slaves». Journal of Roman Studies, 74, pp. 124-156.

SALOMONSON, Jan W. (1980): «Der Trunkenbold und die trunkene Alte». BABesch, 55, pp. 65-106.

SALVATIERRA LÓPEZ, Cristina; TORIBIO SANJAUME, Nuria y CHÍMENOS KÜSTNER, Eduardo (1996): «Estudio del desgaste dentario en restos humanos procedentes de la necrópolis tardorromana de "Can Trullas" (Granollers, Barcelona)». En VILLALAÍ́N BLANCO, José D.; GÓMEZ BELLARD, Carlos y GÓMEZ BELLARD, Francisco (ed.): Actas del II Congreso Nacional de Paleopatología. Valencia: Asociación Española de Paleopatología-Universitat de Valencia, pp. 253-262.

SALINSBURY, Joyce E. (2001): Encyclopedia of Women in the Ancient World. Santa Bárbara: ABC-CLIO.

SANAHUJA YLL, María E. (2005): «¿Género o Mujeres?». En SEVILLANO SAN JOSÉ, María C.; RODRÍGUEZ CORTÉS, Juana; OLARTE MARTÍNEZ, Matilde y LAHOZ, Lucía (ed.): El Conocimiento del Pasado. Una herramienta para la igualdad. Salamanca: Plaza Universitaria Ediciones, pp. 87-98.

SÁNCHEZ GRANJEL, Luis (2003): «Apuntes para una historia de la vejez». Monografías Humanitas, 1, pp. 21-26. 
SÁNCHEZ LEÓN, Paco (2003): «Todas fuimos Eva. La identidad de la historiadora de las mujeres». En TUBERT, Silvia (ed.): Del sexo al género. Los equívocos de un concepto. Madrid: Cátedra, pp. 161-213.

SÁNCHEZ VERA, Pedro (2016): «Editorial. Vejez y Género. Algunos conceptos para el Análisis y el Debate». RASP - Research on Ageing and Social Policy, 4:1, pp. 1-21.

SANDBERG, Linn (2013): «Affirmative old age - the ageing body and feminist theories on difference». International Journal of Ageing and Later Life, 8, pp. 11-40.

SANDE, Siri (1995): «An old hag and her sisters». Symbolae Osloenses, 70, pp. 30-53.

SAQUETE CHAMIZO, José C. (2000): Las vírgenes vestales. Un sacerdocio femenino en la religión pública romana. Madrid: CSIC.

SAVUNEN, Liisa (1995): «Women and elections in Pompeii». En HAWLEY, Richard y LEVICK, Barbara (ed.): Women in Antiquity. New Assessments. Londres-Nueva York: Routledge, pp. 194-205.

SCHEIDEL, Walter (2000): «Introduction». En SCHEIDEL, Walter (ed.): Debating Roman Demography. Leiden-Boston-Köln-Brill: Mnemosyme Supplementum, pp. vii-x.

- (2007): «Roman Funerary Commemoration and the Age of First Marriage». Classical Philology, 102, pp. 389-402.

- (2013): «Disease and Death». En ERDKAMP, Paul (ed.): The Cambridge Companion to Ancient Rome. Cambridge: Cambridge University Press, pp. 45-59.

SCHIEBER, Frank (2011): «Vision and Aging». En BIRREN, James E. y SCHAIE, K. Warner: Handbook of the Psychology of Aging. Londres: Elsevier, pp. 129-160.

SCHULTZ, Fritz (1942): «Roman Registers of Births and Birth Certificates». The Journal of Roman Studies, 32, pp. 78-91.

— (1943): «Roman Registers of Births and Birth Certificates. Part II». The Journal of Roman Studies, 33, pp. 55-64.

SCOBIE, Alex (1979): «Storytellers, Storytelling, and the Novel in Graeco-Roman Antiquity». Rheinisches Museum für Philologie, 122, pp. 229-259.

SCOTT, Joan W. (2001): «Fantasy Echo: History and the Construction of Identity». Critical Inquiry, 28:2, pp. 284-304. 
SEBESTA, Judith L. (1997): «Women's Costume and Feminine Civic Morality in Augustan Rome». Gender \& History, 9:3, pp. 529-541.

SEGURA GRAÍ̃NO, Cristina (2005): «La construcción de la Historia de las Mujeres». Revista de Historiografía, 2, pp. 10-14.

- (2006): «Veinticinco años de historia de las mujeres en España». Memoria y civilización, 9, pp. 86-107.

— (2008): «La Historia sobre las mujeres en España». eHumanista, 10, pp. 274-292.

- (2014): «Modelos desautorizadores de las mujeres en los cuentos tradicionales». Arenal, 21:2, pp. 221-241.

- (2015): «Cómo construimos la Historia de las Mujeres desde las universidades españolas». Revista de Historiografía, 22, pp. 255-271.

SEGURA RAMOS, Bartolomé (2007): «Enfermar, envejecer y morir en los tiempos de Tito a Trajano». Cuadernos de Filología Clásica, 27:1, pp. 87-116.

SEPÚLVEDA NAVARRETE, Paula (2010): «Mujer y vejez. Un recorrido histórico hasta nuestros días». Ubi sunt?, 25, pp. 9-17.

SERNA DE PEDRO, Inmaculada de la (2003): La vejez desconocida: una mirada desde la biología a la cultura. Madrid: Ediciones Díaz de Santos.

SERRANO RAMOS, Encarnación y BAENA DEL ALCÁZAR, Luis (1982): «Sobre una escultura femenina aparecida en Santaella (Córdoba)». Baetica, 5, pp. 145-149.

SETTERSTEN, Richard A. (2006): «Ageing and the Life Course». En BINSTOCK, Robert H. y GEORGE, Linda K. (ed.): Handbook of Aging and the Social Sciences. Londres: Academic Press, pp. 3-19.

SHAW, Brent D. (1991): «The Cultural Meaning of Death: Age and Gender in the Roman Family». En KERTZER, David I. y SALLER, Richard P. (ed.): The Family in Italy from Antiquity to the Present. New Haven: Yale University Press, pp. 66-90.

- (1996): «Seasons of death: aspects of mortality in imperial Rome». Journal of Roman Studies, 86, pp. 100-138.

SHAW, Brent D. y SALLER, Richard (1984): «Close-Kin Marriage in Roman Society?». Man, New Series, 19:3, pp. 432-444. 
SHEHAN, Constance L. y KAESTLE, Christine E. (2009): «Gendered Bodies in Family Structures. A Feminist Examination of Constructionist and Biosocial Perspectives on Families». En LLOYD, Sally A.; FEW, April L. y ALLEN, Katherine (ed.): Handbook of Feminist Family Studies. Londres: SAGE, pp. 83-95.

SHELTON, Jo-Ann (2013): The Women of Pliny's Letters. Londres-Nueva York: Routledge.

SHERWIN-WHITE, Adrian N. (1966): The Letters of Pliny: A Historical and Social Commentary. Oxford: Claredon Press.

SICK, David H. (1999): «Ummidia Quadratilla: Cagey Businesswoman or Lazy Pantomime Watcher?». Classical Antiquity, 18:2, pp. 330-348.

SIERRA VALENTÍ, Xavier (2011): «La alopecia en la antigua Roma». Piel, 26:1, pp. 3-6.

SIGISMUND-NIELSEN, Hanne (1999): «Interpreting epithets in Roman epitaphs». En RAWSON, Beryl y WEAVER, Paul (ed.): The Roman Family in Italy: Status, Sentiment, Space. Oxford: Claredon Press, pp. 169-204.

SKINNER, Marilyn B. (2010): Clodia Metelli. The tribune's sister. Nueva York: Oxford University Press.

SMITH, Bonnie G. (2013): «Gender I: From Women's History to Gender History». En PARTNER, Nancy y FOOT, Sarah (ed.): The SAGE Handbook of Historical Theory. Londres: SAGE, pp. 266-281.

SOFAER, Joanna (2011): «Towards a Social Bioarchaeology». En AGARWAL, Sabrina C. y GLENCROSS, Bonnie A. (ed.): Social Bioarchaeology. Oxford: Blackwell, pp. 285-311.

SPAETH, Barbette S. (2010): «"The Terror that Comes in the Night": The Night Hag and Supernatural Assault in Latin Literature». En SCIOLI, Emma y WALDE, Christina (ed.): Sub Imagines Somni: Nightime Phenomena in Greco-Roman Culture. Pisa: Edizioni ETS, pp. 231258.

- (2014): «From Goddess to Hag: The Greek and the Roman Witch in Classical Literature». En STRATTON, Kimberly B. y KALLERES, Dayna S. (ed.): Daughters of Hecate. Women and Magic in the Ancient World. Oxford: Oxford University Press, pp. 41-70.

SPARREBOOM, Anna (2009): Wet-nursing in the Roman Empire. Indifference, efficiency and affection. Vrije Universiteit, Trabajo de Máster inédito. 
STEINER, Katherine y MAHONY, Simon (2016): «How are digital methods changing research in the study of the classical world? An EpiDoc case study». Panta Rei, 6, pp. 125-148.s

STIG SØRENSEN, Marie L. (2006): «Gender, Things, and Material culture». En MILLEDGE NELSON, Sarah: Handbook of gender in archaeology. Lanham: Altamira Press, pp. 105-155.

STONE, Margaret (2013): Women, Ageing and Archetypes. Ideas, Images and Support on the Post-Menopausal Journey. Sheffield: Wildtrack.

STRATTON, Kimberly B. (2007): Naming the Witch: Magic, Ideology \& Stereotype in the Ancient World. Nueva York: Columbia University Press.

STRATTON, Kimberly B. y KALLERES, Dayna S. (ed.) (2014): Daughters of Hecate. Women and Magic in the Ancient World. Oxford: Oxford University Press.

STRONG, Anise K. (2012): «Working Girls. Mother-Daughter Bonds Among Ancient Prostitutes». En HACKWORTH PETERSEN, Lauren y SALZMAN-MITCHELL, Patricia (ed.): Mothering and Motherhood in Ancient Greece and Rome. Austin: University of Texas Press, pp. 121-139.

SUÁREZ, Marcela A. (2003): «Nomen Leaena est: la Construcción Plautina de la Anus en Curculio I 1-2». Phaos, 3, pp. 119-128.

SUÁREZ MARTÍNEZ, Pedro M. (1994): «Horacio y las viejas libidinosas». Estudios Clásicos, 105, pp. 49-62.

SUDER, Wieslaw (1978): «On Age Classification in Roman Imperial Literature». The Classical Bulletin, 55, pp. 5-9.

— (1995): «La mort des vieillards». En HINARD, François (ed.): La mort au quotidien dans le monde romain. París: De Boccard, pp. 31-45.

SUTER, Ann (2015): «The Anasyrma. Baubo, Medea, and the Gendering of Obscenity». En DUTSCH, Dorota y SUTER, Anna: Ancient Obscenities: Their Nature and Use in the Ancient Greek and Roman World. Ann Arbor: University of Michigan Press, pp. 21-43.

SYME, Ronald (1979): «Ummidus Quadratus, Capax Imperii». Harvard Studies in Classical Philology, 83, pp. 287-310.

THOMSON, George (1943): «The Greek Calendar». The Journal of Hellenic Studies, 63, pp. $52-65$. 
TOMÀS WHITE, Mónica (2015): «Hysterical women and wild animals: parallels in the construction of female and animal alterity». Oxímora. Revista Internacional de Ética y Política, 7, pp. 138-159.

TORNÉ TEIXIDÓ, Ramon (2006): «Un nou poema de Safo (P. Oxy. 1787+P. Köln 21351)». Faventia, 28, pp. 199-202.

TORREGO, Esperanza (2014): «La vejez en Roma: el reflejo y la vivencia». En HERNÁNDEZ CRESPO, Rosa M. y DOMÍNGUEZ MONEDERO, Adolfo J. (ed.): Las edades del hombre. Las etapas de la vida entre griegos y romanos. Madrid: Delegación de Madrid de la Sociedad Española de Estudios Clásicos, pp. 209-229.

TRACY, Valerie A. (1980): «Aut Captantur aut Captant». Latomus, 39, pp. 399-402.

TREGGIARI, Susan (1991): Roman Marriage. Iusti Coniuges from the time of Cicero to the time of Ulpian. Oxford: Claredon Press.

- (2007): Terentia, Tullia and Publillia: the Women of Cicero's Familly. Nueva York: Routledge.

TRENTIN, Lisa (2013): «Exploring visual impairment in Ancient Rome». En LAES, Christian; GOODEY, Chris F. y ROSE, M. Lynn (ed.): Disabilities in Roman Antiquity: disparate bodies, a capite ad calcem. Londres: Brill, pp. 89-114.

TRIADÓ TUR, Carme y VILLAR POSADA, Feliciano (2008): Envejecer en positivo. Girona: Editorial Aresta.

— (2014): Psicología de la vejez. Madrid: Alianza.

TROYANSKY, David G. (2016): Aging in World History. Nueva York: Routledge.

TUBERT, Silvia (2003): «Introducción. La crisis del concepto de género». En TUBERT, Silvia (ed.): Del sexo al género. Los equívocos de un concepto. Madrid: Cátedra, pp. 7-37.

TWIGG, Julia (2004): «The body, gender and age. Feminist insights in social gerontology». Journal of Aging Studies, 18, pp. 59-73.

— (2015): «Dress and age: the intersection of life and work». International Journal of Ageing and Later Life, 10, pp. 55-67.

TWIGG, Julia y MARTIN, Wendy (2015): «The field of cultural gerontology. An introduction». En TWIGG, Julia y MARTIN, Wendy (ed.): Routledge Handbook of Cultural Gerontology. Londres-Nueva York: Routledge, pp. 1-15. 
VAL VALDIVIESO, María I. del; SANTO TOMÁS PÉREZ, Magdalena; DUEÑAS CEPEDA, María J. y ROSA CUBO, Cristina de la (coord.) (2004): La historia de las mujeres: una revisión historiográfica. Valladolid: Universidad de Valladolid.

VALCÁRCEL Y BERNALDO DE QUIRÓS, Amelia (1994): Sexo y filosofía. Sobre «mujer»y «poder». Barcelona: Anthropos.

VALDÉS GUÍA, Miriam (2015): «La risa de Deméter: aischrologia y Kalliageneia en las Tesmoforias de Atenas». Arys, 13, pp. 9-25.

VERTINSKY, Patricia A. (1995): «Stereotypes of Aging Women and Exercise: A Historical Perspective». Journal of Aging and Physical Activity, 3, pp. 223-237.

VUOLANTO, Ville (2017): «Grandmothers in Roman Egypt». Greek, Roman, and Byzantine Studies, 57, pp. 372-402.

WACE, Alan J. B. (1904): «Grotesque and the Evil Eye». The Annual of the British School at Athens, 10, pp. 103-114.

WAGNER-HASEL, Beate (2011): «Vieillesse, savoir et genre. Réflexions sur les discours consacrés à la vieillesse dans l'Antiquité». Genre, sexualité \& societé, 6. Disponible en http://gss.revues.org/2222 [Consulta 24/02/2018]

WALCOT, Peter (1991): «On widows and their reputation in antiquity». Symbolae Osloensis, 66:1, pp. 5-26.

WALDHAUER, Oscar (1946): «Myron's Anus Ebria and the Drunken Woman in Munich». American Journal of Archaeology, 50:2, pp. 241-246.

WALKER, Barbara G. (2013): The Crone. Woman of Age, Wisdom, and Power. Londres: HarperCollins.

WARNER, Marina (1999): «The Old Wives' Tale». En TATAR, Maria (ed.): The Classic Fairy Tales. Nueva York: Norton \& Company, pp. 309-317.

WEG, Ruth B. (1983): «Introduction». En WEG, Ruth B. (ed.): Sexuality in the Later Years: Roles and Behavior. Nueva York: Academic Press, pp. 1-10.

WIEDEMANN, Thomas (1996): «Servi senes: the role of old slaves at Rome». Polis, 8, pp. 275-293. 
WILKINS, John (2015): «Medical Literature, Diet, and Health». En WILKINS, John y NADEAU, Robin (ed.): A Companion to Food in the Ancient World. Oxford: Blackwell, pp. 5766.

WILLIAMS, Gordon (1958): «Some Aspects of Roman Marriage Ceremonies and Ideal». The Journal of Roman Studies, 48, pp. 16-29.

WITCHER, Rob (2005): «The extended metropolis: Urbs, suburbium and population». Journal of Roman Archaeology, 18, pp. 120-138.

WITZKE, Serena S. (2016): «Violence against Women in Ancient Rome. Ideology versus Reality». En RIESS, Werner y FAGAN, Garrett G. (ed.): The Topography of Violence in the Greco-Roman World. Ann Arbor: University of Michigan Press, pp. 248-274.

WOOD, Susan E. (2001): Imperial Women. A Study in Public Images, 40 BC-AD 68. Leiden: Brill.

ZANKER, Paul (1989): Die trunkene Alte. Frankfurt: Fischer Taschebunch.

— (1992): Augusto y el poder de las imágenes. Madrid: Alianza.

ZARAGOZA BERNAL, Manuel (2013): «Historia de las emociones: una corriente historiográfica en expansión». Asclepio. Revista de Historis de la Medicina y de la Ciencia, 65, pp. 1-10.

\section{WEBGRAFÍA}

A Bit of History http://abitofhistory.net/ [Consulta 15/01/2018]

“Anciano, na" en Diccionario de la lengua española - Real Academia Española, http://dle.rae.es/?id=2XsOc6q [Consulta 20/10/2016]

Arachne - CIL Open Access, http://arachne.uni-koeln.de/drupal/?q=en/node/291 [10/01/2018]

Checklist of Editions of Greek, Latin, Demotic and Coptic Papyri, Ostraca and Tablets - Duke University, https://library.duke.edu/rubenstein/scriptorium/papyrus/texts/clist_papyri.html [Consulta 10/03/2018]

Club de los 60. Envejecimiento activo - Servicios Sociales de Castilla y León, http://www.serviciossociales.jcyl.es/web/jcyl/ServiciosSociales/es/Plantilla100/1284372564203 / / / [Consulta 17/05/2017] 
Diccionario Griego-Español. CSIC, http://dge.cchs.csic.es/lst/lst-int.htm [Consulta 10/03/2018]

EDCS - Epigraphik-Datenbank Clauss / Slaby, http://db.edcs.eu/epigr/epi es.php [Consulta 24/07/2017]

Epigraphic Database Roma - Electronic Archive of Greek and Latin Epigraphy (EAGLE), http://www.edr-edr.it/default/index.php [15/04/2018]

"Hallan en España una lucerna del siglo I que muestra una exploración ginecológica" CulturaClassica.com, http://www.culturaclasica.com/?q=node/2562 [Consulta 23/03/2017]

Hermitage Museum - Collection Online,

https://www.hermitagemuseum.org/wps/portal/hermitage/explore/artworks?lng=es [10/04/2018]

Lacus Curtius - $\quad$ Greek and Roman Authors,

http://penelope.uchicago.edu/Thayer/E/Roman/Texts/ [Consulta 21/08/2016]

Musei Capitolini - Collezioni, http://es.museicapitolini.org/collezioni [10/04/2018]

Oxford Classical Dictionary Abbreviations, http://classics.oxfordre.com/page/abbreviation-list/ [Consulta 10/03/2018]

Perseus - Latin Texts \& Translations, http://perseus.uchicago.edu/latin.html [15/04/2018]

Petición de retirada del número 778 de la Revista del CSIC Arbor por parte de un grupo de investigadorxs del CSIC - Change.org, https://www.change.org/p/presidencia-del-csic-retiradadel-n\%C3\%BAmero-778-de-la-revista-del-csic-

arbor?recruiter=596350739\&utm_source=share_petition\&utm_medium=email\&utm_campaign =share email responsive [Consulta 31/02/2017]

"Senil" en Diccionario de la lengua española - Real Academia Española, http://dle.rae.es/?id=XZjxUFk [Consulta 20/10/2016]

The British Museum - Collection Online,

http://www.britishmuseum.org/research/collection online/search.aspx [10/04/2018]

The Latin Library, http://thelatinlibrary.com/ [15/04/2018]

The Metropolitan Museum, http://www.metmuseum.org/art/collection [10/04/2018]

The Roman Law Library, https://web.archive.org/web/20120831060912/http://web.upmfgrenoble.fr/Haiti/Cours/Ak/ [Consulta 20/09/17] 
"Vejez" en Diccionario de la lengua española - Real Academia Española, http://dle.rae.es/?id=bSrxBGn [Consulta 20/10/16]

"Vetusto, ta" en Diccionario de la lengua española - Real Academia Española, http://dle.rae.es/?id=biJnALa [Consulta 20/10/16]

"Viejo, ja" en Diccionario de la lengua española - Real Academia Española, http://dle.rae.es/?id=bnRGe0W [Consulta 20/10/16] 